Deutsche Gesellschaft für

Geschichte und Theorie der Biologie

Annals of the History and Philosophy of Biology

Volume 11 (2006)

formerly Jahrbuch für

Geschichte und Theorie der Biologie

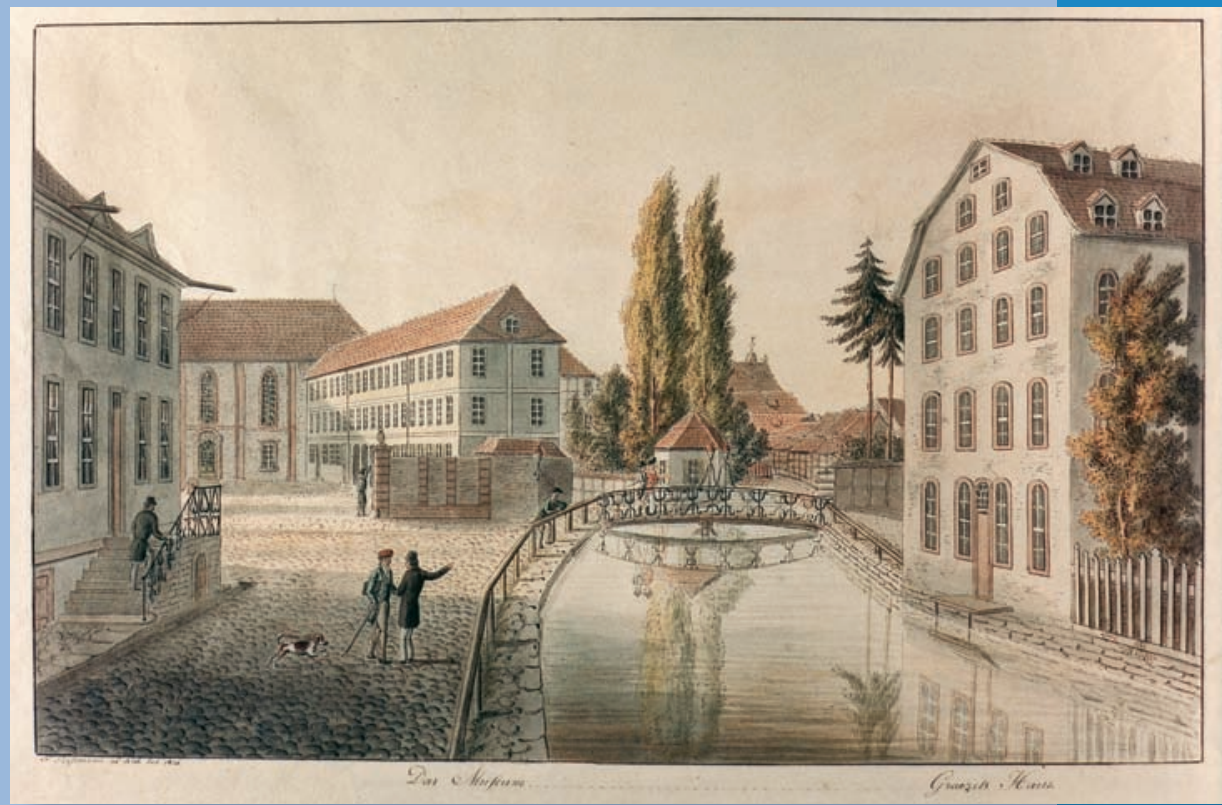

\title{
Universitätsverlag Göttingen
}


From January 1, 2006 manuscripts should be submitted to the managing editor V. Wissemann. Submissions will be peer reviewed. The preferred language is English.

Articles in German should be accompanied by a short (max. 1.000 words) summary in English.

\section{Editors}

Uwe Hoßfeld, Jena, Germany

Kristian Köchy, Kassel, Germany

Lennart Olsson, Jena, Germany

Volker Wissemann, Gießen, Germany - managing editor-

Institut für Allg. Botanik und Pflanzenphysiologie

Bereich Allgemeine Botanik, AG Spezielle Botanik

Justus-Liebig-Universität Gießen,

Senckenbergstraße 17, D-35390 Gießen

volker.wissemann@bot1.bio.uni-giessen.de

\section{Editorial Board}

Peter Bowler, Belfast, UK

Olaf Breidbach, Jena, Germany

Eve-Marie Engels, Tübingen, Germany

Christoph Friedrich, Marburg, Germany

Nick Hoprood, Cambridge, UK

David L. Hull, Evanston, USA

Thomas Junker, Frankfurt/Main, Germany

Ulrich Kutschera, Kassel, Germany

Jane Maienschein, Tempe, USA

Renato Mazzolini, Trient, Italy

Peter McLaughlin, Heidelberg, Germany

James R. Moore, Milton Keynes, UK

Kaerin Nickelsen, Bern, Switzerland

Ronald L. Numbers, Wisconsin-Madison, USA

Wolf-Ernst Reif, Tübingen, Germany

Hans-Jörg Rheinberger, Berlin, Germany

Marsha L. Richmond, Detroit, USA

Robert Richards, Chicago, USA

Alexander Rosenberg, Durham, USA

Nicolaas A. Rupke, Göttingen, Germany

Michael Ruse, Tallahassee, USA

Hans-Konrad Schmutz, Winterthur, Switzerland

Marcel Weber, Basel, Switzerland

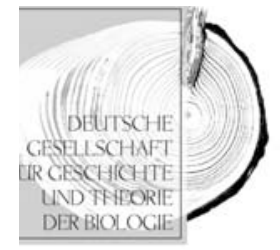



Deutsche Gesellschaft für Geschichte und Theorie der Biologie (Ed.)

Annals of the History and Philosophy of Biology Vol. 11 (2006)

Except where otherwise noted, this work is licensed under a Creative Commons License

(c)

SORE RIGHIS RESERVED 
Annals of the History and Philosophy of Biology; Volume 11 (2006)

Universitätsverlag Göttingen 2007 
Deutsche Gesellschaft für

Geschichte und Theorie der

Biologie (Ed.)

Annals of the History and

Philosophy of Biology

Vol. 11 (2006)

formerly Jahrbuch für Geschichte und Theorie der Biologie

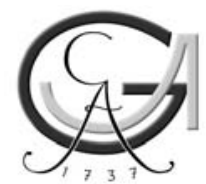

Universitätsverlag Göttingen 2007 
Bibliografische Information der Deutschen Bibliothek

Die Deutsche Bibliothek verzeichnet diese Publikation in der Deutschen Nationalbibliographie; detaillierte bibliografische Daten sind im Internet über < http://dnb.ddb.de> abrufbar.

Managing Editor of the Annals of the History and Philosophy of Biology Prof. Dr. Volker Wissemann

Institut für Allg. Botanik und Pflanzenphysiologie

Bereich Allgemeine Botanik, AG Spezielle Botanik

Justus-Liebig-Universität Gießen,

Senckenbergstraße 17, D-35390 Gießen

volker.wissemann@bot1.bio.uni-giessen.de

Cover Picture: Friedrich Besemann: Leinekanal mit akademischem Museum und Graetzelhaus. Aquarellierte Federzeichung 1860. Graphische Sammlung des Städtischen Museums Göttingen

Layout: DGGTB

Cover Design: Kilian Klapp, Maren Büttner

(C) 2007 Universitätsverlag Göttingen

ISSN 1863-0197 
Annals of the history and philosophy of biology, Volume 11 (2006)

\section{Contents}

\section{Olaf Breidbach, Michael T. Ghiselin}

Baroque Classification: A Missing Chapter in the History of Systematics

Rudolf Hagemann: Curt Stern (1902 - 1981)

Drosophila-Genetiker und Human-Genetiker in Deutschland und den USA

David Hull

Essentialism in Taxonomy: Four Decades Later

Hans Werner Ingensiep

Organism, Epigenesis, and Life in Kant's Thinking - Biophilosophy

between transcendental philosophy, intuitive analogy, and empirical ontology

Ulrich Kutschera, V. M. Epshtein

Nikolaj A. Livanow $(1876-1974)$ and the living relict

Acanthobdella peledina (Annelida, Clitellata)

Georgy S. Levit \& Lennart Olsson

"Evolution on Rails": Mechanisms and Levels of Orthogenesis

James Moore

Wallace in Wonderland

Kärin Nickelsen

„In deutlichen Beschreibungen und richtigen Zeichnungen gemeinnütziger“ Abbildungen in der Gesellschaft Naturforschender Freunde zu Berlin (GNF), 1773-1800

Rosemarie Nöthlich, Nadine Wetzel, Uwe Hoßfeld \& Lennart Olsson „Ich acquirirte das Schwein sofort, ließ nach dem Niederstechen die Pfoten abhacken u. schickte dieselben an Darwin" -

Der Briefwechsel von Otto Zacharias mit Ernst Haeckel (1874-1898) 177

Hans-Jörg Rheinberger

Internationalism and the History of Molecular Biology 



\title{
Baroque Classification: a Missing Chapter in the History of Systematics
}

\author{
Olaf Breidbach \& Michael T. Ghiselin
}

\section{Abstract}

Systematic biology as it has evolved since the renaissance has been strongly influenced by various forms of occultism, including the Hermetic tradition. In the thirteenth century Ramon Lull developed combinatorics as a mechanism for generating all possible propositions. This became, along with mnemonics, one of the bases for notions of universal science and a universal language that became particularly fashionable in the 1600s. The Jesuit polymath Athanasius Kircher developed such notions and applied them to classification. Such notions were available to Linnaeus and there are indications that he made use of them. Combinatorics helps to explain his use of the artificial system and his reasoning about the multiplication of species through bybridization.

\section{Introduction}

The ancient naturalists, such as Aristotle, Theophrastus and Pliny, were part of the tradition in which mediaeval naturalists such as Albertus Magnus did their work (Albertus Magnus, 1867; Reeds, 1980; Stannard, 1980). That tradition continued, with important differences, unbroken into the Renaissance. Such naturalists as Aldrovandi (1522-1605) accumulated collections of naturalia as a basis for their research. In the $17^{\text {th }}$ century such collections were described and organized as inventories of the natural world. According to Findlen (1994) these collections were the first to be documented in catalogues presented according to categories of order. These categories were confirmed by the spatial arrangement of specimens within the museum. The arrangements, manifested in the design of cupboards, rooms and buildings, have been analyzed in much detail by modern historians (Stafford, 1999; Te Heesen and Spary, 2001). After all, these storage facilities were conceived as libraries of naturalia. This analogy, more than just a metaphor, was sometimes worked out in much detail. Thus, in the collection of the botanical garden in Padua, a bookshelf was located in front of the display cabinet with the herbarium material, paralleling natural objects with text. Accordingly it makes sense that ordering principles for natural objects can be compared to earlier models of knowledge organization, such as those presented in the theatre of Guilio Camilio (Camillo, 1552; Yates, 1964) or the models of memory used by Robert Fludd (Schmidt-Biggemann, 1993). The Baroque museum represented an encyclopedia of natural entities, in which "all nature was on display" (Findlen, 1994:220). 
In this essay we reconsider the metaphysical traditions from which modern taxonomy emerged in the $18^{\text {th }}$ century. We suggest how Linnaeus was still operating in that spirit when he wrote about a bibliotheca Botanica (Linnaeus, 1789:xxv). Elements of that older tradition affected the structure of his organizing schemes and also impacted his proto-evolutionary thinking. Although much of the material reviewed here has already been discussed in the historical literature, its bearing upon the history of systematic biology is not well appreciated. Our attention was drawn to these matters during the course of investigations on the influence of occult metaphysics on pre-Darwinian systematic biology, especially the relationship between alchemy and the Naturphilosophie of Lorenz Oken (Ghiselin, 2000; Breidbach and Ghiselin, 2002). It has become increasingly obvious that the older ways of thinking continued to influence biological thought long after they became unfashionable, or ceased to be treated explicitly in scientific publications.

\section{Systematics as the organization of knowledge}

\section{Antique Traditions}

The classification systems used by biologists are often characterized as information storage and retrieval devices (Godfray, 2005). Although they do function that way, this characterization hardly does justice to the role that they play in the lives of scientists. Treating classification as the organization of knowledge may help us better to understand its significance in the life of the mind (Ghiselin, 1997, 2005). There is a major difference between classification systems and some other intellectual structures, such as the taxonomic keys used in identification, and mere lists that are perhaps arranged in alphabetical order. By organizing our knowledge we mean structuring our understanding of things and concepts, not filing our reprints or arranging the instruments in a laboratory or a kitchen. From this point of view, classification in science is not really classification unless it is part of a scientist's organon. The classification systems of modern biology definitely function in just that way, and the history of the subject can be very enlightening in understanding that role.

Aristotle created a science of natural history. He is also esteemed as the father of logic. Given those two interests one might expect that he would have created something like the formal classification system that is used by modern biologists. But he did nothing of the sort (cf. Eucken, 1872; Kullman, 1979; Harig, 1983; Pellegrin, 1986; Kullman and Follinger, 1997). For Aristotle, logic was an instrument of investigation, but in his thinking about animals classification systems were not. His Historia Animalium is arranged along physiological lines, illustrating the principles that he discusses in his shorter "physical" works such as De Generatione Animalium. He discusses groups of animals, but these are taken over from folk taxonomy and ordinary language. He does provide lists and arrangements of his materials in his various works, but there is no enumeration or explication of a system for the animals as a whole. It would seem that once knowledge had been attained, it had become organized by definition. Aristotle's successor Theophrastus proceeded in very much the same way in his treatise on plants.

Where, in some passages, Aristotle seems to be discussing the principles of classification, his interest really lies elsewhere. He is discussing how the material of interest should be arranged for the purposes of reasoned discourse and argument, and not as an aid to 
understanding and investigation. For syllogistic reasoning it was important that the terms be properly arranged, divided up and distributed. Therefore when he argues against Plato's method of division, we misinterpret the context if we treat it as a means of reaching something like a scientific classification. Aristotle did not reject Plato's aphorism that one should cut nature at her joints. Nor did he deny that it might be appropriate to divide a group on the basis of a single character, but only insisted that it did not necessarily lead to the best results and was generally hard to accomplish. For that reason, he should not be treated as an advocate of so-called "upward classification" in which organisms are put together on the basis of many similarities, first into smaller and then increasingly larger groups as suggested by Mayr (1982: 150-151.) Both Aristotle and Plato were concerned with rhetoric, which is the management of materials to be used in disputation, applying knowledge that was already structured, and not with how to organize the materials for scientific research and investigation.

Aristotle tells us that the proper way to proceed is to start with ordinary language. This means in effect that the vernacular, i.e. Greek, was the real basis for the taxonomic groups that Aristotle uses in his physical treatises. This shows up long afterward in scholastic discussion in which nature was classified according to philological principles that refer back to Aristotle. The evolution of scientific taxonomy out of folk classification has been discussed by various authors, notably Atran (1998). To make a long story short, as the study of biotic diversity evolved, folk taxonomy was adapted so as to meet the needs of scholarship, and of course was transformed substantially over the course of centuries. The transformation was in part the natural consequence of an increasingly large number of organisms being discovered, and in part of changing conceptions of the natural world and of knowledge itself.

In addition to Aristotle's followers there were various other schools of philosophy including the followers of Plato. In the first few hundred years A.D., these diverse schools, influenced by both Judaism and Christianity, gave rise to a rather heterogeneous movement called Neoplatonism (Wallis, 1972). We find quite a number of adumbrations and beginnings of later developments in classification. Not the least of these was the habit of placing everything upon a theological foundation. The Creation was conceived of as the product of an anthropomorphic deity, and understanding the Creation was an important motivation for organizing knowledge however general or particular. Natural language had been seen as a valuable source of information, but Hebrew, the language of the Bible, took on new significance (Goodmann, 1992). Jewish mysticism, especially the Cabbala, attempted to extract occult messages from the Hebrew alphabet (Idel, 1988, 2005). There was an obvious question as to what was the language of God, if not necessarily Hebrew. Platonism with its Pythagorean roots would naturally suggest that mathematics was God's language, and strong undercurrents of numerology have influenced biological classification and much else besides. Another possibility is the Creation itself, which might be one vast symbolic message. And since man is made in God's image, the human body might be a particularly useful source of information (see Fludd, 1623). The creation myth in Plato's Timaeus suggested that the whole world might be treated as a kind of divine animal, and that dialogue provided much of the inspiration for macrocosm-microcosm analogizing, as was especially common within the so-called Hermetic 
tradition (Grote, 1994). Such notions are quite obtrusive in the thinking of mediaeval philosophers.

\section{Mediaeval Combinatorics}

Before the time of Gutenberg, the culture of mediaeval science had to rely on books that were copied by hand and not readily available (see Eisenstein, 1978). For that reason scholars had to train their memory to obtain personal knowledge, and this was accomplished by methods derived from the rhetoric of antiquity (see Yates, 1966). Among the principal techniques was to form, in the imagination, a kind of interior landscape, into which certain objects representative of things that needed to be memorized could be placed. Thereafter the memory could be guided by the features of that landscape, which

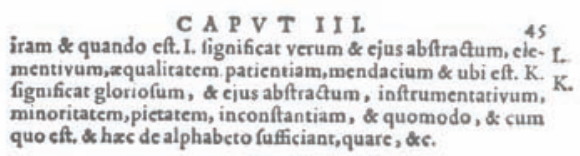

$P R I M A$ FIGVRA.

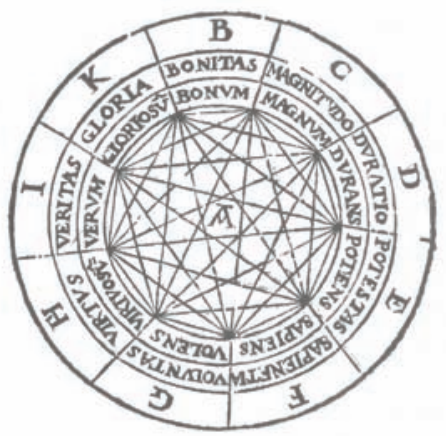

DE FIGVRIS, PARS SECVNDA $\checkmark$ primum ate prima.

CA P V T II

Flgurz quidem in hac feientia inventz fuere \& conftitatx Ratio fig. fcibillundum intelleaus operationes, qux tres iunt, videlicet, $\mathrm{I} .2$. feibillum omnium conceptuum apprehenfio, divifio, \& com-3. 4. pofitio corundem, \& difcurfus in eis, quz figurx quatuor ${ }_{\mathrm{I}}$. fig. $A$. funt. Prima quarum intitulatur A. \& eft circularis five f pheri- 1. V/ow. ca: deferviens converfioni fimplici primorum principiorum omnium, \& regularum hujus fapientiz, ut in ca manifeftè ap. Conferfoparet, qux quidem converfio prafupponit copulationem nis exemfubjecti, \& pradicati. Exemplum converfionis fimplicis: ef. fe eft bonum . bonum eft effe: magnum eft effe: effeeft ma- plom . guum:
Fig. 1: Scheme showing the mode of character combinations according to Lull's Ars Brevis (1651). Lullus, Raimundus: Opera. Reprint of the Strasbourg 1651 edition with an introduction by Anthony Bonner. Frommann-Holzboog. Stuttgart - Bad Cannstatt $1996=1651 \mid 45$.

showed ideas or trains of ideas. If properly constructed, such a memory landscape would place things that should be associated with one another in close proximity.

In the $13^{\text {th }}$ century Ramon Lull (or Lullus) (ca. 1232-1315) combined these ars memorativa with cabbalistic ideas (Bonner, 1996; Leinkauf, 2001). According to that tradition, the Talmud represented the actual words of God, albeit somehow misspelled by the translator when transforming the message from the language of God into that of man. 
To obtain the lost language of God, the idea was to recombine the elements of the text in such a way that its inner order became manifest (Strasser, 1988). Thus, even if the whole semantic structure of the text has been spoiled, the underlying syntactic organization might be preserved. Then a technique has to be installed that will reconstruct the semantics of the syllables, in other words the lost language. Thereby the real names of things will be recorded, showing the actual order in which God has placed everything that he created. This should be done by figuring out all those combinations that are preserved irrespective of the misspellings of the human translator. Lull specified that idea in a more scholastic way. According to the epistle of St. John, the word is the essence of God's idea of creation.

Lull developed combinatorics, or the ars combinatoria, which was a kind of technology for generating all of the propositions that might be asserted of anything and making them available for argument by means of traditional syllogisms. The names of everything (literally!) were arranged in tables with corresponding letters that could be combined so as to go from more general to more particular, or analyzed so as to proceed from the more particular to the more general. (Figure 1.) A list of kinds of predicates on one side was combined with headings under which there are corresponding examples. For example, the class of subjects had nine examples: God, Angel, Heaven, Man, Rationality, Sensitivity, Vegetivity, Elementativity and Instrumentality. The next row down consists of the nine virtues: Justice, Prudence, Fortitude, Temperance, Faith, Hope, Charity, Patience and Piety. And below that a list of nine vices: Avarice, Gluttony etc. (Lull, 1651; see also Alsted, 1609.) Each of these terms or attributes was given a symbolic place denoted by a letter. Various levels of such symbolic spaces existed. Lull defined rules for sorting out

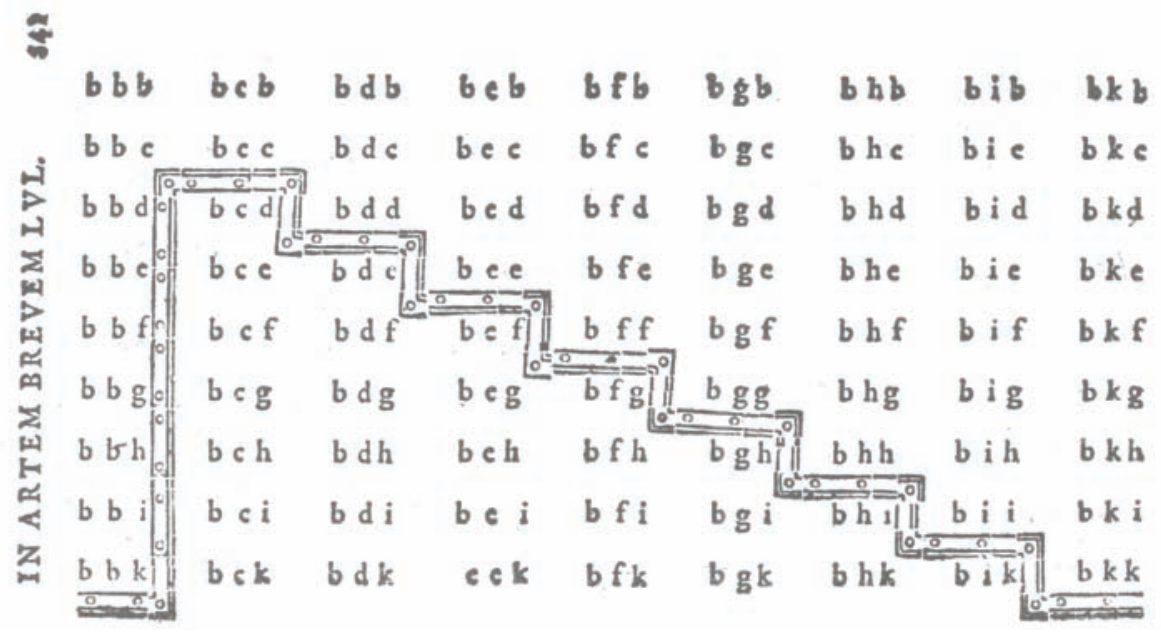

Fig. 2: . Printout of character combinations from Lull's Ars Brevis (1651). Lullus, Raimundus: Opera. Reprint of the Strasbourg 1651 edition with an introduction by Anthony Bonner. Frommann-Holzboog Stuttgart - Bad Cannstatt. $1996=1651 \mid 841$. 
which term was represented at which level and what symbol should be attributed to it. Then one was able to combine the different levels in all possible combinations. He then combined the symbols to get the possible combinations: BC, BD ... IK, or 36 in all arranged as in Figure 2. He could then combine at lower levels, and get combinations of 4, then more of them until reality was exhausted. The general table looks rather like a periodic table of the elements, the combined one rather like a representation of the possible combinations of nucleotides in DNA. And like these DNA combinatorics, the system merely provided ideas of possible combinations. It did not provide a genealogy, for it had omitted any time dimension.

Although Lull's combinatorics was designed to deal with all branches of knowledge, the basic intent was theological (Schmidt-Biggemann, 1998). Lull was interested in making it easier for Christians to win arguments with Muslims and heretics. Naturally the body of theological, scientific and philosophical knowledge that was accepted at the time was presupposed, and was what Lull attempted to organize. The term "scholasticism" is often used in this context, and it is appropriate, provided that we recognize the diversity and richness of that intellectual tradition. Although it incorporated many elements of derived from Aristotle and his followers, much else had been added. In the case of Lull, there was a substantial amount of Neoplatonism and so-called "Hermetic" philosophy, as well as much that was derived from occult sources including the Cabala (Rossi, 1983).

\section{Renaissance Categorization of Knowledge}

Lullism was rediscovered at the outset of the Italian renaissance by such neoplatonists as Pico della Mirandola (Robb, 1935; for integration into natural history see also Ficino, 1595). In this context the idea that the proper order of things depended on the proper grammar of language was transferred to the discussion of natural entities. It was in northern Italy that this neo-neoplatonism evolved which was so crucial for the emergence of empirical research (French, 1994). Vesalius, Fabricius ab Aquapendente and Galileo developed their ideas there. In particular it was at Florence, the university of Padua and the publishing houses of Venice where these new conceptions of knowledge were formulated. In that region neoplatonists put forward new discussions on the proper organization of knowledge. So questions of classification were by no means a specialty of natural history, but were interwoven into a larger discourse in which ideas about knowledge and how it might be organized related to philology.

In the $16^{\text {th }}$ century, the initial attempts to describe nature were quite close to mediaeval inventories. Conrad Gesner (1516-1565) presented animals that live on earth, and birds and animals that live in water, whereby each group was described in a different volume (Gesner, 1551-58). Within these volumes the animals were listed in a merely alphabetical order. Gesner has been considered the founder of bibliography (Bay, 1916; Fischer, 1966). Although he listed works alphabetically by author in his Bibliotheca Universalis, he also provided a classification by subject matter (Fischer, 1966: 274). Evidently the need for organizing and cataloging libraries was felt before the need for classifying natural objects. Once that happened, the next step in natural history was the establishment of arrangements that were classifications rather than mere lists. The obvious way to proceed was to press vernacular classifications into service, including arrangements that had been used by classical authors and later adaptations thereof. 
Renaissance humanists were very much interested in the texts themselves, and philology was an important aspect of their studies. This interest is explicable in terms of the recovery of older texts in the late mediaeval period. As new manuscripts became available they were compared with existing ones, and often translated from Greek into Latin. It was easier to do this job properly if one was familiar with the organisms. Such literary scholarship evolved into something increasingly empirical, and was facilitated by botanical gardens and other collections. Identifying the plants and animals in ancient texts and in vernacular languages was therefore an important part of natural history.

Pierre Belon du Mans (1517-1564) is a particularly good example of a scholarly renaissance naturalist, as can be seen from his book on birds (Belon, 1555). Like other renaissance authors he took particular pains to cite ancient authors with respect to the birds that he discussed. But he was a creative scientist rather than a mere compiler or antiquary, and the work is rich in original observations. The material is presented in a sequence determined by the likely interests of the reader, rather than the nature of the subject matter. He begins with the raptors, which are birds likely to interest the aristocratic purchasers of the book. Birds are also grouped according to where they might be encountered in nature. Such an arrangement is not exceptional. Something very much like it was used by his slightly younger contemporary Aldrovandi (1645).

Such renaissance humanists of course organized their materials, but what they organized was not knowledge, but literary discourse. Reading such a work is like being taken on a field trip, or on a guided tour, perhaps of a cabinet of curiosities (Findlen, 1994). The author parades his erudition, and the reader is duly impressed and informed. But the order of presentation does not correspond to what a modern biologist would consider a classification system. As the purely literary culture became transformed into something more like a modern scientific one, it became increasingly desirable to organize the materials in a way that rendered them manageable and related them to theory. In such endeavor naturalists gradually developed methods and principles of classification that were largely appropriated from other branches of knowledge. As we shall see, Baroque encyclopedias were an important source for such endeavors.

\section{Aesthetic Classification of Objects}

Sixteenth and seventeenth century classification schemes were presented also by the display of objects in the devices of wonders (Bredekamp, 1993; Stafford and Terpak, 2001). The structures used for the presentation of such collections manifested certain ideas about systematics. Those might be just certain morphological symmetries in various types of organisms, habitual analogies or the presentation of series in morphological variation of exotic life forms such as shells or snails (Bonanni, 1709). The idea, however, was not to classify the natural entities, but rather our knowledge about them (Findlen, 1994). That made sense in a culture that thought nature had been created only a few thousand years earlier. In that view, the world was a stage on which God represented Himself (Schmidt-Biggemann, 1993). Baroque natural philosophy tried to re-represent the order categories according to which this stage had been created. In such an approach, human knowledge could be formulated as something that was designed to reflect the absolute knowledge of God. Knowledge about naturalia had to be integrated into the overall representation of knowledge to give access to the fundamental design of those 
structures which God had formed through his creation. These devices of wonder, such as that of Aldrovandi (Findlen, 1994), were not mere presentations of curiosities, but representations of natural entities. Somehow they provided a kind of frozen narrative, something that must be explained by the collector to get its real meaning. Aldrovandi provided his visitors with tours that presented them with an understanding of the relevance of natural history within the complete framework of human knowledge.

With the growth of natural history collections and a more detailed picture of organic structure and diversity, the more or less arbitrary arrangements became increasingly cumbersome, and knowledge harder to manage. Combinatorics, as developed by Lull and carried on by others, had already been adapted to such tasks and became increasingly popular, especially in the Baroque period (Schmidt-Biggemann, 1983). The ars combinatori aimed at a complete system of knowledge that could derive everything from the basic syllables of human language (Breidbach, 2003). It would construct not only names, but knowledge itself. (For post-Linnean developments see Daston and Park, 1998; Farber, 2000.) The idea was to rediscover the lingua universalis and to encompass all possible combinations within the elements of that language. Thus a table of all possible sentences in the original language in which God had spoken to men could be uncovered. Thereafter the problem was to find some set of rules by which the meaningful sentences could be selected from the mass of rubble. Employing such combinatorics one could produce a complete summary of all logically possible demonstrative arguments. Knowledge thereby becomes a representation of that which God had created. Accordingly the structure of knowledge is not derived from the taxonomy and systematics of things, but from the order and the pattern of discourse about those things. This makes sense only if speech is more than the accidental form of expression of a living creature on this planet.

According to the baroque universal science, this living creature was a part of a creation in which man was formed in the image of God. Adam and Eve spoke the same language that God did, and that language was only lost after the Tower of Babel (see Kircher, 1679). The commandments that God gave to Moses had been written on the tablets by God himself, and in His own handwriting. This language however had been lost, and it was now necessary to develop a procedure for recovering it. The Jesuit polymath Athanasius Kircher (1602-1680) sought to develop the old combinatoric arts as a technical procedure for this purpose (Leinkauf, 1993; background in Findlen, 2004). His book Oedipus Aegypticus describes hieroglyphs as the symbols of the old language, but he himself formulated a more technical schematism using a set of simplified symbols (Schmidt-Biggemann, 2001; Marrone, 2002). These he believed to represent the essentials to which any language could be reduced. Thus he formulated a set of rules that allowed him to describe a machine capable of automatic translation from one language into another (Kircher, 1663). Then he even thought up rules that allowed him to construct any possible sentence and thereby any possible qualification (Breidbach, 2003). From that set of rules he would be able to derive the entire complex of knowledge attainable by man and to draw up a table of all possible knowledge. He sought to reconstruct the primordial language in order then to be able, on the basis of its grammar, to say what is possible for us to know. 


\section{Universal Language Classification}

Thus conceived, language is not merely a rule-book for possible expressions, but a pattern of relationships of associations, which, in the Adamite language, everything that is thinkable and capable of representation had been bound together (Schmidt-Biggemann, 2001). Language represents that which it delimits. So it is a matter of developing an art that reconstructs that which was outlined in these delimitations. Kircher accomplished this in his Ars Magna Sciendi.

In his writings, which encompass the whole range of science, Kircher always and everywhere sought for order and system. For him the key to knowledge lay in this systematics, which could use the right language, and which could provide something that had been lost with the Tower of Babel: a universal language (Slaughter, 1982; SchmidtBiggemann, 1983; Eco, 1993, 2001). Thus he tried to establish a tableau wherein each combination of terms is given (Kircher, 1669: 406-480). That idea of a fixed tableau of knowledge became very celebrated in the $17^{\text {th }}$ century. Unlike the genealogies that provided only a contingent series, that order referred to the absolute, and thereby objective, order of things given by God (Weigel, 2006).

For Kircher, the tableau represents a system of interrelated concepts. Those concepts are defined by their position within the system. The truth of its statements derives from its universal character and resides, not in the individual propositions, but in the system in its entirety.

The procedure that emerges from this perspective is, at least in principle, simple. The world is built up in the structure of the language in which we describe it. This structure can now be reconstructed in formal rules. As has been mentioned, in his Polygraphia Kircher (1663) had described the procedure whereby it was possible, by means of a combination of basic syllables, to translate any language into any other language. In his Ars Magna Sciendi, he begins with this idea, but also maintains a higher one (Kircher, 1669). For him every concept is the reflex of the context in which it is embedded. If the context is formed out by referring to every possible relation, its position and thereby its meaning is the result of the sum of all specific differences from all other objects. Thus, a single event in itself is without meaning, for its meaning is an effect of its position in the system of all possible relations. As the number of possible relations is finite, there is a definitive system that gives any entity its meaning. This idea handles two problems. First, the system is not defined by the qualifications that the human spirit attributes to each entity. Its definition reflects only its position relative to any other element of knowledge. Second, knowledge is not spoiled by the imperfections of the human sensory equipment. This is because knowledge is not derived from empirical demonstrations of what has been experienced in regard to one object, but from a merely terminological approach whereby any entity of knowledge is characterized by its proper place in a prearranged system of definitions.

Was there, then, something like a principle of signs, back to which the diversity of concepts could be traced? Here Kircher again gives a very simple answer. Since all concepts are positioned in their relationship to one another, when all possible relationships of concepts to one another are portrayed it is possible to recognize their natural order (Kircher, 1669: 169-174). 


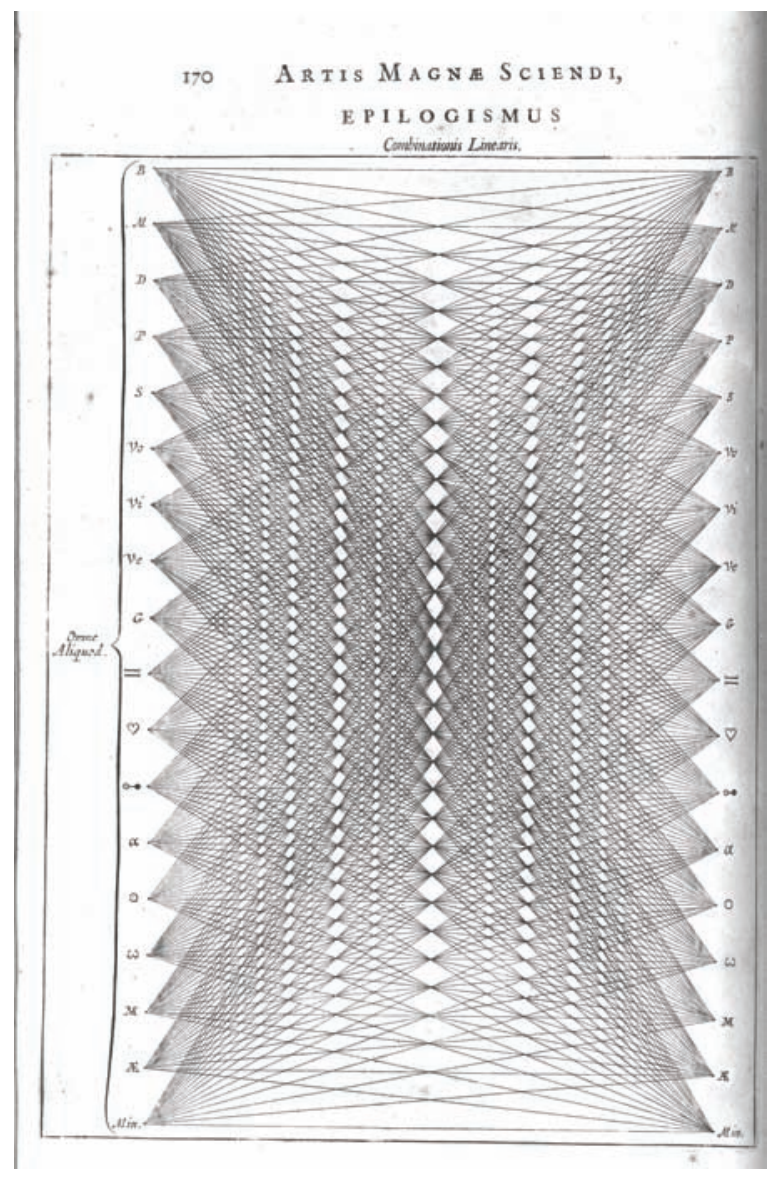

Fig. 3: Network of character combinations from Kircher's Ars Magna Sciendi. Kircher, Athanasius| Ars Magna Sciendi Sive Combinatoria: in XII libros digesta $\mid$ Weijerstraet $\mid$ Amstelodamil 1669.

Therein consists for him the cultivation of the totality of relational representations of concepts. However he linked up this idea of a relational understanding with a categorizing of knowledge. That is to say, he prestructured the space of concepts, such that he delimited particular concept spaces from one another. Within each concept space there was also a layering, since the relationships of various concepts encompass different distances by which these concepts refer to each other. Within these distances sub-clusters of loosely or tightly related concepts can be defined. Thus far, the closer analysis of the syntax of interrelations enfolds some kind of hierarchy.

Kircher now derived a scheme of all possible definitions from the analysis of the relationships that seemed possible to him, from which emerged a basic scheme of all kinds of relations. As a consequence the three-staged beginning of each definition (Definitio est differentia specificum et genus proximum) is the principal form of every relation. In consequence the relationships of the system of relationships are always hierarchical. Since he also found, in the trinity, a theological model for the grounding of this scheme of all possible knowledge, this became obligatory for him, and now could serve to formulate the structure of possible relations. 
This triune relationship created a hierarchy of delimitation functions. In this hierarchy of delimitation-functions there is sketched out a catalog of possible fundamental operations for the definition of knowledge, which according to Kircher then gets put together into a catalog of the possibilities of "standings in relation." With that Kircher obtained a kind of basic syllabic structure of his meta-language, which he took as a pattern of possible species of the "standings in relation." Accordingly concepts are nothing but a detailing of these possible standings-in-relation. Thereby it was possible for him to sketch a pattern of possible relationships of these "concepts."

Then, according to Kircher, this pattern merely needed to have everything filled in. This is the basic methodology of his "synthetic scientific discipline." To carry out that task all that remains is finding further rules for applying the definitions of any particular science.

Accordingly Kircher's approach offers a new kind of access to classification. The basic aim is to encompass all possible relations between all possible things. If our list of such things is numerically complete, all relations are known and all interrelations can be depicted. Then there will be just one solution, in which any element occupies a position in which it is optimally interrelated to every other element in the network of all possible terms. It provides access to the natural order among things. This idea is compatible with the older conception of an ars memorativa or mnemonics. In this case, however, it is not a matter of dealing with the idiosyncratic language of an individual human being, but with the perfect language spoken by God. The combinatorics provided the order in which things occur. In spite of the obvious occultism the formal operation used is a purely logical one. The relations are defined by sorting out all the possible combinations in all possible sequences.

\section{Architectonics of Knowledge}

In that intellectual environment classification played a somewhat different epistemological role than it does at the present time. It was believed that a finite being is severely handicapped in efforts to understand the works of an infinite one. Our reasoning capacity was understood to be severely limited, no matter how powerful the logical instruments at hand. Therefore knowledge had to be organized in a way that corresponded to the organization of the world in itself. The task was like finding a proper place for stones that are to be used in constructing a cathedral. Indeed knowledge was often described in terms of architectural metaphors and architectural models often played an important role in mnemonic techniques.

The central text in this representational model is the description of the theater by Guilio Camillo, who, in the middle of the $16^{\text {th }}$ century prepared a place for the organization of conceptual content (Camillo, 1552). His procedure in this was more complicated than the Kircherian schematism, since he organized not just concepts or symbols in this space, but meaning-bearers as well. In his case these were statues that connote an entire conceptual relationship, arranged in an order that defined an association space in which all possible knowledge appeared to be positioned. Camillo then was part of a neoplatonic tradition, which coexisted with the more Aristotelian tradition of the Jesuits. At the beginning of the $17^{\text {th }}$ century this tradition was incorporated in an anthropomorphic conceptual scheme by the Rosicrucian Robert Fludd. He too represented the world as a theater of the spirit. Robert Fludd's "Theatrum Mundum", the representation of which 
Francis Yates still wanted to use for the reconstruction of Shakespeare's Globe Theater, is the picture of an inner world of the spirit, which now itself becomes a theater. (See Yates, 1966: 342-367.) The spirit becomes the stage of that which is known to us, now to be interpreted as nothing less than the world itself: So we should not marvel that the subject, who here becomes the world stage, itself is treated as the analog of the cosmos (Breidbach, 2006).

This subject corresponds to this outer world: it is formed as the image of God, and likewise in this image of God is also an image of the world. It is the Cosmos, which God has conceived. It finds its ultimate expression in the form in which God is found in the

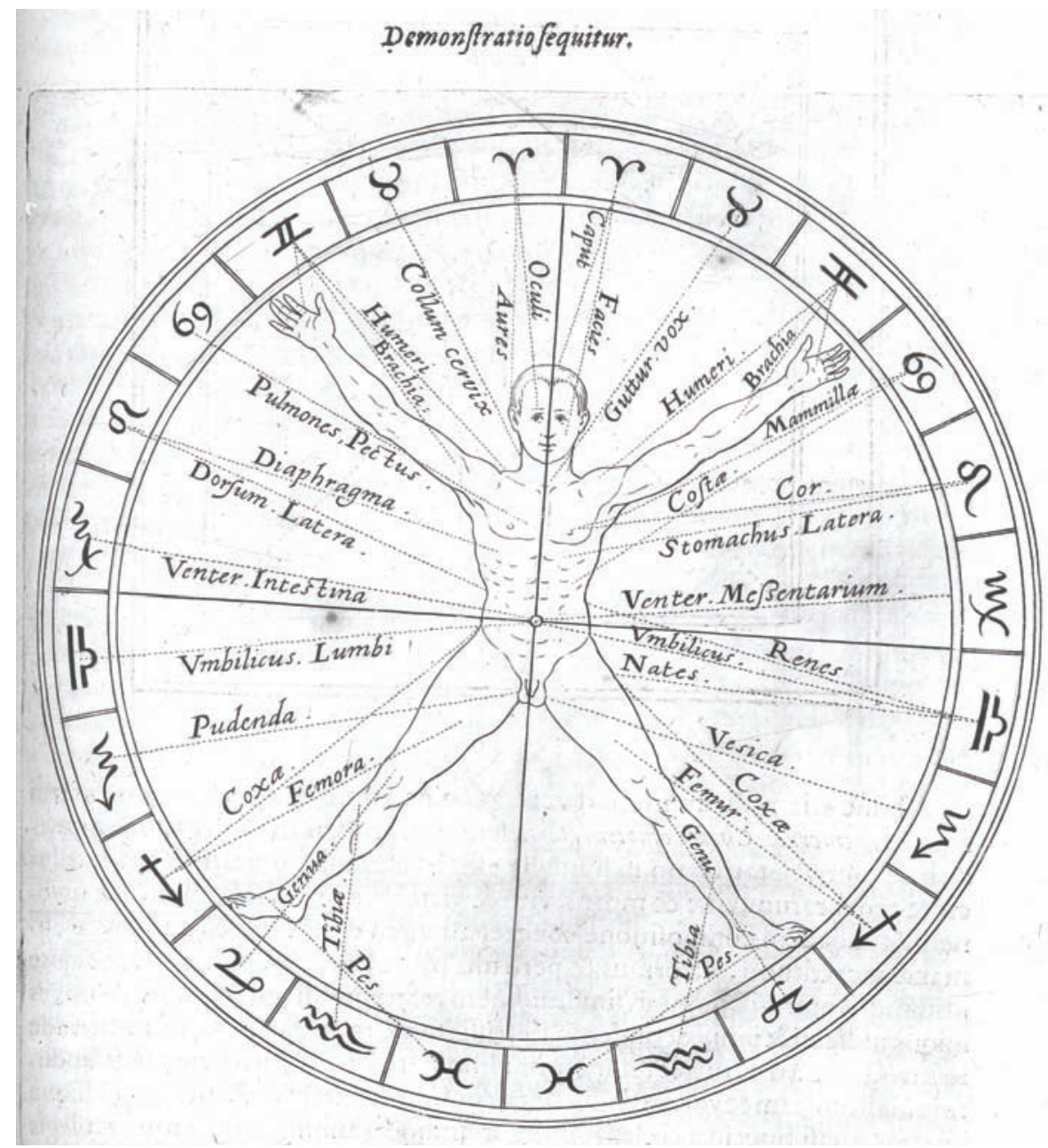

Fig. 4: Alchemical characterization of buman anatomy by Robert Flud's Microcosmi Historia of 1619. Fludd, Robert: Microcosmi bistoria. Gallerus Oppenheim. 1619. S. 113. aus: Fludd, Robert: Utriusque Cosmi Maioris scilicet et minoris metaphysica, physica atque technica historia. In duo Volumina secundum cosmi differentiam divisa. Tomus Secundus. De supernaturali, naturali, praenaturali et contranaturali Microcosmi historia, in Tractatus tres distributa. Oppenheim: Hieronymus Gallerus, 1619. 
world: in Man. The God who takes the form of man is the God who also created man in His own image. Man becomes the yardstick and the foundation of the order that is manifest in him as the world order. His form, which corresponds to the form of Christ, is this standard of the cosmos (Fludd, 1619: 82f.). Fludd thereby creates a new alternative systematics, which interprets the diversity of forms by analogy to a speculatively formulated metaphysics of the anatomy of the human body.

Thus Fludd, in his Microcosmi historia, shows the memory system of the mind as a stage, onto which the sensory system delivers certain impressions that are then stored in this imaginary edifice. Thus, the idea of memory traces is not derived from neurobiological facts, but is a reminiscence of the ars memorativa, with the brain designed in accordance with such notions as a place where memory traces are stored. Thus this systematizing tradition stands outside of the tradition of a logical concept representation followed by Kircher and the encyclopedaists. Common to both, however, is a spatial concept, hence a systematics giving a direct arrangement of a relational series: on the one hand the arrangement of concepts and on the other the divine order itself, depicted in the body of man. Both traditions run together again in the early19 ${ }^{\text {th }}$ century, as in the systematics of Lorenz Oken (Bach, 2001; Breidbach \& Ghiselin, 2002).

\section{The Tableau}

All these antique notions that employ architectural features argue that things are defined by the relations to one another that are manifested by their special arrangement. These ideas suggest for a proper representation of such a relational systematization the idea of a "tableau," which was something quite different from the stairways or scales employed to describe natural order as early as the seventeenth century, especially by Bonnet (Cheung, 2004). The tableau was a kind of diagram that would simultaneously and immediately depict the manifold interrelationships of things. It was an ideal representation of the categorization procedures carried out by practitioners of the ars combinatoria. Athanasius Kircher consequently offers a whole series of such tableaux to illustrate the order in which he described human knowledge (Kircher, 1669: 408-480). The Baroque assumption was that everything was interrelated in such a manner that it could be mapped on to everything else. Hence diagrams like the one shown in figure 3 (network) allowed one to envision all of the fundamental relationships from a unitary point of view.

These diagrams were used to describe the order of terms and were applied to such collections of knowledge as those presented in the former encyclopaedian tradition. One of the best examples of a Baroque approach to classification is the vast Encyclopaedia of Alsted (1630). The author, Johann Heinrich Alsted (1588-1638), made an heroic effort to organize all branches of knowledge, and to do so in a consistent manner. The material is arranged in a topical order. Combinatorics is highly conspicuous, taking the form of treelike branching diagrams. These may be described as decision-trees that allow one to place each and every item in its appropriate location. The ars combinatoria is manifest in the arrangement of the various topics. He begins with logic and such related topics as rhetoric and poetry. The theoretical sciences are arranged into metaphysics, pneumatics, physics, arithmetic, geometry, cosmography, uranography, geography, optics and music. What we would call systematic biology is a minor part of physics. There are groups within groups, depicted by a logical schematism enriched with those speculative elements de- 
scribed above. The particulars were evidently borrowed from earlier authors but it is not obvious who they were. The interesting feature of the classification however, is that it is summarized by means of tree-like diagrams. Such diagrams are formally equivalent to class-inclusion or whole-part incorporation hierarchies, but alternative means of notation are not necessarily equally perspicuous. Although there are degrees of relationship in Alsted's system, there is little indication of categorical rank in his treatment of animals. Nonetheless Alsted (1630:748) does say, with respect to fish, that Ordines sive classes illorum sunt quator.

It is significant that although many of Alsted's divisions are dichotomous, some of them are not, and also that an effort has also been made to arrange the material in a series from lower to higher, so that the traditional scala naturae plays a significant role in organizing the materials. Perhaps even more significant is that the arrangement into topics gives as much a classification of the branches of knowledge as it does of the things classified. The classification attempts to be natural, in the sense that the materials are arranged on the basis of the supposed causal order.

Alsted's Encyclopaedia and other "pansophistic" works were intended to provide a complete and comprehensive summary of knowledge in its entirety. The person who mastered such a work would know everything that was worth knowing. They were widely available and much used in the Baroque period (Garrett, 1999). And they formed the rationale of educational practices. It would have been difficult to avoid their direct or indirect influence. Modern scientific classification systems would therefore be the direct descendants of such pansophistic schemes and the underlying philosophy would influence the procedures of later scientists.

\section{Empiricism and Classification}

Although Francis Bacon (1561-1626) was considerably older than Kircher (1601 or 16021680), his name is strongly associated with efforts to overthrow older traditions and to place science on a new philosophical foundation. Scientists and philosophers alike have treated him as the great reformer and modernizer of science. He is viewed as the champion of the inductive over the deductive approach, and as an opponent of scholasticism (Hesse, 1981). One naturally wonders how much of his public image corresponds to reality. Some historians have suggested that Bacon was much more strongly rooted in the past than one might think. There are indications that various authors in the Platonic and Hermetic traditions influenced him (Linden, 1974). Furthermore, there is no reason why Bacon's emphasis on empirical research could not be reconciled with Aristotelianism, especially with the version of it that was used by the author of Historia Animalium himself. In the context of the present essay, viewing Bacon as someone who operated from a rather traditional point of view makes a great deal of sense. If his ideals of knowledge were more or less in line with those of pansophistical philosophers, but with some important differences, it is much easier to see what he was up to. Bacon definitely realized that science had made important advances since antiquity, and wanted to see that trend continue. That does not necessarily mean, however, that he wanted to discard what had been accomplished and start over from scratch. Indeed, his ideals could be accommodated within the pansophistical tradition by shifting the emphasis to empirical research, and without having to modify the more fundamental assumptions. In principle, all that 
would be required would be a great deal of work. Through induction from particulars the various gaps in knowledge would be filled up and pansophistical ideal of a complete system of knowledge would be attained. That seems clear enough from the organizational arrangements that he proposed. There would be a college of specialists who would collaborate so as to gather the data together and synthesize them into a unitary scheme. That conception of research was widely endorsed by the members of the Royal Society of London (Hunter, 1989).

Under such a conception of science, knowledge itself did not have to be reorganized. Some errors might have to be disposed of, and many gaps filled in, but progress would be a natural development of right thinking and correct investigative behavior. There would be no expectation of something that we would call a scientific revolution, and the system would not be set up so as to accommodate major theoretical innovations, much less provide for basic assumptions being invalidated and quite different ones taking their place. That demanded a change in outlook that resulted from the innovations of Lavoisier and Darwin, prepared by many gradual changes that tended to undermine the system.

John Ray (1627-1705) deserves much of the credit for the changes that are generally attributed to Linnaeus. More importantly, his work provides some revealing evidence as to how the pansophistic ideal got implemented in systematic biology. Although Ray is largely remembered for his massive empirical contributions to systematics and anatomy, he was by no means a narrow specialist and can hardly have been unaware of efforts to organize knowledge on a vast scale. Evidently the impetus for combinatorics in England about that time was a visit by Alsted's former student Comenius to London in 1641. In 1666, Ray read a variety of natural philosophy books, including Kircher's Mundus Subterraneus (Raven 1950: 142-3). Ray endorsed efforts to apply mnemonic methods and combinatorics in his Historia Plantarum Generalis (Rossi, 1983: 252). The development of an artificial language was endorsed by the British Baconians and became part of their program. In 1668 John Wilkins's Essay Toward a Real Character and a Philosophical Language was published. Ray approved of this effort to switch to an artificial language, but found it difficult to apply that ideal to plants. He and his collaborator Willoughby cooperated with Wilkins in trying to bring this program to fruition (Sloan, 1972).

Gottfried Wilhelm Leibniz (1646-1716), for whom the creation of symbolic logic and an artificial language were major tasks (Kramer, 1991), reacted quite favorably to the English efforts along those lines. As Rossi (1983) has shown, Leibniz, who was also influenced by both Lull and Kircher, was very much in the Alstedian tradition of combinatorics, but the approach in his system is a less technical one (cf. Alsted, 1609). According to him the conceptual operations of a rationally operating knowledge-storing machine are the rationale, still under the control of reason, which puts the order of concepts in a broader context and thereby they are defined. In this further development of combinatorics, the tableau is embedded in a comprehensive philosophy in which the simple technical operative function of the tableau as utilized by Alsted and Kircher, is abandoned. Later, however, Linnaeus would again begin with just such a technical operation.

Experience, according to Kircher, requires the authority of a knowledge that stands prior to experience, and it thus makes a place for single observations. Therefore Kircher is certain of his knowledge, as he derives his knowledge from faith (Kircher, 1669: 481f.). And yet the question remains of how far belief is delimitable for the subject who is so 
uncertain of his experience. Can a knowing subject really be something certain? Kircher's answer is simple: this happens when his thinking can be positioned in the totality of definitions that are possible for thought.

Kircher and Leibniz both lent certitude to their experience in an inwardly defined absolute knowledge. This knowledge, to which the term "theosophy" is sometimes applied, knows no history. The possible unfolding of knowledge in time is, for grasping that which this knowledge tells us, ephemeral. It is the order of knowledge, the pre-ordained structure of a conceptuality, in which our experience and out of which our picture of nature had to be defined.

Kircher, and before him Alsted, both explicitly referring to Lull, offered furthermore a technology for insuring this kind of knowledge (Alsted, 1609; Kircher, 1669). The justification for their action is the idea that in our inner order everything that can be thought about also would be depicted. The entirety of the universe thus gets broken down into the formulae of a construct of rules of universal understanding. Kircher describes a space of thinking, the order of which is weaved into the system of conceptual relations that are explicit therein. In this system every concept has its place. Topics, the science that deals with these places (loci or topor), lends certitude to judgments and defines the possibilities of judgment in such knowledge founded in God (Schmidt-Biggemann, 1998.)

When, a bit more than fifty years later, Linnaeus formulated his idea of botany as a divine science, he was explicitly bound to that tradition (cf. Lindroth, 1983). Linnaeus, as our thesis maintains, designed his representation of an ultimate systematics of nature in precisely the form of this conceptual ordering system. The contingencies of possible definitions of particulars in the net of the possible relations according to his schema provided him with certitude that his systematics could be represented as a legitimate expression of the order of the world. A topic is not simply a representation of the world. It would be more accurate to define the world as a representation of the topic, expressing itself as the thought of the Creator.

Hence we stand not only far from any experience, we likewise stand in a certitude that denies any historicity. This first form of synthetic judgment a priori, which is established by the Geltungszusammenhang of the topic (Kant also then had his categories) positions itself not only before any experience, but locates itself beyond any history. In this sense a self-defined knowledge always stands immediately before God in a closed definitional context. The certitude of experience lies in the authority of knowledge. Anybody who possesses the magic wand by means of which the ordering relations of concepts were represented had on hand one of the views of the world that are legitimate for us. He had the combination of lenses, in which the picture of the world can be reinterpreted through the reversal of an illusion in the reflection of the absolute (Kircher, 1646). That this knowledge must ossify, and that the construction of the possibly new can have no place in such a system, is obvious. Likewise a Jesuit can experience nothing really new, when for him everything thinkable is derived from the combination of all possible propositions. 


\section{Linnaeus}

One aspect of the philosophical and historiographic tradition that needs to be seriously reconsidered is the assumption that in folk taxonomy, and in the more scientific kind of taxonomy that supposedly evolved out of it, species are classes of similar things. Accordingly the issues have been addressed from the point of view of essences and nominalism versus realism. Given that species are individuals, not classes, the very idea of their having essences can no longer be taken seriously (Ghiselin, 1997). Pre-Darwinian species concepts often had a dual aspect, such that both similarity and reproductive continuity were treated as defining of the category. The former aspect meant treating them like classes, so that they were treated as having essences and being ahistorical. The latter aspect made them seem more concrete, and perhaps subject to change, hinting at the possibility that the taxonomic units that do not have essences and can be interpreted as historical entities can evolve.

Slaughter (1982) says that essentialist taxonomy collapsed in the 1690s thanks to Locke making the distinction between nominal essences and real essences. Supposedly we know only the former, and anyway (Slaughter, 1982: 194): "Taxonomy was supplanted by mathematics as the method and the language of science." In the long run of course nothing of the sort happened: witness the role of taxonomy in the chemistry of Mendeleev and the evolutionary biology of Darwin and us moderns. Furthermore, mathematics in the form of combinatorics as presented by Kircher and Leibniz was fundamental to the essentialist taxonomy of Baroque universal science. The mathematical presentation of natural order was fundamentally ahistorical, and it was a major impediment to the development of evolutionary thinking.

Linnaeus is generally esteemed the founder of modern taxonomy. He drew heavily on his predecessors, such as Caesalpino and Ray, who are not always given due credit for their contributions. Furthermore, the tradition has been that he was an Aristotelian, who pressed Scholastic philosophy into the service of taxonomy. To whatever extent that view of Linnaeus is correct, it seems appropriate to consider other influences, especially the kind of Baroque metaphysics that he might have derived from Kircher and others (see Larson, 1971). Arthur Cain, in particular, asked the question of whether Linnaeus was a Rosicrucian (Cain, 1992). There are some vague similarities with views attributed to Rosicrucians and those of Linnaeus, but we need hardly go that far. Linnaeus was obviously familiar with Baroque metaphysics. His friend Peter Artedi seems to have been an alchemist. Linnaeus's personal library includes alchemical works, including one attributed (wrongly of course) to Lull. He also owned a copy of Kircher's Ars Magna Lucis et Umbrae. Cain also draws attention to analogies between different groups in Linnaeus's classification systems that indicate his use of combinatorics.

There are other examples. Of particular interest is a dissertation entitled Metamorphosis Humana, which dates from 1767 (Linnaeus, 1798: 326-344). It deals with the human life cycle in correspondence to the months and seasons of the year, and is nicely worked out in combinatorial style. It also refers to the work of alchemists. But the most obvious use of combinatorics is in the "artificial" or sexual classification system for plants. This system coexisted with the "natural system" that ultimately prevailed. The artificial system can be treated as something like an identification key, whereas the natural system would be an approximation to more fundamental relationships the nature of which was not 
manifest until the emergence of evolutionary thinking. But that interpretation seems anachronistic and inaccurate when we confront it with the manner in which Linnaeus actually treated the artificial system. Many of his "artificial" groups turned out to be perfectly good "natural" ones as well. Linnaeus seems to have taken the artificial system too seriously for it to have served as nothing more than a "key" for locating specimens. This may seem anomalous to us moderns, but there need not have been any contradiction in the mind of Linnaeus himself. The "artificial" system was not merely the product of human artifice, for he believed that it was grounded in the laws of nature. Therefore the "artificial" taxa may be interpreted as what are now called "natural kinds." His use of reproductive characters was backed up by experimental reproductive physiology (MüllerWille, 1999). A reproductive tableau, combinatorially generated, revealed what is possible. Hence there was, for Linnaeus himself, no contradiction in the coexistence of the natural and artificial systems.

The combinatorial approach also helps us to make sense of another aspect of Linnaeus's life that to many historians has seemed almost paradoxical. This is the "protoevolutionism" that he espoused late in his career. He suggested that in the beginning God had created a small number of initial forms. These then diversified as a result of hybridization. This was by no means the first use of hybridization to account for increasing biotic diversity. Kircher (1675: 67-70) argued that it was necessary for the camel and the leopard to be on board Noah's Ark, but not the giraffe, because the giraffe (camelopard) is a hybrid between the other two. Given that combinatorics provides the key to understanding God's language, it makes perfectly good sense that He would proceed combinatorially in the act of creation. The initial organisms contained within themselves the potentiality for producing the full range of diversity, but only later was that potentiality actualized, as a good "Aristotelian" might put it. This was by no means the same thing as evolution in our modern sense, in which something that had no prior existence comes into being. Let us now consider his approach to classification in greater detail.

Linnaeus's system of flowering plants was based on an analysis of the symmetry in the components of the flower. In this complex of organs the basic components of the progeny that were generated in it were expressed. From an analysis of the various components of stamens, pistil, calyx and corolla Linnaeus developed a tableau, which allowed the possible combinations of the components to be listed. Thus there were plants with three stamens, which a particular analysis of petals and sepals, or also plants with three stamens the petals and sepals showed other relationships. Corresponding to this Linnaeus provided a list of the possible combinations with which he was able to establish a table wherein every possible combination of characters could be located. The lack of two anatomical types in this list was indicative of a distance in systematic relationship of the corresponding species having these traits.

This system is simple. In its limitation to a well-characterized character complex it is visible at a glance. Linnaeus could thus establish a comprehensive plan of the relationships of order of plant species to one another. Organisms showing various similar symmetry relationships then again occurred in closely connected systematic entities. Thereby, according to Linnaeus: Every appropriate definition depends on a clear method that allows one to distinguish similar and dissimilar objects. From that method, which allowed a proper categorization of objects, we can get an idea of those groups of objects 
that we classify. Omnia, quae a nobis vere diagnosci possunt, dependent a clara Methodo, qua distinguimus similia a dissimilibus. Haec Methodus quo magis naturales comprehendit distinctionis, eo clarior rereum nobis nascitur idea (Linnaeus, 1789: xi). Thereby Linneus demonstrates that the method he is employing is not just superficially spread out over the natural entities, but is formed according to their natural attitudes. The results are distinct classes, which could be ordered like the terms of a register forming a relation network that looks like a search tree diagram and describes the hierarchies within more distinct and less distinct interrelations of objects (Linnaeus, 1789: xvi, xx). So far botanical systematics offers a system of knowledge: Botany is that science that allows us to distinguish similar and dissimilar plants and give them their correct names. Botanicus est ille, qui Vegetabilia similia similibus, \& distincta distinctis Nominibus, cuicunque intelligibilibus, noscit nominare (Linnaeus, 1789: xi). Herein, all species with diversified and constant shape perform an infinite existence on this globe and, according to the inexplicit laws of generation, form out a multitude of life-forms that persist in their individual character distributions throughout the series of generations: Species tot sunt, quot diversas formas ab initio produxit Infinitum Ens; qua deinde forma secundum generationis inditas leges produxere plures, at sibi semper similes, ut Species nunc nobis non sint plures, quam qua fure ab initio (Linnaeus, 1751: ii). Later, when he became a protoevolutionist, he modified this pronouncement as follows: Species tot sunt, quot diversas \& constantes formas in hoc globo produxit Infinitum Ens; quae formae, secundum generationes inditas leges, producunt plures, sibi similes, quam quae fuere (Linnaeus, 1789: xii). Here we find a shift to more of an Enlightenment view of things, with God creating a lesser number of initial species and ordaining laws that would provide for their multiplication. And yet the metaphysics, especially its combinatorial rationale, is not fundamentally altered.

\section{Botanical Classification as Combinatorics}

To describe their relationships, Linnaeus applied the Baroque knowledge classification scheme to a group of natural objects. According to the idea of that universal science, even in his system, Linnaeus is presenting nothing else than the structures of God's plan of creation: Nature is in agreement with God's law: Natura est lex dei (Linnaeus, 1757: 494). Neither will it change its form nor will it be changed, for it is a representation of God (Lindroth, 1983). Consequently, systematics is able to embody that basic plan of the construction of the natural realm in reconstruction of the persisting order characteristics of life forms. It is that science which could announce the proper place of any entity in the system of nature. Thus it will describe the plan by which nature is formed. According to the method applied, the various combinations of various characters spanned the relational space in which genera and species could be localized and positioned in relation to each other. Thereby, he deals with the plants in a way that could not be formed out in a logical or mathematical deduction, but depended on the observation of the singular entity and its attributes, which allows one to place the individual species at its particular place in the tabulae relationis (Linnaeus, 1786: 551). And thus it resulted: [ $1 n]$ hoc argumentum usu in communi vita \& Theologia naturali non contemnendis rationibus sese commendet (Linnaeus, 1786: 552). Thus the resulting system is formed sicque aut Classes Naturales interrumpere, aut, si hoc non fieret, contra assumtas Regulas Systematicas peccare, adeoque finem distruere, qui erat alios secundum certa principia Logica ad cognotionem cujuscunque generis ducere, baud mirum quod vires plantarum, in quibusdam classibus, a se invicem multum recedere videantur. (Linnaeus, 1757: 4). 
Accordingly this system resulted in the definition of classes of naturalia that constitued the true system of botany. As that system is described in a table where each possible combination is listed in a strictly formal construction of all possible combinatorics, there will be empty spaces in that table, when reducing the perspective to just one part of the world, namely the European continent.

Initially Linnaeus included combinations of characters that were unknown in the European flora. Later, as a professor at Uppsala, he was able to send his students on excursions to the tropics. In this newly-discovered flora his students were successful and were able to fill in the still open positions of character combinations in the Linnaean tableau with real specimens (Mägdefrau, 1973: 54-57; Eriksson, 1983).

Thus we find that Linnaeus actually realized something that Kircher, in his comprehensive search for a synthetic science of science, sought to formulate on a very general level. Linnaeus therefore naturalized something that for Kircher was still a purely conceptually based scheme of possible order relationships. The symmetry relationships of flowers in the plant kingdom correspond to the syllable combinations of the universal language that Kircher sought for. Linnaeus (1751: vii (sect. 11) is quite explicit about this analogy. After listing the parts of the fructification he writes: "Plures sane bic partes, hic litera, quam in literis singularum seu alphabetis. Ha Nota omnes sunt nobis litere vegetabilium, ex quibus lectis characteres (10) addiscamus plantarum; has inscripsit Condiror; has legere nostrum erit studium." Thus the order characteristics were to be found by direct analogy with the order characteristics of knowledge itself. By combining the various entities of language every possible proposition could be conceived. As in language, the taxonomic groups have their meaning only in regard to the one who is classifying. The real entities of the natural system are the basic units of language, which are the species that are expressed in the individual organisms.

On that basis a principle of propositions of natural order relationships becomes accessible. Their arrangement offers the system of rules for obtaining the totality of the possible statements with these propositions, that is to say, determinations of adult plant forms, can be derived from these. As noted earlier, botany describes the Lex Dei (Linnaeus, 1757: 494). It should be obvious that there is no contradiction between God having created the world and having ordained its laws. Pre-Darwinian natural theology accepted both the argument from design and the argument from law (Whewell, 1853).

Much as Kircher had for the sciences in general, Linnaeus formulated a table of the possible realizations of vegetable existence in the combination of the possible combinations of attributes that a botanist can make about the elements of the structure of flowering plants. The flower, as the highest expression of the Gestalt of plants and as the character complex that realizes the reproductive function, corresponds for Linnaeus to the essence of plant existence. Consequently the scheme of vegetable organization is depicted in its blueprint. Linnaeus treats the table formulated by him as a synthesis of the order in which the knowledge of nature is explicable. Unlike a mere key, it does far more than make it possible to identify a plant species. (For details see Frigo, 2001; Breidbach, 2006a.) 


\section{Natural Versus Artificial Systematics}

In this manner the systematist Linnaeus gained access to the Absolute through his classification. As a system of naturalia, his was nothing other than the definitive report on the order of Creation, and therefore the representation of the thinking of the Creator in his formation of the world (Linnaeus, 1751). Consequently systematics also became a divine science. Botany, thus conceived, was not merely a classificatory activity, or merely an auxiliary science for pharmacy based on natural products. Botany gained something that was otherwise excluded from the sciences during the middle of the $18^{\text {th }}$ century. In Linnaeus the divine entered into the investigation of nature. Systematics was the first science, because it alone among the sciences connected human knowledge with the divine. That which Kircher and his Jesuits sought to formulate in a tediously deduced act of self definition was merely the representation of possible knowledge. In the possibilities of his combinatoric, which dealt with the order in real objects, Linnaeus attained the certitude of having found the ultimate order in reality. The dimension of the absolute was not merely grasped: it was experienced. The statements of botany were expressed as a sermon that was striking to everybody. Science and belief collapsed into one, so that in this science belief in the representation of the thinking of God became immediate and demonstrable for everybody (Lindroth, 1983). That which the philosophical Jesuits had derived only out of speech was now, in the new natural history, attained directly from the light of experience. As reflecting the language of God, systematics was artificial in practice but nevertheless gave the real nature of things.

A second, and related, piece of good news was that scientific investigation was not just to be interpreted as technology or as a speculative entertainment in the approach to such applied sciences as medicine, navigation, or architecture. In the form of natural history, research took on an exalted significance. In this systematics each thought was verified through an absolute order. Botany had become philosophical. Things in their reality were not just illustrations of perception, for their details manifested true knowledge. It is no coincidence that likewise in the middle of the $18^{\text {th }}$ century there arose natural theologies, such as those of François de Salignac de la Mothe Fénélon (1651-1715) and not much later William Paley (1743-1805), in which the Creation was described as a clockwork which, in its precision and order, made the reality and quality of the Deity manifest to observation. (Fénélon, 1731; Paley, 1805).

Linnaeus likewise linked up a diversity of forms in a map of the variations which according to him could be formulated in a simple mathematical fashion, through the demonstration of the symmetry relations of floral anatomy. If this system was natural, it would mean that with the demonstrated organs all variants of plant form could be represented.

What, however, will be the outcome of the sexual system of Linnaeus, when a representation of plant anatomy is extended to other organs, and perhaps the anatomy of the fruit, which of course arises from the flower, or to even more distinct structural peculiarities? On practical grounds it would be significant that only a few plants remain in bloom for very long. Identification keys for corresponding plant forms would therefore also have to work with other kinds of characters. So a problem arises. When the different keys, based on different combinations of characters, give other relative positions to the 
plants under consideration, how could one distinguish between the resultant arrangements (Stevens, 1994)?

A debate about the configuration of the sexual system among the successors of Linnaeus began early in the second half of the $18^{\text {th }}$ century (Duris, 1993). According to that discussion, which started in the second half of the eighteenth century, this system is incomplete. It does not give all the possible combinations of plant anatomy, and therefore cannot mirror the true order among plants. It would then be merely regarded as an artificial system, one that would allow us to classify a series of characters in an unambiguous and intelligible fashion (taxonomy).

\section{Extending the Scheme}

With his flower complex Linnaeus was able to show a clearly represented character space. To what extent, however, did the order relationships arrived at by him also coordinate with respect to other combinations of characters? If a new kind of character was added and it spoiled the relationships would this new character be of greater importance than the distribution of floral organs? This question is not just abstract, for the Linnean systematics became problematic when perhaps mosses or algae had to be integrated in the comparative treatment. Both of these plant groups have no flowers, but they do have reproductive organs. Would it not then be appropriate to introduce a division of the plants on the basis of an analysis of other organs and organ systems? If one accepts such a prefigured scheme of organization, then other systematic relationships become manifiest, as they are revealed in the sexual system of Linnaeus. (Daudin, 1926; Stevens, 1994; Polianski, 2004: 45-67.) In order to attain a natural system, there must also be criteria that allow one to weight the different kinds of characters.

Therefore taxonomists took other organ systems into consideration, and had to evaluate alternative ordering schemes. Laurence Antoine-Laurent de Jussieu (1748-1836) was interested in the seeds and the fruit, in other words the organs that develop out of the flowers (Stevens, 1994). Goethe, and the Jena botanist August Batsch (1761-1802) got involved in this controversy (Breidbach, 2006a). On the basis of a general comparative analysis of the habitus of plants Batsch proposed his own natural system (Batsch, 1787/88). It was not the schema, or tableau, that represented a combination table of possible synthetic judgments in botany, but the dynamics of a natural unfolding that provided the yardstick for encompassing the order of plants. This order provided a comprehensive, and also dynamically conceived Gestaltlehre (Breidbach, 2006a). This dynamic morphology was formulated according to Goethe in the doctrine of metamorphosis. An explicit Goethian scheme of natural systematics was expounded by Friedrich Sigmund Voigt (Voigt, 1808; see Breidbach, 2004).

As has often been noted, Linnaeus's idea of a system of naturalia was not a matter of simple experience of nature (Diekmann, 1992). He used the pattern of thinking and systematizing that has been briefly sketched here as the basis for his classification. (See Cain, 1995.) His tableaux are nothing but tables, which name the possible combinations of characters, arrange them according to geometrical patterns, and thereby allow one to work out a consistent-appearing scheme of possible relationships of order that is then to be filled in by experience. In this connection it is particularly noteworthy that the first edition of his Systema Naturae consists of aphorisms followed by tables (Linnaeus, 1735). 
From our perspective the Linnaean quest for a combinatorics of plant organs must seem remarkably attenuated compared to the more comprehensive efforts at systematizing of the Jesuits. It worked like a laboriously worked out naturalizing of the old concept of a topic. The application of combinatorial rules, by means of which Linnaeus brought the structural properties of plants (and consequently the species) into relationship with one another worked like former topics. As has been described, Linnaeus obtained a network of definitions in which each species was positioned. Analogously to the trees used for finding loci in Baroque encyclopedias (Casciato et al., 1986), he formulated identification keys, wherewith anybody who wanted to identify a plant could go through successive eliminations of the possible combinations of organs and position the specimen in the network of possible definitions.

\section{Conclusions}

The missing chapter in the history of systematics turns out to have been the philosophical context in which Linnaeus did his work. It has been easy for historians to place him in a tradition of natural history that sought to inventory the natural world and to catalog the objects therein contained. But the very motivation for that endeavor derived from the ideal of universal science, and that ideal profoundly affected both the conduct of research and the resulting products. From this perspective, Linnaeus turns out to have been operating within a well-established and widely accepted intellectual tradition. To dismiss Linnaeus as a "scholastic" without explaining what he was really up to has long been a common vice among historians (Sachs, 1875). The religious aspect of his work has been treated from a superficial point of view, neglecting the manner in which theology underlay his metaphysics. And ignoring the metaphysics in order to dwell upon the logic introduces other distortions and anachronisms.

Viewed in this light, quite a number of problems now become soluble. Combinatorics makes sense out of Linnaeus's views on species multiplying through hybridization, and it also explains why the artificial, sexual system was so important to him. Was Linnaeus a Rosicrucian? Probably not, but he shared some of their goals. Was he an alchemist? No, except insofar as alchemy was part of the tradition in which he was operating, at a time when alchemy was becoming gradually differentiated from chemistry.

Was Linnaeus some kind of pre-Darwinian evolutionist? Definitely not, although it depends on what one means by an evolutionist. There was nothing really historical in the views of Linnaeus. God had thought out the plan of creation in advance and likewise had ordained the laws of nature that govern the created beings. There was a repeated generation of the pre-existent, not the emergence of something ontologically new. The increase in the number of species through hybridization had nothing to do with evolution. It was just the actualization of potentialities that God had created in the beginning, according to the laws that He had ordained.

Linnaeus does not come across as a revolutionary figure either in his own eyes or in ours. Rather he may be seen as the culmination of a long tradition that managed to put its basic research program into effect. Once the science got itself organized, it would only be a matter of gathering more data and filling in the blanks. As it happened, his framework for classifying and naming proved admirably successful in coping with an 
ever-expanding body of material. It was later adapted, more or less successfully, to meet the needs of evolutionary biologists. That development, however, was unanticipated, and the underlying metaphysics fell into oblivion.

\section{References}

Albertus Magnus (1867) De vegetabilibus Libri VII. Ed. E. Meyer and C. Jessen. Georg Reimer., Berlin.

Aldrovandi, U. (1645) Ornithologiae hoc est de Avibus Historiae Libri XII. Typographia Manolesiana, Bologna.

Alsted, J. H. (1609) Clavis Artis Lullianae et Verae logices Duos in Libellos Tributa. Lazarus Zetznerus, Straßburg.

Alsted, J. H. (1630) Encyclopaedia Septem Tomis Distincta. Corvinus, Herborn.

Atran, S. (1998) Folk biology and the anthropology of science: cognitive universals and cultural particulars. The Behavioral and Brain Sciences 21, pp. 547-609.

Bach, T. (2001) 'Was ist das Thierreich anders als der anatomirte Mensch...?’ Oken in Göttingen 1805-1807. In: Lorenz Oken 1779-1851. Ein politischer Naturphilosoph (Breidbach, O.; Fliedner, H.-J. and Ries, K.; eds.) Böhlau, Weimar: pp. 73-79.

Batsch, J. G. C. (1787/88) Versuch einer Einleitung zur Kenntniss und Geschichte der Pflanzen. 2 Vols. Gebauer, Halle.

Bay, J. C. (1916) Conrad Gesner (1515-1565) the father of bibliography and appreciation. Papers of the Bibliographical Society of America 10, pp. 52-88.

Belon, P. du Mans (1555) L'Histoire de la Nature des Oyseaux, avec leurs Descriptions, \& Naifs Portraicts Retirez du Naturel. Guillaume Cauellat, Paris.

Bonanni, F. (1709) Musaeum Kircherianum sive musaeum a P. Athanasio Kirchero in Collegio Romano Societatis Iesu iam pridem incoeptum. Nuper restitutum, auctum, descriptum \& iconibus illustratum... a P. Philippo Bonanni. Georgii Plachi, Romae.

Bonner, A. (1996) Introduction. In: Opera (Lullus, R.; ed.) vol. 2, part 1, Frommann-Holzboog, Stuttgart: pp. 9-37.

Bredekamp, H. (1993) Antikensehnsucht und Maschinenglauben. Die Geschichte der Kunstkammer und die Zukunft der Kunstgeschichte. Wagenbach, Berlin.

Breidbach, O. (2003) Zur Repräsentation des Wissens bei Athanasius Kircher. In: Kunstkammer, Laboratorium, Bühne. Schauplätze des Wissens im 17. Jahrhundert. (Schramm, H.; Schwarte, L.; and Lazardig, J.; eds.) De Gruyter, Berlin: pp. 283-302.

Breidbach, O. (2003a) Post-Haeckelian comparative biology - Adolf Naefs idealistic morphology. Theory in Biosciences 122, pp. 174-193.

Breidbach, O. (2004) Friedrich Siegmund Voigt - Botanik nach Lesart von Goethes Metamorphosenlehre. Goethe Jahrbuch 121, pp. 239-252. 
Breidbach, O. (2004a) Die letzen Kabbalisten, die neue Wissenschaft und ihre Ordnung. Bemerkungen zu den Traditionslinien bio- und neurowissenschaftlicher Forschung. In: Form, Zahl, Ordnung. (Seising, R.; ed.) Steiner, Stuttgart: pp. 63-76.

Breidbach, O. (2006) Weltordnungen und Körperwelten. Das Tableau des Gewussten und seine Repräsentation bei Robert Fludd. In: Kunstkammer, Laboratorium, Bühne. Schauplätze des Wissens im 17. Jahrhundert. (Schramm, H.; Schwarte, L.; and Lazardig, J.; eds.) De Gruyter, Berlin: pp. 41-65.

Breidbach, O. (2006a) Goethes Metamorphosenlehre. Fink Verlag, München.

Breidbach, O. and Ghiselin, M.T. (2002) Lorenz Oken and Naturphilosophie in Jena, Paris and London. History and Philosophy of the Life Sciences 24, pp. 219-247.

Cain, A. J. (1992) Was Linnaeus a Rosicrucian? Linnean 8, pp. 23-44.

Cain, A. J. (1995) Linnaeus's natural and artificial arrangements of plants. Botanical Journal of the Linnean Society 117, pp. 73-133.

Camillo, G. (1552) L'idea del theatro dell'eccellentissimo m. Giulio Camillo. Lorenzo Torratino, Fiorenza.

Casciato, M., Ianniello, M. G. and Vitale, M. (eds.) (1986) Enciclopedismo in Roma barocca. Athanasius Kircher e il Museo del Collegio Romano tra Wunderkammer e museo scientifico. Marsilio, Venezia.

Cheung, T. (2004) Die Organisation des Lebendigen. Die Entstehung des biologischen Organismusbegriffs bei Cuvier, Leibniz und Kant. Campus Verlag, Frankfurt.

Daston, L., and Park, K. (1998) Wonders and the Order of Nature: 1150-1750. Zone Books, New York.

Daudin, H. (1926) De Linné à Jussieu: Méthodes de la Classification et Idée de Série en Botanique et en Zoologie (1740-1790). Alcain, Paris.

Diekmann, A. (1992) Klassifikation - System - "Scala naturae". Das Ordnen der Objekte in Naturwissenschaft und Pharmazie zwischen 1700 und 1850. Wissenschaftliche VerlagsGesellschaft, Stuttgart.

Duris, P. (1993) Linné et la France (1780-1850). Droz, Genève.

Eco, U. (1993) La Ricerca della Lingua Perfetta nella Cultura Europaea. Laterza, Roma.

Eco, U. (2001) Kircher tra stegamografia e poligrafia. In: Athanasius Kircher: Il Museo del Mondo (Lo Sardo, E.; ed.) Da Luca, Roma: pp. 209-213.

Eisenstein, E. (1978) The Printing Press as an Agent of Change, 2 vols. Cambridge University Press, Cambridge.

Eriksson, G. (1983) Linnaeus the Botanist. In: Linnaeus. The Man and his work (Frängsmyr, T.; ed.) University of California Press, Berkeley: pp. 63-09. 
Eucken, R. (1872) Die Methode der Aristotelischen Forschung: in ihrem Zusammenhang mit den philosophischen Grundprincipien des Aristoteles dargestellt. Weidmann, Berlin.

Farber, P. L. (2000) Finding Order in Nature: the Naturalist Tradition from Linnaeus to E. O. Wilson. Johns Hopkins University Press, Baltimore.

Fénélon, F. de Salignac de la Motte (1731) Oeuvres philosophiques, ou démonstration de l'existence de Dieu. 2 vols. Zacharie Chatelain, Amsterdam.

Ficino, M. (1595) De vita libri tres, recèns iam à mendis sitùque vindicati, ac summa castigati diligentia, quorum primis, de studiosorum sanitate tenda, secundus, de vita producendo, tertius, de vita coelitus comparando. Jean Le Preux, Genève.

Findlen, P. (1994) Possessing Nature: Museums, Collections, and Scientific Culture in Early Modern Italy. University of California Press, Berkeley, Los Angeles, London.

Findlen P. (ed.) (2004) Athanasius Kircher. The Last Man Who Knew Everything. Routledge, New York \& London.

Fischer, H. (1966) Conrad Gesner (1516-1565) as bibliographer and encyclopedist. Library (5)21, pp. 269-281.

Flud[d], R. (1619) Microcosmi historia. Tomus secundus de supernaturali, naturali et contranaturali microcosmi historia in tractatus tres distribute. Johann Theodore De Bry, Oppenheim.

Flud[d], R. (1623) Anatomiae Amphitheatrum effigie triplici, more et conditione varia, designatum. Johann Theodore De Bry, Frankfurt.

French, R. K. (1994) William Harvey's Natural Philosophy. Cambridge University Press, Cambridge.

Frigo, G. F. (2001) 'Der stete und feste Gang der Natur zur Organisation.' Von der Naturgeschichte zur Naturphilosophie um 1800. In: Naturwissenschaften um 1800. Wissenschaftskultur in Jena Weimar (Breidbach, O.; Ziche, P.; eds.) Böhlau, Weimar: pp. 27-45.

Garrett, J. (1999) Redefining Order in the German Library, 1775 - 1825. Eighteenth-Century Studies 33(1), pp. 103-123.

Gesner, C. (1551-1558) Historiae animalium. 4 vol. Cristoph Froschoverum, Tiguri.

Ghiselin, M. T. (1997) Metaphysics and the Origin of Species. State University of New York Press, Albany.

Ghiselin, M. T. (2000) The founders of morphology as alchemists. In: Cultures and Institutions of Natural History: Essays in the History and Philosophy of Science (Ghiselin, M. T. and Leviton, A. E.; eds.) California Academy of Sciences, San Francisco: pp. 39-49.

Ghiselin, M. T. (2005) Taxonomy as the organization of knowledge. Proceedings of the California Academy of Sciences 56 (Suppl. 1, No. 2), pp. 3-11.

Godfray, H. C. J. (2005) Taxonomy as information science. Proceedings of the California Academy of Sciences 56 (Suppl. 1, No. 2), pp. 170-181. 
Goodmann, L. E. (ed.) (1992) Neoplatonism and Jewish Thought. State University of New York Press, Albany.

Grote A. (ed.) (1994) Macrocosmos in Microcosmos. Die Welt in der Stube. Zur Geschichte des Sammelns 1450-1800. Verlag Leske \& Budrich, Opladen.

Harig, G. (1983) Zur Charakterisierung der wissenschaftstheoretischen Aspekte in der Aristotelischen Biologie und Medizin. In: Aristoteles als Wissenschaftstheoretiker. Schriften zur Geschichte und Kultur der Antike 22 (Irmscher, J. and Müller, R.; eds.) Akademie-Verlag, Berlin: pp. 159-170.

Heesen, A. te, Spary, E.C. (eds.) (2001) Sammeln als Wissen. Das Sammeln und seine wissenschaftliche Bedeutung. Wallstein Verlag, Göttingen.

Hesse, M. P. (1981) Bacon, Francis. In: Dictionary of Scientific Biography (Gillispie, C. C.; ed.) vol. 1, pp. 371-377.

Hunter, M. (1989) Establishing the New Science: the Experience of the Early Royal Society. Boydell Press, Woodbridge.

Idel, M. (1988) Kabbalah. New Perspectives. Yale University Press, New Haven.

Idel, M. (2005) Kaballah and Eros. Yale University Press, New Haven.

Kircher, A. (1646) Ars magna lucis et umbrae in mundo, atque adeó universa natura, vires effectusque uti nova, ita varia novorum reconditiorumque speciminum exhibitione, ad varios mortalium usus, panduntur. Hermann Scheus, Roma.

Kircher, A. (1663) Polygraphia nova et universalis, ex combinatoria arte detecta. Typographia Varesij, Roma.

Kircher, A. (1669) Ars magna sciendi. In XII libros digesta, qua nova et universali methodo per artificiosum combinationum contextum de omni re proposita plurimis et propre infinitis rationibus disputari, omniumque summaria quaedam cognitio comparari potest. Joannem Janssonium à Waesberge, Amsterdam.

Kircher, A. (1675) Arca Noë, in Tres Libros Digesta, quorum I. De Rebus quae ante Diluvium, II. De iis, quae ipso Diluvio ejusque Duratione, III. De iis, quae post Diluvium à Noëmo Gesta Sunt, quae Omna Novâ Methodo, nec non Summa Argumentorum varietate, explicantur, \& demonstrantur. Janssonio-Waesbergiana, Amsterdam.

Kircher, A. (1679) Turris Babel, sive Archontologia. Janssonio-Waesbergiana, Amsterdam.

Krämer, S. (1991) Berechenbare Vernunft. Kalkül und Rationalismus im 17. Jahrhundert. DeGruyter, Berlin.

Kullmann, W. (1979) Die Teleologie in der aristotelischen Biologie: Aristoteles als Zoologe, Embryologe und Genetiker. Carl Winter, Heidelberg.

Kullmann, W. and Follinger, S. (1997) Aristotelische Biologie. Intention, Methode, Ergebnisse. Steiner, Stuttgart. 
Larson, J. L. (1971) Reason and Experience: the Representation of Natural Order in the Work of Carl von Linné. University of California Press, Berkeley.

Leinkauf, T. (1993) Mundus Combinatus. Studien zur Struktur der barocken Universalwissenschaft am Beispiel Athanasius Kirchers SJ (1602-1680). Akademie Verlag, Berlin.

Leinkauf, T. (2001) Der Lullismus. In: Grundriss der Geschichte der Philosophie Bd. 4. Das römische Reich deutscher Nation. Nord-und Ostmitteleuropa (Holzhey, H. and SchmidtBiggemann, W.; eds.) Schwabe \& Co., Basel: pp. 239-268.

Linden, S. J. (1974) Francis Bacon and alchemy: the reformation of Vulcan. Journal of the History of Ideas 35, pp. 547-569.

Lindroth, S. (1983) The two faces of Linnaeus. In: Linnaeus. The Man and his work (Frängsmyr, T.; ed.) University of California Press, Berkeley: pp. 1-62.

Linnaeus, C. (1735) Systema Naturae, sive Regna tria Naturae Systematicae Proposita per Classes, Ordines, Genera, \& Species. Theodore Haak, Lugduni Batavorum.

Linnaeus, C. (1751) Philosophia Botanica, in qua Explicantur Fundamenta Botanica, cum Defitionibus Partium, Exemplis Terminorum, Observationibus Rariorum, Adjectis Figuris Aeneis. Kiesewetter, Stockholm.

Linnaeus, C. (1786) Transmutatio frumentorum quam praesidi O. D. Carolo Linneao proposuift Bogislaus Hornborg Petropolitanus. Upsala. In: Fundamentorum botanicorum pars prima (Linnaeus, C.) Tomus II. Piester and Delamolliere, Coloniae- Allobrogum.

Linnaeus, C. (1786) Fundamentorum botanicorum pars prima. Tomus II. Piester and Delamolliere, Coloniae-Alloburgum.

Linnaeus, C. (1789) Genera plantarum. Eorumque characteres naturales secundum numerum, figuram, situm et proportionem omnium fructificationis partium . Vol. 1. Varrentrapp und Wenne, Frankfurt am Main.

Linnaeus, C. (1798) Amoenitates Academicae; seu Dissertationes variae Physicae, Medicae, Botanicae antehac Seorsim Editae nunc Collectae et Auctae cum Tabulis Aeneis Accedit. Ed. 2, Vol. 7. Jacob Palm, Erlangen.

Lullus, R. (1651) Ars brevis. In: Opera (Lullus, R.) Lazaari Zettzneri, Strasbourg: pp. 1-111.

Mägdefrau, K. (1973) Geschichte der Botanik: Leben und Leistung grosser Forscher. Gustav Fischer Verlag, Stuttgart.

Marrone, C. (2002) II geroglifici fantastici de Athanasius Kircher. Stampa Alternativa \& Graffiti, Viterbo.

Mayr, E. (1982) The Growth of Biological thought: Diversity, Evolution, and Inheritance. Harvard University Press, Cambridge.

Müller-Wille, S. (1999) Botanik und weltweiter Handel. Zur Begründung eines natürliches Systems der Pflanzen durch Carl von Linné (1707-78). Verlag für Wissenschaft und Bildung, Berlin. 
Paley, W. (1805) Natural Theology: or, Evidences of the Existence and Attributes of the Deity, Collected from the Appearances of Nature. R. Faulder, London.

Pellegrin, P. (1986) Aristotle's Classification of Animals: Biology and the Conceptual Unity of the Aristotelian Corpus. University of California Press, Berkeley.

Polianski, G. (2004) Die Kunst die Natur vorzustellen. Die Ästhetisierung der Pflanzenkunde um 1800. Verlag der Buchhandlung Walther König, Jena.

Raven, C. E. (1950) John Ray Naturalist: his Life and Works. Ed. 2. Cambridge University Press, Cambridge.

Reeds, K. (1980) Albert on the natural philosophy of plants. In: Albertus Magnus and the Sciences. Commemorative Essays (Weisheipl, J.A.; ed.) Pontifical Institute of Medieval Studies, Toronto: pp. 341-354.

Robb, N. A. (1935) Neoplatonism of the Italian Renaissance. George, Allen \& Unwin, London.

Rossi, P. (1983) Clavis universalis. Arti della memoria e logica combinatoria da Lullo a Leibniz. Il Mulino, Bologna.

Sachs, J. (1875) Geschichte der Botanik vom 16. Jahrhundert bis 1860. R. Oldenberg, München.

Schmidt-Biggemann,W. (1983) Topica Universalis: Eine Modellgeschichte humanistischer und baroker Wissenschaft. Meiner, Hamburg.

Schmidt-Biggemann,W. (1989) Vorwort. In: Encyclopaedia (Alsted, J. H.) Vol. 1. Frommann \& Holzboog, Stuttgart: Bad Cannstatt: pp. v-xviii.

Schmidt-Biggemann, W. (1993) Robert Fludds Theatrum memoriae. In: Ars memorativa. Zur kulturgeschichtlichen Bedeutung der Gedächtniskunst 1400-1750 (Berns, J. J. and Neuber, W.; eds.) Niemeier, Tübingen: pp. 154-170.

Schmidt-Biggemann, W. (1998) Philosophia perennis. Historische Umrisse abendländischer Spiritualität in Antike, Mittelarter und Früher Neuzeit. Suhrkamp, Frankfurt am Main.

Schmidt-Biggemann, W. (2001) Hermes Trismegistos, Isis und Osiris in Athanasius Kirchers 'Oedipus Aegyptiacus'. Archiv für Religionsgeschichte 3, pp. 37-88.

Seeck, G. A. (ed.) (1975) Die Naturphilosophie des Aristoteles. Wissenschaftliche Buchgesellschaft, Darmstadt.

Slaughter, M. (1988) Universal Languages and Scientific Taxonomy in the Seventeenth Century. Cambridge University Press, Cambridge.

Sloan, P. (1972) John Locke, John Ray, and the problem of the natural system. Journal of the History of Biology 5, pp. 1-53.

Stafford, B. M. (1999) Visual Analogy. Consciousness as the art of Connecting. MIT Press, Cambridge Ma. \& London.

Stafford, B. M. and Terpak, F. (2001) Devices of Wonder. From the World in a Box to Images on a Screen. Getty Research Institute, Los Angeles. 
Stannard, J. (1980) Albert on the natural philosophy of plants. In: Albertus Magnus and the Sciences. Commemorative Essays. (Weisheipl, J. A.; ed.) Pontifical Institute of Medieval Studies, Toronto: pp. 355-377.

Stevens, P. F. (1994) The Development of Biological Systematics. Antoine-Laurent de Jussieu, Nature, and the Natural System. Columbia University Press, New York.

Strasser, G. F. (1988) Lingua universalis: Kryptologie und Theorie der Universalsprachen im 16. und 17. Jahrhundert. Harrassowitz, Wiesbaden.

Voigt, F. S. (1808) System der Botanik. Akademische Buchhandlung, Jena.

Wallis, R. T. (1972) Neoplatonism. Duckworth, London.

Weigel, S. (2006) Genea-Logik. Generation, Tradition und Evolution zwischen Kultur- und Naturwissenschaften. Fink, München.

Whewell, W. (1853) Of the Plurality of Worlds: an Essay. John W. Parker and Son, London.

Yates, F. A. (1964) Giordano Bruno and the Hermetic Tradition. University of Chicago Press, Chicago.

Yates, F. A. (1966) The Art of Memory. Routledge \& Kegan Paul, London.

\section{Address for correspondence:}

Olaf Breidbach

Institut für Geschichte der Medizin, Naturwissenschaft und Technik

Ernst-Haeckel-Haus

Friedrich-Schiller-Universität Jena

Berggasse 7

D-07745 Jena, Germany

olaf.breidbach@uni-jena.de 


\title{
Curt Stern (1902 - 1981): Drosophila-Genetiker und Human-Genetiker in Deutschland und den USA
}

\author{
Rudolf Hagemann
}

Abstract

A survey is given about the life and the scientific achievements of the great geneticist Curt Stern (1902 1981). He was both an excellent Drosophila geneticist and a bighly respected human geneticist. The first three decades of his life he spent in Germany. In 1933, he had to leave his native country for the United States where he successfully continued his scientific work in the fields of Drosophila, buman and general genetics. Having passed primary and high school (gymnasium), Curt Stern subsequently studied biology in Berlin. He did his doctoral work under supervision of the protozoologist Max Hartmann and his associates Victor Jollos and Karl Belar. He received his PhD from the University of Berlin with a cytological thesis on the mitosis of a beliozoon. Afterwards, his interests turned fully to genetics. Fortunately Richard Goldschmidt recommended him for a fellowship of the Rockefeller Foundation. This enabled him in 1924 to work for almost two years in T. H. Morgan's Drosophila group at Columbia University, New York. Returned back to Germany, he was considered to be the most promising Drosophila geneticist in the country. Soon Stern turned out to meet the high expectations by the publishing a paper which put him into the first row of international Drosophila and general geneticists (1931): The proof that genetic crossing-over is based on the physical exchange of pieces of chromatids between homologous chromosomes. Interesting details connected with this important finding are reported and additional work of Stern during this period is reviewed. In 1932, Stern won a second Rockefeller Fellowship and continued to work successfully in Morgan's lab in Pasadena. But soon a transformative moment in his path of occurred: In January 1933, Hitler and his Nazi party came into power, and soon they enacted laws which expelled all Jewish scientists and state employees from their posts.

As an immediate consequence, Curt Stern had to stay in the US and to look for a position. Fortunately, he soon received a position as research scientist at the University of Rochester where he worked as research associate, associate professor and finally as full professor and chairman of the department of zoology and of the division of biological sciences. The most prominent piece of work from this period was the proof and the detailed description of mitotic crossing over in somatic cells of Drosophila published in 1936. Soon afterwards, it turned out that similar events also happen in many other species, notably in fungi, where mitotic crossing over is the basis of a parasexual cycle. In the following years, Stern studied many other research topics, including isoalleles, ontogenetic patterns, autonomous and non-autonomous gene action). In 1947, Curt Stern became professor of zoology at the University of California in Berkeley, succeeding Richard Goldschmidt; in 1958 he was also appointed professor of genetics. Hence, he engaged in teaching 
both zoology and genetics. Soon be found out that several of his genetics students were inclined to switch to medicine. He therefore decided to design a lecture series on buman genetics, but immediately noticed the lack of a suitable modern textbook for this field. To fill this gap, he decided to write a textbook entitled "Principles of Human Genetics". This book was a great scientific success. There appeared altogether three English editions (published in 1949, 1960, 1973) and the book was also translated into German, Japanese, Polish, Russian und Spanish. For a long time, courses on buman genetics in many universities were largely based on this textbook.

In bis Berkeley years Curt Stern published many original and review papers on Drosophila and buman genetics, and also several papers on general genetic topics and on the history of genetics. He obtained many bonours: membership of academies, numerous science awards, presidency of professional societies and bonorary doctoral degress. His presidency of the XIII International Congress of Genetics held in Berkeley (1973) and his presidential address represented the final emotional highlight of his long and successful career in science. Suffering from progressing Alzheimer disease, he lived reclusively for the rest of his life and died of cardiac failure in 1981.

\section{Curt Sterns wissenschaftlicher Werdegang in Deutschland}

In den ersten Jahrzehnten nach Wiederentdeckung der Mendelschen Gesetze war Deutschland eines der aktivsten Zentren genetischer Forschung und Lehre. Die drei Wiederentdecker, der Deutsche Carl Correns, der Holländer Hugo de Vries und der Österreicher Erich von Tschermak-Seyssenegg forschten an Pflanzen und publizierten ihre Veröffentlichungen zur Wiederentdeckung der Mendelschen Gesetze in deutscher Sprache.

Der deutsche Genetiker Erwin Baur arbeitete auch mit Pflanzen. Der zoologische Genetiker Valentin Haecker studierte cytologische Probleme und war an genetischer Entwicklungs-physiologie sowie der Genetik des Menschen interessiert; und das Arbeitsgebiet von Richard Goldschmidt bezog sich auf die Genetik der Geschlechtsbestimmung bei tierischen Objekten und auf die Genetik des Schwammspinners Lymantria dispar.

Aber eine genetische Bearbeitung der Taufliege Drosophila melanogaster, die seit 1911 von der Arbeitsgruppe um Thomas Hunt Morgan an der Columbia University in New York auf eine feste Basis gestellt wurde, war in Deutschland in den ersten zwei Jahrzehnten des zwanzigsten Jahrhunderts „kein Thema“. Bekannt waren die Arbeiten der Morgan-Schule sehr wohl, und 1921 übersetzte Hans Nachtsheim - auf Anregung von Erwin Baur - das Morgansche Buch „The Physical Basis of Heredity“ ins Deutsche: „Die stofflichen Grundlagen der Vererbung“".

Einer der ganz wenigen Forscher, die sich in den zwanziger und Anfang der dreißiger Jahre in Deutschland experimentell mit der Genetik und Cytogenetik von Drosophila befassten, war Curt Stern. Er rückte in der zweiten Hälfte der zwanziger Jahre und Anfang der dreißiger Jahre in die internationale Spitze der Drosopbila-Genetik vor, musste aber bereits 1933 ,aus rassischen Gründen“ Deutschland verlassen. In den USA setzte er seine Forschungs- und Lehrtätigkeit sehr erfolgreich fort.

Im Folgenden sollen Person und Leistungen von Curt Stern (Abbildung 1) genauer geschildert werden. Glücklicherweise ist Curt Stern in drei Publikationen auf seinen wis- 
senschaftlichen Werdegang ausführlicher eingegangen, so dass wir bei der Würdigung seiner Leistungen auf einer soliden Basis aufbauen können (Stern 1971, 1974 a,b).

Curt Stern wurde am 30. August 1902 in Hamburg geboren. Sein Vater, Barned Stern, war Kaufmann für Dentalartikel (als englischer Staatsbürger wurde er während des 1. Weltkrieges interniert.) Seine Mutter, Anna Stern, geb. Liebrecht, entstammte einer Lehrer-Familie; ihr Vater war im Jahre 1854 auf der Basis einer mathematischen Dissertation von der Universität Breslau promoviert worden. Die Sterns siedelten bald nach Curts Geburt nach Berlin über.

Curt Stern besuchte das Realgymnasium „Hindenburgschule“ in BerlinOberschöneweide und legte dort 1920 das Abitur ab.

Seine Mutter förderte Curts wissenschaftliche Interessen sehr und unterstützte seinen Studienwunsch. Curt Stern studierte ab 1920 Zoologie an den Universitäten Berlin und Marburg. In den frühen zwanziger Jahren besuchte er eine Vorlesungsreihe über Allgemeine Biologie, die Professor Max Hartmann vom Kaiser-Wilhelm-Institut für Biologie an der Berliner Universität hielt. Diese Vorlesungen beeindruckten ihn außerordentlich und veranlassten ihn, sich bei Max Hartmann um die Aufnahme als Doktorand zu bemühen. Unter Betreuung von Max Hartmann, Karl Belar und Victor Jollos führte er Untersuchungen über die Mitose in den Acanthocystideen (Heliozoa) durch. Im Jahre 1923 wurde er auf der Basis dieser Dissertation von der Berliner Universität promoviert.

Stern berichtet, dass er nach der mündlichen Doktor-Prüfung von einem der Prüfer gefragt wurde, welches biologische Gebiet ihn denn am meisten interessiere. Der Prüfer hatte offenbar die Antwort: „Protozoologie“ erwartet. Zur etwas erstaunten Überraschung des Prüfers antwortete Stern ohne Zögern: die Genetik. Darauf entgegnete der Prüfer: „Oh , Genetik; nun ja, das pfeifen ja gegenwärtig die Spatzen von den Dächern“.

In der Tat las Curt Stern die damals erschienenen deutschen Veröffentlichungen über Genetik, aber auch die Arbeiten der Morgan-Gruppe mit größtem Interesse. Er konnte in der Abteilung von Professor Richard Goldschmidt, dem zweiten Direktor des KaiserWilhelm-Institutes für Biologie (der erste Direktor war Carl Correns), eine auf kurze Zeit befristete Stelle erhalten. Er reichte Goldschmidt ein kleines Manuskript über Hypothesen zum Crossing-over zur Begutachtung ein, in dem er eine vorher publizierte Hypothese von Goldschmidt vorsichtig kritisierte und die Theorie von Morgan unterstützte. Dieses Manuskript gefiel Goldschmidt offenbar gar nicht, aber er nahm Stern dies nicht übel. (Stern hörte von ihm nie etwas über dieses sein erstes Manuskript, und Goldschmidts Sekretärin gab es ihm nach sechs Monaten ohne Kommentar zurück.)

Wenig später wurde Curt Stern zu Richard Goldschmidt bestellt: Er eröffnete ihm, dass die Rockefeller Foundation wenige Stipendien für junge Post-Doktoren ausgeschrieben habe für einen einjährigen Studienaufenthalt in den USA. Er beabsichtige, ihn für ein solches Stipendium vorzuschlagen, und zwar für einen Aufenthalt im Labor von Professor Morgan; er wolle wissen, ob Stern einverstanden sei. Stern war von Glück überwältigt und brachte nur mühsam ein ,Ja“ heraus.

So konnte er 1924 in die USA reisen und an der Columbia University in New York bei Thomas Hunt Morgan arbeiten. Er blieb dort etwa zwei Jahre lang. Bei Studien an bobbed Mutanten von Drosophila wies er nach, dass das Gen bobbed nicht nur auf dem $\mathrm{X}$-Chromosom liegt, sondern dass es ein homologes Gen auf dem Y-Chromosom gibt (vorher hatte man das Y-Chromosom von Drosophila für ,genetisch leer' gehalten). 
Die bobbed Mutanten haben - im Vergleich zum Wildtyp - deutlich verkürzte Borsten. (Die Morgan-Gruppe bezeichnete das Gen nach der damals verbreiteten FrauenMode „Bubi-Kopf“ als bobbed.)

Stern gelang weiter der Nachweis, dass es in Nachkommenschaften von Kreuzungen mit bobbed Ausnahme-Tiere vom Typ XXY gibt. Jetzt zeigte sich bereits seine besondere Fähigkeit, genetische Analysen mit cytologischer Untersuchung zu kombinieren und so wichtige neue Resultate zu erzielen. Hierbei zahlte sich seine gute cytologische Ausbildung durch Karl Belar aus. Weiter fand er eine Drosophila-Mutante, bei der der lange Arm des Y-Chromosoms an ein X-Chromosom transloziert worden war.

Diese Mutante, die Curt Stern - neben vielen anderen Mutanten - nach seinem Studienaufenthalt in den USA mit nach Deutschland brachte, sollte die Basis sein für Sterns erste überragende Forschungsleistung, die ihn weltbekannt machte.

Nach Deutschland zurückgekehrt, wurde er 1926 Assistent von Richard Goldschmidt im Kaiser-Wilhelm-Institut für Biologie in Berlin und führte dort seine Drosophila-Arbeiten fort.

Im Jahre 1927 gehörte er zum Organisationskomitee des V. Internationalen GenetikKongresses, der im September unter der Präsidentschaft von Erwin Baur in Berlin stattfand. Er arbeitete u. a. bei der Registrierung der Tagungsteilnehmer und lernte so - wie er 1973 schilderte - direkt alle führenden Genetiker der damaligen Zeit persönlich kennen. Er beschrieb auch, dass seine Mutter das noch unfertige Manuskript von H. J. Muller über die „Artificial transmutation of the gene“ mit Schreibmaschine ins Reine schrieb und er selbst noch Mullers Abbildungen fertigstellte.

Curt Stern hatte schon länger der cytogenetische Mechanismus des Crossing-over interessiert.

Morgan hatte die Hypothese entwickelt, dass während der meiotischen Prophase homologe Chromatiden brechen und dass es danach zu einer Vereinigung von Chromatiden-Stücken ursprünglich unterschiedlicher Chromosomen kommt. Vielen deutschen Biologen erschien dies zu „mechanisch“, und sie entwickelten alternative Vorstellungen. Besonders detailliert ausgearbeitet war die Alternativ-Hypothese, die der Hamburger Botaniker Hans Winkler unter der Bezeichnung „Konversion der Gene“ in Vorträgen und in Buch-Form publizierte. Winkler nahm an, dass sich die unterschiedlichen homologen Allele während der Meiose-Paarung der Chromosomen durch einen ,physiologischen Prozess" gegenseitig verändern (dass es aber zu keinem physischen Austausch von Chromatiden-Stücken kommt). Richard Goldschmidt hatte vorher schon eine ähnliche Hypothese entwickelt.

Curt Stern war von diesen Alternativ-Hypothesen nicht überzeugt; er war sicher, dass Morgan recht hatte. In diesem Zusammenhang erinnerte er sich an eine protozoologische Publikation von Karl Belar. Dort hatte dieser den Gedanken ausgedrückt, dass man an cytologisch identischen Chromosomen keine Folgen von Crossing-over cytologisch erfassen könne - ebenso nicht, wenn an homologen Chromosomen nur eine Heteromorphie vorliegt. Eine cytologische Analyse sei nur möglich, wenn zwei homologe Chromosomen an zwei unterschiedlichen Stellen Heteromorphie zeigen.

Diese theoretisch ausgedrückte Idee wandte Stern jetzt konkret bei Drosophila an. Eine cytologische Heteromorphie hatte er ja in der Hand: Die Mutante mit dem Y-Fragment, transloziert an das X-Chromosom. 
Was Stern nun brauchte, war eine zweite Heteromorphie an einer anderen Stelle des X-Chromosoms. Dann konnte er in einem Experiment mit genetisch und cytologisch markierten Chromosomen prüfen, ob ein Crossing-over mit dem Austausch von Chromatidenstücken verbunden ist.

Nach längerem Überlegen und Zögern schrieb er an H. J. Muller, von dem er wusste, dass er bei seinen Mutationsversuchen mit Röntgenstrahlen nicht nur Genmutationen, sondern auch Chromosomenmutationen bei Drosophila erhalten hatte. Er erklärte ihm den Plan seines ins Auge gefassten Experimentes (allerdings befürchtete er, dass ihm Muller eventuell entgegnen würde, er selbst plane ein solches Experiment). Aber Muller antwortete ihm sehr freundlich, dass er selbst ein derartiges Experiment nicht plane und dass er ihm gerne mehrere Drosophila-Stämme mit Chromosomenmutationen schicke. Nach längerem Suchen erwies sich die „Bar-Stone“-Translokation für Sterns Plan als gut geeignet. Bei den „Bar-Stone“-Tieren war es zu einer Translokation zwischen dem XChromosom und dem 4. Chromosom von Drosophila gekommen; dadurch ist das XChromosom in zwei Hälften geteilt. Der eine Teil des X-Chromosoms besitzt das eigene Centromer; die andere Hälfte das Centromer des 4. Chromosoms.

Nun nahm er das Experiment in Angriff und nach wenigen Monaten erhielt er - im Jahre 1931 - tatsächlich das erhoffte Resultat: Er konnte zeigen, dass ein Crossing-over zwischen den beiden heteromorphen Stellen im X-Chromosom von Drosophila mit dem physischen Austausch von Chromatiden-Stücken verbunden war (vgl. Abbildung 2). Er verfasste ein Manuskript und reichte es im „Biologischen Zentralblatt“ zum Druck ein. Gleichzeitig sandte er es an Professor Thomas Hunt Morgan und widmete es ihm zum 65. Geburtstag. Morgan antwortete ihm freundlich und brachte zum Ausdruck, er freue sich, dass jetzt ein objektiver Beweis erbracht worden sei, auf dem die Crossing-overTheorie basiert. Stern meldete einen Vortrag für die Tagung der Deutschen Gesellschaft für Vererbungswissenschaft an, die für den Herbst 1931 in München geplant war. Seine Arbeit erschien im Band $51 \mathrm{im}$ „Biologischen Zentralblatt“ unter dem Titel „Zytologisch-genetische Untersuchungen als Beweis für die Morgansche Theorie des Faktorenaustausches" (1931: 547-587).

Jetzt müssen wir aber doch einen Blick in die USA werfen. Morgan wusste durch das Schreiben von Stern von dessen erfolgreichem Experiment. Im Frühsommer 1931 kam er zu einem Vortrag an die Cornell-Universität und besuchte anschließend die einzelnen Labore, weil ihn interessierte, was die einzelnen Arbeitsgruppen forschten. So besuchte er auch das kleine Labor, in dem Barbara McClintock und ihre Doktorandin Harriett Creighton arbeiteten. Harriet Creighton berichtete ihm über die vorläufigen Ergebnisse ihres Forschungsprojektes, dem beim Mais eine ähnliche Fragestellung zugrunde lag wie den Experimenten von Curt Stern. Morgan war sogleich außerordentlich interessiert und fragte, ob Creighton und McClintock diese Resultate schon veröffentlichen wollten. Creighton verneinte, da sie erst noch die Ergebnisse der diesjährigen Ernte auswerten wolle.

Morgan erhob hiergegen energisch Einspruch und meinte, das bisherige Material reiche aus, und sie sollten diese Ergebnisse sofort publizieren. H. Creighton, Dr. McClintock und Professor Sharp erhoben hiergegen Einwände; Sharp erklärte, dass es sich hierbei um die Daten für die Dissertation von Frau Creighton handele, für die sie noch weitere drei Jahre bezahlt werde. Außerdem wussten und schilderten Creighton, McClintock 
und Sharp, dass ihr bisher vorliegendes Material „sehr mager“ sei; denn die MaisVegetationsperiode in Ithaca war 1931 sehr schlecht gewesen (Wallace 1992).

Aber Professor Morgan bestand darauf, dass diese Ergebnisse sofort publiziert werden müssten. Er erbat sich Papier und Feder und schrieb am selben Tag einen Brief an den Herausgeber der „Proceedings of the National Academy of Sciences (PNAS)“, dass er in zwei Wochen einen Artikel von Creighton und McClintock erhalten werde, und der Herausgeber der PNAS möge dafür im nächsten Heft sechs Druckseiten reservieren. In kleinem Kreis erklärte Morgan: Dieses sehr wichtige genetische Resultat müsse zuerst in den USA veröffentlicht werden. Morgans Kollege R. A. Emerson reichte dann die Arbeit bei den PNAS ein. Tatsächlich traf das Manuskript von Creighton und McClintock am 7. Juli 1931 beim Herausgeber der PNAS ein und wurde im August 1931 publiziert (vgl. Keller 1983, 1995, Wallace 1992, Kass 2003, Coe and Kass 2005).

Professor Morgan vertraute später (1932) Harriet Creighton an, dass er von Curt Sterns Ergebnissen gewusst habe und sie deshalb so intensiv zur schnellen Publikation gedrängt habe. Er sagte ihr etwa ein Jahr später: "Ich glaube, es ist an der Zeit, dass sich dem Mais eine faire Chance bietet, Drosophila zu schlagen!" (Dass dies eine Ausflucht war, liegt auf der Hand.)

Curt Stern fuhr im September 1931 zur Tagung der Deutschen Gesellschaft für Vererbungs-wissenschaft nach München und trug dort - wie er sagte - mit dem Enthusiasmus eines erfolgreichen jungen Wissenschaftlers' seine an Drosophila erarbeiteten Ergebnisse über den Chromatiden-Austausch als Grundlage des Crossing-over vor.

Stern berichtet weiter: „Kurz danach kam einer meiner Kollegen von KaiserWilhelm-Institut zu mir und sagte: ,Ich will Ihnen Ihre Freude nicht verderben. Aber während Sie im Urlaub waren, ist eine Arbeit von Creighton und McClintock erschienen, in der beim Mais von Experimenten berichtet wird, die den Resultaten äquivalent sind, die Sie gerade vorgetragen haben." Stern fährt fort: „Ich muss gestehen, dass ich diesem Kollegen noch heute dankbar dafür bin, dass er mir zumindest für eine halbe Stunde das Gefühl des Triumphes vergönnt hat, den ich nicht gehabt hätte, wenn er mir von der Creighton-McClintock-Arbeit vor meinem Vortrag erzählt hätte“ (Stern 1971).

Dieses Eingreifen von Morgan und dem dadurch bewirkten etwa 1 Monat früheren Publikationstermin der Arbeit von Creighton und McClintock hat bis heute seine Nachwirkungen: In den meisten amerikanischen Genetik-Lehrbüchern wird noch heute nur der Versuch von Creighton und McClintock geschildert (eine Ausnahme sind: Sturtevant und Beadle: An Introduction to Genetics, 1939, Sinnott-Dunn-Dobzhansky, Principles of Genetics 1958, und Redei, Genetics 1982); in den deutschen Genetik-Lehrbüchern wird meist der Versuch von Curt Stern geschildert.

In den Sammelwerken von Taylor, J.H.: „Selected Papers on Molecular Genetics“ (Academic Press 1965) sowie Phillips, R.L. and Burnham, C.R. "Cytogenetics", Benchmark Books, (Dowdon, Hutchinson \& Ross 1977) wird jeweils nur die Publikation von Creighton und McClintock abgedruckt; die Arbeit von Stern wird nicht erwähnt.

Wallace (1992) weist darauf hin, dass R.A. Brink und D.C. Cooper im Jahre 1935 eine sehr ausführliche und auf großem Material basierende Arbeit zum gleichen Thema publiziert haben; in dieser Veröffentlichung kritisieren sie, dass der Publikation von Creighton und McClintock (1931), ,insufficient data“ zugrunde liegen. Diese durchaus verdienstvolle Arbeit von Brink und Cooper wird heute praktisch überhaupt nicht mehr zitiert. 
Stern galt nach seiner Rückkehr aus den USA im Jahre 1926 - und ganz besonders seit 1931 - als d e r führende deutsche Drosophila-Genetiker. Im Jahre 1928 habilitierte er sich an der Berliner Universität. Er veröffentlichte neben seinen Original-Publikationen mehrere Übersichtsartikel, in denen er die Ergebnisse der Drosophila-Forschung den deutschen Lesern nahe brachte (in Ergebnisse der Biologie, 1928, und im Züchter, 1929). Außerdem verfasste er auf Einladung von Erwin Baur und Max Hartmann zwei Beiträge zum „Handbuch der Vererbungswissenschaft“: Multiple Allelie (Bd. I G, 1930, 147 S.) sowie Faktorenkopplung und Faktorenaustausch (Bd. I H, 1933, 333 S.).

Wie weit seine genetischen Interessen schon damals reichten, zeigt sein Aufsatz: „Welche Möglichkeiten bieten die Ergebnisse der experimentellen Vererbungslehre dafür, dass durch verschiedene Symptome charakterisierte Nervenkrankheiten auf gleicher erblicher Grundlage beruhen ?" (Der Nervenarzt 2: 257-262, 1929).

Curt Stern hatte während seines ersten USA-Aufenthaltes an der ColumbiaUniversität im Jahre 1925 die amerikanische Staatsbürgerin Evelyn Sommerfield kennengelernt. Beide heiraten im Jahre 1931.

Im Zeitraum 1932-33 hielten sich Curt Stern und seine Frau mit Hilfe eines zweiten Rockefeller-Stipendiums nochmals in den USA auf, und zwar am California Institute of Technology in Pasadena; denn die Morgan-Gruppe war in der Zwischenzeit von New York nach Pasadena übergesiedelt. Dort traf Stern mit einer großen Anzahl bedeutender Genetiker zusammen: Morgan, Sturtevant, Bridges, Schultz, Emerson, Darlington, Kaufmann and Lindegren. Dies war für ihn eine Zeit intensiver wissenschaftlicher Anregungen.

Im August 1932 fand in Ithaka, USA, der VI. Internationale Genetik-Kongress statt. Auch Curt Stern nahm daran teil; er hielt - in deutscher Sprache - einen zusammenfassenden Vortrag über die genetischen und cytologischen Vorgänge beim Crossing-over.

Vor einem Kongress-Meeting hielten sich McClintock sowie Creighton und Stern in gewisser Distanz zueinander. Hier schaltete sich wieder Professor T. H. Morgan ein: Er ging auf Curt Stern zu, brachte ihn in Kontakt zu McClintock und Creighton und sagte: „Curt, sei nett zu diesen beiden Ladies. Sie arbeiten mit Mais und erhalten gerade eine Pflanzen-Generation pro Jahr. Du und ich, wir arbeiten mit Fliegen und erhalten eine Generation nach zwei Wochen." Mit dieser Argumentation hat er offenbar das gespannte Verhältnis aufgelöst und die Beziehung zwischen den beiden Damen und Curt Stern normalisiert (Wallace 1992).

Geplant war, dass Curt Stern nach Ablauf des zweiten Rockefeller-Stipendiums nach Deutschland zurückkehren und Kurator an dem von Karl von Frisch geleiteten Zoologischen Institut der Universität München werden sollte.

Aber dazwischen kam im Januar 1933 die „Machtergreifung“ der Nationalsozialisten. Sehr bald wurde das berüchtigte „Gesetz zur Wiederherstellung des Berufsbeamtentums“ erlassen, das die Entlassung der Juden aus dem Öffentlichen Dienst verfügte (anfangs mit einigen Ausnahmen, die aber bald wegfielen). Damit schien eine NeuAnstellung von Curt Stern in München ebenso hinfällig wie die Weiterbeschäftigung in Berlin.

Sterns Ehefrau Evelyn, geb. Sommerfield - mit amerikanischem Pass - fuhr nach Deutschland, um sich an Ort und Stelle genau über die Situation zu informieren. Ihr wurde in vielen Gesprächen klar (gemacht), dass an eine Rückkehr von Curt Stern nach 
Deutschland, nach Berlin oder nach München, unter den schon 1933 bestehenden Umständen nicht zu denken war. Stern tat daraufhin das einzig Richtige; er blieb in den USA. Er bat über Professor Richard Goldschmidt um seine Entlassung aus der KaiserWilhelm-Gesellschaft. Gleichzeitig begründete er in einem Brief vom 16. Mai 1933 an Professor Max Hartmann sein Bleiben in den USA:

„...Die neuen Gesetze schliessen aber von der Mitarbeit nicht bestimmte Personen aus, die sich einer Mitarbeit nicht würdig gezeigt haben, sondern ohne Ansehen der Leistungen und Bemühungen alle „Nicht-Arier“...Es fällt mir und meiner Frau furchtbar schwer, uns äusserlich von Deutschland zu trennen. Sie wissen, dass ich mich stets ganz als Deutscher gefühlt habe, und ich kann auch sagen, dass die Anerkennung, die meine wissenschaftliche Arbeit im letzten Jahre hier im Ausland gefunden hat, mich immer besonders erfreut hat, weil sie mir als deutschem Wissenschaftler entgegengebracht wurde. Aber unter der Ausnahmegesetzgebung kann ich meine Aufgaben als Deutscher im Auslande eher erfüllen als in der Heimat... In tiefer Dankbarkeit

Ihr Curt Stern.“ (zitiert nach Reinboth 2004).

\section{Curt Sterns Tätigkeit in den USA}

Nachdem die Entscheidung für den Verbleib in den USA gefallen war, erhielt Curt Stern eine kurze befristete Anstellung an der „Western Reserve University“ in Cleveland, Ohio, bald jedoch glücklicherweise eine langfristige Anstellung an der „University of Rochester", New York, zunächst als Research Associate, von 1935 an als Assistant Professor und von 1941 an als Full Professor; später war er dort auch Chairman des Department of Zoology und schließlich Chairman der Division of Biological Sciences.

Im Jahre 1939 hat er die US-amerikanische Staatsangehörigkeit erhalten - was für ihn und seine ganze Familie sehr wichtig war. Die Familie von Curt und Evelyn Stern hatte drei Töchter: Hildegard, Elisabeth und Barbara.

Die Forschungstätigkeit von Curt Stern in den USA führte bald zu einem neuen, ganz wichtigen Resultat: dem Nachweis des mitotischen Crossing-over (oder: somatischen Crossing-over).

Ausgangspunkt war eine Beobachtung, die schon mehrere Forscher, z.B. Bridges, vor ihm gemacht hatten: Auf dem Körper von heterozygoten Drosophila-Tieren treten selten kleine Flecke auf mit dem Phänotyp der rezessiven, heterozygot vorliegenden Mutation. Manchmal sind es einzelne Flecke, manchmal - wenn Heterozygotie für mehrere Mutationen vorliegt - auch sog. Zwillingsflecke.

Curt Stern analysierte diese somatische Fleckenbildung mit Hilfe geeigneter Markierungsgene sehr genau und konnte so ihren cytogenetischen Mechanismus aufklären.

Aus cytologischen Untersuchungen war bekannt, dass bei Drosophila eine somatische Paarung der Chromosomen vorliegt. Bei der Untersuchung sich teilender Zellen beobachtet man, dass die homologen Chromosomen relativ dicht nebeneinander liegen.

Stern konnte zeigen, dass es in somatischen, sich durch Mitose teilenden Zellen zu Austauschvorgängen zwischen homologen Chromosomen kommt, die dem „Faktorenaustausch“, dem Crossing-over, zwischen homologen Chromosomen während der Meiose (der meiotischen Prophase) im Prinzip ähnlich sind. 
Er verwendete zwei Mutationen, die beide im X-Chromosom von Drosophila liegen: die Mutation „yellow“ (y) für gelbe Körperfärbung (anstelle normaler hellbrauner Farbe) und die Mutation „singed“ (sn) für gekrümmte Haare und Borsten (anstelle normaler gerader).

Die Gene yellow und singed liegen 21 Morgan-Einheiten voneinander entfernt und singed ist 45 Einheiten vom Centromer entfernt.

Wie in der schematischen Abbildung 3 dargestellt, führt ein Chromatiden-Austausch in der Region II zum Auftreten von einander direkt benachbarten „Zwillingsflecken“: Einer ist homozygot für yellow, der andere ist homozygot für singed (Abb. 4).

Da die Verteilung der Chromatiden während der ersten Mitose nach dem Crossingover zufällig ist, entstehen die Zwillingsflecke mit einer Häufigkeit von 50\% (linke Seite der Abbildung); in den anderen 50\% (rechte Seite) werden Wildtyp-Zellen gebildet: normale hellbraune Körperfarbe und normal geformte Borsten.

Wesentlich ist, dass bei einem Crossing-over in Region I und auch bei einem ZweiStrang-Doppelaustausch nur Einzelflecke entstehen (yellow oder singed).

Durch diese genaue Analyse und Erklärung konnte Stern das Auftreten sowohl von Zwillingsflecken als auch von Einzelflecken erklären und damit ein Problem lösen, mit dem sich erfahrene Drosophila-Genetiker wie Bridges seit über einem Jahrzehnt „herumgeschlagen" hatten.

Die Veröffentlichung dieser Ergebnisse erfolgte in einer langen, nahezu monographischen Publikation in der amerikanischen Zeitschrift „Genetics“ (Vol. 26: 625-730, 1936) und mit dieser Publikation wurde Stern nunmehr stets zitiert.

Curt Stern löste mit dieser Arbeit nicht nur ein Problem der Drosophila-Genetik. Er hat vielmehr gezeigt, dass es bei verschiedenen Organismen, in denen die homologen Chromosomen in somatischen, sich mitotisch teilenden Zellen (zumindest zeitweilig) gepaart sind, zu mitotischem Crossing-over kommen kann - also zu genetischen Veränderungen in sich mitotisch vermehrenden Zellen.

Vergleichbare Zwillingsflecke wurden auch bei anderen Tieren und Pflanzen gefunden. (Ich selbst fand Zwillingsflecke auf den gelben Blättern von Tomaten-Pflanzen, die heterozygot für die dominante Mutation Xanthophyllic waren: der eine Zwillingsfleck war gelblich-weiß (=Xanthophyllic homozygot), der andere rein grün.)

Besondere Bedeutung erlangten die Erkenntnisse von Curt Stern in der Pilz-Genetik. In der Gattung Aspergillus konnte - vor allem von G. Pontecorvo und vielen anderen britischen Forschern - ein ,parasexueller Zyklus“ nachgewiesen werden, bei dem mitotisches Crossing-over (neben Diploidisierungen und Haploidisierungen) eine entscheidende Rolle spielt. Damit eröffnete sich ein Weg, um auch genetische Arbeiten an ,imperfekten Pilzen“ durchzuführen, die den sexuellen Zyklus verloren haben (Pontecorvo 1958).

Im Jahre 1948 wurde Curt Stern als Nachfolger von Richard Goldschmidt als Professor für Zoologie an die Universität von Kalifornien in Berkeley berufen. Später wurde diese Professur auf Zoologie und Genetik erweitert.

In den vierziger und fünfziger Jahren hat sich Curt Stern genetisch-entwicklungsphysiologischen Problemen bei Drosophila zugewandt, und dabei insbesondere auf dem Gebiet der Genwirkung. Er führte mit Ernst Hadorn Organ-Transplantationen bei Drosophila durch, um autonome oder nicht-autonome Genwirkungen zu analysieren, und 
studierte die Wirkung unterschiedlicher Translokationen in Heterozygoten auf die Lebensfähigkeit der Tiere. Große Aufmerksamkeit erzielte er mit dem Nachweis der Existenz von „Isoallelen“ unterschiedlicher Gene und deren Bedeutung für Evolutionsfragen. Außerdem lieferte er wesentliche Beiträge zum genaueren Verständnis der ontogenetischen Musterbildung. In den Jahren des 2. Weltkrieges gehörte er zu einer Forschungsgruppe, die sich mit den genetischen und anderen biologischen Effekten von radioaktiver und Röntgen-Strahlung befasste, vor allem auch mit der Wirkung kleiner Dosen von Strahlung.

Curt Stern interessierte sich über lange Zeit auch für Fragen der Geschichte der Genetik. Mit Eva Sherwood gab er ein Buch über Gregor Mendel und die Wiederentdeckung seiner grundlegenden Arbeit heraus; er hatte nämlich Schwächen und Fehler in den vorherigen Übersetzungen der Mendelschen Arbeiten ins Englische erkannt (die zu verschiedenen Missverständnissen und Fehldeutungen geführt hatten); so lieferte er eine neue korrekte Übersetzung der Mendelschen Arbeit von 1866. Auch würdigte er die Leistungen mehrerer verdienstvoller Genetiker.

Nach der Erweiterung seiner Professur in Berkeley auf Zoologie und Genetik hielt Stern auch regelmäßig eine Vorlesung über „Allgemeine Genetik“. Da viele seiner Studenten sich später einer medizinischen Karriere zuwenden wollten, bereitete er eine Vorlesung über Genetik des Menschen vor - stellte aber sogleich das Fehlen eines geeigneten modernen Lehrbuches der Humangenetik fest, das nicht mit dem Label ,Eugenik' verknüpft war.

So entschied er sich, selbst ein Lehrbuch über die „Principles of Human Genetics“ zu schreiben. Die erste Auflage erschien 1949, die zweite Auflage 1960 und die dritte 1973. Dieses Buch wurde wissenschaftlich und verlegerisch ein großer Erfolg. In den USA und in vielen anderen Ländern basierten zahlreiche Humangenetik-Vorlesungen auf diesem Buch. Die 1. und die 2. Auflage wurden auch ins Deutsche übersetzt, außerdem erschienen Übersetzungen ins Japanische, Polnische, Russische und Spanische.

Dieses Buch war deshalb so erfolgreich, weil es in einer klaren Sprache von einem Genetiker verfasst war, der in allgemeiner Genetik intensiv geschult, die Besonderheiten der Humangenetik von dieser Warte aus hervorragend und didaktisch geschickt darstellen konnte.

Dass er keine Zugeständnisse an Rassentheorien und Eugenik-Vorstellungen vergangener Zeiten machte, ist selbstverständlich.

Später befasste er sich auch mit spezifischen Problemen der Humangenetik, insbesondere mit der Frage, ob es außer den Genen für männliche Geschlechtsbestimmung und Fertilität im Y-Chromosom auch noch andere Gene gibt, die für Gestalt-Merkmale verantwortlich sind. Er analysierte anhand genauen Aktenstudiums den Erbgang des „porcupine man“ (Stachelschwein-Menschen) Edward Lambert und seiner Nachkommenschaft; dabei konnte er zeigen, dass - im Gegensatz zu vielen Berichten in der medizinischen Literatur - hier offensichtlich kein Y-chromosomaler Erbgang vorlag. - Auch die genealogischen Befunde über die Schwimmhaut-ähnliche Verbindung von Zehen in der Familie Schoefield wurden als nicht-Y-chromosomal aufgedeckt. Lediglich bei der starken Behaarung der Ohr-Ränder in mehreren, besonders indischen, Familien konnte er eine Y-chromosomale Vererbung nicht ausschließen. 
(Natürlich sind im letzten Viertel-Jahrhundert nach Erscheinen der 3. Auflage von Sterns Buch von der molekularen Humangenetik mehrere Gene für biochemische Marker auf dem menschlichen Y-Chromosom lokalisiert worden.)

Auch terminologische Vorschläge konnte Curt Stern durchsetzen, so „DownSyndrom“ anstelle von ,mongoloider Idiotie’. Auch schlug er die Bezeichnung „HardyWeinberg-Gesetz" vor und würdigte so Priorität und Leistungen des deutschen Arztes Wilhelm Weinberg, der vorher international unbeachtet geblieben war.

Insgesamt veröffentlichte Curt Stern fünf Bücher und etwa 230 Zeitschriften-Artikel.

Curt Stern musste 1933 wegen seiner jüdischen Vorfahren aus Deutschland emigrieren, konnte sich aber in den USA als erfolgreicher Drosophila-Genetiker und HumanGenetiker sehr gut behaupten und durchsetzen. Seine Herkunft aus Deutschland konnte er nicht verbergen; denn er sprach mit eindeutig deutschem Akzent wie ein deutscher Studienrat.

Vortrags-Einladungen nach Deutschland nahm er dankend an. Viele Teilnehmer an der 103. Versammlung der Gesellschaft Deutscher Naturforscher und Ärzte in Weimar im Oktober 1964 - auch ich war unter ihnen - haben mit großer innerer Bewegung gehört, dass Curt Stern am Beginn seines Vortrages über „Entwicklung und die Genetik von Mustern“ seine Freude darüber zum Ausdruck brachte, dass er seinen Vortrag wieder ,in seiner deutschen Muttersprache“ halten könne.

Die wissenschaftlichen Leistungen von Curt Stern wurden im Laufe der Jahre gebührend gewürdigt. Er wurde zum Mitglied der National Academy of Sciences der USA (1948), der American Philosophical Society (1954) und der American Academy of Arts and Letters (1959) gewählt. Die National Academy of Sciences vergab an ihn den Kimber Award of Genetics (1963) und die Tschechoslowakische Akademie der Wissenschaften verlieh ihm die „Mendel Silber Medaille“ (1965). Von der American Society of Human Genetics erhielt er 1974 den „Allan Award“. Die Ehren-Doktor-Würde wurde ihm von der McGill University in Montreal (1958) und von der Ludwig-MaximiliansUniversität München (1972) verliehen.

Die Deutsche Akademie der Naturforscher Leopoldina in Halle wählte Curt Stern 1965 zu ihrem Mitglied und verlieh ihm 1975 die Mendel-Medaille.

Er war Präsident der Genetics Society of America (1950), der American Society of Human Genetics (1957) und der American Society of Zoologists (1962).

Eine große Ehre für Curt Stern war seine Präsidentschaft des XIII. Internationalen Genetik Kongresses in Berkeley, den er mit seiner Presential Address „The Domain of Genetics“ am 20. August 1973 eröffnete.

Er meisterte diese Ansprache sehr gut, obwohl er bereits von seiner Krankheit gezeichnet war.

Anfang der siebziger Jahre waren bei ihm die Anfangsstadien der ParkinsonErkrankung diagnostiziert worden, die sich in der Folgezeit laufend verstärkte. Curt Stern starb am 23. Oktober 1981 in Sacramento, Kalifornien, als Resultat dieser Erkrankung an Herzversagen.

Gerade die deutschen Genetiker sollten das Andenken dieses aus Deutschland stammenden bedeutenden Genetikers und Humangenetikers in Ehren halten. 


\section{Literatur:}

Veröffentlichungen von Curt Stern mit biographischen Angaben:

Stern, C. (1971) From Crossing-over to Developmental Genetics. Stadler Genetics Symposia Vol. $1+2$, pp. 21-28.

Stern, C. (1974) A Geneticist's Journey. In: Chromosomes and Cancer (German, J.; ed.) Vol. 1. Wiley, New York [u.a.]: XIII-XXV, 1974.

Stern, C. (1974) The Domain of Genetics (Presidential Address, XIII International Congress of Genetics). Genetics 78, pp. 21-33.

\section{Im Text genau besprochene Publikationen:}

Stern, C. (1931) Zytologisch-genetische Untersuchungen als Beweis für die Morgansche Theorie des Faktorenaustausches. Biolog. Zentralblatt 51, pp. 547-587.

Stern, C. (1936) Somatic crossing over and segregation in Drosophila melanogaster. Genetics 21, pp. 625-730.

Nachrufe und Gesamtübersicht über die Veröffentlichungen von Curt Stern:

Caspari, E. (1981) Curt Stern. In: Dictionary of Scientific Biography (Holmes, F. L.; ed.) Vol. 18: 860-867.

Lucchesi, J. C. (1983) Curt Stern (1902 - 1981). Genetics 103, pp. 1-4.

Neel, J. V. (1983) Curt Stern, 1902 - 1981. Annual Review of Genetics 17, pp. 1-10.

Neel, J. V. (1987) Curt Stern. August 30, 1902 - October 23, 1981. Biographical Memoirs of the National Academy of Sciences, Vol. 56, pp. 443-473. (mit vollständiger Publikationsliste).

\section{Veröffentlichungen anderer Autoren:}

Brink, R.A. and Cooper, D.C. (1935) A proof that crossing over involves an exchange of segments between homologous chromosomes. Genetics 20, pp. 22-35.

Coe, E. and Kass, L.B. (2005) Proof of physical exchange of genes on the chromosomes. Proceed. Natl. Acad. Sci., USA 102, pp. 6641-6646.

Kass, L.B. (2003) Records and Recollections: A new look at Barbara McClintock, Nobel-PrizeWinning Geneticist. Genetics 164, pp. 1251-1260.

Keller, E.F. (1983) A Feeling for the Organism: The Life and Work of Barbara McClintock. W.H. Freeman, San Francisco.

Keller, E.F. (1995) Barbara McClintock. Die Entdeckerin der springenden Gene. Birkhäuser Verlag, Basel, Boston, Berlin. (Übersetzung von Keller 1983)

Pontecorvo, G. (1958) Trends in Genetic Analysis. Columbia University Press, New York. 
Reinboth, R. (2004) Reflexe der Jahre 1933-1948 im brieflichen Nachlaß von Max Hartmann.

Dahlemer Archivgespräche (Hening, E.; ed.) Bd. 10. Archiv für Geschichte der Max-Planck-

Gesellschaft, Berlin: pp. 178-208.

Wallace, B. (1992) The Search for the Gene. Cornell University Press, Ithaca, NY. and London.

Winkler, H. (1930) Die Konversion der Gene. Gustav Fischer Verlag, Jena.

\section{Address for correspondence:}

Rudolf Hagemann

Jägerplatz 3

D-06108 Halle/S., Germany

hagemann@genetik.uni-halle.de

\section{Abbildungen:}
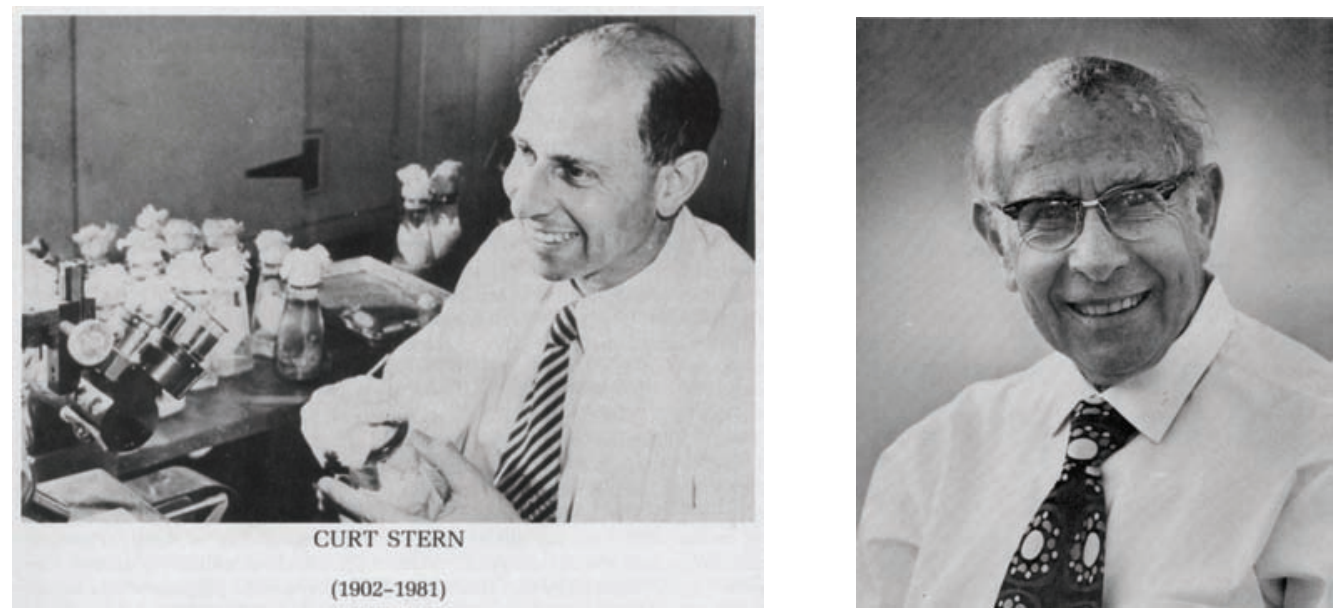

Abb. 1: Foto von Curt Stern, (a) in den vierziger Jahren, (b) in den siebziger Jabren. 


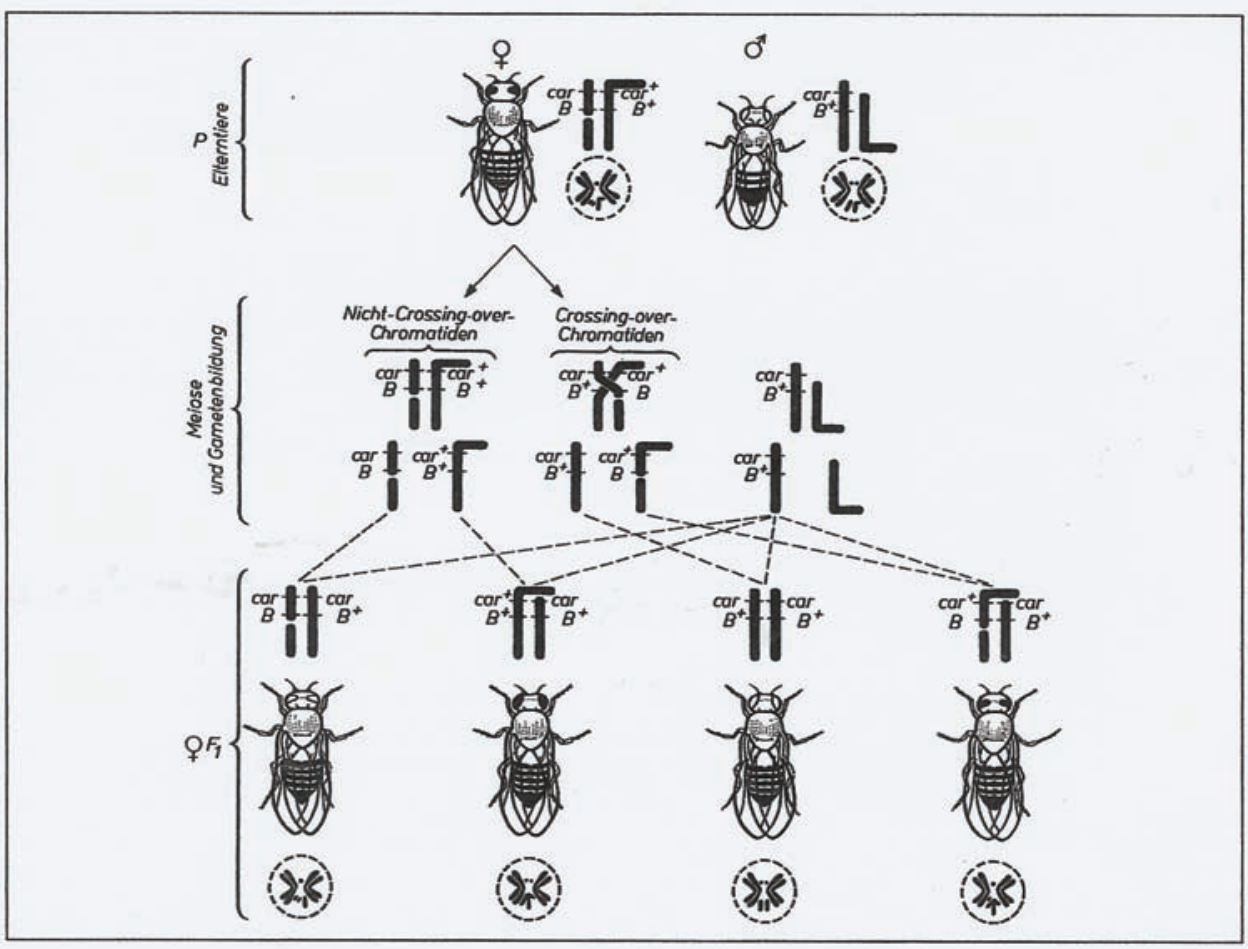

Abb. 2: Versuch von Curt Stern (1931) an Drosophila zum Nachweis des Chromatiden-

Stückaustausches, der dem genetischen Faktorenaustausch - dem Crossing-over - zugrunde liegt. Die zum Versuch verwendeten Weibchen besaßen ein doppelt heteromorphes Paar von X-Chromosomen: Ein X-Chromosom ist (durch eine Translokation mit dem 4. Chromosom) „zweigeteilt"; an das andere X-Chromosom ist (durch eine Translokation) ein Teil des Y-Chromosoms angelagert. Als Markierungs-Gene in den Weibchen wurden verwendet: car fleischrote Augen (carnation), car ${ }^{+}$normal dunkelrote Augen; B bandförmige Augen (Bar), $B^{+}$normale Augen. Diese Weibchen wurden gekreuzt mit Männchen, welche die rezessiven Allele car und $B^{+}$trugen. Die Analyse der $F_{1}$-Weibchen zeigte, dass Tiere, die auf Faktorenaustausch im Bereich zwischen car und B zurückgingen, cytologisch fassbare neue Typen von X-Chromosomen besaßen (rechte Hälfte der Abb.). Hingegen hatten Tiere, die keinen Faktorenaustausch zwischen car und B zeigten, dieselben Chromosomen wie ibre Eltern (linke Hälfte). 


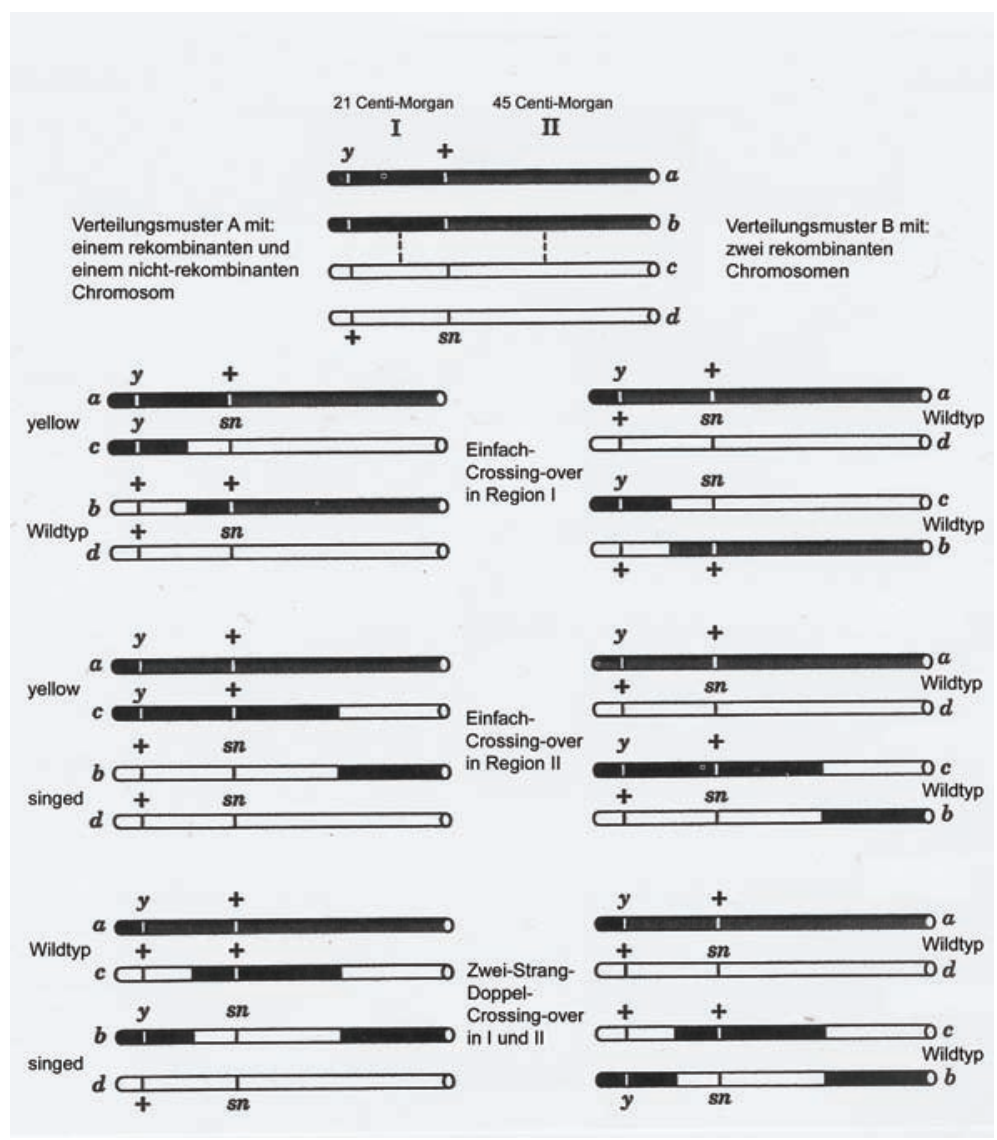

Abb. 3: Versuch von Curt Stern (1936) über das Auftreten von mitotischem Crossing-over bei Drosophila, das zum Auftreten von Zwillingsflecken oder Einzelflecken fübrt.. Genaue Erklärung im Text. Nach einem Schema von Sager und Ryan 1961, verändert. 


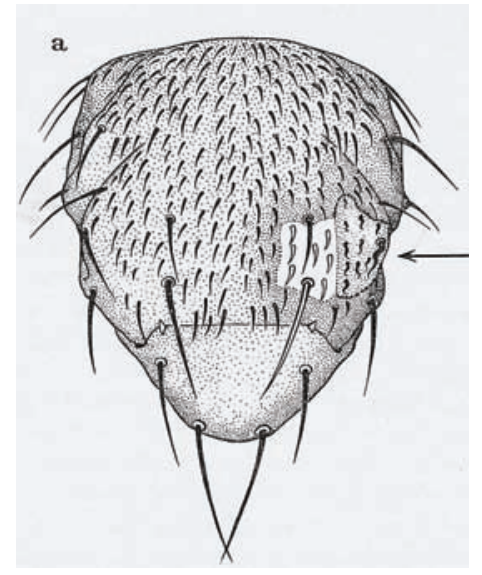

Abb. 4: Thorax von Drosophila. Ein Weibchen ist doppelt heterozygot für yellow und für singed $(y+y ; s n+s n)$ und weist Zwillingsflecke auf (Pfeil). Im linken Fleck stehen auf hellem Grund sieben gelbe Haare und eine gelbe Borste (= Homozygotie für yellow). Der rechte Fleck ist wildfarbig pigmentiert und trägt eine Borste und zehn Haare vom singed-Phänotyp (= Homozygotie für singed). Aus Hadorn 1955. 


\title{
Essentialism in Taxonomy: Four Decades Later
}

\author{
David L. Hull
}

\section{Abstract}

In one of my first papers I argued that essentialism, the view that natural kind terms must be defined via necessary and sufficient conditions, should be replaced by cluster analysis. A series of recent papers criticizing my xobjections to essentialism has led me to re-examine my early views on essentialism to see precisely how much I had change my mind. In my original paper, I argued that biological taxa can be defined only in terms of statistically covarying traits. In addition, the species category should be defined disjunctively. Within ten years I rejected the first claim and expressed doubts about the second. The names of biological taxa cannot be defined as cluster concepts because they cannot be defined at all. Species are spatiotemporal individuals, and their names are proper. The case with respect to the species category is not so clear cut. Disjunctive definitions fit in well with pluralism. Unfortunately, I am partial to monism.

In 1965 I published a paper with the pugnacious title "The Effect of Essentialism on Taxonomy: Two Thousand Years of Stasis." This view fitted nicely with the positions held by Karl Popper (1950), Ernst Mayr (1942, 1957), and A. J. Cain (1958, 1959a, 1959b) among others. Biological taxa might well be defined in terms of similarity but not essential similarity. Since then, opposition to essentialism has become widespread among systematists, so widespread that Steve Gould (2002: 110) has complained that "essence" is a "concept that dare not speak its name." However, a movement is now afoot, led by Polly Winsor (2003), to downplay the prevalence and importance of essentialism in systematics. The claim is that systematists through the generations were not as fixated on essences as philosophers of biology and theoretical biologists have claimed.

I agree with Winsor that most practicing systematists, both before the Origin and after, just classified their specimens, and that was pretty much that. Discussions about natural kinds and essentialism were left to theoretical systematists and philosophers of biology. As I remarked at the time, "It is not being claimed here that the typical practicing taxonomist is consciously aware of the logic of Aristotelian definition and has opted for it rather than for some other type of definition" (Hull 1965: 317; see also Hull 1983). Even so, I think that there is a point to investigating what theoretically sophisticated systematists have had to say on the subject of classification.

Another reason to revisit this paper is that I now take its main themes to be wanting in several important respects. It is better that I point out these weaknesses than wait for someone else to do it for me. First and foremost, I have complained about the evil ef- 
fects of treating biological species as essential natural kinds so often and at such length that I have been interpreted by some as opposing essences altogether (Grene 2002: 298). To the contrary, I think that essential natural kinds are essential to science. Only there are not many of them, and biological taxa do not belong on this list.

The species problem has been around for so long and has been dealt with in so many books and papers that we seem to be condemned to go round and around without making much in the way of progress. I can certainly appreciate the frustration that so many have felt about the species problem through the years. Conceptual change in science can be painfully slow, but in this respect the species concept is not in the least unusual. Genes pose an equally frustrating set of problem for biologists (Hull 1965: 16). In the olden days, genes were held to be like beads on a string, but this characterization was soon recognized as being way too simple. With the advent of molecular biology, this complexity has only increased. Although many more papers and books have been written about species than about genes, genes are fast catching up (Stotz and Griffiths 2004; Pearson 2006). It won't be long before these workers will be accused of going round and around without making much in the way of progress.

\section{Homologies and Homoplasies}

One of the most long-standing difficulties with the species concept is the tendency to treat species as both highly variable entities that evolve and as kinds that cannot evolve. As Darwin remarked in 1849 in a letter to J. D. Hooker:

Systematic work would be easy were it not for this confounded variation, which, however, is pleasant to me as a speculatist, though odious to me as a systematist. (L\&L 1: 397-8).

Darwin found the variation so common in the living world pleasant because variation was one of the fundamental elements in his theory of evolution. By and large species evolve through the differential perpetuation of numerous small variations. These variations are not something to be explained away. They are essential to the evolutionary process. But by this same token systematists found variation odious because it made classification so much more difficult. If species evolve the way that we think that they do, then they cannot be defined in terms of necessary and sufficient conditions. They cannot have essences.

The contrast between homologies and homoplasies has also been a source of considerable confusion. Homologies are the characteristics that result from common ancestry. To the extent that these characteristics are similar, they are similar because of descent. For example, the spiracle in sharks is homologous to the Eustachian tube in human beings, even though the two are not all that similar. Homoplasies may also be similar to each other but not because of propinquity of descent. Not all wings are wings. Both birds and insects have wings, but from a phylogenetic perspective, they are not the "same" characters.

Homologies provide information that allows biologists to reconstruct phylogenetic trees while homoplasies are the entities that function in the evolutionary process. Giving birth alive has evolved numerous times. Instances of this characteristic are not homologous, but to the extent that being able to fly fulfills comparable functions in the evolu- 
tionary process, it is a homoplasy. With respect to phylogeny reconstruction, homologies provide information; homoplasies are noise. With respect to theory construction, homoplasies provide information; homologies are noise. Although it took a while for molecular biologists to recognize this distinction, eventually even they came to realize the difference between homologies and homoplasies at the molecular level. The molecule UUU may be the "same" in the sense of homoplasic characters wherever it may appear, but UUU is not always the same homologous character as UUU (Sanderson and Hufford 1996).

But the distinction between homologies and homoplasies goes even deeper. "Homology" is a genealogical term. Traits that are homologous to each other must be traceable back in space and time. Homoplasies have no such requirements. That is why they can function in scientific laws. Although it has taken a very long time, the implications of the spatiotemporal character of homologies has finally made its way into the taxonomic literature (Ghiselin 1974 and Hull 1976). Biological taxa can be defined literally in terms of homoplasies, but not homologies. Homologies characterize lineages, and lineages are spatiotemporal wholes -- historical entities.

One of the shortcomings of my 1965 paper was that I did not emphasize sufficiently a distinction closely connected to the distinction between homologies and homoplasies -between physical and conceptual space. The lineages that form phylogenies exist in physical space. They have ranges and boundaries -- physical boundaries. The characters that cluster do so in conceptual space, not physical space. These clusters also have "boundaries," but they occur in conceptual space, not physical space.

When Wittgenstein (1953: 32e) introduced his notion of family resemblances, he used two examples -- games and threads. In both examples "we see a complicated network of similarities overlapping and criss-crossing." Games might well be treated as a cluster. They can occur anywhere, and some games are more typically "games" than others. They might even exhibit a bell curve. But neither families nor threads form clusters in this sense. Families are first and foremost genealogically connected. If a child were born who possessed none of the characteristics of its family, it would still be part of that family, and a thread consisting of numerous fibers provides a clear case of an individual, not a class or cluster concept.

\section{Biological Classification}

In my 1965 paper, I argued for two positions: (1) that particular taxa such as biological species should be treated as cluster concepts exhibiting only family resemblances, and (2) that taxonomic categories, such as the species category, can be defined only disjunctively. How do systematists define "Bos bos"? By listing a series of characters that most, though not all, cows have in common; e.g., horns, cloven hooves, several "stomachs," etc. How should we treat the species category, not Bos bos but species as such? My answer at the time was in terms of disjunctive definitions. The species category can be defined in terms of interbreeding, or potential interbreeding, or cohesion, or overall similarity, or something.

In my essentialism paper, I failed to distinguish adequately between those characters that are genealogically connected (homologies) and those characters that are just similar 
(homoplasies), but in that paper I was more interested in the species category than taxa. I argued that both taxa and categories are best defined in terms of clusters of characteristics. All they need display is enough of the more important characteristics of the group developed to a sufficiently high degree. Unfortunately, with respect to the species category, I elided from disjunctive definitions to cluster concepts. The species category might well be definable only disjunctively, but it does not thereby form a cluster. Particular species form clusters; the species category itself does not. Evolution requires that species evolve. Nothing requires that the species category itself evolve.

In the first half of this paper I set out the distinctions that have caused so much confusion with respect to biological taxa and categories -- essences, cluster concepts, family resemblances, disjunctive definitions, homologies, homoplasies, and historical entities. In the second half of this paper I turn to scientific theories. Can particular scientific theories, such as evolutionary theory, be construed usefully in the same terms as biological species? I think that they can. How about scientific theories in general? Are all scientific theories essentially the same or can this notion be defined only disjunctively?

I realize that in comparing biological species and scientific theories I am engaged in metaphorical reasoning. Biological species and scientific theories are quite different things. Why mix up the two? Because reasoning back and forth between biological species and scientific theories can lead us to think our way out of old ruts. We have certain deeply held beliefs about species that we do not have about theories, and vice versa. These old ruts may turn out to be mistaken, maybe not, but they nevertheless deserve further investigation.

In sum, in this paper I address four issues. Do particular biological species possess essences or can they be classified only in terms of clusters? How about the species category? Do particular scientific theories possess essences or can they be defined only as clusters? How about the class of all theories? And a final issue: what difference does it make? One might agree that evolving species as well as scientific theories are best construed as historical entities but find the cost too high.

\section{Biological Species}

Certain fundamental terminological distinctions make discussing species more difficult than it should be. For example, the term "species" like "shrimp" is the same both in the singular and in the plural. A species can evolve. So can species. The species category as the class of all species might also evolve, but such an "evolution" has nothing to do with biology. Of greater importance are the sorts of characters that appear in these definitions. Taxa, such as Bos bos, are defined in terms of phenotypic characters that individual organisms possess. These characters are not universally and exclusively distributed. Not all cows have horns, and not all organisms with horns count as cows. At best these characters cluster in conceptual space. Parallel observations hold for genes.

For the past three decades biologists and philosophers of biology have been debating the implications that characters as homologies have for classification. If the characters used to define biological taxa depend on descent, then they cannot be spatiotemporally unrestricted. Hence, they cannot function in laws of nature, that is, if laws of nature are held to be spatiotemporally unrestricted. Of course, a common belief among philoso- 
phers of science today is that there are no natural kinds (Duprè 1981) or laws of nature (Cartwright 1983, Giere 1999). If so, then the distinctions I am drawing in this paper are beside the point. Of course, these conclusions follow only if natural kinds and laws of nature are defined very strictly. On more reasonable interpretations, they might well exist and play important roles in science (see also Elgin 2006).

\section{The Species Category}

The preceding discussion has dealt with species as biological taxa. However, the species problem concerns the species category, not particular biological species. The characters that appear in the list of traits that define a particular species are such things as the presence of feathers, lungs, radial symmetry or a particular song. The characteristics that define the species category are quite different. They include such things as the presence of pre-mating isolating mechanisms, cytoplasmic interactions, and ecological constraints (Templeton 1989). Certainly the characteristics that "define" biological taxa differ significantly from those used to define the species category.

Disjunctive definitions differ significantly from cluster concepts. In cluster analysis traits are mapped onto conceptual space. If a cluster forms a cluster in conceptual space, so much the better, but any distribution might well emerge. Disjunctive definitions do not form such distributions. For example, dishonesty comes in three forms -- lying, cheating and stealing. To most people's surprise, these three types of dishonesty tend not to covary. There are people who would lie but never cheat or steal, others who would steal and lie but not cheat, and so on. Periodically, authors have suggested that the species category be defined in this way. There is no such thing as the species category, just several different sorts of species.

One of the most common requirements for the species category is universality -- the more universal the better. In 1997 an anthology of papers on species in various taxa appeared (Claridge, Dawah and Wilson 1997). In this anthology, experts in a wide variety of fields examined their organisms of choice to see which, if any, of the twenty or so most prevalent definitions of the species category apply to them. Included on this list are viral species, cultivable bacteria, uncultured prokaryotes, eukaryotic algae, lichens, fungi, plants, marine invertebrates, nematodes, insect herbivores and parasitoids, parthenogenetic insects, terrestrial non-insect vertebrates, birds and mammals. How could all these diverse organisms form species, not just species but species of the same sort?

Does a single level of organization exist across all organisms such that this level is the same for all organisms and can be properly considered as the species level? I don't think so. No such level exists, but even if it did, it would not accord all that well with what systematists through the years have considered species. Many organisms form biospecies; asexual organisms do not. The contrast is between those organisms that form species of the sort that systematists seem to have in mind when they refer to species but are not widely distributed and those organisms that are widely distributed but are not exactly the sorts of species that systematists have in mind.

It would be nice if all organisms formed species of the same sort, but they do not. However, it does not follow that we should ignore those organisms that do belong to species of the same sort. For example, organisms that reproduce sexually may well form 
a natural kind even if not all organisms reproduce sexually. If anything, sexual reproduction is relatively rare. There was nothing like sexual reproduction during the first half of life on Earth, and sexual reproduction is still far from universal. Even so, evolution took place. Replication and environmental interaction may be necessary for selection but not for evolution. The distinction between vertebrates and invertebrates concerns phylogeny; the distinction between sexual and asexual organisms does not.

\section{Laws of Nature and Natural Kinds}

What follows of any importance from the preceding distinctions? One implication concerns natural kinds and laws of nature. Critics commonly complain that there are few if any laws in biology, and by this they mean statements about particular taxa; e.g., the familiar "all swans are white." However, if species are historical entities, then it follows that they cannot function in laws of nature. If they could, biologists would be inundated with laws of nature -- millions of them, certainly many more laws than physicists could possibly muster. One message of this paper is that biological taxa as historical entities cannot function in laws of nature. Of course, for anyone who thinks that there are no laws of nature, this conclusion is of no importance.

More plausible candidates for biological laws refer to biological categories, not taxa. For example, J. B. S. Haldane (1922: 101) suggested the following as a biological law: when in the first filial generation of offspring of two different animal races and one sex is absent, rare, or sterile, that sex is the heterogametic sex. With the exception of the reference to animals, this statement is general enough to count as a law of nature, and "animal" can be replaced by "all living creatures" without loss.

Certainly we should strive to make our putative laws as general as possible. For example, if mode of reproduction is so crucial, there should be systematic differences between the various sorts of reproduction -- sexual, parasexual, asexual, etc. Selection provides another example. Selection requires both replication and environmental interaction. It does not require that genes be the only entities that function in replication. Perhaps prions can also fulfill this requirement. Selection also requires environmental interaction. Organisms as well as other entities interact with their environments in such a way that replication is differential (Hull 1980).

With respect to evolutionary theory, both genealogy (homologies) and similarity (homoplasies) matter, but when they do not coincide, which is prior? The answer is neither. Both are necessary. The species category along with other conceptual entities may well evolve, but this evolution is conceptual, not biological. Biological taxa must be treated as historical entities. I don't see how it can be avoided. Nothing about the evolutionary process requires that the species category be treated as a natural kind. Even so, conceptual entities like the species category might be viewed as historical entities. Before treating conceptual evolution, a few words need to be said about one special sort of evolution that has played an overweening role in the controversy over essentialism -- human nature. 


\section{The Human Species}

For millennia scholars as well as ordinary people have taken Homo sapiens to be a paradigm example of a class. Perhaps Homo sapiens cannot be defined in terms of necessary and sufficient conditions, perhaps few people can agree about what traits characterize this species, but throughout intellectual history, the common convection has been that the human species is best construed as a class. Too many philosophical and religious systems depend on Homo sapiens being a class. There just has to be something called "human nature."

The anthropologist Donald Brown (2004: 47-48) insists that hundreds of human universals have been discovered, features that are found among all peoples no matter where or when. However, he distinguishes between various kinds of universals -- absolute universals, near universals, conditional universals, statistical universals and universal pools. Given this variety of uses, just about everything turns out to be a universal. Incidentally, one of these universals that Brown lists is the tendency to perceive the world in terms of universals (see Haslam 1998, Hull 1998).

My response is that all species, including the human species, are best construed as historical entities. A human being is a human being because of its place in a genealogical nexus, not because of any characteristics it might or might not have. Do all people have apposable thumbs? No. If you are born without an apposable thumb, does that mean that you are not a human being? I don't think so. Do any other organisms possess apposable thumbs. Yes. Does that make them human? No. But most importantly, why are anthropologists so fixated on finding "universals"? What can anthropologists do with universals once they have been discovered? One possibility is for them to function in laws of nature, but the univerals listed by Brown do not seem to be very good candidates for laws. People may well perceive the world in terms of univerals, but this claim itself is hardly a law of nature.

\section{Scientific Theories}

In 1988 I published a book in which I presented an evolutionary account of the social and conceptual development of science. One of the messages in the 586 pages of this book is that, if you want others to read your work, avoid publishing big, heavy tomes -like mine. I also argue that scientific theories are best viewed as historical entities; e.g., evolutionary theory itself. Not many people took up this perspective. They preferred treating scientific theories as kinds, possibly natural kinds, and in this preference they are joined by most evolutionary biologists. Time and again evolutionary biologists have claimed that Darwin's theory of evolution has an essence. The problem is that little agreement exists among evolutionary biologists about what this essence is.

In this paper, I concentrate on Steve Gould's exposition in his The Structure of Evolutionary Theory (2002), in part because Gould is an evolutionary biologist who is willing to take on these philosophical issues, in part because he takes treating scientific theories as historical entities seriously. Incidentally, his book runs to 1433 pages.

Biological evolution requires that species evolve. Nothing requires that the species category itself must evolve. And certainly, nothing about the evolution of species as a biological phenomenon entails anything about scientific theories evolving. The main goal 
of my Science as a Process was to argue that treating scientific theories as historical entities might contribute to our understanding of science. For most of the history of science, the elements that comprise science have been analyzed in terms of inference. What is a scientific theory? A set of axioms from which laws can be derived. What is a scientific explanation? The derivation of an explanandum from an explanans. What is reduction? The derivation of one theory from a more fundamental theory.

Analyzing just about everything characteristic of science in terms of inference has increased our understanding of science, but this methodology has progressed way past the point of diminishing returns. A novel perspective seems called for. Species must be treated as historical entities. Nothing requires that scientific theories must be viewed as historical entities, but it might prove profitable.

\section{History and Philosophy of Science}

Although considerable effort through the years has been put into integrating history and philosophy of science, the two discipline still remain largely independent. One might think that philosophically sophisticated historians of science should be able to write better histories than those historians who have no feel for philosophy. Similarly, philosophers who are well-versed in history of science might well be in a better position to contribute to the philosophy of science than those that are not. Such has not proven to be the case. Philosophers of science have tended to denigrate historians of science -- "They are not all that bright, you know" -- and historians of science frequently look down upon philosophers of science -- "They are too prone to idle speculation. For sure, they should not be allowed to do history."

One point of difference between history of science and philosophy of science is central to this paper -- homology versus homoplasy. When philosophers write history, they do so by listing similar concepts through time. Historians object. Genealogy also matters. Arthur Lovejoy's magisterial The Great Chain of Being (1936) is a case in point. He discusses various authors from the ancient Greeks to his more immediate historical predecessors, whether or not they actually profited from the work of these predecessors. Lovejoy treats the "Great Chain of Being" as a series of homoplasies. Similar ideas are similar ideas. Historians object. Genealogy matters. They study science to discover who got what from whom.

Michael Ruse's The Darwinian Revolution (1979) is another case in point. Most philosophers who write about the Darwinian Revolution trace back such notions as evolution and natural selection through time regardless of any actual connections. Who were the various authors who advocated evolution before Darwin? Darwin himself in the third English edition of the Origin (1861) added a list of his precursors. Ruse, to the contrary, discusses the workers who actually contributed to Darwin's theory most of whom rejected the evolution of species, authors such as William Buckland, John Herschel, Charles Lyell, Hugh Miller, Richard Owen, Adam Sedgwick and William Whewell. We do not get to Darwin until half-way through the book on page 160. 


\section{The Essence of Darwinism}

One of the reasons why Gould published his mammoth The Structure of Evolutionary Theory (2002) was to gather together in a single book all of his views about the evolutionary process. He begins with a long discussion of "individuality". The Milan Cathedral is an individual. So are individual organisms. More controversially, Gould adopts the position that species are also individuals -- historical entities or, more poetically, children of time. Convincing people that species are best treated as historical entities is difficult enough, but Gould goes on to argue that scientific theories are also historical entities, a position that is even more problematic. According to Gould (2002: 6), a scientific theory such as evolutionary theory must be treated as a genuine thing-- an "entity with discrete boundaries and definable history." It must also possess a "structure". After all, the title of his book is The Structure of Evolutionary Theory.

Gould then goes on to characterize scientific theories in terms of two apparently contradictory positions. Scientific theories are individuals, but in addition they have essences. Theories need both essences and histories. To use the biological terms, theories must be characterized as both homoplasies and homologies:

...shared content, not only historical continuity, must define the structure of a scientific theory; but this shared content should be expressed as a minimal list of the few defining attributes of the theory's central logic -- in other words, only the absolutely essential statements, absent which the theory would either collapse into fallacy or operate so differently that the mechanism would have to be granted another name (Gould 2002: 10).

Gould views scientific theories as consisting of a central core surrounded by less important beliefs. The less important beliefs can be changed without any modification of the scientific theory, but the core must remain fundamentally the same (see Lakatos 1970). Gould's claim would sound more convincing if the historical record supported him. From his return on the Beagle until he published the Origin, Darwin modified his theory, adding parts, eliminating other parts, etc. Even after the Origin appeared, Darwin continued to modify his views. This is what scientists do. Which of these many versions count as exhibiting the "absolutely essential" statement of Darwin's views?

Nor did Darwin's allies agree completely with Darwin or each other even about basics. Supposedly Darwin and Wallace held the same theory; e.g., Darwin (1889, 2: 69) observed that Wallace's paper "contained exactly the same theory as mine," while Wallace proclaimed that he and Darwin had reached "identically the same theory" (Shermer, 2002:302). But if one reads the works of Darwin and the Darwinians, one is struck by how much they differ, and if I might repeat myself, as far as natural selection is concerned, variation is good, not bad. The compulsion to find the essence of evolutionary theory is a remnant of our strong predilection for essences.

At the turn of the 19th century, Mendelian geneticists insisted that Mendelism and Darwinism were mutually incompatible. It took a while, but eventually both sides came to realize that these two theories, with a little modification, could be synthesized. Today numerous biologists claim to be Darwinian or neo-Darwinian; while others claim just as vehemently that they are anti-Darwinian or non-Darwinian. Motoo Kimura (1983) set out his Neutral Theory of Molecular Evolution which he claimed conflicted with Darwinian theory, but eventually it was incorporated into Darwinian theory. Gould consid- 
ered himself a "Darwinian" and justifiably so. He contributed to a Darwinian tradition throughout most of his life. He began by accepting a version of evolutionary theory that included a strong commitment to adaptationism. Later he abandoned this position and adopted a punctuational view. And so on.

Each of the scientists who claim to hold a Darwinian theory of evolution can present very compelling arguments to support their claims. Conversely, those scientists who think of themselves as holding an anti-Darwinian theory can also be very persuasive in their rejection of Darwin's theory. The problem is that there is no strong correlation between the positions held by these authors and the groups with which they identify. As far as the views that they held is concerned, St. George Jackson Mivart was closer to Darwin than T. H. Huxley was, but as far as conceptual genealogy is concerned, Mivart was an enemy of the Darwinians while Huxley was an ally.

In biology, homologies do not always coincide with homoplasies. The same can be said with respect to conceptual evolution. The question then becomes which perspective takes priority when they conflict. In history, as I understand it, conceptual genealogies take precedence to similarity in views. Scientific biographies are absolutely essential in understanding the history of science. The chief drawback of the genealogical perspective is that such relations are very difficult to come by. Darwin and Wallace held similar views, at times more similar, at times less so. They both held the principle of divergence, but who got it from whom? Did Darwin really steal it from Wallace as some commentators have claimed or did they both come up with it independently? Deciding similarity in views is hard enough. Discovering actual causal chains is even more difficult.

With respect to characteristics, homologies must be distinguished from homoplasies, and both have roles to play in biological evolution and science, respectively. In biological evolution, homologies help us to reconstruct phylogenies, while homoplasies produce kinds that might well expand our understanding of the evolutionary process. The contrast is between pattern and process. Parallel observations hold for conceptual change. The discovery of who got which views from whom is necessary to write genuine history. Such knowledge is not necessary if all you want to do is to understand a particular scientific theory. Very few science teachers begin by teaching the history of science. Their students are not interested. What they want to learn is the best views then current.

Finally, how about science itself? Is there an essence to science? Can necessary and sufficient traits be found that are characteristic of all instances of science? If not, how about clusters of such traits? Or does descent trump similarity? Was Aristotle really a scientist? Aristotle's philosophy of science was certainly different from that proposed at the scientific revolution and later. Discovering similarities is one thing; finding actual connections is much harder, so hard that one might throw up one's hands in despair. In 1982 I presented a paper at a meeting of the Philosophy of Science Association setting out the preceding view of science (Hull 1983). In the discussion period afterwards several in the audience registered dismay. Providing a series of conceptual homoplasies is difficult enough; working out conceptual homologies is more than a body could bear. Most historians and a few philosophers are willing to do the research necessary to produce conceptual homologies. Conceptual homoplasies will have to do. 


\section{References}

Darwin, C. D. (1899) Life and Letters of Charles Darwin, 2 vols. D. Appleton and Company, New York.

Brown, D. (2004) Human Universals. Deadalus 133(4), pp. 47-54.

Cartwright, N. (1983) How the Laws of Physics Lie. Oxford University Press, Oxford.

Claridge, M. F., Dawah, H. A. and Wilson, M. F. (eds.) (1997) Species: The Units of Biodiversity. Chapman \& Hill, London.

Duprè, J. (1981) Natural Kinds and Biological Taxa. Philosophical Review 90, pp. 66-90.

Elgin, M. (2005) There May Be Strict Empirical Laws in Biology, After all, Biology \& Philosophy 21, pp. 119-134.

Ghiselin, M. T. (1974) A Radical Solution to the Species Problem. Systematic Zoology 23, pp. 536-544.

Giere, R. N. (1999) Science without Laws. University of Chicago Press, Chicago.

Gould, S. J. (2002) The Structure of Evolutionary Theory, The Belnap Press of Harvard University, Cambridge, MA.

Haldane, J. B. S. (1922) Sex-ratio and Unisexual Sterility in Hybrid Animals. Journal of Genetics 12, pp. 101-109.

Haslam, N. O. (ed.) (1998) Natural Kinds, Human Kinds, and Essentialism. Social Research 65, pp. 292-314.

Hull, D. L. (1965) The Effect of Essentialism on Taxonomy: Two Thousand Years of Stasis. The British Journal for the Philosophy of Science 15, pp. 314-326 \& 16, pp. 1-18.

Hull, D. L. (1976) Are Species Really Individuals? Systematic Zoology 25, pp. 174-191.

Hull, D. L. (1980) Individuality and Selection. Annual Review of Ecology and Systematics 11, pp. 311-332.

Hull, D. L. (1983) Exemplars and Scientific Change. In: PSA 1982, vol. 2 (Asquith, P. D. and Nickles, T.; eds.) Philosophy of Science Association, East Lansing, MI: pp. 479-503.

Hull, D. L. (1988) Science as a Process: An Evolutionary Account of the Social and Conceptual Foundations of Science. University of Chicago Press, Chicago.

Hull, D. L. (1998) Species, Subspecies and Races. Social Research 65, pp. 351-367.

Hull, D. L. (2003) Darwin's Science and Victorian Philosophy of Science. In: The Cambridge Companion to Darwin (Hodge, J. and Radick, G.; eds.) Ch. 7, Cambridge University Press, Cambridge: pp. 168-191.

Kimura, M. (1983) The Neutral Theory of Molecular Evolution. Cambridge University Press, Cambridge. 
Lakatos, I. (1970) Falsification and the Methodology of Scientific Research Programs. In: Criticism and the Growth of Knowledge (Lakatos, I. and Musgrave, A.; eds.) Cambridge University Press, Cambridge: pp. 91-196.

Lovejoy, A. O. (1936) The Great Chain of Being. Harvard University Press, Cambridge, MA.

Pearson, H. (2006) What Is a Gene? Nature 441, pp. 399-401.

Ruse, M. (1979) The Darwinian Revolution: Science Red in Tooth and Claw. University of Chicago Press, Chicago.

Sanderson, M. J., and L. Hufford (eds.) (1996) Homoplasy: The Recurrence of Similarity in Evolution. Academic Press, San Diego.

Shermer, M. (2002) In Darwin's Shadow. Oxford University Press, Oxford: pp. 396-397.

Stotz, K. and Griffiths, P. (2004) Genes: Philosophical Analyses Put to the Test. History and Philosophy of the Life Sciences 23, pp. 5-28.

Templeton, A. R. (1989) The Meaning of Species and Speciation: A Genetic Perspective. In: Speciation and Its Consequences (Otte, D. and Endler, J. A.; eds.) Sinauer Associates: Sunderland, MA: pp. 3-27

Winsor, M. P. (2003) Non-Esentialist Methods in Pre-Darwinian Taxonomy. Biology \& Philosophy 18 , pp. 387-400.

Wittgenstein, L. (1953) Philosophical Investigations. Macmillan, New York.

\section{Address for correspondence:}

David Hull

Department of Philosophy

Northwestern University

Evanston, IL 60208-131, USA

David.Hull@etss.net 


\title{
Organism, Epigenesis, and Life in Kant's Thinking - Biophilosophy between transcendental philosophy, intuitive analogy, and empirical ontology
}

\author{
Hans Werner Ingensiep
}

Abstract

During the last decades historians of the sciences and philosophers have delivered important analyses of details of Kant's theoretical biological ideas, as there are the concepts of organism, race, preformation, epigenesis, and of their functions and roles in and for Kant's theory of knowledge and life. That is the topical background in front of which some of the key concepts of Kantian biophilosophy are examined. The analysis starts with Kant's mature concept of organism in the Critique of the Teleological Judgement. A detailed examination illustrates what Kant has in mind when speaking of 'organism', e.g. illustrated as a tree, related to the basic problems of transcendental philosophy and empirical ontology and especially with regard to the relations to Blumenbach's ideas of the "Bildungstrieb". Difficult questions arise concerning the concept of epigenesis, its ambivalent function as an analogy, or its ontological role in Kant's biophilosophy (e.g. discussed by Ingensiep 1994, Sloan 2002, Zammito 2003). Finally some considerations to the different use of the word "life" in Kant's philosophy are presented with respect to the topical debate on biophilosophy and bioethics.

\section{Introduction - trends in biophilosophy with Kant}

Since Kant's third Critique of teleological Judgement (C III, 1790) Kant's philosophy of biology has repeatedly been examined from the viewpoints of the history of science, the history of ideas, and systematic philosophy. These analyses mostly started out from the first main work (C I) and presupposed the results of both editions of the Critique of Pure Reason (1781/1787). Thus, in a theoretical, especially epistemological and natural philosophical way, the analysis of C III was interest-orientated. Since the year 1790 Kant's analysis of teleological concepts and principles have been questioned with regard to their fruitfulness and relevance for the newly emerging biology, ${ }^{1}$ early in the philoso-

\footnotetext{
${ }^{1}$ In the following paper I use the term „Biologie“ in a general manner, but it must be considered that the term changed its meaning around the year 1800 (see Kanz, Kai Thorsten: Von der BIOLOGIA zur Biologie. Zur Begriffsentwicklung und Disziplingenese vom 17. bis zum 20. Jahrhundert. In: Uwe Hoßfeld/Thomas Junker (Eds.): Die Entstehung biologischer Disziplinen II. Verhandlungen zur Geschichte der Theorie der Biologie Bd. 9. Berlin 2002, p. 9-30.
} 
phy of natural history, ${ }^{2}$ more comprehensively and speculatively by the German idealists (Schelling, Hegel), then from the critical distance of Neo-Kantianism after the mid of the $19^{\text {th }}$ century again, finally in the philosophy of sciences in the $20^{\text {th }}$ century. ${ }^{3}$ In the first third of the $20^{\text {th }}$ century Kant was intensively referred to by the Neovitalists, especially by zoologists and botanists. But in the last third of the 20 th century the biologists' theoretical interest in Kant noticeably vanished. ${ }^{4}$ But during the last decades historians of the sciences have delivered important analyses of details of Kant's theoretical biological ideas, as there are the concepts of race, preformation, epigenesis, and of their functions and roles in and for Kant's theory of knowledge. ${ }^{5}$ Parallel, the philosophical discussion of Kant's critique of teleology goes on. ${ }^{6}$ In so far, currently on the one hand a historical and on the other hand an epistemological-systematic interest can be observed for modern biophilosophy. ${ }^{7}$

2 One of the first was Christoph Girtanner (1760-1800): Ueber das Kantische Prinzip für die Naturgeschichte. Ein Versuch diese Wissenschaft philosophisch zu behandeln. Vandenhoek \& Ruprecht. Göttingen 1796; concerning Kant/Blumenbach see Lenoir, Timothy: Kant, Blumenbach and Vital Materialism in German Biology. ISIS 71 (No. 256) 1980, p. 77-108.

3 The theoretical and historical interest in Kant's philosophy of biology is indicated by diverse approaches at making Kant's critique of teleology fruitful for the contemporary philosophy of biology e.g. Stadler (1874), Menzer (1911), Roretz (1922), Adickes (1925), Ungerer (1926), Driesch (1928), Cassirer (1950/1957/1973), Stegmüller (1969/1983), Mc Farland (1970), Löw (1980), Zumbach (1984), McLaughlin (1989), Toepfer (2004).

${ }^{4}$ For example the zoologist and Neovitalist Hans Driesch (1867-1941) in his „Philosophie des Organischen“ (4. A. Quelle \& Meyer, Leipzig 1928) tried a vitalist interpretation as „Ganzheitskausalität“ (Driesch 1928, S. 366-368). Kant's approach inspired biologists like Jakob von Uexküll (1864-1944) to reflect on animal subjectivity in his „Umweltlehre“, further the botanist Emil Ungerer (1888-1976) in „Die Regulationen der Pflanzen. Ein System der ganzheitsbezogenen Vorgänge bei den Pflanzen.“ (2nd ed. Julius Springer, Berlin 1926 , p. 9-18). But in the last third of the 20th century even such important researchers and historians of evolutionary biology like Ernst Mayr (1904-2005) in his „Eine neue Philosophie der Biologie“ (Piper. München, Zürich 1991) refer to Kant only very shortly and negatively (1991, p. 78f.). Modern dictionaries like the one of Evelyn Fox Keller / Elisabeth A. Lloyd (Eds.): Keywords in Evolutionary Biology. Harvard University Press. Cambridge, Massachusetts 1992) or historical collections of important texts as presented by Michael Ruse (ed.): „Philosophy of Biology“ (Prometheus Books. McMillan. 1998) do not mention Kant.

5 E.g. Wubnig (1968/9), Genova (1974), Lenoir (1980), Debru (1980), Ingensiep (1994), Mc Laughlin (1994), Sloan (2002), Shaw (2003), Zammito (2003). A current analysis of the controversies on race between Kant and Georg Forster presents Tanja van Hoorn: Dem Leibe abgelesen. Georg Forster im Kontext der physischen Anthropologie des 18. Jahrhunderts. Hallesche Beiträge zur Europäischen Aufklärung 23. Niemeyer Tübingen 2004.

${ }^{6}$ E.g. Düsing (1968/1986); Mc Farland (1970), Bartuschat (1972); Löw (1980), Wettstein (1981); Zumbach (1984); McLaughlin (1989); Zammito (1992), Peter (1992); Toepfer (2004).

7 I use the term „Biophilosophy“ in a wider sense, not only limited to the epistemological foundation of a single science or philosophical school like Gerhard Vollmer does as a representative of an Evolutionary Epistemology in his collection „Biophilosophie“ (Reclam, Stuttgart 1995). In the 1960s the biologist and philosopher Bernhard Rensch (1900-1990) used the term as the title of his book „Biophilosophie auf erkenntnistheoretischer Grundlage. Panpsychistischer Identismus“ (Stuttgart 1968). In a wider sense the philosophy of Helmuth Plessner (1892-1985) in his book „Die Stufen des Organischen und der Mensch. Einleitung in die philosophische Anthropologie." (Walter de Gruyter \& Co. Berlin, Leipzig 1928) can be seen as „Biophilosophie“, as the anthropologist Egon Frh. von Eickstedt (1892-1965) did (Homo 14. Bd., 1. 1963; see Plessner $3^{\text {rd }}$ ed. Berlin 1975, p. XIf. note 1). With good reasons one can say that the approach by Hans Jonas (1903-1993): „Organismus und Freiheit. Ansätze zu einer philosophischen Biologie.“ (Vandenhoeck \& Ruprecht. Göttingen 1973) or by Humberto M. Maturana: „Erkennen: Die Organisation und Verkörperung von Wirklichkeit“ (Friedrich Vieweg \& Sohn. Braunschweig, Wiesbaden 2nd ed. 1985) can be summarized under the title of "biophilosophy”. In a wider sense also Kristian Köchy uses the term in : „Perspektiven 
Concerning the practical ethical interest in Kant, the reception was quite different. It increased not as late as with the rise of life sciences in modern bioethics, especially as an continental opposition to the Anglo-American utilitarianism in bioethics. Here Kant's concept of a person is referred to as an end in itself or an ethical "Grenzbegriff' (marginal concept) in order of prevent human life being instrumentalized. Strictly speaking persons are human beings and human beings are organisms. At least the latter relationship is hardly mentioned in modern bioethical debates because the concept of organism seems to be clear. The question whether persons as organisms are living beings or whether non-personal organisms like lower animals or plants are subjects of life and worth of moral consideration, seems to be more problematic.

But what is "life"? This question is not unimportant for practical philosophy and needs to be theoretically and systematically clarified in biophilosophy. From a historical philosophical viewpoint, since the beginning of modern times after Descartes and Locke the concept of 'life' has been an ambiguous concept which can be determined in a more or less narrow way, metaphysically, psychologically, or even in no clear and distinct way at all. A historical semantic analysis of the concepts of organism, epigenesis, and life shows rudiments of a Platonic-Aristotelian heritage, which only insufficiently seems to be overcome after the automation of life in modern times. ${ }^{8}$ In the modern philosophy of mechanism and materialism 'life' is only able to denote a metaphysical gap or a psychic quality. 'Organisms' determined by natural laws were lifeless automats in Descartes' eyes, although these Cartesian automats went on to stay important representatives of 'life'.? The modern biotheoretical debate on the question of "what is life?", raised again by the physicist Erwin Schrödinger, ${ }^{10}$ rapidly shows the substitution of the concepts of organism, epigenesis, and life by physico-chemical concepts, laws, and explanations. ${ }^{11}$

The concept of organism survived, the concept of epigenesis declined, the one of life got ahead in philosophy in spite of various transformations and vaguenesses. But the term 'life' survived in philosophy after Nietzsche in the "Lebensphilosophie" during the first third of the $20^{\text {th }}$ century, and also within modern bio(!)ethics in the last third of the century. 'Life' does not only denote states of human life starting from the lowest sense of touch to the highest faculty of self-consciousness, from vegetating without consciousness up to the conscious process of dying. ${ }^{12}$ In addition, being a subject-of-life became

des Organischen. Biophilosophie zwischen Natur- und Wissenschaftsphilosophie“ (Ferdinand Schöningh. Paderborn, 2003).

${ }^{8}$ Concerning the philosophical history of the concepts of life, see the contributions to „Leben“ by P. Hadot, H. Hübner, J. Vennebusch, R. Piepmeier, U. Dierse/K. Rothe und R. Toellner in: Historisches Wörterbuch der Philosophie. Ed. by Joachim Ritter and Karlfried Gründer. Vol. 5. Schwabe \& Co. Ag, Basel Stuttgart 1980, p. 52-103.

${ }^{9}$ See Alex Sutter: Göttliche Maschinen. Die Automaten für Lebendiges bei Descartes, Leibniz, La Mettrie und Kant. Athenäum. Frankfurt a. M. 1988.

${ }^{10}$ Schrödinger, Erwin: What is Life? The Physical Aspect of the Living Cell. Cambridge University Press. Cambridge 1944.

11 See Michael P. Murphy / Luke A. J. O’Neill (Eds.): Was ist Leben? Die Zukunft der Biologie. Eine alte Frage in neuem Licht - 50 Jahre nach Erwin Schrödinger. Spektrum Akademischer Verlag. Heidelberg, Berlin, Oxford 1997.

12 See Peter Singer: Practical Ethics. Cambridge: Cambridge University Press 1979 and Ingensiep (2004b). 
the decisive criterion for moral consideration in modern animal ethics ${ }^{13}$ or in a biocentric approach including all living beings in environmental ethics.

That is the topical background in front of which some of the key concepts of Kantian biophilosophy must be examined. The analysis will start with Kant's mature concept of organism in the Critique of the Teleological Judgement (part II.). This detailed examination shall illustrate what Kant has in mind when speaking of 'organism', related to the basic problems of transcendental philosophy and empirical ontology and especially with regard to the relations to Blumenbach's ideas of the "Bildungstrieb" (formative drive). These explanations are followed by critically reflecting topical approaches that try to reconstruct Kant's theory of knowledge in the light of present biological terms, especially referring to his concept of epigenesis, its function as an analogy, or its ontological role in Kant's biophilosophy (part III.). In front of this background Kant's attempt to define a concept of life will be introduced in the last analysis of this article (part IV.) This will offer insight into the problematic and ambiguous relation between basic concepts of Kant's biophilosophy which will be relevant for the use of the concepts of organism and life in the topical debate on biophilosophy and bioethics, too (part V.).

\section{II. "Organism” between transcendental philosophy and empirical on- tology}

\section{II.1. Kant's philosophy of organism in the Critique of Judgment (C III)}

Although already introduced in the $17^{\text {th }}$ century, Kant does not use the term ,organism" until the Opus postumum. But implicite the term is enclosed in Kant's talking about "natural ends", like in the central paragraph of C III ( $\mathbb{S} 65)$, "Things considered as physical ends are organisms."14 But what is an organism? Answering this question with Kant means, at first, defining a special object of nature. The beginning of $\int 66$ shows that Kant's critical analysis of the teleological judgement being a regulative principle of the reflecting power of judgement aims at the close connection between object and method in biology: "This principle, the statement of which serves to define what is meant by organisms, is as follows: an organized natural product is one in which every part is reciprocally both end and means." Afterwards, the totality of the claim of the principle is underlined: "In such a product nothing is in vain, without an end, or to be ascribed to a blind mecha-

\footnotetext{
13 Tom Regan: The Case for Animal Rights. Berkley 1983; see Flury, Andreas: Der moralische Status der Tiere. Alber. Freiburg, München 1999.

14 German quotation: Akademie-Textausgabe: Kants Werke. Walter de Gruyter \& Co. Berlin 1968. Bd. V (abbreviation: Ak V, p. 372); in English: Immanuel Kant: The Critique of Judgement. Part II Translated with Analytical Indexes by James Creed Meredith. Clarendon Press. Oxford. First published 1952. (abbreviation: C III p.). In some cases I used the translation from Werner S. Pluhar: Immanuel Kant. Critique of Judgemend. Including the First Introduction. Hacket Publishing Company, Indianapolis, Cambridge 1987 (abbreviation: C III Pluhar p.)- Concerning Kants use of the term organism see Debru 1980 and in general Gereon Wolters: „Organismus“, in: Mittelstraß, Jürgen (ed.): Enzyklopädie Philosophie und Wissenschaftstheorie. Wissenschaftsverlag Bibliographisches Institut. Mannheim, Wien, Zürich. Bd. 2, 1984, S. 1091-1093. The cited sentence of Kant in English not correctly translated: „Things considered as physical ends are organisms." (C III 19). C III Pluhar 251: "Things [Considered] as Natural Purpose Are Organized Beings".
} 
nism of nature."15 But such formulations already nourish modern doubts concerning Kant's analysis and raise further questions. Do Kant's explanations clearly and distinctly define an "organism"? Do they justify a specific method that may be fruitful for natural history in biology as a heuristic method? Is the totalitarian claim of the principle justified? Is his rough distinction from the "blind mechanism of nature" necessarily connected to the concept of organism? Some of these questions shall be examined, after spending time for attention to the concept of life and its relations to the concept of organism as well as to Kant's special concept of epigenesis. At first, Kant's illustration of his concept of organism in $\ 64$ shall be discussed in greater detail. ${ }^{16}$

At the beginning of $\int 64$ Kant states that understanding is not sufficient to recognize that a thing is possible only as a physical end. This means for Kant that the "Dasein" (existence) of such a thing cannot be comprehended by understanding because understanding looks for a principle of explanation for organisms exclusively ,,in the mechanism of nature“. ${ }^{17}$ Rather, a principle of reason is necessary as an element of determination in order to perceive organisms. Such a reason-based principle to judge a thing of that sort called "organism" and therefore the "contingency of the form of the thing in relation to reason" is a ground for Kant, "for making us look upon the origin of the thing as if, [...] it could only be possible through reason". ${ }^{18}$ In short, the concept of teleology arises from reason, not from understanding. That is why the latter owes only as-ifteleological concepts concerning the object and method in the field of organic things. Certainly, by help of this concept understanding cannot explain the existence of an organism according to natural laws, but it allows to justify the concept of an "organism" as well as a method of research. At first, Kant illustrates the absolute necessity of going back to reason in order to possess a principle that gives unity to the concept of ends with the fictitious example of a geometrical figure, suddenly perceived by an observer in an uninhabited country. Reasonable beings would infer an end-defining reason from a regularly drawn triangle. Thus, they would regard this thing as a "product of art"19 In this case, however, the productive cause of ends cannot be found in nature but in the ends considered by human reason itself. In so far, the only statement that could be justified is that these objects are a product of human reason but not a product of nature - but the latter statement would be the decisive one concerning organisms.

\section{II.2 The organism as a tree - empirical, systematic, and historical aspects}

How does it work regarding the concept of organism? Until now Kant has not definitely determined it. He offers a provisional definition of a "product of nature" that must be

\footnotetext{
${ }^{15} \mathrm{Ak} \mathrm{V} \mathrm{376.} \mathrm{„This} \mathrm{principle,} \mathrm{the} \mathrm{statement} \mathrm{of} \mathrm{which} \mathrm{serves} \mathrm{to} \mathrm{define} \mathrm{what} \mathrm{is} \mathrm{meant} \mathrm{by} \mathrm{organisms,} \mathrm{is} \mathrm{as} \mathrm{fol-}$ lows: an organized natural product is one which every part is reciprocally both end and means. In such a product nothing is in vain, without an end, or to be ascribed to a blind mechanism of nature" (C III 24f.) More precise C III Pluhar 255: "This principle, which is also the definition of organized beings, is: An organized product of mature is one in which everything is a purpose and reciprocally also means. In such a product nothing is gratituitous, purposeless, or to be attributed to a blind mechanism."

16 See Ingensiep 2004.

$17 \mathrm{Ak} \mathrm{V} 369$.

$18 \mathrm{Ak} \mathrm{V} 370$.

$19 \mathrm{Ak}$ V 370.
} 
judged a "physical end” at the same time: „As a provisional statement I would say that a thing exists as a physical end if it is (though in a double sense) both cause and effect of itself." 20 But how is it possible that a natural thing is "cause and effect of itself"? Kant considers the possibility of a contradiction in the statement recognizing a thing as a "natural product" on the one hand, that is determining it by means of understanding, but at the same time judging it as a "physical end" on the other hand, that is reflecting it by means of the faculty of judgement with an end as a concept of reason. For Kant it is true to think a teleological physical causality without logical contradiction, but understanding ("Verstand") is not able to comprehend it by a constitutive use of the categories. Therefore, for Kant a teleological physical causality is a "ungereimter Begriff" (muddled term). Up to here Kant is not yet interested in precising and resolving that potential antinomy but he strives to illustrate this complicated concept of such a natural product which is later called "organism". Thus, Kant tries to produce clear diverse natural reproductive relationships by help of concrete biological examples which are able to be subsumed under such a concept. Thus, now "this idea of a physical end" 21 is illustrated in detail by special relations of reproduction and the growth of a tree, that is a vegetable, not an animal or a human being. ${ }^{22}$

This example is interesting when keeping in mind that plants were considered more a machina hydraulica in a Cartesian manner by scholars of the $18^{\text {th }}$ century. Usually a plant was viewed either as a physical vessel with canals and valves in which liquids are flowing or as an organic machine or as a chemical laboratory. In those days, plants sometimes served as paradigms for mechanistic or materialistic considerations of organisms, not for instance in La Mettrie's well known comparison of humans with machines but in his less known small writing about "The human as a plant"; furthermore other botanists and philosophers of the $18^{\text {th }}$ century tried to understand plants according to the new mechanistic physics. ${ }^{23}$ Thus, plants seemed to be an unsuitable prototype of the organic nature during this time of the rise of physics, chemistry, and physiology. This background of the history of sciences makes it understandable that also Kant had no clear conception of the nature of plants through all his work, especially after irritability and sensitivity of plants became again a topic of research and speculation during the second half of the $18^{\text {th }}$ century. ${ }^{24}$ So it is fairly interesting that Kant tries to illustrate his concept of organism particularly by the paradigm of a tree.

\footnotetext{
20 Ak V 370. (C III 18), C III Pluhar 249: “natural purpose“ instead of „physical end“.

$21 \mathrm{Ak}$ V 371. (C III 18).

22 In modern interpretations there is not found much concerning the background of Kant's "tree"illustration.

23 Julien Offray de La Mettrie (1709-1751): L’Homme Plante (Potsdam 1748). The machine-terminology and mechanistic concept of plants can be found in works by very different scholars like Christian Wolff, Carl von Linné, Stephen Hales, Henri Louis Duhamel du Monceau, Charles Bonnet or Hermann Samuel Reimarus. For instance Stephan Hales (1677-1761) and Duhamel du Monceau (1700-1782) can be seen as prototypic mechanists in experimental plant physiology with their works „Vegetable staticks“ (London 1727) and „La physique des arbres“ (Paris 1758). See also Hans Werner Ingensiep: Geschichte der Pflanzenseele. Philosophische und biologische Entwürfe von der Antike bis zur Gegenwart. Kröner. Stuttgart 2001.

${ }^{24}$ I mention the work of Johannes Friedrich Gmelin (1748-1804), who is inspired by Albrecht's von Hallers (1707-1777) experiments on irritability and sensibility of animals, as in: Irritabilitatem Vegetabilium in sindulis plantarum prtibus exploratam (Tübingen 1768), further on the „Speculations on the Perceptive Power of Vegetables“, first written in 1784 by the physician Thomas Percival (1740-1804) with a German anony-
} 
Kant's statement about the impossibility of a ,Newton of a blade of grass' in $\int 75$ is fairly well known. ${ }^{25}$. Even the production and organisation of this very low weed shall not be recognizable according to mechanical laws. Thus, plants are no anorganic things but "organisms" for Kant, but why? What is specific of Kant's concept of organism that enables it to distinguish plants, as the lowest organisms, from anorganic things?

Kant starts the illustration of his concept of organism by going back to the natural modes of the self-production of a tree, namely regarding the genus and regarding the individual. Firstly, one tree produces another tree of the same genus. "Hence, in its genus, it produces itself." 26 This relation of production can be regarded from two perspectives. On the one hand, a tree may be considered an effect that is a new concrete individual of the same genus. On the other hand, it may be viewed as the cause in this process because it is a tree that produces this other new individual. Thus, a tree gives the causal impulse for the real production of a new organism. In Linnés era it was well known that the ongoing preservation of the genus by an ongoing reproduction of individuals is the end in this natural reproductive process in the kingdom of plants.

From a historical perspective this causality of genus corresponds in its main elements with Aristotle's first basic faculty of the anima vegetativa (psyche threptike), recorded by his commentators Averroës and Avicenna up to the time of scholasticism to Albertus Magnus in a modified way. It is the faculty of generation or vis generativa that makes possible to keep the typical form of species. ${ }^{27}$ In spite of the distance to these former theories this basic function can still be found in the well known writing „Über den Bildungstrieb und das Zeugungsgeschäfte“ (1781) where Johann Friedrich Blumenbach (1752-1840) demonstrates the function of his nisus formativus also within lowest plants. ${ }^{28}$ This is remarkable because Kant was well acquainted with Blumenbachs concept of the "Bildungstrieb" and his theory of epigenesis. Kant explicitly preferred them to his own former and other contemporary concepts of an individual preformation or "Einschachtelungstheorie", also called "evolution" in $\int 81.29$

Kant's second illustration refers to the self-generation of a tree as an individual, usually called growth, but understood as "entirely different from any increase according to mechanical laws". ${ }^{30}$ Kant distinguishes this growing process from a mere quantitative composition in the field of anorganic things. He explicitly underlines the inner transformation of the matter, assimilated by the vegetable, into a new "specifically distinctive quality". In this process of growing an original material mixture of products is produced

mous translation in 1790 under the title: „Also hätten die Pflanzen Vorstellungen und Bewußtseyn ihrer Existenz? Eine Diatribe für Liebhaber der Naturkunde und Psychologie“ (Frankfurt a. M. 1790). See Ingensiep 2004, 275-277 u. 307-312; 317-322.

25 Ak V 400. See Plessner, Helmuth: Ein Newton des Grashalms? In: Ders.: Die Frage nach der Conditio humana. Aufsätze zur philosophischen Anthropologie. Suhrkamp. Frankfurt a. M. 1976, p. 82-99.

26 Ak V 371. C III Pluhar 249 translates „species“ instead of ,genus“ for „Gattung“ thinking that the literal meaning of ,genus“" is ,more technical“ (see footnote 30 ).

27 See. for that and concerning the functions of the aristotelian-scholarly anima vegetativa in Ingensiep (2001, p. 38-60 u. p. 154-175)

28 Blumenbach, Johann Friedrich: Über den Bildungstrieb und das Zeugungsgeschäfte. Johann Christian Dieterich. Göttingen 1781 (§ $\left.2 ; \int 7\right)$.

29 Ak V 424. See Lenoir 1980.

$30 \mathrm{Ak} \mathrm{V} 371$. 
that goes beyond the artificial chemical separation or synthesis of substances. Such a

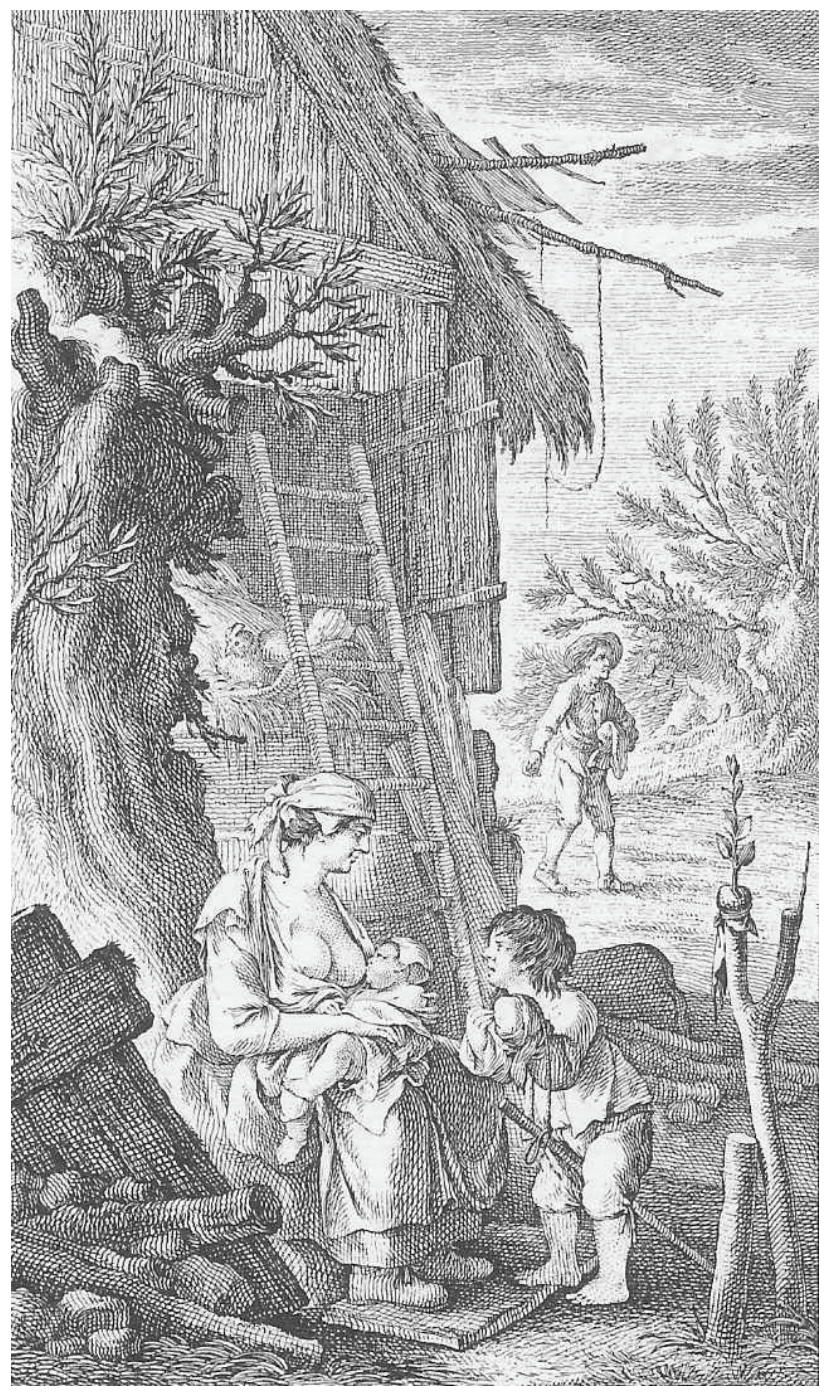

Fig. 1: Engraving beside the title page of Blumenbach's programmatic book about the "Bildungstrieb".

natural organismic way of production is "infinitely outdistances" 31 from all the efforts of chemical art. When comparing a vegetable with a sort of chemical laboratory, then Kant remembers to keep in mind that this organism produces qualitatively new substances itself whereas in a chemical laboratory substances are produced on behalf of a human outer causality.

Besides these allusions to contemporary chemistry this second basic faculty hints to the Aristotelian-scholastic heritage, too, as there are two further faculties of the anima

$31 \mathrm{Ak} \mathrm{V} 371$. 
vegetativa, i. e. the vis nutritiva and the vis augmentativa. The first one causes nutrition, the second proportional growth. Also these organic functions can be found in Blumenbach's concept of the Bildungstrieb. Like Blumenbach, Kant emphasizes that the process of growing must be viewed as a process of individual self-production, that is a sort of "generation", if under a different name"32. It is Blumenbach who considers nutrition "a universal but imperceptably continous [...] generation" 33 . It must be kept in mind that the process of proportional growth the individual as a whole is concerned. Thus, it represents a qualitative unity of production.

Thirdly, Kant adds a variety of phenomena and considerations in order to testify the reciprocally dependent preservation of the parts of a tree. At first, the artificial faculty of producing scions by a gardener is mentioned. On this occasion a part of a plant is transferred to a strange vegetable base where it attaches and produces the specific form of its genus - a proof from practice for the coordinated attachment of different parts of an organism. Kant adds the speculation that every natural individual of a tree could be considered a mode of natural inoculation, that is as a unit consisting of many parts of branches and leaves which coordinate themselves during the process of growing. Kant even speculates about the possibility to denote this organic entity of the tree as "parasitically" 34 because every part of the plant is nourished by others. Similarly, the tree produces leaves and depends on them for growing, a further indicator for the reciprocal preservation of the parts within the whole plant. This second complex of growing and preserving productivity in the organic can be subsumed under the later so called botanical concept of the correlation of growth. But the "parasitically" consideration must be assigned to the conception of an aggregative nature of a plant. ${ }^{35}$

Finally, Kant mentions nature's "own aid in the case of injury" when cut or missing parts of the organism must be completed. In this case the specific organic phenomenon of regeneration is introduced, which has also been known since antiquity. Blumenbach explicitly includes "replacement” („Wiederersetzung“) as a modification into his concept of the "Bildungstrieb" and talks about a faculty able to "repair" (eine Kraft, die „reparirt!"). Blumenbach thinks of this kind of "reproduction” as "a repeated but only partial generation”. 36 At last, in passing Kant adds anomalies of growth, ,abortions or malformations in growth", or completely new formations as characteristic phenomena of organic life. ${ }^{37}$

Kant's illustration of his concept of organism and its specific cause-effect-relations raise the assumption that Kant should have known the only engraving beside the title page of Blumenbach's programmatic book. This engraving illustrates the diverse basic functions of Blumenbach's "Bildungstrieb". Mother Nature as a farmers wife nurses and

\footnotetext{
$32 \mathrm{Ak} \mathrm{V} 371$.

33 Vgl. Blumenbach 1781 \$2, §7: „eine allgemeine, aber unmerklich continuirte [...] Generation“.

$34 \mathrm{Ak} \mathrm{V} 371$.

35 Hegels natural philosophy of plant subjectivity is inspired by the concept of a plant as a multiindividual aggregate similar to parasites working together: „Die Pflanze findet sich nicht in sich, weil ihre Glieder selbstständige Individuen gegen sie sind“. (Hegel, Enzyklopädie 1830 S 337, Theorie Werkausgabe, Suhrkamp. Frankfurt a. M. 1986, Bd. 9 II, S. 342; Ingensiep 2004, S. 350-354).

36 Blumenbach 1781 \ 7: „Reproduction“ als „,eine wiederholte aber nur partielle Generation“.

$37 \mathrm{Ak} \mathrm{V} 372$, again similar Blumenbach.
} 
feeds her children (faculty of nutrition); behind that we find a sitting hen (faculty of augmentation), in the background there is a sowing farmer (generation). Finally, at the left edge of the image, out of the stumps of the branches of a mighty old trunk, may be a willow, new shoots with young leaves come up (regeneration). Furthermore, the stump of the left arm of a boy illustrates an anomaly of growth (natural anomaly) (see figure 1.)..$^{38}$

These heterogeneous examples make the specific cause-effect relations concrete of which Kant is thinking under his concept of organism. At first these examples illustrate the a priori transcendental function of as-if-teleological judgements about an organic natural product. A thing can only be judged as such a natural product under the condition of the concept of an organism. Secondly, Kant includes such phenomena, which incorporate theoretical aspects of the epigenetic model of Blumenbach's "Bildungstrieb", and which must be considered phenomena on the level of an empirical ontology. Thirdly, a tree, that is a plant, is chosen as a prototype for these kinds of phenomena. Thus, plants are explicitly referred to as real organisms and not as a mechanic product of nature. For Kant a tree ideally demonstrates that its parts do not only exist for the other parts or for the whole, but further on, that its organs must be judged to be reciprocally productive both in mutual relationship and with regard to the whole. „Only under these conditions and upon these terms can such a product be an organized and self-organized being, and, as such, be called a physical end." 39 Kant summarizes his theoretical approach in a decisive passage $(\$ 65)$. - Further relations of Kant's concepts of organism to his theory of epigenesis as well as to his concept of life will be examined now, in more detail.

\section{Epigenesis and its ambivalent Role in Kants Philosophy}

Not until the last decades of the $20^{\text {th }}$ century, that is after a state of hibernation of about one and a half century Kant's concept of epigenesis and its significance for and its influence on other scholars were studied more intensively. This happened quite independently of the common significance of Kant's concept of organism. Although Kant's concept of epigenesis was noticed early in relevant Kant-dictionaries and commentaries, particularly Neokantianism underestimated its theoretical significance. ${ }^{40}$ Kant's concept of epigenesis became more important for systematic interests and for the philosophy of sciences when the significance of Biology grew since the 1960s. Especially the epistemo-

\footnotetext{
38 Engraving beside the title page of Blumenbach 1781, also in the 2nd German edition from 1789 which Blumenbach sent to Kant.

${ }_{39} \mathrm{Ak}$ V 374, (C III 22). C III Pluhar 253: „Only if a product meets that condition [as well], and only because of this, will it be both an organized and a self-organizing being, which therefore can be called a natural purpose."

40 The concept is in most cases shortly presented in relevant Kant-dictionaries and handbooks where its role in the Critique of Pure Reason is emphasized, e.g. early in Carl Christian Schmid: Wörterbuch zum leichtern Gebrauch der Kantischen Schriften (4th ed. Crökersche Buchhandlung, Jena 1798, p. 129 u. 216), in more detail in Mellin, G. S. A.: Encyclopädisches Wörterbuch der Kritischen Philosophie (Frommann, Züllichau und Leipzig 1797-1804) where you can find it under the Lemma „Bildungstrieb“ (I. vol. II. Abtheil 1798, S. 710-719), then shortly under „Epigenesis”, but also under „Kategorie“ (III. vol. II. Abtheil 1801, p. 583). Present literature usually does not take these references of Mellin into their account. The concept can also be found in Eisler, R.: Kant Lexikon 1930 / 2 $2^{\text {nd }}$ ed. 1972) under the entries „Bildungskraft“ (p. 70) and „Epigenesis, Entwicklung, Präformation, Kategorie“.
} 
logical dimension of the Critique of Pure Reason became a central issue of interest ${ }^{41}$ as well as its relations to Blumenbach's "Bildungstrieb" 42 , not at least with regard to the critical consideration of evolutionary epistemology ("Evolutionäre Erkenntnistheorie") 43 . Recently its relationship to Herder's ideas and its significance for the roots of Kant's understanding of the categories became a growing issue of interest. ${ }^{44}$ Zammito has not only comprehensively reconstructed the emergence of Kant's Critique of Judgement, he also considered Kant's concept of epigenesis in a new way. ${ }^{45}$ Modern historians of the sciences emphasized Kant's interaction with his contemporaries, the change and the reception of Kant's concept of epigenesis and supported its significance for a nativist interpretation of Kant's a priori. Whether this interpretation goes right or wrong will be discussed now by help of the current dispute and from a systematic point of view.

Beforehand I summarize Kants mature position concerning his view of epigenesis in C III $\int 81$ using the translation of my earlier interpretation by Shaw:

"The substantial characteristic of the epigenesis theory is that the organism eventually comes about and a completely new product will be brought forth, the reality of which is not contained in anything preceeding it. This product always comes about when the following is given: 1. the raw material, 2. the purposive foundation (Anlage) and 3. the inclination to development as the executing agent, which under the guidance of the legislative foundation brings forth the specific form of the organism."

This interpretation seems to be a useful key, also to understand Kants complex formulation in the last sentence of C III $\int 81$, where Kant speaks of "an original organization, a principle that is inscrutable to us, ..." 47 and for its relations to the "formative impulse" and "formative force". 48

41 Wubnig 1969; Genova 1974, Ingensiep 1994

42 z.B. Lenoir (1980)

43 Vollmer 1975, Engels 1989, Ingensiep 1994, note 15.

44 Sloan, Phillip R.: Preforming the Categories: Eighteenth-Century Generation Theory and the Biological Roots of Kant's A Priori. Journal of the History of Philosophy, vol. 40, no. 2 (2002) p. 229-253.

45 John H. Zammito: The Genesis of Kant's Critique of Judgement. The University of Chicago Press, Chicago/London 1992; 'This inscrutable principle of an original organization': epigenesis and 'looseness of fit' in Kant's philosophy of science. Studies in History and Philosophy of Science. 34 (2003) p. 73-109.

46 Shaw 2003, 72 footnote 65. This is a translation of Ingensiep 1994, 383: "Das wesentliche Charakteristikum der Epigenesis-Theorie ist, daß der Organismus nach und nach entsteht und ein völlig neues „Product“ hervorgebracht wird, welches realiter als solches in nichts Vorhergehendem enthalten ist. Dieses "Product" entsteht immer, wenn folgendes gegeben ist: 1. die „,rohe Materie“, 2. die „,zweckmäßige Anlage“ und 3. der „Bildungstrieb“ als das exekutive Agens, welches unter der Anleitung der legislativen „Anlage“ die spezifische Form des Organismus hervorbringt."

${ }^{47}$ C III Pluhar 311.

48 Pluhars translation of this sentence obviously is wrong. It is correct to distinguish between "formative impulse" for german "Bildungstrieb" and "formative force" for german "mechanische Bildungskraft". But the "formative impulse" is not under the guidance "of that formative force" (C III Pluhar 311). Rather the "formative impulse" or "inclination" (Shaw 2003, 72) is subordinated to " an original organization", but never to a "mechanical formative force". Furthermore in this complex sentence of Kant I would emphasize the german word "gleichsam" originaly found in brackets: "(gleichsam unter der höheren Anleitung und Anweisung der ersteren stehender)". This again indicates from my point of view that Kant also here illustrates his understanding of the relation between 1. raw material (moved by a "formative force"), 2. the "Bildungstrieb" ("formative impulse" or "inclination"), acting under the higher guidance and direction of 3. "an original organization", expressed in "the purposive foundation" ("Anlage"). The word "gleichsam" here seems to indicate a kind of analogy and an as-if-teleological description of Kant's thinking about epigenesis according to Blumenbach's concept. But the systematic problem in Kant's thinking is not solved, because he calls this 
In the earlier paper I briefly tried to demonstrate Kant's use of the contemporary biological analogies in his second edition of the Critique of Pure Reason (B \27: "Results of this deduction of the concepts of the understanding". 49 The purpose of my work was to explain the meaning of the biological terms 'generatio aequivoca, epigenesis, preformation' within a systematic and historical context, to show Kant's intentions by using them. In short, Kant used these terms as biological analogies to illustrate the different epistemological positions he was dealing with, especially those of Locke (sensualism), Leibniz (rational dogmatism), and Hume (scepticism). “... it was only for 'intuitive illustration , 50 Zammito echoes my interpretation in order to emphasize that "we must be sensitive to the uses of the analogy, which Kant was prepared to acknowledge..." Z1 Zammito acknowledges: "Indeed, spontaneity and systematicity, two crucial ideas in Kant's theory of reason, find their empirical analogs in the idea of epigenesis in nature." 52 I agree again and maintain further on that epigenesis represents apodicticity, apriority, spontaneity, and productivity of the categories of the intellect, as just mentioned earlier. ${ }^{53}$ I wanted to show that this biological term allowed Kant a dynamic imagination of knowledge as a product of pure intellect (form) and sensuality (matter). Zammito summarizes my explication as follows: "At most, Kant gestured to 'structural similarities', and 'accordingly in no way can it be construed as a claim for any compelling ontological connection between the respective philosophical and biological positions". He translates my intentions and my emphasis of "a clear structural correlation:"

'As, accordingly to the epigenesis theory, unformed inorganic matter gets transformed under the direction of a 'purposive endowment' into something entirely new via the Bildungstrieb and an organism is produced, so via the categories and the raw material of sensibility empirical knowledge is 'produced'. The organizing productivity, however, lies entirely on the side of categorizing understanding. As, via the requisites of the epigenesis theory, from something unformed and unpurposive gradually something specially formed, purposive (according to the most inward interfusion of generative fluids) gets produced, so, similarly, one can conceive the unifying ordering of the manifold by the categories. 154

Thus far, Zammito describes exactly my interpretation, and starts to criticize: "But this does not yet clarify the tension between the concepts of epigenesis and preformation as they featured in Kant's thinking." 55 After that, Zammito continues to deliver important insights into the eighteenth century's debate between preformationists and epigenetisists,

\footnotetext{
"original organization" in german: "unerforschlich" (Pluhar: “inscrutable"). Is the principle "inscrutable" because of it has a priori and not a posteriori-status - a kind of good transcendental metaphysics - or is it "inscrutable" because it contains a relic of bad dogmatic metaphysics?

${ }^{49}$ Ingensiep 1994; following quotation of: The Cambridge Edition of the Works of Immanuel Kant. Critique of pure reason. Translated and edited by Paul Guyer and Allan W. Wood. Cambridge University Press, Cambridge UK, New York USA; Melbourne Australia 1998 (= C I).

50 Zammito 2003, 82: "Ingensiep suggests that Kant did not intend by analogy to extend his formal argument for transcendental philosophy, nor was analogy serving here as a heuristic to enable further discoveries (as in the Kuhnian sense of paradigm); rather it was only for 'intuitive illustration '”

51 Zammito 2003, 82.

52 Zammito 2003, 82.

53 Ingensiep 1994, 392.

54 Zammito 2003, 82f.

55 Zammito 2003, 83.
}

Annals of the History and Philosophy of Biology, Vol. 11 (2006) 
and also into the specific forms of preformation in Kant's thinking based on Sloan's thorough works that show the changes and importance of the concepts of Keime and Anlagen for Kant and their relevance for "the more famous analogy of 1787 to epigenesis." 56 Now, a few remarks to this ongoing debate regarding the role of epigenesis and preformation in Kant's thinking should be made.

Firstly, I agree with Zammito in the systematic point replacing 'autonomy' with 'spontaneity' in Genova's earlier approach to Kant's "epigenesis of pure reason". 57 Genova identified autonomy, community, and reflexivity as three crucial elements in the concept of epigenesis. Community in Kant's first Critique is well known as a category of relation in Kant's table of categories: "Of Community (reciprocity between agent and patient)". ${ }^{58}$ Kant saw some difficulties to its correlation with the form of a disjunctive judgement, "which is what corresponds to it in the table of logical functions" and gives an explanation in his remarks:

"In order to be assured of this agreement one must note that in all disjunctive judgements the sphere (the multitude of everything that is contained under it) is represented as a whole divided into parts (the subordinated concepts), and, since none of theses can be contained under any other, they are thought of as coordinated, so that they do not determine each other unilaterally as in a series, but reciprocally, as in an aggregate (if one member of the division is posited, all the rest are excluded, and vice versa).

Now a similar connection is thought of in an entirety of things, since one is not subordinated, as effect, under another, as the cause of its existence, but is rather coordinated, with the other simultaneously and reciprocally as cause with regard to its determination (e.g., in a body, the parts of which reciprocally attract yet also repel each other), which is to be found in the mere relation of cause to effect (of ground to consequence), in which the consequence does not reciprocally determine the ground and therefore does not constitute a whole with the latter (as the world creator with the world)." 59

Köchy emphasizes that beside its transcendental function "Wechselwirkung" (interaction) in this context concerns not only the things of the world, but is also an attempt to mediate between "Subsistenz" (subsistency) and "Kausalität" (causality) within a synthetic connection of thesis and antithesis. ${ }^{60}$ But there remains a problematic gap between the autonomous elements on the one hand and their interaction as a whole on the other - a transcendental and no longer an ontological gap as in earlier works by Kant. According to Köchy's diagnosis, Leibniz's older metaphysical problem of how homogeneity of a cosmic continuum is compatible with the heterogeneity of autonomous substances is at stake. ${ }^{61}$ This corresponds to a reciprocal exclusion of the interaction elements in the "community", which is indicated by the term "aggregate" - that means a loose collection but not an organic unity. Thus, there remains a mechanistic connotation even in the term community. Later on, in the chapter on schematism, Kant presents "the scheme of com-

\footnotetext{
56 Zammito 2003, 84; Sloan 2001, 2002.

57 Genova 1974; Zammito 2003, 87.

58 B 106, C I 212.

${ }^{59}$ B 112, C I 215-216. See also the work by Kristian Köchy: Das Konzept der „Wechselwirkung“ bei Kant“ in: Ingensiep/Baranzke/Eusterschulte 2004, p. 78-106.

60 Köchy 2004, 87f.

61 Köchy 2004, 89.
} 
munity" as an important synthetic principle on the way from "Anschauung" (intuition) to "Begriff" (concept) as a "Zugleichsein" (co-occurence) of the parts, but not until the level of "synthesis of recognition" is reached it is understandable as simultaneousness. From this point on, only a Newtonian approach at one's own body is possible. ${ }^{62}$ This interpretation of community in Kant's Critique of Pure Reason does not allow to make differences between organic and anorganic things in nature and it seems as if Kant introduced this category in such a way as if organisms did not exist in the material world but only aggregates of matter.

Further on, the problem of spontaneity is connected with this problem of community. From a Newtonian point of view, the organism as a whole does not seem to be spontaneous. But as soon as epigenesis is accepted by Kant as a vital force within a "vital materialism" (Lenoir) or "teleomaterialism" there remains a fundamental problem in the material world of things, since ends and spontaneous forces are only possible within a kind of intelligible monads but not between them. Thus, it is difficult to understand how the concept of community within the Critique of Pure Reason B is compatible to Kant's use of epigenesis in this work.

My second remark regards not the historical analysis but the new interpretation of Kant according to Sloan "Preforming the Categories" and "The Biological Roots of Kants's Apriori" "63. Zammito maintains: "An inadequate grasp of these terms has marred all treatment of Kant's passage at B167 until Philipp Sloan [...]" ${ }^{64}$ First, it must be mentioned that the hint to Crusius" "Mittelweg" (golden mean) can be found not only in modern comments. ${ }^{65}$ It has already been recognized in Mellin's article about Crusius, also regarding the footnote in Kant's Prolegomena. ${ }^{66}$ Further on, the critique of this third way - a system of preformation of the categories - shows indeed more parallels between Leibniz and Crusius than differences. Thus, I agree with Zammito's judgement, "This is Leibnizian to its core", as well as with his following interpretation: "Kant's whole point against the intermediate position of Crusius was that we need a stronger bond between the categories and experience if we are to take seriously the necessity that is the essence of transcendental grounding. That bond could only be achieved if it were selff-formed [selbstgedachA. That is why Kant suddenly invoked the idea of epigenesis." ${ }^{67}$ I would prefer to add that the thinking self is a spontaneous actor in its act of thinking. But necessity relates to the content of these acts, thus we must consider a difference between "Denkakt" und "Denkinhalt", noesis and noema in Husserl's terms, a matter of principle in order to have a better understanding of the systematic point of apodicticity in this context. But beside this, regarding the problem of the subjectivity of causality in B 27 Kant does not refer to Leibniz or Crusius but to Humes's scepticism.

My third remark regards Zammito's following questions: "What could Kant possibly have been thinking at B167? Why, for the first time, would he have put preformation in a

\footnotetext{
62 Köchy 2004, 91.

${ }^{63}$ Sloan 2002.

${ }^{64}$ Zammito 2003, 89.

${ }^{65}$ Zöller 1988; Ingensiep 1994.

${ }^{66}$ Ingensiep 1994, 389 note 11; Mellin 1798, p. $870 f$.

67 Zammito 2003, 90.
}

Annals of the History and Philosophy of Biology, Vol. 11 (2006) 
negative context and epigenesis in a remarkably and unprecedentedly positive one?“ Zammito tries to give an answer by other questions:

"Was there something that Kant now saw in the idea of epigenesis that could help bim elucidate the peculiar and essential spontaneity of the understanding in his transcendental deduction? What did the phrase 'self-thought first principles a priori' signify? If epigenesis needs to be understood on the model of a product, what were the necessary preconditions for immanent emergence? ${ }^{68}$

Zammito asks the right questions, but the answers do not lead to a nativism in Kant's system as seems to be assumed. Indeed, as Zammito points out, not the categories themselves should be seen as preformed, "but only as produced spontaneously by an innate capacity or power - a 'faculty' of mind, whose own origin was utterly inscrutable."69 Thus far I can agree again, but I do not follow when Zammito emphasizes spontaneity and productivity in connection with an "ordering force of the innate ('epigenetic') powers of mind [...]" bound "to be able to produce new knowledge [...] That is, it had to be a real cause (of knowledge), [...] Kant's epigenesis analogy, in short, built intellectual causation (determination; constitution) into the fundamental structure of the transcendental deduction of the possibility of experience." 70 Zammito's conclusions lead not only to the missing of the level of the state of analogy, but also of the fundamental difference between a reflection on genesis and a reflection on validity (Geltung) is neglectet. Indeed, the use of categories in Kant's sense is necessary, not as ontological but as transcendental conditions and a priori grounds (not real causes!) in synthetic judgements with empirical contents. Otherwise, Kant would not have emphasized the necessity in this context. Further on, Kant stresses the circularity of a genetic explanation and asserts that there are no innate notions. On the contrary, all are acquired insofar as they are also self-made by the mind. But in respect of the categories it is sufficient for Kant to show in the transcendental deduction that their necessity and validity is self-thought with rational grounds, but not selfmade by real causes. ${ }^{71}$

My last remark regards the problem of spontaneity as "any radical spontaneity in matter itself' 72 , leading to the problem of bylozoism and further on to the problem of 'life' in Kant's thinking. In his mature philosophy Kant opposes any kind of bylozoism, especially in his Critique of Judgement. This problem leads to the question "What is life?" in Kant's thinking. In the next part this question shall be considered in respect of the modern use of the concept of life. ${ }^{73}$

\section{Considerations to "life" in Kants philosophy}

In contrast to Kant's classical concept of organism in systematical significance and to his concept of epigenesis in historical significance, his concept of life has not been paid all

\footnotetext{
68 Zammito 2003, 92.

69 Zammito 2003, 92.

70 Zammito 2003, 92.

71 Ingensiep 1994, footnote 13.

72 Zammito 2003, 94.

73 See also Zammito 1992.
} 
too much attention to in the era of bioethics. ${ }^{74}$ Especially his concept of life shows how Kant's thinking is still influenced by the traditional doctrine of soul and the so called step-order of souls (Seelenstufenordnung). His notion of life does not coincide with his conceptions of organism or epigenesis. In his critique of teleology "organism" functions as a transcendental, "epigenesis", as an ontological and theoretical concept of biophilosophy. At first, Kant's notion of life serves as a theoretical term, but he uses it as conceptional bridge between his theoretical and his practical philosophy. His concept of life is determined not only by theoretical but also by practical interests. In a theoretical perspective, Kant's special consideration of life is demonstrated in his limitations against physics and hyperphysics as well as in his critical teleological reflections of the concept of organism. Since an organism can neither be conceived as an analogue of a machine, e.g. a clock, nor as an analogue of art or an "analogue of life" ("Analogon des Lebens") a figure of speech that shall be a starting point for the following analysis: ${ }^{75}$

„We might perhaps come nearer to the description of this impenetrable property if we were to call it an analogue of life. But then either we should have to endow matter as mere matter with a property (bylozoism) that contradicts its essential nature; or else we should associate with it a foreign principle standing in community with it (a soul). But, if such a product is to be a natural product, then we have to adopt one or other of two courses in order to bring in a soul. Either we must presuppose organized matter as the instrument of such a soul, which makes organized matter no whit more intelligible. Or else we must make the soul the artificer of this structure, in which case we must withdraw the product from (corporal) nature. Strictly speaking, therefore, the organisation of nature has nothing analogous to any causality known to us."

Zammito convincingly explains that none of these positions seemed to be acceptable for Kant and on this background he wants to clarify Kant's form of "vital materialism" (Lenoir) against Zumbach's reproach for "animism" in Kant's thinking. ${ }^{77}$ The problem is that Kant, indeed, seems to denounce vitalism and materialism. But nevertheless he asserts an "objective reality of forces which could not be reduced to those he admitted in the Newtonian order of physics." 78 In this context some remarks to Kant's concepts of "life", independently of his concept of organism, might be helpful. After that a connection can be looked for. ${ }^{79}$

First of all, concerning the problem of the "analogue of life" in C III, it must be realized why it is a deep epistemological problem for Kant in his transcendental philosophy to explain an organized product of nature as an "analogue of life". Kant used the term "life" in different contexts with different meanings. Transcendental, metaphysical, physi-

\footnotetext{
${ }^{74}$ However, Reinhard Löw (Philosophie des Lebendigen. Suhrkamp, Frankfurt a.M. 1989) has already delivered a scarcely noticed sketch of „Kant's notion of life“ (p. 153-168). Regarding the relationship between organism and life in Kant's thinking, see Ingensiep: „Organismus und Leben bei Kant“ in: Hans Werner Ingensiep, Heike Baranzke und Anne Eusterschulte (Eds.): Kant Reader. Königshausen und Neumann. Würzburg 2004, p. 107-136.

$75 \mathrm{Ak}$ V 374. C III 23.

76 Ak V 374f.; CIII 23. C III Pluhar 254: „We might be closer if we call this inscrutable property of nature an analogue of life."

77 Zammito 2003, 82. Zumbach, C.: The transcendent science: Kant's conception of biological methodology. The Hague: Nijhoff 1984.

78 Zammito 2003, 82.

79 Ingensiep 2004.
} 
cal, physiological, psychological, anthropological, medical and practical dimensions use of this term can be distinguished. ${ }^{80}$ It is fairly important to notice the complex definition in Kant's Metaphysische Anfangsgründe der Natumissenschaft (1786): „Leben ist das Vermögen einer Substanz, sich aus einem inneren Prinzip zum Handeln, einer endlichen Substanz, sich zur Veränderung, und einer materiellen Substanz, sich zur Bewegung oder Ruhe als Veränderung ihres Zustandes zu bestimmen." ${ }^{81}$ (Life is the ability of a substance to determine itself from an internal principle towards action, a finite substance, towards change, and a material substance, towards movement or quietness as a change of its state.) Kant's intention in this context was to specify and to clarify the Newtonian approach to an inanimate, lifeless matter. For Kant there is no space for any kind of "life" in a Newtonian world in the traditional sense of anima as a moving principle within or separated from the matter. In his transcendental view this would lead to statements of traditional metaphysic, to contradictions and circularities in arguments, in short, to a "death of all philosophy of nature". ${ }^{2}$ Even the Newtonian notion of inertia, "Trägheit", is for Kant a concept that is only clear for living beings, not for lifeless matter. Kant is looking for a strong boundary between the anorganic matter and organic "life".

But what does "life" represent in that context of his philosophy of organism? Is the term "life" congruent with the term "organism", including man, animals and plants? Obviously it does not refer to another short definition of „life“ in his Critique of Practical Reason (1788): "Leben ist das Vermögen eines Wesens, nach Gesetzen des Begehrungsvermögens zu handeln." 83 (Life is a being's ability to act according to laws of the ability to desire) In a detailed footnote Kant explains general anthropological and psychological preconditions of human nature in respect to its relevance for practical philosophy - subjective circumstances of human life, like inclination, desire, interests. These aspects of "life" are for Kant only subjective and empirical starting points for his analysis that leads to the formulation of the categorical imperative as a basis for a moral "life" of humans. Here it seems that Kant defines "life" within the very narrow bounds of anthropological interests in practical philosophy. In this narrow sense of an interpretation of "life" only an animal rationabile would be able to have insights into these "laws of the ability to desire" but, in general, never an animal. In this sense today's members of a moral community like animals do not have a "life".

On the other hand, in the Critique of Judgement Kant does not defend animals as automatic machines, rather he opposes Descartes. ${ }^{84}$ His lectures on metaphysics contain speculations in a Leibnizian manner, concerning animal souls as monads. Kant seemed to be convinced that "animals have souls", although mostly Kant keeps distance from

\footnotetext{
80 More in detail see Löw 1980, Ingensiep 2004, 116-128.

81 Ak IV 544.

82 Ak IV 544.

$83 \mathrm{Ak} \mathrm{V} 9$.

${ }^{84} \mathrm{Ak} \mathrm{V} 464$ footnote. Kant illustrates his understanding of ,Analogy“ comparing ations of the human reason with those of animal instinct like the buildings of beavers. Kant rejects Descartes' concept of animals "being machines". Further on he notes that animals and man "are still of the same general kind [Gattung] (namely, as living beings)." C III Pluhar $356 f$.
} 
the famous discussion on animal souls in the $18^{\text {th }}$ century. ${ }^{85}$ In reflections on metaphysics Kant designates animals like dogs even as automata spiritualia, indicating that an animal could have a monad-like soul but is not a free being and determined like a machine. ${ }^{86}$ In another case Kant connects the "life" of an animal to "eine absolute Einheit der sich selbst bewegenden Kraft einer Materie" (an absolute unity of the self-moving power of matter), including unity, self-motion, and spontaneity in his concept of animal, and perhaps his epigenetic concept of organism. ${ }^{87}$ It is decisive that animals seem to possess a soul, a soul which is also capable for desire. Insofar also animals as "organisms" do have a soul and "life", but do also plants?

As mentioned above, Kant holds that plants were prototypes of organisms and a possibility to demonstrate phenomena and effects of the "Bildungstrieb" in nature according to Kant's understanding of Epigenesis in the Critique of Judgement. If plants also possessed "life" in the sense as already explained according to man and animals, Kant would have some more problems because, in consequence, even plants should have a kind of soul - though not in an Aristotelian and scholastic sense of psyche and anima like in traditional metaphysics ${ }^{88}$ but probably in the sense of metaphysical psychology (according to the Leibniz-Wolff-school) or in the more modern sense of an empirical psychology connected to an individual subjective consciousness. It is fairly likely that Kant was familiar with and stimulated by the vivid debates on these questions regarding the nature of plants in the $18^{\text {th }}$ century. ${ }^{89}$ Here it is important to know indicators of "life" in the sense of an empirical psychology, e.g. feelings, desire, consciousness. Kant knew the discussion on irritability and sensivity of plants ${ }^{90}$, and sometimes indeed he used the term "life" while speaking of an immaterial principle in plants. ${ }^{91}$ But nowhere Kant defended any kind of a plant soul. Plants were for Kant neither machines nor sensitive beings. Above we have heard ( $\int 64 \mathrm{C}$ III) that plants are prototypes of "organisms", but we must conclude that they are organisms without any kind of "life" in the psychological sense. But in a wider sense of "life" they obviously have an inner principle, an epigenetic life, because plants are real organisms as the famous "blade of grass" indicates, at least

\footnotetext{
85 Metaphysik Dohna, Ak XXVIII 689f. see also Baranzke, Heike: Würde der Kreatur. Die Idee der Würde im Horizont der Bioethik. Würzburg 2002, 189; Narragon, Steve: Kant on Descartes and the brute. KantStudien 81, 1990, 1-23. Ingensiep, Hans Werner: Tierseele und tierethische Argumentationen in der deutschen philosophischen Literatur des 18. Jahrhunderts. International Journal of History and Ethics of Natural Sciences, Technology and Medicine N.S. Vol. 4 Nr. 2 1996, 103-118. The existence of an animal soul and problems of animal ethics are often discussed in German philosophical literature, especially in response to the Cartesian theory of the beast machine. I present insights into early discussions and doctrines from Winkler, Meier and try to unfold some strategies for legitimating the death of animals. Also included are contemporary concepts of obligation to animals within the discussion of natural rights, e.g. Pufendorf, Thomasius, and Kant, and the early considerations on animal rights (Dietler, Smith).

86 Ak XVII 313.

87 Ak XV 957; Löw 1980, 165.

88 In Träume eines Geistersehers (1766) Kant mentions a „principle of the inner life“ („Principium des inneren Lebens“ Ak II 331) and he criticises the traditional three-step-order of souls: „Die Alten glaubten nämlich dreierlei Art von Leben annehmen zu können, das pflanzenartige, das thierische und das vernünftige."

89 See Ingensiep 2001.

90 In his Physische Geographie (1802) he notes Mimosa pudica, the sensitive plant with a specific reaction of its leaves after touch, "als wenn sie Empfindungen hätte" (as if it is sentient) Ak IX 364.

91 Ak XXI 196, Ak XXII 510.
} 
from a theoretical point of view. On the other hand, in moral contexts plants are never compared with animals, rather they have the same status as inorganic matter. ${ }^{92}$

We may summarize: Kant has a zoocentric concept of "life" when using the narrow definitions of "life" covering animals and man. His fear of bylozoism tries to avoid endowing inorganic matter with any kind of psychological life as a principle of motion whether within or separated from, although in community with matter. Nevertheless, we can find different stages of "life" according to the traditional three-step-order of souls (Seelenordnung), well known since Aristotle and its functions of psyche - anima vegetativa, sensitiva, rationalis. Plants are very useful prototypes for illustrating a vegetative life as "organisms". But this kind of life is only mediated by a nisus formativus in the sense of Blumenbach's Bildungstrieb. Plants were demonstrated as ideal prototypes of epigenetic organisms, as shown in his illustrations in C III $\int 64$. This short summery of all the steps done in the given analysis reveal that Kant's considerations on organisms, epigenesis, and life mark a critical point within the history of ideas. Kant cleverly uses plants in this systematically important context after splitting off the term "life" in different meanings according to the traditional three-step-order in the kingdom of organisms.

On this occasion I add some remarks on the detailed analysis recently presented by Zammito (2006) concerning Kant's concept of teleology taking into consideration my interpretation of the distinction between organism and life in Kant's thinking. ${ }^{93}$ I agree that Kant "wanted to eschew metaphysics" and that Kant's passage referring to an 'analogue of life' in C III "brings all this to a decisive head." The same way: "Life, it appears, comes with heavy metaphysical baggage." Indeed hylozoism was an anathema to Kant and it remains a deep metaphysical problem within the concept of live if this concept is restricted to intelligent will leading to the question: is man the only living thing? Difficult as it may be we have to consider how far life can be understood in "terms of the Aristotelian scale of being" and to discuss my statement: "Thus, plants epitomize Kant's conceptual discrimination of life from organism" indicating that the "notion of organism is broader than that of life, and the failure of these two terms to have the same extension expresses the insufficiency Kant acknowledged in his ‘analogy of life' for natural purpose.”

So far this analysis of the biophilosophical situation confirms my observation: "Not only the Kantian but also the modern struggle to discriminate a conceptual difference between "organism" and "life" leads ultimately back to the roots of entelechy in Aristotelian substance theory." I repeat there exists a hidden trap in Kant's concept of teleology on the bio-ontological level concerning plants, animals and human beings. But nevertheless I disagree with Zammito on the point that all this is of high relevance for Kant's transcendental philosophy and his system in general. It is not necessary to claim: "Organism is a capital anomaly. It will not fit in Kant's system of science, and yet without a good account of it, the system itself must in the end appear inadequate". ${ }^{4}$ First, beyond contemporary talk about naturalism and functionalism it is still necessary to go into more details concerning the meaning of organism and life from a systematic Kantian point of view i.e. with strict distinction of analogy, bio-ontology and transcendental philosophy in these con-

\footnotetext{
92 See Metaphysische Anfangsgründe der Tugendlehre (1797 \$17) Ak VI 443.

93 Zammito 2006 pp. 761-764.

94 Zammito 2006 pp. 763-764.
} 
texts. Next we have to ask how far the distinction of the two concepts organism and life is relevant for modern bioethics. ${ }^{95}$

\section{Is it relevant for modern biophilosophy and bioethics?}

What is the output of the analysis of the Kantian concepts of organism, epigenesis, and life for our present? Firstly, the Kantian concept of organism is relevant for biophilosophy only within limits; secondly, Kant's concept of epigenesis is completely irrelevant for modern biophilosophy and biology but fairly helpful as a historical phenomenon in order to achieve a more adequate understanding of Kant's argumentation. But thirdly, Kant's concept of life is of surprisingly topical interest, thus the meaning of the concepts of organism and life can be questioned again.

Ad 1. The short analysis of Kant's term of organism from a systematic and empiricalhistorical viewpoint have already shown that Kant connected various components close to or inspired by contemporary concepts, e.g. Blumenbach's, with his concept of ,selforganisation“ in the organic field. The example of the tree shows how the term of ,selforganisation" is tailored to very concrete biological phenomena. Thus, the concept of epigenesis cannot easily be removed from this concept of "self-organisation". In consequence, Kant's concept of "self-organisation" does not correspond to the modern universal term of self-organisation although some interprets believe so. ${ }^{96}$

Further on, it is important to notice that Kant confronts the organism as a totalitarian idea of reason with empirical cases. The totalitarian claim can be noticed when Kant describes the organism as follows: "In such a product nothing is in vain, without an end, or to be ascribed to a blind mechanism of nature." 97 Today, this claim of totality can be justified as a method of searching for concepts and as a heuristic principle of research. For: how should, for example, an identical reproduction, a partial regeneration, or an anomaly be judged without the biophilosophical and biological key concept of "organism"? For Kant, organism is an a priori and as-if-teleological ideal concept with regulative function. "Organism" does not only define a central object of biology that allows to describe, classify, and explain an infinite variety of such objects in concrete phenomenological derivations and variations. Furthermore, in such an ideally determined concept of organism its heuristic function can be found in order to search methodically for causes of the described phenomena and alterations. In so far, Kant's concept of organism is still useful for the determination of objects.

However, Kant's concept of organism is not restricted to the justification of mere biological definitions and of methods as indicated by Kant's later speculative use of the

\footnotetext{
95 In this place is not possible to discuss the extensive and fruitful questions of Zammito's new analysis. Concerning the relevance for criteria in bioethics, brain-death, plants etc. see Akerma 2006 chap. 13.

96 Krohn, Wolfgang; Krug, Hans-Jürgen; Küppers, Günther: Die natürlichen Ursachen der Zwecke. Kants Ansätze zu einer Theorie der Selbstorganisation. In: Niedersen, Uwe (ed.): Selbstorganisation. Jahrbuch für Komplexität in den Natur-, Sozial- und Geisteswissenschaften. Bd. 3, 1992, 31-50.
}

${ }^{97} \mathrm{Ak} \mathrm{V} 376$. 
term in the Opus postumum, and as this was also noticed by the Neo-Kantians. ${ }^{98}$ That Kant already is going beyond this limited use in the critique of the teleological faculty of judgement can be noticed not only in the following paragraphs and in the architecture of his whole work. Also the smooth formulation in the passage about the organism, which Kant does not want to "ascribe anything to a blind natural mechanism", indicates this extended use. This may be true to the transcendental justification of the idea of the organism, but it does not apply for the reality of concrete organisms, that means for the wide field of objects of empirical and theoretical biology. By help of this kind of formulation Kant left open the door for the hypothesis of a quasi-Newtonian vital power, that is the "Bildungstrieb" in the sense of Blumenbach. Today, after Darwin or after the knowledge of modern theories of biogenesis, we know that Kant carried the concept too far. Certainly, he conceded that some parts of organisms, e.g. of animals, can be understood according to mechanical laws, "yet the cause ... must always be estimated teleological. Hence, everything in the body must be regarded as organized, and everything, also, in a certain relation to the thing is itself in turn an organ." ${ }^{\text {"99 }}$ This formula serves only as a principle of judgement for a static morphology, anatomy, and physiology, but not any longer for modern biology. Certainly, also the latter needs a concept of organism and questions for the function of the value of adaptation of certain organs; but the evolutionary and dynamical biology of modern times does not start with fixed organisms or species but with a 'Newton of a leaf' in order to conceive phylogenesis and ontogenesis as dynamical natural processes. Kant, too, lives on the Aristotelian heritage when connecting the transcendental concept of an organism to an ontological concept of epigenesis, although he definitely settles the teleological principle of judgement into the subject and does not suppose an entelechy in the object but a teleological and productive faculty.

After all, Kant seems to have tied back a theoretical bridge when conceptually determining the maxim of the judgement of organisms because he did not trust in ,blind natural mechanism" to be capable of the original production, nutrition, maintenance, and reproduction of organisms. Thus, he holds it as logically possible to be thought by reason, but not as conceivable according to the causality of natural laws by the intellect. Therefore, the theoretical reason had to help with the idea of the reflective faculty of judgement in order to understand something in the frame of the a priori system which for the categorical determining intellect in the empirical field is only possible when introducing the minimal metaphysics of epigenesis.

Ad 2. Thus, there concludes that Kant's appreciation of the epigenesis does not serve modern biophilosophy and biology. It is true that this epigenetic concept of organism could draw attention on the neovitalistic biology in the first third of the $20^{\text {th }}$ century, but

\footnotetext{
98 Heimsoeth, Heinz: Kants Philosophie des Organischen in den letzten Systementwürfen. Untersuchungen zum Anlaß der vollendeten Herausgabe des Opus postumum. Blätter für Deutsche Philosophie. Vol. 14., Issue 1/2, 1940, 81-108. See: Ingensiep, Hans Werner: „Die Welt ist ein Thier: aber die Seele desselben ist nicht Gott“. Kant, das Organische und die Weltseele. In: Hans Werner Ingensiep und Richard Hoppe-Sailer (Eds.): NaturStücke. Zur Kulturgeschichte der Natur. Edition tertium. Ostfildern 1996, p. 101-120.

$99 \mathrm{Ak}$ V 377.
} 
for modern biology, essentially based on molecular biology and evolutionary theory, it is heuristically not fruitful. This is well known. ${ }^{100}$

Ad 3. This is wholly different in respect of Kant's concept, or rather a variety of concepts of life, but probably he prefers a psychological concept. From that point of view a surprising neighbourhood to an utilitarian concept of life, although not to utilitarian bioethics, may be discovered. What does this mean? If life is reduced to individual conscious experience and connected to the psyche of an individual and its interests or striving for happiness, then "life" will be ascribed to most of human beings and higher animals but neither to plants nor to lower organisms nor to any anorganic entities. In modern bio(!)ethics this narrowed concept of life is fundamental, at least of highly relevance in pathocentric or sentientistic utilitarian versions like e.g. Peter Singers pathocentric preference utilitarianism. ${ }^{101}$ Because the capabilities of having feelings, desires, or a conscious will are central and enables to be considered in the utilitarian moral calculus. From this ethical background there concludes that certain human states of existence like early embryos, sick people in a persistent vegetative status, so called "human vegetable", or those dying people who fall in a coma, are not any longer called "living beings" but only "organisms". 102

Consequently, the term "life" becomes irrelevant for plants and lower organisms which do not have any experiences. They, too, can no longer be called „living beings“ but only „organisms“, as Akerma states, who this way reveals an important theoretical problem of this concept of life. Today, traditional functions of the anima vegetativa like nutrition, growth, reproduction as well as regeneration and correlation in the organism are considered purely physiological processes which can be explained through physico-chemical laws without any psyche. A special criterion that distinguishes these organisms from anorganic entities like the special vital power in the case of epigenesis is out of the question. Thus, so-called buman vegetable and plants sink down to the level of an organic machinery which owns a recognizable life only in a metaphorical sense. Such organisms do function but do not live. This theoretical and reduced concept of life serves to install a two-tier society like in pathocentric utilitarianism. But two significant differences to Kant's position, a theoretical and a practical one, should be emphasized now.

The theoretical analysis of the concepts of organism and epigenesis showed that Kant judged both of them from the perspective of an object-centered inner teleology. This connection puts a strain on Kant's theory of knowledge although he puts the concept of ends inside the reason of the subject of knowledge. But in case of the concept of life Kant obviously takes on the subject-centered perspective of feeling, experiencing, willing and acting. Indeed, Kant ties life to the state of subjectivity that appears psychic only in time but not materialistic in space and time. In so far, the theoretical biophilosophical analysis is interested in separating the concept of life from that of organism.

\footnotetext{
100 Zumbach 1984.

101 Peter Singer: Practical Ethics. Cambridge: Cambridge University Press 1979. Second Edition 1993.

102 See Akerma, Karim: Wann beginnt menschliches Leben? In: conceptus. Zeitschrift für Philosophie. No. 82, Jg. XXXIII/1 2000, p. 133-146.
} 
Secondly it should be mentioned that Kant knows the state of vegetating with regard to humans as a pejoratively evaluating concept in the spirit of the $18^{\text {th }}$ century. Thus, he uses it e. g. in his early work Allgemeine Naturgeschichte und Theorie des Himmels (1755) where not only cosmological, but also morally anthropological ideas are illustrated: „Wenn man das Leben der meisten Menschen ansieht: so scheint diese Creatur geschaffen zu sein, um wie eine Pflanze Saft in sich zu ziehen und zu wachsen, sein Geschlecht fortzusetzen, endlich alt zu werden und zu sterben." 103 (If you look at the lives of most people: this creature seems to be made for taking in juice, like a plant, and for growing, for continuating its lineage, for finally becoming old and die.) But with regard to ethics neither this comparison nor Kant's concept of life is constitutive like it is in modern utilitarianism. On the contrary, the Kantian version of life delivers an object for critical ethical analysis. In short: living in the sense of experiencing is not a quality by itself. Pure experience, that means an ontological state or process, does not sufficiently qualify life in ethical respect. Rather, life is evaluated deontological, according to the Categorical Imperative delivering an ideal standard for respecting persons as ends in themselves. Quality in Kant's eyes is what supports the rational project of humanizing, civilizing, and moralizing humans in the world, but not living as experiencing by itself. This point is crucial to be considered when believing to separate the concepts of life and organism. That is the decisive difference between the Kantian and the utilitarian ethical perspective towards life. ${ }^{104}$

\section{Literatur}

Akerma, K. (2000) Wann beginnt menschliches Leben? Conceptus. Zeitschrift für Philosophie 82 Jg. XXXIII/1, pp. 133-146.

Akerma, K. (2006) Lebensende und Lebensbeginn. Philosophische Implikationen und mentalistische Begründung des Hirn-Todeskriteriums. LIT, Münster.

Baranzke, H. (2002) Würde der Kreatur? Die Idee er Würde im Horizont der Bioethik. Königshausen \& Neumann, Würzburg.

Blumenbach, J. F. (1781) Über den Bildungstrieb und das Zeugungsgeschäfte. Johan Christian Dieterich, Göttingen.

Cheung, T. (2006) From the organism of a body to the body of an organism: occurrence and meaning of the word 'organism' from the seventeenth to the nineteenth centuries. British Society for the History of Science 39 (3) pp. 319-339.

\footnotetext{
$103 \mathrm{Ak}$ I 356.

104 On this background it would be interesting to go in further examinations of the history of the significance and the ambiguities of the word ,life" in the $18^{\text {th }}$ century with regard to plants and humans before and after Kant. E.g. in an informative passage of Crusius' Entwurf der notwendigen Vernunftwabrheiten (Leipzig 1745) it is criticised by him that plants and trees were living things. He argues to use the word "live" in this context only as a tropical application. (see: Akerma 2000, S. $141 \mathrm{f}$., Ingensiep 2004, p. 134f.). Treviranus, too, noticed the ambiguity in the word life in his Biologie (Göttingen 1802, p. 21). Concerning the use of "vegetative, life etc." see Ingensiep, H. W.: Leben zwischen "Vegetativ" und "Vegetieren". International Journal of History and Ethics of Natural Sciences, Technology and Medicine (NTM) 14 2006, 65-76.
} 
Driesch, H. (1928) Philosophie des Organischen. 4th ed. Quelle \& Meyer, Leipzig.

Eisler, R. (1930) Kant Lexikon 2nd ed., Reprint 1989 Olms, Hildesheim.

Flury, A. (1999) Der moralische Status der Tiere. Alber. Freiburg, München.

Fox Keller, E., Lloyd, E. A. (eds.) (1992) Keywords in Evolutionary Biology. Harvard University Press, Cambridge Mass.

Girtanner, C.(1796) Ueber das Kantische Prinzip für die Naturgeschichte. Ein Versuch diese Wissenschaft philosophisch zu behandeln. Vandenhoek \& Ruprecht, Göttingen.

Heimsoeth, H. (1940) Kants Philosophie des Organischen in den letzten Systementwürfen. Untersuchungen zum Anlaß der vollendeten Herausgabe des Opus postumum. Blätter für Deutsche Philosophie. Vol. 14, 1/2, pp. 81-108.

Ingensiep, H. W. (1994) Die biologischen Analogien und die erkenntnistheoretischen Alternativen in Kants Kritik der reinen Vernunft B \ 27. Kant-Studien 85, pp. 381-393.

Ingensiep, H. W. (1996) Tierseele und tierethische Argumentationen in der deutschen philosophischen Literatur des 18. Jahrhunderts. International Journal of History and Ethics of Natural Scieneces, Technology and Medicine (NTM) 4 Nr. 2 pp. 103-118.

Ingensiep, H. W. (1996) “Die Welt ist ein Thier: aber die Seele desselben ist nicht Gott”. Kant, das Organische und die Weltseele. In: Ingensiep, H. W., Hoppe-Sailer, R. (Ed.): NaturStücke. Zur Kulturgeschichte der Natur. Edition tertium. Ostfildern, pp. 101-120.

Ingensiep, H. W. (2004) Organismus und Leben bei Kant. In: Ingensiep, H.W., Baranzke, H., Eusterschulte, A. (Ed.): Kant Reader. Was kann ich wissen? Was soll ich tun? Was darf ich hoffen? Königshausen \& Neumann, Würzburg pp. 107-136.

Ingensiep, H. W. (2006) Leben zwischen "Vegetative" und "Vegetieren". International Journal of History and Ethics of Natural Sciences, Technology and Medicine (NTM) 14, pp. 65-76.

Jonas, H. (1973) Organismus und Freiheit. Ansätze zu einer philosophischen Biologie. Vandenhoeck \& Ruprecht, Göttingen.

Kant, I, Akademie-Ausgabe. Kant's gesammelte Schriften (ed. Königlich Preußischen Akademie der Wissenschaften), Berlin, Leipzig, $1902 \mathrm{ff}$.

Kant, I. (1952) The Critique of Judgement. Part II Translated with Analytical Indexes by James Creed Meredith. Clarendon Press, Oxford.

Kant, I (1987) Critique of Judgement. Including the First Introduction. Translated by Werner S. Pluhar. Hacket Publishing Company. Indianapolis, Cambridge.

Kant, I (1998) The Cambridge Edition of the Works of Immanuel Kant. Critique of pure reason. Translated and edited by Paul Guyer and Allan W. Wood. Cambridge University Press, Cambridge, UK, New York, Melbourne. 
Kanz, K. T. (2002) Von der BIOLOGIA zur Biologie. Zur Begriffsentwicklung und Disziplingenese vom 17. bis zum 20. Jahrhundert. In: Die Entstehung biologischer Disziplinen II. Verhandlungen zur Geschichte der Theorie der Biologie Bd. 9 Hoßfeld, U., Junker, T.;eds.) Berlin pp. 9-30.

Köchy, K. (2003) Perspektiven des Organischen. Biophilosophie zwischen Natur- und Wissenschaftsphilosophie. Ferdinand Schöningh, Paderborn.

Köchy, K. (2004) Das Konzept der „Wechselwirkung“ bei Kant. In: Ingensiep, H. W., Baranzke, H., Eusterschulte, A. (Ed.): Kant Reader Was kann ich wissen? Was soll ich tun? Was darf ich hoffen? Königshausen \& Neumann, Würzburg pp. 78-106.

Krohn, W., Krug, H-J., Küppers, G. (1992) Die natürlichen Ursachen der Zwecke. Kants Ansätze zu einer Theorie der Selbstorganisation. Jahrbuch für Komplexität in den Natur-, Sozial- und Geisteswissenschaften. Vol. 3 pp. 31-50.

La Mettrie, J. Offray de (1748) L'Homme Plante. Potsdam.

Lenoir, T. (1980) Kant, Blumenbach and Vital Materialism in German Biology. ISIS 71 (No. 256), pp. $77-108$.

Löw, R. (1989) Philosophie des Lebendigen. Suhrkamp, Frankfurt a.M.

Maturana, H. (1985) Erkennen: Die Organisation und Verkörperung von Wirklichkeit. 2nd Ed. Friedrich Vieweg \& Sohn, Braunschweig, Wiesbaden.

Mayr, E. (1991) Eine neue Philosophie der Biologie. Piper, München, Zürich.

Mellin, G. S. A. (1797-1804) Encyclopädisches Wörterbuch der Kritischen Philosophie. Fromann, Züllichau, Leipzig.

Mittelstraß, J. (ed.) (1984) Enzyklopädie Philosophie und Wissenschaftstheorie. Bd. 2 Wissenschaftsverlag Bibliographisches Institut. Mannheim, Wien, Zürich.

Murphy, M. P., O’Neill, L. A. J. (Eds.) (1997) Was ist Leben? Die Zukunft der Biologie. Eine alte Frage in neuem Licht - 50 Jahre nach Erwin Schrödinger. Spektrum Akademischer Verlag. Heidelberg, Berlin, Oxford.

Plessner, H. (1976) Ein Newton des Grashalms? In: Plessner, H., Die Frage der Conditio humana. Aufsätze zur philosophischen Anthropologie. Suhrkamp, Frankfurt a. M., pp. 82-99.

Plessner, H. (1975) Die Stufen des Organischen und der Mensch. Einleitung in die philosophische Anthropologie. 3rd ed. Walter de Gruyter \& Co, Berlin, Leipzig.

Regan, T. (1983) The Case for Animal Rights. Routledge, London, New York.

Rensch, B. (1968) Biophilosophie auf erkenntnistheoretischer Grundlage. Panpsychistischer Identismus. Fischer, Stuttgart.

Ritter, J., Gründer, K. (Ed.) (1980): Historisches Wörterbuch der Philosophie Vol. 5. Schwabe \& Co. Ag., Basel, Stuttgart, pp. 52-103.

Ruse, M. (ed.) (1998) Philosophy of Biology, Prometheus Books, Amherst, New York. 
Schmid, C. C. (1798) Wörterbuch zum leichtern Gebrauch der Kantischen Schriften. 4th ed. Crökersche Buchhandlung, Jena.

Schrödinger, E. (1944) What is Life? The Physical Aspect of the Living Cell. Cambridge University Press, Cambridge.

Shaw, B.W.(2003): Function and Epigenesis in Kant's Critique of Pure Reason. Thesis. Master of Arts. Philosophy. The University of Georgia, Athens, Georgia. (Full-text Document: shaw_brandon_w_200308_ma.pdf)

Singer, P. (2005) Practical Ethics. 2nd ed. (1993) Cambridge University Press, Cambridge UK.

Sloan, P. R. (2002) Preforming the Categories: Eighteenth-Century Generation Theory and the Biological Roots of Kant's A Priori. Journal of the History of Philosophy, vol. 40, no. 2 , pp. 229-253.

Sutter, A. (1988) Göttliche Maschinen. Die Automaten für Lebendiges bei Descartes, Leibniz, La Mettrie und Kant. Athenäum, Frankfurt a.M.

Ungerer, E. (1926) Die Regulationen der Pflanzen. Ein System der ganzheitsbezogenen Vorgänge bei Pflanzen. 2nd ed. Julius Springer, Berlin.

Van Hoorn, T. (2004) Dem Leibe abgelesen. Georg Forster im Kontext der physischen Anthropologie des 18. Jahrhunderts. Hallesche Beiträge zur Europäischen Aufklärung 23. Niemeyer, Tübingen.

Vollmer, G. (1995) Biophilosophie. Reclam, Stuttgart.

Zammito, J. H. (1992) The Genesis of Kant's Critique of Judgement. The University of Chicago Press, Chicago, London.

Zammito, J.H. (2003) 'This inscrutable principle of an original organization': epigenesis and 'looseness of fit' in Kant's philosophy of science. Studies in History and Philosophy of Science 34, pp 73-109.

Zammito, J. (2006) Teleology then and now: The question of Kant's relevance for contemporary controversies over function in biology. Studies in History and Philosophy of Biological and Biomedical Sciences 37, 748-770.

Zumbach, C. (1984) The transcendent science: Kant's conception of biological methodology. Nijhoff, The Hague.

\section{Address for correspondence:}

Hans-Werner Ingensiep

Universität Duisburg-Essen

FB 1 Philosophie

Universitätsstr. 12

D- 45117 Essen, Germany

h.w.ingensiep@uni-essen.de 


\title{
Nikolaj A. Livanow (1876 - 1974) and the living relict Acanthobdella peledina (Annelida, Clitellata)
}

\author{
U. Kutschera \& V. M. Epshtein
}

Abstract

The Clitellates are segmented worms (Annelida) that are characterized by a glandular girdle responsible for cocoon production. They are usually classified as the Oligochaeta (earthworms and allies) and the Eubirudinea (true leeches); these carnivorous clitellates use two suckers for attachment and crawling. In 1850, A. E. Grube discovered a primitive leech with only one (posterior) sucker and earthworm-like cephalic chaetae for attachment to its host. The anatomy of this living relict (Acanthobdella peledina) was described by N. A. Livanow in 1906. Our knowledge of A. peledina is based on Livanow's detailed and comprehensive monograph in which this fish parasite is identified as an ancient hirudinean. In this article we describe the life and major scientific works of N. A. Livanow and summarize his contributions to annelid systematics. We also review the life cycle and phylogenetic position of the connecting link, A. peledina, based on anatomical studies and DNA sequence data. It is concluded that both Livanow's bypotheses concerning the phylogenetic relationships within the clitellata and his interpretation of the living fossil A. peledina were correct. In addition, the second Acanthobdella species, A. livanowi Epshtein 1966, is briefly described and commented on.

\section{Introduction}

One century ago a seminal paper was published in the German periodical Zoologische Jahrbücher, Abteilung für Anatomie und Ontogenie der Tiere that later became a citation classic in the literature on the taxonomy of the "segmented worms" (class Annelida). The Zoologische Jahrbücher were founded in 1886 by J. W. Sprengel and are nowadays continued under the new title, Zoology. In 1906, the Russian zoologist N. A. Livanow published a comprehensive monograph entitled "Acanthobdella peledina Grube, 1851" (230 pages, with numerous figures and plates) that was supplemented and updated by the author Livanow in a famous publication of 1931. In this second article, which was largely based on his classical original paper, the relationships between the Hirudinea (leeches) and the Oligochaeta (earthworms and related taxa) were analysed, and a phylogenetic hypothesis was proposed (Livanow 1906, 1931).

In the year 2001, an international team of invertebrate zoologists published a paper in the journal Molecular Phylogenetics and Evolution, wherein the authors confirmed the basic conclusions of the Russian scientist that were drawn exclusively on the basis of anatomical studies, combined with the strict use of the comparative method. In the title of this multiauthor-article the Russian zoologist is explicitly acknowledged: " Validating Livanow: Molecular data agree that ..." (Siddall et al. 2001). In spite of the fact that N. A. 
Livanow is still frequently cited in the scientific literature, nothing is known in the Western world about the life and work of this eminent biologist. The aim of this historical account is to describe the career and achievements of Livanow, with special reference to the "living fossil-leech" Acanthobdella peledina (Grube 1850).

\section{Nikolaj A. Livanow: a short biography}

The biographical data summarized here were obtained from several journal articles published in Russian. The senior author (V. M. Epshtein) translated the pertinent literature into English so that a brief summary of the life and scientific work of Livanow could be

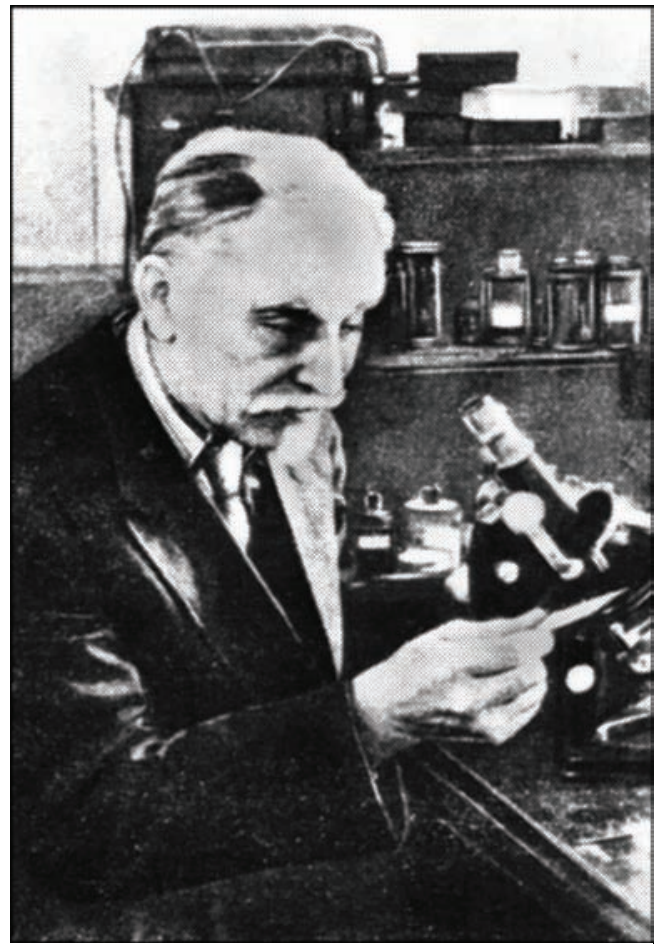

Fig. 1: Nikolaj Alexandrovich Livanow (1876 - 1974) in his laboratory. compiled.

The Russian zoologist and evolutionist Nikolaj Alexander Livanow (1876 - 1974) was born 20. November 1876 in Saratow. A few months after his birth the family moved to the town Wjatka, where Nikolaj's father was employed as a school inspector.

When he lived in Wjatka and Kazan he attended a Gymnasium and left school in 1895 with excellent credits (Livanow was awarded the prestigious "gold medal"). In the same year, he began his studies in natural science at Kazan University and received his diploma (1st. grade) in 1899. In 1902 the 26-year old biologist published a monograph on leeches of the genus Hemiclepsis (Livanow 1902); this contribution was his first scientific publication. His pioneering paper on Acanthobdella peledina was published in 1905 in German (a Russian version appeared one year later). In 1907 Livanow was promoted to the rank of a Magister of Science at the University of St. Petersburg and became an assistant at $\mathrm{Ka}$ zan University. Due to the generosity of his supervisor, Prof. E. A. Meyer, Livanow was permitted to work from 1907 to 1910 at the Biological Station in Naples (Italy), where he studied the invertebrate fauna of the Mediterranean.

In 1914/1915 Livanow left Kazan to live in Moscow, where he was a lecturer in the department headed by Professor A. N. Severtzoff (Levit et al. 2004). Thereafter, Livanow was employed at the Petrowskaja Academy as an assistant of Professor L. S. Berg. One year later he returned to Kazan, where Livanow was appointed to the position of Professor and head of the Chair of Zoology of Invertebrates (1918). Thirty years later he retired (1948) but lectured on a variety of topics until 1970. On 7. December 1974 Livanow died at the age of 98 years. 
During his active time as Professor of Invertebrate Zoology, Livanow went on expeditions to the White Sea (1920 - 1922), the North Sea (1928), and Lake Baikal (1931). He received many honours and ranked among Russia's most famous naturalists.

Livanow published articles and book chapters on the following topics: systematics, morphology and anatomy of invertebrates (Hirudinea, Oligochaeta, Polychaeta, Echiuroidea, Nemertini, Planaria, Pogonophora), the evolution of the nervous system, and general aspects of evolutionary morphology. Fifty years ago he published a textbook in Russian, entitled The Direction of Evolution in the Animal World (Livanow 1955), that became widely known. This monograph was translated into German, the language of science during the 1950 s.

At the age of 94 (1970) Livanow published his last contributions to the zoological sciences, a book chapter on general rules in organismic evolution (Livanow 1970a) and a theoretical journal paper on the origin of the metazoa (Livanow 1970b). The Russian biologist remained active into his ninety-seventh year.

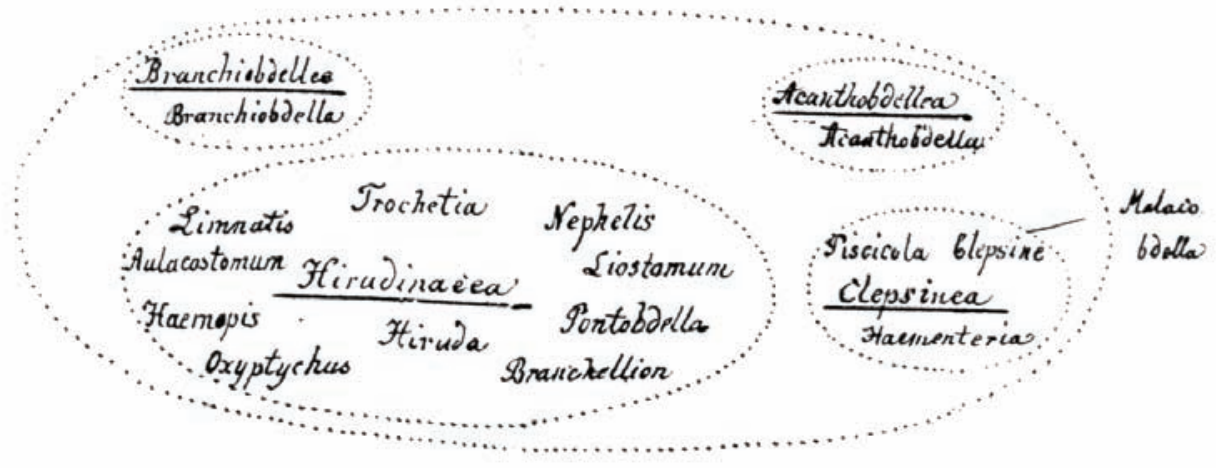

Fig. 2: Systematic position of the family Acanthobdellea (one genus, Acanthobdella). Scheme that is part of a larger drawing entitled "Survey of the families and genera (of annelids) according to their relationships" (Adapted from Grube 1850).

\section{Acanthobdellidae: ancient leeches with chaetae}

In 1850, the zoologist A. E. Grube published a comprehensive paper entitled "The Families of the Annelids". The class Annelida sensu Cuvier was defined by this author as a group of metamerically segmented worms in which the nerve cord is located ventrally. According to Grube (1850) the annelids are comprised of the orders Polychaeta, Oligochaeta, Hirudinea (Discophora) and Onychophora. Today we know that onychophorans (velvet worms such as Peripatus) are not annelids. They are classified as Proarthropoda, a sister group of the Euarthropoda (insects, crustaceans etc.). However, the other three orders established by Grube have "survived", i.e., the basic classification of this early annelid researcher is still valid (Herter 1968; Sawyer 1986 a, b, c; Mann 1962; Edwards and Bohlen 1996; McHugh 2000; Kutschera 2006). 
Under the headline "Discophora" (i. e., Hirudinea), the naturalist A. E. Grube (1850) summarized the following taxa: Hirudinacea, Clepsinea, Branchiobdellea and Acanthobdellea. According to Nesemann and Neubert (1999), the Phylum Annelida contains the Subphylum Clitellata, a term that was coined by Michaelsen (1919). The clitellates are comprised of the classes Hirudinea, Branchiobdellida and Acanthobdellea; this modern taxonomy largely corresponds to Grube's original classification (Hirudinacea + Clepsinea: true leeches; Branchiobdellea: epizoic annelids that live on freshwater crustaceans; Acanthobdellea: leeches with chaetae). On the last page of his monograph, Grube (1850) introduced the family Acanthobdellea Gr. with one genus, Acanthobdella Gr., and one species (A. peledina, Grube 1850). In this original description, the author refers to an obscure publication (Middend. Sibir. Reise Bd II. Th. I. Annelid. p. 20. Taf. I. Fig. 1. a, 1. b), which we have identified as a chapter in a book edited by A. T. v. Middendorff (Grube 1851). In accordance with Nesemann and Neubert (1999), we have used the correct taxon name, A. peledina
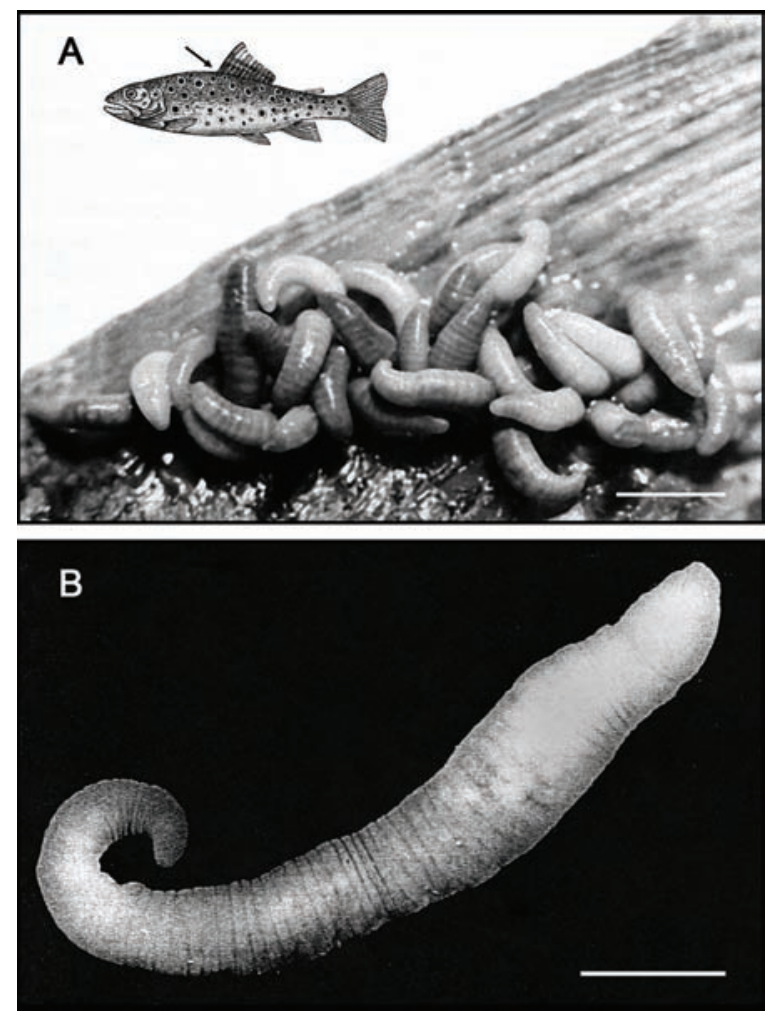
Grube 1850, and we do not refer to A. E. Grube's subsequent paper of 1851, as other zoologists have done (Livanow 1906; see Sawyer 1986 a, $\mathrm{b}, \mathrm{c})$.

In his monograph, Grube (1850) repeatedly referred to the taxon Acanthobdella. On pages 280/281 he defines the genus as follows: "Discophora (i. e., Hirudinea) with chaetae instead of an anterior sucker". In a hand-written scheme he depicted the taxa Branchiobdellea, Hirudinacea/Clepsinea and Acanthobdellea according to their presumed relationships (Fig. 2).

Fig. 3: The ancient leech Acanthobdella peledina. About 35 live individuals attached to the base of the dorsal fin of a salmonid fish (A). Alcohol-preserved leech (B). Bars $=1 \mathrm{~cm}(A)$ and $5 \mathrm{~mm}$ (B). (Adapted from Sawyer 1986 b and Epshtein 1987).

However, Grube (1850) pointed out that it is necessary to elucidate the anatomy of Acanthobdella to further explore the systematic position of this ancient leech with chaetae.

By the end of the 19th century, field naturalists had discovered that Acanthobdella inhabits cold water lakes in the northern regions of Europe. It is a parasite on salmonid fishes that attaches its head region to a host by the use of its hook-shaped chaetae (Fig. 3). 
However, no details about the life cycle of this rare annelid were provided by these early biologists.

\section{The pioneering work of A. N. Livanow and its confirmation}

The Russian biologist Livanow (1906) was the first to study the internal organisation of Acanthobdella peledina, using classical histological techniques and the light microscope. He collected living specimens during the summer of 1902 in the Onega Lake close to Wytegra. About 100 leeches were picked up by him from salmonid fishes and preserved in a fixative. The anatomy of $A$. peledina was reconstructed based on stained sections. Livanow's monograph is of such a high quality that it formed the basis for much theoretical speculation over the subsequent decades. Figure 4 shows the anatomy of $A$. peledina;

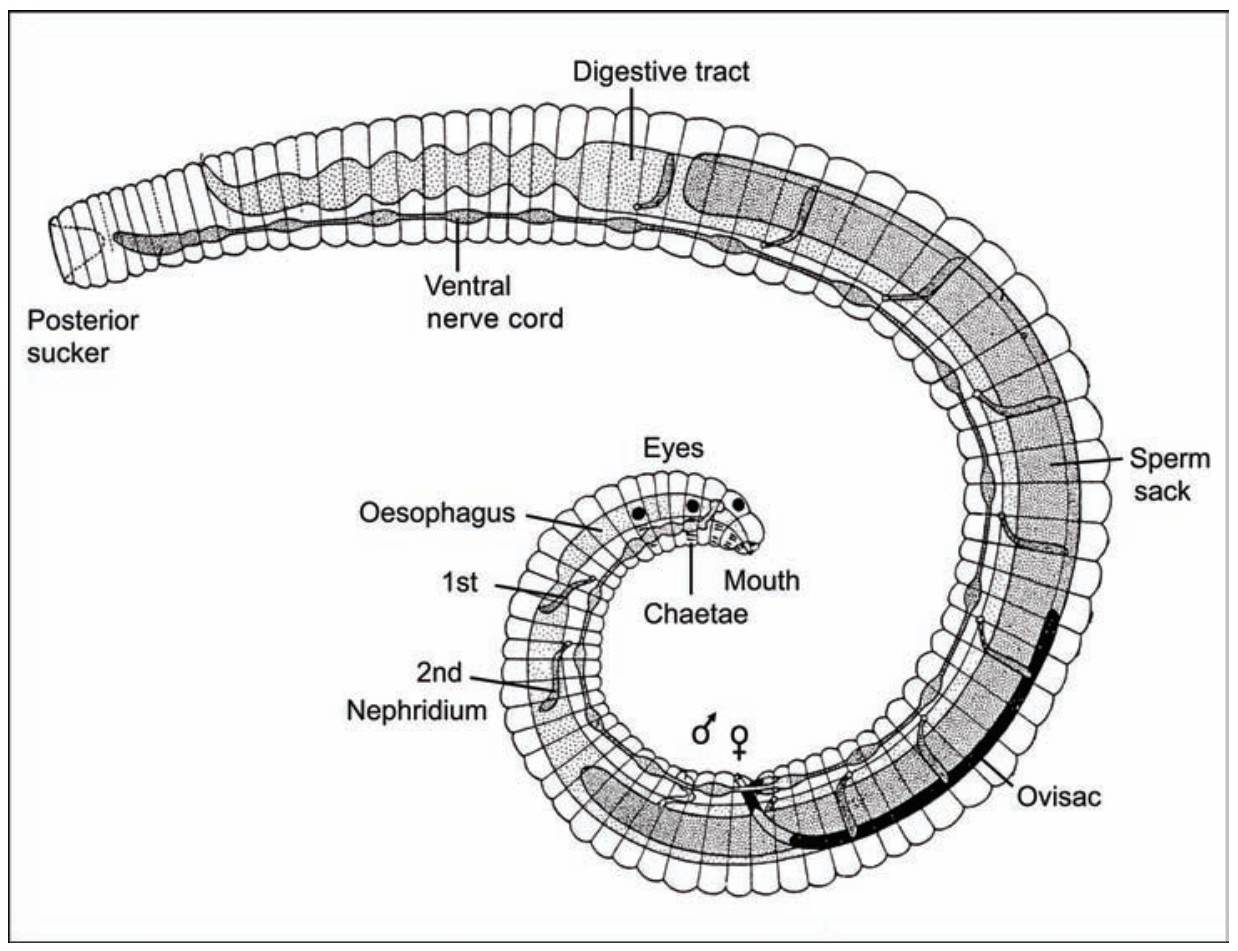

Fig. 4: Diagram of the anatomy of Acanthobdella peledina, reconstructed from bistological studies of alcohol-preserved individuals (Adapted from Livanow 1906).

this scheme is based on drawing 1 in Livanow's original publication. Adult living specimens of this species are $20-35 \mathrm{~mm}$ long and about $3 \mathrm{~mm}$ wide. In the middle of the cylindrical body each segment is comprised of four annuli. Additional information on the morphology and anatomy of $A$. peledina was provided by Epshtein (1987), Franzén 
(1991), and Purschke et al. (1993). These authors confirmed Livanow's classical results (with the exception of a few unimportant details) that can be summarized as follows.

The mouth pore of $A$. peledina is a small opening on the ventral side of the unspecialized head, which is characterized by three pairs of eyes and five transverse rows of chaetae (Fig. 4, 5 C). Each row consists of four pairs of hook-shaped chaetae. According to Dahm (1962), these chaetae occur on somites $1-5$ of the anterior end of the body in a species-specific pattern. In all $A$. peledina populations investigated so far 5 x 8 (i.e., 5 x 2 . 4 ) $=40$ hook-shaped chaetae were counted (Livanow 1906, Epshtein 1987, Purschke et al. 1993). These investigators agree that the 40 "hooks" (Fig. 5 D) are functionally equivalent to an anterior sucker, which is a specific feature of the "true leeches" (Euhi-
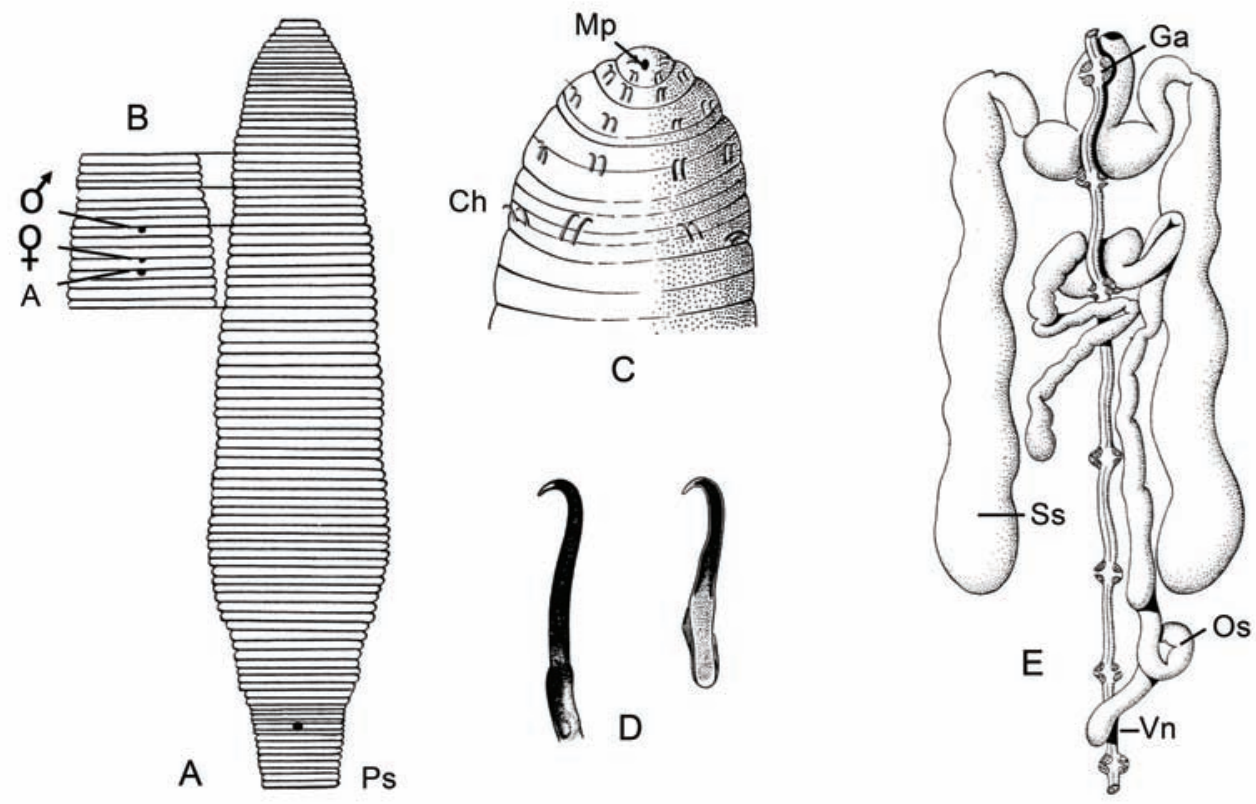

Fig. 5: Morphology and anatomical details of Acanthobdella peledina. Dorsal view of an adult individual (A), ventral view with male and female gonopores (B). Head with mouth and chaetae (C), isolated book-shaped chaetae (D). Genital system, ventral view (E). $A=$ accessory genital pore (area copulatrix), $C h=$ Chaetae, $G a=$ ganglion, $M p=$ mouth pore, $O s=$ Ovisack, $P s=$ posterior sucker, $S_{s}=$ sperm sack, $V n=$ ventral nerve cord (Adapted from Epshtein 1987).

rudinea). It should be noted that this conclusion is in accordance with the hypothesis of Grube (1850), who speculated that the chaetae of $A$. peledina may fulfil the role of the missing oral sucker in this ancient hirudinean.

According to Sawyer (1986 a) the digestive tract of A. peledina is, with respect to its shape, intermediate between that of oligochaetes and members of the Euhirudinea. Ten pairs of nephridia have been documented; in the region of the clitellum these organs (that are responsible for water balance) are absent. The central nervous system consists 
of a supraoesophageal ganglionic mass (brain), the suboesophageal ganglionic mass, the ventral nerve cord (chain of free ganglia), and the ganglionic mass close to the posterior sucker. The body of $A$. peledina consists of 29 segments and contains 31 pairs of ganglia (Fig. 4, 5 E).

Like all members of the Clitellata, $A$. peledina is a protandric hermaphrodite. The male genital organs consist of paired sperm sacks, and the female organs are made up of paired ovisacs. In Figures 4 and $5 \mathrm{~A}$ the positions of the genital openings are indicated by the biological symbols for male and female, respectively. In addition, the area copulatrix, which fulfils an unknown function during sperm transfer, is indicated in Fig. 5 B.

The results summarized here document that $A$. peledina is characterized by a mosaic of "oligochaetous" (i.e. earthworm-like) and hirudinean features, as described by Livanow (1906) and corroborated by subsequent investigators (Dahm 1962; Epshtein 1987; Sawyer 1986 a, c; Purschke et al. 1993).

\section{Behaviour and life cycle}

The ancient leech $A$. peledina inhabits cold-water lakes of alpine Scandinavia and northern Alaska/Eurasia. Sawyer (1986 b) summarized the literature on the biology of A. peledina and concluded that this archaic freshwater leech is a semi-permanent parasite, restricted almost exclusively to salmonid fishes. Most common hosts are brown trout (Salmo trutta) and grayling (Thymallus thymallus). The ectoparasite may occur anywhere on the body of its host, but usually the leeches attach to the base of the dorsal fin by the posterior (caudal) sucker (Fig. 3 A, B). After attaching the chaetae of the head region to the skin of a
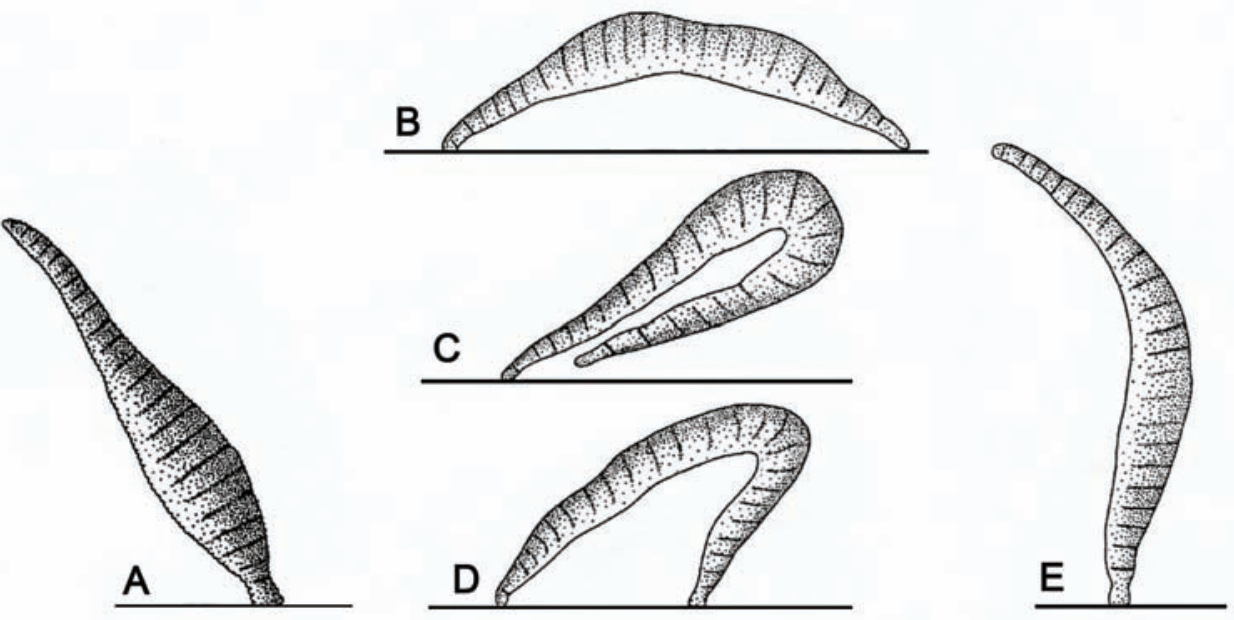

Fig. 6: Searching movements (alert posture) $(A, E)$ and inchworm crawling $(B, C, D)$ of the leech Acanthobdella peledina (Adapted from Dabm 1962).

fish the leech feeds on blood and tissue of its vertebrate host.

Dahm (1962) observed and documented the behaviour of adult A. peledina individuals that were attached to a salmonid fish. After the fish had been killed by the experimenter, 
the leeches continued to feed on their host. About one hour later, the Acanthobdella individuals left their dead host and moved around by "inchworm crawling" (Fig. 6). The caudal (posterior) sucker is used by the leech as a holdfast organ that sticks to the substrate via viscous mucoid secretions from adhesive glands (Livanow 1906). A. peledina individuals, isolated from a fish, perform searching movements that are reminiscent to those of fish leeches of the genera Piscicola or Hemiclepsis (Herter 1968, Sawyer 1986 a, b).

The life-cycle of $A$. peledina was elucidated by Andersson (1988), who studied freeliving populations in a Lake in the northern part of Sweden and groups of leeches kept in freshwater aquaria. These containers were maintained at $4{ }^{\circ} \mathrm{C}$ and $10{ }^{\circ} \mathrm{C}$, respectively. Copulation occurred more often at $4{ }^{\circ} \mathrm{C}$ than at the higher temperature. Details of the mode of sperm transfer are not known. Figure $7 \mathrm{~A}$ gives an impression of the sexual behaviour of this annelid. About one week after copulation the free-living fish parasites

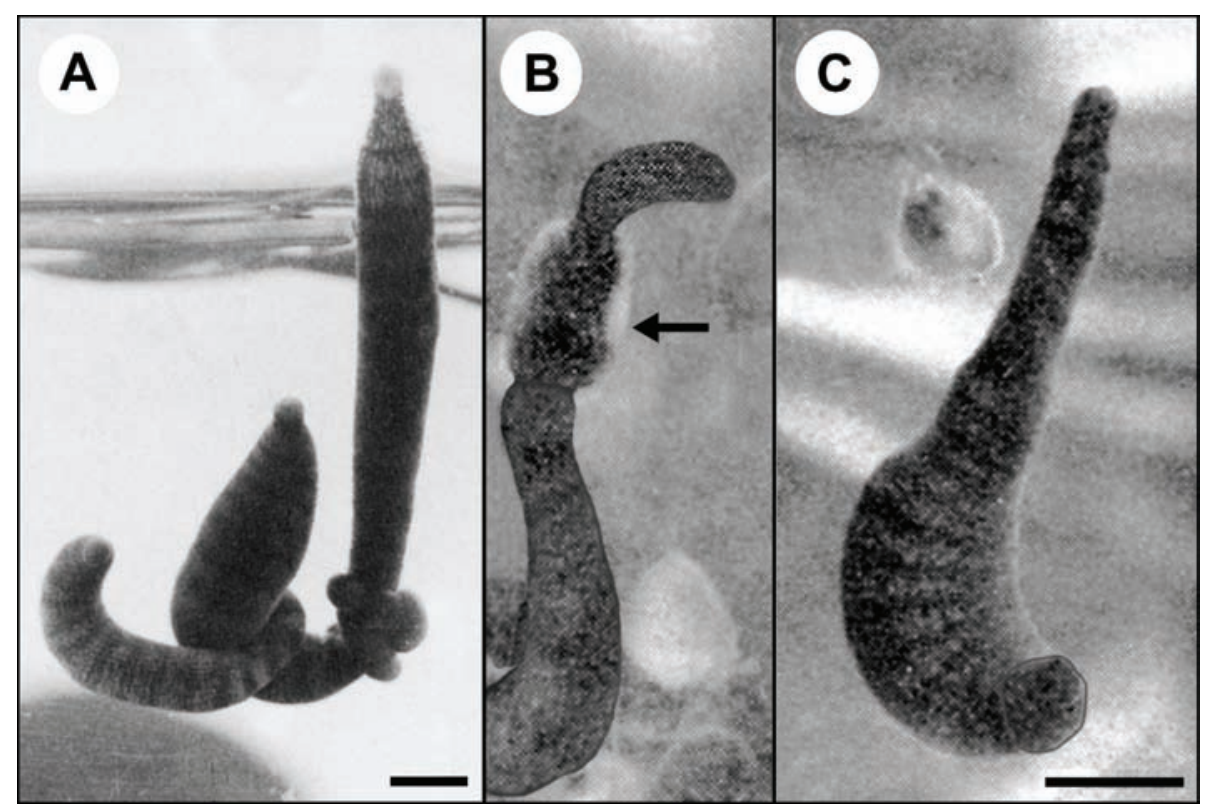

Fig. 7: Copulation (A), cocoon production (B) via the clitellum (arrow) and behaviour after cocoon fixation $(C)$ in the leech Acanthobdella peledina. Note the fresh (transparent) and fully hardened (dark) cocoon attached to the glass plate of the aquarium $(B, C)$ (Adapted from Andersson 1988).

produce cocoons. During the process of cocoon secretion via the clitella glands the leech is attached to a solid substrate with its caudal sucker. The worm rotates the anterior part of its body to shape the inner wall of the cocoon (Fig. 7 B). Thereafter, the soft translucent cocoon is attached to the substrate and later becomes hard and dark brown (Fig. 7 C). The entire process is reminiscent to that observed in earthworms (Edwards and Bohlen 1986) and leeches of the genus Erpobdella (Sawyer 1970, 1971, 1986 a, b; Kutschera $1983,1989)$. This mode of cocoon production is considered to be the original state in 
leech evolution (Sawyer 1971, Siddall and Burreson 1995, 1996, Kutschera and Wirtz 2001, Borda and Siddall 2004 a, b, Kutschera 2006) and is also retained in members of the fish leeches (Pisciolidae).

The cocoons of $A$. peledina are about $5 \mathrm{~mm}$ long and contain 13 - 33 eggs (Andersson 1988). At $4{ }^{\circ} \mathrm{C}$, the young (length ca. $2 \mathrm{~mm}$ ) hatched after 7 months. They react to the water movement caused by a fish with intensified searching movements (Fig. $6 \mathrm{~A}, \mathrm{E}$ ), and try to fasten their hook-shaped chaetae on the ventral side of the host.

The life cycle of $A$. peledina in nature can be summarized as follows. Cocoons are deposited during August/September. Thereafter, free-living young leeches can be observed over a period of several months. The first infested fishes were found by the end of September of the following year. Young $A$. peledina remain attached to their host over the subsequent year and reach maturity. Thereafter, the adult individuals leave their host, produce cocoons and die a few months later (Andersson 1988). It should be noted that the data base on which this deduction rests is rather poor. Young (2002) provided a much more detailed account of the life cycle of the freshwater leech Erpobdella octoculata. However, these common clitellates are much more abundant than the "living relict" $A$. peledina so that studies of large leech populations in natural habitats were possible.

\section{The significance of Acanthobdella: historical controversies}

As a result of Livanow's monograph (1906), a controversial discussion commenced on the taxonomic status of this ancient leech that continues to the present (Siddall et al. 2001, Borda and Siddall 2004 a, b). The eminent zoologist Michaelsen (1919) was led to a study of the relationships between leeches and oligochaetes by noticing a figure in a paper on Sudanese Hirudinea. The schematic drawing represented an organ that was interpreted by the author as a diverticulum of the alimentary tract of leeches. Similar organs had been described in certain leeches from Sumatra, in which they are paired, and the external pores are situated ventrally. The organ strongly resembles the spermathecae of certain oligochaete species in the families Enchytraeidae and Lumbriculidae, in which the spermathecae communicate internally with the alimentary tract. Similar relations have also been found in certain species of other families of Oligochaeta.

As a result of his studies, Michaelsen (1919) reached the conclusion that the Hirudinea are, in reality, Lumbriculidae which have undergone special modifications in adaptation to a predatory mode of life. This conclusion receives much support from a careful comparison of the structure of two intermediate types of annelids: the Branchiobdellidae, and Acanthobdella peledina. The former are parasitic in the gill chambers and on parts of the surface of crawfishes and, as their name indicates, were formerly regarded as leeches. However, in the meantime their close relationship with the Oligochaeta has been documented (Brinkhurst 1999, Siddall and Burreson 1996). On the ventral surface of $A$. peledina (head region) are paired bundles of chaetae, and the characters of the reproductive organs and the body cavity appear to be closer to those of the Oligochaeta than to those of the leeches. Michaelsen (1919) concluded that, although there is some justification for including these two groups in the family Lumbriculidae, it is preferable to recognize them as two distinct families of Oligochaeta, i.e., Branchiobdellidae and Acanthobdellidae. 
In addition, Michaelsen (1919) noted that there is a wide range of variation among different representatives of the Oligochaeta, and that most of the characters which one is accustomed to think of as typical of the Oligochaeta are not present in all members of the group. He also showed that many of the characters of Hirudinea, which one is likely to assume as distinguishing them from Oligochaeta, may be found present in certain members of the latter group. Absence of chaetae occurs in a genus of the oligochaete family Enchytraeidae, as well as in Branchiobdellidae, and they are greatly reduced in numbers and size in various other taxa. As previously mentioned, four pairs of welldeveloped chaetae are present on each of several anterior somites in A. peledina.

According to Michaelsen (1919), the most significant characteristics which distinguishes the Hirudinea from the Oligochaeta is the position of the "spermaries" in somites posterior to the one which contains the ovaries. This relative position of the two kinds of gonads is the opposite of that normally found in Oligochaeta, and in the apparent "connecting forms", Branchiobdellidae and Acanthobdella. To account for this reversal of relations, Michaelsen (1919) refers to instances where Oligochaeta are found with a considerable number of consecutive somites containing gonads and also to papers by different authors, in which gonads of certain oligochaete species have been shown to produce one kind of germ cells at one time, and at other times to produce those of the opposite kind. From individuals with series of gonads of this type, he regards it not improbable that there may have been derived descendants in which the relative position of the gonads of the two sexes is in the reverse order from that of the ancestors. On the basis of these and additional observations, Michaelsen (1919) regarded it desirable to modify the classification of the Annelida. He proposed the class Clitellata that includes two orders, Oligochaeta and Hirudinea; they can be distinguished by the differences in the degree of development of the body cavity and the relative order of the gonads.

Livanow (1931) did not accept Michaelsen's (1919) opinion that Acanthobdella is a oligochaete that had evolved hirudinean-like features (e. g. posterior sucker) convergently to the "true" leeches (Euhirudinea). The Russian zoologist described $A$. peledina as a "living fossil" leech that is an early offspring of the line of descent (with modifications) that led over millions of years to the Euhirudinea. Autrum (1936) considered A. peledina as the most primitive living leech species that represents a connecting link between the Oligochaeta and the Euhirudinea. This conclusion was also reached by Sawyer (1986 a, b), who interpreted $A$. peledina as a "living fossil (or relict) of special phylogenetic interest" that "connects leeches to oligochaetes".

In summary, the conclusions of Michaelsen (1919) regarding the position of $A$. peledina have not survived (Ax 1999, Brinkhurst 1999, Martin 2001, Westheide and Rieger 1996). However, this pioneer in annelid research coined a key term that is still in use today. He introduced the taxon (class) Clitellata, which was comprised of the orders Oligochaeta and Hirudinea (inclusive of Acanthobdella and the Branchobdellidae) (Autrum 1936; Sawyer 1986 a, b; Mc Hugh 2000). Today we know that Michaelsen's clitellates are a monophyletic group of segmented worms. This topic is discussed in the last section of this article. 


\section{Conclusions: Validating Livanow with molecular data}

The classical paper of Livanow (1906) had far-reaching implications for the question as to the evolutionary relationships between oligochaetes and hirudineans. Sawyer (1986 a, $\mathrm{b}, \mathrm{c})$ was the first to summarize all pertinent data on the "living fossil-leech" A. peledina and concluded that this fish parasite represents an "intermediate form" between the Oligochaeta and the true Hirudinea. Siddall and Burreson $(1995,1996)$ analyzed the phylogenetic relationships among clitellates and suggested that Acanthobdella may be regarded as a sister group to the Euhirudinea, as proposed by Livanow (1906, 1931). These authors became the pioneers in a research program that is based on mitochondrial DNA sequence data for the elucidation of the phylogenetic relationships within the Clitellata (Siddall and Burreson 1998, Apakupakul et al. 1999). Methods introduced by these scientists are also of importance for the identification of new (or imported) annelid species within the framework of "DNA barcoding" studies (Trontelj and Sket 2000, Pfeiffer et al. 2004, 2005).

In a series of papers it was shown that the "living relict" $A$. peledina is in fact a primitive but typical hirudinean and that the Acanthobdellida is a sister taxon to the Euhirudinea (plus Branchiobdellida) (Apakupakul et al. 1999, Siddall et al. 2001, Borda and Siddall

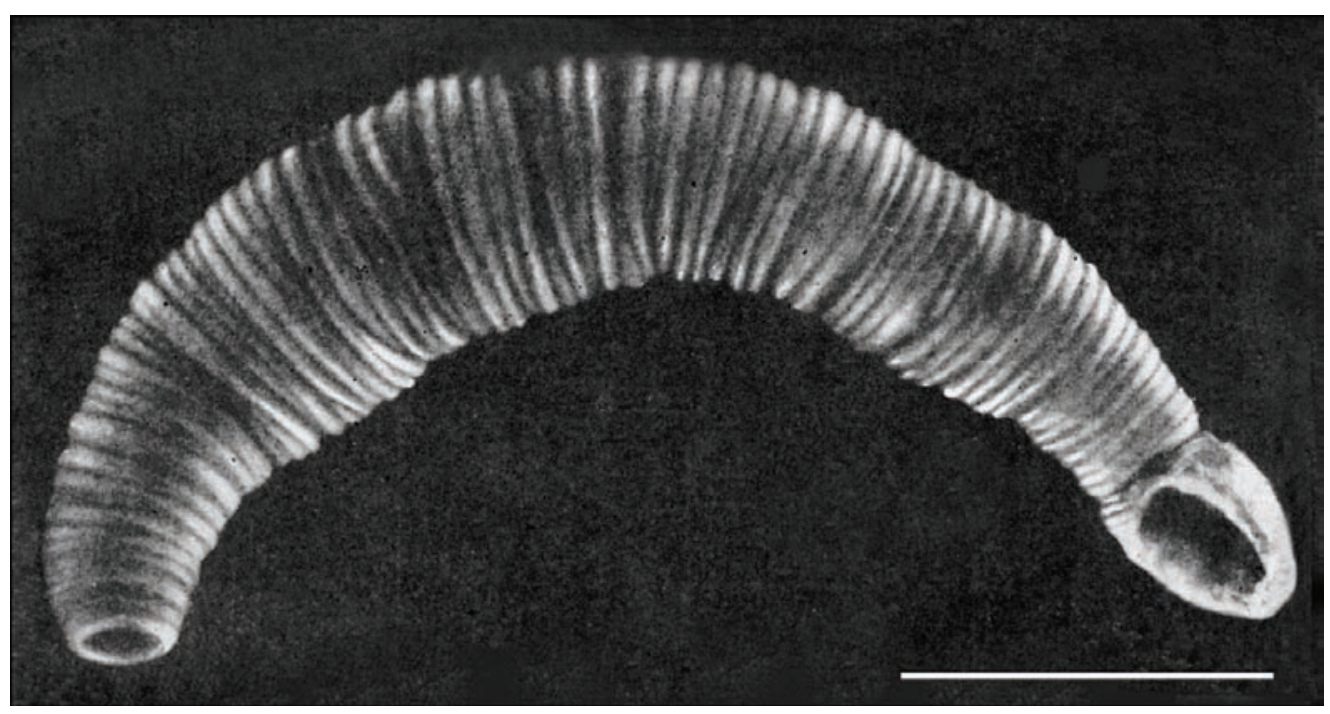

Fig. 8: The ancient leech Acanthobdella livanowi Epsthein 1966, adult individual, preserved in ethanol. The caudal sucker points to the left. Note the head region with the sucker-like disc that is equipped with chaetae.

2004 a, b). These reports document that Livanow's conclusions, which were exclusively based on anatomical studies, are in accordance with DNA sequence data. Independent evidence in support of a hypothesis is strong proof for the validity of a proposed evolutionary scenario. Other case studies where morphological and molecular data agree with each other are summarized in the recent literature on molecular phylogenetics and evolution of various taxa (Kutschera 2005, 2006, Kutschera and Niklas 2004). 
Finally, it should be noted that 40 years ago a second acanthobdellid species, $A$. $l i$ vanowi Epshtein 1966 (Syn.: Paracanthobdella livanowi, Epsthein 1987) was discovered (Fig. 8 ) and named in honour of the Russian zoologist (Fig. 1). The significance of this primitive leech with chaetae has been questioned (Brinkhurst and Gelder 1989, Brinkhurst 1999) so that more scientific work is required "in the wake of Livanow".

\section{References}

Andersson, E. (1988) The biology of the fish leech Acanthobdella peledina Grube. Zool. Beitr. 32, pp. $31-50$.

Apakupakul, K., Siddall, M.E., Burreson, E. M. (1999) Higher level relationships of leeches (Annelida: Clitellata: Euhirudinea) based on morphology and gene sequences. Mol. Phylogenet. Evol. 12, pp. $350-359$.

Autrum, H. (1936) Hirudineen. Charakteristik und Systematik. In: Klassen und Ordnungen des Tierreichs (Bronn, H. G.; ed.) Band 4, Abt. III, Buch 4, Teil 1, pp. 1 - 96.

Ax, P. (1999) Das System der Metazoa II. Ein Lehrbuch der phylogenetischen Systematik. Gustav Fischer Verlag, Stuttgart.

Borda, E., Siddall, M. E. (2004 a) Arhynchobdellida (Annelida: Oligochaeta: Hirudinidae): phylogenetic relationships and evolution. Mol. Phylogenet. Evol. 30, pp. 213 - 225.

Borda, E., Siddall, M. E. (2004 b) Review of the evolution of life history strategies and phylogeny of the Hirudinida (Annelida: Oligochaeta). Lauterbornia 52, pp. 5 - 25.

Brinkhurst, R. O. (1999) Lumbriculids, branchiobdellidans and leeches: an overview of recent progress in phylogenetic research on clitellates. Hydrobiologia 406, pp. $281-290$.

Brinkhurst, R. O., Gelder, S. R. (1989) Did the lumbriculids provide the ancestors of the branchiobdellidans, acanthobdellidans and leeches? Hydrobiologia 180, pp. 7 - 15.

Dahm, A. G. (1962) Distribution and biological patterns of Acanthobdella peledina Grube from Sweden (Hirudinea, Acanthobdellae). Kungl. Fysiogr. Sallsk. Hand. 73, pp. 4-35.

Edwards, C. A., Bohlen, P. J. (1996) Biology and Ecology of Earthworms. 3. Ed. Chapman \& Hall, London.

Epshtein, V. M. (1966) Acanthobdella livanowi sp. n. - a new species of the ancient leeches (Archihirudinea) from Kamchatka. Dokl. Akad. Nauk SSSR 168, pp. 955 - 958 [in Russian].

Epshtein, V. M. (1987) Klass Pijawki (Hirudinea Lamarck 1818). Opredelitel parazitiv presnovodnykh ryb fauni SSSR 3, Moscow: pp. 340 - 342 [in Russian].

Franzén, Å. (1991) Spermiogenesis and sperm ultrastructure in Acanthobdella peledina (Hirudinea) with some phylogenetic considerations. Invert. Reprod. Dev. 19, pp. 245 - 256.

Grube, A. E. (1850) Die Familien der Anneliden. Arch. Naturgeschichte 16, pp. 249 - 361.

Grube, A. E. (1851) Annulaten. In: Reise in den äußersten Norden und Osten Sibiriens (Middendorff, A. T. v.; ed.) Bd. II, pp. 1 - 24, St. Petersburg.

Herter, K. (1968) Die medizinischen Blutegel und seine Verwandten. A. Ziemsen Verlag, Wittenberg Lutherstadt. 
Kutschera, U. (1983) Dichteregulation durch intraspezifische Kokonzerstörung und Untersuchungen zur Fortpflanzungsbiologie beim Egel Erpobdella octoculata L. (Hirudinea: Erpobdellidae). Zool. Jb. Syst. 110, pp. 17 - 29.

Kutschera, U. (1989) Innerartliche Kokonzerstörung beim Egel Erpobdella octoculata. Beobachtungen an Aquarienkulturen. Mikrokosmos 78, pp. 237 - 241.

Kutschera, U. (2005) Predator-driven macroevolution in flyingfishes inferred from behavioural studies: historical controversies and a hypothesis. Ann. Hist. Phil. Biol. 10, pp. 59 - 77.

Kutschera, U. (2006) Evolutionsbiologie. 2. Auflage. Verlag Eugen Ulmer, Stuttgart.

Kutschera, U., Wirtz, P. (2001) The evolution of parental care in freshwater leeches. Theory Biosci. 120 , pp. $115-137$.

Kutschera, U., Niklas, K. J. (2004) The modern theory of biological evolution: an expanded synthesis. Naturwissenschaften 91, pp. $255-276$.

Levit G.S., Hossfeld U., Olsson L. (2004) The integration of Darwinism and evolutionary morphology: Alexej Nikolajevich Sewertzoff (1866-1936) and the developmental basis of evolutionary change. Mol. Dev. Evol. 302B (4): 343 - 354.

Livanow, N. (1902) Die Hirudineen-Gattung Hemiclepsis Vejd. Zool. Jb. Syst. 17, pp. 339 - 362.

Livanow, N. (1906) Acanthobdella peledina Grube, 1851. Zool. Jb. Anat. 22 , pp. 637 - 866.

Livanow, N. (1931) Die Organisation der Hirudineen und die Beziehungen dieser Gruppe zu den Oligochaeten. Ergeb. Fortschr. Zool. 7, pp. 378 - 484.

Livanow, N. (1955) Die Richtungen der Evolution der Tierwelt. Staatsverlag Sowjetwissenschaft, Moskau.

Livanow, N. (1970 a) Allgemeine biologische Gesetzmäßigkeiten der Evolution. In: Probleme der evolutionären Morphologie und Biozönologie. Verlag der Kazan Universität: pp. 1 - 21 [in Russian].

Livanow, N. (1970 b) Von der Entstehung der Metazoa. Zool. Zeitung 49, pp. 517 - 533 [in Russian].

Mann, K. H. (1962) Leeches (Hirudinea). Their Structure, Physiology, Ecology and Embryology. Pergamon Press, Oxford.

McHugh, D. (2000) Molecular phylogeny of the Annelida. Can. J. Zool. 78, pp. 1873 - 1884.

Michaelsen, W. (1919) Über die Beziehungen der Hirudineen zu den Oligochaeten. Mitt. Zool. Mus. Hamburg 36, pp. $131-153$.

Nesemann, H., Neubert, E. (1999) Annelida, Clitellata: Branchiobdellida, Acanthobdellea, Hirudinea. In: Süßwasserfauna von Mitteleuropa (Schwoerbel, J.; Zick, P.; eds.) Bd 6/2. Spektrum Akademischer Verlag, Heidelberg, Berlin.

Martin, P. (2001) On the origin of the Hirudinea and the demise of the Oligochaeta. Proc. R. Soc. Lond. B 268, pp. 1089 - 1098.

Pfeiffer, I., Brenig, B., Kutschera, U. (2004) The occurrence of an Australian leech species (genus Helobdella) in German freshwater habitats as revealed by mitochondrial DNA sequences. Mol. Phylogenet. Evol. 33, pp. 147 - 151. 
Pfeiffer, I., Brenig, B., Kutschera, U. (2005) Molecular phylogeny of selected predaceous leeches with reference to the evolution of body size and terrestrialism. Theory Biosci. 124, pp. $55-$ 64.

Purschke, G., Westheide, W., Rohde, D., Brinkhurst, R. O. (1993) Morphological reinvestigation and phylogenetic relationship of Acanthobdella peledina (Annelida, Clitellata). Zoomorphology 113, pp. $91-101$.

Sawyer, R. T. (1970) Observations on the natural history and behaviour of Erpobdella punctata (Leidy) (Annelida: Hirudinea). Am. Midl. Nat. 83, pp. 65 - 80.

Sawyer, R. T. (1971) The phylogenetic development of brooding behaviour in the Hirudinea. Hydrobiologia 37, pp. $197-204$.

Sawyer, R. T. (1986 a) Leech Biology and Behaviour I. Anatomy, Physiology and Behaviour. Clarendon Press, Oxford.

Sawyer, R. T. (1986 b) Leech Biology and Behaviour II. Feeding Biology, Ecology and Systematics. Clarendon Press, Oxford.

Sawyer, R. T. (1986 c) Leech Biology and Behaviour III. Bibliography. Clarendon Press, Oxford.

Siddall, M. E., Burreson, E. M. (1995) Phylogeny of the Euhirudinea: Independent evolution of blood feeding by leeches? Can. J. Zool. 73, pp. 1048 - 1064.

Siddall, M. E., Burreson, E. M. (1996) Leeches (Oligochaeta?: Euhirudinea), their phylogeny and the evolution of life-history strategies. Hydrobiologia 334, pp. 227 - 285.

Siddall, M. E., Burreson, E. M. (1998) Phylogeny of leeches (Hirudinea) based on mitochondrial cytochrome c oxidase subunit I. Mol. Phylogenet. Evol. 9, pp. 156 - 162.

Siddall, M., Apakupakul, K., Burreson, E. M., Coates, K. A., Erseus, C., Gelder, S. R., Källersjö, M., Trapido-Rosenthal, H. (2001) Validating Livanow: Molecular data agree that leeches, Branchiobdellidians, and Acanthobdella peledina form a monophyletic group of Oliochaetes. Mol. Phylogenet. Evol. 21, pp. 346 - 351.

Trontelj, P., Sket, B. (2000) Molecular re-assessment of some phylogenetic, taxonomic and biogeographic relationships between the leech genera Dina and Trocheta (Hirudinea: Erpobdellidae). Hydrobiologia 438, pp. $227-235$.

Westheide, W., Rieger, R. (1996) Spezielle Zoologie. Erster Teil: Einzeller und Wirbellose Tiere. Gustav Fischer Verlag, Stuttgart.

Young, J. O. (2002) A long-term, ecological study of leeches in the stony, litteral zone of British lakes. Arch. Hydrobiol. Suppl. 139, pp. 139 - 201.

\section{Address for correspondence:}

Ulrich Kutschera

Institut für Biologie

Universität Kassel

Heinrich-Plett-Str. 40

D-34109 Kassel, Germany

kut@uni-kassel.de 


\title{
"Evolution on Rails" : Mechanisms and Levels of Orthogenesis $^{1}$
}

\author{
Georgy S. Levit \& Lennart Olsson
}

\begin{abstract}
Coined in 1893 by the German zoologist Wilhelm Haacke, the concept of orthogenesis became quite influential in the life sciences in the first half of the 20th century. In certain countries this influence lasted until after WWII. However, the dominance of the Modern Synthesis of Evolution in the 1960-70s in most countries with a research tradition in evolutionary biology, and in the majority of biology-related disciplines ultimately pushed the concept of orthogenesis into the shadow of this dominating paradigm. In this paper, we make a brief survey of the history of ideas of directed evolution. We also give a historically founded definition of orthogenesis and describe possible structural levels and mechanisms of orthogenesis. Our perspective is international, but special attention is paid to the German lands, where the orthogenesis tradition was very strong and persisted well into the post-WWII era.
\end{abstract}

In the broadest sense orthogenesis [from Greek ortho - straight] is the idea that biological evolution is governed by an intrinsic directionality. In this sense the idea of directed evolution can be found already in Jean-Baptiste Lamarck's (1744-1829) work, as the concept of the "ladder to perfection". However, the very concept of orthogenesis appeared much later, and in opposition to Darwinian selectionism, which is based on the idea that variation is very extensive or even unlimited. The champions of orthogenesis, by contrast, asserted that variation is limited, and that living organisms are predisposed to vary in certain directions, and also that this bias determines major transitions in evolution (Popov, 2005). Because the advocates of directed evolution were explicit opponents to Darwinism, the term "orthogenesis", or analogous terms, was coined to demarcate this borderline.

Given that orthogenesis is a heterogeneous theoretical construct, various hypotheses have been proposed to explain the directionality of evolution. In the present paper, we give a brief overview of the history of orthogenesis and introduce the major mechanisms proposed to explain directed evolution. It is not our objective to overview the entire history of orthogenesis, but to present theories that describe its possible structural levels and mechanisms. We take an international perspective, but give special attention to the developments in Germany, since orthogenesis was born in Germany and persisted in the

1 The metaphor "Evolution on rails" was used for the first in an oral presentation given by I.Y. Popov \& G.S. Levit at the ISHPSSB 2005 Meeting in Guelph. 
German-speaking countries well into the period when the Modern Synthesis of evolutionary biology was created, and beyond.

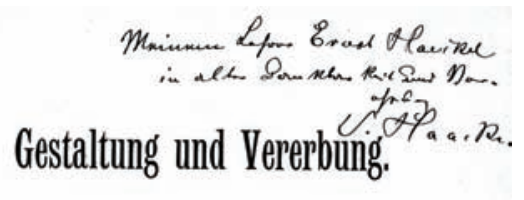

Eine Entwickelungsmechanik der Organismen.

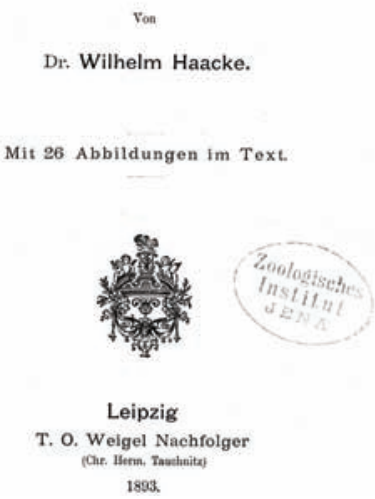

Fig. 1: Title page of the Haacke's "orthogenetic" book Gestalt und Vererbung (Gestalt and Heredity) signed by the author and given to Ernst Haeckel. Haacke has written: "Meinem Lehrer Ernst Haeckel in alter Dankbarkeit und Verebrung." (to my teacher Ernst Haeckel in gratitude and reverence).

contact with his mentor Haeckel. The Archive of the Ernst-Haeckel-Haus in Jena, Germany includes approximately 30 letters from Haacke to Haeckel (Hoßfeld \& Breidbach, 2005). Here we find, for example, detailed reports on Haacke's research in Australia. However, Haeckel immediately changed his mind, when Haacke published his Gestalt und Vererbung (1893) and two years later Die Schöpfung des Menschen und seiner Ideale (1895), where he tried to reconcile science and religion. In this period, Haeckel wrote to his closest friend Wilhelm Breitenbach (1856-1937): "In the last 2 years Dr. W. Haacke has made the most incredible things [...]. I have broken all relations with him, because he deeply disappointed me in Jena and with his negligently written books [...]. Most people

2 Archive of the Ernst-Haeckel-Haus: Letter from K. Priemel to V. Franz (February 3, 1944).

${ }^{3}$ Archive of the Ernst-Haeckel-Hau: Letter from E. Haeckel to W. Breitenbach [45], October 11, 1895. 
who know him well think he is a talented, but irresponsible scientific con-man. Others think he is blinded by megalomania" "4 Yet in contrast to Haeckel's pejorative characterization, the Frankfurt colleagues pictured the founder of orthogenesis as a "loner" and "closed personality" in rather positive tones. ${ }^{5}$

Haacke, in his turn, stigmatized Haeckel's worldview as an "outmoded heresy" and (this was perhaps most painful for Haeckel) choose August Weismann's (1834-1914) neo-Darwinism as a major object for his criticism. Experimenting with mice, Haacke came to a hereditary scheme quite similar to that of Gregor Mendel (1822-1884) (Haacke, 1895b), although he experimented with a limited number of individuals, and his ultimate results differed from those of Mendel (Hoppe, 1998, p. 414).

Haacke was convinced that his debate with Weismann was of a fundamental nature. The first sentences in Gestalt und Vererbung are devoted to accusing Weismann of using a preformistic methodology. As representatives of preformationism Haacke, in addition to Weismann, also counts the mutationist Hugo de Vries (1848-1935) and the vitalist Wilhelm Roux (1850-1924). Haacke's primary objective was to disprove preformationism by proving that the Lamarckian inheritance of acquired characters is a "mechanistic necessity" for evolutionary change, i.e. that this is the only logically consistent explanation (Haacke, 1893, p. I). He proposed that there are two principally different kinds of heredity: somatogenic heredity, which includes all forms of heredity to the exclution of propagative cells, and blastogenic heredity, i.e. hereditary processes taking place exclusively in the propagative cells (Haacke, 1893, p. 44). Whereas the "preformationists" (Weismann, de Vries, Roux) negate somatogenic heredity, the "epigeneticists" claim that somatogenic heredity is of primary importance for evolution. The agents of heredity are located mostly in the cytoplasm (as opposed to the nucleus) and will be determined by its struc-
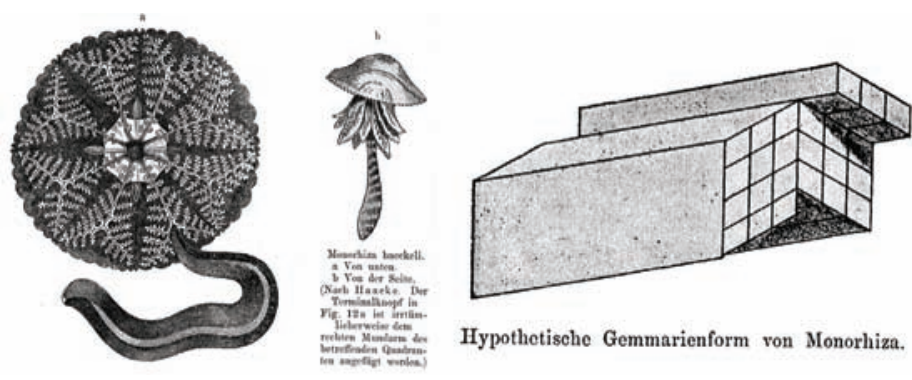

Hypothetische Gemmarienform von Monorhiza,

Fig. 2: Haacke's reconstruction of the bypothetical Gemmaria form for Monorhiza baeckelii. ture. It is important to emphasize, Haacke argued, that not only such evident cases as Haeckel's radiolaria reveal the deep symmetry of living organisms. The cytoplasm of any cell is built in accordance with geometrical laws. This view is not only consistent with observations, Haacke

\footnotetext{
${ }^{4}$ Ibid.: Complete quotation in German: "Dr. W. Haacke macht seit zwei Jahren die unglaublichsten Sachen u. wandelt jetzt (seit dem Frühjahr) in den Bahnen Hamanns'. Ich habe allen Verkehr mit ihm abgebrochen, da er mir in Jena u. durch seine liederlich hingeschmierten Bücher den größten Verdruß bereitete. [...] Die Meisten, die ihn näher kennen, halten ihn für einen talentvollen, aber leichtsinnigen wissenschaftlichen Hochstapler. Andere meinen, dass er von Größenwahn geblendet sei."

${ }^{5}$ Letter from K. Priemel to V. Franz (February 3, 1944).

${ }^{6}$ Ibid.: Haeckel quoted (in the letter to Breitenbach) Haacke's abusive labelling of the "Jena-Darwinism" in one of his lectures to the students.
} 
claimed, but is also fully consistent with Haeckel's theory of basic forms (Haacke, 1893, p. 117) and it seems logical to propose that the cells consist of further "individuals". Haacke labelled these individuals gemmaria [Gemmarien]. Gemmaria, in their turn, consist of even more primitive individuals, the so-called gemmae [Gemmen] (Ibid, p. 118). [Fig. 2.]. Gemmae are rhombic figures, which can be combined in different ways to build all basic forms of animals and plants. Gemmae are "very small" and their number in one single gemmarium is countless. Gemmaria attract each other mutually and can enter into different combinations. They reside, with all probability, in the centrosome of the cell and in the "plasmatic rays" (microtubules in modern terminology) (Ibid., p. 120). This is the cornerstone of Haacke's theory, and he deduced all other elements of the theory logically from this initial concept of heredity. First of all, the gemmaria concept gives an explanation of neo-Lamarckian inheritance: "Thus the structure of the organism must be explained based on the form of the gemmaria, and thereby an explanation would be given for the inheritance of acquired characteristics" (Ibid., p. 120). ${ }^{7}$ External influences can transform the structure of gemmaria and therefore the structure of the organism, because the combination of gemmae build a balancing system. The gemmaria are to be found in every cell, including the propagative cells, and also function as hereditary units. Haacke believed that it is possible to reconstruct the exact form of the gemmaria of any organism and did so himself for Monorhiza haeckeli [Fig. 3.]. He claimed that the basic

a
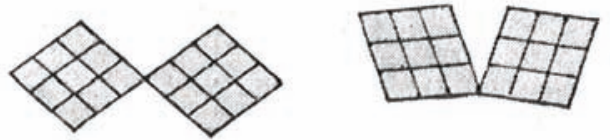

$\mathrm{C}$

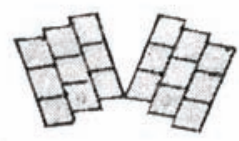

Schemata zur Erläuterung der Gemmarienumformung.

Fig. 3: Haacke's illustration of Gemmaria and their transformation. Orthogenesis is due to the geometric properties of Gemmaria. There is no finalism or mysticism in this bypothesis.

form of the Monorhiza is a regular quadratic pyramid, but with elements of asymmetry (because there is only one "terminal head" [Terminalkopf]). Based on this speculative theory of heredity Haacke introduces two interconnected concepts: orthogenesis and epimorphism.

In Haacke's view, orthogenesis is a concept of constrained variation, as opposed to amphigenesis, which refers to an undirected variability (Ibid., p. 32). The evolution of eyes provides an example of orthogenesis: "Let us at first consider one single organ, for instance, the eye; in so doing we see that it developed from a simple pigmented cup with a lens towards a more and more advanced sensory tool as can be found, for example, in raptors" (Ibid., p. 32). Haacke claims that whenever eyes have disappeared, as has happened in several phylogenetic lines, they never re-evolve into the initial forms within these lines. He provides caecilians as an example. It was to facilitate the discovery of this kind of phenomena that Haacke coined the term orthogenesis: "Within each phyloge-

\footnotetext{
7 German original: "Aus der Form der Gemmarien muss also der Aufbau des Organismus erklärt werden, und damit wäre eine Erklärung der Vererbung überkommener Eigenschaften gegeben.”
} 
netic line the development ${ }^{8}$ has always proceeded only in one specific direction, orthogenesis has taken place everywhere" (Ibid., p. 32). 'The gemmaria theory of heredity is most appropriate for explaining orthogenesis, Haacke argued, because this epigenetic theory postulates the "dependence of all cells in the body of the entire germplasm" (Ibid., p. 33). External influences are constantly confronted with the sum total of hereditary material, and therefore the environment in each moment exerts an influence upon a unique plasmatic composition. Haacke gave the credit for the invention of this holistic approach to, among others, Theodor Eimer (Haacke, 1893, p. 314), who later became one of the most well known advocates of orthogenesis.

Orthogenesis as a concept of directed evolution is accompanied, in Haacke's theoretical system, by the theory of epimorphism, which asserts that evolution proceeds towards increasing perfection: "With epimorphism we mean an increasing degree of developmental [= evolutionary - auth. $]$ perfection, which comes into being in the course of phylogenetic history" (Ibid., p. 204). ${ }^{10}$ Haacke explains epimorphism by the "rigidity" of plasmatic structures accompanied by a kind of selection: organisms with more rigid plasma grow more intensely and are more resistant to environmental influences (Ibid., p. 204).

In other words Haacke clearly separated orthogenesis from the concept of evolutionary progress. Haacke's orthogenesis is based on the structural properties of "plasma" as a universal agent of hereditary information, which determines the evolutionary direction within a phylogenetic line. There is no finalism in this approach to the directionality of evolution.

Although Haacke was the first to use the term orthogenesis, he emphasised that his theory had profited significantly from the ideas of the German botanist Carl von Nägeli (1817-1891): "I owe very much to Nägeli, and it almost looks like that the theory I present here is nothing more than an elaboration of Nägeli's ideas" (Ibid., p. 312). ${ }^{11}$ Indeed, being formally a "pre-orthogenetic" author, Nägeli articulated a number of ideas crucial for orthogenesis. In his ambitious book Mechanisch-physiologische Theorie der Abstammungslehre (Mechanical-physiological theory of descent) Nägeli provided severe criticism of selectionism from a neo-Lamarckian standpoint. His major argument against Darwinism was that it does not explain the causes of evolutionary transformations, but only assumes that "the causes of the manifold variability is to be found in climatic and nutritional influences" (Nägeli, 1884, p. 292). In accord with the "selection theory", Nägeli argued, every evolutionary step depends on the haphazard environmental circumstances and we would never find the same organism under other conditions. Evolution could take another direction, and it is imaginable that there would be, for example, no mammals under other circumstances. Yet Nägeli's evolution does not follow environmental changes blindly. Along with the Lamarckian "theory of direct causation" Nägeli introduces the concept of "interior forces", which operate autonomously in relation to external influences (Nägeli,

\footnotetext{
8 "Development" [Entwickelung] in Haacke's vocabulary corresponds to "evolution" in modern usage.

${ }_{9}^{9}$ German original: "Innerhalb jeder Abstammungslinie ist die Entwickelung immer nur nach einer Richtung hin vor sich gegangen, überall hat Orthogenese stattgefunden."

10 German original: "Wir haben unter Epimorphismus die zunehmende Höhe der Entwicklungsvollkommenheit verstanden, die im Laufe der stammesgeschichtlichen Entwickelung zu Tage tritt [...]."

${ }_{11}$ German original: "Sehr viel verdanke ich Nägeli, und es könnte fast scheinen, dass die hier vorgetragene Lehre weiter nichts ist, als eine Ausführung der Nägeli'schen Ideen.”
} 
1884 , p. 294). These autonomous "forces" determine the course of phylogeny to such an extent that the stages of evolutionary progress and adaptations "could not be much different from what they are" (Ibid., p. 294). Nägeli, just like Haeckel, compared living organisms with growing crystalline structures following their "inner forces", whereas external influences are of minor significance for this process. There is, however, a significant dissimilarity between Nägeli's and Haacke's concepts. The general idea that the organisms, on one hand, adapt to their environments due to various Lamarckian-like mechanisms but, on the other hand, are guided by internal regularities, is common to both authors. But Haacke rejected Nägeli's "inner forces" (Haacke, 1893, p. 313) and therefore orthogenesis cannot predict the entire course of evolution. Haacke's "gemmaria" show no tendency towards auto-perfection, his orthogenesis and epimorphism are rather due to passive structural properties of the plasma.

Haacke's orthogenesis was adapted by the Swiss-German zoologist Theodor G. H. Eimer (1843-1898). Born in Lahr (Switzerland) Eimer studied at the universities in Tübingen, Freiburg, Heidelberg and Berlin and after having graduated started his scientific career under the guidance of Albert Kölliker (Würzburg) and August Weismann (Freiburg). This explains Eimer's passage on the first pages of his Orthogenesis, where he asks Weismann to forgive him for neglecting his theory in favour of orthogenesis and neo-Lamarckism (Eimer, 1897, p. XII). In the period from 1875 till 1896, Eimer held the Chair in Zoology and Comparative anatomy in Tübingen, where he also passed away.

Eimer wrote several books in which he defended orthogenesis and the "inheritance of acquired features" (Eimer, 1888, 1897, 1901). The best known is his voluminous book named Orthegenesis (Eimer, 1897) written as the second part of his Die Entstehung der Arten (The Origin of Species). Just like Haacke, Eimer choose Weismann's neo-Darwinism as a major target for criticism, as can be seen already in the full title of the book: Orthogenesis der Schmetterlinge: ein Beweis bestimmt gerichtete Entwickelung und Ohnmacht der natürlichen Zuchtwabl bei der Artbildung. Zugleich eine Erwiderung an August Weismann (Orthogenesis in butterflies: Evidence for definitely directed evolution and the poverty of natural selection in speciation. Also a response to August Weismann). Already in the first part of this ambitious work Eimer claimed that the major theoretical debate in contemporary evolutionary theory is the controversy between Weismann and Nägeli (Eimer, 1888, p. 9), i.e. whether evolution proceeds by means of Darwinian (natural selection) or Lamarckian (inheritance of acquired characters) mechanisms. Eimer pleaded for Lamarckism accompanied by orthogenesis, although he, as well as Haacke, abandoned Nägeli's concept of immanent "drive to perfection" and denied any impact of "inner forces" on evolution (Eimer, 1897, p. 15). "What I have in common with Nägeli", - Eimer stressed, - "is the theory of evolution in a few definite directions and the suggestion, that natural selection performs a truly negligible, subordinate role for evolutionary transmutations" (Eimer, 1897, p. II). ${ }^{12}$ Eimer emphasised that the neo-Darwinian idea of random variation has no empirical support, because in any given moment there is only variation in a few directions and thus natural selection has little to select from.

\footnotetext{
12 German original: "Was Nägeli und mir gemeinsam ist, das ist die Lehre von der Entwickelung nach wenigen bestimmten Richtungen und der Hinweis darauf, dass diese Entwickelung die Bedeutung der Zuchtwahl für die Transmutation als eine vollkommen nebensächliche, untergeordnete erscheinen lässt."
} 
Orthogenesis is explanained by organophysis, i.e. the concept of "organic growth" (in modern terms - ontogenetic development). This concept (but not the term) was coined already in the Entstehung der Arten: "Heat, air, light, humidity, food determine the growth of individuals and appear to our eyes as the most powerful driving forces determining the forms of living beings. They determine the growth through the physical and chemical changes of the living organic mass, the plasma, through the formation of new and more complex interconnections" (Eimer, 1888, p. 25). ${ }^{13}$ In other words, evolution proceeds

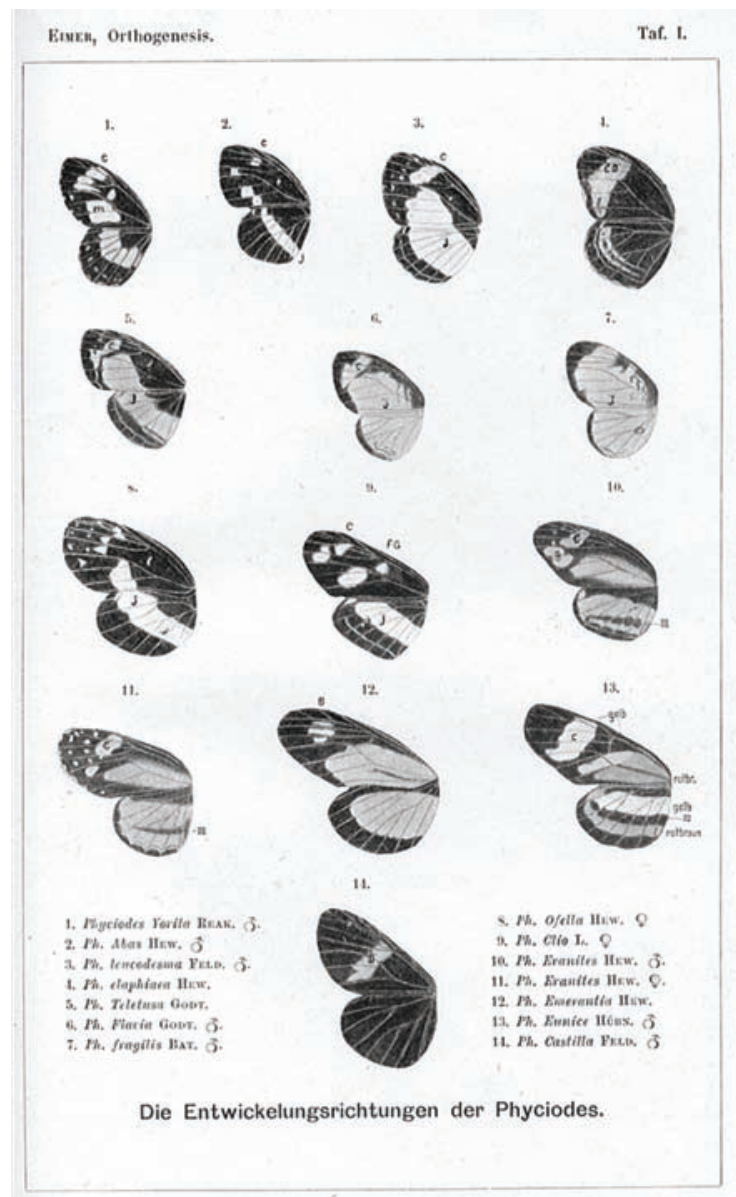

Fig. 4: Eimer's illustration of orthogenesis as an example of evolutionary directions of the wings of Phyciodes. orthogenetically because it is reducible to chemical and physical processes. Eimer, as well as Haacke, drew an analogy between living beings and crystals growing in accord with chemical-physical laws and without any relation to the potential usefulness of their features. Nothing indicates, Eimer stated, the predominance of the useful features in the organisms as claimed by the Darwinians. The so-called adaptations are "due to the physiological necessity of organic growth" (Eimer, 1897, p. III-IV).

Orthogenesis is, in Eimer's theory, a dichotomous concept. On the one hand, it is a historical concept documenting phylogenetic history, but on the other hand, it is also the major mechanism of evolution: "Orthogenesis or, respectively, organophysis determining it, is the dominant instrument of transformation, not selection" (Eimer, 1897, p. IV). ${ }^{14}$ In addition, Eimer claimed to be the first to realize that orthogenesis is a "universal law", and this is an important step which distinguishes Eimer's theory from the ideas of the prominent American neoLamarckians Edward D. Cope (1840-

\footnotetext{
13 German original: "Wärme, Luft, Licht, Feuchtigkeit, Nahrung bedingen das Wachsen der Einzelwesen, erscheinen vor unseren Augen als die mächtigsten, die Manichfaltigkeit der Formgestaltung der Lebewesen bedingenden Kräfte. Sie bedingen das Wachsen durch die physikalische und chemische Aenderung der lebenden organischen Masse, des Plasma, durch Bildung neuer und zusammengesetzterer Verbindungen."

14 German original: "Die Orthogenesis bezw. die dieselbe bedingende Organophysis ist das herrschende Mittel der Umbildung, nicht die Zuchtwahl.”
} 
1897) and Alpheus Hyatt (1838-1902), which also postulated the directedness and irreversibility of evolution (Ibid., p. 13).

The ultimate cause of orthogenesis lies, or so Eimer claimed, in the "external" (environmental) factors (climate, nutrition), which influence an organism's "constitution". Eimer insisted that this is not a Lamarckian mechanism, because Lamarck neglected this kind of influence. It is this special organismic constitution that canalises evolution into a few lines (body plans) "having nothing to do with adaptation" (Ibid., pp. 15-16).

The bulk of Eimer's Orthogenesis is devoted to the empirical evidence which supports his view. One example is the evolution of the butterfly Phyciodes [Fig. 4, Table I]: "Yet it is important to note that evolutionary analagousness (Homeogenesis) produced alone by Phyciodes as many types of patterns as we have described as "basic forms" in a diversity of butterflies" (Ibid., p. 195). "It is always about stages in particular evolutionary pathways of coloration and patterns, also when it comes to the similarity between the PhyciodesEresia species, on the one hand, and Heliconidae and Danaidae on the other hand, but not about mimicry due to selection, because selection is in this case completely excluded, as all Heloconidae and Danaidae described here are much smaller then PhyciodesEresia..." (Ibid., p. 197). ${ }^{15}$ Thus mimicry makes no sense inthis case. Along these lines Eimer came to his major conclusion: "The definitely directed evolution, orthogenesis, dominates all alterations of butterflies including the proven lawfulness of the sequences of colours and patterns" (Ibid., 467).

Eimer introduced a mechanism of evolution, which could be seen as quite Lamarckian, because of the inheritance of acquired characters, but at the same he clearly and correctly pointed out the difference between orthogenesis and Lamarckism. While Lamarckism was put forward as a theory of adaptation, orthogenesis proved and explained long-term non-adaptive trends in evolution.

Thus towards the end of the 19th century, orthogenesis became a well defined theoretical construct. Although the initial steps were made simultaneously by Haacke and Eimer, the concept was later mostly associated with Eimer's name. Eimer's theory became influential not only in German-speaking countries. Due to the support of the British marine biologist Joseph T. Cunningham, Die Entstehung der Arten was translated into English (Bowler, 1983, p. 154). Because German was an international scientific language, his ideas found influential followers also in other major national traditions such as in Russia and in Scandinavia.

\footnotetext{
15 The complete German original: "Bei allen diesen Faltern haben wir also noch die gewöhnliche Flügelform und nichts von Querlagerung der Zeichnung. Es ist aber hochwichtig, zu sehen, wie unabhängige Entwickelungsgleichheit, Homoeogenesis, allein bei dieser Gattung Phyciodes so viele der Zeichnungstypen entstehen lässt, welche wir als Grundformen der Zeichnung bei den verschiedensten Faltern beschrieben haben” (Ibid., p. 195). "Es handelt sich überall auch in der Ähnlichkeit zwischen den Phyciodes-Eresia Arten einerseits und Helikoniden und Danaiden andererseits um Stufen bestimmter Entwickelungsrichtungen in Farbe und Zeichnung, nicht aber um durch Zuchtwahl entstandene Verkleidung, denn diese ist gerade im vorliegenden Falle dadurch vollkommen ausgeschlossen, dass alle die behandelten und andere, Helikoniden und Danaiden nachahmen sollenden Phyciodes-Eresia viel kleiner sind als die letzteren, wodurch eine Verwechselung vollkommen ausgeschlossen sein muss, wie dies auch Hahnel nach Beobachtung an Ort und Stelle hervorhebt" (Ibid., p. 197).
} 


\section{Orthogenesis in the first half of the $20^{\text {th }}$ century: Networks of resistance?}

By the early $20^{\text {th }}$ century, the unambiguous identification of Darwinism with selection theory became widespread in various countries. At the same time, due to the incomplete and sometimes even contradictory data from palaeontology, anatomy/morphology, biogeography, systematics, and genetics, the reconstruction of evolutionary history and evolutionary mechanisms still had to be provisional and even speculative (Gould 1977). Accordingly, the Darwinian theory of natural selection became just one of several more or less plausible hypotheses for how evolution proceeds (Junker \& Hoßfeld 2001). The controversies over Darwinism nourished the self-confidence of alternative theories of evolution. Therefore, the first third of the twentieth century became the heyday of the alternative theories, which were flourishing at the same time in various countries and around that time achieved conceptual maturity. The Swedish historian of biology Erik Nordenskiöld (1872-1933) noted in this regard: "The history of biology might really close with the establishment of the dissolution of Darwinism" (Nordenskiöld 1928, p. 574). At that time orthogenesis became one of the most powerful alternatives to Darwinism. Below we give some examples of the most influential and original champions of orthogenesis in the $20^{\text {th }}$ century.

The American palaeontologist Henry Fairfield Osborn (1857-1935) played a significant role in the history of orthogenesis and his works, both empirical and theoretical, were actively quoted by the German-speaking authors. Educated in Princeton, Osborn became a professor of comparative anatomy there, until he was jointly hired by Columbia University and the American Museum of Natural History, becoming the President of AMNH in 1908. Under Osborn's leadership, the AMNH acquired the best fossil collections worldwide. Material from collection was used by him for making brave evolutionary generalisations. Osborn was fully aware of the international theoretical discussions and included Nägeli's "ideoplasm hypothesis" (Osborn, 1925, p. 93) and early paleontological work of Othenio Abel (see below) in his discussions. Osborn was, however, very influenced by his mentor Edward Drinker Cope (1840-1897), one of the early advocates of directed evolution, who, just like the early orthogeneticists in Germany, supported the Lamarckian theory of inheritance. In the earliest works Osborn followed "Cope's orthogenetic Lamarckism", but later, during the 1890s, he abandoned this hypothetic evolutionary mechanism (Bowler, 1983, pp. 131, 174) and appealed to the mechanism of "coincident" or "organic selection", which later became known as the "Baldwin affect" (after James M. Baldwin, 1861-1934, who expressed this idea at the same time). Osborn expressed his view on "organic selection" clearly in a discussion at the Detroit meeting of American Association published in Science (Osborn, 1897): "Organic selection is the term proposed by Professor Baldwin and adopted by Professor Morgan ${ }^{16}$ and myself for this process in nature which is believed to be one of the true causes of definite or determinate variation. The hypothesis is briefly as follows: That ontogenetic adaptation is of a very profound character. It enables animals and plants to survive very critical changes in their environment. Thus all the individuals of a race are similarly modified over such long periods of time that very gradually congenital or phylogenetic variations,

16 Conway Lloyd Morgan (1852-1936). 
which happen to coincide with the ontogenetic adaptive variations, are selected. Thus there would result an apparent but not real transmission of acquired characters." As Hall (2001) explained this phenomenon in modern terms: "Organic selection (or the Baldwin Effect as it became known) describes the situation where an environmentally elicited phenotypic adaptation subject to natural selection comes under genotypic control". This idea has its own history and was later developed further by the English geneticist Conrad Hal Waddington's (1905-1975) and the Russian evolutionary biologist Ivan Ivanovich Schmalhausen (1884-1963) into a Darwinian concept. Osborn, by contrast, believed that this hypothesis could reconcile Darwinian and Lamarckian approaches to evolution, if it was universal and able to explain all cases of "determinate variation". Yet, Osborn argued, this mechanism is not universal, since there are such structures as teeth and the inner parts of the skull, which cannot be improved by individual use. So, Osborn concluded, there must also be other reasons for variation in certain directions: "My study of teeth in a great many phyla of Mammalia in past times have convinced me that there are fundamental predispositions to vary in certain directions" (Osborn, 1897). If Osborn had used the term "orthogenesis" here, it would be one of the best concise definitions of orthogenetic evolution.

In his mature work Osborn maintained that "neither the Lamarckian nor the Darwinian explanation accords with all that we are learning though paleontology and experimental zoology" (Osborn, 1925, p. 145) and proposed that evolution may be explained by the study of the four "physicochemical" complexes, including physical and living environments, the developing organism, and the hereditary substance "chromatin". In the very last works (since 1932) Osborn developed his "physicochemical" approach by proposing a concept of aristogenesis. Aristogenes replaced, in Osborn's theory, the term "rectigradations", which he used in the earlier works. Aristogenes are new "biomechanisms" occurring in the "geneplasm" as constrasted to the "somaplasm". Osborn derived this term from the Greek "aristos" (best of its kind) and emphasised that aristogenesis is a descriptive, fully empirically based concept in contrast to such "theoretical" concepts as entelechy or vitalism. Osborn saw his aristogenesis not as a hypothesis or a theory, but rather as a description of evolution as a natural process bringing into being new biological mechanisms: "Aristogenesis is the gradual, secular, continuous, direct, reactive, adaptive origin of new biomechanisms. It is a creative process from the geneplasm of entirely new germinal characters. It is the orderly creation of something better or more adaptive. Certain lines of descent are distinguished by the potentiality of creative origin from the geneplasm of new adaptive biomechanisms. Germinally predetermined origin of new characters tends toward betterment, arises independently, in widely separated geographic areas, at the same or different aristogenic rates. Aristogenesis is a secular genetic and adaptive reaction rather than an immediate adaptive reaction to new habit or environment as in Lamarck's theory. Aristogenes are independent in origin and early development of the Natural selection principle of Darwin" (Osborn, 1933). Once a new class has appeared, it undergoes the process of "adaptive radiation" (the term coined by Osborn as early as 1902) due to the novel "biomechanisms", and subsequently comes into the phase of stable, linear evolution closing with the phase of overdevelopment, which Osborn often illustrated by the evolution of titanotheres. 
As Osborn himself noted "comparable results" (Osborn, 1926) concerning the linear and non-adaptive character of evolution were achieved by Dollo and Abel. Othenio Abel (1875-1946) was one of the best known German-speaking champions of orthogenesis, who, in his turn, was obviously influenced by Osborn's arguments and paleontological findings. He was born and educated in Vienna (Ehrenberg, 1975; Khittel, 2005), where he studied law and geology. At the University of Vienna, Abel also met the geologist Eduard Suess (1831-1914) (one of the pioneers of the global approach who coined the term biosphere in 1875) and made the $\mathrm{PhD}$ in geology under his guidance (1899). A year later Abel was invited to Brussels to visit the paleozoologist Louis Dollo (18571931), best known for introducing the principle of irreversibility in evolution (Dollo's law). Although "Dollo's law" does not necessarily imply orthogenesis (Bowler, 1983, p. 144), it was interpreted by the advocates of orthogenesis as one of the strongest arguments in favour of directed evolution. As Abel himself asserted, Dollo was the most important figure in his scientific education. ${ }^{17}$ The most important aspects for Abel was the Dollo's methodology, his general approach to paleontology implying not only classification but also explanation of fossil findings (Ehrenberg, 1975, p. 56). Between 1900 and 1907 Abel worked at the State Geological Institute [Geologisches Reichsanstalt]. In 1907 he became an extraordinary professor of paleontology. It is worth noting that the Chair of Paleontology at that time was Karl Diener (1862-1928), who supported orthogenesis unambiguously, ranking it, among Darwinism and Lamarckism, among the major competing evolutionary theories (Diener, 1910, pp. 11, 92-98). In 1911 Abel was awarded the Bigsby Gold Medal for Geology and a year later he was offered a full professorship in paleontology. In 1920 Abel published a textbook of paleozoology (Lehrbuch der Paläozoologie, Abel, 1920) and a year later (1921) the zoological-botanical society gave him the Rainer gold medal for his contributions in paleozoology. Afterwards he was crowned with many other accolades including a Corresponding Membership of the Geological Society of London (1928), and a Honorary Membership of the Boston Society of Natural History. The works which are central for Abel's theoretical contribution in evolutionary theory and the concept of orthogenesis were written when he was already a well known and mature scientist (Abel, 1928; 1929). In 1932 Abel was elected Rector of Vienna University. However, two years later, at the age of 59, Abel retired because of his explicit commitment to the ideology of national socialism. After his retirement he got a professorship in Göttingen (1935-1940), and later returned to Austria. Thereafter his influence on German paleontology decreased. This was partly due to the appearance of new very influential figures such as Otto Schindewolf (see below).

Abel based his ideas not only on the works of such classic figures of orthogenesis as Nägeli, Eimer, and his friend Dollo, but paid much attention to other pioneering approaches to directed evolution such as those developed by Ludwig Plate (see below) and, as already mentioned, Osborn. Considering the data available in the literature and earned in his own paleontological studies Abel claimed that there can be no doubt that evolution proceeds in accord with orthogenesis, including the directedness of evolution and its

\footnotetext{
${ }^{17}$ In Abel's own words: "Unter vielen Fachgenossen, mit denen mich mein Weg zusammengeführt hat, hat kein einziger einen so bestimmenden Einfluß auf meine geistige und wissenschaftliche Entwicklung und Ausbildung genommen wie Louis Dollo" (quoted from: Ehrenberg, 1975 p. 56).
} 
irreversibility. He insisted, however, that both "laws" are only the consequences of a more general law, "the governing principle of the entire organic world" , which must deliver ultimate explanation of all evolutionary phenomena (Abel, 1928, p. 15). Abel believed that he had found this principle, which he labelled the Trägheitsgesetr. [the law of inertia]. According to this law the "organic world" obeys the same law of inertia as the "inorganic world". An important part of this law is Carl Gauss's (1777-1855) principle which - in Abel's interpretation - postulates that an inertially moving body experiencing various forces will turn in the direction of least resistance. This idea, Abel argued, can be applied directly to the explanation of evolutionary phenomena: "The mechanical principle of inertia can be understood in the organic world also purely mechanically" (Abel, 1928 , p. 96). It would have nothing to do with the idea of a "vital force", Abel claimed, or other mystical or philosophical approaches. Thus the concept of movement in mechanics can be paralleled with the biological idea of function, since function is an activity and therefore a kind of movement. The possible mechanism illustrating the application of this law to the "organic world" he described as follows. The organism reacts on its environment and this reaction results either in true adaptation or in a "maladaptation". In most of the cases we know from paleontology, a reaction once it has appeared, will be acquired by further generations. If an environmental pressure persists, the organismic reaction also persists and increases. If the same environmental pressure persists for long enough and a certain mode of reaction develops over many generations, then a novel feature will be fixed in such a way that it will not disappear again, even if the environment changes. Only radical environmental changes would lead to a significant change of evolutionary pathway, although also in this case the previously acquired specialisation will persist and influence the organism's evolution. Drawing a parallel to Gauss, Abel explains this phenomenon with the concept of the "weakest resistance" claiming that the further evolution of an organism will with the highest probability proceed along the same lines as its former adaptations, because it would mean for an organism going the way of the "least resistance" (Abel, 1928, pp. 98-100). Dollo's principle of irreversibility is then the mechanical consequence of his law of phylogenetic inertia.

Thus, Abel was sure that his hypothesis could explain both orthogenesis and Dollo's principle in a causal manner. In addition, he persistently emphasised that "the law of inertia" rests on solid ground (the paleontological record) and this distinguishes his approach from that of the "theoreticians of heredity" (geneticists), who worked with very restricted amounts of empirical data in Abel's view.

Edwin Hennig (1882-1977) ${ }^{18}$ developed his ideas along similar lines as Othenio Abel and his work was based on Abel's. Hennig became an influential supporter of orthogenesis in Germany (Reif, 1986). Born in Berlin, Hennig studied geology and biology in Freiburg and was awarded with a Ph.D. in 1906 for the thesis Gyrodus und die Organisation der Pycnodonten. ${ }^{19}$ Thereafter Hennig accepted a position of an "Assistent" ("assistant professor" in the US system) at the Geological-Paleontological Institute in Berlin. Already in 1912, he was awarded with the Kronenorden IV (order of crown of the forth degree) and a year later completed his Habilitation (second dissertation) in Berlin (1913).

\footnotetext{
${ }^{18}$ Not to be confused with Willi Hennig (1913-1976) known as the founder of cladistics.

${ }^{19}$ UAT, Bestand 407: Nachlaß Edwin Hennig.
} 
After the Habilitation Hennig became Privatdozent at the University of Berlin and officially kept this position until 1917 although he, in parallel, completed his military service during WWI. In 1917 Hennig took up the Chair in Geology and Paleontology at the University of Tübingen and held this position until October 25, 1945. One of his assistants was Karl Beurlen, who later developed one of the most consequent orthogenetic theories (see below). In addition, in 1929 Hennig became the Rector of Tübingen University. When WWII was over, Hennig underwent the usual procedure of denazification ${ }^{20}$ and retired in 1951. He died in Tübingen in 1977.

In a short paper published at the beginning of the 1920s Hennig formulated his view on paleontology and its role for evolutionary theory. Hennig defined Darwin's concept of natural selection as a brilliant idea, which however needs to be examined empirically (Hennig, 1922, p. 5). In this connection paleontology has an important role, according to Hennig. Paleontology teaches us that evolution is a historical fact. It also shows that evolution is a "definitely directed expansion of the living forms" as contrasted to the random changes in the inorganic world (Hennig, 1922, p. 9). Whether this directed development can be defined as progress or perfection is a question of definitions. It is also important, Hennig argues, that paleontology can contribute to investigations into the mechanism of evolution. Anticipating the later concepts of Beurlen and Schindewolf, Hennig draws an analogy between ontogenetic cycles and phylogeny, and claims that the various branches of the phylogeny manifest the same dynamics as can be observed in ontogeny: rapid evolution in the stage of juvenile plasticity, followed by the stage of stable and moderate evolution and ultimately the phase of stagnation or even degradation (senile variability). A new type can appear as a result of saltation [Hennig, 1922, p. 11], although in the later works (Hennig, 1932) Hennig was more cautious with respect to saltational evolution. The basic question he posed was whether the new types come into being randomly or follow internal laws. In a paper in the prestigious journal Naturwissenschaften Hennig analysed the problem of orthogenesis, which he defines simply as "parallel development", and puts the question on the Triebkräfte (driving forces) to be discovered behind the evolutionary phenomena (Hennig, 1927). He points out that there are countless possibilities for the environment to influence plants and animals, but the general course of evolution gives an impression of consistency. "Life looks almost determined", in his own words (Hennig, 1927). The essence of this directed process is a movement from the lowest to the highest level of complexity. At the same time, it would be wrong to discuss this process in terms of the escalation of vitality, since protozoa are immortal. However, where cells get together in assemblageses there is division of labour and they obey the rule of "forced growth", i.e. tend to grow larger. Examples are the large inocerams and rudists of the Cretaceous, dinosaursetc.. This however mostly has no advantage for the organism. Very often the "forced growth leads" to the complete reconstruction of the body plan, the chemistry and even the mental abilities of the organism. Hennig proposed that this irresistible growth is connected with the succession of generations. In Hennig's words "the wedge will be almost inexorably driven further in a

\footnotetext{
20 The process of re-training people involved with the Nazi regime during the Third Reich into democratic
} citizens of post-WWII Germany. 
direction once taken" (Hennig, 1927). Thus Hennig, almost simultaneously with Abel, formulated the concept of evolutionary inertia as the cause of orthogenetic evolution.

At the same time as Abel and Hennig, and based on the ideas of Abel, Nägeli, Eimer, Osborn, Dollo and many other Western orthogenesis thinkers, the Russian geographer and biologist Lew (Leo) S. Berg (1876-1950) developed his ideas. His nomogenesis theory developed in the early 1920s arguably belongs to the most consistent and influential orthogenetic theories. Born and initially educated in Moldova (then part of the Russian Empire) Berg enrolled at Moscow University, where he studied hydrobiology and geography. Soon he made himself a name as an ichthyologist and geographer, and in 1928 was awarded corresponding membership (in 1946 full membership) of the Soviet Academy of Science. A towering figure in Russian geography, Berg was also important for the history of orthogenesis. His book Nomogenesis, first published in Russian (Berg, 1922) and later translated into English (Berg 1926 [2nd ed. 1969]), was based on a large amount of empirical data and offered a comprehensive and strong criticism of Darwinian evolutionary theory (Levit \& Hoßfeld 2005). In his review of Nomogenesis Osborn claimed that in this book "all the arguments against selection are cited from the works of a list of authors which fairly cover the whole field of literature from Darwin to the present time" (Osborn, 1926). Osborn, in his turn, belongs to the most cited authors in the book.

Berg's theory combined arguments from paleontology, zoology, and botany, and consists of a number of logically relatively independent claims. The most basic assertion common to all orthogenetic theories is that evolution is a directed process: "Darwin believed that characters vary in all directions, like, let us say, rays issuing from the sun. [...] We, on the contrary, claim that variation of characters is confined within certain limits, that it follows a definite course, like an electric current moving along a wire" (Berg 1969, p. 158). The limits Berg talks about were supposed to be determined by both internal and external factors. The internal factors are reflected by the term autonomic orthogenesis (Berg, 1969, p. 114) and are expressed, for example, in the fact that organisms often evolve contrary to environmental changes, as can be exemplified by extinctions. The external factors refer to the impact of the geographical landscape on the evolutionary process. The landscape affects a species "in an imperative manner" by the combination of elements which constitute this landscape as far as the organisation of species permits variation in a determined direction (Berg 1969, p. 265).

In effect, the actual evolution follows a middle course determined by the internal and external factors. Such double limitation of the variability, Berg argues, does not leave much space to natural selection, a fact also supported by the paleontological record, because all phylogenetic branches look more or less like straight lines. Berg distanced himself not only from Darwinism but also from Lamarckism (which he understood as a theory of use/disuse accompanied by the inheritance of acquired chararcters) and proposed the concept of directed mass mutations as a major mechanism of directed evolution. Following Wilhelm Waagen (1841-1900), he labeled them Waagen-mutations: "New species arise by means of a mass transformation of a great number of individuals, which happens due to Waagen mutations [...]. This mass transformation is a phenomenon of geological magnitude. It is connected with the alteration of the fauna of a certain horizon and comes about in certain periods only to be absent for a long time" (Berg 1977, p. 317). Thus, evolution proceeds essentially by mass mutations, which are canalized by 
external and internal factors, in such a way that a new species occurs with a high probability almost perfectly adapted. A newly evolved species then begets the subordinate taxonomic categories, which appear to be perfectly adapted to their environments. "Adaptation" in this context means the incorporation into a specific landscape. There are no "more or less" adapted species in this respect. In other words, Berg proposed a theory which, being anti-Darwinian, was at the same time anti-Lamarckian, but nevertheless advocated adaptive evolution.

Paradoxically, Berg's anti-Darwinian criticism was directed mostly against the German zoologist Ludwig H. Plate (1862-1937), who in his later works himself proposed a theory advocating orthogenesis. For Berg, as well as for Osborn, Plate was one of the major representatives of the Darwinism of their time. Plate himself labeled the theoretical system he developed "old-Darwinism" to contrast his views with the neo-Darwinism of Weismann (Levit \& Hoßfeld, 2006).

Plate was born in Bremen and in 1882 he started to study mathematics and natural sciences in Jena, Bonn and Munich. He had developed an interest in evolutionary theory already by attending Ernst Haeckel's lectures in Jena. However, in his own words, "the proper training in zoology" Plate owes to his teacher Richard Hertwig (1850-1937) (Plate 1935), who lectured in Munich and Bonn and who impressed the young scientist very much. Plate gained his doctorate in 1886 from Jena University after submitting his thesis on Rotatoria (Rotifera). Already two years later (1888) Plate obtained his habilitation in zoology at Marburg University and soon established himself as an expert in the fields of zoology and the theory of descent. In 1909, due to the active support of Ernst Haeckel, Plate was offered Haeckel's Chair of Zoology at Jena University. Plate officially held the chair in Jena until 1935 and died soon thereafter in 1937. For his scientific services Plate was awarded membership of the Leopoldina Academy (Halle/Saale) (1933) as well as of the science academies in Budapest and Stockholm. He was also honoured with the Coburger Ritterkeuz I and the Roter Adlerorden IV.

Having been seriously involved in genetic studies already before coming to Jena, Plate continued them in Jena. These studies accompanied, by Plate's research in zoology and morphology, resulted in Plate's own theory of heredity, the final version of which was summarized in the three volumes of his Vererbungslehre (Genetics), comprising more than 3000 pages [Plate, 1932-38] and also including his theory of orthogenesis.

Plate proposed a concept combining all valuable theoretical movements and new disciplines of the biology of his time. According to Plate, his old-Darwinism follows exactly the initial ideas of Darwin, while at the same time adapting and processing all healthy and empirically verifiable later scientific achievements. Plate tried to combine all fruitful theoretical approaches (Lamarckism, selectionism, orthogenesis) with the most innovative fields of experimental biology like genetics. The core of Plate's evolutionary theory can be condensed into two theses:

- 'Darwinism is a 'stochastic theory' taking into account variations occurring by chance in the individuals of a certain species" (Plate 1913, p. 222).

- "However the harmonic modification of various features is easier conceivable from the Lamarckian standpoint" (Plate 1913, p. 224).

In Plate's later works (Plate 1932-38), we find all the basic factors of evolution later adapted by the Synthetic Theory of Evolution (STE). Thus Plate claimed that random 
mutations and recombinations deliver the bulk of the raw material of evolution. Natural selection and geographical isolation perform a major role in evolution (Plate 1933, p. 1045). Also what is now known as "population thinking" is of great importance for Plate, and he analyses the "laws of populations" with some mathematics (Plate 1933, pp. 10471052). Yet Plate also allowed other evolutionary mechanisms, which went far beyond the STE. Plate accepted both macro- and directed mutations, the inheritance of acquired characters and orthogenesis, which performs one of the central roles in his theoretical system and, perhaps for first time, are given a detailed explanation.

It was Plate who coined the term orthoselection, which was later adapted by Julian Huxley $(1974$, p. 500) and Bernhard Rensch (1947, p. 74, 144, 160) and thus incorporated into the Modern Synthesis. Yet in Plate's original theory, orthoselection was a part of the more general theory of orthoevolution (directed evolution) (Plate, 1922, p. 11), which included both orthogenesis and orthoselection. Plate's objective was to combine the idea of random variation with orthogenesis.

To make his position clear Plate separated facts from the bypotheses explaining these facts. Plate postulated that any basic form (Stammform) gives rise to only a few side branches and never produces an innumerable variety of side branches. He also claimed that almost all phylogenetic branches look more or less like straight lines and do not oscillate zigzag-like between progress and degradation.

There are two ways to explain these facts. The first is orthogenesis, which, according to Plate, means that certain factors influence and modify all individuals in such a way that natural selection has almost nothing to select from (Plate, 1913, p. 508; 1922, pp. 10-11; 1925, pp. 115-116). The second way is orthoselection, which asserts that, although individual variations are random, only a few phyletic directions are progressive (in any sense of the word) and therefore persist under selective pressure [Plate, 1913, p. 508]. The difference in principle between orthogenesis and orthoselection is that orthogenesis is usually associated with Lamarckism, whereas orthoselection implies the Darwinian idea of random mutations processed by natural selection. According to Plate, both mechanisms (orthogenesis and orthoselection) can work simultaneously and independently, and Plate's orthogenesis is in no way a universal evolutionary mechanism. He wrote: "Definitely directed variation and selection are not mutually exclusive, but can work together. It does not matter to selection, if a certain change is in the same direction as the one before or not, if the change continues in the same direction or not." (Plate, 1913, p. 510). He was convinced of exactly following Darwin's initial ideas here (Ibid., p. 511).

In the Vererbungslehre (1932-38), Plate attempted to substantiate his view on the problem of directed evolution with the help of genetics, which dominated his late works. A significant theoretical challenge was to separate the directed evolution on the gene level from orthogenesis and orthoselection at higher levels.

Orthoselection on the level of separate genes operates among the "superior number of variations" (Plate, 1933, p. 1088), since nature creates in the course of time more and more new genes, thereby varying characters "downwards or upwards" (Plate, 1933, pp. 10881089). This is a purely selectionist explanation of directed evolution.

Orthogenesis on the level of separate genes takes place under constant external environmental pressure due to the heritable cytoplasmatic reactions and polyallely. This is a Lamarckian explanatory model. 
On the level of complex features (whole organs) orthoselection acts not on the various alleles of a certain gene, but on their sets (radicals - see below) or on the whole genotype [Plate, 1933, p. 1095]. The latter can lead, for example, to an immediate selective advantage for the whole race. Nevertheless, also on this level orthoselection cannot explain the whole panoply of phenomena, because "there are cases, when selection is excluded", for example the complete disappearance of vestigial organs or the excessive development of certain features [Ibid. p. 1095-1096].

Orthogenetic evolution on this level (whole organs) means the occurrence of new characteristics by the process of capturing "freely mendeling genes" by the "Erbstock", as described below. In any case this kind of orthogenesis is thought to be the response to the continuous stimuli over the course of phyletic history (e.g. the light-sensitive spot on the skin evolved into a retina and further to the human eye due to the continuous light stimulus).

Plate formulated the Erbstock-hypothesis in 1924 and then developed it further. The hypothesis proceeds from the assumption that chromosomes contain genes bearing hereditary information. All genes together form a genotype. However, genes do not bring about the organs themselves, but rather their properties. For instance, Plate argued, we do not know any gene for Drosophila's eye as it is, but we can identify more than 80 genes determining its colour, form, the number of ommatidia and so on. There are no genes for general body constitution, head, thorax, brain etc., whereas there are various genes determining, for example, colour, form and structural details of the Drosophila head. Along these lines Plate concluded: "It appears to me as the inevitable inference that the variety features have other genetic roots as compared to the features of general organisation and higher systematic categories" (Plate, 1933, p. 931). In other words Plate supposed that there are carriers of hereditary information crucial for establishing general structural patterns and representing another level of genetic information than the ordinary genes. In this respect Plate's ideas seem to be similar to the "systemic mutations" of Richard Goldschmidt's (1878-1958), whose early works Plate had analysed critically. However, their concepts differ significantly. Goldschmidt defined systemic mutations as "a change of intrachromosomal pattern" (Goldschmidt, 1940, pp. 206). Plate wrote, in contrast, about the imaginable out-of-chromosomal super-genes, which control the characters of genus, family and higher taxa. The name "Erbstock" was invented by Plate to contrast it to the "Mendelstock", i.e. the genotype consisting of ordinary genes. The "Erbstock" is made up of rigid sets of genes situated in the cell's nucleus but outside of chromosomes and undergoing only slow modifications (Plate, 1933, p. 933). Plate called these clusters of hereditary entities "radicals" and defined them as "groups of correlatively connected genes" (Plate, 1933, p. 935). "Radicals" operate only jointly, as a whole (this is why they are called radicals). They are responsible for shaping most essential structural characters. "Radicals" are phyletically much older than ordinary genes and do not obey Mendel's laws, because individual genes lose their independency by getting attached to the radicals. Since radicals are rigid and have only few possibilities to vary, the Erbstock-hypothesis delivers a molecular biological explanation of orthogenesis (Ibid., p. 1141).

At the same time as Plate developed his molecular explanation of orthogenesis the idea of explaining orthogenesis by morphological constraints was put forward by Karl 
Beurlen (1901-1985). According to his own autobiography, ${ }^{21}$ Karl Beurlen was born (1901) in Aalen (Württemberg, Germany) into the family of a school teacher. While enrolling at Tübingen University (1919) Beurlen has choosen natural science but "with a heavy heart", because ancient and modern philosophy and history of literature were still important for him. This was probably one of the reasons of incorporating metaphysical and even mystical elements in his late theoretical constructions (Beurlen, 1937), which are not covered in this overview.

Beurlen was a student of another champion of orthogenesis, Edwin Hennig (see above), and after completing his $\mathrm{PhD}$ in 1923 later worked as an Assistent under his guidance (Reif, 1986). He concentrated mostly on the Jurassic ammonites of Swabia in southern Germany, as well as on snails and decapods. Afterwards Hennig helped Beurlen to get a position in Königsberg, where he was an Assistent to Karl E. Andrée (18801959), who was in charge of the geological-paleontological institute. In Königsberg Beurlen was engaged in the study of decapods (crabs) and came to the first generalisations questioning the "mechanical" theory of natural selection. Afterwards he changed to Echinoidea and ultimately habilitated (1929) with a more general work on the geology of Prussia. In 1934 Beurlen moved to Kiel to take up the Chair in Geology and Paleontology, and later to Munich (in 1941). According to Beurlen himself, he was unwillingly involved in the social and political activities after 1933 and became the Chair of the German Geological Paleontological Societies as well as reviewer for the Deutsche Forschungsgemeinschaft, the main funding body for German science. After the end of the Second World War, Beurlen lost his academic positions and was forced to earn his livelihood as an assistant to a building worker and at the brickyard. Facing the hopelessness of his situation in Germany, Beurlen moved to Brazil. In the Brazilian period Beurlen published more than 100 scientific works. In 1969 he returned to Germany and since that time resided in Tübingen, where he died in 1985. Beurlen was awarded with memberships in various societies and academies, including the membership in the famed Leopoldina Academy in Halle (since 1936) (Kaasch, 2003).

In the Vergleichende Stammesgeschichte (Comparative Phylogeny, 1930) Beurlen devotes to the analysis of orthogenesis a whole chapter of the same name. He begins with a historical survey of orthogenetic concepts, starting with Th. Eimer, and claims that Eimer succeeded in convincingly describing empirical evidence in favour of orthogenesis. Eimer's observations were supported by the works of C. v. Nägeli and Ludwig H. P. Döderlein (1855-1936). The latter claimed that specialisation of biological forms goes far beyond their usefulness and proposed a concept of "Trägheit" analogous to Abel's law of inertia. Beurlen emphasised that orthogenesis is not a sideline of evolutionary research , and was supported by a variety of outstanding scientists such as Daniele Rosa (18571944), Ernst Koken (1860-1912), Edwin Hennig and many others. Beurlen especially highlighted Abel's paleontological contributions on the evolution of horses and his "biological law of inertia". Beurlen was nevertheless convinced that there is no need for replacing the term "orthogenesis" with some other analogous term, because the concept goes along the lines initially described by Nägeli and Eimer. In addition, Beurlen disagreed with both Abel and Eimer because they declared orthogenesis to be a central

21 Archiv der Leopoldina Akademie, File N 4376. All biographical data follow this source. 
evolutionary concept. Beurlen, however, found orthogenesis to be unable to explain adaptation (Beurlen, 1930, p. 548).

Paleontology, Beurlen argued, confirmed Darwin's hypothesis of gradual evolution, because all initial questions came from Darwinian biology (Beurlen, 1930, p. 535). An unbiased look at the fossil records shows, however, that there were clearly definable periods of explosive appearance of new taxa: "The paleontological findings allow an assumption other than that of the explosive developments only with the aid of auxiliary hypotheses. The findings unambiguously show saltations" (Beurlen, 1930, p. 537). ${ }^{22}$ Is the picture we see only due to the incompleteness of the fossil record, or does it reflect actual phylogenetic history? Beurlen assumes that each major taxonomic group can vary only within the framework of a certain type of adaptation [Anpassungstyp]. Transitional forms between different types of adaptation are impossible. As an example Beurlen gives the body types [Bautypus] of various groups of molluscs. Due to the different design of their shells, the snails can be clearly separated into different types. However, the anatomy of their soft parts correlates with the form of the shells and the mantle and mantle cavity makes no sense in the absence of the shell. These features (mantle, etc.) should have evolved initially only after the appearance of the shell, but the shell can appear only in one saltation, becasue it only makes sense as a whole. Thus, molluscs could appear only as a result of saltation during a "phylogenetic explosion", considering that, for example, annelid-like organization is incompatible with the shell. This is also true for various classes of Mollusca itself, Beurlen argued.

The phylogenetic explosions do not only create adaptive types, but also types unable to adapt to their environments. The inadaptable types either disappear from the evolutionary scene or give birth to persisting or degenerating forms like Limulava, Aglaspina, Conularida, Scaphopoda, Ascoceratidae etc. (Beurlen, 1930, p. 539). So Beurlen comes to the conclusion that the phylogenetic explosion is an undirected process (Beurlen, 1930, p. 540-541).

Beurlen, like Berg, rejected both Darwinism and Lamarckism. He criticized Abel for assuming Lamarckian evolutionary mechanisms. ${ }^{23}$ In Beurlen's view "the establishment of a new type is not a result of a certain adaptation, not a result of a function", but on the contrary a randomly created form represents the ultimate basis for the following process of development and adaptation. Correspondingly, the second evolutionary phase following the phase of phylogenetic explosion proceeds under the dictatorship of form and takes place in the framework of an already existing type. It is this second phase that proceeds orthogenetically. As well as the founder of orthogenesis Haacke, Beurlen did not believe that evolution is necessarily progressive, and claimed that orthogenetic series can go both in the progressive and the regressive direction. Beurlen appealed to the phenomenon discovered by the German paleontologist Otto Jaekel (1863-1929) and later confirmed by the Swedish scientist Erik Stensjö (1891-1984). They described the degeneration of bony tissue into cartilage in, for example, cyclostomes.

\footnotetext{
22 German original: "Der paläontologische Befund lässt eine andere Annahme, als die der explosiven Aufspaltung, nur unter Zuhilfenahme von Hilfshypothesen zu. Er zeigt eindeutig, dass diese sprunghaft erfolgt ist."

23 Compare to Rensch's classification of Beurlen as a "Lamarckian" (Rensch, 1980).
} 
The newly established type is predestined to evolve either in a progressive or in a regressive direction. The adaptively advantageous types will inevitably progress, whereas the non-adaptive types will degrade. Along these lines Beurlen arrives at the conclusion that orthogenetic evolution proceeds "compulsory" and cannot leave the pathways determined by the "form type" [Formtypus], since "every form type has only certain given possibilities to be reshaped; the reshaping is a process directed by the underlying type and leading by necessity to a certain final stage" (Beurlen, 1930, p. 551). ${ }^{24}$

Besides, Beurlen believed that the phase of orthogenesis is characterised by the phenomenon described by the Italian zoologist Danielle Rosa as the "principle of progressive reduction of variability" postulating the progressive decrease of variability throughout a clade's evolution. At the same time Beurlen was unhappy with the term "principle of progressive reduction" and preferred the formulation of Ludwig Plate: "The law of the increasingly reduced amplitude of evolution". Beurlen claims that orthogenetic evolution is an irreversible process in the sense in which ontogenetic development is irreversible: "The irreversibility is thus a typical characteristic of the orthogenetic development representing an immediate consequence of the restrained character of orthogenetic process. Furthermore this law implies that orthogenesis means not only getting rigid within a certain basic type, but also that an orthogenetic series only goes forward, and that backward development is impossible" (Beurlen, 1930, p. 556). ${ }^{25}$

Beurlen proposed the exact mechanisms, which, in his view, can explain both evolutionary stages (phylogenetic explosion and orthogenesis). Proceeding from the idea of primacy of ontogeny in relation to phylogeny, he postulated metakinesis as a mechanism for the evolutionary explosions, while palinkinesis explains the orthogenesis phase.

The concept of metakinesis was coined by Otto Jaeckel, who described the cases of appearance of the new characters at the very early stages of ontogenesis, which however only much later in the course of phylogeny manifest in the adult forms. In this way, for example, Orthoceras evolves into Nautilus. Beurlen connected the idea of explosive developments in phylogeny with sudden changes in the early stages of ontogeny. It is not clear, Beurlen argued, what the causes of such sudden changes in ontogeny are, although one can assume that environmental influences modify the metabolic processes (Beurlen, 1930, p. 570). These initial modifications are random and only subsequent evolution decides about their adaptive value. Beurlen also remarked that the "chambered shell" of cephalopods appeared not to allow them to evolve into fast swimmers, the shell having developed according to the laws of phylogeny and environmental influences. Further water adaptation of cephalopods was a process independent from the initial stage. In that sense, the following stage of orthogenesis will be driven by other developmental mechanism, which Beurlen labels palingenesis.

Beurlen's palingenesis "means that an individual repeats the ontogenesis of his parents, i.e. that each succeeding generation arrives at the final stage by the same pathway [as its

\footnotetext{
${ }^{24}$ German original: "Jeder Formtypus hat eben nur bestimmte Umbildungsmöglichkeiten; die Umbildung ist zwangsläufig auf ein durch den zugrunde liegenden Typus bestimmtes Endstadium gerichtet."

25 German original: "Darüber hinaus aber erlaubt dieses Gesetz die Feststellung, dass die Orthogenese nicht nur zwangsläufig innerhalb des bestimmten Grundtypus verharrt, sondern dass die Entwicklung orthogenetischer Reihen unbedingt vorwärts schreitet, dass keine rückläufige Entwicklung orthogenetsischer Reihen möglich ist."
} 
ancestors]" (Beurlen, 1930, p. 571). In other words palingenesis means that ontogeny recapitulates the ontogeny of the ancestors. In contrast to Haeckel's "ontogeny recapitulates phylogeny", palingenesis is not a universal law, because metakinesis is responsible for phylogenetic explosions. However, metakinesis is an exceptional case of ontogeny, while normally ontogeny proceeds palingenetically, thus serving as the basic mechanism of orthogenesis: "Thus the basic type of orthogenesis is the palingenetic form of ontogeny" (Beurlen, 1930, p. 573). Thus in Beurlen's theory palingenesis is the cause and ultimate explanation of orthogenesis (Beurlen, 1930, p. 574).

Beurlen's theory strongly influenced one of the most well-known representatives of orthogenesis after the Second World War, Otto Heinrich Schindewolf (1896-1971). Schindewolf was the most influential paleontologist in post-war Germany and his theory of evolutionary change dominated German paleontology (Reif, 1993). Schindewolf studied at the Universities of Göttingen and Marburg, where he obtained his doctoral degree under the supervision of Rudolf Wedekind (1883-1961), a paleontologist who applied statistical methods to analyzing the fossil record. Schindewolf taught in Marburg until he moved (1927) to Berlin to the Department of Paleozoology at the Prussian Geological Institute (Preussische Geologische Landesanstalt). In 1933 he became the director of this Institute. After WWII Schindewolf for a short time acted as paleontology Professor at the Humbold University in Berlin (1947), but a year later he was given a Chair in Geology and Paleontology at Tübingen University, which he held until 1964. Schindewolf died in 1971, and was active until his last years.

Schindewolf championed a complex theory embracing saltationism, orthogenesis and typology. Typology was for Schindewolf the sound foundation for proper morphological studies. In a paper from 1962 he complained about the decreasing influence of typology/idealistic morphology, which was unjustly categorized as a subjective approach to morphology. Yet in Schindewolf's opinion it was the Darwinians who had pushed morphology towards the unsteady ground of transient hypotheses: "The old morphology 26 was unbiased and free of hypotheses, i.e. it conducted comparative form studies with the greatest possible objectivity. It was the phylogenetic turn which introduced strongly subjective elements into morphology" (Schindewolf, 1962, p. 60).

Schindewolf proposed a definition of species that could be applied to classifying fossil remains: "Species are series of individuals, which coincide in the totality of their typical characters and manifest only minor and fluent variability in the spatially or temporally interfacing populations" (Schindewolf, 1962, p. 67). With this definition he proclaimed the priority of morphological methods in paleontology. Based on the historical and logical priority of morphology, Schindewolf created his theory of "typostrophy" [Fig. 5]. The theory is based on a combination of orthogenetic and saltationist principles as well as on the idea of cyclicity (Reif, 1986). Cyclicity in this case means that evolution proceeds through a succession of relatively autonomous cycles. Within a certain cycle several morphological forms replace each other in the course of time, representing various stages of development of a certain type (Schindewolf, 1956). Schindewolf divided evolutionary development into three successive stages, which differed in both velocity and other important characteristics: typogenesis, typostasis, and typolysis. Following in Beulen's foot-

26 "Old" in the sense of "pre-Darwinian". 


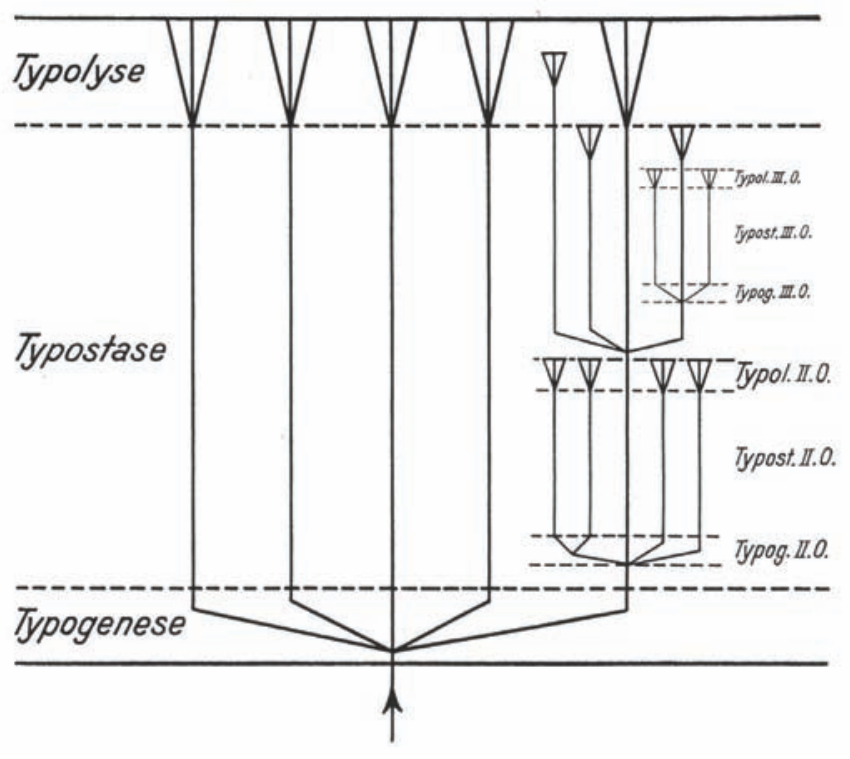

Fig. 5: Schindewolf's view of the evolutionary process as schematically divided into the three phyletic phases: typogenesis, typostasis and typolysis. In the phase of typogenesis Bauplan (body plan) of a new clade appears, which immediately splits up into subtypes. These remain unchanged during typostasis. In the following short phase of typolysis the subtypes lose their self-identity and undergo degenerative split-ups (from: Schindewolf 1964, $p$. 89).

environment and governed by the internal potency of the type in question (Schindewolf 1947, p. 370). Thus evolution is regarded as an autonomous process. This position led him to an interpretation of evolution, within which the question of the origin of types was never seriously asked, and Schindewolf was unable to explain the mechanism of appearance of new "body plans". New types occur through parallel deviation in numerous individuals. According to Schindewolf, neither Lamarckian nor Darwinian explanations could suffice for understanding the evolutionary process. The typogenetic "explosion" can be due to physical or chemical conditions in the environment leading to a radical escalation of mutability in a certain group of organisms (Schindewolf, 1936, p. 93). Schindewolf speculated about the possible internal mechanisms of mutations and favoured Richard Goldschmidt's theory of macromutations ("hopeful monsters"). However, this concept has only a secondary role in Schindewolf's own theory and he abandoned Goldschmidt's hypothesis in later publications (Schindewolf, 1969, p. 10). Typostasis is the second stage, which is characterised by slow progressive development of a new type driven by natural selection, which is degraded to a subsidiary evolutionary mechanism (Rensch, 1980) responsible for the occurrence of minor adaptations in the "body plans" and operating within the framework of morphogenetic constraints. Due to these 
constraints the type's evolution in the phase of typostasis proceeds orthogenetically, although Schindewolf excluded all finalistic and mystical explanations of orthogenesis (Schindewolf, 1950, pp. 319-321). The third phase (typolysis) is the decay stage of a type. At this stage the organism becomes over-specialised and this leads to the disintegration of the type. The decay is determined by internal laws and proceeds in a manner analogous to the aging of individuals (Schindewolf, 1956).

Schindewolf's theory was of a very descriptive nature, although phrased in exotic terminology. His arguments against the Darwinians were also based directly on comparing their claims, e.g. that evolution is gradual, with what he observed as a paleontologist. Although Schindewolf appealed only to the second phase in terms of orthogenesis, one could say that the entire evolution of the type following the phylogenetic explosion proceeds orthogenetically, because the direction of the type's development including its potential decay) is preprogrammed at the phase of typogenesis.

In summary, during the first half of the $20^{\text {th }}$ century orthogenesis achieved clarity and conceptual maturity. It was not an accidental concept appearing on and off in the work of various authors, but rather a consistently developed and empirically based scientific theory. This can be seen particularly well in the German-speaking countries, where orthogenesis, supported by a very strong typological tradition remained influential even in the post-war era (due to the great influence of Schindewolf). The majority of orthogenesis advocates in various countries were very aware of each others work, as shown by mutual citation, although they developed theories with significant differences. They also appealed to Haacke, Eimer, or Nägeli as the founders of the concept, and defined their concepts more or less along the lines proposed by the pioneers of directed evolution. Sometimes we are dealing with real scientific traditions, where the idea of orthogenesis was relayed from teacher to the assistant as in the cases of Hennig-Beurlen, CopeOsborn, or Dollo-Abel. A logical development of the initial theoretical postulates is evident in the case of Beurlen-Schindewolf.

There are, however, several approaches to the problem of directed evolution, which do not fit into the tradition initiated by Haacke. Below we briefly discuss these special cases.

\section{The experimental research program of Victor Jollos}

Jollos was probably the only biologist who approached the problem of orthogenesis experimentally. He was born in 1887 in Odessa (then in the Russian Empire, now in the Ukraine) into a supposedly Jewish family, although he points out in his autobiography that he belonged to the Evangelical church. ${ }^{27}$ This was, however, not very untypical. Another Russian advocate of orthogenesis, Leo Berg, was also of Jewish origin and also joined the evangelical church in order to avoid repressions. When Victor Jollos was three years old his family moved to Germany. He grew up and was educated in Germany but remained a Russian citizen. Jollos studied biology and natural sciences at the Universities in Munich and Berlin and received his $\mathrm{PhD}$ in 1910 from the Philosophical Faculty of Munich University with a thesis on Dinoflagellates (microscopic flagellated protists).

27 Archiv der HU Berlin, Phil. Fak. 1238, Bl. 4V. 
Then he worked shortly in a Protozoa laboratory of the Robert Koch Institute in Berlin and later at the Biological Institute of Munich University (1910-1912), and afterwards again at the Koch Institute as an "assistant for infectious diseases" and later became deputy head of the protozoa laboratory (1914). On September 1, however, he was forced to leave the Institute, because WWI started and Jollos still remained a Russian citizen. In this situation he decided to enrol at the Faculty of Medicine of Berlin University and in 1918 passed through the "state examinations" (= Diploma) in Medicine. ${ }^{28}$ This medical qualification opened up the possibility to collaborate at the Charité Policlinic and Kaiser Wilhelm Institute for Experimental Therapy (Berlin), while working in parallel at the Berlin Kaiser Wilhelm Institute for Biology, where he became an assistant in 1920. ${ }^{29}$ As Jollos himself emphasised, his research during these years was concentrated on protists and their genetics. His Habilitation with the title Experimental Studies on Protists was devoted to the analysis of variation and inheritance of the isolated lines of Paramecium caudatum and P. aurelia. Jollos was awarded with the "Privatdozent" title in 1921 from the Friedrich-Wilhelms University Berlin (now the Humboldt University Berlin) and in 1930 he became an extraordinary professor. Yet already on September 7, 1933, 9 months after Adolf Hitler became Chancellor of Germany, Jollos was fired from this position because of his "non-Aryan" origin.

To avoid further repressions, in 1933 Jollos emigrated to Great Britain (Edinburgh) and later to the USA (University of Wisconsin at Madison), where he continued his experimental research (Deichmann, 1996, p. 19). From 1934 to 1935 he was supported by the Rockefeller foundation. Afterwards he made several attempts to get a position, which failed although "his scientific accomplishments were generally recognised and appreciated in the United States" (Deichmann, 1996, p. 20). After having lived in poverty in the last years of his life, he died in 1941 of a heart attack.

Perhaps trying adapt to the Anglo-Saxon scientific world Jollos, who made his name in Germany studying protists, concentrated his orthogenetic experiments on Drosophila mutations. When constructing the theoretical framework for his experiments, Jollos distinguished several kinds of phenotypically explicable transformations. The first kind he called modifications, i.e. non-heritable phenotypic changes. The second kind was strictly heritable mutations and recombinations. An intermediate stage between mutations and simple modifications were so-called Dauermodifications.

To explain this phenomenon, Jollos assumed that there are three factors shaping a phenotype (Jollos, 1934): (1) The totality of all chromosomes in the nucleus; (2) The substrate with which the genes interact, i.e. the cytoplasm or plasma; (3) The environmental factors. Three kinds of transformations correspond to the above three factors. Mutations are caused by changes in single genes (gene mutations) or genomic changes (polyploidy, translocations, inversions etc.). Modifications are explained through the environmental influences. And, ultimately, dauermodifications are due to cytoplasmic inheritance (dauermodifications sensu stricto), plastids and other similar structures in the cytoplasm.

\footnotetext{
28 Archiv der HU Berlin, Phil. Fak. 1238, Bl. 4L+5V.

29 According to Dietrich (1996) Jollos became assistant in 1919.
} 
Dauermodifications were mostly observed in Protozoa (Paramaecium, Arcella, Actinophrys, Jollos, 1913, 1921, 1924, 1934), but also in metazoans (Drosophila, Jollos, 1932, 1935). The most characteristic feature of dauermodifications is that they do not possess a constancy of mutations and, in the absence of genomic changes, disappear in a certain time over a series of generations. The disappearance of dauermodifications is accelerated through fluctuating environments (temperature, food) or through zygosis and parthenogenesis by infusorians (Jollos, 1935). The disappearence of dauermodifications can be distinguished from back-mutations due to the slow and lawful character of the dauermodifications' disappearance.

Plasmatic inheritance is for Jollos a general term covering all cell elements except the nucleus. Plasmatic inheritance includes cytoplasmic inheritance and the inheritance of autonomous cell organelles such as plastids, blepharoplasts, or the macronucleus of infusorians. Dauermodifications should not be confused with the "weak mutations" of Ludwig Plate (Levit \& Hossfeld, 2006), because they never convert into mutations and also do not influence mutation rates (Jollos, 1935). Jollos strictly separated dauermodifications and "directed mutations", and showed this difference experimentally (for example, Jollos, 1930; 1931).

In his programmatic papers, written when he was still in Germany, Jollos asked whether "mutations are really absolutely random" or whether prolonged exposure to certain external influences would induce mutations in a certain direction (Jollos, 1931). To answer this question Jollos applied what he called "Goldschmidt's method". He put 12-20 pairs of Drosophila on syrup-maize-agar and yeast and let them lay eggs at $25^{\circ} \mathrm{C}$ over 48 hours. This procedure was repeated many times to produce numerous bottles with eggs from the same parental flies. Afterwards he exposed the 5-6 days old eggs to temperatures around $35-37^{\circ}$ during 15-23 hours, and then put them back to the "normal" $25^{\circ} \mathrm{C}$. Many eggs died under such extreme heat-shock conditions and many which survived became sterile. Nevertheless, compared to only one mutation in 250000 control -flies, 50000 experimental flies gave more than 100 mutations in $F_{1}$ and $F_{2}$. The results achieved in the experiments with the Drosophila (Florida wild line, homozygote) are summarized in Fig. 6 (redrawn and translated from Jollos, 1931).

As Jollos reported, in his experiments he never observed a back-mutation from pale to dark eyes. He also never observed a direct transition from wild type to a pale-eosin. Along these lines he comes to the inference that different alleles of the "white" series appearing randomly under haphazard environmental conditions demonstrate a clearly definable directionality in the controlled environments.

Similar results were achieved also in experiments with the "ebony" (sooty) gene. Under heat-shock at temperatures of $35-36^{\circ} \mathrm{C}$ mutations with slightly dark scutum appeared. Crossing this mutation with the typical "sooty" of an American wild type line showed that the induced mutation was a "weakest sooty". Under further high temperature treatment of the "weakest sooty" (s 1) "weak sooties" (s 2) appeared with darker scutum. The lines s 1 and s 2 without further treatment showed constancy of features. However, renewed heat-shock treatment of s 2 brought into being typical "sooties" with no difference to the wild type line "sooties". The treated s 3 "sooties" then made it into the final stage of heritably stable "ebony" (Fig. 6). 
History of " $W 7$ "

Initial line: Florida wild line (homozygote)

Time and kind of treatment: $12 \mathrm{hrs} 37^{\circ}$

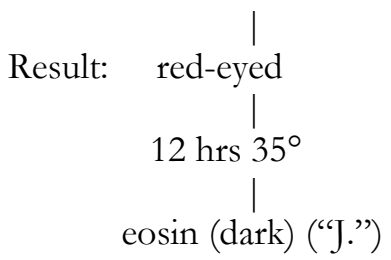

$12 \mathrm{hrs} 35^{\circ}$

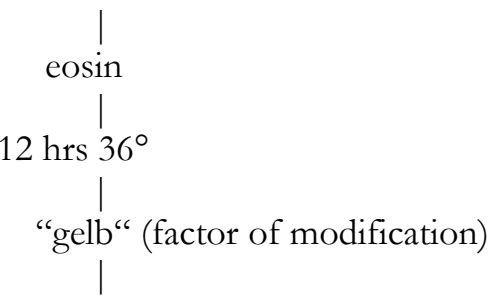

14 hrs $36^{\circ}$

"gelb"

$20 \mathrm{hrs} 35^{\circ}$

"gelb"

$24 \operatorname{hrs} 35^{\circ}$

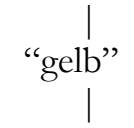

18 hrs $35^{\circ}$

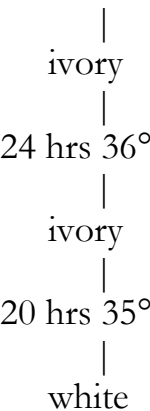

In: Jollos, Victor: Die experimentelle Auslösung von Mutationen und ihre Bedeutung für das Evolutionsproblem. Die Naturwissenschaften 19 (1931), 171-177; p. 174. 
Directed mutations of the "ebony"-gene

Initial line: Florida wild line (homozygote)

Time and kind of treatment: $14 \mathrm{hrs} 35^{\circ}$

eosin $(\mathrm{M})$ sooty $1 \rightarrow$ continued untreated, remains sooty 1

12 hrs $37^{\circ}$

("black"-free)

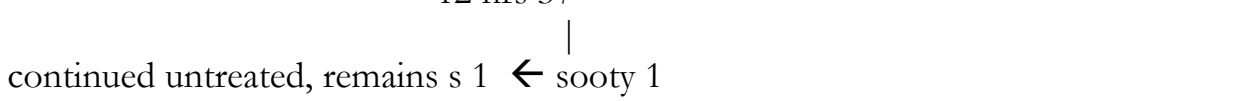

("black"-free) |

$14 \mathrm{hrs} 35^{\circ}$

sooty $2 \rightarrow$ continued untreated, remains sooty 2

15 hrs $35^{\circ}$

("black"-free)

continued untreated, remains s $2 \leftarrow$ sooty 2

("black"-free)

18 hrs $36^{\circ}$

continued untreated, remains s $2 \leftarrow$ sooty 2

("black"-free)

22 hrs $36^{\circ}$

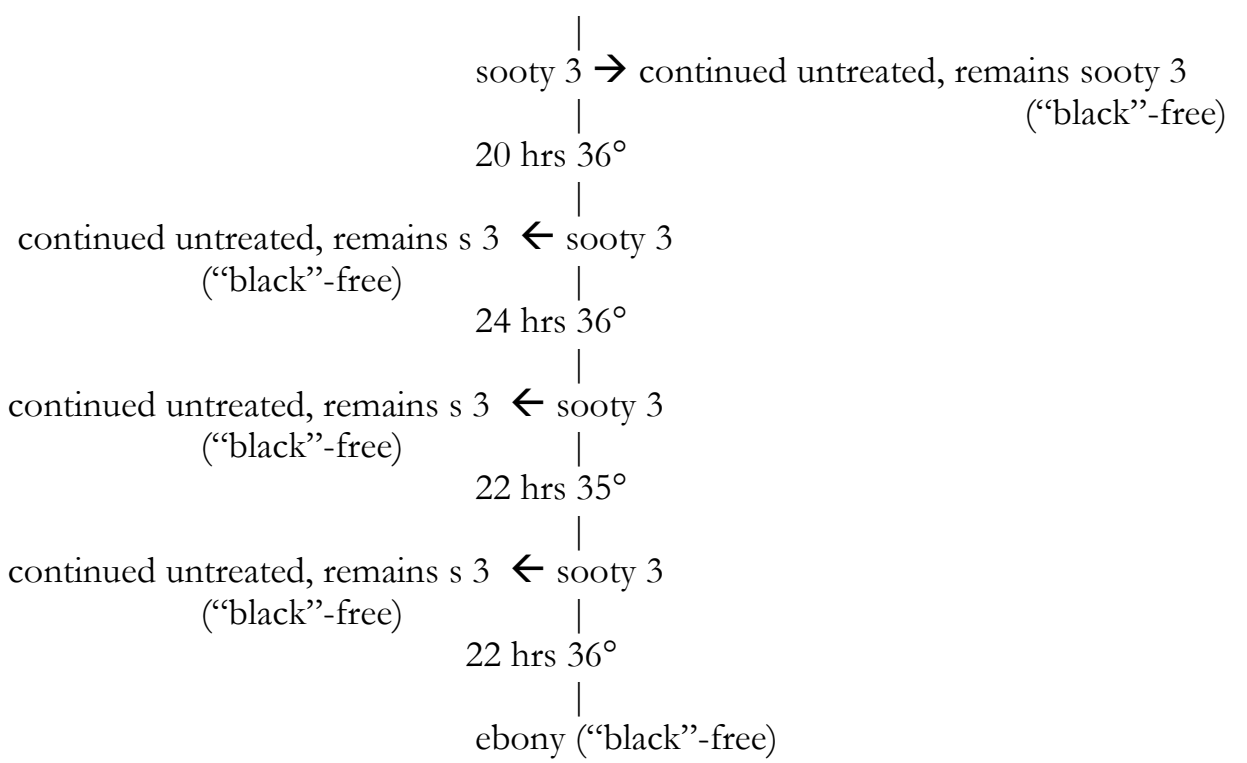

In: Jollos, Victor: Die experimentelle Auslösung von Mutationen und ihre Bedeutung für das Evolutionsproblem. Die Naturwissenschaften 19 (1931), 171-177; p. 175.

Fig. 6: Jollos' experiments showing orthogenetic mutations. 
After the series of analogous experiments Jollos arrived at the conclusion that in this case we are also faced with "directed mutations". Although "directed" in this case does not mean "adaptive", i.e. "directed" in a Lamarckian sense. Under constant environmental influences one can observe the series of mutation going in the direction of strengthening a certain character (Jollos, 1931).

Jollos was convinced that his description of the non-adaptive directed mutations was an important contribution to solving the problem of orthogenetic sequences, and thus reconciling geneticists and paleontologists, who, Jollos argued, convincingly demonstrated the existence of orthogenetic phenomena. Non-adaptive directed mutations are especially applicable to explaining regressive orthogenetic sequences, which can be exemplified by the evolution of the limb skeleton in horses. At the same time Jollos was far from the idea that his experiments could explain the entire problem of orthogenesis.

By contrast, dauermodifications cannot be applied to explaining orthogenesis, because there are no interdependencies between mutations and dauermodifications. In addition, Jollos demonstrated that the dauermodifications undergo reorganisations through the "alien" genomes and so the "restricted heredity" is unable to explain both adaptive and orthogenetic phenomena. With this Jollos felt he had disproved the hypothesis articulated by the American zoologist Ernest Everett Just (1883-1941), who tried to explain adaptation by cytoplasmatic inheritance (Just, 1933).30

Thus the non-adaptive directed mutations of Jollos were explained by a determined sequence of certain alleles, and it was not possible to explain these sequences by morphological constraints, because in Jollos' example there are no morphological prohibitions for certain eye colours. Besides, all colours in the experiments are equally possible and only follow a certain order. This is the principal methodological difference between Jollos and the major trend in orthogenesis represented, for example by Haacke, Beurlen and Schindewolf: a directive force excludes a multitude of structural possibilities contradicting an initial body plan. Jollos, by contrast, describes successions of mutations and it is the direction of this succession that determines an orthogenetic series and not a multitude of unrealised possibilities.

\section{Directed Evolution on a Global Scale: Teilhard de Chardin and Vladimir Vernadsky}

Although the French palaeontologist and Jesuit Pater Pierre Teilhard de Chardin (18811955) and the Russian geochemist Vernadsky (1863-1945) differed in age, they were in the 1920s at a comparable level of scientific maturity concerning the growth of their biosphere-noosphere theories. Vernadsky first presented his views on the biosphere systematically when he published The Biosphere in 1926 (Vernadsky, 1926), although he began using the term biosphere much earlier (1911). In his Essays on Geochemistry (Vernadsky, 1994), lectures written in Petrograd (St. Petersburg) in 1921, Vernadsky used both of the most important terms of his theory: living matter and the biosphere, although he made the first clear definition of the biosphere in 1923 (Vernadsky, 1923). At

30 The parallel between concepts and theories of Jollos and Richard Goldschmidt was drawn by Dietrich (1996). This is however beyond the scope of our paper. 
the same time (1921), Teilhard used the term biosphere in his The Face of the Earth for the first time (Grinevald, 1996). From 1938-40 Teilhard wrote one of his basic works Le phénomène bumain (The Phenomenon of Man) (Teilhard, 1955) where he presented both the biosphere and the noosphere concepts. At the same time (1936-38), Vernadsky wrote his Scientific Thought as a Planetary Phenomenon (Vernadsky, 1997) where he used the same terminology. Both scientists adopted the term 'biosphere' from the works of the Austrian geologist Eduard Suess (1831-1914), who had coined this term in 1875 (Suess, 1875). Developing the theoretical insights of Suess, both scientists left the boundaries of descriptive natural science and tried to create all-embracing theoretical systems including elements of philosophy, social science and authorised interpretations of evolutionary theory. The most general objective of the two theoreticians was also similar: to prove the "non-accidental" character of the Earth's biota by creating a global theory of life. Both thinkers tried to combine separate segments of the science of their time by creating an integrated picture.

It is remarkable that both scientists derived global theoretical generalisations from descriptive natural disciplines, and in general, were at a comparable level of scientific knowledge. Teilhard was a professor of geology at the Institut Catholique in Paris, and was known as a Jesuit Pater, paleontologist, and paleoanthropologist. Vernadsky was a professor of mineralogy at Moscow University, a geologist and crystallographer by profession, however best known as the founder of biogeochemistry. Furthermore, the two scientists were personally acquainted and are said to have been influenced by each other. Bailes (1990, p. 162) reports that Vernadsky's lectures at the Sorbonne in the 1920s were attended by Teilhard de Chardin and his close friend the French philosopher Edouard Le Roy (1870-1954). The latter was influenced by the biogeochemical ideas of Vernadsky and cited Vernadsky many times (e.g., Le Roy, 1927, pp. 142, 143, 159, 163). Teilhard also cited Vernadsky in connection with his biosphere concept. Vernadsky himself wrote that Teilhard de Chardin and Edouard Le Roy elaborated the theory of the noosphere based on his biogeochemical concept of the biosphere (Vernadsky, 1965). Vernadsky, in his turn, borrowed the term 'noosphere' from lectures, writings, and conversations with Le Roy. Grinevald writes: "Together, the two unorthodox Catholic thinkers (Teilhard de Chardin and Le Roy - auth.) discussed the new scientific idea of the biosphere and, in collaboration with the Russian scientist, Vladimir Vernadsky, then in Paris, developed the notion of the noosphere" (Grinevald, 1996).

Although Teilhard appealed to the concept of orthogenesis, whereas Vernadsky never used this term, both of them saw evolution as a directed process.

„Life ...is a controlled (dirigé) process"(Teilhard, 1961, p. 151).

„We take the evolutionary process over geological time as a directed process“ (Vernadsky, 1965, p. 193). The directedness of evolution means, in both cases, a movement from the primitive (rudimentary) forms of life and intelligence to their more advanced forms. In both cases the directedness is guaranteed by a controlling instance of the highest order, namely, by the biosphere. At the same time their concepts differ in crucial points (Levit, 2000).

In the theoretical system of Vernadsky, the concept of the biosphere is required by a new branch of science created by him: biogeochemistry. Biogeochemistry studies the geo- 
logical manifestations of life and considers biochemical processes in living organisms in relation to their impact on the geosphere (Vernadsky 1997, p. 156): "The competence of biogeochemistry is defined, on the one hand, by the geological manifestations of life taking place under this aspect, and on the other, by the internal biochemical processes in the organisms - the living population of our planet. In both cases (for biogeochemistry is a part of geochemistry) one may identify as study objects not only chemical elements, i.e. the usual mixtures of isotopes, but also various isotopes of one and the same chemical element". Neither living organisms by themselves nor their environment abstracted from them are, Vernadsky argued, the specific objects of biogeochemistry. A biogeochemist is interested, first of all, in studying the cyclic processes of the exchange of chemical elements between living organisms and their environment. In order to define this specific geological domain as the research field of the newly created science, biogeochemistry, Vernadsky introduced his concept of the biosphere. The biosphere of the Earth appears as a geosphere occupied and organized by life and thus can be seen as a geological envelope.

Examining living matter from the biogeochemical viewpoint, Vernadsky (1994) arrived at the conclusion that the chemical compounds of the different species do not reflect the chemical composition of their environment, but, on the contrary, living matter has determined the geochemical history of almost all elements of the Earth's crust in the process of making the environment favorable to itself. Thus, living matter shapes the biosphere into a self-regulating system. The structure of the biosphere is described as a dynamic equilibrium: "Not a single point of this system is fixed during the course of geological time. All points oscillate around a certain midpoint" (Vernadsky 1997, pp. 225227).

A good example of such dynamic equilibrium is the troposphere. Vernadsky claimed (1965, p. 238) that "all basic gases of the troposphere and of the higher gaseous envelopes - $\mathrm{N}_{2}, \mathrm{O}_{2}, \mathrm{CO}_{2}, \mathrm{H}_{2} \mathrm{~S}, \mathrm{CH}_{4}$, etc., - are produced and quantitatively balanced by the total activity of living matter. Their sum total is quantitatively invariable over geological time...". Thus, Vernadsky concludes, "life, i.e. living matter creates the troposphere and constantly maintains it in a specific dynamic equilibrium". It can be remarked here, that what is known now as the $1^{\text {st }}$ Gaian principle of atmospheric regulation (Lovelock \& Margulis 1974) actually was derived by Vernadsky on the basis of his biogeochemical research 50 years before Lovelock. The evolution of the biosphere, Vernadsky claimed, is a directed process. The directedness of evolution is expressed, first of all, in the acceleration of the biogenic migration of atoms: "According to the second biogeochemical principle, the evolution of a species must move in a certain direction, namely, in the direction of increasing the biogenic migration of atoms. That means that evolution must have a directionality" (Vernadsky 1965, p. 272). Vernadsky saw the second biogeochemical principle as a geochemical version of Darwin's principle of natural selection and believed that in this way the evolution of species turns into the evolution of the biosphere. In the last version this principle sounds as follows: "The evolution of species (over geological time), tends towards the creation of stable life forms in the biosphere and moves in the direction of increasing biogenic migration of the atoms" (Vernadsky 1965, p. 270). The last stage of biospheric evolution is the noosphere, i.e. the stage at which the human mind becomes a regular part of the biosphere and gradually but lawfully takes the bio- 
sphere under control. That is why it is more correct to talk about the theory of the biosphere and its transition into the noosphere. In sum, Vernadsky saw evolution as a biospheric (global) phenomenon, so that all crucial evolutionary events can be seen as having their specific function in this larger scale process.

Teilhard de Chardin applied a kind of mathematical approach to the analysis of life processes by extrapolating a straight line in a coordinate system from a field of positive values to a field of negative values. He began at the atomic level and tried to represent the state of affairs as if the so-called Dana principle 31 in the living world was a special case of a more general principle of the evolution of matter. Evolution begins with elementary particles which appear "suddenly" and, from the very beginning, manifest the "granular" property of matter (Teilhard, 1961, p. 49). "Granulated" and still unified matter evolves towards more complex forms and, thus, underlies from the beginning "the great biological law". The universe is a "closed quantum" and nothing can appear which did not already exist. When a material body moves with a velocity comparable to the velocity of light, a correlation between mass and velocity becomes significant. In everyday life this correlation is insignificant, but this does not mean that we in our everyday life break the laws of relativity. By analogy, an evident presence of consciousness or "inner world" in the human being shows that this property, in the terminology of Teilhard "the within of things", must be inherent to matter in general. Under the cover of inert matter, a "biological layer" exists and existed from the very beginning. This means that the beginning of "biology" and the beginning of the initial granulated world were simultaneous events. In other words, Teilhard assumed that life is an eternal, constant phenomenon, because each single atom contains a rudimentary form of life inherent to all matter. The occurrence of terrestrial life is only a local manifestation of a universal cosmic process. Due to this "interior" living matter from the beginning showed the property of a self-organising system. The pre-biosphere is an interconnected system from the very beginning. The living film on the Earth was the surface of organised totality from the beginning. The psychic, interior side of matter, however, directs matter further to higher levels of organisation, which culminate at the end of the evolutionary process. This end is external to evolution itself. The Earth's biosphere will transit into the noosphere, which then will be replaced by a super-mind and will coalesce into a so-called OmegaPoint. In contrast to Vernadsky, who showed the holistic nature of biogeochemical cycles, Teilhard only proclaimed the unity of the biosphere and delivered no scientific arguments in favour of this claim.

Therefore, although both scientists used the same terminology and partially the same empirical data, Vernadsky's inferences on the directed character of evolution of the biosphere followed from his scientific biogechemical research program, whereas Teilhard's biosphere-noosphere concept is ultimately a mystical conception. Nevertheless the basic

\footnotetext{
31 The American geologist and zoologist James D. Dana (1813-1895) had noted that in the course of geological time, a certain part of the planet's inhabitants acquired an increasingly complex central nervous system. Dana formulated the principle that "the higher centralization of the superior grades, and the less concentrated central forces of the inferior ... This centralization is literally a cephalization of the forces" (Dana, 1852, pp. 1396-1397). The irreversibility of cephalisation was of crucial importance both for Vernadsky and Teilhard de Chardin.
} 
idea of the superior role of the biosphere in evolution as a holistic entity was propagated by both theoreticians.

Vernadsky's theory was only the beginning of the extensive global studies, including biogeochemistry, that exist today, and various versions of the biosphere theory are supported, at present, by the Russian microbiologist Georgii A. Zavarzin (e.g., Zavarzin 1997, 2003), the English inventor James Lovelock and the American microbiologist Lynn Margulis (e.g., Lovelock 1986, 1996, Lovelock \& Margulis 1974, Margulis 1996) and the German geomicrobiologist Wolfgang E. Krumbein (Krumbein \& Schellnhuber 1992).

Although modern advocates of the global approach are much less explicit than Vernadsky when it comes to the directedness of evolution, they still support the idea in its most general form that the Biosphere (the sum total of living organisms and their environment) as a dynamic, self-regulating system evolving in accordence with its own laws. In the most articulated contemporary version, as represented e.g. by Zavarzin (1997, 2003), the biosphere theory claims that phylogenetically independent prokaryotes are of fundamental importance for the function of the biogeochemical cycles of the biosphere. This implies that (1) the strict monophyletism propagated by Darwinians cannot be applied to the early stages of biospheric evolution; (2) evolution has an additive character ("new" + "old" and not "new" instead of "old"); (3) the Biosphere functions as a wellbalanced system of functionally complementary organisms and the ordinary evolutionary laws (such as natural selection) work only on the lowest level of this system.

\section{Conclusions and Epilogue}

The term "orthogenesis" was coined in 1893 by Wilhelm Haacke, who introduced this concept based on the ideas of Carl v. Nägeli (1884) and Theodor Eimer (1888). Eimer, in his turn, has later (1897) adapted Haacke's term and made it widespread. Thereafter the concept of orthogenesis was developed by an international network of scientists, who in the majority of cases were reflecting upon the work of their predecessors and also mutually influenced each other. In the German-speaking world orthogenesis was especially strong and persistent. This is related to the generally strong opposition to Synthetic Darwinism in Germany even after WWII. Ernst Mayr (Mayr, 1999) reported in this respect on the "Phylogenetic Symposium" in Hamburg (1956), 32 where he presented the basic principles of the Synthetic Theory of Evolution and where "all those attending (with exception of the geneticist de Lattin) argued against the Synthesis". Orthogenesis was part of this broad opposition.

Considering its history, orthogenesis can in general terms be defined as a concept of interior or exterior constraints restricting variation in such a way that evolution will be canalized in a certain, theoretically explicable, and therefore predictable direction. In a more narrow sense advocated by Haacke himself and several other theoreticians (for example, Eimer, Osborn, Beurlen, Schindewolf) orthogenesis means that fundamental organismic structures exist, which predispose living beings to vary only in certain direc-

32 The "Phylogenetic Symposium" (1956-) was founded as an annual event by Curt Kosswig (1903-1982), Wolf Herre (1909-1997), and Adolf Remane (1898-1976) (Kraus \& Hoßfeld, 1998). 
tions. In the majority of theories, orthogenesis is opposed to the idea of evolution as an immediate and permanent adaptation of organisms to their environments, although there is no logical necessity for orthogenetic evolution to be non-adaptive, as was shown by Berg for directed and adaptive mass mutations. Rather, orthogenesis implies that there are trends in development and evolution, which can be seen as non-adaptive considering the immediate needs of the organisms.

Both definitions imply that there are various levels for which such constraints can be described. As we have shown, orthogenesis is historically recordable (and theoretically thinkable) at four basic structural levels: molecular-genetic (Plate, Jollos), cellular (Haacke), morphological (Beurlen, Schindewolf), and biospheric (Teilhard de Chardin, Vernadsky). Several theoreticians attempted to integrate various levels of orthogenetic constraints into their theories. Thus Berg in his nomogenesis postulated both moleculargenetic (manifested in directed mutations) and morphological constraints.

A variety of hypotheses exists on the mechanisms of orthogenesis. Early orthogenesis (Haacke, Eimer) appeared in opposition to Weismann's neo-Darwinism, and was closely related to neo-Lamarckism, although already at that time Lamarckism was not seen as an explanation for orthogenesis. For example, Haacke explained orthogenesis by the structural characteristics of "plasma", whereas adaptation was described in terms of accumulation of acquired characters, but this does not mean that orthogenesis was explained in terms of Lamarckian inheritance. Several mature orthogenetic theories (Berg, Schindewolf) explicitly distanced themselves from Lamarckism. These authors see orthogenesis is an auxiliary evolutionary mechanism, which can be combined with different hypothetical hereditary mechanisms. Below we have collected some historically recordable mechanisms of orthogenetic evolution in a table. It can be seen that the idea of constraints can be incorporated into theoretical systems combining various mechanisms of evolution, including the mechanism of natural selection.

\begin{tabular}{|l|l|}
\hline Mechanism & Advocates \\
\hline Constraints + inheritance of acquired features & $\begin{array}{l}\text { Nägeli, Haacke, D. de } \\
\text { Rosa, Osborn }\end{array}$ \\
\hline Constraints + exercises, use/disuse & Cope \\
\hline Constraints + non-material directive force & Teilhard de Chardin \\
\hline Constraints + macromutations & Berg, Schindewolf \\
\hline $\begin{array}{l}\text { Constraints + natural selection +inheritance of ac- } \\
\text { quired characters }\end{array}$ & Plate \\
\hline External constraints on macroevolutionary processes & Vernadsky \\
\hline
\end{tabular}

Our historical overview also demonstrates that Ernst Mayr's well-known claim that orthogenesis necessarily implies non-physical forces is wrong: "Until natural selection was fully understood, many evolutionists, from Lamarck to H.F. Osborn and Teilhard de Chardin, postulated the existence of a non-physical (perhaps even non-material) force which drove the living world upward toward ever greater perfection (orthogenesis)" (Mayr, 1982, p. 50). Teilhard de Chardin was here rather the exception. In most cases, 
which also include the concept of its founder Haacke, orthogenesis was explained quite "physically".

In contrast to Bowler's claim that "orthogenesis was, like Lamarckism, supported mainly on the grounds of indirect evidence" (Bowler, 1996, pp. 8-9), we argue that mature orthogenesis theories were mainly based on direct paleontological evidence and it was because of this, that it was so difficult for paleontologists to accept the Darwinian idea of random variation. The Darwinian way of explanation demanded much higher levels of abstraction then orthogenetic descriptions.

Despite the extensive theoretical heritage left by the pioneers of orthogenesis, the dominance of the Modern Synthesis of Evolution in the 1960-70s in most countries with a research tradition in evolutionary biology, and in the majority of biology-related disciplines ultimately pushed the concept of directed evolution into the shadow of this dominating paradigm. Yet, the idea of evolutionary and developmental constraints, this crucial orthogenetic concept, was rediscovered and is now used in evolutionary development biology and paleobiology (e.g., Wimsatt \& Schank 1988; McShea 2005). The radical version of this idea was articulated in the Anglo-Saxon world by the so called "process structuralists", who attribute to natural selection only a secondary role in evolution (Goodwin 1984). In Germany the Frankfurt school of "constructional morphology" represents an extreme version of the concept (Gudo 2001). McShea includes orthogenesis into his concept of constraint-driven trends, although without actual appeal to the historical roots of the concept. At present there are a variety of concepts employing the idea of constraints: The "canalization" or "hardening"; "spontaneous order" or "crystallisation of life"; "developmental biases"; "evolutionary channelling", "non-random production of variants" and many others. ${ }^{33}$ Considering our definition of orthogenesis, many of these concepts can be classified as weak or strong versions of orthogenesis.

\section{Acknowledgments}

GL appreciates the support of the DFG (Ho 2143/5-2). The authors are grateful to Dr. Michael Kaasch and Dr. Joachim Kaasch from Leopoldina Academy (Haale/Saale) for supplying us with archival materials. LO's research in evolutionary developmental biology is supported by the DFG (Ol 134/2-4).

\section{Archives consulted}

Archive of the Ernst-Haeckel-Haus, Jena (EHH)

Archive of the Humbold University of Berlin (HU)

Archive of the University of Thuringia (UAT)

Archive of the Leopoldina Academy

33 This collection of terms was first used in the oral presentation by I.Y. Popov \& G.S. Levit at the ISHPSSB 2005 Meeting in Guelph. 


\section{References}

Abel O. (1920) Lehrbuch der Paläozoologie. Gustav Fischer Verlag, Jena.

Abel O. (1928) Das biologische Trägheitsgesetz. Emil Haim \& Co, Wien und Leipzig.

Abel O. (1929) Paläobiologie und Stammesgeschichte. Gustav Fischer Verlag, Jena.

Bailes K. E. (1990) Science and Russian Culture in an Age of Revolutions: V.I. Vernadsky and His Scientific School, 1863-1945. Indiana University Press, Bloomigton,Indianapolis

Berg, Leo (Lew) S. 1922. Nomogenez. GIZ, Petrograd [in Russian].

Berg, Leo (Lew) S. 1926. Nomogenesis or evolution determined by Law. Constable, London. (2nd ed. 1969, M.I.T Press, Cambridge, London).

Berg, Leo (Lew) S. 1977. Trudi po teorii evoluzii. Nauka, Leningrad [in Russian].

Beurlen K. (1930) Vergleichende Stammesgeschichte. Borntraeger, Berlin.

Beurlen K. (1937) Die Stammungsgeschichtlichen Grundlagen der Abstammungslehre. Gustav Fischer Verlag, Jena.

Bowler P. (1983) The eclipse of Darwinism. The John Hopkins University Press, Baltimore, London.

Bowler P. (1996) Life's splendid drama. The University of Chicago Press, Chicago, London.

Dana J. D. (1852), Crustacea. Philadelphia. [reprint. 1972 by Antiquariat junk, Lochem]

Deichmann, U. (1996) Biologists under Hitler. Harvard University Press, Cambridge, Mass., London.

Diener K. (1910) Paläontologie und Abstammungslehre. G.J. Göschen'sche Verlagshandllung, Leipzig.

Dietrich M.R. (1996) "On the Mutability of Genes and Geneticists: The "Americanization" of Richard Goldschmidt and Victor Jollos," Perspectives on Science 4, pp. 321-345.

Ehrenberg K. (1975) Othenio Abel's Lebensweg. Unter Benützung autobiographischer Aufzeichnungen. Österreichische Hochschülerschaft Universität Wien, Wien.

Eimer Th. (1888) Die Entstehung der Arten auf Grund von Vererben erworbener Eigenschaften nach den Gesetzen organischen Wachsens. Verlag von Gustav Fischer, Jena.

Eimer Th. (1897) Orthogenesis der Schmetterlinge. Ein Beweis bestimmt gerichteter Entwickelung und Ohnmacht der natürlichen Zuchtwahl bei der Artbildung. Verlag von Wilhelm Engelmann, Leipzig.

Eimer Th. (1901) Vergleichend-anatomisch-physiologische Untersuchungen über das Skelett der Wirbeltiere. Verlag von Wilhelm Engelmann, Leipzig.

Goldschmidt R.B. (1940) The material basis of evolution. Yale University Press, New Haven.

Goodwin, B. C. 1984. Changing from an evolutionary to a generative paradigm in biology. In: Evolutionary Theory: Paths into the Future (Pollard, J. W.; ed.) Wiley, Chichester: pp. 99-120. 
Gould S.J. (1977) Ontogeny and Philogeny. Belknap Press of Harvard University Press, Massachusetts.

Grinevald J. (1996) Sketch for a History of the Idea of the Biosphere. In: Gaia in Action (Bunyard, P.; ed.) Floris Books, Edinburgh: pp. 34-53.

Gudo, M. 2001. The development of the critical theory of evolution: The scientific career of Wolfgang F. Gutmann. Theory in Biosciences 121(1), pp. 101-137.

Haacke W. (1893) Gestalt und Vererbung. Eine Entwickelungsmechanik der Organismen. T.O. Weigel Nachfolger, Leipzig.

Haacke W. (1895) Die Schöpfung des Menschen und seiner Ideale: ein Versuch zur Versöhnung zwischen Religion und Wissenschaft. Costenoble, Jena.

Haacke W. (1895b) Über Wesen, Ursachen und Vererbung von Albinismus und Scheckung und über deren Bedeutung für vererbungstheoretische und Entwicklungsmechanische Fragen. Biologisches Centralblatt 15, pp. 44-78.

Hall B.K. (2001) Organic Selection: Proximate Environmental Effects on the Evolution of Morphology and Behaviour. Biol Phil 16, pp. 215-237.

Hennig E. (1922) Paläontologische Beiträge zur Entwicklungslehre. J.C.B. Mohr in Kommission, Tübingen.

Hennig E. (1927) Wege und Triebkräfte organischer Entfaltung. Naturwissenschaften 18(3), pp. 260-262.

Hennig E. (1932) Wesen und Wege der Paläontologie: Eine Einführung in die Versteinerungslehre als Wissenschaft. Borntraeger, Berlin.

Hoppe B. (1998) Das Aufkommen der Vererbungsforschung unter dem Einfluß neuer methodischer und theoretischer Ansätze im 19. Jh. In: Geschichte der Biologie (Jahn, I.; ed.) Gustav Fischer Verlag, Jena: pp. 386-419.

Hoßfeld U., Breidbach O. (2005) Haeckel-Korrespondenz. Übersicht über den Briefbestand des Ernst-Haeckel-Archivs. VWB-Verlag, Berlin.

Huxley J. (1974) Evolution: The Modern Synthesis. 3d ed. Hafner Press, New York.

Jahn, I. (ed.) 1998. Geschichte der Biologie. Gustav Fischer Verlag, Jena.

Jollos V. (1913) Experimentelle Untersuchungen an Infusorien. Biol. Zentralblatt, 1913, Bd. 33, pp. 222-236.

Jollos V. (1921), Experimentelle Protistenstudien I: Untersuchungen über Variabilität und Vererbung bei Infusorien. Archiv für Protistenkunde, Bd. 43, H. 1+2, pp. 1-222.

Jollos V. (1924a) Untersuchungen über die Variabilität und Vererbung bei Arcellen. Archiv für Protistenkunde, Bd. 49, H. 3, pp. 307-374.

Jollos V. (1924b) Untersuchungen über die Variabilität und Vererbung bei Arcellen. Biologisches Centralblatt, Bd. 22, pp. 194-207. 
Jollos V. (1930) Studien zum Evolutionsproblem I. Über die experimentelle Hervorrufung und Steigerung von Mutationen bei Drosophila melanogaster. Biolog. Zentralblatt, Bd. 50, H. 9, pp. 541-554.

Jollos V. (1931), Genetik und Evolutionsproblem. Leipzig, Zool. Anzeiger Sppl. 5, 1931, pp. 252295.

Jollos V. (1932) Weitere Untersuchungen über die exp. Auslösung erblicher Veränderungen bei Drosophila. Zeitschrift für induktive Abst. Vererbl. Bd. 62.

Jollos V. (1934) Dauermodifikationen und Mutationen bei Protozoen. Archiv für Protistenkunde. Band 83, Heft 1, pp. 197-219.

Jollos V. (1935) Studien zum Evolutionsproblem II. Dauermodifikation, ,plasmatische Vererbung“" und ihre Bedeutung für die Entstehung der Arten. Biolog. Zentralblatt, 1935, Bd. 55, H. 7/8, pp. 390-436.

Junker T., Hoßfeld U. (2001) Die Entdeckung der Evolution. WBG, Darmstadt.

Just E.E. (1933) Cortical Cytoplasm and Evolution. American Naturalist, 67, pp. 20-29.

Kaasch M., Kaasch J. (2003) For and against Darwin - Darwinists and their opponents as members of the German Academy of natural scientists Leopoldina. In: In the Shadow of Darwinism: Alternative Evolutionary Theories in the 20th Century (Levit, G., et al.; eds.) FinedayPress, St-Petersburg: pp. 49-70 [in Russian with Engl. Abstr.].

Khittel S.R.F. (2005) Von der "Paläobiologie” zum “biologischen Trägheitsgesetz”. Peter Lang, Frankfurt am Main.

Kraus O. \& Hoßfeld U. (1998) 40 Jahre "Phylogenetisches Symposium“ (1956-1997): eine Übersicht - Anfänge, Entwicklung, Dokumentation und Wirkung. Jahrbuch für Geschichte und Theorie der Biologie V (5), pp. 157-186.

Krumbein, W. E. \& Schellnhuber H.-J. 1992. Geophysiology of mineral deposits - a Model for a Biological Driving Force of Global Changes through Earth History. Terra Nova 4, pp. 351362.

Le Roy E. (1927) L’Exigence Idéaliste et le Fait de l’Évolution. Boivin et Cie, Paris.

Levit G. S. (2000) „The Biosphere and the Noosphere Theories of V. I. Vernadsky and P. Teilhard de Chardin: A Methodological Essay“, Archives Internationales D'Histoire des Sciences, 50(144), pp. 160-176.

Levit G.S., Hoßfeld U. (2005) Die Nomogenese: Eine Evolutionstheorie jenseits des Darwinismus und Lamarckismus, Verhandlungen zur Geschichte und Theorie der Biologie, VWB Berlin, Vol. 11, pp. 367-388.

Levit G.S., Hossfeld U. (2006) The Forgotten "Old Darwinian" Synthesis: The Evolutionary Theory of Ludwig H. Plate (1862-1937) NTM International Journal of History and Ethics of Natural Sciences, Technology and Medicine, 14: pp. 9-25. 
Lovelock, J. \& Margulis, L. (1974) Atmospheric homeostasis by and for the biosphere: the Gaia hypothesis. Tellus 26: pp. 2-10.

Lovelock, J. (1986) The Biosphere. New Scientist 1517, pp. 51.

Lovelock, J. (1996) The Gaia Hypothesis. In: Gaia in Action (Bunyard, P.; ed.) Floris Books, Edinburgh: pp. 15-16.

Margulis L. (1996) James Lovelock's Gaia. In: Gaia in Action, (ed. P. Bunyard), Floris Books, Edinburgh, pp. 54-65.

Mayr, Ernst. 1982. The growth of biological thought: Diversity, evolution and inheritance. The Belknap Press of Harvard University Press, Cambridge.

Mayr, E., 1999. Thoughts on the Evolutionary Synthesis in Germany. In: Die Entstehung der Synthetischen Theorie: Beiträge zur Geschichte der Evolutionsbiologie in Deutschland (Junker, Th., Engels, E.-M.; eds.)VWB-Verlag, Berlin: pp. 19-30.

McShea D. (2005) The evolution of complexity without natural selection, a possible large-scale trend of the fourth kind. Paeobiology 31(2), pp. 146-156.

Nägeli C. v. (1884) Mechanisch-physiologische Theorie der Abstammungslehre. Verlag von R. Oldenbourg, München, Leipzig.

Nordenskiöld E. (1928) The history of biology. Tudor Publishing, New York.

Osborn H.F. (1925) The origin and evolution of life. On the theory of action, reaction and interaction of energy. G. Bell and Sons, London.

Osborn H.F. (1926) Book review: Nomogenesis or Evolution determined by law. Nature 30, pp. 617-618.

Osborn H.F. (1933) Aristogenesis, the observed order of biomechanical evolution. P.N.A.S. 19, pp. 699-703.

Osborn, H.F. (1897), ‘Organic Selection', Science 15, pp. 583-587.

Plate, Ludwig (1913) Selektionsprinzip und Probleme der Artbildung: Ein Handbuch des Darwinismus. 4. Auflage. Verlag von Wilhelm Engelmann, Leipzig, Berlin.

Plate, Ludwig (1932/33/38) Vererbungslehre: Mit besonderer Berücksichtigung der Abstammungslehre und des Menschen. Bd. I: Mendelismus. 1932. Bd. II Sexualität und Allgemeine Probleme. 1933. Bd. III: Spezielle Genetik einiger Nager. 1938. Gustav Fischer Verlag, Jena.

Plate, Ludwig (1935) „Kurze Selbstbiographie“. Archiv für Rassen- und Gesellschaftsbiologie 29, pp. 84-87.

Plate, Ludwig (1922) Allgemeine Zoologie und Abstammungslehre. Gustav Fischer Verlag, Jena.

Plate, Ludwig (1925) Die Abstammungslehre: Tatsachen, Theorien, Einwände und Folgerungen in kurzer Darstellung. Gustav Fischer Verlag, Jena.

Popov I.Y. (2005) Ortogenez protiv darwinizma. St. Petersburg University Press, St. Petersburg. 
Reif W.-E. (1986) The search for a Macroevolutionary Theory in German Paleontology. Journal of the History of Biology, 19 (1), pp. 79-130.

Reif, W.-E. (1993) Afterword. In: Basic questions in palaeontology (Schindewolf, O., Reif, W.-E.; eds.) University Press, Chicago: pp. 435-453.

Rensch B. (1947) Neuere Probleme der Abstammungslehre. Die transspezifische Evolution. Ferdinand Enke Verlag, Stuttgart.

Rensch B. (1980) Historical development of the present synthetic neo-Darwinism in Germany. In: The Evolutionary Synthesis (Mayr. E., Provine W.B.; eds.) Harvard University Press, Cambridge, Mass. [u.a.]: pp. 284-303.

Schindewolf, O. H. (1936) Paläontologie, Entwicklungslehre und Genetik. Kritik und Synthese. Bornträger, Berlin.

Schindewolf, O. H. (1947) Fragen der Abstammungslehre. Aufsätze u. Reden der senckenbergischen naturforschenden Gesellschaft 1. Kramer, Frankfurt.

Schindewolf, O. H. (1950) Grundlagen der Paläontologie. E. Schweizerbart'sche Verlagsbuchhandlung, Stuttgart.

Schindewolf, O. H. (1956) Zeugnisse der Vorzeit. Universität Tübingen 45, Reden bei der feierlichen Übergabe des Rektorates zu Beginn des Sommersemesters am 8. Mai 1956. Mohr, Tübingen.

Schindewolf, O. H. (1962) Neue Systematik. Palaeontologische Zeitschrift 36, pp. 59-78.

Schindewolf, O. H. (1964) Erdgeschichte und Weltgeschichte. Abh. Akad. Wiss. U. Lit., math.nat. Kl. 2, pp. 53-104.

Schindewolf, O. H. (1969) Über den "Typus" in morphologischer und phylogenetischer Biologie. Akademie der Wissenschaften und der Literatur, Mainz.

Suess E. (1875) Die Entstehung der Alpen. Braunmüller, Wien.

Teilhard de Chardin P. (1961) The Phenomenon of Man. Harper \& Row, and Evanston, New York.

Teilhard de Chardin, P. (1955) Le Phénomène humain. Éditions du Seuil, Paris.

Vernadsky V. I. (1994) Living Matter and the Biosphere. Nauka, Moscow [in Russ].

Vernadsky V.I. (1923) Living Matter in the Chemistry of the Sea, Scientific Chemical-Technical Publishing House, Petrograd [in Russ].

Vernadsky V.I. (1926) Isotopes and Living Matter. Reports of Acad. of Sc. of the USSR, series A, Dec., pp. 215-218 [in Russ].

Vernadsky V.I. (1991) Scientific Thought as a Planetary Phenomenon. Nauka, Moscow [in Russ].

Vernadsky V.I. (1997) Scientific Thought as a Planetary Phenomenon, Nongovernmental Ecological V.I. Vernadsky Foundation, Moscow. 
Vernadsky, V.I. (1965) The Chemical Structure of the Biosphere of the Earth and of its Environment. Nauka, Moscow [in Russ.].

Wimsatt, W. C. \& Schank J. C. (1988) Two constraints on the evolution of complex adaptations and the means for their avoidance. In: Progress in Evolution (Nitecki, M.; ed.) The University of Chicago Press, Chicago: pp. 213-273

Zavarzin Georgii A. (2003) Evolution of the Geosphere-Biosphere System. Priroda 1, pp. 27-35 [in Russian].

Zavarzin, Georgii A. (1997). The Rise of the Biosphere. Microbiology, 6(66), pp. 603-611.

\section{Address for correspondence:}

Georgy S. Levit

Ernst-Haeckel-Haus

Friedrich-Schiller-Universität Jena

Berggasse 7

D- 07745 Jena, Germany

Georg.Levit@uni-jena.de

Lennart Olsson

Institut für Spezielle Zoologie und Evolutionsbiologie mit Phyletischem Museum, Friedrich-Schiller-Universität Jena

Friedrich-Schiller-Universität Jena

Erbertstr. 1

D- 07745 Jena, Germany

Lennart.Olsson@uni-jena.de 


\title{
Wallace in Wonderland ${ }^{1}$
}

\author{
James Moore
}

... so many out-of-the-way things had happened lately, that Alice had begun to think that very few things indeed were really impossible...

[Said Alice to the Cheshire Cat], "I wish you wouldn't keep appearing and vanishing so suddenly: you make one quite giddy."

"All right," said the Cat; and this time it vanished quite slowly, beginning with the end of the tail, and ending with the grin, which remained some time after the rest of it had gone.

"Well! I've often seen a cat without a grin," thought Alice; "but a grin without a cat! It's the most curious thing I ever saw in all my life!"

Lewis Carroll, Alice's Adventures in Wonderland (1865)

\section{Abstract}

In heroic history of science, Alfred Russel Wallace (1823-1913) is ever the foil, a lesser light reflecting a greater glory. One biographer dubs him "Darwin's Moon." No lunatic, W allace independently worked out a theory of evolution, which Darwin called "natural selection" and for which he scooped the kudos by rushing into print with On the Origin of Species. Wallace remained the perfect gent but stubbornly went his own way. Within a decade he and Darwin had parted company on a range of issues. Most remarkably, Wallace came out believing in a world of purposive spirits and a Spiritual Power directing evolution. He saw séances as "a new branch of Anthropology." Darwin and his defenders were unconvinced. How they dealt with Wallace illustrates the making of Science (with a capital "S") and reminds us that sciences once made can be made again.

\footnotetext{
1 This essay derives from lectures given at Bennington College, Bunkyo Gakuin University, Case Western Reserve University, the Open University, Oregon State University, the history of science section of the British Association for the Advancement of Science, the 2005 Shrewsbury Darwin Festival, and the 2003 conference Transformism, Evolutionism and Creationism, sponsored by the French Ministry of Foreign Affairs (Fond D'Alembert) and the Wellcome Trust Centre for the History of Medicine at University College London. The substance of the lectures was adapted from material prepared for the Open University foundation course A103, An Introduction to the Humanities.
} 
Today the world stands in awe of "Science" with a capital "S." It towers above us, mighty and austere, a colossus of "unnatural" knowledge, our secular providence (Wolpert 1992; Midgley 1992). This is a chimera. Scientists may send us to Mars, scientific research may root out Aids, but Colossus Science dazzles and distracts, blinding us to debates about natural knowledge-claims - about what may count as science - that took place over time. Two centuries ago there were only small- "s" sciences, local knowledges claiming to be scientific. These raw materials were then shaped, pounded and developed into the monolithic Science the world now reveres. As a biographer, I am as intrigued by the fabricating as the end- product: my job is to show how the Colossus was made. For Science is as much a natural product of history as any religious system and was formed by similar forces. This is now a commonplace among historians, and I want to illustrate it from the critical years when the British scientific mainstream acquired its anti-spiritual slant. I focus on the individual who, perhaps more than anyone, helped clinch this outcome, the brilliant, self-taught naturalist best remembered as Darwin's co-discoverer of natural selection, Alfred Russel Wallace (1823-1913). ${ }^{2}$

Biography makes science memorable. Who can forget the charming Ladybird "Lives of the Great Scientists" or the sumptuous TV biopics about Robert Oppenheimer and the Bomb, Rosalind Franklin and DNA, and the voyage of Charles Darwin? All these portraits, great and small, strengthen one of history's commonest preconceptions: that of the scientist as hero. Complex he or she may be; wracked by conscience, driven by ambition, tragically slighted or overlooked: nevertheless, like a lone mountaineer, the scientisthero inspires and lifts our thoughts, leading us to new vistas of progress.

Heroes need human challenges as well as natural ones, men to master as well as mountains. Such is the drama of discovery endlessly scripted in our time. The scientist must have an adversary, an evil institution such as "the church" or a corrupt individual, preferably a politician. This becomes his stumbling-block, frustrating free enquiry, impeding progress. Or a rival scientist may fit the bill: a vainglorious upstart, a grandiloquent imposter, a muddle-headed friend. Heroism consists in surmounting all such obstacles and, shunning self-pride and pretence, pursuing nature wherever "she" may lead (Golinski 1998, 192-94).

High in the first division of scientific heroes is the "Newton" of natural history, Charles Darwin (Ruse 1979, 31). It was he who slowly and methodically, with infinite patience and perseverance, singlehandedly solved that "mystery of mysteries," how living species originate. Or so hero-worshippers say. And to them Darwin had fiendish foes bishops mostly, the odd politician, countless minor bigots - who fought in vain to stem the tide of truth. Less is heard of Darwin's professional rivals. Science with a capital "S" is supposed to be united; in heroic history, only renegades break ranks. Yet Victorian men of science did break ranks, and one of them is routinely cast as Darwin's opposite number, Wallace. ${ }^{3}$

\footnotetext{
${ }^{2}$ No attempt is made here to take into account the recent spate of Wallace books, the most substantial of which are biographical studies by Raby (2001), Shermer (2002), Fichman (2004) and Slotten (2004), and anthologies by Smith (1991), Berry (2002) and Camerini (2002). For a critical view, see Endersby (2003).

${ }^{3}$ In his lately much celebrated textbook, The Darwinian Revolution $(1979,280)$, Michael Ruse explains: "Like nearly everyone else, I find myself relegating Wallace to the notes. This is unfair, since Wallace really did
} 
Not that he is all ogre. As often as Wallace is made a whipping-boy or laughing-stock he is the genial seer or saint. Winsome and likeable, he sometimes plays constructive parts - the resourceful Tonto to Darwin's Lone Ranger, the helpful Watson to Sherlock Holmes. Even so, Wallace remains the anti-hero. In all roles he is the foil, a lesser light reflecting a greater glory. "In Darwin's shadow," according to a recent biographer (Shermer 2002), he is still "Darwin's moon" (Williams-Ellis 1966).

Wallace, no lunatic, is made a mere satellite because of his part in one of the most poignant ironies in the history of science. In February 1858 (the story goes) he had the brilliant misfortune to hit on a scientific "principle" twenty years too late. Unknown to him, Darwin, working privately, had got to it - natural selection - first, and when he heard of Wallace's work he scooped the kudos by rushing into print with On the Origin of Species. Wallace, his originality eclipsed, remained the perfect gent but stubbornly went his own way. Within a decade he and Darwin had parted company on a range of issues. Most remarkably, Wallace came out as a believer in disembodied spirits and gave them a role in evolution. In this he played the crank to Darwin's correctness and, it was said "lost caste terribly" (J. D. Hooker, in Colp 1992, 11). Only as an afterthought was he asked in 1882 to bear Darwin's coffin in Westminster Abbey (Moore 1982).

Ever since then, commentators on Wallace and Darwin have tended to take a moralizing line. They assess whose science was better or worse, superior or inferior, right or wrong. The question is always how much praise Wallace or Darwin deserves, how much credit the one should get relative to the other. This illustrates the peril of judging past science by present standards (Hardin 1960, 45; Ghiselin 1969, 150-51; Hardy 1984, 6-61, 64; White and Gribbin 1995, 233). The sense of science's making, of how the boundaries of science came to be drawn and of how Wallace and Darwin ended up on opposite sides over the spirits is lost by assuming in advance what "science" should mean.

Today's history of science tries not to take sides. It is anti-heroic, not because it favours anti-heroes but because it seeks to level the playing pitch and let everyone join in. The historian is not a referee, imposing our scientific rules on the past, but rather like a sports commentator, following the game of science as it was played, explaining strategies, describing the drama, the brilliant saves, the own-goals. The rules sometimes change, the goalposts move. Uproar ensues. Rival fans invade the pitch. Players are sent off and substitutions made. Order is restored. The game goes on, and its currrent state-of-play is known. But this knowledge should not skew the commentary. The match could have gone differently. By now another side might have been winning. Or in future another will be - who knows?

So I propose to deal evenhandedly with Wallace and Darwin. By following the game of science as it was played in Victorian Britain, we not only learn about Wallace's efforts to make spiritual knowledge scientific; we also glimpse the processes by which what we now call "Science" was made.

discover natural selection as an evolutionary mechanism, but not totally unfair. Wallace's creative work came twenty years afer Darwin's, he did not write out a full theory, and he did not form a party of supporters." 


\section{New scientists, new science}

Wallace does not wear labels lightly. Born in Wales to an impoverished lawyer, schooled to the age of thirteen, then apprenticed as a land surveyor, he was always awkward, independent, his mind shaped by a plebeian culture in which do-it-yourself science knew no bounds.

His opinions were typical of his age and class. Having renounced his parents' Anglicanism, he filled the void with utopian socialism and remained a radical freethinker for life. The latest would-be sciences attracted him. He learned to mesmerize from an itinerant performer and he gave demonstrations before small audiences. He took up phrenology and had his character "delineated" by getting his head shaved and "read." He hung out at Mechanics' Institutes, taught himself botany and geology, and in 1845, at the age of twenty-two, converted to the latest scientific heresy, evolution. Three years later he quit surveying and sailed for Brazil to search for a "theory of the origin of species." He drew a blank but persevered, sailing again in 1854 to the Dutch East Indies, where he hit on what Darwin already called natural selection (Moore 1997).

In 1862 Wallace returned to London like Rip Van Winkle waking to a new world. Famous now as Darwin's co-discoverer, but eight years out of touch, he made the rounds of scientific society, catching up on all the latest. Everywhere he heard about young men manoeuvring and new names rising. Victorian science was being transformed. The young guard called themselves "men of science" (only later "scientists"), and they owed their status more to merit than rank or wealth. Overworked and underpaid, they had won their spurs the hard way; engineers and naval doctors, surveyors and civil servants who had fought for funds and clawed their way to power. Some were taking top scientific jobs in the capital, pushing out the old genteel fat cats, their bêtes noires. The Oxbridge clergy with their cushy chairs, the City gents and dusty dilettantes all had divided loyalties; their science was yoked with God or mammon. The new men saw themselves as singleminded professionals, beholden to no one; a rising elite uniquely qualified to lead an emerging "scientific culture" (Yeo 1993, 32).

Their science matched their social ambition. It too was comprehensive, taking in life, the universe - everything. The older naturalists' world was split into material and spiritual parts and, the new men insisted, was destined for history's dustbin. Nothing now was sacrosanct, nothing taboo. Spiritual specialists like the Anglican clergy were worse than useless. Far from adding to knowledge, they blocked it. Asked how the universe was formed or living species originated, they answered "God." Asked about the human mind and morals, they dragged in the immortal soul. For such men all questions of origins and human nature lay shrouded in miracle and mystery, even despite the enormous gifts of science to material progress - steam traction, public sanitation, the electric telegraph and more.

Science produced the goods - this was the new men's knock-down argument. All the great life and labour-saving advances of the century had come from knowledge of natural law. Further progress would be made only as men like themselves discovered law and order everywhere, from nebular condensation to the evolution of humans. The origins and ends of things; life, mind, and morals - all would be shown to result from uniform material processes. Miracles and mysteries were finished; the spiritual specialists had to go. Britain's coming culture would be not just scientific but wholly secular. 
Radical freethinkers had mooted this for decades. But here were respectable chaps, Fellows of the Royal Society, sounding off in public, baiting bishops, and even touting that old heresy, evolution. When Wallace arrived back in London it was the hottest scientific topic in town. Darwin had published his Origin of Species in 1859, arguing clearly and convincingly, with immaculate credentials, how living things had come into existence by a purely natural process. While older naturalists loathed the book, the new men loved it, and some were using Darwin's name to settle scores.

Darwin's book deliberately skirted that most sensitive subject, human origins. Not Thomas Huxley (1825-1895), Darwin's self-appointed "bulldog," a naval doctor made FRS and now, still in his thirties, a new professor at the elite Royal College of Surgeons. He had his capacious jaws clamped on the darling of the Oxbridge divines, Richard Owen, head of the natural history collections at the British Museum. Owen at sixty was a brilliant anatomist and fossil expert - he invented the dinosaur-concept - and he had a fatal attraction for power. He was courtly, condescending, a Tory Anglican autocrat who hated evolution. His latest boast was that the brains of apes and humans are anatomically distinct; the latter could never have evolved from the former because the human brain had been "especially adapted to become the seat and instrument of a rational and responsible soul" (quoted in Desmond 1989, 288). Huxley let out a snarl and set upon him. The tussle spilled into the press. He savaged Owen for shoddy methods and betraying science. The structural differences between humans and the Gorilla were in fact "not so great as those which separate the Gorilla from the lower apes," Huxley growled. Humans had evolved in body and brain, and the only theory with "any scientific" claim to explain it was the one "propounded by Mr. Darwin" (Huxley 1894, 144, 147).

\section{The origin of mind}

Wallace was no stranger to this controversy. An old radical himself, though barely forty year old, he had lived with apes in the Far East, comparing them with the native Dyaks, and hit on a "principle," which Darwin called natural selection, while pondering the origin of human races. He felt honoured to have prodded the great Darwin into print; overawed by the Origin of Species, he even admitted, 'I really feel thankful that it has not been left to me to give the theory to the public" (Marchant 1916, 1: 73). Yet the men's names were inseparably linked, Wallace's modesty notwithstanding. The public counted him a member of the scientific avant garde and, like Huxley, a Darwinian defender of an ape ancestry for humans.

Not that the company Wallace kept was always respectable by Huxley's standards. He sought out radical allies in the new, men-only Anthropological Society of London. Its rooms were graced by a savage's skeleton and the meetings brought to order with a negro's-head mace. Here all subjects were debated with virile directness, and in an unseemly reaction to the prudery of the age, the gents dwelt obsessively on such bare essentials as female "circumcision," phallic symbolism, and the anatomy of the "Hottentot Venus" (Stocking 1987, 247-54; Richards 1989; Qureshi 2004). The main theme, though, was race, and the tone fiercely racist. Wallace did not share the extremists' views, but the "Cannibal Club" (as members dubbed it) was the perfect place to stick his neck out. In a 
paper read before a meeting in March 1864 he became the first naturalist in Britain publicly to apply the theory of natural selection to the evolution of "man."

Rushing in where Darwin feared to tread, he tackled the fraught question of the origin of the human races. Were they separate species, as the racists claimed, with the Caucasian the highest and the Negro next to apes? Or did all races descend from a single ancestor and share a common humanity (as Darwin believed)? Wallace's answer was a clever compromise. He agreed with the extremists that the different bodily features of the human races - skin colour, hair texture, and so on -were developed from a homogeneous subhuman population in prehistoric times. These features had evolved by natural selection (or he would say, "survival of the fittest") as adaptations to different environments, just like the skins and furs of animals. But once the races acquired human mental qualities, their bodily evolution ceased. When humans began to control their environment, building shelter, making weapons, raising food, and above all aiding one another, all further advance was due to the power of mind. Natural selection now affected, not brawn, but brain. The fittest to survive were no longer physically the strongest, but mentally the brightest and most moral. Their "wonderful" faculties enabled them to escape the struggle for existence and enter a "social state" in which life was preserved and enhanced.

Where did the these mental faculties come from? If "that subtle force we term mind" (as Wallace called it) had brought about a "grand revolution ... in nature," surely its appearance at a given "moment" was an even grander event, demanding explanation. Yet here he is strangely silent. His paper nowhere states how mind originated. Wallace is less concerned about the remote past than the not-so-distant future, when mind will be perfected. The fittest individuals, the brightest and most moral of every race will, he declares, transform the earth into "as bright a paradise as ever haunted the dreams of seer or poet." Utopia will simply evolve (Wallace 1864, clxvii-xx).

However, six years later, in 1870, Wallace's tune had changed. By now he realized that natural selection was not working as he had hoped. The "fittest" (by his standards) weren't surviving; "the mediocre" in "morality and intelligence" were swamping them. That year he reprinted his racial origins paper with a new conclusion, and here for the first time, publicly and dramatically, in a scientific text, he staked his utopian faith not just on the "glorious qualities" of mind that distinguish humans from animals, but also amazingly - on "other and higher existences than ourselves, from whom these qualities may have been derived, and towards whom we may be ever tending" (Wallace 1891, 185). Not "which" but "whom" - Wallace now sought the origin of mind among supernatural beings.

Darwin's co-discoverer was the cuckoo in the new scientists' nest. Between 1864 and 1870 he turned traitor to their programme of universal explanation by natural law. Indeed, his "glorious qualities" and "higher existences" were reminiscent of the immortal souls touted by the parsons and Professor Owen. Just when their spiritual world was being banished, Wallace seemed to let in through the back door. Why? Why did a respected naturalist suddenly break ranks and risk ridicule by embracing the supernatural? Was he stupid or just gullible? Maybe he was a crank after all. Instead of judging Wallace by today's scientific standards or those of his Victorian critics, we can try to account for his spiritual science in a constructive historical way. 


\section{Conversion}

Wallace's interest in spirits had been piqued years earlier. While still in the tropics he heard about the parlour craze sweeping Britain and America, the weird rappings and rocking tables, the "miracles" and ghostly messages. Deploring superstition like a good freethinker, he resolved to investigate when he got home.

At first he was sceptical, and understandably. The spirit fad, or spiritualism, was the last wave in a tide of rural enthusiasms that engulfed upstate New York in the early nineteenth century. The wave spilled over like the rest and in the 1850 s rolled into Britain behind a gypsy train of hucksters and hustlers calling themselves "mediums" (Cross 1950; These adepts claimed to have contacts beyond the grave; for a fee they would prove it with a séance. Parlours were darkened and hands held round a table. The spirits were invoked. Then the bumps would start, the table tilt, bells ring, breezes blow, candles burn, and objects would float in air. A message might be tapped out as if by telegraph or appear written on a slate. The showmanship was often spectacular, baffling unbelievers, who dismissed it all as fraud.

Yet many worthy persons were converted. Spiritualism satisfied the curious and soothed the bereaved (though some thought them self-deluded); equally it inspired political radicals, keen to underwrite their hopes. As a practical, empirical science, spiritualism served them well, like the old heresies phrenology and mesmerism. Its appeal, too, was direct and democratic - all were potential mediums, anyone could join a séance plus it guaranteed an upward social evolution. Spirit was seen as a progressive force, immune to earthly failure; the supernatural world would transform the natural, bringing in the millennium (Barrow 1986).

Spiritualism also held a special place for women. From the society matrons who launched the movement to the working girls who joined it in the 1870s, females of every age and class thrived in the charmed circle of the séance. As a domestic circle it was of course one in which Victorian women were thought to function best, yet the spirits seemed specially drawn to them and would perform avidly in their presence. Shrewd ladies turned this to advantage, becoming star "public mediums." Impresarios such as Mrs Mary Marshall and Mrs Agnes Guppy put on theatrical displays of power. Besides bringing messages from the dead, they were known to cause objects - even themselves to levitate, materialize and disappear. Under spirit control such women apparently held sway over the material world in a manner only dreamt of by male scientists and politicians. For this they were lionized, while radicals hailed the work of sister spiritualists as "invaluable ... for the furtherance of meaningful social reform" (Owen 1990, 28).

Make no mistake: the spiritual world of spiritualism was remote from that of the old men of science and the clergy. Their spiritual world was sacred and lay outside proper science. It could not be tampered with, for God and the soul were not experimental subjects. Also in this world, as in the material, a male elite officiated and policed the common boundary. There was no power-sharing with women. In spiritualism, by contrast, anyone could participate; the spirits could be beckoned and cajoled, and their antics manipulated. Females were spiritual specialists.

All this novelty, all this heresy, gave spiritualism a special allure, and Wallace was drawn to it helplessly after his paper on racial origins. This was a turning-point in his life. Single, shy, and over forty, he was also tall - six feet plus - gangly and gauche. Never 
mind, he resolved to marry, and was soon smitten with a woman of a superior class, still in her twenties. At first she resisted his attentions, but he persevered, and in mid-1864 her father agreed to an engagement and a wedding date was set. ${ }^{4}$ Wallace himself takes up the story in a confessional letter to Darwin, dated 20 January 1865 :

For the last six months I have been doing absolutely nothing, \& fear I shall not be inclined for work for some time to come. The reason is that I have suffered one of those severe disappointments few men have to endure. I was engaged to be married at Xmas, $\&$ had every reason to look forward to happiness, when at the last moment, when everything was arranged, \& even the invitations sent out by the lady's father, all was suddenly broken off? No cause has been given me except mysterious statements of the impossibility of our being happy, although her affection for me remains unchanged. Of course I can only impute it to some delusion on her part as to the state of her health. You may imagine how this has upset me when I tell you that I never in my life before had met with a woman I could love, \& in this case I firmly believe I was most truly loved in return. ${ }^{5}$

Wallace never again saw or heard of the woman or her family. Nor, he reflected, did he ever experience "such intensely painful emotion" (Wallace 1905, 1: 410)

Darwin's blunt advice - "banish painful thoughts" through "hard work" - was useless (Marchant 1916, 1: 160). Life had ground to a halt; serious work was impossible. There was nothing for it but to up stakes and start over, so just before Easter 1865, Alfred left lodgings in his sister's house and moved across London to live with his mother near the Regent's Park Zoo.

Three months later, as Alice's Adventures in Wonderland was published, Wallace tumbled headlong into the wonderland of séances.

At first he sat with friends and picked up the usual tapping and vibrations. Then in the autumn he visited the matronly Mrs Marshall, who astonished him by making a table levitate and revealing details about his long dead brother Herbert. Maybe an old mesmerist had such powers: Alfred practised at home for months without success. His sister Fanny came to the rescue; she said that her new lodger, young Miss Agnes Nicholl, could produce "curious phenomena." So in 1866 Alfred, Fanny and friends began regular sittings with Miss Nicholl - later the redoubtable Mrs Guppy. They met on Friday nights, and now for the first time Alfred witnessed "miracles" in his own parlour. Stunned by the show, he immediately published detailed reports, giving the sitters' names and addresses lest sceptics doubt his word.

Here is Alfred on a cold December night. He sits in a stuffy shuttered room with a doctor, a lawyer, and other west London worthies, waiting expectantly. An hour has passed, the gas is turned down to a blue point and hands are joined in a circle.

... in a few moments several of the party said faintly that something was appearing on the table. The medium saw a hand, others what seemed flowers. These became more distinct, and some one put his hand on the table and said, "There are flowers here." Obtaining a light, we were all thunderstruck to see the table half covered with fern leaves, all

\footnotetext{
4 From manuscript notes for Wallace's autobiography, now in the Natural History Museum, London, Raby (2002, 170-71, 180-81) has identified the fiancée as Marion Leslie, elder daughter of Wallace's chess-playing friend Lewis Leslie, a London auctioneer and widower who lived in Kensington with offices in Mayfair.

5 Dar 106/7 (ser. 2), 20-21, Darwin Archive, Cambridge University Library.
} 
fresh, cold, and damp, as if they had that moment been brought out of the night air. They were ordinary winter flowers which are cultivated in hot houses, for table decoration, the stems apparently cut off as if for a bouquet. They consisted of fifteen chrysanthemums, six variegated anemones, four tulips, five orange-berried solanums, six ferns of two sorts, one Auricula sinensis with nine flowers, thirty-seven stalks in all.

"Curiouser and curiouser." Wallace might have been botanizing in Brazil. He saw the "miraculous" with unblinking scientific eyes, and Miss Nicholl soon showed him that she could defy physics as well as biology by raising herself, chair and all, "instantaneously and noiselessly," to sit on a parlour table. She did so, he claimed, "some half dozen times, in different houses in London," before "at least twenty persons, of the highest respectability." This to Wallace was conclusive proof of spiritualism. He now knew not just "the reality of the facts," but also their implication: they had to be "the manifestation of some strange and preterhuman power" (Wallace 1867).

Why then did he convert to spiritualism? To say he was a fool would make a nonsense of his attainments in natural history; to say he was religiously motivated would deny his initial scepticism and rugged freethought. Spirits no more persuaded him of their existence than natural selection did of its reality. The conversion was neither a superhuman event, nor irrational, but merely a logical development of Wallace's long-term radical interests and convictions (Fichman 2001). He had been a phrenologist, a mesmerist and an evolutionist for over twenty years. He believed that big brains in big skulls had enormous powers - unique powers, common to all humans without respect of race or class. Mesmeric phenomena showed him that mind was a "subtle force," evolution that this force arose in a body descended from apes, and natural selection that the human body ceased evolving when it acquired a mind. The unanswered question in his 1864 paper was, How?

Wallace made the mind a spiritual entity added to the body, not evolved, only after witnessing Mrs Marshall and Miss Nicholl produce phenomena that he himself could ascribe to nothing but some "preterhuman" power. In 1866 this was, for him, a scientific solution to a scientific problem. He sought out these women, however, only after a severe emotional crisis, which adds a further twist to the tale. Living with his mother, swayed by his sister, he remained vulnerable to forces - social forces - outside the male scientific establishment. No sooner had his fiancée misled him than he entrusted himself to female mediums, staking his reputation on their integrity. And he continued to do so after his mother's death in 1868, as when Miss Nicholl - now Mrs Guppy - revealed that her spirit would appear on a photographic plate. Sure enough, on 14 March 1874 Guppy produced the goods - Wallace describes the action $(1874,190 \mathrm{n})$ :

At the third sitting, after placing myself, and after the prepared plate was in the camera, I asked that the figure would come close to me. The third plate exhibited a female figure standing close in front of me, so that the drapery covers the lower part of my body ...[T] he additional figure started out the moment the developing fluid was poured on, while my portrait did not become visible till, perhaps, twenty seconds later ... [T] he moment I got the proofs, the first glance showed me that the third plate contained an unmistakeable portrait of my mother, - like her both in features and expression; not such a likeness as a portrait taken during life, but a somewhat pensive, idealised likeness - yet still, to me, an unmistakeable likeness. 
In such events, perhaps, lies a deeper reason for Wallace's conversion to spiritualism, but fathoming it would require a full-scale biography.

\section{Parting with Darwin}

Wallace had seen the light. "The facts beat me," he insisted; "if I have now changed my opinion, it is simply by the force of evidence." Miss Nicholl's levitation had been the turning point, and afterwards he threw down the gauntlet: "Let those who believe it to be a trick, devote themselves to practise it, and when they are able to succeed in repeating the experiment, under exactly the same conditions, I will allow that some far more conclusive proof of the reality of these manifestations is required" (Wallace 1867).

So the onus of replication was now on sceptics. Wallace made sure by publishing a small pamphlet with a big title, The Scientific Aspect of the Supernatural: Indicating the Desirableness of an Experimental Enquiry by Men of Science into the Alleged Powers of Clairvoyants and Mediums. In late 1866 he rushed copies to the men of science he respected most, including Darwin's pit-bull terrier Thomas Huxley. "I have been writing a little on a new branch of Anthropology," Wallace explained disarmingly. "I fear you will be much shocked, but I can't help it; and before finally deciding that we are all mad I hope you will come and see some very curious phenomena which we can show you, among friends only ... We wish for the fullest investigation, and shall be only too grateful to you or anyone else who will show us how and where we are deceived" (Marchant 1916, 2:187).

Huxley had had his fill of séances years before and he hated the supernatural. Spiritualism "may be all true, for anything I know to the contrary," he dissembled, "but really I cannot get up any interest in the subject." He was not shocked, nor did he think Wallace mad. The poor man had merely been duped by dotty ladies into wasting precious time. "I never cared for gossip," Huxley scowled, "... and disembodied gossip, such as these worthy ghosts supply their friends with, is not more interesting to me than any other." For his part, he had "half-a-dozen investigations of infinitely greater interest" to conduct, which left him no "spare time" for spiritualism. "I give it up for the same reason I abstain from chess - it's too amusing to be fair work, and too hard work to be amusing" (Marchant 1916, 2: 187-88).

Wallace was not amused, and he tried to raise the tone. He cared for gossip as little as Huxley did, "but what I do feel an intense interest in is the exhibition of force where force has been declared impossible, and of intelligence from a source the very mention of which has been deemed an absurdity." He invoked the name of Faraday, the foremost experimental physicist, who had declared that anyone who could prove the existence of "a power not yet recognised by science" would receive "applause and gratitude." "I believe I can ... show such a force," Wallace insisted, adding that he now hoped physicists would "admit its importance" and look into it (Marchant 1916, 2: 188).

Here then were two accomplished naturalists of the same generation, both "Darwinians," disagreeing about the significance of spirit phenomena. Which of them was being "scientific"?

They both were, each according to his lights. Theirs was a dispute about what should count as science. To Huxley, being "scientific" meant investigating natural phenomena on 
naturalistic assumptions. Spiritualism violated these assumptions, so its phenomena could have no place in his science. To Wallace, being "scientific" meant investigating all alleged phenomena, even those deemed impossible or absurd. Spiritualism to him was proved by its phenomena, so they became integral to his science. This science included the super- or preternatural; Huxley's denied its existence. Wallace saw himself as working on 'a new branch of Anthropology'; Huxley remained loyal to Darwin's. Neither anthropology, however, was seen as "scientific" by older naturalists and the clergy, who not only kept spiritual things out of science but rejected evolution also. The question for everyone in the 1860s was: Whose science shall win?

\section{Ostracism}

By the time Wallace's pamphlet reached Darwin, they had struck up a lively correspondence. Socially and intellectually Wallace was the junior partner, but his transparency, encyclopaedic knowledge, and persuasive powers impressed Darwin enormously - so much that in 1868 he confessed to Wallace, "I grieve to differ from you, and it actually terrifies me, and makes me constantly distrust myself” (Marchant 1916, 1: 227).

Conflicts were now emerging, mostly technical ones about the application of their theory. Wallace defended natural selection brilliantly, arguing only about how much it could explain. Darwin had admired his paper on racial evolution, but after receiving the spiritualist pamphlet, he worried more and more. In 1869, after learning that Wallace was to review the new edition of his old mentor Charles Lyell's Principles of Geology, he despaired. Lyell had crushed him by refusing to "go the whole orang" on human origins. Now Wallace threatened worse - to backslide. "I hope," Darwin shuddered, "you have not murdered too completely your own and my child" (Marchant 1916, 1: 241).

Infanticide it was. The review was brutal. Its conclusion seemed to Darwin so unscientific that he thought it might have been "added by someone else" (Marchant 1916, 1: 243). Wallace now argued that neither the mind nor all bodily features of humans could have evolved by natural selection. Primitive people possessed mental capacities far in excess of their survival requirements; they had physical features that were apparently useless except in a civilized state. Big brains, exquisite hands, naked skin, speech organs - such things must have evolved prospectively, long before they were needed, which showed intelligent foresight. Natural selection, being blind, could not have been the cause, so Wallace detected a supernatural "Power" guiding evolution.

Darwin, feeling betrayed, stabbed exclamation marks and scrawled indignant notes in the margins. "No!!!!" "I think the same argument could be applied to any animal - what use 5 toes to dogs foot"? Or what use a fine hand - "ties knots" - "opening fruit". 6 Suddenly he realized how "grievously" they differed; he was "very sorry for it" and told Wallace so (Marchant 1916, 1: 243). It was a watershed in their relationship. Never again would he fully trust his colleague's scientific judgement.

Wallace's review said nothing about spiritualism; his pamphlet only called for an "experimental enquiry" into its phenomena, but Darwin still read blank credulity between

\footnotetext{
${ }^{6}$ Darwin's marginalia on his copy of Wallace's review are in the Darwin Reprint Collection, Cambridge University Library.
} 
the lines. It was all too much, even if Huxley could see an advantage: proving spiritualism true would cut the suicide rate. "Better live a crossing sweeper," he laughed, "than die and be made to talk twaddle by a "medium" hired at a guinea a séance" (in Anon. 1871, 230).

More sober scientists, or those with less to lose, took up Wallace's experimental challenge (Noakes, 1999, 2002, 2004; Gay 1996). William Crookes, the analytical chemist who discovered the element thallium, constructed special apparatus and in 1870 began séances with the respected American medium Daniel Home. Darwin's true-blue cousin Francis Galton, a total sceptic, attended one and was "utterly confounded." In "full gaslight," with "perfect apparent openness," Home produced the most "extraordinary" phenomena - even the playing of an accordion suspended by one hand. This was no "vulgar legerdemain'; Crookes had taken "thoroughly scientific" precautions (Pearson 1924, 64). Galton begged Darwin to come and see for himself, but he refused, pleading ill-health.

Darwin only once sat in a séance, in 1874, at his brother's house in London. The novelist George Eliot was present as well as Galton and other relatives. The performance was about to start when Darwin suddenly broke the spell, made excuses, and went upstairs to lie down. When he returned, he found the table stacked with chairs, which reportedly had been lifted over everyone's heads, with sparks flying, and wind rushing, and strange rapping. "The Lord have mercy on us all, if we have to believe in such rubbish," he groaned (F. Darwin 1887, 3: 187). His wife Emma, who had seen the show, explained, "He won't believe it, he dislikes the thought of it so very much." Smiling sweetly, she branded him a "regular bigot" (Wedgwood 1980, 305). Only after Huxley had attended another séance and declared the medium a cheat did Darwin relax. It would now take "an enormous weight of evidence," he to convince him that there was anything in spiritualism but "mere trickery" (Pearson 1924, 67).

The issues boiled up again at the 1876 meeting of the British Association for the Advancement of Science. By now Huxley's new model scientists dominated the annual road-show, so there was uproar when Wallace, presiding over the Anthropology section, allowed a paper on thought transference to be read. The author was another physicist, W. F. Barrett, who had worked under Faraday. The row splashed into the Times and got linked with the case of Henry Slade, a American medium being sued by Huxley's protégé, the fiery Darwinian zoologist Ray Lankester. Lankester had caught Slade cheating in a séance; Wallace had sat with him and seen only miracles. The case ended up in London's Bow Street magistrate's court with Wallace as the star defence witness. Behind the scenes Darwin bankrolled the prosecution, which he considered a "public benefit" (Milner 1990, 29). Slade was convicted and fled the country, his career as a con-artist in ruins. Wallace wiped the egg from his face and walked out of the British Association.

This was a defining moment. Spiritual phenomena were now ruled scientifically out of bounds. At the British Association's 1878 meeting, Huxley took Wallace's place as chair of the Anthropology section and uttered a stern warning: "If any one should travel outside the lines of scientific evidence, and endeavour either to support or oppose conclusions which are based upon distinctly scientific grounds, by considerations which are not in any way based upon scientific logic or scientific truth ... I, occupying the chair of the Section, should, most undoubtedly, feel myself called upon to call him to order, and 
to tell him that he was introducing topics with which we had no concern whatever" (Huxley 1879, 576). Wallace, who was absent, had got the message already. His disgracing in the Slade trial had been deliberate; his spiritual science was beyond the pale. He now met with a ginger group of intellectuals who, in 1882, joined Barrett, Crookes and fellow physical scientists to form the Society for Psychical Research (Gauld 1968; Haynes 1982). Its force was spent within a few decades.

For all his fame as Darwin's co-discoverer, Wallace was a radical round peg among the neat square holes of the rising scientific professions. He never fitted in, never specialized, never unlearned. His science sprawled untidily, from phrenology and mesmerism to spiritualism and socialism, confirming Darwin's fear that he might "turn renegade to natural history" (Marchant 1916, 1: 318). Even allies became uneasy. Oliver Lodge, a noted physicist and spiritualist, thought him "a good observer ... with a great deal of selfconfidence in the midst of much simplicity and modesty," but equally "a crude, simple soul, easily influenced, open to every novelty and argument” (Hill 1932, 34).

Amiable and honest, stubborn and naive, this was the wonderful Wallace, author of ten major scientific tomes, who, when proposed for a Fellowship of the Royal Society in 1893, at the age of seventy, could not see why he should be so honoured: "I really have done so little of what is usually considered scientific work," he demurred politely (quoted in Durant 1979, 33).

Well, he had and he hadn't. Much of his "scientific work" - for which he was indeed elected FRS - belonged to the new Darwinian sciences of the late-Victorian age. Much, too, belonged to the do-it-yourself, democratic sciences of the past. These sciences no longer counted in the new professionals' eyes, but for Wallace and many like him they remained vital. Understanding why this was so helps us to see how "Science" has changed, and it may give us hope. For in a day when Colossus "Science" - with a capital "S" - is revered, when scientists still draw boundaries, excluding competitors, defying critics; in a day when Intelligent Design is said to put the supernatural back in science and some evolutionists dare to see non-selective forces at work in evolution, Wallace's case reminds - and warns - us that sciences once made can be made again.

Said Alice to herself: "Dear, dear! How very queer everything is today ... Who in the world am I? Ah, that's the great puzzle!'

\section{References}

Anon. (1871) Report on Spiritualism, of the Committee of the London Dialectical Society, together with the Evidence Oral and Written, and a Selection from the Correspondence. Longmans, London.

Barrow, L. (1986) Independent Spirits: Spiritualism and English Plebeians, 1850-1910. Routledge and Kegan Paul, London.

Berry, A. (2002) Infinite Tropics: An Alfred Russel Wallace Anthology. Verso, London.

Camerini, J. R. (2002) The Alfred Russel Wallace Reader: A Selection of Writings from the Field. Johns Hopkins University Press, Baltimore. 
Colp, R., Jr (1992) "I will gladly do my best": How Charles Darwin obtained a Civil List pension for Alfred Russel Wallace. Isis 83, pp. 3-26.

Cross, W. R. (1950) The Burned-Over District: The Social and Intellectual History of Enthusiastic Religion in Western New York, 1800-1850. Cornell University Press, Ithaca, New York.

Desmond, A. (1989) The Politics of Evolution: Morphology, Medicine, and Reform in Radical London. University of Chicago Press, Chicago.

Durant, J. R. (1979) Scientific naturalism and social reform in the thought of Alfred Russel Wallace. Brit. J. Hist. Sci. 12, pp. 31-58.

Endersby, J. (2003) Escaping Darwin's shadow. J. Hist. Biol. 36, pp. 385-403.

Fichman, M. (2001) Science in theistic contexts: A case study of Alfred Russel Wallace on Human Evolution. Osiris 16, pp. 227-50.

Fichman, M. (2004) An Elusive Victorian: The Evolution of Alfred Russel Wallace. University of Chicago Press, Chicago.

Gauld, A. (1968) The Founders of Psychical Research. Routledge and Kegan Paul, London.

Gay, H. (1996) Invisible resource: William Crookes and his circle of support, 1871-1881. Brit. J. Hist. Sci. 29, pp. 311-36.

Ghiselin, M. T. (1969) The Triumph of the Darwinian Method. University of California Press, Berkeley.

Golinski, J. (1998) Making Natural Knowledge: Constructivism and the History of Science. Cambridge University Press, Cambridge.

Hardin, G. (1960) Nature and Man’s Fate. Cape, London.

Hardy, A. (1984) Darwin and the Spirit of Man. Collins, London.

Haynes, R. (1982) The Society for Psychical Research, 1882-1982: A History. Macdonald, Londoin.

Hill, J. A. (ed.) (1932) Letters from Sir Oliver Lodge: Psychical, Religious, Scientific and Personal. Cassell, London.

Huxley, T. H. (1879) [Address before the Department of Anthropology]. Report of the FortyEighth Meeting of the British Association for the Advancement of Science; Held at Dublin in August 1878. John Murray, London: pp. 573-78.

Huxley, T. H. (1894) Man’s Place in Nature and Other Anthropological Essays. Macmillan, London.

Marchant, J. (1916) Alfred Russel Wallace: Letters and Reminiscences, 2 vols. Cassell, London.

Midgley, M. (1992) Science as Salvation: A Modern Myth and its Meaning. Routledge, London.

Milner, R. (1990) Darwin for the prosecution, Wallace for the defense, Part I: How two great naturalists put the supernatural on trial. North Country Naturalist 2, pp. 19-35. 
Moore, J. (1982) Charles Darwin lies in Westminster Abbey. Biol. J. Linnean Soc. 17, pp. 97-113.

Moore, J. (1997) Wallace's Malthusian moment: The common context revisited. In: Contexts of Victorian Science (Lightman, B., ed.) University of Chicago Press, Chicago: pp. 290-331.

Noakes, R. (1999) Telegraphy is an occult art: Cromwell Fleetwood Varley and the diffusion of electricity to the other world. Brit. J. Hist. Sci. 32, pp. 421-59.

Noakes, R. (2002) "Instruments to lay hold of spirits": Technologising the bodies of Victorian spiritualism. In: Bodies / Machines (Morus, I. R., ed.) New York University Press, New York: pp. $125-63$

Noakes, R. (2004) Natural causes? Spiritualism, science, and the Victorian supernatural. In: The Victorian Supernatural (Brown, N., Burdett, C. and Thurschwell, P., eds.) Cambridge University Press, Cambridge: pp. 23-43.

Oppenheim, J. (1985) The Other World: Spiritualism and Psychical Research in England, 18501914. Cambridge University Press, Cambridge.

Owen, A. (1990) The Darkened Room: Women, Power and Spiritualism in Late Victorian Britain. University of Pennsylvania Press, Philadelphia.

Pearson, K. (1924) The Life, Letters and Labours of Francis Galton, vol. 2, Researches of Middle Life. At the University Press, Cambridge.

Qureshi, S. (2004) Displaying Sara Baartman, the "Hottentot Venus”. Hist. Sci. 42, pp. 233-57.

Raby, P. (2001) Alfred Russel Wallace: A Life, Chatto and Windus, London.

Richards, E. (1989) Huxley and woman's place in science: The "woman question" and the control of Victorian anthroppology." In: History, Humanity and Evolution: Essays for John C.

Greene (Moore, J., ed.). Cambridge University Press, Cambridge: pp. 253-84.

Ruse, M. (1979) The Darwinian Revolution, University of Chicago Press. Chicago.

Shermer, M. (2002) In Darwin's Shadow: The Life and Science of Alfred Russel Wallace; A Biographical Study on the Psychology of History. Oxford University Press, Oxford.

Slotten, R. A. (2004) The Heretic in Darwin's Court: The Life of Alfred Russel Wallace. Columbia University Press, New York.

Smith, C. H. (ed.) (1991) Alfred Russel Wallace: An Anthology of His Shorter Writings. Oxford University Press, Oxford.

Stocking, G. (1987) Victorian Anthropology. Macmillan, Free Press, New York.

Wallace, A. R. (1864) The origin of human races and the antiquity of man deduced from the theory of "natural selection". J. Anthro. Soc. London 2, pp. clviii-clxx.

Wallace, A. R. (1867) Notes of a seance with Miss Nicholl at the house of Mr. A. S---, 15th May, Spiritual Magazine, new series 2 pp. 254-55.

Wallace, A. R. (1881) On Miracles and Modern Spiritualism, 2d ed., Trübner, London. 
Wallace, A. R. (1891) Natural Selection and Tropical Nature: Essays on Descriptive and Theoretical Biology. Macmillan, London.

Wallace, A. R. (1905) My Life: A Record of Events and Opinions, 2 vols, Chapman and Hall, London.

Wedgwood, B. and H. (1980) The Wedgwood Circle, 1730-1897: Four Generations of a Family and Their Friends. Eastview Editions, Westfield, New Jersey.

White, M. and Gribbin, J. (1995) Darwin: A Life in Science. Simon \& Schuster, London.

Williams-Ellis, A. (1966) Darwin's Moon: A Biography of Alfred Russel Wallace. Blackie, London.

Wolpert, L. (1992) The Unnatural Nature of Science. Faber \& Faber, London.

Yeo, R. (1993) Defining Science: William Whewell, Natural Knowledge, and Public Debate in Early Victorian Britain. Cambridge University Press, Cambridge.

\section{Address for correspondence:}

James Moore

Faculty of Arts

The Open University

Milton Keynes MK7 6AA, UK

j.r.moore@open.ac.uk 


\title{
„In deutlichen Beschreibungen und richtigen Zeichnungen gemeinnütziger" - Abbildungen in der Gesellschaft Naturforschender Freunde zu Berlin (GNF), 1773-1800*
}

\author{
Kärin Nickelsen
}

\section{Abstract}

The Berlin Society of Friends of Natural History was one of the most important learned societies of late eighteenth-century Europe. Based on previously overlooked archival sources, the role of illustrations within this society is investigated, focusing on the society's actual practices. The drawings on which illustrations for the society's journal would be based were usually handed in by the authors themselves. They were then meticulously evaluated by the ordinary members of the society at their weekly meetings, who would also oversee the process of making the drawings into engravings and printing them. With the help of examples, it is demonstrated how, at all stages of the manufacturing process, the society struggled to ensure that the illustrations were executed to the highest possible standards. The making and evaluating of illustrations, it emerges, were an integral part of the society's activities, which accords with the conviction of its members that illustrations were an indispensable resource for communicating information on natural bistory.

\section{Einleitung}

Spätestens in der zweiten Hälfte des 18. Jahrhunderts wurden gelehrte Gesellschaften zu einer wesentlichen Größe im Wissenschaftsbetrieb. ${ }^{1}$ Unter den vielen Neugründungen, die aller Orten verzeichnet wurden, war die Gesellschaft Naturforschender Freunde zu Berlin (GNF), gegründet 1773, eine der ersten, die sich auf die Naturgeschichte konzent-

\footnotetext{
* Ich danke Hannelore Landsberg (Berlin) sowie Katrin Böhme-Kaßler (Berlin) für ihre Unterstützung meiner Recherchen im Archivbestand der GNF (einzusehen im Museum für Naturkunde der HumboldtUniversität zu Berlin; Historische Arbeitsstelle). Katrin Böhme-Kaßler (Berlin) danke ich weiterhin für ihren Kommentar zu einer ersten Version dieses Artikels.

${ }^{1}$ Die Literatur zur Bedeutung wissenschaftlicher Gesellschaften im 18. Jahrhundert ist immens; für einen Einstieg seien exemplarisch zwei neuere Sammelbände genannt, in denen sich zahlreiche weitere bibliografische Angaben finden: Döring und Nowak (2000-2002) sowie Zaunstöck und Meumann (2003). Weiterhin sei auf McClellan (1985) verwiesen, das klassische Werk zu dem Thema mit Blick auf die Wissenschaftsgeschichte.
} 
rierte; für lange Zeit blieb sie auch eine der erfolgreichsten: Fast alle namhaften Naturforscher des 18. und 19. Jahrhunderts finden sich unter ihren Mitgliedern. ${ }^{2}$

Zentraler Angelpunkt der GNF - und sogar wesentliche Motivation für ihre Gründung - war die Anlage einer umfangreichen Naturaliensammlung, deren Geschichte und Bedeutung bereits ausführlich untersucht wurde. ${ }^{3}$ Doch sollte das hier in Form von Naturalien gesammelte Wissen von Anfang an auch Naturforschern außerhalb Berlins zugänglich gemacht werden: Zu diesem Zweck begründete die Gesellschaft ihre eigene Schriftenreihe, die seit 1775 unter wechselnden Titeln kontinuierlich erschien. ${ }^{4}$ Gerade in den ersten Jahrzehnten nahmen die darin publizierten Abhandlungen häufig von Sammlungsobjekten ihren Ausgang: ${ }^{5}$ Neue Präparate wurden präsentiert, bisher nicht beschriebene Arten vorgestellt, merkwürdige Beobachtungen berichtet; und in vielen Fällen gehörte zu einem solchen Beitrag auch die Abbildung des präsentierten Naturobjektes ein Befund, der bisher in der Literatur nur wenig Aufmerksamkeit erfuhr. Der Umgang mit Abbildungen, ihre Herstellung, Diskussion und Publikation, bildeten einen wichtigen Bestandteil des Gesellschaftsalltags. Waren es Tischler, Naturalienhändler und Präparatoren, die von der Sammelwut der Berliner Naturforscher lebten, ${ }^{6}$ so profitierten Zeichner, Kupferstecher und Drucker von dem hohen Stellenwert, den man wissenschaftlichen Abbildungen beimaß.

In diesem Artikel möchte ich nachzeichnen, wie sich der Umgang mit Abbildungen in der GNF in den ersten Jahrzehnten ihres Bestehens rekonstruieren lässt. Dazu werde ich zunächst die Stellung von Abbildungen innerhalb der Gesellschaft (und den Gesellschaftsschriften) charakterisieren; anschließend wird anhand einzelner Episoden die Behandlung von Abbildungen in den verschiedenen Stadien ihrer Herstellung beschrieben. Wie aus diesen Episoden hervorgeht, bemühte sich die GNF insbesondere darum, dass alle Arbeitsschritte in bestmöglicher Weise ausgeführt wurden und somit ein optimales Ergebnis erbrachten. Dabei war nicht nur die Korrektheit der Zeichnungen zu sichern, sondern auch die Anfertigung der Kupferstiche sowie ihre nachfolgende Illuminierung brachten erhebliche Schwierigkeiten mit sich. Die hohe Sorgfalt, die man auf diesen Zweck verwandte, spiegelt eindrücklich die zentrale Bedeutung, welche die Mitglieder der GNF Abbildungen zubilligten, als unverzichtbarer Bestandteil der Kommunikation über naturhistorische Gegenstände.

\footnotetext{
2 Zur Geschichte der GNF siehe aktuell Böhme-Kaßler (2005); hierin findet sich eine ausführliche Bibliographie zum Thema. Ergänzend seien lediglich noch Böhme (2001) sowie Becker (1973) erwähnt, beide sind Artikel mit Überblickscharakter.

3 te Heesen (2001); siehe für die englische Übersetzung: te Heesen (2004). Böhme-Kaßler (2005), Kapitel VIII, analysiert die Bedeutung der Sammlung im Lichte der deistischen Ausrichtung der Naturgeschichte im 18. Jahrhundert.

${ }^{4}$ Die ausführlichste Liste der Gesellschaftsschriften und ihrer Verlage gibt Becker (1973), p. 26. Die Schriften der GNF wurden im Rahmen des DFG Projekts „Retrospektive Digitalisierung von Bibliotheksbeständen" digitalisiert und können über den Server der Universitätsbibliothek Bielefeld eingesehen werden (siehe http://www.ub.uni-bielefeld.de/diglib/aufklaerung/index.htm). Leider wurden die Abbildungen nicht in die Digitalisierung einbezogen.

5 Siehe te Heesen (2001), p. 70.

${ }^{6}$ Siehe te Heesen (2001), p. 64.
} 


\section{Abbildungen in der Gesellschaft Naturforschender Freunde zu Berlin}

Die Gründung der GNF im Jahr 1773 erfolgte in erster Linie auf Initiative des Berliner Arzt und Naturforschers Friedrich Wilhelm Heinrich Martini (1729-1778); dieser hatte zuvor in den Berliner Neuen Mannigfaltigkeiten - an deren Herausgabe er beteiligt war einen detaillierten Plan zur Gründung einer Gelehrten Gesellschaft veröffentlicht, deren Hauptgegenstand die Naturgeschichte sein würde. Die Mitglieder sollten einander ihre Sammlungen, Bibliotheken und anderen Hilfsmittel zur Verfügung stellen, und sich jede Woche zum freundschaftlichen Austausch über naturhistorische Themen treffen. ${ }^{7}$

Schon in diesem ersten, grundlegenden Entwurf zu einer Naturforschenden Gesellschaft wurden Abbildungen als wesentlicher Bestandteil erwähnt: Martini rief die zukünftigen Mitglieder unter anderem dazu auf, aus den eigenen Sammlungen diejenigen Fundstücke herauszusuchen, die bisher noch gar nicht oder noch nicht richtig beschrieben und abgebildet worden waren; diese Objekte sollten in der Gesellschaft erörtert und anschließend ,in deutlichen Beschreibungen und richtigen Zeichnungen gemeinnütziger“ gemacht werden. Die Mitglieder würden auf diese Weise, neben dem Zugewinn neuer Kenntnisse und Freundschaften, ,endlich das Vergnügen haben, durch ihre Beyträge zur Naturgeschichte, auch entfernten Liebhabern der Natur nützlich zu werden".8 Martini deutete also bereits hier als ein weiteres Ziel der zukünftigen Gesellschaft die Einrichtung und Unterhaltung einer eigenen Schriftenreihe an, deren Themenbereich in den ersten „Gesetzen der hiesigen Gesellschaft“ folgendermaßen umrissen wird:

Um den auswärtigen geneigten Beförderern unseres Instituts die Wabl der einzuschickenden Beyträge zu erleichtern, versichern wir, dass uns nicht bloss Nachrichten von ganz unbekannten oder unbeschriebenen, sondern auch richtigere Beschreibungen oder Abbildungen von bereits bekannten Körpern, Wabrnebmungen an Thieren, Insekten, ibrer Oekonomie und Einrichtung, [...] unter ibren gütigen Beyträgen böchst willkommen seyn werden. ${ }^{9}$

Neben Texten waren demnach von Anfang an ausdrücklich auch Abbildungen in dieser Schriftenreihe vorgesehen. Dass dieser Aufruf wahrgenommen und auch entsprechend umgesetzt wurde, zeigt sich bereits im ersten Band des Journals, das ab 1775 unter dem Titel Beschäftigungen der Berlinischen Gesellschaft Naturforschender Freunde erschien. Insgesamt zehn Kupfertafeln wurden dem Band beigefügt, jede von ihnen mit zahlreichen Einzelfiguren zu verschiedenen Abhandlungen. Nicht nur Martini, sondern auch die Autoren selbst schätzten dabei die Bedeutung dieser Figuren äußerst hoch ein: „Beynahe scheint es überflüssig, bey der genauen Zeichnung dieser Schnecke noch eine Beschreibung davon zu geben“, bemerkte etwa Lorenz Spengler (1720-1807) zu Beginn seiner „Beschreibung einer neuen Art Schnecken aus der Südsee“.10 Insbesondere bei der Vorstellung neuer Arten waren die Texte in der Regel eng auf die Abbildungen bezogen oder bestanden sogar einzig aus einer Erläuterung derselben. Aber auch Martinis Ermunterung, in Text und Bild nicht nur ganz Neues vorzustellen, sondern auch bereits Publi-

\footnotetext{
7 Die Neuen Mannigfaltigkeiten erschienen ab 1770 in Berlin mit dem Untertitel Gemeinnütrige Wochenzeitschrift, Martini war einer ihrer Herausgeber. Auszüge aus diesem Plan wurden erneut abgedruckt in der ersten Ausgabe der Gesellschafts-Zeitschrift: Martini (1775a); siehe dort für den Nachdruck seines ersten Aufrufs die Seiten 5-11.

8 Beide Zitate im Absatz: Martini (1775a), p. 10.

${ }^{9}$ Martini (1775b), p. 33.

10 Spengler (1775b), p. 395.
} 
ziertes zu ergänzen oder zu korrigieren wurde aufgegriffen. So lieferte etwa Spengler im ersten Band der Schriften auch die „Beschreibung eines besonderen Meerinsekts“, das er zwar nicht entdeckt hatte, über das jedoch in der bestehenden Literatur einige Verwirrung herrschte; vorwiegend deswegen, so Spengler, weil dieses Tier in höchst variablen Formen auftrat, die bisher nur ungenügend im Bild präsentiert worden waren:

Daher [d.h. aufgrund der hohen V ariabilität] kömmt es, dass die Schriftsteller, welche Nachrichten davon gegeben, sich bier und da zu widersprechen scheinen, zumal wo entweder nur schlechte, oder wobl gar keine Kupfer die Beschreibungen begleiten. Hierdurch wurde ich nun veranlasset, auf ganz genaue und deutliche Abbildungen bedacht zu seyn. Ich wählte daher dreyerlei verschiedene Arten, die ich in Kupfer bringen lies. ${ }^{11}$

Insbesondere durch ,genaue und deutliche Abbildungen“, auf deren Herstellung er besondere Mühe verwandt hatte, wollte Spengler also diesem verwirrenden Zustand ein Ende bereiten und die taxonomische Einordnung der verschiedenen Formen endgültig klären; bei jeder seiner Figuren und Beschreibungen hob er daher insbesondere hervor, mit welchen Autoren diese übereinstimmten, wo Abweichungen vorlagen und warum er sich im Recht sah. Auch im Beitrag von Marcus Elieser Bloch (1723-1799) zur Schleicheidechse wurden Abbildungen als entscheidender Beitrag zur Lösung der verwickelten Sachlage angesehen; er wollte ,hier nur eine genaue Beschreibung und Abzeichnung meiner beyden Exemplare von Schleicheidechsen liefern, alsdann wird sich der Ort, wo dieses Thier hingehöret, und eine Rechtfertigung seiner Benennung, von sich selbst darbieten." $" 12$

Bevor jedoch ein Beitrag - Text oder Abbildung - in der Schriftenreihe erschien, wurde beides an den wöchentlichen Sitzungen der Gesellschaft diskutiert. Im Regelfall verlasen zunächst die Mitglieder eigene oder zugeschickte Abhandlungen, und falls nicht direkte Ablehnung erfolgte, wurde im Anschluss daran der Beitrag zur Begutachtung abgegeben: Entweder erhielten nacheinander alle ordentlichen Mitglieder das Manuskript zur Lektüre und gaben schriftlich ihr Votum ab, oder ein ausgewähltes Mitglied der Gesellschaft, zumeist der Experte auf dem Gebiet, erhielt die Abhandlung samt allfälligen Zeichnungen zur Revision. ${ }^{13}$ Auch dessen Anmerkungen ließ man häufig noch einmal unter den Mitgliedern zirkulieren, und erst bei allgemeiner Zustimmung wurde der Beitrag zum Druck freigegeben. Die Mitgliederversammlung blieb also die letzte Instanz, die über Korrektheit, Eignung und Notwendigkeit sowohl von Text, als auch von Abbildungen entschied.

Dementsprechend bezeugen die Protokolle der wöchentlichen Gesellschaftssitzungen - die im Archiv der GNF vollständig erhalten sind ${ }^{14}$ - die regelmäßige Diskussion von Abbildungen: So hieß es etwa im Februar 1778, dass ,unser würdiger Freünd, H. Kadettenrath Herbst, [...] der Gesellschaft richtige Zeichnungen der von dem Dr

\footnotetext{
11 Spengler (1775a), p. 296.

12 Bloch (1776), p. 30.

13 Böhme-Kaßler (2005), p. 54.

14 Der Archivbestand der GNF ist einzusehen im Museum für Naturkunde der Humboldt-Universität zu Berlin (Historische Arbeitsstelle). Die Sitzungsprotokolle finden sich in laufend nummerierten ,Tagebüchern" (abgekürzt als TB); diese werden unter anderem ergänzt durch die separate Sammlung der Korrespondenz einzelner Mitglieder in „Personalakten“ (abgekürzt als PA). Sofern nicht anders angegeben stammen alle im Artikel zitierten ungedruckten Dokumente aus diesem Archiv.
} 
König aus Tranquebar erhaltenen u. beschriebenen seltenen Ameisenarten“ überlieferte; ${ }^{15}$ und im Juni 1787 übergab ,der Herr von Wangenheim zu unsern Schriften eine Abhandlung, nemlich Beschreibung der Poleyblättrigen Kalmia, u. der gelbblübenden Rosskastanie; nebst einer Zeichnung“"16, um nur zwei Beispiele zu nennen. Abhandlungen mit beigefügten Illustrationen wurden auch schriftlich zugesandt, so war etwa ein anderes Mal „ein Schreiben vom Grafen von Mattuschka unter dem 20. Januar [1783] eingelauffen, nebst Beylage eines mit lebendigen Farben abgebildeten Affen". ${ }^{17}$ Diese wie auch alle anderen eingereichten Zeichnungen gingen in den Besitz der Gesellschaft über und wurden gewissenhaft archiviert. ${ }^{18}$

\section{Die Zeichnungen}

Die eingesandten Beiträge und Zeichnungen wurden in der Regel von erläuternden Briefen begleitet; so erhielt etwa die GNF am 28. April 1778 folgenden Brief von einem ihrer Mitglieder, Johann Andreas Benignus Bergsträsser (1732-1812):

[...] Nur mit ein par Worten so viel, als mir das Gedränge wegen der Messe verstattet. Hier gebt erstlich ein kleiner Aufsatz über den Weißdornspanner nach Herrn Sepp in der Handschrift für den gefälligen Abdruck in den gesellschaftlichen Beschäftigungen bei. Die dazu gehörige Tafel ist von meinem hiesigen Künstler genau vorgezeichnet. Den vergrößerten Kopf hatte er anfänglich nicht getroffen. Er mußte ibn noch einmal zeichnen, und so kam es daß er nun aufgeleimt ist. Vielleicht sende ich noch vor Johanni Ew. Woblgeb. eine kleine andere Abhandlung über den scopolischen Heros und des Linnes Cerambyx Cerdo zu, vorerst gebrach es mir an Zeit. [... $]^{19}$

Der „hiesige Künstler“, den Bergsträsser erwähnt, mochte der Zeichner und Kupferstecher Johann Jakob Müller (1743-1790) sein, mit dem Bergsträsser bei anderen Gelegenheiten zusammenarbeitete. ${ }^{20}$ Wie aus diesem Brief hervorgeht, musste der Zeichner in diesem Fall den Kopf des Falters ein zweites Mal zeichnen, weil der erste Entwurf fehlerhaft war - die verbesserte Version hatte Bergsträsser nachträglich aufgeklebt.

Wie Bergsträsser bemühten sich die meisten Naturforscher seiner Zeit nach Kräften, die Anfertigung von Zeichnungen so zu kontrollieren, dass Fehler vermieden oder doch rechtzeitig korrigiert werden konnten. ${ }^{21}$ Da die Anfertigung wissenschaftlicher Abbildungen neben den künstlerischen Fähigkeiten auch eine gewisse Sachkenntnis erforderte,

\footnotetext{
15 Tagebuch (TB) II, p. 164; 10. Februar 1778. Der Beitrag wurde publiziert als König (1779).

16 TB V, p. 241; 26. Juni 1787. Der Beitrag wurde publiziert als von Wangenheim (1788).

17 TB IV, p. 475; 28. Januar 1783. Johann Graf von Mattuschka (1735-1804) war ein eifriger Korrespondent der Gesellschaft, obwohl seine Beiträge von den ordentlichen Mitgliedern der GNF im allgemeinen nur wenig geschätzt wurden; vgl. Böhme-Kaßler (2005), p. 56.

18 Sie finden sich heute im Bildbestand des GNF-Archivs.

19 Personalakte (PA) Bergsträsser; Blatt 4. 28. April 1778. Der Beitrag zum Weißdornspanner wurde publiziert als Bergsträsser (1779).

20 Müller signierte unter anderem die Darstellung des im Brief erwähnten Cerambyx, welche Bergsträsser zu einem späteren Zeitpunkt tatsächlich einschickte. Vgl. PA Bergsträsser; Blatt 9: Manuskript einer Abhandlung zum Cerambyx Inquisitor. Tafel 3 ist signiert mit „Joh. Jacob Müller pinx. Hanoviae“. Vgl. zu J. J. Müller beispielsweise den Eintrag im Standardwerk Thieme und Becker (1992), Band 25, p. 237. Müller wird dort als Zeichner und Kupferstecher u.a. von Illustrationen zu naturwissenschaftlichen Werken beschrieben.

${ }^{21}$ Für eine Rekonstruktion der Herstellung botanischer Abbildungen im 18. Jahrhundert am Beispiel des Nürnberger Arzt und Botanikers Christoph Jacob Trew siehe Nickelsen (2006a), Chapter 3; siehe weiterhin Nickelsen (2000), Kapitel IV, für generelle Ausführungen zum Thema.
} 
sowie eine Kenntnis der speziellen Konventionen des Genre, war bei weitem nicht jeder Zeichner dieser Aufgabe gewachsen. Eine Reihe der Autoren, die ihre Abhandlungen in den Schriften der GNF publizierten, erstellten daher selbst die Zeichnungen zu ihrem Beitrag; selbst wenn das Ergebnis in ästhetischer Hinsicht den Abbildungen professioneller Künstler unterlegen sein mochte, galt dies als ein möglicher und auch für viele erstrebenswerter Weg, das Fehlerrisiko zu minimieren. ${ }^{22}$ In einem Beitrag von Otto Friedrich Müller (1730-1784) zum zweiten Band der Beschäftigungen wird dieses Verfahren sogar ausdrücklich hervorgehoben:

Bereits vor 6 Jahren sandte mir Herr Doktor König, Königl. Dänischer bey der Tranquebarischen Kolonie in Ostindien tätiger Militärmedikus, gegenwärtige Zeichnung zwoer fremder Medusen, nebst beygefügter kurzer Lateinischer Beschreibung dieser Betrachtungswürdigen Meerthiere. Die Zeichnung ist von ibm selbst mit einer Bleyfeder gemacht, und die Zuverlässigkeit der karakteristischen Theile kann uns für die Schönheit der Malerey Schadlos balten. ${ }^{23}$

Wer jedoch nicht selbst zeichnen konnte - und das galt für sehr viele Wissenschaftler war gezwungen, mit Zeichnern zu kooperieren; für die GNF ist belegt, dass sie zumindest in einigen Fällen offizielle Aufträge für die Anfertigung von Zeichnungen vergab und auch auf ihre Kosten entlöhnte. ${ }^{24}$ Je nach Eignung des Zeichners war das Ergebnis solcher Kooperationen hervorragend, befriedigend oder niederschmetternd. Bergsträsser schien zumindest nach eingeforderter Korrektur mit der Leistung von Müller zufrieden zu sein; in anderen Fällen waren Mitglieder weniger erfolgreich. So heißt es etwa im Protokoll zur Gesellschaftssitzung am 4. März 1783:

Während dieser Verbandlungen batten sich der Herr Geheim. Berg Rath Gerbard und der Herr Forstrath von Burgsdorff in die Gesellschaft eingefunden, und da kurz, zwor vom Herrn Hofrath Gleditsch die vor 8 Tagen vorgelesene Abhandlung des Herrn Geheimen Berg-Rath über die Entstehung der faserreichen Steine und Erzarten [...], ins Reine gescbrieben und mit einer Zeichnung begleitet, war abgegeben worden, so erklärten sich der Herr Geheime Berg-Rath, daß Sie mit dieser Zeichnung welche der Mabler Krïger verfertigt bätte, nicht ganz vollkommen zufrieden wären, und es der Gesellschaft überlassen wollten, selbige bey gedachter Abhandlung anzuwenden oder weg zu lassen. ${ }^{25}$

In diesem Fall hatte der Mineraloge Karl Abraham Gerhard (1736-1821) die Zeichnung eines Gesteins bei einem lokalen Künstler ${ }^{26}$ in Auftrag gegeben; das Ergebnis fiel jedoch so wenig in seinem Sinne aus, dass er die Möglichkeit aufwarf, auf die Abbildung gänzlich zu verzichten. Man folgte seinem Vorschlag, und in den Schriften erschien Gerhards Beitrag ohne Erwähnung einer zugehörigen Tafel. ${ }^{27}$

\footnotetext{
22 Unter den Autoren, die der GNF aus eigener Hand gezeichnete botanische Tafeln lieferten, waren etwa Friedrich Julius von Wangenheim, Olof Swartz und Erich Acharius, um nur einzelne Beispiele zu nennen.

${ }^{23}$ Müller (1776), p. 290.

${ }^{24}$ So heißt es etwa im Protokoll der 500. Sitzung der Gesellschaft am 18. Mai 1784: „Hr. Prediger Herbst übergab eine Quittung über 4 rthl, die er an den Mahler Blanckenhagen bezahlet hat." Transkribiert in Böhme-Kaßler (2005), p. 153.

25 TB IV, p. 490; 4. März 1783.

${ }^{26}$ Der hier genannte „Maler Krüger“ lässt sich anhand dieser Angaben nicht sicher identifizieren; Gleditsch publizierte indessen eine Abhandlung in den Schriften, deren Bild „Krüger d. J.“ signierte, das mag derselbe Zeichner gewesen sein, der im Fall von Gerhard so wenig erfolgreich arbeitete (siehe Gleditschs Beitrag in den Schriften, Band 7 (1787), pp. 403-417; Tab. 6).

${ }^{27}$ Die Abhandlung erschien tatsächlich ohne Abbildung, siehe Gerhard (1783).
} 
Doch die GNF verließ sich nicht nur darauf, dass eingereichte Zeichnungen bereits vom Autor mit größter Umsicht kontrolliert worden waren, sondern, wie bereits erwähnt, die Revision, Kontrolle und allenfalls Korrektur von Abbildungen war Teil der allgemeinen Begutachtung. Dabei konnten auch weitere, für nötig befundene Abbildungen ergänzt werden; so liest man etwa im Protokoll der Sitzung vom 28. Januar 1783:

Es hatte $H$. Forstrath von Burgsdorff eine Abzeichnung der Dermestes Typographica verfertiget, über welchen $H$. von Trebra eine Abhandlung nebst Abbildung eines von diesem Insecte beschädigten Stückes Holz eingesandt batte, diese Abreichnung wurde mit einigen wichtigen Berichtigungen des Trebrayschen Aufsatzes begleitet. Die Arbeiten wurden zum Abstechen bestimmt und die Anmerkungen sollen zum Gutachten circuliren. ${ }^{28}$

Ein auswärtiges Mitglied der Gesellschaft, Friedrich Wilhelm Heinrich von Trebra (17401819), hatte in diesem Fall einen Aufsatz über einen Holzschädling, die Dermestes Typographica, eingereicht (heute bekannt als Borkenkäfer oder Buchdrucker); dieser Aufsatz wurde von einer Zeichnung begleitet, welche die Folgen des Schädlings an einem Stück Borke demonstrierte. Als Gutachter wirkte in diesem Fall der Berliner Forstbotaniker Friedrich August von Burgsdorf (1747-1802). Er erhielt beides zur Revision, und neben einigen Korrekturen im Text bereicherte er den Beitrag kurzerhand durch eine weitere Abbildung, nämlich von dem betreffenden Holzschädling selbst, die ebenfalls abgedruckt wurde.

Auch in einem anderen Fall erstellte von Burgsdorf die Abbildung zu einem fremden Beitrag; so überschickte etwa der Autor „,[d]es H. Professoris Beireis Beschreibung von einem bisher unbekannt gewesenen amerikanischen Frosches" keine Zeichnung zu seinem Beitrag, sondern das entsprechende Präparat selbst - allerdings nicht als Geschenk für die Sammlungen der Gesellschaft, sondern nur zum Augenschein. ${ }^{29}$ Warum der Autor, Gottfried Christoph Beireis (1730-1809), den Frosch nicht zeichnen ließ, ist unklar: möglicherweise kannte er keinen geeigneten Zeichner oder er scheute die Kosten eines solchen Auftrags; möglicherweise sollte auch die Vorstellung des Originalobjekts die Gutachter besonders beeindrucken. Da die Gesellschaft eine Abbildung zum Beitrag für wünschenswert hielt, beauftragte sie eines ihrer Mitglieder, und zwar wiederum von Burgsdorf, den Frosch für ihre Schriftenreihe abzuzeichnen, woraufhin man das ,in einem Glase, mit Steinen gefüllet, befindliche] Original[“ dem Autor zurückschickte.30 Dies blieb eher die Ausnahme als die Regel, doch forderte die Gesellschaft in mindestens einem weiteren Fall von sich aus die Vorlage des Originalobjekts, um die Wahrhaftigkeit einer Zeichnung zu überprüfen: Als nämlich der Notar Hübner aus Halle ihr die Beschreibung „eines von einem Hunde geworfenen kleinen Elephanten“ anbot,

indem er einige Tage vorher, ehe er geworfen, von einem Elephanten geschlagen worden; er habe hiervon eine Kupfertafel stechen lassen, die er unentgeltlich der Gesellschaft einschicken wolle. Die Gesellschaft nahm zwar dieses Anerbieten mit Dank an, wünscht aber vorher das Thier in natura zu sehen. ${ }^{31}$

\footnotetext{
28 TB IV, p. 475f.; 28. Januar 1783. Der Beitrag wurde publiziert als von Trebra (1783).

29 TB IV, S. 476; 28. Januar 1783. Der Beitrag wurde gedruckt als Beireis (1783).

${ }^{30}$ Ebd.: TB IV, p. 476; 28. Januar 1783.

31 TB IV, p. 374; 20. Februar 1782.
} 


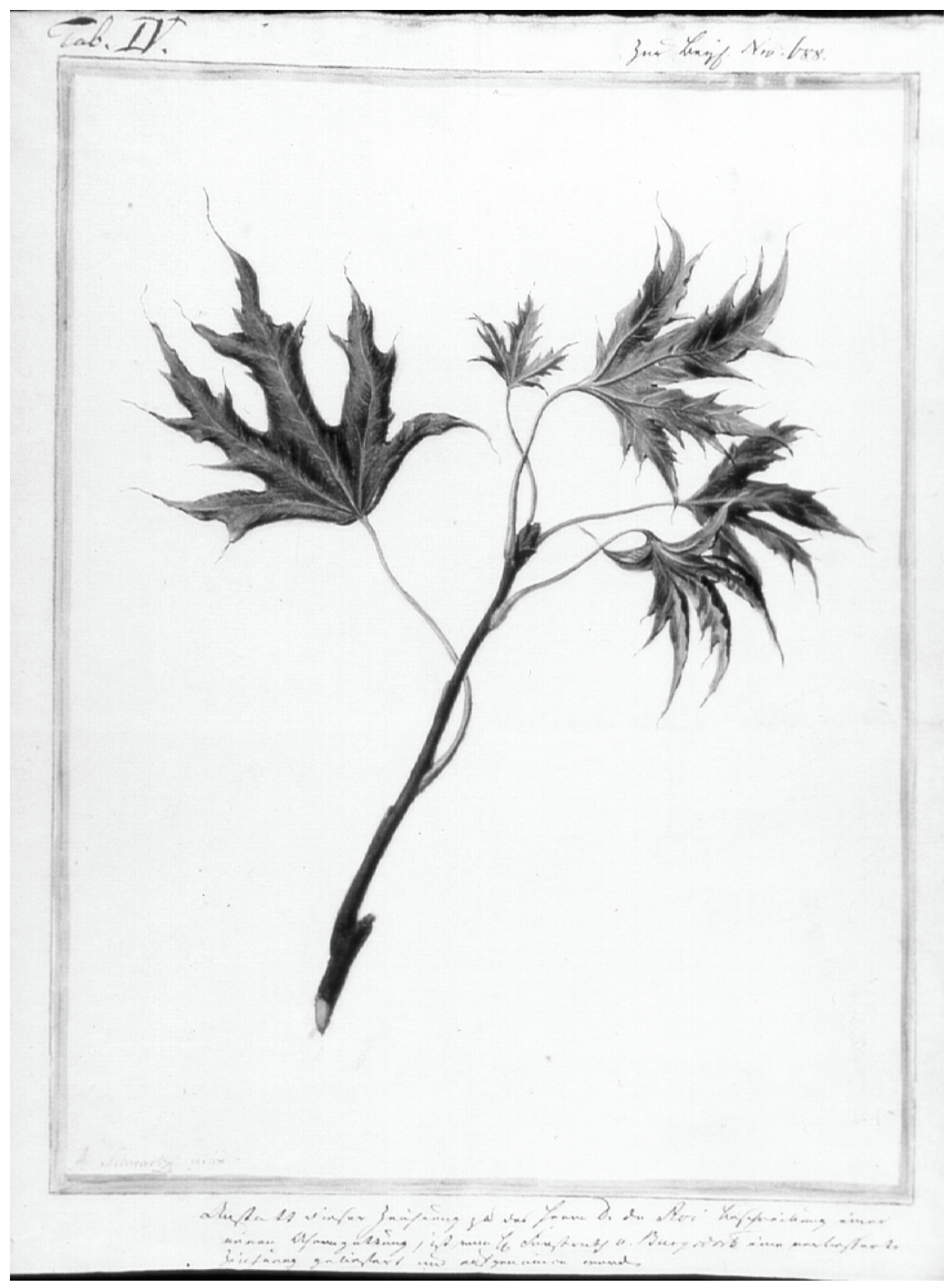

Abb. 1: Originalzeichnung des Acer laciniatum von Johann Philipp du Rois Zeichner „A. Schwartz"“ (Signatur links unten). Unter der Abbildung eingefügt: „Anstatt dieser Zeichnung zu des Herrn D. du Roi Beschreibung einer neuen Aborngattung, ist von H. Forstrath v. Burgsdorff eine verbesserte Zeichnung geliefert und aufgenommen worden. "Original: Museum für Naturkunde der HumboldtUniversität qu Berlin, Historische Schrift- und Bildgutsammlungen. Bestand: GNF; Signatur: BVIII/ 32 (G-533). Abdruck mit freundlicher Genebmigung des Museums für Naturkunde vom 20.09.2006.

Ob Hübner dieser Aufforderung tatsächlich nachkam, ist unklar; zumindest wurde kein Beitrag von ihm in den Gesellschaftsschriften publiziert. 
Das Zeichentalent von Burgsdorfs sollte der GNF noch manches Mal nützen. So hatte etwa, laut Protokoll, der Forstbotaniker Johann Philipp du Roi (1741-1785) der Gesellschaft im Februar 1784 die Beschreibung einer neuen Ahorngattung namens Acer lacinatus überschickt, ,welche als ein Anhang zu der Herrn Forstrath von Burgsdorfs Reise kommen soll. Sie wurde vorgelesen und Herr Hofrath Gleditsch nahm sie zur Beurtheilung mit."32 Schon an der nächsten Sitzung legte der erwähnte Johann Gottlieb Gleditsch (1714-1786) die Abhandlung wieder vor, und während er den Text billigte, befand er die zugehörige Zeichnung für falsch. Anders als im Fall von Gerhard wurde jedoch nicht erwogen, den Beitrag ohne Tafel abzudrucken, sondern es war wiederum von Burgsdorf, der die Aufgabe übernahm, ,selbige [Tafel] richtiger zu machen“.33 Der Text hingegen wurde bereits zum Abdruck an den Verleger geschickt - man war demnach optimistisch, dass von Burgsdorf den Auftrag prompt und erfolgreich erledigen würde. Tatsächlich lieferte von Burgsdorf nicht lange darauf, im März 1784, eine korrigierte Version der Zeichnung, begleitet von einem Brief, der in der Sitzung verlesen wurde:

\section{Verehrungswürdige Gesellschaft!}

Es erfolgt biermit die versprochene Zeichnung des A. Lacin. so, wie sie würklich seyn muß. Des Hn. J. du RoiMabler, hat nach einem trockenen, eingelegten Exemplar gezeichnet! Im natürlichen Zustande aber, welchen ich genau kenne, sind die Blätter nie zusammen gerollet, welches auch die du Roische Beschreibung bemerket. Auch das Grün, - - ist im Leben der Pflanzen das meinige; nach einem trockenen Stücke mag wobl der Mabler Recht haben. Folia opposita sind dem ganzen Ahorn-Geschlechte karakteristisch: Man verkennet die GeschlechtsKennzeichen, durch die Stellung der Blätter-Stiele; welchem Fehler ich abzuhelfen mich bemühet habe. Ich vertrete übrigens die Richtigkeit meiner Zeichnung; [...].

der Ihrige

Burgsdorf.

zu Tegel, am $6^{\text {ten }}$ März 1784. ${ }^{34}$

Beide Zeichnungen sowie der veröffentlichte Kupferstich sind im Archivbestand der GNF erhalten. ${ }^{35}$ Interessanterweise erscheint die verworfene Zeichnung, signiert von „A. Schwartz", für den naiven Betrachter zunächst qualitativ besser: Sie ist stärker konturiert und somit exakter in ihrer Beschreibung; die Zeichentechnik ist professioneller und der Farbauftrag vorsichtiger, so dass keine Strukturen überdeckt werden (vgl. Abb. 1). Doch wie von Burgsdorf kritisch anmerkte, unterschlägt sie den gegenständigen Blattansatz,

\footnotetext{
32 TB IV, p. 590; 24. Februar 1784.

33 TB IV, p. 592; 2. März 1784.

34 PA Friedrich August von Burgsdorf; Blatt 9; 6. März 1784. Mit Verweis auf TB IV, p. 593. Der Brief wird im Wortlaut, wenn auch nicht in voller Länge, an dieser Stelle im Tagebuch zitiert.

35 Der Beitrag wurde gedruckt als du Roi (1784). Beide Originalabbildungen sind im Bildbestand des GNFArchivs erhalten, einzusehen unter der Signatur B VIII/32 sowie B VIII/37. Am unteren Blattrand der Originalzeichnung von du Roi wurde handschriftlich vermerkt: „Anstatt dieser Zeichnung zu des Herrn D. du Roi Beschreibung einer neuen Ahorngattung, ist von H. Forstrath v. Burgsdorf eine verbesserte Zeichnung geliefert und aufgenommen worden."
} 
der für Ahorn-Arten typisch ist. Dieser Fehler, den auch Gleditsch moniert haben mag, sowie von Burgsdorfs Aussage, ein frisches Exemplar habe einen völlig anderen Habitus und Farbton als die von du Roi vorgelegte Abbildung, waren hinreichende Gründe für die GNF, der korrigierten Version den Vorzug zu geben, mochte das Original in ästhetischer Hinsicht noch so überlegen sein.

Wenn der Zeichner wirklich, wie von Burgsdorf vermutete, nach einem Herbarexemplar gearbeitet hatte, erklärt sich der falsch dargestellte Blattansatz recht einfach: Das

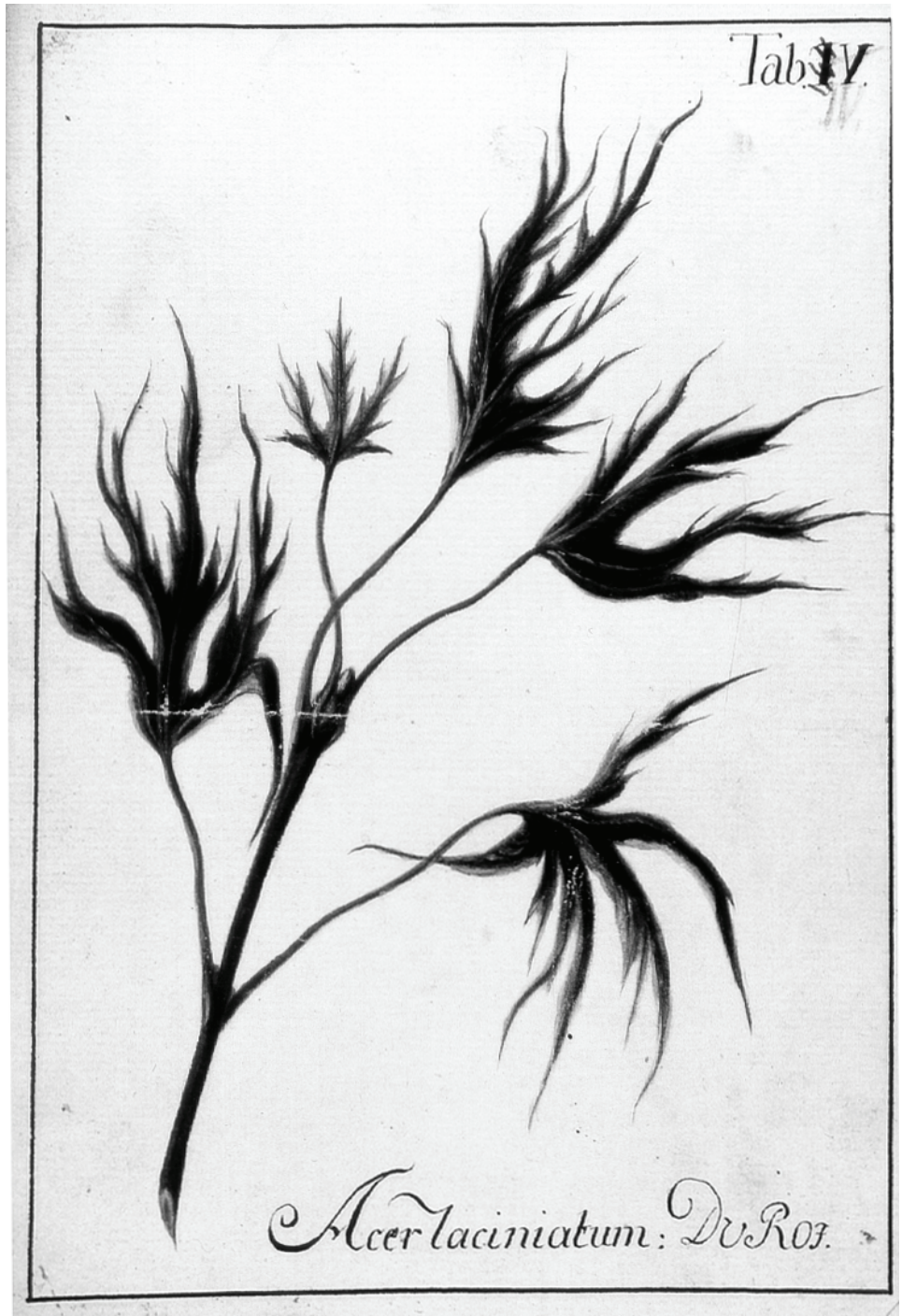

Abb. 2: Korrigierte Zeichnung des Acer laciniatum von Friedrich August von Burgsdorf. Original:

Museum für Naturkunde der Humboldt-Universität zu Berlin, Historische Schrift- und

Bildgutsammlungen. Bestand: GNF; Signatur: BVIII/37 (G-538). Abdruck mit freundlicher

Genebmigung des Museums für Naturkunde vom 20.09.2006. 
Exemplar mag beschädigt gewesen sein, möglicherweise hatte der Zweig bereits einige Blätter verloren, wie dies im getrockneten Zustand leicht der Fall ist. Die Aufgabe eines kundigen botanischen Zeichners wäre es nun gewesen, die fehlenden gegenständigen Blätter ungeachtet der Vorlage zu ergänzen. Doch dazu fehlten wohl Schwartz die entscheidenden Kenntnisse: Weder vermochte er die vorhandenen (und auch abgebildeten!) Blattnarben korrekt zu deuten, noch wusste er, dass gegenständige Blätter ein charakteristisches Merkmal der Gattung Acer sind. Statt dessen dokumentierte er lediglich das ihm vorgelegte Objekt, so wie es sich darstellte; doch das entsprach nicht den Anforderungen der GNF.

Von Burgsdorf, auf der anderen Seite, verfertigte überraschenderweise keine völlig neue Zeichnung, sondern hielt sich eng an die Vorlage von Schwartz: Er versetzte lediglich den Ansatz des unteren Blattes auf die linke Seite der Sprossachse und rückte das darüber stehende Blatt nach unten, so dass die beiden Blätter nun korrekt gegenständig angeordnet waren (vgl. Abb. 2). Weiterhin wählte er einen dunkleren Farbton mit rötlichem Einschlag für die Blätter. Es ist sehr unwahrscheinlich, dass von Burgsdorf ein Zweig vorlag, der dem von du Roi in diesem Ausmaß ähnelte. Auch er arbeitete demnach nicht nach einem lebendigen Original, was er doch bei Schwartz noch kritisiert hatte; vielmehr verbesserte von Burgsdorf die Fehler der eingeschickten Version in erster Linie gemäß seiner theoretischen Kenntnis der Pflanze. ${ }^{36}$

\section{Die Kupferstiche}

Doch auch wenn die Zeichnungen zu allseitiger Befriedigung vorlagen, war damit nur der erste Schritt getan; zur Publikation mussten sie noch in Kupferstiche umgesetzt werden - und auch dieser Arbeitsschritt war höchst fehleranfällig. Wie im 18. Jahrhundert allgemein üblich, vergab auch die GNF ihre Aufträge zum Kupferstechen an freie Kunsthandwerker, die in Berlin ihre Dienste anboten. Zumindest zeitweilig scheint sie dabei die Vermittlung ihrer Verleger in Anspruch genommen zu haben, die in der Regel zur Verfertigung von Buchillustrationen über einen Stamm freier Mitarbeiter verfügten; doch nicht immer mit gutem Erfolg. ${ }^{37}$

Den Signaturen, die sich auf vielen Tafeln in den Schriften der GNF finden, lässt sich entnehmen, dass spätestens ab 1799 der Berliner Zeichner und Stecher Friedrich Guimpel (geb. 1774) nahezu alle Kupferstiche für die GNF verfertigte, die dann als fertige Platten dem Verleger geliefert wurden. ${ }^{38}$ Guimpel war zu dieser Zeit Berlins führender

\footnotetext{
36 Die Teilkopie bereits vorhandener Abbildungen bei gleichzeitiger Optimierung des Bildes gemäß dem eigenen Kontext und Kenntnisstand war bei der Verfertigung botanischer Illustrationen ein sehr gängiges Verfahren. Siehe für eine Analyse dieser Praxis die bereits zitierten Bücher Nickelsen (2006a) und Nickelsen (2000), sowie weiterhin Nickelsen (2006b).

37 Vgl. zum Geschäft der Buchillustration im 18. Jahrhundert beispielsweise Thanner (1987), worin sich eine ausführliche Rekonstruktion zum Wirken Johann Rudolf Schellenbergs als Illustrator findet. Martinis entsetzte Bemerkung über die Qualität einiger Kupferstiche im zweiten Band der Beschäftigungen spricht sowohl dafür, dass zeitweilig die Anfertigung der Tafeln durch den Verlag besorgt wurde, als auch dafür, dass das Ergebnis alles andere als zufrieden stellend ausfiel: siehe Martini (1776), Fußnote p. XVII.

$38 \mathrm{Zu}$ Guimpel siehe den Eintrag in Thieme und Becker (1992), Bd. 15, p. 320. Guimpel verfertigte neben seiner Arbeit für Zeitschriften (unter anderem) die Tafeln für ein voluminöses Kompendium der Arzneipflanzen (Hayne, 1805-37); für ein forstbotanisches Werk, das Guimpel selbst gemeinsam mit Hayne und
} 
Kupferstecher naturhistorischer Abbildungen, so verfertigte er unter anderem die meisten Illustrationen für die Schriften der Berliner Akademie der Wissenschaften. Insbesondere mit dem Botaniker der Akademie, Karl Ludwig Willdenow (1765-1812), verband Guimpel ein enges und langjähriges Arbeitsverhältnis, im Verlauf dessen Willdenow ihn im Verfertigen botanischer Abbildungen unterwies. ${ }^{39}$ Da Willdenow zugleich eines der aktivsten Mitglieder der GNF war, mag er Guimpel guten Gewissens für die Gesellschaftsschriften empfohlen haben. Vor und neben Guimpel waren es vorwiegend J. W. Schleuen, Mitglied der berühmten Berliner Kupferstecherfamilie Schleuen, und Carl Christian Glassbach (1751- ca. 1789), die als Stecher der GNF signierten. Beide arbeiteten ebenfalls regelmäßig für die Akademie. Zudem hatte Christian Benjamin Glassbach (1724-1779), der Vater von C. C. Glassbach, mit großem Erfolg die Tafeln für Martinis berühmtes Werk zur Konchyliologie gestochen; da Glassbach senior seinen Sohn im Stechen naturhistorischer Tafeln unterrichtet hatte, hatte auch dieser somit beste Referenzen. ${ }^{40}$ Es waren insgesamt erstaunlich wenige Personen, die um das Jahr 1800 in Berlin wissenschaftliche Abbildungen verfertigten, obwohl es an Zeichnern und Kupferstechern generell nicht mangelte; ${ }^{41}$ doch nur wenige waren den spezifischen Anforderungen des wissenschaftlichen Genres gewachsen.

Wie bereits erwähnt, überschickten die meisten Autoren zu ihren Beiträgen nur Zeichnungen und ließen die Umsetzung in Kupferstiche durch die Gesellschaft besorgen; doch gab es Ausnahmen von dieser Regel. So erhielt etwa die GNF am 21. November 1789 einen Brief von dem Zürcher Arzt und Botaniker Johann Jacob Römer (17631819), in dem er eine neue Abhandlung in Aussicht stellte, ,worin ich mehrere neüe Raupen und Schmetterlinge beschreibe“; dazu gehörten auch drei Kupfertafeln. Römer wollte die entsprechenden Platten bei nächster Gelegenheit überschicken, und falls die Gesellschaft diese des Abdrucks für würdig befände, sollte sie die Kupferplatten als Geschenk des Autors behalten. Anderenfalls bat er hingegen um Rücksendung. ${ }^{42}$ Im Juli des folgenden Jahres 1790 versicherte Römer schließlich, er habe die „3 Kupferplatten, nebst den dazu gehörigen illuminirten Abdrücken“ abgeschickt; und fügte hinzu: „Sobald ich weiß, daß die Täfelchen den Beyfall der Gesellschaft haben, werde ich auch den Text dazu schicken. “43

Die Zeichnungen zu seinem Beitrag wie auch die Kupferplatten, die Römer der GNF als Dankesgeschenk für seine Aufnahme in die Gesellschaft vermachte, hatte Johann Rudolf Schellenberg (1740-1806) verfertigt, der über die Schweiz hinaus für seine Insektendarstellungen berühmt war - nicht zuletzt stammten aus seiner Hand auch die Abbil-

\footnotetext{
Willdenow herausgab (Guimpel et al. 1815) sowie die Stiche zu den Abbildungen einer Neuausgabe der linnéschen Flora Lapponica (Wahlenberg, 1812).

39 Vgl. Nissen (1966), p. 201.

$40 \mathrm{Zu}$ Glassbach sen. und fil. siehe Thieme und Becker (1992), Bd. 14, pp. $241 \mathrm{f}$.

41 Friedrich Nicolai erwähnt in seiner Beschreibung von Berlin und Potsdam für das Jahr 1786 fünfzehn männliche Kupferstechermeister sowie eine Witwe; siehe Nicolai (1968), p. 591. Zeichner gab es eher noch mehr, wenn man die Absolventen der Berliner Akademie der Künste in Betracht zieht; doch erstellte kein anderer als der „Naturalienmaler“ der Akademie Andreas Friedrich Happe (1733-1802) die Zeichnungen für Martinis Werk zur Konchyliologie.

42 PA Römer; Blatt 6.

43 PA Römer; Blatt 7. Brief vom 31. Juli 1790.
} 
dungen zu Römers eigenem Werk, den Genera insectorum (1789). ${ }^{44}$ Römer selbst hatte sehr hohe Ansprüche an die Qualität entomologischer Abbildungen und gar einen Katalog von Kriterien erstellt, die nur von wenigen Künstlern erfüllt wurden; ${ }^{45}$ einer von ihnen war Schellenberg, dessen Meisterschaft Römer wiederholt ausdrücklich hervorhob. Insbesondere war Schellenberg aus Römers Sicht einer der wenigen Künstler, die es verstanden, naturhistorische Kupferstiche so auszuführen, dass sie sich für eine nachträgliche Kolorierung eigneten. ${ }^{46}$ Das Geschenk war demnach nicht ganz uneigennütziger Art, denn die GNF verpflichtete sich mit der Annahme der Kupferplatten zugleich dazu, diese auch abzudrucken, woran Römer selbst ein erhebliches Interesse hatte.

Bemerkenswert ist dabei, dass Römer seine Tafeln vor dem zugehörigen Text einsandte. Bei Ablehnung der Tafeln wollte er sogar darauf verzichten, den Text überhaupt einzureichen, sondern erbat sich in diesem Fall die Platten prompt zurück - vermutlich um beides an anderer Stelle zu veröffentlichen. Auch Römer verstand offensichtlich Text und Tafeln als untrennbare Einheit: Bevor er auf die Tafeln verzichtete, nahm er lieber Abstand von der Publikation des Beitrags in den Beschäftigungen der GNF. Doch diese Vorsicht erwies sich als unnötig, denn als die Platten endlich ihr Ziel erreichten, ${ }^{47}$ zeigte sich die Gesellschaft höchst angetan:

Die überschickten Kupferplatten haben unsern völligen Beifall, wir sehen daher auch der versprochenen dazu gehörigen Beschreibung mit Vergnügen entgegen, um davon [...] in unsern Schriften Gebrauch zu machen. ${ }^{48}$

Trotz allen Beifalls ließ jedoch die Publikation derselben auf sich warten: Erst nach mehreren Jahren, und einer weiteren Nachfrage Römers, ${ }^{49}$ erschienen schließlich die Tafeln sowie ihre Beschreibung 1794 in den Gesellschaftsschriften. ${ }^{50}$

Die Übersendung gestochener Kupferplatten als Dankesgeschenk illustriert deutlich die hohe Wertschätzung dieser Platten. Der Zeichner und Kupferstecher Schellenberg stand in der zeitgenössischen Naturgeschichte in hohem Ansehen, und auch die GNF schätzte Könner dieses Kunsthandwerks und zollte ihnen gebührende Anerkennung. So widmete sie einen ihrer ersten Nachrufe, publiziert im ersten Band der Gesellschaftsschriften, der Lebensgeschichte des „Malers und Universitätskupferstechers Herrn Gottfried August Gründler zu Halle“, der bereits 1774 als Ehrenmitglied in die Gesellschaft aufgenommen worden war. ${ }^{51}$ In diesem Nachruf wird einerseits Gründlers Kenntnis der Natur gewürdigt sowie die beachtlichen Sammlungen, die er im Laufe seines Lebens angelegt hatte; andererseits hebt der (anonyme) Autor ${ }^{52}$ die großen Verdienste hervor,

\footnotetext{
44 Siehe zu J. R. Schellenbergs Leben und Werk insbesondere das bereits zitierte Werk Thanner et al. (1987).

45 Thanner (1987), p. 142.

46 Siehe Geus (1987), pp. $239 f$.

${ }^{47}$ Die Sendung war zwischenzeitlich verloren gegangen, ohne dass die GNF ihren Verbleib angeben konnte.

48 PA Römer; Blatt 10. Entwurf eines Briefes der GNF an Römer vom 28. September 1790.

${ }^{49}$ Vgl. Römers Brief an die GNF vom 15. November 1794 (PA Römer, ohne Blattnummer): ,Wenn die vor einigen Jahren an die Gesellschaft gesandten Kupferplatten nicht in den Verhandlungen der Gesellsch. erscheinen sollen, so bitte ich mir selbige, nebst der Beschreibung, wieder zurück aus [...].“

${ }^{50}$ Der Beitrag wurde publiziert als Römer (1794).

51 Anonymus (1775).

52 Man mag vermuten, dass es sich um Johann Ernst Immanuel Walch (1725-1778) handelte, der Gründler als Kupferstecher für den von ihm herausgegebenen Naturforscher angestellt und auch Gründlers Aufnahme in die GNF betrieben hatte.
} 
die Gründler der Wissenschaft durch seine Könnerschaft im Zeichnen und Kupferstechen erwiesen hatte:

[B]ey den Kupferstichen, die er für Schriften zu verfertigen hatte [...] leistete er dieser durch die Genauigkeit und Sauberkeit, mit der er sie ausarbeitete, keine geringen Vortheile. Hatte er in seinem Naturalienkabinett die Originale zu den vorgelegten Zeichnungen, und dieses trug sich oft zu, so verglich er sie unter einander, stach mehr nach den Originalen, als nach der Kopie der Zeichnung, und war immer in diesem Fall Revisor und Kupferstecher zugleich. Bisweilen auch, wenn ibm ein Gegenstand interessant genug zu seyn schien, sahe er die Beobachtungen nach, deren Zeichnungen er abstechen sollte, und wenn er darinnen Abweichungen, Unrichtigkeiten, oder nicht Vollständigkeit genug wabrnahm, zeichnete er seine nachgemachten Beobachtungen ab, und überlies es ibnen, ob sie davon zu ibrem Vortheil Gebrauch machen wollten..$^{53}$

Ein guter Kupferstecher wissenschaftlicher Tafeln, wie beispielsweise Gründler, aber auch Schellenberg, begnügte sich nicht damit, die ihm vorliegende Zeichnung nur zu kopieren; die Umsetzung in das neue Medium erforderte eine kundige Interpretation der Zeichnung, ohne dabei Fehler einzuführen oder wesentliche Eigenschaften zu unterschlagen. Ein solches Verfahren erforderte sowohl Sachkenntnis des dargestellten Gegenstandes als auch, im besten Fall, eine enge Zusammenarbeit mit dem Autor und dem Zeichner. Gründlers Besonderheit, beim Kupferstich neben der Zeichnung auch noch das Objekt selbst zu Rate zu ziehen, war eine seltene Ausnahme, doch genau darin konnte sich ein erstklassiger Kupferstecher naturhistorischer Gegenstände von einem nur befriedigendem unterscheiden.

\section{Die Illuminierung}

Noch aufwändiger als der Kupferstich selbst und sein Abdruck war die Kolorierung oder Illuminierung, wie es damals hieß - der gedruckten Tafeln. ${ }^{54}$ Im ersten Band der Schriften wurde denn auch darauf verzichtet, doch ließen die kritischen Rückmeldungen der naturhistorischen Leserschaft nicht lange auf sich warten, wie Martinis Vorbemerkung zum zweiten Band zu entnehmen ist:

Verschiedene unserer auswärtigen Mitglieder schienen zu wünschen, dass bey unsern gesellschaftlichen Beschäftigungen auch, wo es nöthig wäre, illuminirte Kupfer statt finden mögten. Es that uns leid, dem ersten Band einen Vortheil entzogen zu haben, zu dessen Erfüllung der Verleger sich so willig finden lies. In gegenwärtigem Bande sind also die Vorstellungen, welche durch lebendige Farben mehr Deutlichkeit erhalten konnten, sämmtlich illuminiret )*, andere bingegen, wo es nicht nöthig zu seyn schien, zu billiger Einschränkung der Kosten, schwarz gelassen worden. ${ }^{55}$

Demnach hatte der Verleger der Gesellschaftsschriften, Joachim Pauli (1733-1812), auf Nachfrage die zusätzliche Leistung durchaus angeboten; und ungeachtet Martinis Einschränkung, dass nur ausgewählte Tafeln koloriert werden sollten, erschienen in den nächsten Bänden alle Stiche in Farbe. Erst später wurde die Illuminierung nur bei zoologischen Tafeln beibehalten; denn insbesondere in Tierbeschreibungen spielte die Diskus-

\footnotetext{
53 Anon. (1775), pp. 464f.

54 Zum Problem der Kolorierung im 18. Jahrhundert am Beispiel botanischer Abbildungen siehe Nickelsen (2006a), pp. 161-184, sowie Nickelsen (2006c).

55 Martini (1776), p. XVII.
} 
sion von Farbvarianten eine entscheidende Rolle, wie etwa bei dem bereits erwähnten Beitrag über einige Nachtfalter von Römer. So wird in seiner „Erklärung der Kupfertafeln“ etwa Fig. 1 als „Das Weibchen“ der betreffenden Falterart eingeführt, während es zu Fig. 2 heißt: „Das etwas schmutziger grüne Männchen“: hier markierte also die Färbung den Unterschied zwischen verschiedenen Geschlechtern. ${ }^{56}$ Auch für die Beschreibung der Raupen verwies Römer ausführlich auf die in der Abbildung dokumentierten Farben:

Die noch jungen Räupgen sind grün mit einer Menge ganz kleiner weisser Pünktgen: erst nachdem sie zum letzten Mal ibre Haut abgestreift haben, bekommen sie die Farbe und Zeichnung, welche die Abbildung reigt: auch giebt es solche, deren Farbe noch mehr ins bräunlichte fällt: überall aber trift man den etwas dunkler gefärbten Strich an, welcher der ganzen Länge der Raupe nach, über die Mitte des Rückens herunterläuft, und zwey Nebenlinien, die aufjedem Ringe ein lateinisches $V$ bilden. ${ }^{57}$

Indem er dies schrieb, bezog Römer sich vermutlich auf die Kolorierung der ursprünglichen Zeichnung, die Schellenberg verfertigt hatte; ob er mit dem letztlich kolorierten Zustand der gedruckten Tafel zufrieden war, ist nicht überliefert - denn obschon er selbst die Kupferplatten geliefert hatte, die Qualität des Stiches also garantiert war, konnte die Illuminierung immer noch das Endresultat verderben. Dass dies in den Schriften der GNF durchaus der Fall sein konnte, lässt sich Martinis Fußnote zu seiner Vorbemerkung zum zweiten Band bezüglich kolorierter Tafeln (siehe Zitat oben) entnehmen:

)* Keinen geringen Schreck empfanden wir aber bey Erblickung der nach den grösten Meisterstücken der Malerey gestochenen und illuminirten Figuren, besonders der XI-XIII Platte, bey welchen wir alle Kenner der Natur und Kunst ergebenst bitten müssen, ja nicht unsern Geschmack nach diesen Mustern, sondern bier bloss die zur Ausfübrung, obne unser Zuthun, gebrauchten Künstler zu beurtheilen. ${ }^{58}$

Wie das Zeichnen und Stechen war auch die Illuminierung wissenschaftlicher Abbildungen kein triviales Geschäft, sondern verlangte erhebliche Kenntnis der Materie wie auch des Kunsthandwerks - und die verbreitete Praxis der Verleger, zu diesem Zweck schlecht ausgebildete Laien anzustellen, führte häufig zu entsprechenden Ergebnissen. Doch auch so war die Handkolorierung von Kupfertafeln noch teuer genug und machte die Herausgabe der Gesellschaftsschriften für Verleger zunehmend unattraktiv. Nur bis 1779 blieb die GNF bei Pauli, und auch in den folgenden Jahren hielt kaum ein Verleger die Schriften länger als fünf Jahre im Programm. Der Wechsel 1780 erfolgte aus Sicht der GNF vor allem deswegen, weil man „besonders bei dem letzten Theil so wenig auf die äußerliche Zierde unserer Schriften wandte. "59 Der neue Verleger schien in dieser Hinsicht viel versprechend, doch stellte er gleich im Vorhinein gewisse Bedingungen an die Illustrierung der Hefte; diese sah sich die Gesellschaft gezwungen, im Januar 1780

\footnotetext{
56 Römer (1794); Erklärung der Kupfertafeln, p. 158.

57 Römer (1794), p. 160.

58 Martini (1776), Fußnote p. XVII. Die von Martini hier als misslungen hervorgehobenen Tafeln begleiteten eine Abhandlung von ihm selbst sowie einen weiteren Beitrag aus seinem Spezialgebiet, d.h. der Konchyliologie, die er am besten beurteilen konnte. NB: Tab. XI, XII waren Tafeln zu einer Abhandlung von Martini selbst (Konchyliologische Rhapsodien. Autor: Martini, F. H. W., pp. 347-375); Tab XIII: zur Beschreibung einer besondern, schönen Korallenmuschel. (Autor: Spengler, L., pp. 451-457); Martini: Neues systematisches Conchyliencabinett (11 Bände, 1768-1796).

59 Vgl. PA Bergsträsser, Blatt 5. Entwurf eines Briefes an Bergsträsser vom Januar 1780.
} 
ihrem Mitglied Bergsträsser zu erläutern. So heißt es in dem Entwurf eines Briefes an ihn:

Vorläufig müssen wir Ibnen, geliebter Freund, zu wissen thun, daß wir genöthigt gewesen sind, mit einem anderen Verleger zu accordiren [...]. Dieser neue Verleger machte es sich zwar zur Bedingung, daß keine Abhandlung über Insecten, wenigstens nicht mit Kupfern, darin vorkommen mögten, weil die Maler vor das Illuminiren derselben so viel fordern, daß er sich genöthigt sähe, auf dieses Werk einen böhern Preiß zu setzen, wie er wünsche. Wir antworteten aber, daß wir uns hierüber nicht einlassen könnten, aber daß wir doch so viel wie möglich die Kupfer zu ersparen suchen wollen. Wir müssen also mit ausgemablten Insecten etwas geizig sind [sic]. ${ }^{6}$

Für Bergsträsser war dies insofern von Bedeutung, als der Gesellschaft bereits einige Abhandlungen von ihm vorlagen, allesamt über Insekten und reichlich illustriert mit kolorierten Tafeln. So heißt es weiter in dem Brief:

In Ibren schönen Beiträgen finden wir nun erstlich etwas über die eine Phaläne, welche der H. Doctor Käfer [sic] im 9 ten Stück des Naturforschers beschrieben, nebst einer doppelten Abbildung derselben; die eine stimmt genau mit der Käferschen im Naturforscher überein, die andere ist nur durch etwas mehr olivengrün unterschieden, welches auch obne Abbildung leicht verständlich gemacht werden kann. Wären Sie es also wobl zufrieden, dass wir diese beiden Abbildungen zur Ersparung der Kupfer wegließen, und nur die Raupen u. Puppen abbilden, die eigentlich nur neu sind.

In der Tat ging es in diesem Beitrag Bergsträssers um einen Nachtfalter, der bereits im Naturforscher beschrieben worden war (wenn auch Bergsträsser in seinem Beitrag nicht von einem „Doctor Käfer“ sprach, sondern von einem „Doctor Kühn“). Und in der Tat war der Falter selbst bereits von seinem Vorgänger abgebildet worden; doch hatte Bergsträsser als neuen Befund eine Farbvariation der Falter entdeckt, die bisher übersehen worden war, wie er in seinem Beitrag erklärte:

Von denen herausgekommenen Eulen babe ich 2 Arten. Die Eulen habe ich nach zweien wohl aufbewahrten Exemplarien zeichnen lassen. Die eine trift genau mit der Kübnschen Beschreibung, und eben so genau mit der Natur; aber nicht mit der Abbildung im Naturforscher überein. Hier fehlt das Olivenfarbige, und die Abbildung stimmt mehr mit Fig. 3 überein. Von der letzten Eule weiss ich, weil sie hier gelegt hat, mit Gewissheit, dass sie das Weibchen ist. Aber unterscheiden darum nun die Farben das Geschlecht, und ist die erste das Männchen? Dies will ich obne weitere Beobachtung nicht behaupten, ob es gleich einige Wabrscheinlichkeit hat. Genug wir lernen wenigstens so viel mit Gewissheit, dass es Stücke giebt, welche das Olivengrüne in keinem so starken Auftrage haben. ${ }^{61}$

Bergsträsser war demnach bei Kühn auf einen Widerspruch gestoßen: Während Kühn in seiner Beschreibung die olivenfarbigen Oberflügel des Falters betont hatte, fehlte dieses Merkmal in der von Kühn publizierten Abbildung. Diesen Widerspruch löste nun Bergsträsser, indem er zwei unterschiedlich gefärbte Varianten des Falters unterschied und auch abbilden ließ. Interessant ist nun, dass der Schreiber des oben zitierten Briefentwurfs an Bergsträsser bei näherer Überlegung seine Position änderte; als Randbemerkung findet sich zu dem bereits zitierten Vorschlag folgende Alternative eingefügt:

${ }^{60}$ Dieses und das folgende Zitat: PA Bergsträsser, Blatt 5. Entwurf eines Briefes an Bergsträsser vom Januar 1780 .

61 Bergsträsser (1780), p. 300. 
Wären Sie es also wobl zufrieden, dass wir diese beiden Abbildungen zur Ersparung der Kupfer wegließen, und nur die Raupen $u$. Puppen abbilden, die eigentlich nur neu sind. < (am Rand als Anmerkung eingefügt:) $u$. damit derjenige der den Naturforscher nicht hat, doch die ganze Geschichte zusammen babe, die eine olivengrüne abstechen ließen $u$. uns bei der anderen auf den Naturforscher bezögen. $>62$

Während also der Schreiber bei den Nachtfaltern einen Kompromiss suchte, sah er für einen anderen Aufsatz von Bergsträsser nur eine Lösung des Problems:

Der lezte Beitrag betrifft den bekannten großen schwarzen Bockekäfer Cerambix Cerdo Lin.; und Sie haben die vielen bei diesem Käfer vorkommenden Verschiedenheiten, die sebr viel Verwirrung anrichteten, sebr gründlich auseinander gesetzt. Allein, obne die Abbildungen derselben werden nur noch Missverständnisse übrig bleiben, und diese Abbildungen sind zu viele, indem allein 3 Kupferplatten damit ausgefüllet werden müßten, welches denn die Kupfer unseres Werkes zu sebr anbäufen würde; daher wir denn diese Abhandlung mit dem verbindlichsten Dank. zurückschicken werden, $[\ldots] \cdot{ }^{63}$

Da für diesen Aufsatz auch aus Sicht des Schreibers alle Abbildungen wesentlich waren, wollte man lieber auf den Abdruck verzichten, als die Einheit von Bildern und Text durch das Herausstreichen von Figuren zu beeinträchtigen.

Die hohen Anforderungen an naturhistorische Kupferstiche blieben ein ständiger Streitpunkt mit den Verlegern der Gesellschaftsschriften: Während die GNF darauf bestand, die Tafeln in bester Qualität gedruckt zu sehen, waren die Verleger bemüht, den Kostenaufwand so gering wie möglich zu halten. 1795 entschied darum die Gesellschaft, zum Selbstverlag der Schriften überzugehen, was sie in ihrer Vorrede zum ersten, auf diese Weise herausgegebenen Band folgendermaßen rechtfertigte:

Wir wurden so oft genöthigt, mit den Verlegern zu wechseln, weil sie uns zwar allezeit die sichersten Versprechungen gaben, alle Sorgfalt anzuwenden, dass Druck, Papier und vorzüglich die Kupfer die möglichste Genanigkeit und Schönheit bekämen; aber am Ende hatten wir denn doch immer Ursach, unzufrieden zu seyn; so wie auch diejenigen Herrn Mitglieder, welche uns Abhandlungen mit Zeichnungen zuschickten, oft ibr Missvergnügen über die schlechte Ausführung derselben zu erkennen gaben. Es war dies aber nicht unsre Scbuld; denn der Verleger batte gemeiniglich die Arbeit so genau bedungen, und so gering bezablt, dass die Künstler wohl nicht den besten Fleiss anwenden konnten; und wenn wir unsre Unzufriedenheit äusserten, so war immer die Ausrede, der Absatz. sey so gering, dass man nicht die ausgelegten Kosten erstattet bekäme. ${ }^{64}$

Bei aller Motivation und guten Gründen für diesen Schritt wurde jedoch schnell klar, dass die Gesellschaft sich mit diesem Projekt nicht zuletzt in finanzieller Hinsicht übernommen hatte: Nur vier Bände ihrer Schriften erschienen im Selbstverlag (1795, 1799, 1801, 1803), bevor man mit dem Band des Jahres 1807 wieder zum Verlag G. Reimer zurückkehrte - und damit zu dem alten Problem des Interessenkonflikts. ${ }^{65}$

\footnotetext{
${ }^{62}$ Alle Zitate: PA Bergsträsser, Blatt 5. Entwurf eines Briefes an Bergsträsser vom Januar 1780.

${ }^{63}$ PA Bergsträsser, Blatt 5. Entwurf eines Briefes an Bergsträsser vom Januar 1780.

${ }^{64}$ Anonymus (1795), pp. IIIf.

${ }^{65}$ Angaben gemäß Becker (1973), p. 26.
} 


\section{Konklusion}

Ungeachtet aller Schwierigkeiten, finanzieller wie organisatorischer Art, blieben jedoch Abbildungen in den Schriften der GNF reich vertreten, und zumindest ein Teil der Tafeln wurde auch weiterhin koloriert: Deutlicher lässt sich kaum belegen, als wie zentral man diese Illustrationen erachtete. Bereits in den ersten Plänen zur Gründung der GNF und zur Einrichtung ihrer Schriften wurden Abbildungen als wesentlicher Bestandteil hervorgehoben. Martini vertrat die Unverzichtbarkeit von Abbildungen auch anderen Ortes - so kritisierte er etwa an einer zeitgenössischen französischen Enzyklopädie zur Naturgeschichte, dass hierin auf Abbildungen vollständig verzichtet wurde, obschon doch, wie Martini in seinem eigenen, analog angelegten Werk hervorhob, „die Natur [...] gesehen oder durch die Sinnen erkannt, nicht bloß aus Beschreibungen erlernet seyn [will]“. ${ }^{66}$ Der Schwerpunkt auf empirischer Evidenz und auf der unmittelbaren Beobachtung von Naturgegenständen war ein Charakteristikum der GNF, das zumindest in der Frühzeit dieser Gesellschaft mit dem deistischen Naturverständnis ihrer prägenden Mitglieder zusammenhing; und wenn die Beobachtung nicht direkt erfolgen konnte, waren Abbildungen der betreffenden Gegenstände die bestmögliche Alternative. ${ }^{67}$ Nicht zufällig waren es jedoch insbesondere Artbeschreibungen, die von Abbildungen begleitet wurden: Morphologische Eigenschaften lassen sich selbst mit exakter Terminologie nur sehr umständlich in Textform vermitteln, während sie in einer Zeichnung sehr viel klarer und unmissverständlicher auszudrücken sind. Für andere Typen der Information wiederum waren Texte das geeignetere Medium. Wenn es darum ging, Arten umfassend zu beschreiben, galt daher in der Fachliteratur des 18. Jahrhunderts eine Kombination von beiden Ausdrucksformen als die bestmögliche Variante - trotz des hohen Aufwands zur Herstellung von Abbildungen. ${ }^{68}$

Doch war nicht jede beliebige Abbildung erwünscht, auch nicht in der GNF. An den hier beschriebenen Episoden zeigt sich, welche Anstrengungen man in jedem Stadium ihrer Herstellung unternahm, um die bestmögliche Qualität der Tafeln zu sichern: Die Zeichnungen wurden sowohl von den Autoren als auch von den Gesellschaftsmitgliedern in ihrer Ausfertigung kontrolliert und die Kupferstecher sorgsam ausgewählt; die Illuminierung der Tafeln, welche die Verleger zu besorgen hatten, blieb hingegen ein Problem - nicht zuletzt deswegen standen in bester Qualität kolorierte Kupferstiche, etwa von Schellenberg, in so hohem Ansehen; doch bemühte sich die GNF auch in diesem Punkt, ihren Einfluss so weit wie möglich geltend zu machen.

Für bloß dekoratives Beiwerk hätte man kaum einen solchen Aufwand an Zeit, Mühe und Kosten betrieben; und dies gilt für die Beschäftigung mit der Naturgeschichte generell in dieser Zeit. Die Herstellung von Abbildungen sowie insbesondere die Kontrolle ihrer Qualität waren allgegenwärtiger Bestandteil des damaligen Wissenschaftsbetriebs, in Gesellschaften und Akademien wie auch für Privatpersonen, die erhebliche Ressourcen investierten, nicht nur um illustrierte Werke zu erwerben, sondern auch um sie selbst

\footnotetext{
${ }^{66}$ Martini (1774), Bd. 1, XIII. Zitiert nach Böhme-Kaßler (2005), p. 122.

${ }^{67}$ Siehe zur deistischen Naturauffassung in der GNF und ihrem Einfluss auf die Arbeit der Gesellschaft Böhme-Kaßler (2005), Kapitel VIII.

${ }^{68} \mathrm{Zu}$ einer eingehenderen Diskussion des Verhältnisses zwischen Bild und Text im Fall botanischer Abbildungen siehe Nickelsen (2006a), Chapter 5, Section 5.3.
} 
herzustellen. Die enormen Schwierigkeiten, die sich solchen Projekten in den Weg stellten, und die vielfältigen Lösungsversuche treten jedoch erst bei einer Rekonstruktion konkreter Episoden zu tage - bei dem Blick hinter die Kulissen. Nur auf diese Weise erhält man Einsicht in die Praktiken, die auch den Alltag der GNF prägten, die aus den Publikationen selbst in keiner Weise ersichtlich werden.

\section{Literatur}

Anonymus (1775) Kurze Lebensgeschichte des berühmten Herzogl. Sächs. Malers und Universitätskupferstechers Herrn Gottfried August Gründler zu Halle. Beschäftigungen der Berlinischen Gesellschaft Naturforschender Freunde 1, pp. 454-467.

Anonymus (1795) Vorrede. Der Gesellschaft Naturforschender Freunde zu Berlin, Neue Schriften 1 , pp. III-XII.

Becker, K. (1973) Abriss einer Geschichte der Gesellschaft Naturforschender Freunde zu Berlin. Sitzungsberichte der Gesellschaft Naturforschender Freunde zu Berlin 13, pp. 1-58.

Beireis, G. C. (1783) Beschreibung eines bisher unbekannt gewesenen amerikanischen Frosches. Schriften der Berlinischen Gesellschaft Naturforschender Freunde 4, pp. 178-182.

Bergsträsser, J. A. B. (1779) Über den Weissdornspanner nach Herrn Sepp. Beschäftigungen der Berlinischen Gesellschaft Naturforschender Freunde 4, pp. 29-41.

Bergsträsser, J. A. B. (1780) Etwas von der Naturgeschichte der Phalaena Fimbria Lin. Schriften der Berlinischen Gesellschaft Naturforschender Freunde 1, pp. 297-300.

Bloch, M. E. (1776) Beschreibung der Schleicheidechse, Lacerta serpens. Beschäftigungen der Berlinischen Gesellschaft Naturforschender Freunde 2, pp. 28-34.

Böhme, K. (2001) Die Gesellschaft Naturforschender Freunde zu Berlin - Bestand und Wandel einer gelehrten Gesellschaft: Ein Überblick. Berichte zur Wissenschaftsgeschichte 24, pp. 271-283.

Böhme-Kaßler, K. (2005) Gemeinschaftsunternehmen Naturforschung. Modifikation und Tradition in der Gesellschaft Naturforschender Freunde zu Berlin 1773-1906. Steiner, Stuttgart (Pallas Athene 15).

Döring, D., Nowak K. (eds.) (2000-2002) Gelehrte Gesellschaften im mitteldeutschen Raum (1650-1820). Hirzel, Stuttgart.

Gerhard, K. A. (1783) Über die Entstehung der fasrigen Stein- und Erzarten. Schriften der Berlinischen Gesellschaft Naturforschender Freunde 4, pp. 291-305.

Guimpel, F., Willdenow, K. L., Hayne, F. G. (1815) Abbildung der deutschen Holzarten für Forstmänner und Liebhaber der Botanik. Berlin. 
Geus, A. (1987) Die entomologischen Illustrationen Johann Rudolf Schellenbergs. In: Johann Rudolf Schellenberg. Der Künstler und die naturwissenschaftliche Illustration im 18. Jahrhundert (Thanner, B., Schmutz, H.-K., Geus, A.; eds.). Winterthur: pp. 209-243.

Hayne, F. G. (1805-37) Getreue Darstellung und Beschreibung der in der Arzneykunde gebräuchlichen Gewächse. Berlin.

te Heesen, A. (2001) Vom naturgeschichtlichen Investor zum Staatsdiener: Sammler und Sammlungen der Gesellschaft Naturforschender Freunde zu Berlin um 1800. In: Sammeln als Wissen. Das Sammeln und seine wissenschaftsgeschichtliche Bedeutung (te Heesen, A., Spary, E.; eds.) Wallstein, Göttingen: pp. 62-84.

te Heesen, A. (2004) Natural Historical Investment to State Service: Collectors and Collections of the Berlin Society of Friends of Nature Research, c. 1800. History of Science 42, pp. 62-84.

König, J. G. (1779) Naturgeschichte der sogenannten weißen Ameise. Beschäftigungen der Berlinischen Gesellschaft Naturforschender Freunde 4, pp. 1-28.

Martini, F. H. W. (1774) Allgemeine Geschichte der Natur in alphabetischer Ordnung. Berlin.

Martini, F. H. W. (1775a) Entstehungsgeschichte der Gesellschaft Naturforschender Freunde in Berlin. Beschäftigungen der Berlinischen Gesellschaft Naturforschender Freunde 1, pp. 1-26

Martini, F. H. W. (1775b) Gesetze der hiesigen Privatgesellschaft Naturforschender Freunde nach den Verbesserungen vom 3ten May 1774. Beschäftigungen der Berlinischen Gesellschaft Naturforschender Freunde 1, pp. 27-40.

Martini, F. H. W. (1776) Vorerinnerungen. Beschäftigungen der Berlinischen Gesellschaft Naturforschender Freunde 2, pp. IX-XXVI.

McClellan, J. E. (1985) Science Reorganized. Scientific Societies in the Eighteenth Century. Columbia University Press, New York.

Müller, O. F. (1776) Beschreibung zwoer Medusen. Beschäftigungen der Berlinischen Gesellschaft Naturforschender Freunde 2, pp. 290-298.

Nickelsen, K. (2000) Wissenschaftliche Pflanzenzeichnungen - Spiegelbilder der Natur? Botanische Abbildungen aus dem 18. und frühen 19. Jahrhundert. Bern Studies in the History and Philosophy of Science, Bern.

Nickelsen, K. (2006a) Botanists, Draughtsmen and Nature. The Construction of EighteenthCentury Botanical Illustrations. Springer, Dordrecht etc.

Nickelsen, K. (2006b) Botanists, Draughtsmen and Nature: Constructing Eighteenth-Century Botanical Illustrations. Studies in History and Philosophy of the Biological and Biomedical Sciences 37, pp. 1-25. 
Nickelsen, K. (2006c) The Challenge of Colour. Eighteenth-Century Botanists and the HandColouring of Illustrations. Annals of Science, pp. 3-23.

Nicolai, F. (1968) Beschreibung der Königlichen Residenzstädte Berlin und Potsdam. Neudruck der Originalausgabe der 3. Aufl. 1786, Berlin.

Nissen, C. (21966) Die botanische Buchillustration. Ihre Geschichte und Bibliographie. Hiersemann, Stuttgart.

Römer, J. J. (1794) Beschreibung einiger Nachtvögel und ihrer Raupen. Schriften der Berlinischen Gesellschaft Naturforschender Freunde 11, pp. 156-166.

du Roi, J. P. (1784) Beschreibung einer neuen Ahorngattung, des krausblättrigen Ahorns, (Aceris laciniati.) Schriften der Berlinischen Gesellschaft Naturforschender Freunde 5, pp. 216-220.

Spengler, L. (1775a) Beschreibung eines besonderen Meerinsekts, welches bey den Isländern Oskabiörn, oder auch Oenskebiörn, Wunschbär, Wunschkäfer heisset. Beschäftigungen der Berlinischen Gesellschaft Naturforschender Freunde 1, pp. 292-331.

Spengler, L. (1775b) Beschreibung einer neuen Art Schnecken aus der Südsee. Beschäftigungen der Berlinischen Gesellschaft naturforschender Freunde 1, pp. 395-397.

Thanner, B. (1987) Johann Rudolf Schellenberg und die schweizerische Buchillustration im Zeitalter der Aufklärung. In: Johann Rudolf Schellenberg. Der Künstler und die naturwissenschaftliche Illustration im 18. Jahrhundert (Thanner, B., Schmutz, H.-K., Geus, A.; eds.). Winterthur: pp. 7-182.

Thanner, B., Schmutz, H.-K., Geus, A. (eds.) (1987) Johann Rudolf Schellenberg. Der Künstler und die naturwissenschaftliche Illustration im 18. Jahrhundert. Winterthur.

Thieme, U., Becker, F. (1992) Allgemeines Lexikon der bildenden Künste von der Antike bis zur Gegenwart. Unveränderter Nachdruck der Lizenzausgabe 1909/10. Deutscher Taschenbuchverlag, München.

von Trebra, F. W. H. (1783) Nachrichten vom schwarzen Wurm und der Wurmtrockniß in den Fichten oder Rothtannen. Schriften der Berlinischen Gesellschaft Naturforschender Freunde 4, pp. 78-98.

Wahlenberg, G. G. (1812) Flora Lapponica. Verlag der Realschule, Berlin.

von Wangenheim, F. A. J. (1788) Beschreibung der Poleyblättrigen Kalmia und der gelbblühenden Rosskastanie. Schriften der Berlinischen Gesellschaft Naturforschender Freunde 8, pp. 129-138.

Zaunstöck, H., Meumann, M. (eds.) (1985) Sozietäten, Netzwerke, Kommunikation. Neue Forschungen zur Vergesellschaftung im Jahrhundert der Aufklärung. Niemeyer, Tübingen. 


\section{Adress for correspondence:}

Kärin Nickelsen

Wissenschaftstheorie und Wissenschaftsgeschichte

Institut für Philosophie

Universität Bern

Sidlerstrasse 5

CH-3012 Bern, Schweiz

nickelsen@philo.unibe.ch 


\title{
„Ich acquirirte das Schwein sofort, ließ nach dem Niederstechen die Pfoten abhacken u. schickte dieselben an Darwin" - Der Briefwechsel von Otto Zacharias mit Ernst Haeckel (1874-1898)
}

\author{
Rosemarie Nöthlich, Nadine Wetzel, Uwe Hoßfeld \& Lennart Olsson
}

Abstract

The substantial collection of letters in the Ernst-Haeckel-Haus in Jena, Germany, most of which were sent to Haeckel, is an important source for the history of biology in the 19th and early 20th centuries. Only selected parts have been published, including correspondence with family and friends, as well as with other scientists like the Hertwig brothers, T. H. Huxley and A. Weismann. The journalist and plankton researcher Otto Zacharias (1846-1916) was an important popularizer of Haeckel's "Darwinismus" and corresponded with Haeckel throughout the last quarter of the 19th century. We here present all 52 letters available from this correspondence. Most letters are from Zacharias to Haeckel, but 6 letters from Haeckel to Zacharias are also included. One of the recurrent topics in the correspondence is the effort to found a popular science journal devoted to popular science and especially to the popularization of Darwinism. Zacharias asked for Haeckel's support in this endaevour, but the project never took off. Instead, another popularizer of Darwinism, Haeckel's friend Carus Sterne, founded a very similar journal called "Kosmos", with Haeckel's support. As an independent journalist, and as an editor of several magazines, Zacharias published many articles and book reviews on evolution and on Haeckel's main ideas. In several letters to Haeckel he asked for Haeckel's point of view on certain embryological or morphological topics, or wanted clarification of passages in Haeckel's books and articles. Inspired by Haeckel, Zacharias later embarked on a new career as a biologist working mostly on plank.ton. He founded a private research station in Plön in northern Germany, which developed into a limnological station of the Kaiser-Wilhelm-Gesellschaft and later into the Max-Planck-Institute for Limnology. If the first and second parts of the correspondence are dominated by discussions about the interpretation of Darwinism and by embryological questions, the last part also includes more philosophical topics, such as Haeckel's monism and quarrels with the clergy. The title of our paper has been choosen to illustrate the importance of Haeckel's so-called Biogenetic Law for discussions about evolution in this era. In a letter from 1877, Zacharias describes how he came across, at a local marketplace, a pig with "thumbs", which are normally completely absent, developed on both forelimbs. Such atavistic mutations, which bring forth characters that have long been lost in the evolutionary line leading to an extant species, were seen as "throwbacks" to earlier eras, and as important evidence for evolution as descent with modification. So 
excited was Zacharias by this discovery, that he bought the pig, and after it had been slanghtered and the forelimbs "backed off", sent at least one of the pig's feet to Charles Darwin and asked for his comments on the phenomenon and its importance for the theory of evolution.

\section{Einleitung}

Der Nachlass von Ernst Haeckel (1834-1919) ist mit seinem umfassenden Briefbestand sowohl für die Geschichte der Biowissenschaften des 19. und beginnenden 20. Jahrhunderts als auch für eine Darstellung der Kultur der Wissenschaften um/nach 1900 bedeutsam. Der Bestand basiert auf dem Privatarchiv des Jenaer Zoologen, das durch Ankäufe und Schenkungen bis heute erweitert wird. ${ }^{1}$ Im Jahre 2005 haben Uwe Hoßfeld und Olaf Breidbach eine Übersicht über den ca. 40000 Briefe umfassenden Briefbestand des Ernst-Haeckel-Archivs in Jena vorgelegt, welche erste Einblicke in die enorme Korrespondenz des Jenaer Zoologen ermöglicht (Hoßfeld \& Breidbach 2005).

Bisher sind nur einige Teile der Haeckelschen Korrespondenz veröffentlicht worden. Von besonderem Stellenwert sind natürlich die aus dem familiären und privaten Umfeld Haeckels publizierten Schriftstücke, so die Briefe Haeckels an seine Eltern (Haeckel 1921a), an seine Braut Anna Sethe 1859/60 (Haeckel 1921b), der Briefwechsel von Ernst und Agnes Haeckel (Huschke 1950), die Korrespondenz Haeckels mit seinem langjährigen Freund, dem Kunstmaler Hermann Allmers (Franz 1944) sowie der im Jahre 2000 von Norbert Elsner unter dem Titel „Das ungelöste Welträtsel“ vorgelegte Briefwechsel mit Frida von Uslar-Gleichen. ${ }^{2}$ Einblicke in den Gedankenaustausch Haeckels mit Wissenschaftlern geben ferner eine Reihe weiterer bislang veröffentlichter Korrespondenzen. So publizierte der Zoomorphologe Victor Franz den Briefwechsel von Haeckel mit seinen Schülern, den Brüdern Richard und Oscar Hertwig (Franz 1943) oder es erschienen die Korrespondenzen mit Thomas Henry Huxley und August Weismann. ${ }^{3}$ Aus dem

\footnotetext{
${ }^{1}$ Haeckel führte diese Sammlung ab 1909 als Phyletisches Archiv, bezeichnete es dann aber ab 1916 selbst als Haeckel-Archiv. Noch zu seinen Lebzeiten wurde es 1918 durch einen Schenkungsvertrag um weitere Nachlassteile vermehrt, der Universität Jena übereignet - und als Resultat einer komplexeren Entwicklung dem von Haeckel selbst in seinem Wohnhaus begründeten Ernst-Haeckel-Museum angeschlossen. Heute ist dieses Museum mit seinem Archiv Teil des Instituts für Geschichte der Medizin, Naturwissenschaft und Technik der Friedrich-Schiller-Universität Jena (Krauße \& Hoßfeld 1999).

2 Weitere Briefe finden sich in den Auflagen von Haeckels Reisebüchern „Von Teneriffa bis zum Sinai. Reiseskizzen“ (1923a), den „Berg- und Seefahrten 1857/1883“ (1923b) sowie in dem Buch „Himmelhochjauchzend .... Erinnerungen und Briefe der Liebe“, in dem Heinrich Schmidt Briefe Haeckels an seine erste Braut edierte (1927), abgedruckt.

${ }^{3}$ Im gleichen Jahr (wie Franz 1943) gab der Mathematiker Max Bense ausgewählte Briefe von Haeckel in einem Band „Briefe grosser Naturforscher und Mathematiker“ heraus. Auf Briefen basierte auch die 1956 erschienene Arbeit von Georg Uschmann „Ernst Haeckel - Forscher, Künstler, Mensch“, die später zu der Arbeit „Ernst Haeckel - Biographie in Briefen“ (1983) erweitert wurde. Im Darwin-Jahr (1959/60) erschien schließlich die von Georg Uschmann und Ilse Jahn herausgegebene Korrespondenz zwischen Thomas Henry Huxley und Ernst Haeckel; 1965 publizierte Uschmann zusammen mit Bernhard Hassenstein den Briefwechsel zwischen Haeckel und August Weismann, und 1985 präsentierte Ilse Jahn schließlich noch eine Auswahl von Briefen Haeckels an seine Berliner Kollegen. Anläßlich des 100. Geburtstages des Haeckel Schülers, Embryologen und theoretischen Biologen Julius Schaxel, publizierte Erika Krauße 1987 die Korrespondenz von Schaxel mit seinem Lehrer. Die Briefe Haeckels an Charles Darwin wurden 1996 von Thomas Junker und Marsha Richmond erfasst. Im Jahre 1999 erschien der Briefwechsel zwischen Carl Vogt, Jacob Moleschott, Ludwig Büchner und Ernst Haeckel (Kockerbeck 1999). Die schwedischen Korrespondenten von Ernst Haeckel wurden von Lennart Olsson und Uwe Hoßfeld erfasst (2003, 2004, 2006). Eine
} 
umfangreichen Fundus der Haeckelbriefe wurde aber auch der Briefwechsel mit Wilhelm Bölsche, dem erfolgreichsten Sachbuchautor um 1900, ediert und damit die Thematik „Wissenschaftspopularisierung“ angesprochen. ${ }^{4}$ Neben Bölsche war Haeckel von einem ganzen Kreis von Popularisatoren aus unterschiedlichen sozialen Kontexten umgeben, welche in Deutschland seit der Mitte des 19. Jahrhunderts im zunehmenden Maße besonders die Diskussion um die Evolutionslehre Darwins mitbestimmten. An dieser Stelle seien stellvertretend der Verleger Wilhelm Breitenbach, der Schriftsteller Carus Sterne, Carl Neumann und Adolf Heilborn genannt.

Auch der Journalist und Planktonforscher Emil Otto Zacharias wirkte als Vermittler für die populärwissenschaftliche Verbreitung naturwissenschaftlicher Erkenntnisse und belieferte im letzten Drittel des 19. Jahrhunderts mit seinen Artikeln zahlreiche deutsche Zeitschriften. Zacharias wurde, wie auch viele andere, bislang nicht in diesem Umfeld verortet. ${ }^{5}$ Durch den Kontakt zu Haeckel, der sich selbst durch umfangreiche populärwissenschaftliche Arbeiten hervortrat, erhoffte sich Zacharias Mitte der 1870er Jahre wertvolle Unterstützung bei seiner wissenschaftlichen Profilierung, aber auch Protektion bei seiner weiteren beruflichen Entwicklung. Zacharias korrespondierte auch mit Charles Darwin, für den er dann als Übersetzer tätig wurde (Junker \& Richmond 1996). An Haeckel wandte er sich mit zahlreichen naturwissenschaftlichen Fragestellungen und erbat sich von diesem fachlichen Rat und Literatur. Zacharias avancierte zudem zu einem der ersten Haeckel-Biographen ${ }^{6}$ und förderte dessen Popularität durch Rezensionen seiner Werke wie der „Anthropogenie“ (1874)7 und den „Arabischen Korallen“ (1876) ${ }^{8}$. Er verfasste von 1874 bis 1876 allein für die Zeitschrift „Das Ausland“ 11 Artikel und unterstützte dabei Haeckel auch entschieden in den Kontroversen mit seinen Gegnern. Von der Verbindung zu Haeckel versprach sich Zacharias ebenso Unterstützung bei der Gründung einer ersten, rein darwinistisch-populärwissenschaftlichen Zeitschrift. Trotz intensiver Bemühungen zur Realisierung dieser Idee endete das Vorhaben für ihn in

\footnotetext{
Publikation des Briefwechsels von Ernst Haeckel mit dem Chemiker und Nobelpreisträger Wilhelm Ostwald befindet sich - auch aus Anlaß des 100jährigen Gründungsjubiläums des Deutschen Monistenbundes (1906) - ebenfalls im Druck (Nöthlich et al. 2006).

${ }^{4}$ Vgl. Nöthlich, R. (Hg.) (2002): Ernst Haeckel - Wilhelm Bölsche. VWB, Berlin; ebenso Nöthlich (2006).

5 Obwohl das „Forschungsfeld Wissenschaftspopularisierung“ immer mehr in den Mittelpunkt wissenschaftshistorischen und kulturgeschichtlichen Interesses rückt, gibt es bislang nur wenige biographische bzw. briefeditorische Arbeiten zu den eigentlichen Akteuren dieser Wissenschaftspopularisierung. Ausgenommen sind hier natürlich die Personen welche sich als renommierte Wissenschaftler oder Personen des Zeitgeschehens für die Vermittlung allgemeiner Grundlagen auf dem Gebieten der Naturwissenschaften für Laien einsetzten: an dieser Stelle seien nur die Namen Alexander von Humboldt und Justus von Liebig genannt. Die Person des eigentlichen Bildungsvermittlers oder populären Vortragsredners blieb und bleibt bislang oft unzureichend beleuchtet. Dabei bietet die Herausgabe von entsprechenden Editionen bspw. die Möglichkeit, umfangreiches Quellenmaterial zur Popularisierungsgeschichte zu ermitteln, auszuwerten und zu analysieren, wobei „im besonderen die Privatkorrespondenzen der Vermittlerpersönlichkeiten [...] für die Frage nach Kommunikationszusammenhängen, Popularisierungsmotiven und -strategien eine große Bedeutung“" besitzen (Daum 1998: 24).

${ }^{6}$ Zacharias, O. (1874) Ernst Heinrich Häckel. Illustrirte Zeitung, LXIII. Bd., Nr. 1630 (26. Sept. 1874), S. 235-238.

7 Zacharias, O. (1875) Ernst Häckel's „Anthropogenie“. Illustrirte Zeitung, LXIV. Bd., Nr. 1646, S. 42; Nr. 1647, S. 68-69; Nr. 1650, S. 119; Nr. 1651; S. 140-142.

8 Zacharias, O. (1876) Arabische Korallen. Illustrirte Zeitung, Nr. 1701, Bd. LXVI, 5. Februar 1876, S. 103 und 106 (Abbildung S. 108).
} 
einem Eklat, als Haeckel den Redakteursposten Zacharias' Gegenspieler, Ernst Krause (1839-1903), übertrug. Der bis dato freundschaftliche Kontakt mit Haeckel wurde getrübt und brach in den nachfolgenden Jahren gänzlich ab. ${ }^{9}$ Nach dem Scheitern dieses Vorhabens wandte sich Zacharias vom Journalismus immer mehr der Fauna-Forschung zu und gründete 1892 die erste biologische Station für Süßwasserforschung in Plön als außeruniversitäre Einrichtung.

\section{Otto Zacharias - Wissenschaftspopularisator und Zoologe}

Emil Otto Zacharias wurde am 27. Januar 1846 als Sohn eines Möbelhändlers und Dekorateurs in Leipzig geboren. Er besuchte dort die 1. Bürgerschule und die Sonntagsschule der polytechnischen Gesellschaft. Nach dem Schulabschluss begann er 1865 eine Lehre als Mechaniker an der Universitätssternwarte in Leipzig. ${ }^{10}$ Dessen Direktor, Carl Christian Bruhns, fiel die Begabung und Interessenvielfalt Zacharias' auf und er ermöglichte ihm zunächst Privatunterricht und später durch Fürsprache bei verschiedenen Professoren sogar ein Studium der Philologie, Philosophie und Naturwissenschaften an der Universität. ${ }^{11}$ Der Titel seiner 1869 erschienenen Promotionsschrift lautete „Über einige metaphysische Differenzen zwischen Herbart und Kant" ${ }^{\prime 12}$

Zacharias übernahm danach zunächst für drei Jahre die Stelle des Hauslehrers bei einem Kaffeeplantagenbesitzer, der in Gelnhausen ansässig war ${ }^{13}$, 1872 eine Stelle als Hauslehrer in einer deutsch-italienischen Familie in Catania (Sizilien). Neben dieser Lehrtätigkeit beschäftigte er sich mit zoologischer Forschung, was er bspw. in späteren Briefen an Bölsche öfters erwähnte. Zacharias beschreibt darin sein außeruniversitär gewecktes Interesse an planktonischen Lebewesen, was zugleich Anhaltspunkte für seine frühesten empirischen Kontakte und Erfahrungen mit naturwissenschaftlichen Sachverhalten gibt:

„Ich war heuer 9 Monate auf Sicilien [...], um das mikeroskop. Plankton des Meeres dort zu studiren. Früber war ich jabrelang als Eržieher in Catania u. Syrakus, kenne also die schöne Insel genau. Aber dieses Mal habe ich dort eine Geliebte binterlassen, die mich nächstens wieder dorthin qiehen wird. Das ist die Gruppe der Radiolarien, die ich früher zum ersten Male ordentlich (mit gründlichen Studien) angeschnitten babe u. von der ich so leicht nicht wieder loskommen dïrfte. "dt

Wenn sich ihm die Gelegenheit bot - das galt auch für die Zeit nach seiner Rückkehr nach Deutschland - nutzte er regelmäßige Reisen und Ausflüge nach Italien, um diesem Interesse nachzugehen und seine Kenntnisse durch vermehrte praktische Anschauung zu

\footnotetext{
${ }_{9}$ Interessanterweise pflegte Zacharias nach 1900 engen brieflichen Kontakt mit Wilhelm Bölsche, Haeckels Freund und ,Hauspopularisator'.

10 Thienemann, A. (1917) Otto Zacharias. Ein Nachruf. Archiv für Hydrobiologie und Planktonkunde [AHP] 1917 (11), Hft. 4, Stuttgart 1917, S. I.

11 Thienemann (1917), S. II.

12 Zacharias, O. (1869) Über einige metaphysische Differenzen zwischen Herbart und Kant. Leipzig. Diese Dissertationsschrift war zunächst in Leipzig abgelehnt, dann aber in Rostock angenommen worden. Vgl. Wetzel, N. (2004) Emil Otto Zacharias - Ein Lebensweg als Bildungsvermittler. Univ. Jena, Magisterarbeit, S. 14.

13 Thienemann (1917), S. III (wie Anm. 10).

${ }^{14}$ Brief von Zacharias an Bölsche vom 8. November 1905, UBW, Böl. Prz. Nr.: 1513.
} 
vertiefen. So hatte er bereits in Italien, vermutlich ohne genaue fachliche Anleitung, meeresbiologische Untersuchungen durchgeführt und dabei sein Interesse an Wasserlebewesen und deren Lebensbedingungen entdeckt.

Bereits Mitte der 70er Jahre des 19. Jahrhunderts arbeitete Zacharias journalistisch und redaktionell für verschiedene Nachrichtenblätter Deutschlands. Daneben publizierte er als freier Mitarbeiter in zahlreichen großen deutschen ,Fachzeitschriften' der damaligen Zeit. ${ }^{15}$ Hierbei zeigte sich seine Vorliebe für die Verteidigung und allgemeine Darstellung der darwininschen Abstammungslehre. Er rezensierte zahlreiche Werke, die sich dieses Themas annahmen und übersetzte bspw. auch das Werk von Charles Darwins Sohn George „Marriages between First Cousins“ ins Deutsche ${ }^{16}$. Zacharias schwebte aber zu diesem Zeitpunkt bereits die „Stelle eines Assistenten bei dem Director eines zoologischen Gartens oder Aquariums als erstrebenswerthes Ziel vor" ${ }^{\text {‘17 }}$, denn der expandierende Bücher- und Zeitschriftenmarkt in Deutschland bot zwar einerseits Raum für die sich stärker etablierende populärwissenschaftliche Journalistenschicht, war aber natürlich zugleich von Konkurrenz und verschiedenen Existenznöten bestimmt.

Mitte der 1870er Jahre formulierte Zacharias dann gegenüber Haeckel die Idee der Gründung einer „darwinistischen Monatssschrift“ namens „Darwinia“.18 Er hatte das Unternehmen bereits genauestens geplant und konnte zunächst mit Haeckels Hilfe Kontakt zu verschiedenen Wissenschaftlern knüpfen und diese als potentielle Autoren gewinnen. Doch mit der Konkretisierung der Pläne nahmen offensichtlich auch die Bedenken Haeckels gegenüber Zacharias und dessen fachlicher Qualifikation als Redakteur der ersten rein darwinistisch-populärwissenschaftlichen Zeitschrift zu. Unbeeindruckt von Zacharias' Bemühungen favorisierte Haeckel insgeheim seinen Freund, den Schriftsteller Ernst Krause (Carus Sterne) und unterbreitete diesem den fertigen Zeitschriftenplan für die „Darwinia“. Sterne war wie Zacharias populärwissenschaftlicher Autor, Anhänger und Verfechter der darwinschen Entwicklungslehre und hatte in Anlehnung an Haeckels „Natürliche Schöpfungsgeschichte“ (1868) mit seinem Buch „Werden und Vergehen“ (1876) ebenso ein populärwissenschaftliches Erfolgswerk geschaffen. Haeckel konnte Sterne als Redakteur gewinnen und so erschien im April 1877 das erste Heft der Zeitschrift unter dem geänderten Titel „Kosmos“. ${ }^{19}$ Zacharias gegenüber hatte sich Haeckel über seine Absichten bedeckt gehalten und statt dessen diesem geraten, sein Glück als Autor in Amerika zu versuchen:

\footnotetext{
15 Vgl. Brief von Zacharias an Haeckel vom 11. Juni 1875, Bestand EHH: „Was mich selbst betrifft, so suche ich mir jetzt mit allem Fleiße einen halbwegs gut klingenden Namen zu machen u. wie mich dünkt, wird mir das auch gelingen. Ich bin jetzt Mitarbeiter der Gegenwart, des Grenzboten, des Auslandes, der Illustr. Ztg., des Athenäums, der Ersch u. Gruberschen Encyclopaedie, der Blätter für literar. Unterhaltung etc. “

${ }^{16}$ Briefe von Zacharias an Haeckel vom 2. und 23. Oktober 1875, Bestand EHH.

${ }^{17}$ Brief von Zacharias an Haeckel vom 28. Juli 1876, Bestand EHH.

${ }^{18}$ Briefe von Zacharias an Haeckel vom 19. Mai und 11. Juni 1875, Bestand EHH.

${ }^{19}$ Zur Geschichte der Zeitschrift ,Kosmos’ vgl. Wetzel, Nadine \& Nöthlich, Rosemarie: Vom „Homo literatus“ zum „Self made man“ - Der Werdegang des Emil Otto Zacharias (erscheint 2006 in: Mauritiana, Bd. 19, Heft 3). Andreas Daum verfaßte bereits 1995 einen Artikel über die Zeitschrift „Kosmos“. Seine hier getroffenen Einschätzungen über die Geschichte der Zeitschrift und über das Verhältnis Krause/Zacharias müssen jedoch auf Grund dieser neuen Recherchen ergänzt und revidiert werden. Vgl. Daum, A. (1995) Naturwissenschaftlicher Journalismus im Dienst der darwinistischen Weltanschauung: Ernst Krause alias Carus Sterne, Ernst Haeckel und die Zeitschrift Kosmos. Eine Fallstudie zum späten 19. Jahrhundert. Mauritiana 15 (1995) 2, S. 227-245.
} 
„Bei Ibren activen Eigenschaften, Ihrer Arbeits-Energie und Ihrem Fleiße, glaube ich, daß Sie als Self-made man Ibr Glück weit eher in Nord-America als in Europa machen [werden]. Dort kann ein popu[lär]wissenschaftl. Schriftsteller Ibres Schlages weit mehr vor sich bringen als hier in Deutschland, wo der Kampf ums Dasein für einen Homo literatus viel schwerer ist! ${ }^{20}$

Trotz dieser Enttäuschung blieb Zacharias in den Jahren zwischen 1877 und 1888 überwiegend journalistisch tätig, verstärkte aber später seine Hinwendung zu praxisorientierten naturwissenschaftlichen Aufgaben. Im Jahr 1884 vermaß er verschiedene Seen Holsteins, Mecklenburgs, des Riesen- und Isergebirges und führte in ihnen - gegründet auf seinen Erfahrungen aus den Untersuchungen an ozeanischem Plankton in Italien - süßwasserbiologische Analysen durch. Dabei wurde er finanziell von der Preußischen Akademie der Wissenschaften, verschiedenen Vereinen und Privatpersonen unterstützt (Thienemann 1917, S. V). Um sich bei der populärwissenschaftlichen Ausrichtung seiner journalistischen Arbeit intensiver naturwissenschaftlich orientieren zu können und besonders um Zweifeln an seiner Kompetenz entgegenzuwirken, hatte er in den Jahren 1883/84 in Leipzig mehrmals Vorlesungen naturwissenschaftlicher Fächer gehört. So nahm er an Veranstaltungen des Zoologen Rudolf Leuckart (1822-1898) teil und absolvierte im Sommer 1883 ein Praktikum bei dem Anatomen August Rauber (1841-1917), womit er sein wissenschaftlich fundiertes Vorgehen im Bereich der Zellkunde und der Mikroskopie deutlich ausbaute. Diese spezifische Ausbildung und die auf seinen Exkursionen gewonnenen Erkenntnisse boten ihm danach die ersehnte Möglichkeit, den bisherigen Zeitschriftenartikeln größere Publikationen mit Forschungscharakter zur Seite zu stellen. ${ }^{21}$ Im Jahr 1885 arbeitete er schließlich in einem privaten zoologischzootomischen Laboratorium in Hirschberg. ${ }^{22}$

Das Hauptziel seines Engagements war jedoch der Einsatz für die Einrichtung einer festen Forschungsstation für die Süßwasserbiologie. Mit Hilfe privater Spenden und staatlicher Unterstützung aus dem Preußischen Landwirtschaftsministerium konnte Zacharias 1892 schließlich in Plön (Schleswig-Holstein) eine „Biologische Station für Hydrobiologie und Planktonkunde“ als privates Forschungsinstitut eröffnen ${ }^{23}$. Dieses widmete sich erstmals in Deutschland in ähnlicher Intensität der Erforschung von Binnenseen, wie dies schon seit längerem in ozeanischen Stationen der Fall war. Seit 1872 leitete Anton Dohrn in Neapel eine Zoologische Station, die seitens Preußens subventioniert wurde und innerhalb weniger Jahre große internationale Anerkennung erfuhr. Zum Konzept der italienischen Einrichtung zählte der wissenschaftliche Austausch zwischen Gelehrten aller Nationen. Tatsächlich hielten sich zu jener Zeit sehr viele bekannte Personen dort auf. Hierzu zählten nicht nur Zoologen, sondern auch Schriftsteller und Ma-

\footnotetext{
${ }^{20}$ Brief von Haeckel an Zacharias vom 17. Januar 1877, UBK.

${ }^{21}$ Zacharias, O. (1885) Ergebnisse einer zoologischen Untersuchung der beiden Koppenteiche. Hirschberg; Ders. (1886) Ein Ausflug nach den Hochmooren des Isergebirges. Kurze Beschreibung der Thier- und Pflanzenwelt beider Iserwiesen nebst klimatologischen Notizen. Leipzig. Ders. (1886) Ein Spaziergang nach den Seefeldern bei Reinerz. Kurze Beschreibung der Thier- und Pflanzenwelt dieses Hochmoors. Leipzig 1886.

22Vgl. Brief von Zacharias an Haeckel vom 14. Juni 1885, EHH. Möglicherweise wurde dieses Laboratorium von Zacharias selbst unterhalten und Auftragnehmer der bereits erwähnten Forschungsexkursionen.

${ }^{23}$ Landesarchiv Schleswig-Holstein (LASH), Akte Abt. 309, Nr. 12279: ,Akta der königlichen Regierung zu Schleswig betreffend die biologische Station am Plöner See'.
} 
ler. Diese „Erfolgsgeschichte“ vor Augen, erhoffte sich Zacharias mit der Gründung einer Station auf deutschem Boden, die sich zudem auch noch mit der Erforschung von Süßwasser beschäftigen sollte, einen festen Stand im Kreise der Wissenschaft. Er plädierte für die Gleichberechtigung von Salz- und Süßwasserforschung und forderte eine ebensolche Station wie in Neapel - in Höhe der Subvention und Unterstützung, wie auch Anerkennung - für das Süßwasser. Die aus seinen Exkursionen gesammelten Erfahrungen ließen keinen Zweifel daran, daß die Erkenntnisse des Meeres und dessen Lebewesen nicht auf Binnenseen zu übertragen waren.

Den Bau des Stationsgebäudes finanzierte schließlich die Stadt Plön, deren Bürgermeister Kinder Anhänger von Zacharias' Ideen war. ${ }^{24}$ Die technische Ausrüstung für die Laboratoriumsräume der Station wurde von Carl Zeiss Jena gestellt. ${ }^{25}$ Das Haus bot zunächst genügend Platz für das gleichzeitige Arbeiten mehrerer Forscher, hatte einen lichtdurchfluteten Laboratoriumsraum, mehrere Kähne, um die Seenlandschaft zu erkunden und zu beobachten sowie Geräte zum Fang von Forschungsmaterial für die hydrobiologischen Studien. Die Ergebnisse seiner Mitarbeiter und Gäste präsentierte er in der von ihm 1906 ins Leben gerufenen Zeitschrift „Archiv für Hydrobiologie und Planktonkunde“"26, deren Redaktion Zacharias selbst führte. Ein großer Teil der Berichte und Artikel stammen auch aus seiner Feder.

Um die staatlichen Subventionen der Station kämpfte Zacharias stetig. Seinem Antrag aus dem Jahr 1890 folgend, wurde die Einrichtung zunächst sechs Monate mit 750 M gefördert. 1891 bis 1894 erhielt er 1500 M, später 3000 M jährlich, was jedoch die finanzielle Situation der Station nicht sichern konnte. So schreibt Zacharias: „Ich arbeite aus allen Kräften u. erreiche wissenschaftlich viel - wie altbekannt ist. Aber dazu contrastiert die Situation voller Sorgen, in der ich mich befinde, schneidend. "27 Zeitweilig mußte Zacharias die Station als ,völlig mittellos“ einstufen. ${ }^{28}$ Schließlich wurden am 30. Oktober 1895 jeweils 5000 M für die drei darauffolgenden Jahre gewährt, zudem erstmals auch Mittel aus wissenschaftlichen Fonds zugestanden. ${ }^{29}$ In den Folgejahren bemühte sich Zacharias zusätzlich, seitens des Deutschen Fischereivereins, Gelder einzuwerben $^{30}$, da das Fischereiwesen von den in Plön stattfindenden Forschungen profitieren

\footnotetext{
${ }^{24}$ Vgl.: Die Gründung der Biologischen Station in Plön 1888. Sonderdruck aus den Nummern 41 und 42 des Ost-Holsteinisches Tageblatts von 18. und 19. Februar 1931; Eine Erinnerung an Bürgermeister Kinder. Die ersten Anfänge der Biologischen Station in Plön 1888-1891. Ost-Holsteinisches Tageblatt, Nr. 18/19, 1960. (MPI, Zettelsammlung Zacharias).

25 Zacharias, O. (1894) Ueber den wissenschaftlichen Zweck und die praktische Bedeutung der Biologischen Station zu Plön. Plön S. 6. In den Produktionslisten des Carl-Zeiss-Werkes Jena ist diese Schenkung nicht verzeichnet. Allerdings sind mehrere Mikroskope an Zacharias verschickt worden.

${ }^{26}$ Vorgängerzeitschrift war von den Jahren 1894-1905 die ,Forschungsberichte der Biologischen Station zu Plön'.

${ }^{27}$ LASH, Akte Abt. 309, Nr. 12279, Brief von Zacharias an Regierungspräsident, Plön 14. Februar 1894.

${ }^{28}$ LASH, Akte Abt. 309, Nr. 12279, Brief von Zacharias an Regierungspräsident, Plön 4. Oktober 1895.

${ }^{29}$ Ebd.

30 So fungierte Zacharias 1896 in Abstimmung mit dem Deutschen Fischereiverein als Herausgeber der ,Orientierungsblätter für Teichwirte und Fischzüchter', deren Ertrag aus dem Verkauf der Plöner Station zu Gute kommen sollte.
} 
konnte. ${ }^{31}$ Der Verein selbst war bereits vom Ministerium dazu autorisiert worden, die staatlichen Zuwendungen für die Station zu verwalten. ${ }^{32}$

Besonders wichtig für das Fortbestehen der Station war aber Zacharias' Arbeit als Lehrender. Er begann in den Sommermonaten 1909 - aus eigener Initiative, aber mit Zustimmung des Kultusministeriums - mit der Durchführung hydrobiologischer Kurse, die für die Lehrerschaft verschiedener höherer Schulen angeboten wurden. ${ }^{33}$ Seit 1906 verteidigte/propagierte er in seinen Publikationen und während zahlreicher Treffen mit Abgeordneten aus verschiedenen Ministerien (wie seinerzeit Haeckel) die Biologie als Schulfach. ${ }^{34}$ In den letzten Jahren seines Lebens beschäftigte sich Zacharias neben den hydrobiologischen Studien auch mit zytologischen und histologischen Beobachtungen. Die Biologische Station existierte 25 Jahre unter seiner Leitung. ${ }^{35}$

\section{Zoologiegeschichte und Wissenschaftspopularisierung}

Die ausführlichen Anmerkungen zum Briefwechsel ${ }^{36}$ machen deutlich, welch umfassende Themata zwischen Ernst Haeckel und Otto Zacharias im Verlauf von fast 25 Jahren brieflich diskutiert wurden. Bereits in seinem ersten Schreiben an Haeckel erkundigte sich Zacharias nach einer bedeutenden Schrift von Carl Gegenbaur:

„Wie ich höre ist durch Gegenbaurs Arbeit über das Kopfscelet der Selachier" ${ }^{37}$ ein wichtiger Beitrag zur ganzen Descendenafrage geliefert worden. Ist das Buch für unser einen verständlich oder erfordert es großes vergleichendanatomisches Detail?

Ich würde Ihnen für die kurze Beantwortung dieser Fragen sehr dankbar sein. Nach meiner Meinung hat sich jeder, der Anspruch auf wirkliches Verständniß von Welt, Natur u. Menschbeit macht, mit dem Darwinismus so eng zu befreunden wie nur möglich. In diesem Sinne betreibe ich das Studium Ibrer u. Darwins Schriften. Viele Tropfen höhlen den Stein. "as

Haeckel wies in seinem Antwortschreiben daraufhin, dass

„[er] Gegenbaurs Buch über das Kopf-Skelet der Selachier [...] für eine der wichtigsten und geistreichsten [?] Anwendungen der Descendenz-Theorie [bielt], jedoch ist das beherrschte [?] Material so außerordentlich [?]

31 Zacharias, O. (1905) Über die Beziehung der Hydrobiologie zur modernen Fischerei. Bei Gelegenheit d. Landwirtschaftl. Prov.-Ausstellung zu Altona d. Fischzüchtern. Plön.

32 LASH, Akte Abt. 309, Nr. 12279.

33 Zacharias, O. (1909) Ferienkurse in Hydrobiologie und Planktonkunde an der Biologischen Station zu Plön, AHP 1909 (4), S. 267-272.

34 Zacharias, O. (1907) Das Plankton als Gegenstand der naturkundlichen Unterweisung in der Schule. Ein Beitrag zur Methodik des biologischen Unterrichts und zu seiner Vertiefung, Leipzig.

351917 wurde die Station von der ,Kaiser-Wilhelm-Gesellschaft' als Träger übernommen. 1966 wurde sie in ,Max-Planck-Institut für Limnologie' umbenannt und erhielt ein neues Gebäude.

${ }^{36}$ Vgl. 4. Teilkapitel.

37 Gegenbaur, Carl (1872) Untersuchungen zur vergleichenden Anatomie der Wirbelthiere, H. 3: Das Kopfskelett der Sechalier: ein Beitrag zur Erkenntnis der Genese des Kopfskelets der Wirbelthiere. Leipzig: Engelmann.

${ }^{38}$ Brief von Zacharias an Haeckel vom 15. April 1874, EHH. 
schwierig und der Ideengang so schwer zu verfolgen, daß das Buch obne gründliche vergleich. - mater. Studien kaum verständlich ist. ${ }^{69}$

Auch im weiteren Verlauf des Briefwechsels dominieren zunächst embryonale und entwicklungsgeschichtliche Fragestellungen, wobei Zacharias aus der Sicht des Populärwissenschaftlers betonte: „Ich ergreife jede sich auf Descendenztheorie beziehende Novität mit wahrem Heißhunger $u$. suche mir daraus irgend etwas Förderliches zu entwickeln. “40 In der Diskussion zeigt sich ferner, dass besonders die Embryologie/Entwicklungsgeschichte (heute Evo-Devo) - ähnlich der vergleichenden Anatomie und Morphologie - im Fokus der damaligen wissenschaftlichen Auseinandersetzungen stand und die „Entwicklungsgeschichte der Tiere“ als Wissenschaftsdisziplin im Verlaufe ihrer langen Entwicklung zahlreiche Höhen und Tiefen erlebte. Nach einer ersten Blütezeit der Embryologie (die in den Briefen ausschließlich thematisiert ist) und vergleichenden Anatomie, die insbesondere im deutschen Sprachraum auf die Arbeiten von Carl Gegenbaur (1859) und Ernst Haeckel (1866) zurückzuführen ist, folgten schließlich auch hier verschiedene Krisensituationen (Dominanz des Vitalismus etc.). Außerdem deutet sich teilweise schon ein Desinteresse an den Ergebnissen der aufkommenden Vererbungslehre an, zumal im Gegensatz zu biologischen Teildisziplinen wie der Systematik und (Populations-)Genetik es der Embryologie nicht gelang (ähnlich der Morphologie und vergleichenden Anatomie), sich aktiv an der Ausgestaltung der Evolutionsbiologie/Deszendenzlehre zu beteiligen (Junker \& Hoßfeld 2001). Zu dieser speziell deutschen Entwicklung bemerkte der Evolutionsmorphologe Dietrich Starck 1980 mit Blick auf die vergleichende Anatomie und Morphologie:

„, [...] daß der Fortschritt nicht in einer abrupten Aufeinanderfolge neuer Denksysteme bestand, sondern durch das dauernde Nebeneinander parallellaufender Richtungen gekennzeichnet ist. Dabei sind neben vielfachen Divergenzen auch Querverbindungen auf jeder Betrachtungsebene festzustellen. Die historische Betrachtung lehrt, die zeitliche Bedingtheit vieler Meinungen zu erkennen und zugleich die Persistenz alten Gedankengutes, entsprechend der jeweiligen Zeitsignatur, in neuem Gewande nachzuneisen. Verständnis für die jeweilige Problemlage kann auch in den Naturwissenschaften nur gewonnen werden, wenn die historischen Voraussetzungen in die Überlegungen einbezogen werden" (Starck 1980, S. 54).

Charles Darwin hatte in seinem gesamten wissenschaftlichen Werk nie einen direkten Zugang von vergleichend-anatomischer mit entwickelungsgeschichtlicher Forschung angestrebt, Haeckel hingegen einen solchen mit seinen zahlreichen Schriften postuliert und weit über die Grenzen Deutschlands hinaus bekannt gemacht. Um nun im Gefolge von Darwins Origin of Species (1859) zu beweisen, dass die darwinsche Lehre auch hinsichtlich der Embryologie etc. nicht nur hypothetischen bzw. spekulativen Charakter hatte, schenkte man frühzeitig der Frage nach dem Zusammenhang zwischen Phylogenese und Ontogenese besondere Beachtung. Es ist das Verdienst von Haeckel, die vergleichende Anatomie und Entwicklungsgeschichte zu Beweismitteln der Descendenztheorie gemacht zu haben. Ähnlich wie F. Meckel und dessen Anhänger legte auch er das größte (theoretische) Gewicht in seinen Darstellungen auf diese Parallele, welche sich zwischen der Stufenfolge embryonaler Entwicklungsformen und der Reihe niederer

\footnotetext{
39 Brief von Haeckel an Zacharias vom 21. April 1874, UBK.

${ }^{40}$ Brief von Zacharias an Haeckel vom 22. Februar 1875, EHH.
} 
und höherer Tierformen beim Studium der vergleichenden Anatomie und Systematik erkennen ließ. Zu beiden fügte er noch eine dritte Parallele, welche man aus den Ergebnissen der paläontologischen Forschungen gewinnen konnte. Im dreifachen Parallelismus der phyletischen (paläontologischen), biontischen (individuellen) und systematischen Entwicklung sah er eine der größten, merkwürdigsten und wichtigsten allgemeinen Erscheinungsreihen der organische Natur (Haeckel 1866, Bd. II, S. 371ff). Die Erklärung dieser „dreifache(n) genealogische(n) Parallele“ bezeichnete er als das „Grundgesetz der organischen Entwickelung oder kurz das 'biogenetische Grundgesetz"“ (ebd.). Auch in seiner „Natürlichen Schöpfungsgeschichte“ (1868) stellte Haeckel später das Verhältnis von Ontogenie und Phylogenie (Causal-Nexus der biotischen und phyletischen Entwicklung) als wichtigstes und unwiderleglichstes Beweismittel der Deszendenztheorie dar.

Die umfassendste Anwendung des „Biogenetisches Grundgesetz“ (BG), die über mehrere Seiten im Briefwechsel diskutiert wird, unternahm Haeckel dann mit der „Gastraea-Theorie“. Bei der Gastraea handelt es sich um die hypothetische Urform aller vielzelligen Tiere (Metazoa). Sie läßt sich nicht paläontologisch, sondern laut Haeckel nur in der Embryonalentwicklung vieler Tiere als Gastrula-Stadium nachweisen:

„Aus dieser Identität der Gastrula bei Repräsentanten der verschiedensten Thierstämme, von den Spongien bis ₹u den Vertebraten, schliesse ich nach dem biogenetischen Grundgesetze auf eine gemeinsame Descenden z der animalen Pbylen von einer einzigen unbekannten Stammform, welche im Wesentlichen der Gastrula gleichgebildet war: Gastraea" (Haeckel 1872, 1: 467).

Haeckel hoffte mit dieser Theorie den monophyletischen Ursprung aller vielzelligen Tiere nachzuweisen. Falls die beiden primären Keimblätter tatsächlich bei allen Metazoen homolog sind, wie Haeckel postulierte, dann hätte er den frühesten und wichtigsten embryologischen Vorgang, die Entstehung der Keimblätter, evolutionistisch erklärt (Haeckel 1874, 1875). Auch, wenn Haeckels weitgehende Verallgemeinerungen nicht allgemein anerkannt wurden, galt die Embryologie doch bald als unverzichtbares Werkzeug, um ansonsten unsichere Homologien zu erkennen. Mit dem BG schuf Haeckel ein Konstrukt, das noch heute in der wissenschaftlichen Literatur zu finden ist. Die eigentliche Benennung und exakte Formulierung gehen dabei unmittelbar auf ihn zurück, doch war diese dem BG zugrunde liegende Gesetzmäßigkeit schon vorher zahlreichen Forschern bekannt (Junker \& Hoßfeld 2001, S. 118-124).

Verschiedene Interpretationen und Argumentationen zum Darwinismus bilden dann die zweite Säule, die neben der erste - Embryologie - in den beiden ersten Dritteln des Briefwechsels thematisiert wird. Im letzten Drittel treten dann zudem auch verstärkt weltanschauliche und philosophische Probleme (Monismus etc.) in den Vordergrund der Diskussionen.

Der Briefwechsel dokumentiert aber nicht nur diese Ebenen, sondern zeigt nebenbei auch Ebenen der Sprachkultur und des Umgangs miteinander auf, reflektiert verschiedene gesellschaftliche Verhältnisse, Zwänge und dokumentiert bspw. auch den Stand der Haeckelschen Wissenschaft in jener Zeit; schließlich gehörte Otto Zacharias zu den zentralen Haeckel-Popularisatoren jener Epoche. Damit verschmelzen hier Zoologiegeschichte und Wissenschaftspopularisierung des endenden 19. Jahrhunderts. 


\section{Der Briefwechsel ${ }^{41}$}

[1]

\section{Zacharias an Haeckel}

15. April, Gera: 1874.

\section{Hochgeehrter Herr Professor!}

Sie erinnern sich gewiß unserer flüchtigen Begegnung von neulich. Ein glücklicher Zufall fügte es, daß ich Sie vor dem Thüringer Bahnhofsgebäude traf.

Ich glaube ich sagte Ihnen schon da, daß mich die Illustr. Zeitung ${ }^{42}$ beauftragt hätte, eine kurze Biographie von Ihnen zu bringen. ${ }^{43}$ Sie waren so freundlich u. wollten mir Bild u. sonstiges Material zur Verfügung stellen. Ich erneuere nun meine Bitte u. ersuche Sie mir das Versprochene recht bald zuzusenden.

Neulich habe ich fürs Ausland ein Referat über Wigands Darwinkritik geschrieben, ${ }^{44} \mathrm{u}$. Dr. Hellwald ${ }^{45}$ hat mir baldige Veröffentlichung zugesagt. ${ }^{46}$

Ich gedachte auch eine gedrängte Darstellung Ihrer Gasträa-Theorie mit Metschnikow's ${ }^{47}$ Ausstellungen zu bringen und möchte Sie bitten mir gelegentlich zu sagen, ob Sie mittlerweile Ihre Meinung modificirt haben, oder nicht.

Neuerdings hat sich auch Claus ${ }^{48}$ über Ihre Typentheorie vernehmen [?] lassen. Ist Claus, den ich nicht weiter kenne, berücksichtigungswerth?

${ }^{41}$ Die 46 Briefe von Otto Zacharias an Ernst Haeckel sind Bestandteil des Archivs des EHH in Jena. Von den Gegenbriefen Ernst Haeckels an Otto Zacharias konnten nur sechs Schreiben im Bestand der Universitätsbibliothek Kiel ermittelt werden. Trotz umfangreicher Recherchen liessen sich keine weiteren Schreiben auffinden, so dass von dem Verlust einiger Schreiben ausgegangen werden muss. Die Brieftexte wurden unter Beibehaltung der originalen Orthographie und Interpunktion transkribiert und entsprechen einer vollständigen Wiedergabe.

42 [Leipziger] Illustrierte Zeitung. 1843-1934. Leipzig: J. J. Weber.

43 Zacharias, Otto (1874): Ernst Heinrich Häckel. Illustrirte Zeitung, LXIII. Bd., Nr. 1630 (26. Sept. 1874), S. 235-238.

44 Wigand, Albert (1821-1886), Botaniker. Wigand studierte in Marburg Naturwissenschaften und Philologie, in Berlin und Jena Botanik und Zoologie. Er wurde 1846 promoviert. Wigand war ab 1851 ao. Prof., ab 1861 o. Prof. sowie Direktor des Botanischen Gartens in Marburg. Er veröffentlichte u.a. die Schrift „Die Genealogie der Urzellen als Lösung des Descendenzproblems“ (1872) sowie das dreibändige Werk: „Der Darwinismus und die Naturforschung Newtons u. Cuviers. Beiträge zur Methodik der Naturforschung". Braunschweig: Vieweg. (1874).

${ }^{45}$ Hellwald, Friedrich Anton Heller von (1842-1892), Geograph, Anthropologe, Kunsthistoriker. Er wurde Mitglied der Wiener Geographischen Gesellschaft, und war 1872-81 Redakteur der Zeitschrift „Das Ausland“,. Als Anhänger Darwins und Haeckels, zahlreiche kulturwissenschaftliche Veröffentlichungen. Zum Verhältnis Hellwald-Haeckel vgl. auch Briefwechsel zwischen Ernst Haeckel und Friedrich von Hellwald. Ulm: 1901, Kerler.

46 Zacharias, Otto (1874): Zur Kritik des Darwinismus. Das Ausland, 47. Jg., Nr. 28, 13. Juli 1874, S. 541548.

47 eigentl. Metchnikoff, Elia (1845-1916), russischer Bakteriologe. Studierte Naturwissenschaften in Charkow und begab sich von 1864-67 auf Studienreise durch Deutschland, wo er u.a. in Gießen bei Leuckart forschte. Metchnikoff betrieb embryologische Studien auf Helgoland, in Neapel und Triest. Er wurde 1868 promoviert und erhielt 1870 eine Professur für Zoologie in Odessa. Hier gründete er 1886 ein Privatlabor, welches später das erste russische bakteriologische Institut für Infektionskrankheiten wurde. Metchnikoff ging 1887 nach Paris, war von 1888-1905 Chef de Service und von 1905-1916 stellvertretender Direktor am Institut Pasteur. Er erhielt 1908 den Nobelpreis. 
Wie ich höre ist durch Gegenbaurs ${ }^{49}$ Arbeit über das Kopfscelet der Selachier ${ }^{50}$ ein wichtiger Beitrag zur ganzen Descendenzfrage geliefert worden. Ist das Buch für unser einen verständlich oder erfordert es großes vergleichend-anatomisches Detail?

Ich würde Ihnen für die kurze Beantwortung dieser Fragen sehr dankbar sein. Nach meiner Meinung hat sich jeder, der Anspruch auf wirkliches Verständniß von Welt, Natur u. Menschheit macht, mit dem Darwinismus so eng zu befreunden wie nur möglich. In diesem Sinne betreibe ich das Studium Ihrer u. Darwins Schriften. Viele Tropfen höhlen den Stein. Ich habe mit Genugthung bemerkt, daß ich in descendenztheoretischen Dingen manchmal ebenso leidlich orientirt war, wie Prof Leuckart ${ }^{51}$. Ich verschaffe mir aber auch die geringste Broschüre in der ich etwas neues über die Angelegenheit wittere.

Hochachtungsvoll u. ergebenst

Dr. Otto Zacharias

Redakteur der Geraer Zeitung. ${ }^{52}$

[2]

Haeckel an Zacharias

Jena 21 April 74

Verehrter Herr Doctor!

Beifolgend sende ich Ihnen die gewünschte „Introduction biographique“ welche Charles Martins $^{53}$ (ein sehr denkender Naturforscher, und in Frankreich einer der überzeugtesten

48 Claus, Carl Friedrich (1835-1899), Zoologe. Nach einen Studium der Medizin, Mathematik und Zoologie wurde Claus 1857 promoviert und habilitierte sich 1859 in Gießen für Zoologie. Ein Jahr später wurde er als ao. Prof. für Zoologie nach Würzburg berufen, es folgten Prof. in Marburg, Göttingen und ab 1873 in Wien. Hier wurde Claus als Ordinarius der Zoologie Chef des Zoologisch-anatomischen Museums und leitete die von ihm gegründete Zoologische Station in Triest. Er veröffentlichte u.a. Grundzüge der Zoologie (1868).

49 Gegenbaur, Carl (21.8.1826-14.6.1903), Anatom, Zoologe. Er studierte 1845 Naturwissenschaften u. Medizin in Würzburg und promovierte 1851. Nach der 1854 Habilitation in Würzburg wurde er 1855 ao. Prof. der Zoologie, ab 1858 o. Prof. der Anatomie u. Zoologie in Jena, ab 1873 in Heidelberg. Gegenbaur wurde durch seine vergleichend-anatomische Untersuchungen bekannt. Er gründete 1874 das „Morphologische Jahrbuch“. Auf Betreiben von Gegenbaur wurde Haeckel in Jena Zoologieprofessor; die jahrzehntelange Freundschaft zerbrach später an den unterschiedlichen Auffassungen über Haeckels „Welträthsel”.

${ }^{50}$ Gegenbaur (1872), wie Anm. 36.

${ }^{51}$ Leuckart, Rudolf (1822-1898), Mediziner, Zoologe, Studium der Naturwissenschaften und Medizin, 1845 Promotion in der Medizin, 1847 Habilitation in der Zoologie, 1850 Prof. für Zoologie in Gießen, 1870 Lehrstuhl für Zoologie in Leipzig, Begründer der modernen Parasitologie, Mitglied verschiedener wissenschaftlicher Akademien.

52 Fürstliche Reuß-Geraer Zeitung: Tageblatt u. Anzeiger, Amtsblatt, 1866-1918.

${ }_{53}$ Martins, Charles Frédéric (1806-1889), französischer Naturforscher u. Mediziner. Martins promovierte 1834 in Paris, erhielt 1846 eine Professur für Botanik in Montpellier und war von 1851-1880 Direktor des dortigen Botanischen Gartens. Zahlreiche wissenschaftliche Reisen und Expeditionen führten ihn u.a. nach Spitzbergen (1838-1840), Algerien, Mittelasien sowie in die Alpen und Pyrenäen. 
Darwinisten) zur französischen Übersetzung meiner „Natürl. Schöpfungsgesch. “54 verfaßt hat. Ferner schicke ich Ihnen das Schriftchen von León Dumont ${ }^{55}$ und einen Artikel aus Leip. Illustr. Zeitg., den ein früherer Zuhörer von mir, Dr. Hausmann [?] verfaßt hat. ${ }^{56}$ Die beiden Artikel von Martins und Hausmann erbitte ich mir gelegentlich zurück. Hingegen können Sie das Schriftchen von Dumont, der mir mehrere Exemplare geschickt hat, behalten, ebenso die beiden beiliegenden Photographien. [2] Was die Gasträa-Theorie betrifft, so bin ich überzeugt, damit einen guten Grund gelegt zu haben, und baue auch schon beständig darauf fort. Zuerst hatte ich die Grundzüge derselben in der „Philosophie der Kalkschwämme“57 veröffentlicht, die ich Ihnen beilege. Von dem neulich erschienen Separat-Aufsatz besitze ich nur noch das beifolgende Exemplar, welches ich daher zurückerbitte. Dieser Aufsatz hat unter meinen speciellen Fach-Collegen mehr Aufregung verursacht, als alle meine übrigen Schriften. Die von der DescendenzTheorie überzeugten Anatomen und Zoologen (Gegenbaur, Hasse ${ }^{58}$, O. Schmidt ${ }^{59}$, Max Schultze ${ }^{60}$, Weismann ${ }^{61}$, Eilhard Schulze ${ }^{62}$ ) halten denselben für die wichtigste meiner zoolog. Arbeiten. Anderseits sind die Mezzo-Darwinisten (Leuckart, Claus. etc.) sehr

\footnotetext{
54 frz. Übersetzung der Nat. Schöpfungsgeschichte: Historie de la creation des etres organises d'après les lois naturelles. Paris: Schleicher.

${ }^{55}$ Dumont, León (1873): Haeckel et la théorie de l'évolution en Allemangne. Paris: Bailliére; Dumont, León (1837-1876), frz. Advokat und Schriftsteller.

${ }^{56}$ Der o.g. Artikel von Hausmann war in der Illustrirten Zeitung von 1874 nicht nachweisbar.

57 Haeckel veröffentlichte einen Auszug aus dem ersten Band seiner dreibändigen „Monographie der Kalkschwämme“ als Sonderdruck: „Biologie der Kalkschwämme“, welcher aber nur den o.g. vierten Abschnitt „Philosophie der Kalkschwämme“ enthält und während die „Biologie der Kalkschwämme“ den gesamten I. Band der Kalkschwammonographie umfaßt. Vgl. auch Haeckel, Ernst (1872): „Philosophie der Kalkschwämme“. In: Haeckel, Ernst (1872): Monographie der Kalkschwämme. Vierter Abschnitt, siebentes und achtes Kapitel, S. 453-483.
}

${ }^{58}$ Hasse, Karl (1841-1922), Anatom. Medizinstudium in Göttingen und Kiel, 1866 Promotion, 1867 Prosektor in Würzburg. Hasse wurde 1873 ao. Prof. für Anatomie und Direktor des anatomischen Institutes in Breslau, wo er bis 1913 lehrte. Arbeiten über Nervenanatomie, Sinnesorgane bei Tieren und vergleichend anatomische Studien. Beiträge zur allgemeinen Stammesgeschichte der Wirbeltiere (1883).

59 Schmidt, Oskar (1823-1886), Zoologe. Schmidt studierte zunächst Mathematik und Physik in Halle, beschäftigte sich aber zunehmend mit Zoologie. Nach seiner Promotion 1846 habilitierte er sich 1847 für Zoologie in Jena und wurde hier ao. Prof. für Zoologie und Direktor des Zoologischen Museums. 1855 erhielt er einen Ruf nach Krakau, 1857 nach Graz. 1872 wurde Schmidt Ord. für Zoologie in Straßfurt. Er veröffentlichte u.a. Handbuch der vergleichenden Anatomie (1849).

${ }^{60}$ Schultze, Max (1825-1874), Anatom. Studium der Medizin in Greifswald und Berlin, 1849 Promotion und 1850 Habilitation. Er wurde 1854 ao. Prof. für Anatomie in Halle, 1859 o. Prof. und Direktor der Anatomischen Anstalt der Universität Bonn. Er förderte die mikroskopische Forschung und begründete 1865 das Archiv für mikroskopische Anatomie.

${ }^{61}$ Weismann, August (1834-1914), Zoologe, Evolutionsbiologe. W. studierte 1852-56 Medizin in Göttingen und war anschließend als Assistenzarzt in Frankfurt tätig. Er widmete sich 1860 zunehmend zoologischen Studien, u.a. in Paris und in Göttingen. W. erforschte in den folgenden Jahren die Embryonalentwicklung bei Insekten und habilitierte damit 1863 in Freiburg/Br., wo er 1865 a.o. Prof. und 1873 Ordinarius für Zoologie wurde. Weismann wurde durch seine Arbeiten zu einem Begründer von Vererbungs- und Evolutionstheorien.

62 Schulze, Franz Eilhard (1840-1921), Zoologe. Studium der Medizin und der Naturwissenschaften in Rostock und Bonn, Promotion und Habilitation 1863, 1865 wurde er Prosektor am Anatomischen Institut, 1871 o. Prof. der Zoologie. S. erhielt 1873 einen Ruf nach Graz, 1884 nach Berlin. S. beschäftigte sich mit Anatomie und Entwicklungsgeschichte der niederen Tiere. Mitglied der Preußischen Akademie der Wissenschaften. S. legte im Auftrag der Preuß. Akademie ein Verzeichnis aller lebenden Tierarten an: Das Thierreich $1897 \mathrm{ff}$. 
wenig davon erbaut, und die Antidarwinisten ganz außer sich! [3] Mecznikoffs Angriffe (die ich bald gelegentlich widerlegen werde) sind sehr schwach; viel gefährlicher erscheinen die (mir sehr unerwartet gekommenen) Angriffe von Claus, bei denen jedendoch der Neid eine große Rolle spielt (wie überhaupt bei deutschen Collegen vielfach!) Claus ist offenbar von seinem Lehrer Leuckart inspirirt. Beide möchten zwar jetzt mittelst der Descendenz-Theorie (die sie anfangs lange für eine „unbegründete Hypothese“ hielten!) Resultate erzielen, und empfinden immer tiefen Kummer, wenn Anderen das gelingt!

- Gegenbaurs Buch über das Kopf-Skelet der Selachier halte ich für eine der wichtigsten und geistreichsten [?] Anwendungen der Descendenz-Theorie, jedoch ist das beherrschte [?] Material so außerordentlich [?] schwierig und der Ideengang so schwer zu verfolgen, daß das Buch ohne gründliche vergleich. - mater. Studien kaum verständlich ist.

[4] Bastians „offener Brief“ an mich haben Sie wohl gesehen? Die principiellen Gegensätze offenbaren sich darin in erfreulichster Weise. Ganz infam ist nur der Schluß, wo Bastian (seine eigenen Worte verleugnend!) mir eine dreiste Unwahrheit vorwirft und dabei selbst lügt! Ich werde darauf in der V. Auflage antworten, die im Herbst erscheinen wird, und die ich Ihnen zusenden werde.

Da Sie vielleicht die Notiz in der Wiener „N. fr. Presse“ über die „Hkl-Feier“ interessirt, lege ich Sie [sic] Ihnen mit der Bitte um Rückgabe bei. - Hoffentlich besuchen Sie mich einmal in diesem Sommer, wenn auch die Jena-Geraer Bahn leider erst im Bau ist!

Hochachtungsvoll

Mit freundlichsten Grüßen

Ihr ergebenster Haeckel

[3]

Zacharias an Haeckel

Gera am 10. Juni 74.

Hochverehrter Herr Professor! -

Die bewußte biographische Skizze wird innerhalb der nächsten 14 Tage in der Illustr. Zeitung erscheinen. ${ }^{63}$ Der Holzschnitt ist bereits fertig.

Für die beiden Photographien u. für die Schrift von Léon Dumont sage ich Ihnen meinen herzlichsten Dank.

Ich weiß nicht, ob Sie bereits wissen, daß Sie in den letzten Tagen paarmal angegriffen worden sind. Einmal in der Nationalzeitung von einem gewissen Sigismund; dann aber auch in der Kölnischen $\left(\mathrm{N}^{\circ}=157\right)$ von einem, der unter der Chiffre NP schreibt. NP wirft Ihnen „Halbwissen und Mangel an philos. Geiste“vor und stellt in seinem nächsten Artikel eine „,ausführliche Analyse Ihrer natürl. Schöpfungsgeschichte“ in Aussicht. ${ }^{64}$

\footnotetext{
${ }^{63}$ Vgl. Anm. 42.

${ }^{64}$ Entsprechende Zeitungsartikel konnten nicht ermittelt werden.
} 
[2] Früher schrieb Ratzel ${ }^{65}$ unter diesem NP Zeichen, aber der ist jetzt in Nordamerika u. wird also wohl kaum der Autor des Artikels sein. Ueberdies hat er sich in den Wandertagen eines Naturforschers ${ }^{66}$ über Ihre Bestrebungen ganz anders ausgesprochen. Aber möglich ist Alles.

Claus' Kritik der Gasträatheorie habe ich nun auch gelesen. ${ }^{67}$ Aber ich bin, wie ich gern gestehe, noch lange nicht damit fertig, weil ich mir die Bekanntschaft mit dem zoologisch. u. vergl. anatom. Detail erst nach u. nach verschaffen kann. Soviel sah ich indessen, daß Claus ein ganz anderer Kritiker ist, als das Gros Ihrer Fachgenossen, deren Nörgelein lediglich vom Neide u. der Mißgunst herrühren.

Die Art u. Weise wie Claus Ihre Ansicht von der Entstehung des radiären und bilateralen Typus kritisirt, hat in der That etwas Packendes u. Ueberzeugendes für mich u. ich habe ein großes Verlangen eines Tages zu lesen oder zu hören, wie Sie ihn [3] durch Ausführung neuer Argumente ins Enge treiben werden.

Seine Ausführung über den Coelentroismus, betreffs dessen er ganz die Wege Leuckarts einschlägt - haben mich weniger überzeugt. Diese Frage scheint mir doch eine der zartesten (?) und schwierigsten der vergl. Anatomie zu sein.

Ich werde nur noch bis zum 1. Juli hier in Gera sein. Der Verleger des Liegnitzer Stadt$\underline{\text { blattes }}^{68}$ (6000 Abonn.) hat mich mit 1300 rf. engagirt u. ich leiste im pecuniären Interesse diesem Anerbieten Folge. Auf diese Weise lerne ich einmal Schlesien kennen u. genüge auch nebenbei meinem Wandertriebe. Eigentlich will man mich gar nicht ziehen lassen - aber ich gehe doch.

In der Hoffnung früher oder später etwas direkt von Ihnen zu vernehmen, verbleibe ich, hochverehrter Herr Professor, mit ergebenstem Gruße

Ihr Dr. Otto Zacharias

[4]

Zacharias an Haeckel

Liegnitz am 17. Juli. 1874. Freitag.

Hochverehrter Herr Professor! -

Ich bin nun nach Schlesien übergesiedelt u. versuche hier mein Heil mit der Redaktion des hiesigen Stadtblattes. Ich glaube aber es geht auf die Dauer nicht. Man lebt hier unter Hottentotten. Von Bildung u. Gesinnung ist kaum die Rede. Die Hälfte der Einwohner sind Adlige u. Juden. Zudem ist die Gegend ein einziger großer Sumpf. Die

\footnotetext{
65 Ratzel, Friedrich (1844-1904), R. arbeitet zunächst als Apotheker, studierte ab 1866 Naturwissenschaften in Karlsruhe und Heidelberg und wurde 1868 promoviert. R. arbeitete zwischen 1869-70 und 1772-75 als Reisekorrespondent für die „Kölnische Zeitung“ und schrieb Berichte aus Süditalien, den USA, Mexiko und Kuba. 1875 habilitierte er sich in München und erhielt dort eine ao. Professur an der TH. 1886 erhielt R. einen Ruf nach Leipzig, wo er bis 1904 lehrte. Wichtigste Werke: Anthropo-Geographie (1882-91), Völkerkunde (1885-88), Politische Geographie (1897).

${ }^{66}$ Ratzel, F. (1873): Wandertage eines Naturforschers. Leipzig: Brockhaus.

${ }^{67}$ Claus, C. (1874): Die Typenlehre und E. Haeckel's sog. Gastraea-Theorie. Wien: Mainz.

${ }^{68}$ Liegnitzer Stadtblatt. Liegnitz: Krumbholz. 1836-1886.
} 
Menschen, vorzüglich die Weiber sind dürre u. krüppelhaft. Lebensfreude existirt nicht. Ich weiß u. begreife nicht wie das stattliche Preußen zu so einer Provinz kommt! Schlesien gehört unbedingt hinunter an die Militärgrenze! -

Vergessen Sie das eben Gelesene! Der Hauptgrund dieser Zeilen war der - mich bei Ihnen wegen der Verzögerung zu entschuldigen, die der Artikel für die Illustrirte Z. erfahren hat. Er wird aber in den nächsten 14 Tagen - 3 Wochen erscheinen. Ich hatte zuviel mit den neuen hiesigen Verhältnissen zu thun. Nun wird eher Luft u. Licht für das Gedeihen anderer Arbeiten! -

Ist das neue Werk über Entwicklungsgeschichte ${ }^{69}$ bereits erschienen? Sie versprachen mir ein Exemplar zuzusenden u. ich versuche Sie an dieses Versprechen zu erinnern, indem ich die ergebenste Bitte um Zusendung des betreff. Buches von dieser Stelle ausspreche.

Im Auslande (neueste Nummer) habe ich Wigands Buch ${ }^{70}$ über oder vielmehr contra Darwin kritisiert. ${ }^{71}$

Soviel ich von meinem Standpunkte aus für die neue u. vernunftgemäße Lehre wirken kann - soviel geschieht von meiner Seite.

Aus den Zeitungen erfuhr ich, daß Sie nach Bonn, wenn ich nicht irre, übersiedeln sollten. Meine beste Gratulation zu dem Verbleiben in Jena. Ich kann mir Jena garnicht ohne Sie, verehrter Herr Professor, denken.

Mit ergebenstem Gruße Zacharias

[5]

Zacharias an Haeckel

Gera am 29. Juli. 74

Hochgeehrter Herr Professor! -

Die Ahnung von wegen meines kurzen Verbleibens in Liegnitz hat mich nicht betrogen. Ich habe meine dortige Position quittirt und bin bis auf weiteres wieder in Gera. So lange bis ich keine andere Redakteurstelle habe, muß ich frei herumliterarisiren.

Ich habe die Muße nun gleich dazu benutzt, um den bewußten Artikel über Sie u. Ihre Thätigkeit fertig zu machen. Ich möchte nur noch wissen, ob ich am Schlusse desselben noch Einiges über Ihr neues Werk ${ }^{72}$ sagen soll. Da ich Inhalt u. Tendenz desselben nicht genügend kenne, wäre mir ein authentischer Wink sehr willkommen.

\footnotetext{
${ }^{69}$ Haeckel, Ernst (1874): Anthropogenie oder Entwickelungsgeschichte des Menschen. Leipzig: Engelmann.

70 Wigand, Albert (1874): Der Darwinismus und die Naturforschung Newtons u. Cuviers. Beiträge zur Methodik der Naturforschung. Braunschweig: Vieweg. Die Rezension von Zacharias 13. Juli 1874 im Ausland nicht ermittelbar.

71 Vgl. Anm. 46.

72 Vgl. Anm. 69.
} 
Ferner würde ich Ihnen sehr verbunden sein, wenn Sie die Güte hätten und mir gelegentlich sagten, wo sich Prof. A. Wigand, der Antidarwinist befindet. Ich glaube in Marburg (?) [2]

Verschiedene Leute, auch Prof. Leuckart meinten, daß meine Recension im Auslande vom 13. Juli viel zu lang gewesen sei. Indessen läßt sich doch grade an einem derartigen Buche das Widersinnige der Annahme von Schöpfungsakten etc. etc.[?] recht gut zeigen. Man schreibt ja auch im „Auslande“ mehr für das gebildete Laienpublikum als für die Fachleute und den Laien kann nach meiner Ansicht nicht oft genug die Notwendigkeit der von Darwin etc. gemachten Annahmen und Schlußfolgerungen verdreirt werden.

Sie beehrten mich vor einiger Zeit mit dem Auftrage über Ihr neues Werk in der Illustr. Z. $\mathrm{zu}$ referiren. ${ }^{73}$ Ich warte sehnlichst auf das Erscheinen der Entwicklungslehre. Ich schrieb auch Dr. v. Hellwald, ob er geneigt sein würde, ein eingehendes Referat von mir in seiner Zeitschrift aufzunehmen u. suchte meiner Offerte dadurch Nachdruck zu geben, daß ich sagte, Sie hätten mir bereits den Wunsch ausgedrückt, daß [3] Sie das Werk nach seinem Erscheinen bald u. ausführlich besprochen wissen möchten.

Heute schreibt mir nun Dr. Hellwald sehr freundlich u. sagt mir, daß ihm selber die Besprechung von Ihnen, geehrter Herr Professor, übertragen worden sei u. daß er erst bei Ihnen anfragen wolle, ob er oder ich den betreff. Artikel schreiben solle.

Ich habe ihm umgehend geschrieben, daß von einem solchen Wettbewerbe gar keine Rede sein könne, da es selbstverständlich sei, daß der bewährte u. bekannte Redacteur des Auslandes vor einem jungen Anfänger den Vorrang behaupte.

Ich habe mich schon selbst bei Dr. v. Hellwald entschuldigt u. ich thue es Ihnen gegenüber nochmals. Es wäre mir außerordentlich unlieb, wenn ich in den Verdacht geriethe, in dieser Weise Jagd auf fette u. pikante Artikel zu machen.

Der Abdruck des Artikels in der Illustr. Z. wird nun wohl mit dem Erscheinen [4] Ihres Werkes zusammenfallen. Ich halte diesen Umstand, der durch die Verzögerung herbeigeführt worden ist eher für günstig als für nachtheilig.

Mit hochachtungsvollem und ergebenstem Gruße Otto Zacharias Gera, Roßplatzgäßchen No=9.

[6]

Zacharias an Haeckel

Görlitz 26. Oct. 74

Geehrtester Herr Professor!

Dr. v. Hellwald schickte mir heute einen Brief, der die Aufforderung enthielt, Ihre Anthropogenie im „Auslande“ zu besprechen. Ich komme diesem Ansuchen mit Vergnügen nach u. werde in möglichst kurzer Zeit ein Artikel zu Papier bringen. Dr. v. Hellwald wünscht indessen nur die Hauptpunkte des Buches hervorgehoben zu haben u.

${ }^{73}$ Entsprechender Gegenbrief von Haeckel war nicht auffindbar. 
dieser Umstand ist es, der mich veranlaßt, diese Zeilen an Sie zu richten, verehrtester Herr Professor! -

Hauptpunkte - ! Was heißt in diesem Falle Hauptpunkte; man kann darüber debattiren was in Ihrer Darlegung Haupt- oder Nebensachen sind.

Damit mein Referat keinen zu laienhaften Eindruck macht, wollte ich mir die Freiheit nehmen, Ihnen zu sagen, [2] was mir als das hauptsächlich Hervorzuhebende in ihren Deduktionen erscheint.

Die ersten 19 Vorträge beschäftigen sich, wie mir dünkt, damit: den Begriff des Wirbelthieres aufzustellen u. den Nachweis zu führen, daß die Keimesgeschichte der Menschen der Aufstellung dieses Begriffes keine negative Instanzen entgegensetzt. Die Ontogenie des Amphioxus u. der Ascidie, als thatsächlicher Nachweis für die Continuität der phylogenetischen Entwicklung scheint mir in der ersten Hälfte des Buches der wichtigste Punkt zu sein. Der wäre also besonders zu betonen u. auf die daraufbezügliche Darlegung müßte eine abermalige kurze Erörterung über die Nothwendigkeit der Annahme der Descendenztheorie folgen.

Der zweite Theil des Buches beschäftigt sich mit der historischen Aufeinanderfolge der Organsysteme u. hier scheint mir es hauptsächlich darauf anzukommen, daß man in dem Referate auf die Wichtigkeit der Keimblättertheorie u. die der vergleichenden Embryologie hinweist.

Habe ich den Inhalt des Buches so richtig verstanden? Dr. v. Hellwald will mir nur 4-5 Spalten einräumen u. auf einem so kleinem Raum kann mir nur das Allernöthigste referiren.

[3) Das Curriculum vitae in der Illustr. Zeitung ist bedeutend gekürzt u. verändert worden. ${ }^{74}$ Ich hatte Ihre Stellung den Fachgenossen gegenüber geschildert u. gelegentlich auch auf Bastian ${ }^{75}$ angespielt. Der Redacteur Metzsch ${ }^{76}$ fand diese Schilderung nicht „objektiv“" genug u. strich sie fort.

Bastian hat ja jetzt wieder einen Darm mit Sägespänen gefüllt u. das Machwerk für Wurst ausgegeben. Schöpfung oder Entstehung, heißt glaube ich das Buch, was bei Costenoble erschienen ist. Ich habe das Vorwort gelesen u. im Inhalt geblättert. ${ }^{77}$ Die Gedanken, die er äußert, tanzen mir durcheinander, wie ein Haufen Derwische.

Dr. v. Hellwald habe ich vor einiger Zeit einen Artikel über die Blutsverwandtschaft der Typen zugesandt, wo ich in möglichst populärer Sprache die Gasträatheorie u. ihre Consequenzen auseinander gesetzt habe. ${ }^{78}$

\footnotetext{
74 Vgl. Anm. 43.

75 Bastian, Adolf (1826-1905), Ethnologe. Bastian kam 1851 als Schiffsarzt nach Australien, reiste 1859 um die Welt und gab 1860 als Ergebnis seiner ethnologischen Beobachtungen sein dreibändiges Werk „Der Mensch in der Geschichte" heraus. Er gründete 1868 das Berliner Völkerkundemuseum und wurde Dozent für Völkerkunde an der Universität Berlin. Haeckel hatte in seiner 1868 erschienen „Natürlichen Schöpfungsgeschichte“ die Ansichten Bastians kritisiert und lächerlich gemacht, worauf dieser ebenfalls mit Polemik erwiderte.

${ }^{76}$ Metzsch, Franz (1834-1908), trat nach dem Studium in Halle und Berlin im April 1860 in die Verlagsbuchhandlung von J.J. Weber in Leipzig ein. Metzsch war ab 1865 Redakteur, nach dem Tode Webers, von 1880 bis 1908 verantwortlicher Redakteur der Illustrierten Zeitung.

77 Bastian, Adolf (1875). Schöpfung oder Entstehung. Jena: Costenoble.

78 Artikel von Zacharias im „Ausland“ nicht ermittelbar.
} 
Hier in Görlitz befinde ich mich recht wohl. Kein Vergleich mit Liegnitz, aber wirklichen Drang nach Aufklärung findet man auch hier nicht. Die $\underline{\text { Herrnhuter }}^{79}$ haben hier zu sehr gehaust.

[4] Ich habe mir erlaubt, Ihnen einige Exemplare des von mir redigirten Blattes ${ }^{80}$ zu senden. Der Leitartikel Glaube u. Wissenschaft ${ }^{81}$ hat mir die Feindschaft aller hiesigen Frommen eingetragen u. etliche Herrn verließen den Stammtisch, als ich wieder in die gewohnte Kneipe kam.

Unterdessen habe ich auch Gelegenheit gefunden ganz praktisch Ontogenesis u. Entwicklungsgeschichte zu treiben - ich habe mich verheirathet $u$. zwar mit einer recht anständigen Frau, die mir das flotte Junggesellenleben noch einigermaßen gestattet. Sie verzeihen mir diese nicht zur Sache gehörende Mittheilung - aber da ich in Ihnen nicht bloß den scharfsinnigen Gelehrten sondern auch den guten Vater verehre, glaube ich Ihnen die obige Privatmittheilung machen zu dürfen. Ich habe das hübsche Bild noch nicht vergessen, wo sie [sic] in Ihrer Studirstube Ihre zwei Knaben ${ }^{82}$ unterm Tische hatten u. ungestört lasen. Das war bei Gelegenheit meines ersten Besuches in Jena.

Mit ergebenstem Gruße O. Zacharias

[7]

Zacharias an Haeckel

Görlitz d. 3 Febr. 1875.

Geehrtester Herr Professor!

Soeben sendet mir Dr. v. Hellwald den bewußten Artikel über die Anthropogenie zurück - mit der Bemerken, daß derselbe viel, viel zu lang sei u. daß er mit langen Aufsätzen gegenwärtig reich u. überreich versehen sei.

Mein Artikel ist allerdings ungefähr 6-7 Aushandspalten groß - aber ich brachte es in der That nicht fertig über ein Werk von 700 Seiten mich kürzer zu fassen.

Der Aufsatz ist ziemlich gründlich durchgearbeitet u. es täte mir leid, wenn ich ihn ganz umsonst geschrieben hätte. Ich möchte Sie nun fragen, geehrtester Herr Prof., ob Sie mir nicht die Adresse einer wissenschaftl. Zeitschrift angeben könnten, in der der Artikel möglicherweise Aufnahme fände.

Er ist, wie gesagt, fürs Ausland u. daher nicht durchaus populär geschrieben.

[2] Für den Fall daß Sie ihn erst sehen wollten, bevor sie ihn irgend Jemand anbieten, würde ich Ihnen denselben zuschicken.

\footnotetext{
79 Herrnhuter, auch Herrnhuter Brüdergemeinde. Religionsgemeinschaft, welche auf mährische Brüder zurückgeht, die sich auf dem Gut des Grafen N.L. von Zinsendorf 1722 ansiedelten. Sie nannten diese Kolonie in der Nähe von Löbau (Kreis Dresden) Herrnhut.

80 Eventuell sind hier die Görlitzer Nachrichten: Anzeiger und Tageblatt für Görlitz und Umgebung gemeint, welche von 1874-76 erschienen.

81 Artikel von Zacharias nicht ermittelbar.

82 Irrtum Zacharias'. Gemeint sind hier der Sohn Walter und die Tochter Elisabeth Haeckel.
} 
Die Illustrirte Ztg. wird in ihrer nächsten oder übernächsten Nummer, den dritten Artikel über die Anthropogenie bringen. Die zwei ersten werden Ihnen im Abdruck zugegangen sein. ${ }^{83}$

Um gelegentliche freundliche Antwort bittet

Ihr ergebener Otto Zacharias

Görlitz, Mittelstr. No. 9I

[8]

Zacharias an Haeckel

Görlitz d. 6. Febr. 75

Mittags

Geehrtester Herr Professor! -

Gleichzeitig mit dem Ihrigen erhielt ich einen Brief von Dr. v. Hellwald, worin er um Wiederzusendung des in erster Instanz verworfenen Artikels bittet. Er schreibt, daß er ihn unterzubringen suchen werde, wenn er 7 Spalten nicht überfülle.

Es wäre mir nun sehr lieb, wenn Sie Ihr Gewicht mit in die Wagschaale würfen u. an Dr. v. Hellwald umgehend einige Zeilen sendeten, worin Sie ihn um bestimmte Aufnahme des betreff. Artikels ersuchen. Denn es kann leicht sein daß mein Aufsatz 8-9 Spalten ausmacht u. dann wäre ich wieder auf dem alten Fleck. Für die sonstigen Mittheilungen sage ich Ihnen, meinen besten u. ergebensten Dank.

Hochachtungsvoll grüßend

Dr Otto Zacharias

[9]

Zacharias an Haeckel

Görlitz d. 22. Feb. 75.

Geehrtester Herr Professor! -

Ich habe mir die betreff. Nummer des Berl. Centralbl. verschafft u. mich mit der Rauberschen Entdeckung vertraut zu machen gesucht. Ich erlaube mir, Ihnen meine Reflexionen über die Gastrula des Hühnchens zu unterbreiten u. bitte Sie höflichst, mich gelegentlich einer Antwort auf diese Zeilen würdigen zu wollen. Ich ergreife jede sich auf Descendenztheorie beziehende Novität mit wahrem Heißhunger u. suche mir daraus irgend etwas Förderliches zu entwickeln.

83 Zacharias, Otto (1875): Ernst Häckel's „Anthropogenie“. Illustrirte Zeitung, LXIV. Bd., Nr. 1646, S. 42; Nr. 1647, S. 68-69; Nr. 1650, S. 119; Nr. 1651; S. 140-142. 
Ich verstehe Rauber ${ }^{84}$ so wie Figur zeigt:

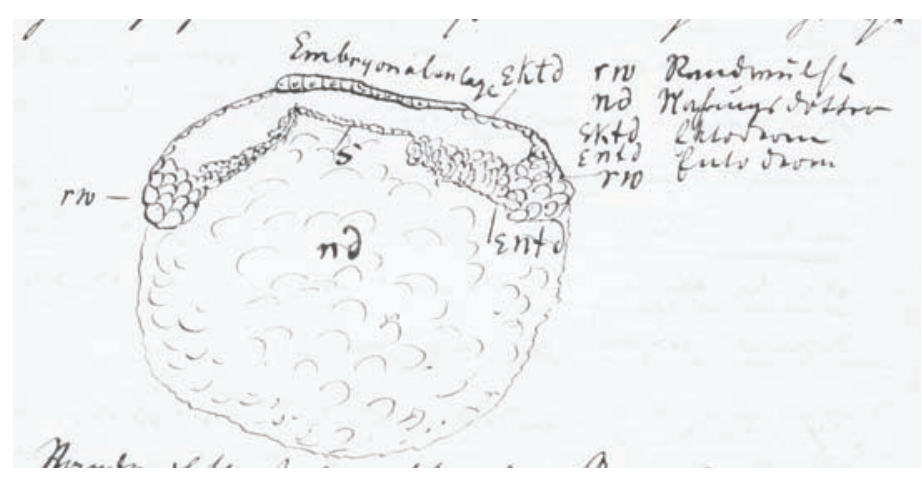

Embryonalanlage Ektd rw Randwulst nd Nahrungsdotter

Ektd Ektoderm

Entd Entoderm

Der Randwulst soll also den „Aequator der Keimblase“ darstellen. S bezeichnet die einzige Schicht die (nach Rauber) das Entoderm des Embryos darstellt.

Wenn man sich also ( nach Rauber) die zusammengedrückte Keimblase des Hühnchens auf die gewöhnliche Kugelform reducirt [denkt], müßte sie wohl so aussehen:

I ausgedehnt

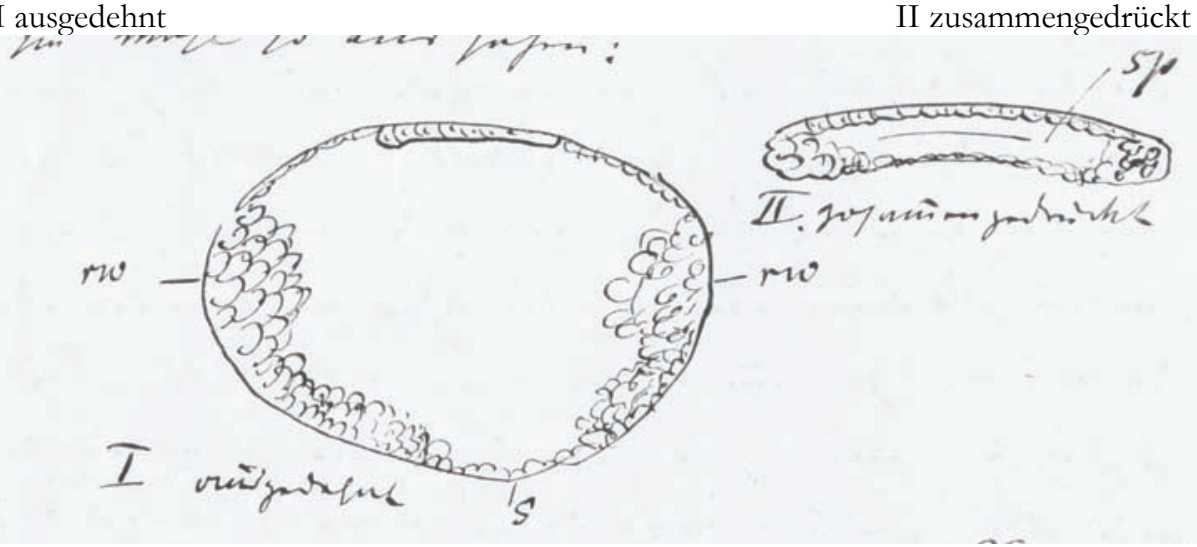

Rauber sagt, daß sich der lineare Spalt (sp) schon in den Eileitereiern vorfindet u. 3 Zellenlängen beträgt.

Ich weiß nicht ob ich in den Rauberschen Aufsatz richtig verstanden habe - aber wenn dies der Fall ist u. wenn meine Abbildung auf der vorhergehenden Seite dem Thatbestande entsprechend ist - glaubte ich einen andern Vergleich zwischen dem Hühnerkeim u. der Gastrula irgend eines niedrigern Thieres ziehen zu müssen.

Ich stelle zunächst beide morpholog. Verhältnisse neben einander u. ersuche dann die Deutung:

${ }^{84}$ Rauber, August (1841-1917), Anatom. Vgl. (Ders.): Über die Stellung des Hühnchens im Entwicklungsplan, Leipzig 1876. 


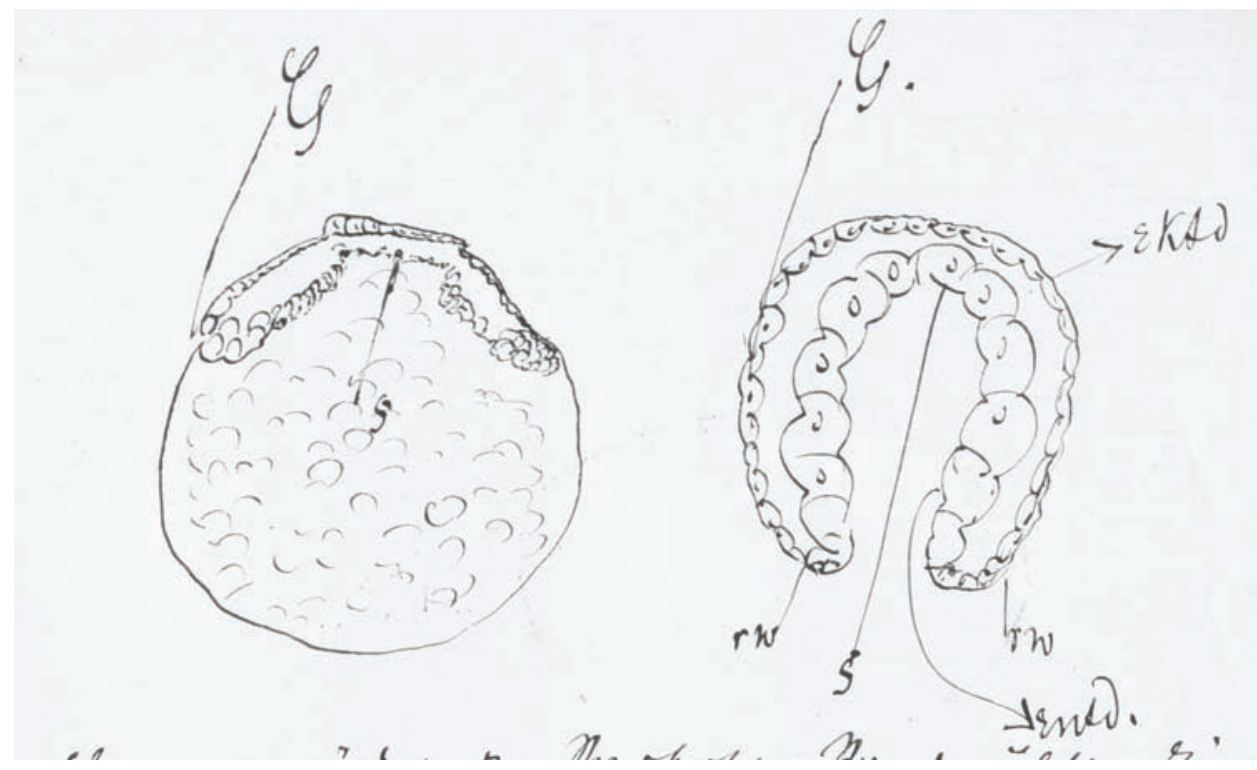

Hiernach würde der Raubersche Randwulst die großen Entodermzellen darstellen, die am Rande der sog. Keimscheibe angehäuft sind u. der ganze Hühnerkeim würde eine Gastrula darstellen, deren Öffnung (Urmund) auf dem Nahrungsdotter (trichterförmig erweitert) aufliegt. Auf diese Weise bekäme dann die Hohlöffnung der höhern Säugethiere eine sehr ungezwungene Deutung. Sie würde dann nämlich das morpholog. Aequivalent für den Urmund der Gastrula sein.

Es ist sehr wahrscheinlich, daß mich die Speculation in diesem Falle zu einem unsinnigen Vergleich veranlaßt hat - aber ich möchte doch gern wissen, ob man die Sache nicht so auffassen könnte.

Hochachtungsvoll grüßend

Otto Zacharias.

[10]

Haeckel an Zacharias

Jena 1 März 75

Geehrter Herr Doctor!

Die Frage nach der Entstehung der Keimscheibe bei den Wirbelthieren mit Nahrungsdotter und ihrem Verhältniß zur Gastrula ist äußerst schwierig. Raubers Darstellung ist zu unklar. Ihre Auffassung - auf die auch ich bei Besprechung mit meinen hiesigen Freunden schon vor längerer Zeit gerieth - ist mir auch heute noch sehr plausibel. [2] Aber sehr schwierig bleibt auch hierbei die Vorstellung der phylogenetischen Entstehung 
des Verhältnisses der Gastrula zum Nahrungsdotter. Irgendwie muß natürlich der letztere secundär zur ersteren hinzugetreten sein und sie modificirt haben - aber Wie?

Ich habe mich daher auch in der Anthropogenie sehr vorsichtig nur über diese dunkle Frage ausgesprochen. Demnächst soll eine große Arbeit von Dr. Goette ${ }^{85}$ in Straßburg über die Ontogenie der Unke (Bombinator) erscheinen, worin gerade dieses Verhältniß und seine Beziehung zur GastraeaTheorie ausführlich besprochen werden soll. ${ }^{86}$ Ich bin sehr neugierig darauf. Nächsten Freitag reise ich auf 2 Monate ans Mittelmeer (wahrscheinlich Riviera, Corsica und vielleicht Sardinien-Sicilien) um die Gastrula weiter zu verfolgen. [3] Für Ihre freundliche Besprechung der Anthropogenie in der Leipz. Ill. Zeitg. nochmals herzlichen Dank. Die Nummern sind mir richtig zugesendet wurden.

Mit freundlichen Grüßen

Ihr ergebenster Haeckel.

Zacharias an Haeckel

Görlitz d. 19. Mai. 1875.

Geehrter Herr Professor! -

In der Voraussetzung, daß Sie sich bereits von Ihrer Studienreise erholt haben u. in den ruhigen Gang des Jenenser Lebens wieder eingetreten sind, nehme ich mir die Freiheit diese Zeilen an Sie zu richten. Der Brief ist diesmal ein wenig länger, weil ich Ihnen den Plan zu einem literar. Unternehmen unterbreiten möchte. Sie würden mich zu großem Danke verpflichten, wenn Sie mir gelegentlich - die Sache hat keine Eile - Ihre Meinung unumwunden über mein Vorhaben sagten.

Es handelt sich um die Gründung einer darwinistischen Monatsschrift. ${ }^{87}$ Ich halte ein solches periodisch erscheinendes Heft für durchaus zeitgemäß, wenn es in dem Tone, den $\underline{\text { Sie }}$ in Ihren sämtl. [2] neueren (für einen größern Leserkreis bestimmten Werken) angeschlagen haben, abgefaßt würde. Ich habe dabei nicht die Gründung einer naturwissenschaftlichen Fachzeitschrift im Sinne, sondern eine populäre aber dabei doch gründliche Darstellung, wie sie beispielsweise im „Auslande“ sich bewährt hat. Der Darwinismus soll darin in seinen Beziehungen zu allen Wissensgebieten besprochen $\mathrm{u}$. discutirt werden. Man gäbe z.B. allmonatlich einen Leit-Artikel über eine schwebende darwinistische Frage. Zum Exempel in der ersten Nummer einen Artikel: „Ueber die Tragweite des biogenetischen Grundgesetzes“ oder über "Göthes Formgesetz" etc. etc. Dann

\footnotetext{
85 Goette, Alexander (1840-1922), Zoologe, Mediziner. Goette studierte Medizin in Dorpat (1860-66). Nach seiner Promotion in Tübingen beschäftigte er sich mit entwicklungsgeschichtlichen Studien. Und habilitierte 1872 an der Universität Straßburg. Er wurde 1877 ao. Prof. und übernahm die Direktion der Zoologischen Sammlung des Städtischen Museums. 1882 wechselte er nach Rostock, wo er als o. Prof der Zoologie bis 1886 lehrte. Er kehrte danach wieder nach Straßburg zurück und wurde hier Nachfolger von Oskar Schmidt. ${ }^{86}$ Goette, Alexander (1874/75): Ontogenie der Unke ,Bombinator igneus' als Grundlage der vergleichenden Morphologie der Wirbelthiere. Mit einem Atlas von 22 Tafeln. Leipzig. Voss.

87 Vgl. hierzu auch Anm. 19.
} 
könnten kleinere Aufsätze u. Besprechungen von Büchern folgen. Ich dachte auch an einen Aquariumsbericht aus Neapel. (Dr. Dohrn ${ }^{88}$ ist mir aus Sicilien bekannt) Ferner auch an ein Vorlesungen- u. [3] Professorenverzeichnis d.h. eine Zusammenstellung aller auf deutschen Universitäten gehaltenen u. den Darwinismus betreffenden Vorlesungen u. eine Liste derjenigen Docenten, die sich notorisch zum Darw. bekennen. Jeder gebildete Laie u. jeder junge Forscher würde eine solche Zeitschrift mit Interesse in die Hand nehmen u. lesen.

Nebenbei könnte eine solche Monatsschrift auch dazu dienen in der wirksamsten Weise Propaganda für Darwins Lehre zu machen, indem man die in den Büchern der Fachmänner vergrabenen Einwände u. Angriffe öffentlich bespricht u. zu widerlegen sucht. Ich denke hierbei an die jüngsten Angriffe des Professor His ${ }^{89}$ in Leipzig (Vergl. Unsere Körperform 1875. Leipzig). Ich habe mich schon mit einigen namhaften Verlegern in Verbindung gesetzt, aber ich wollte erst noch einmal Ihre [4] Meinung hören, ehe ich die Sache weiterverfolge. Die Verleger haben ihre Befürchtungen wegen des (wie sie meinen) nicht ausreichenden Stoffes. Ich lege diesem Briefe eine Zuschrift des Dr. Weber $^{90}$ bei, der Ihnen als Herausgeber der Illustr. Ztg. bekannt sein wird.

Haben Sie die Güte, geehrtester Herr Professor u. sagen Sie mir, ob Sie eine solche Zeitschrift für zeitgemäß u. nützlich halten, dann werde ich nach Leipzig reisen u. weiter verhandlen.

Der Artikel über die Anthropogenie ist im „Auslande“ erschienen (7 Spalten). ${ }^{91}$ Göttes Bombinator besitze ich u. studire ihn mit Vergnügen. Sein „Formgesetz halte ich aber für einen verkappten Schöpfungsplan u. kann mich nicht damit befreunden.

Eben schreibe ich einen Artikel „Über die Consequenzen der Entwicklungstheorie“ “92 anläßlich der anläßlich der Preyerschen Ideen von der Unerschaffenheit (!) des Lebens.

Ergebenst grüßend Otto Zacharias

\footnotetext{
88 Dohrn, Anton (1840-1909), Zoologe, Studium der Medizin und Zoologie Königsberg, Bonn, Berlin und Breslau, Promotion 1868 bei Haeckel in Jena, Gründer und Leiter der Zoologischen Station Neapel.

89 His, Wilhelm (1831-1904), schweiz. Anatom. His studierte Medizin in Bern, Berlin und Würzburg und wurde 1856 promoviert. Nach seiner Habilitation lehrte er an der Universität Basel, wurde dann an die Universität Leipzig berufen, wo er 1875 das Anatomische Institut gründete. His wurde durch seine Forschungen 1883 zum Begründer der Neuronentheorie.

90 Weber, Johann Jacob (1803-1880), Verleger. Weber erlernte in Basel und Paris den Buchhandel und wurde Herausgeber ab 1833 des „Pfennig-Magazin“. Er gründete 1834 in Leipzig einen eigenen Verlag und gab hier ab 1843 die „Illustrierte Zeitung“" als erste deutsche illustrierte Zeitung heraus.

91 Zacharias, Otto (1875): Häckels Anthropogenie. Das Ausland, 48. Jg., Nr. 11, S. 210-213.

92 Artikel von Zacharias nicht ermittelbar, weder im „Ausland“ noch in der „Gegenwart“ erschienen.
} 
Zacharias an Haeckel

Görlitz, den 11. Juni 1875.

Geehrtester Herr Professor! -

Inzwischen habe ich an alle die Herrn, die Sie als eventuelle Mitarbeiter der biologischen Zeitschrift in Vorschlag brachten, geschrieben. Auch bei Oskar Schmidt habe ich angefragt. Das Ergebnis dieser Correspondenz ist ein sehr günstiges. Ich habe dieser Tage eine Reihe von aufmunternden Briefen erhalten, aus denen ich noch manchen nützlichen Wink bekommen habe. Der einzige, der mir die Antwort schuldig geblieben ist - ist Weismann.

Gestatten Sie mir, geehrtester Herr Prof., daß ich Ihnen ganz kurz über die Bedenken referire, die in den eingegangenen Briefen von der $u$. jener Seite ausgesprochen wurden.

I) Oskar Schmidt will zwar bereitwilligst 2-3 Aufsätze (jährlich) liefern, hält aber die Gründung einer biolog. Monatsschrift gegenwärtig nicht für opportun. Die Periode, die der Darwinismus eben durchmache, sei nicht dazu geeignet. Die Darwinianer seien in einem Krieg unter sich selbst verwickelt. [2] II.) Dr. Jäger ist unbedingt für das Unternehmen; macht aber den Vorschlag den Rahmen der Monatsschrift dafür zu erweitern, daß man auch abweichende Meinungen (also antidarwinistische Erörterungen) darin zum Ausdruck bringt. Dadurch, meint er, vergrößern sich das Lesepublikum u. der Kreis der Mitarbeiter. Außerdem werde der Zeitschrift der tendenziöse Anstrich genommen. Dr. Jäger ersucht mich, Ihnen ganz speciell diese seine Ansicht zur Prüfung vorzulegen.

III) Prof. H. Müller (Lippstadt) ist mit der einseitigen Tendenz der Zeitschrift einverstanden u. erbietet sich zur Abfassung kritischer Artikel über literrar. Erscheinungen seines Spezialfaches.

IV) Fr. v. Hellwald ist enthusiastisch für den Gedanken einer darwinistischen Zeitschrift begeistert. Er hat an den Ideen nichts auszusetzen. An ihm dürfte man einen wirksamen u. aufrichtigen Unterstützer haben. V. Fr. Dohrn (Neapel) hat mir von allen Briefen den theilnahmlosesten, um nicht zu sagen, den hochmüthigsten geschrieben. In einem aus dem Palazzo Forlonia datirten Briefe sagt er wörtlich: „Für die [3] Lehre Darwins sei es zu wünschen, daß man endlich einmal aufhöre, sie zu popularisiren. Sie sei zur Modesache geworden u. das tauge nichts."

Dr. Dohrn hat meiner Ansicht nach (ich kenne seine Artikel von Sicilien her) am allerwenigsten Ursache so hoch zu Roß zu sitzen: denn was ich bis jetzt von ihm gelesen habe, trug durchaus nicht den Stempel eines genialen Geistes, sondern reducirte sich so ziemlich auf allgemeine Phrasen. Ich wollte auch von Dr. Dohrn weiter nichts als einen monatl. Aquariumsbericht; zum eigentlichen Mitarbeiter d. h. zum Vertreter irgend einer bestimmten u. ausgeprägten Richtung scheint er mir, seiner ganzen (weiblichen) Statur nach, gar nicht geschaffen. Vielleicht beißt er aber doch noch an, wenn er sieht, daß Männer wie die bereits herangezogenen es nicht verschmähen mitzuthun. Denn Dr. Dohrn ist sehr ehrgeizig, so weit ich ihn kenne. 
Ich denke jetzt immer nach, wen ich wohl noch zur Mitarbeiterschaft auffordern könnte. Dieser Tage fiel mir $\underline{\text { Seidlitz }}{ }^{33}$ in Dorpat u. Moritz Wagner ${ }^{94}$ (München) [4] ein. Prof. Schmidt erwähnt auch in seinem Briefe ein paar Gebrüder Hertwig ${ }^{95}$. u. sagt, daß diese vielleicht Theil nehmen würden. Hätten Sie wohl die Güte mir zu sagen, wo diese Herrn ihren Wirkungskreis haben? Man könnte dann sofort eine Anfrage an sie richten. Wie steht es denn mit Semper? Soviel ich weis, ist er ja auch Darwinist.

An Prof. Fritz Müller ${ }^{96}$ habe ich auch geschrieben und ihn von dem Projecte in Kentniß gesetzt. Ich habe ihn gebeten, für den Fall daß die Zeitschrift wirklich zur Entstehung käme, derselben durch Notizen oder sonstige Beiträge mit auf die Beine zu helfen.

Ich bin gewohnt, jede Sache, die ich ergreife mit Feuer u. Ausdauer zu betreiben u. nicht eher zurückzuweichen, bis ich die offenbare Unmöglichkeit der Realisirung meiner Absichten einsehe. So werde ich auch in diesem Falle handeln. Ich gedenke Alles zu thun, was dem Projecte zur Realität verhelfen kann. Es müsste doch merkwürdig sein, wenn die Darwinia nicht zu Stande käme!

[5] Was mich selbst betrifft, so suche ich mir jetzt mit allem Fleisse einen halbwegs gut klingenden literar. Namen zu machen $u$. wie mich dünkt, wird mir das auch gelingen. Ich bin jetzt Mitarbeiter der Gegenwart, des Grenzboten, des Auslandes, der Illustr. Ztg. , des Athenäums, der Ersch u. Gruberschen Encyclopaedie, ${ }^{97}$ der Blätter für literar. Unterhaltung etc.

\footnotetext{
93 Seidlitz, Georg (1840-1917), Entomologe und Naturforscher. Er reiste weit in Europa umher und beschrieb zahlreiche neue Insektenarten. Seidlitz lehrte in Dorpat (1868-1877) und Königsberg (1877-88).

${ }_{94}$ Wagner, Moritz (1813-1887), Zoologe, Forschungsreisender. Nach einer kaufmännischen Ausbildung und einer ersten Algerienreise studierte Wagner an den Naturalienkabinetten in Erlangen und München. 1836 unternahm er eine weitere Reise nach Algerien, wurde 1838 Redakteur der „Augsburger Allgemeinen Zeitung" und setzte 1840 sein Studium fort. Zahlreiche Reisen führten ihn u.a. nach Persien und Vorderasien, 1852-55 nach Nord- und Mittelamerika und 1857-59 nach Panama und Ecuador. 1862 erhielt er eine a.o. Professur an der Universität München, wo er Vorlesungen über Zoologie und Ethnologie hielt und Direktor des Ethnographischen Museums war.

${ }^{95}$ Hertwig, Oskar (21.4.1849-25.10.1922), Anatom, Zoologe, 1868 Stud. der Med. in Jena, Zürich u. Bonn; 1972 Prom. in Bonn; 1975 Habil. in Jena; ab 1878 Prof. der Anatomie in Jena, ab 1888 in Berlin; Direktor des Anatomisch-biologischen Instituts. H. beobachtete als erster gemeinsam mit seinem Bruder Richard die Befruchtung am Seeigelei. Er war Schüler Haeckels, seine wissenschaftlichen Auffassungen führten aber später zum Abbruch der Verbindung.

Hertwig, Richard (23.9.1850-3.10.1937), Zoologe, Stud. der NW in Jena, 1875 Habil. für Zoologie, 1878 ao. Prof. für Zool. in Jena; 1881 o. Prof. in Königsberg; Mitglied der Leopoldina; 1883 Ordinarius in Bonn; 1885 Professur in München; 1909 nobilitiert; Leiter des Zool. Instituts und der Zool. Staatssammlung. Richard Hertwig war ebenfalls Schüler Haeckels u. blieb mit ihm lebenslang befreundet.

${ }^{96}$ Müller, Fritz (1821-1997), Naturforscher, 1840-44 Stud. der Mathematik u. NW; 1844 Promotion; 1845-48 Stud. der Med. in Greifswald. 1854 Umsiedlung nach Blumenau (Brasilien), wo er eine Beobachtungsstation anlegt und Sammlungen für das naturhistorische Museum in Rio de Janeiro durchführt. Anhänger Darwins, der als „Fürst der Beobachter“ bezeichnete. Wichtige Arbeiten zur Methodik der Evolutionsbiologie. Bekannteste Schrift: „Für Darwin“.

${ }_{97}$ Ersch-Gruber. Allgemeine Encyclopädie der Wissenschaften und Künste, ed. Johann Samuel Ersch Johann Gottfried Gruber. Leipzig 1818-1989. Der Hallenser Professor Gruber ist zusammen mit Johann Samuel Ersch Herausgeber der Fragment gebliebenen „Allgemeinen Encyclopädie“, von der zwischen 1818 und 1889 immerhin 167 Bände erschienen. Der „Ersch-Gruber", die umfangreichste Enzyklopädie des Abendlandes, ist ein Dokument des deutschen Idealismus.
} 
Haben Sie das bei Costenoble ${ }^{98}$ erscheinende Athenäum gesehen? Soll ich irgend etwas über die Anthropogenie dahinein schreiben? Reich hat das Buch zwar schon - aber ein besonderer Artikel könnte doch wohl nichts schaden. ${ }^{99}$

Ich sehe Ihrer gelegentlichen Antwort über Jägers Modificationsvorschlag mit größter Spannung entgegen. Verzeihen Sie mir meine häufigen Anfragen u. Berichten.

Ihr ergebenster O. Zacharias

Zacharias an Haeckel

Redaction und Expedition des Görlitzer Anzeigers.

Görlitz, den 19. Juni 1875

Geehrtester Herr Professor!

Dieser Tage hat mir Darwin selbst bezüglich der zu gründenden biolog. Monatsschrift geschrieben. Der Brief, in dem er mir seine Ansichten darlegt, umfaßt 6 volle Seiten u. geht in der wohlwollendsten Weise auf meine Idee ein. Darwin hat mir fast umgehend geantwortet - ich schrieb ihm vor circa 12 Tagen.

Er giebt mir den Rath, Mitarbeiter für das Unternehmen nicht bloß in Professorenkreisen, sondern auch in andern Sphären zu recrutiren. Vor Allem, meint er, soll ich eine Einladung an die Leser u. Abonnenten der Zeitschrift ergehen lassen, daß Sie der Redaction von allen Fällen, die Licht auf das Entwicklungsprincips werfen, Mitheilung machen. Dadurch werde ein sehr schätzbares Material gewonnen, das sich sehr gut verwerthen lasse. Mit dem sonstigen Plane ist Darwin [2] einverstanden. Er autorisirt mich auch in dem Prospecte oder in dem Vorworte zum ersten Hefte zu veröffentlichen, „daß die Zeitschrift seine volle Sympathie, seine besten Wünsche u. seine Unterstützung haben werde."

Er verspricht mir auch von seinen neuesten Werken sofort ein Exemplar zu zusenden u. wird mit den insectivorious plants ${ }^{100}$ den Anfang machen.

In dem Briefe ergeht er sich noch über Malthus ${ }^{101}$ Lehre u. über Jägers ${ }^{102}$ Buch (in Sachen Darwins“"103, das er nicht genug loben kann.

\footnotetext{
98 Costenoble, Hermann (1826-1901), Verleger und Buchhändler. Verlagsgründung 1850 in Leipzig, 1864 Umzug des Verlags nach Jena. Costenoble wurde vor allem als Verleger der Werke von Friedrich Gerstäcker bekannt. Im Costenoble-Verlag erschien 1875-76: Athenaeum, Monatsschrift für Anthropologie, Hygiene und Moralstatistik.

${ }^{99}$ Evtl. Zacharias, Otto (1875): Der Ursprung des Lebens im Lichte der Entwickelungstheorie. Athenaeum, 1. Jg., S. 413-429.

100 Darwin, Charles (1875): Insectivorous plants. London: Murray.

101 Thomas Robert Malthus (1766-1834), stellte in seinem Werk „Essay on the Principle of Population” (1798) eine These auf, wonach Bevölkerungsentwicklung und Nahrungsmittelproduktion naturgesetzlich auseinander klaffen.

102 Jäger, Gustav (1832-1917), Zoologe, 1977-1879 Mitherausgeber der Zeitschrift „Kosmos“, Lehrbuchautor, populärwissenschaftliche Werke zu evolutionsbiologischen und ökologischen Aspekten abhandelte,
} 
Ich wollte Ihnen diese Zeilen nur als Nachschrift zu meinem Briefe von neulich schicken, in dem ich Ihnen ausführlich über meine Mitarbeiterjagdergebnisse Bericht erstattet habe.

Ergebenst Otto Zacharias

[14]

Zacharias an Haeckel

Görlitz am 20. Aug. 75

Mittags.

Geehrtester Herr Professor!

Soeben lege ich die gegen Sie gerichtete Schmähschrift ${ }^{104}$ des Prof. Michelis ${ }^{105}$ aus der Hand $u$. bin entschlossen diesem Herrn in ernster aber doch seinem eignem Verfahren entsprechender Weise zu antworten.

Ich habe mir dazu die „Gegenwart“ ausersehen, weil ich für diese schon mehrere dergl. Artikel geschrieben habe. Bevor ich aber an Dr. Lindau ${ }^{106}$ schreibe, möchte ich im Stande sein, demselben einen Brief von Ihnen an mich beizulegen, worin Sie mir einfach ausdrücken, daß Sie mein Vorhaben gegen Michelis zu schreiben nicht misbilligen. Lindau ist nämlich über alle Maaßen vorsichtig u. nimmt nichts auf, was ihm Unannehmlichkeiten irgend welcher Art bereiten könnte.

Ueberdies ist Carus Sterne ${ }^{107}$ erbgesessener Lieferant naturwissenschaftl. Artikel bei der Gegenwart u. Lindau würde einen nicht genügend empfohlenen Aufsatz auch wegen Sterne zurückweisen. Damit Sie die Katze nicht im Sack kaufen, könnte ich ja das Essay erst einschicken.

Die Hauptsache ist, geehrter Herr Prof., ob Ihnen an einem derartigen Artikel wie ich ihn schreiben will etwas liegt. Bitte sagen Sie mir dies, möglichst umgehend.

Beschäftigung mit Hygiene und Naturheilkunde, propagierte reformerisch reine Wollkleidung, 1884 Rücktritt von seiner Professur für Zoologie in Stuttgart.

103 Jäger, Gustav (1874): In Sachen Darwins: insbesondere contra Wigand; ein Beitrag zur Rechtfertigung und Fortbildung der Umwandlungslehre. Stuttgart: Schweizerbart.

104 Michelis, Friedrich (1875): Häckelogenie: ein akademischer Protest gegen Haeckels „Anthropogenie“. Bonn.

105 Michelis, Friedrich (1815-1886), kathol. Theologe, Philosoph. Michelis wurde 1838 zum Priester geweiht, war 1844-49 Kaplan und wurde 1849 an der Universität Bonn promoviert. Er unterrichtete anschließend am Seminarium Theodorianum Paderborn und war von 1855-64 als Pfarrer in der Nähe von Münster tätig. M. wurde 1864 a.o. Prof. der Philosophie am Lyceum Hosianum in Braunsberg. Auf Grund seiner antipäpstlichen Haltung 1870 von seinem Amt suspendiert, wirkte er ab 1874 als Pfarrer in Freiburg und wurde zum Hauptführer der Altkatholiken. Als Philosoph bekämpfte Michelis mit seinen Schriften den Darwinismus.

106 Lindau, Paul (1839-1919), Schriftsteller, Journalist, gründete 1871 die Berliner Wochenschrift „Gegenwart".

${ }^{107}$ Krause, Ernst (Carus Sterne) (1839-1903), literarische und publizistische Tätigkeit nach Apothekerlehre, Veröffentlichungen zu Spiritismus und der Verbindung von Naturwissenschaft mit Ästhetik, Befürworter des Darwinismus, Mitarbeiter der „Gartenlaube“, Mitglied der Kosmos-Redaktion. 
Wenn Sie das Ausland geeigneter als die Gegenwart finden, so kann ich auch einen Artikel ins Ausland bringen.

Hochachtungsvoll u. ergebenst Otto Zacharias.

[15]

Brief Haeckels an Zacharias

Jena 20. Aug. 75

\section{Lieber Herr Doctor!}

Für Ihr freundliches Anerbieten, das ich gern annehme, meinen herzlichen Dank. Da Sie eine ostensible Antwort wünschten, die Sie eventuell Lindau vorlegen könnten, erfolgt diese beifolgend. Ich habe übrigens die Streitschrift von Michelis noch nicht zu Gesicht bekommen. Da ich jedoch höre, daß auch die boshafte Kritik der Anthropog. in der „Augsb. Allgem.“ aus seiner Feder ist, kann ich mir schon denken, wie erstere sein wird. [2] Ihren Artikel mir vorher einzusenden, ist nicht nöthig, und auch nicht thunlich, da ich schon in den nächsten Tagen (wahrscheinlich Mittwoch) eine fünfwöchentliche Reise nach Tyrol antrete.

Im Octob. sende ich Ihnen die verbesserte VI. Aufl. der „Nat. Schöpf.“108, sowie eine größere Gastrula-Arbeit ${ }^{109}$. Letztere hat mir glänzende Resultate geliefert und dürfte durchschlagend wirken.

Prof. Krause ${ }^{110}$ in Göttingen hat die blasenförmige Allantois ${ }^{111}$ des Menschen jetzt beschrieben, die bisher noch nicht beobachtet war. (Neuestes Heft des Archiv f. Anat. u. Phys. Berlin.) $)^{112}$

Ich hatte sie in der Anthropogenie - deductiv! - ebenso abgebildet und war deßhalb von His der Fälschung angeklagt worden!

Ein hübsches Beispiel von Deduction: Den Artikel über „Philosophie u. Naturwiss.[“] von Dieterich (in der deutschen Warte ${ }^{113}$ ) haben Sie wohl schon gelesen? ${ }^{114}$

Im Ganzen geht es doch hübsch vorwärts, trotz aller Zöpfe und Kutten!

Mit freundlichstem Gruße Ihr ergebenster Ernst Haeckel

\footnotetext{
${ }^{108}$ Haeckel, Ernst (1868): Natürliche Schöpfungsgeschichte. VI. Aufl. 1875.

${ }^{109}$ Haeckel, Ernst (1875): Die Gastrula und die Eifurchung der Thiere. Jenaische Zeitschrift für Naturwissenschaft, Bd. 9, S. 402-508, Tafel 19-25.

${ }^{110}$ Krause, Wilhelm (1833-1910), Anatom. Er erhielt seine medizinische Ausbildung in Göttingen, Berlin, Wien und Zürich. Er promovierte 1854 und wurde 1860 ao. Prof in Göttingen. Krause wurde 1892 an das Anatomische Institut der Universität Berlin berufen.

111 Allantois (griech.): Wursthaut, Urharnsack. Sackförmige Ausstülpung des fötalen Darms der höheren Wirbeltiere.

112 Krause, W. (1875): Über die Allantois des Menschen. Archiv für Anatomie und Physiologie, S. 215-216.

113 Deutsche Warte: Umschau über das Leben und Schaffen der Gegenwart. Karlsruhe: Braun 1871-75.

114 Dieterich, Conrad (1875): Philosophie und die Naturwissenschaft, ihr neuestes Bündniß und die monistische Weltanschauung. Tübingen: Larupp. Der gleichnamige Zeitungsartikel war in der „Warte“ nicht ermittelbar.
} 
[16]

Zacharias an Haeckel

Görlitz 23. Aug. 75.

Geehrtester Herr Professor!

Ich sage Ihnen meinen besten Dank für die schnelle Erledigung der auf Prof. Michelis' Schrift bezüglichen Angelegenheit.

Damit Sie noch vor Ihrer Abreise wissen, wie weit sich der genannte Herr in Beleidigungen versteigt - theile ich Ihnen eine kleine Blumenlese aus der „Häckelogenie “"115 mit.

S. 1.... der ganze Stand des Häckelschen Denkens berechtigt zu der Frage, ob eine solche Weise die Sache anzugreifen, mit der Ehre der deutschen Wissenschaft besteht.

S. 8. Häckel stellt uns das Resultat seiner Theorie wie ein Bänkelsänger seine Mordgeschichte vor Augen.

S. 23. Häckel dichtet der Descendenztheorie zu Liebe förmliche Romane. S. 29. „Roman der Gasträatheorie“"

S. 29 Häckels Naturforschung - eine Art Hallucination.

S. 54. Häckel ist das enfant terrible der Entwickelungstheorie.

S. 73 So beruht die H.sche „Anthropogenie“ auf einem der ersten logischen Regeln nicht mächtigem Denken; auf einem Denken, welches, in dem nach einer [2] vorgefaßten Meinung die Thatsachen combinirt werden, ein Phantasiegebäude statt der realen Erkenntniß vor unsern Augen aufbaut

S. 74 Häckels „Anthropogenie“ ist so gut wie „Der alte und der neue Glaube“"116 von David Strauß117 ein Schmach u. ein Schandfleck für Deutschland, nicht weil die Männer den Muth gehabt haben, ihre der ewigen Wahrheit abfälligen Überzeugung offen auszusprechen, sondern weil die Kraft des Denkens nach Leibniz und Kant bis zu dem Grade der Impotenz herabgekommen ist, daß es zu solchen Symptomen von senilen Marasmus ${ }^{118}$ kommen konnte.

Das ganze Buch hat 74 Seiten u. strotzt von dergleichen Ausfällen. Ich habe bereits an Lindau geschrieben u. ich gedenke dem guten Professor das, was er ,ideale Entwicklung" im Gegensatz zu der realen nennt, recht klar vor den Augen weg zu demonstriren. Er will nämlich statt der realen Entwickelung, die auf die Vesikel der Vererbung u. Anpassung basirt ist, eine ideale statuiren $u$. dadurch die ganze Naturwissenschaft aus dem Materialismus herausziehen.

Es ist schade, daß Friedr. v. Hellwald verreist ist, sonst hätte ich zuerst im „Ausland“ einen Artikel gebracht.

Ergebenst grüßend Otto Zacharias

\footnotetext{
115 Vgl. Anm. 104.

${ }^{116}$ Strauß, David Friedrich (1872): Der alte und der neue Glaube: ein Bekenntnis. Leipzig: Hirzel.

117 Strauß, David Friedrich (1808-1874), evang. Theologe. Strauß trat im Alter von 13 Jahren in das Seminar Blaubeuren ein und wechselte 1825 an das Tübinger Stift, wo er sich zunächst in die Philosophie Schellings, später Hegels vertiefte. Bereits 1835 veröffentlichte er sein Hauptwerk „Das Leben Jesu“, welches ihn zu einem der umstrittensten Theologen seiner Zeit machte. Mit seiner Schrift „Der alte und der neue Glaube“ (1872) bekannte er sich zu einer monistischen Humanitätsreligion.

118 Degenerative Demenz, Altersschwachsinn.
} 


\section{Geehrtester Herr Professor!}

Sie würden mir eine großen Gefallen thun, wenn Sie mir dieser Tage sagte[n], wann Sie mit Ihren Vorlesungen beginnen. Ich gedenke mich nämlich 14 Tage nach Jena zu setzen, um da von den Mühseligkeiten des schriftstellerischen Handwerks ein wenig aus zuruhen. Ich brauche Ihnen wohl nicht erst zu versichern, daß ich in keinem Falle Ihre Gastfreundschaft in Anspruch nehmen werde. Ich gehe in den „Bärr" ${ }^{\text {"119; }}$; dort finde ich Alles was ich brauche.

Bei diesem Besuche möchte ich auch noch einmal mit Ihnen über die Darwinia sprechen. Ich muß auch wegen eines literarischen Projectes mit Costenoble persönlich sprechen.

Gegenwärtig stehe ich mit George Darwin ${ }^{120}$ in lebhafter Correspondenz. Ich übersetze für denselben seine marriages between first cousins ins Deutsche. Es ist nur eine kleine Broschüre. ${ }^{121}$

[2] In die „Gegenwart“ habe ich in diesen Wochen „Über die Naturwissenschaft als Un-

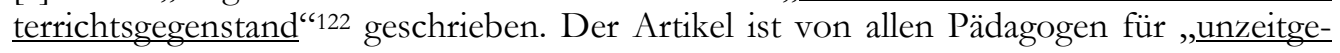
$\underline{\text { mäß }}$ “ gehalten worden.

Eine tüchtige Abfertigung des Verfassers der Häckelogenie habe ich ins „Ausland“ sowohl, ${ }^{123}$ wie ins Athenäum (Jena) gebracht. ${ }^{124}$ Die im Ausland beträgt 5 Spalten. Hellwald hätte sie noch ,gepfefferter“ lieber gehabt.

Nebenbei habe ich auch einen längern Essay über den Ursprung des Lebens im Lichte der Entwicklungstheorie zu Papier gebracht. ${ }^{125}$ Derselbe erscheint demnächst in Jena. Diverse biographische Skizzen über den berühmten Görlitzer Schuster Jacob Böhme126

\footnotetext{
119 Traditionsreiches Hotel in Jena, wo bereits Persönlichkeiten wie Luther und Goethe zu Gast waren.

120 Darwin, George (1845-1912), Engl. Astronom und Physiker, zweiter Sohn von Charles Darwin. Stud. der NW in Cambridge, anschließend Jurastudium. 1868 Mit glied des Trinity College, 1879 Mitglied der Royal Society, 1883 Plumian Professor für Astronomie und experimentelle Philosophie. Arbeiten über geophysikalische Probleme, z. B. Untersuchungen zu Gezeitenreibung.

${ }^{121}$ Darwin, George: Die Ehe zwischen Geschwisterkindern und ihre Folgen. Vorgetr. in der staatl. Gesell. zu London am 16. März 1875. Übersetzt von Dr. V. D. Velde. Mit einem Vorwort von Dr. Otto Zacharias Leipzig: Engelmann.

122 Zacharias, Otto (1875): Die Naturwissenschaft als Unterrichtsgegenstand. Gegenwart 1875 (8), Hft. 35, S. 136-138.

123 Zacharias, Otto (1875): Professor Michelis contra Häckel. Das Ausland, 48. Jg., Nr. 39, S. 773-776.

124 Zacharias, Otto (1875): Professor Michelis und seine Häckelgonie. Athenaeum, 1. Jg., S. 535.

125 Zacharias, Otto (1875): Der Ursprung des Lebens im Lichte der Entwickelungstheorie. Athenaeum, 1. Jg., S. 413-429.

126 Böhme, Jacob (1575-1624), Schumacher, Theosoph. Der gelernte Schuhmacher Böhme hatte um 1600 visionäre Erfahrungen, die er als „Offenbarung Gottes“ verstand und aus denen er eine eigenständige Weltschau entwickelte. Sein Erstlingswerk „Morgenröte im Aufgang“ (1612) führte zu einem Schreibverbot. Während des Dreißigjährigen Krieges begann seine große Schaffensperiode. Das Erscheinen seiner Schriften bewirkte wiederum heftige Anfeindungen.
} 
habe ich auch in die Welt hinaus geschickt. ${ }^{127}$ Alle zusammen erscheinen im November. Sie sollen sich wundern, Herr Professor, wie gesunde „Naturanschauungen“ dieser Böhme trotz seiner Mystik besaß. Ich hoffe der Erste zu sein, der das bemerkt hat. Bitte also um gelegentliche Antwort auf meine obige Hauptfrage.

Ihr ergebener Zacharias.

P Scr.

Für Hellwald projectire ich jetzt einen Artikel über höhere und niedere Organisation. ${ }^{128}$ Mir scheint dieses Thema sehr fruchtbar u. interessant. Ich habe mir viel Stoff aus Darwins u. Ihren Schriften gesammelt. Ein solcher Artikel wäre ein Beitrag zur Philosophie der Zoologie.

Wenn ich meine Ideen über hohe u. niedere Organisation im Geiste Revue passiren lasse, so stören mich immer die Siphon[o]phoren. Diese können nach meiner Ansicht, ebenso zu den hochorganisirten als zu den niederorganisirten Organismen gezählt werden. Es kommt ganz darauf an, ob man Ihre Theorie von der Bildung solcher „Stöcke“ acceptirt oder nicht.

Z.

[18]

Zacharias an Haeckel

Görlitz 23. Oct. 1875.

Geehrtester Herr Professor!

Ich werde, wie ich jetzt sehe, erst am 7. od. 8. Nov. in Jena eintreffen, da ich hier vielfach mit der Inscenirung einer Böhme-Feier zu thun habe. Es sind nämlich in diesem November grade 300 Jahr her, daß der Philosophus Teutonicus geboren wurde. (Ich sende Ihnen das Gedenkblatt, was ich geschrieben habe unter Kreuzband mit.) Sein energisches Betonen der Immanenz Gottes u. die den Papst betreffende Stelle dürften auch für Sie von Interesse sein.

Meinen Aufenthalt bei Ihnen, in dem Mußestädtchen, werde ich dazu benutzen, einen längern Artikel für Lindaus „Gegenwart“ zu schreiben”), der zum Gegenstand haben soll: alle die Männer die in Jena darwinistische Principien vertreten haben. ${ }^{129}$ [2] Ich werde also Jena als Metropole des Darwinismus in Deutschland behandeln u. eine Darstellung

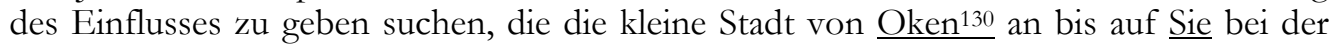
Verbreitung des Evolutionsprincips in Deutschland gehabt hat.

${ }_{127}$ Zacharias, Otto (1875): Zum Andenken an Jakob Böhme. Athenaeum, 1. Jg, S. 515-520.

128 Der angekündigte Vortrag läßt sich im „Ausland“ nicht nachweisen. Im Oktober 1875 erschien aber der Artikel: Zacharias, Otto (1875): Das Problem der Vererbung und Befruchtung. Das Ausland, 48. Jg., Nr. 43, S. 856-858. (25. Oktober 1875).

${ }^{129}$ Der Artikel ist in der „Gegenwart“ nicht erschienen.

130 Oken, Lorenz (1779-1851), eigent. Okenfuß; Naturforscher, Naturphilosoph. 1800-04 Studium der Medizin in Freiburg, wo auch promoviert wurde. Bereits 1802 erschien seine naturphilosophische Arbeit 
Sie würden mir einen großen Gefallen thun, wenn Sie mir die Männer zusammenstellen wollten, die Sie der Erwähnung für werth halten. Ich werde mir dann in Jena deren Schriften ansehen u. ihre Stellung zu den wichtigsten Fragen im Original kennen lernen. Auf Oken habe ich es ganz besonders abgesehen, weil ich finde, daß dieser Mann (trotz aller Philosophasterei) ein Genie ist. In seiner Schrift über die Zeugung finden sich sogar Andeutungen über das biogen. Grundgesetz. Es würde mir lieb sein, wenn Sie die Güte hätten, mir die Liste schon nach hier zu senden. Ich komme dann bereits präparirt nach Jena u. schreibe schneller .

Hochachtungsvoll Ihr Zacharias.

*) Dr. Lindau rechnet sicher darauf.

P. Scr.

Die Broschüre des Herrn George Darwin Marriages between first cousins an their effects habe ich übersetzt. Sie ist fertig u. wird bald bei Engelmann in Leipzig erscheinen.

Bei Costenoble in Jena werde ich demnächst eine Sammlung meiner naturwissenschaftl. Artikel drucken lassen. ${ }^{131}$

d. O.

Daß ich mir erlaubt habe, im Athenäum Einwände gegen Ihre Hypothese der Autogenie zu machen, werden Sie mir wohl nicht verübeln, da Sie wohl sonst genug von meiner Verehrung, die ich für Sie hege, überzeugt sind.

Zacharias an Haeckel

29. Nov. Görlitz 1875

Geehrtester Herr Professor!

Ihre lehrreiche Schrift über die Gastrula u. die Eifurchung der Thiere ${ }^{132}$ hat mich zu den verschiedensten Betrachtungen angeregt; ganz besonders ist meine Phantasie aber gegenwärtig mit dem Processe der Artenmodification selbst beschäftigt. Ich empfinde mannigfache Schwierigkeiten, wenn ich mir (in concreto) einen eclatanten Fall von Abänderung vorstellen will. Sie würden mir einen großen Gefallen thun, wenn Sie mir nur einige Fingerzeige gäben, durch die ich aus dem Labyrinthe herauskommen kann.

Da ich mich nicht gern mit Allgemeinheiten u. wagen Begriffen abgebe, nehme ich einen ganz bestimmten Fall an - z. B. einen augenlosen, höhlenbewohnenden Käfer - u. frage:

\footnotetext{
„Übersicht des Grundrisses des Sistems der Naturphilosofie und der damit entstehenden Theorie der Sinne“. 1805 habilitierte sich Oken in Göttingen, 1807 wurde er durch Fürsprache Goethes als ao. Prof. der Medizin nach Jena berufen. Hier wurde er 1812 zum Prof. der Naturgeschichte ernannt. Von 1817-1848 gab Oken die enzyklopädische Schrift „Isis“ heraus.

131 Zacharias, Otto (1876): Zur Entwicklungstheorie. Jena: Costenoble, 1876.

132 Haeckel (1875), vgl. Anm. 109.
} 
wie ist die Verkümmerung des Sehorganes successive vor sich gegangen?! Wie hat sich beispielsweise bei Anophthalmus capillatus ${ }^{133}$ [2] an die Stelle des Auges ein Hügelchen mit einem Tasthaare gesetzt?!

Angenommen daß eine solche Modification nicht plötzlich auftritt, sondern nur durch generationenlang fortgesetzte Abänderungen zu Stande kommt - das angenommen - so frage ich: wo ist der Angriffspunkt für den Modificationsproceß: im elterlichen (in allgemeinen) noch unmodificirten Körper oder im Embryo oder gar schon im Protoplasma des (den neuen Lebensbedingungen ausgesetzten) Eies. Nach meiner Ansicht u. nach den Anschauungen, die ich mir angeeignet habe, ist der elterliche Körper nur in einem sehr beschränkten Grade modificationfähig; am allerwenigsten könnte sich eine solche Modification auf hochdifferenzierte Organe, wie die Augen, erstrecken. Es ist also nur anzunehmen daß die neuen Lebensbedingungen: (Dunkelheit, Luftveränderung, Temperaturconstanz etc.) auf den Geschlechtsapparat der noch [3] unmodificirten elterlichen Organismen der Art wirken, daß die Folge davon eine minimale Veränderung des Embryos ist, der aus der Vereinigung eines solchen Elternpaares hervorgeht. Der Modificationsproceß einer Art würde also (nach meiner Ansicht) vorzüglich sich am Embryo zeigen u. das reife Individuum würde nur im verstärktem u. vergrößertem Maaßstabe die Modificationen zur Schau tragen. Natürlich ist hier nur von Embryonen die Rede, die sich in der tertiären $u$. in der heutigen Zeit entwickeln, da in früheren geologischen Epochen auch eine größere Biegsamkeit der reifen Organisation (vorzüglich bei niederen Thieren) vorausgesagt werden muß. Ich schiebe also den Angriffspunkt der Artenveränderung u. Artenentstehung auf das Studium der embryonalen Entwicklung, weil mir zu diesem Zeitpunkte die Zellen ein üppigeres Wachsthum u. eine größere Anpassungs[4]fähigkeit zu haben scheinen, wie in erwachsenen Zustande des von ihnen zusammengesetzten Thierkörpers. Hieraus mache ich nun ein weiteren Schluß, daß wir viele Uebergänge in der phylogenet. Reihe gar nicht aufzufinden im Stande sind, weil diese Mittelglieder durch embryol. Stadien repräsentirt werden, die naturgemäß in dem reifen, weit höher entwickelten Organismus, nicht mehr zum Ausdruck kommen konnten. Diesem Gedankengange zufolge dürfte nun als variabelstes Stadium der embryonalen Entwicklung der Gastrula-Zustand angenommen werden u. die veränderten Lebensbedingungen würden ihren Einfluß am meisten bei der embryonalen Gastrulation geltend machen, da von dieser aus eine fundamentale Einwirkung auf alle übrigen Lebensprocesse des entstehenden Thieres auszugehen scheint. Die Gastrula ist nach meiner Ansicht der Ursitz aller der Processe, von denen die Correlation der Thiere im reifen u. entwickelten Individuum [5] abgeleitet werden muß.

Ich gebe zu, daß es sehr schwer ist, den Nachweis für die obigen hypothetischen Darlegungen zu erbringen: aber ich sehe zunächst keine Möglichkeit für andere Annahmen u. Erklärungsweisen.

Sie würden mich - wie gesagt - sehr verbinden, geehrter Herr Professor, wenn Sie mir nur in einigen Zeilen andeuteten, ob ich auf der falschen Fährte bin, oder ob ich auf diesem Wege meine Reflexionen fortsetzen kann. Es ist mir total unmöglich ein Buch zu lesen, ohne die darin enthaltenen Ideen in meinem Sinne umzuformen. Manchmal

133 Ein Käfer der Familie Carabidae. 
kommt bei dieser Sinnesformation auch Unsinn heraus u. um zu erfahren ob dies auch diesmal der Fall ist, schrieb ich Ihnen diese flüchtigen Zeilen.

Ihr ganz ergebener Zacharias.

[20]

Zacharias an Haeckel

Görlitz 5. Dec. 1875

Geehrtester Herr Professor!

Ich werde Ihre kostbare Zeit so kurz als möglich in Anspruch nehmen. Anbei sende ich Ihnen eine Zuschrift der Red. der Illustr. Zeitung an mich, aus der Sie ersehen können, daß die Herrn geneigt sind: Abbildungen aus den Arab. Corallen (mit einem dieselben erklärenden Artikel) in das Blatt aufzunehmen.

Ich bitte Sie nur - falls Ihnen überhaupt etwas an der Sache liegt - mir die Abbildungen, die Sie eingerückt haben wollen, zu bezeichnen u. ferner ersuche ich Sie: mich sobald als möglich in den Stand zu setzen, der Redaction der Illustr. Zeitung über das neue Werk referiren zu können.

Wenn es Ihnen zuviel Mühe macht, will ich mich direct mit $\underline{\text { Reimer }}^{134}$ in Verbindung setzen u. bei ihm das Wei[2]-tere veranlassen. Ich denke es wird Ihrem Herrn Verleger garnicht unangenehm sein, wenn die „Arab. Corallen“ durch die Illustr. Zeitung (12.000 Aufl.) eine weitgehende Publicität erhalten.

Vor allem bitte ich Sie aber, geehrter Herr Professor, mir zu sagen, ob Ihnen mein Vorschlag convenirt.

Sollten Sie in dieser Sache nächster Tage einige Zeilen an mich richten, so bitte ich Sie auch dringend mir mitzutheilen: ob die Gastrulaform zuerst von Ihnen entdeckt worden ist oder ob Sie bereits die bereits gemachte Entdeckung nur für die Descendenztheorie verwerthet $u$. weiter verfolgt habe. Sie nehmen mir diese offene Frage nicht übel - aber ich möchte in meinem Artikel für die Gegenwart nichts aus der Feder fließen lassen, was mir Ihre Neider ausnutzen könnten.

Mit ergebenstem Gruße u. bestem Danke für die Zeilen von neulich Ihr Zacharias.

134 Reimer, Georg Ernst (1804-1885), Verleger. 
[21]

Zacharias an Haeckel

Görlitz 27. Dec. 75

Geehrter Herr Professor!

Soeben erhielt ich $\underline{\text { Sempers }}^{135}$ neuestes Opus: „Der Häckelismus in der Zoologie“136 betitelt. Ich habe den Wisch gelesen $u$. bin erstaunt: wie man auf diese Weise gegen einen Collegen u. einen namhaften Mitarbeiter auf dem gleichen Felde der Forschung losziehen kann.

Der logischen u. stylistischen Schnitzer in der Broschüre sind so viele, daß $\underline{\mathrm{ich}}-$ als Nicht-Zoologe - mich versucht fühle, eine Gegenbroschüre zu schreiben.

Ich habe eben an Hellwald geschrieben. Nimmt der den Artikel ins „, Ausland“ auf, so unterlasse [2] ich die Herausgabe eines speciellen Sendschreibens; nimmt er den Artikel aber nicht: so mache ich mich sicher an die Protest-Broschüre. ${ }^{137}$

Semper ist viel schlimmer als Michelis.

Jeder Zell an dem Würzburger Professor athmet die Arroganz des Neapolitanischen Aquarium-Dirigenten ${ }^{138}$ u. zur gleicher Zeit aber auch die wissenschaftliche Unklarheit dieses letzteren.

Sie würden mir einen großen Gefallen thun, Herr Professor, wenn Sie mir ganz in Nuce Sempers Laufbahn skizziren wollten.

Als unwissender Laie weiß ich von Semper nur, daß er früher auf den Philippinen herumgeforscht hat, u. dann als Kritiker das Darwinismus aufgetreten ist. Daß seine wissenschaftliche Ueberzeugung darin gipfelt, daß die Vorläufer der Wirbelthiere die Anneliden seien, weiß ich auch. Aber sonst kenne ich den in Rede stehenden Herrn nicht. Ich werde mich in meinem Artikel nur an das Logische u Stylistische halten u. zu zeigen suchen, daß ein „Professor “ durchaus kein „Logiker ${ }^{\text {", }}$, geschweige denn ein „Stylist“ zu sein braucht. Gewöhnlich glaubt man ja leider an die Kraft der Titulation.

Prof. Jäger schreibt mir heute, daß er in 3-4 Wochen eine ,Theorie der Vererbung u. Anpassung“" veröffentlichen wird.

Vielleicht hat diese Nachricht für Sie einiges Interesse.

Ergebenst grüßend

Otto Zacharias

\footnotetext{
135 Carl Semper (1832-1893), Zoologe. Studierte Ingenieurwesen, Zoologie und Anatomie und promovierte 1856. Er bereiste 1858-1865 die Philippinen und die Palauinseln. Ab 1866 Privatdozent in Würzburg, ab 1869 Professor für Zoologie und Anatomie. Semper verfaßte länderkundlich-ethnographische Schriften, Studien über Histologie und Entwicklungsgeschichte der Mollusken.

136 Semper, Carl (1875): Der Haeckelismus in der Zoologie: Ein Vortrag. Hamburg: Mauke. Mit dieser Schrift kritisierte er die von Haeckel vertretene Richtung der Zoologie als dogmatisch und phantastisch und versuchte durch die Anklage der Fälschungen von Abbildungen Haeckels Glaubwürdigkeit als Wissenschaftler in Frage zu stellen. Vgl. Krauße, Erika (1984): Ernst Haeckel. Leipzig: Teubner. S. 92.

137 Artikel von Zacharias über Semper nicht ermittelbar.

138 Anton Dohrn, vgl. Anm. 88.
} 
[22]

Zacharias an Haeckel

Görlitz, Sylvester 75 .

Geehrtester Herr Professor!

Besten Dank für die Uebersendung der arab. Korallen. Ich habe die Monographie mit Heißhunger gelesen $u$. bin über die Ausstattung des Buches entzückt.

Die Illustr. Zeitung bringt Fig. 2, 8, 13, 20 und vielleicht noch einige. In 3-4 Wochen mache ich den Artikel druckfertig. Dr. v. Hellwald bekommt seinen kurzen Artikel schon viel eher ${ }^{139}$.

Mit den besten Wünschen zum Jahreswechsel

Ihr Zacharias

[23]

Haeckel an Zacharias

Jena 31. Dec. 75

Lieber Herr Doctor!

Sempers' „Haeckelismus“ hat mich nicht in Erstaunen, wohl aber in Heiterkeit versetzt. Ich kenne dieses aufgeblasene Bürschchen seit 20 Jahren, wo wir (1855) in Würzburg zusammen studirten. Er ist ursprünglich See-Cadet, fiel dann leider auf die Zoologie in der er weder gründliche Bildung sich erworben, noch jemals etwas Tüchtiges geleistet hat. Sieben Jahre saß er auf den Philippinen ( - sein Vater ist Millionär in Hamburg od. Altona). Inmitten dieser herrlichen Schätze ${ }^{140}$ hat er fast Nichts geleistet [2] Außer einigen kleineren Arbeiten ein großes Werk über Holothurien ${ }^{141}$ das durch die zahlreichen prachtvollen Abbildungen (von seiner Frau gemalt!!) berühmt geworden ist. ${ }^{142}$ Gelöst ist darin keine einzige der zahlreichen dunkle[n] Fragen ihrer Naturgeschichte. Gegenbaur erwähnt es deshalb fast gar nicht, worüber Semper wüthend ist.

In Würzburg (wo er seit 5 Jahren Professor der Zoologie ist) hat er sich durch seine maaßlose Arroganz allgemein verhaßt gemacht. Überhaupt ist er wegen seiner Aufgeblasenheit verschrien, besonders seitdem ihn [3] Carl Vogt ${ }^{143}$ im vorigen Jahre (in einem Feuilleton der Frankfurter Zeitg, in dem er die Anthropogenie - aus Neid! - heftig angriff, Semper als genialen (!!) Zoologen im Gegensatz zu mir herausstrich!

\footnotetext{
139 Zacharias, Otto (1876): Häckels neuestes Werk über arabische Korallen. Das Ausland, 49. Jg., Nr. 4, S. 78-79.

140 Im Original steht das Wort „Schätze“ zweimal geschrieben: Einmal in deutlicher Schrift als Einfügung obendrüber geschrieben, das zweite „Schätze“ undeutlich geschrieben. Haeckel vergaß vermutlich, es durchzustreichen.

141 Echinodermata, Seegurken.

142 Semper, Carl (1868): Reisen im Archipel der Philippinen. 2.Teil: Wissenschaftliche Resultate, Bd. Holothurien. Leipzig: Engelmann.

143 Vogt, Carl (1817-1895), Naturforscher, Politiker, Prof. der Zoologie in Gießen; 1848 entlassen, Prof. der Geologie (1852), später Zoologie (1872) in Genf; Vorkämpfer des Materialismus und Darwinismus, Verfasser zahlreicher Schriften, u.a. Forschungsreisen, Lehrbücher, Übersetzungen und Fachpublikationen.
} 
Vogt ist nämlich mit dem berühmten Architecten Semper ${ }^{144}$ sehr befreundet, dem Onkel des Zoologen und schließt aus der Genialität des ersteren leider auf die des letzteren.

Ich stand mit Semper, wie mit Claus, bis vor zwei Jahren ganz gut. Da kündigten mir Beide plötzlich ihre (rein äußerliche) Freundschaft auf Grund der Gastraea. Ich werde S. nicht antworten. [4] Wollen Sie Semper zeigen, wie unglaublich ein ordentlicher Professor der Zoologie mit Logik und deutscher Sprache umgeht und wie bornirt er alle weiteren Beziehungen der Zoologie zur Philosophie etc. ausschließt, so halte ich es für sehr zweckmäßig und dankenswerth, dieses Exempel zu statuiren.

Mit freundlichsten Grüßen

und besten Wünschen für 1876

Ihr E. Haeckel

[24]

Zacharias an Haeckel

Görlitz den 28. Jan. 1876.

Geehrter Herr Professor!

Unter Kreuzband erlaube ich mir Ihnen heute den bewußten Artikel über Jena zuzusenden. ${ }^{145}$ Es wäre mir lieb, wenn Sie ihn durchläsen u. mir dann umgehend die Berichtigungen zuschickten, deren gewisse Angaben wahrscheinlich bedürftig sind. Es wäre mir äußerst unlieb, wenn irgend ein Lapsus Calami resp. cerebri stehen bliebe. Sie haben gewiß die Güte u. erfüllen mir diese Bitte.

Ein größerer Artikel (mit $\underline{\text { Abbildungen) }}$ über die arab. Korallen erscheint über 8 Tage in der Illustr. Ztg. 146

Ergebenst grüßend

Ihr Otto Zacharias

\footnotetext{
144 Semper, Gottfried (1803-1879), Architekt, erbaute u.a. in Dresden 1871-78 das zweite Hoftheater (,Semper-Oper") sowie 1873-88 das Burgtheater in Wien.

$145 \mathrm{Vgl}$. Anm. 139.

146 Zacharias, Otto (1876): Arabische Korallen. Illustrirte Zeitung, No. 1701, Bd. LXVI, 5. Februar 1876, S. 103 und 106. (Abbildung S. 108).
} 
[25]

Zacharias an Haeckel

Görlitz 12. Febr. 76

Geehrtester Herr Professor!

Unter Kreuzband erlaube ich mir Ihnen heute die neueste Nummer der „Gegenwart“ zuzusenden, weil dieselbe einen kurzen Artikel von mir enthält, in welchem ich Ihre Deutung gewisser Äußerungen Göthes in Zweifel gezogen habe. ${ }^{147}$ Es ist möglich, daß ich mich geirrt habe - aber ich fand mich grade auf Grund der Schultze'schen Göthebriefes bewogen, die Zeilen, die Sie lesen werden, niederzuschreiben. Ich gedenke die Sache noch weiter zu verfolgen u. Göthes naturw. Schriften auf die darwinistischen Anklänge hin durchzusehen.

[2] Von Benedens Schrift du dévéloppement embryonnaire des mammiferes d’après des recherches chez le lapin ${ }^{148}$ habe ich mir verschafft. ${ }^{149}$ Sie ist aber schon $\underline{1875}$ in Brüssel erschienen - meinten Sie etwa eine neuere Arbeit? Ich lese auf Seite 31 der 63 Seiten umfassenden Broschüre von einer modificirten Gastrula (Metagastrula) u. begegne der merkwürdigen Schlußäußerung in dem Kapitel: Il ne crois pas que l'on puisse distinguer dans le cours de cette évolution de la meta gastrula, comme l'a fait Häckel, une phase de morula. ${ }^{150}$ Es scheint also, als ob das Morulastadium kein wesentliches embryonales Entwicklungsmoment wäre (!?)

Die Lectüre der Beneden'schen Schrift [3] war mir höchst interessant. Es ist mir nur in dubio geblieben, was die corps directeus (Richtungsbläschen de Fritz Müller) (S. 9) sind. Vorige Woche habe ich mir die Freiheit genommen, Ihnen eine Broschüre George Darwins zu senden. Dieselbe wird wohl, ebenso wie der modificirte Jena-Artikel in Ihre Hände gelangt sein.

Vorigen Sonnabend ist der Korallenartikel in der Leipz. Illustr. Ztg. erschienen. Ich habe, wie Sie gelegentlich sehen werden, ziemlich oft Ihre eigenen Worte gebraucht u. nur die Absicht verfolgt einen so vollständig als möglichen Auszug der Monographie zu geben. Ich hielt das für das Beste.

Hochachtungsvoll Otto Zacharias

\footnotetext{
147 Nicht ermittelbar.

148 Van Beneden, Edouard: Über die Embryonalentwicklung der Säugetiere nach den Forschungen über das Kaninchen. Weitere bibliographische Angaben konnten nicht ermittelt werden.

149 Van Beneden, Edouard (1846-1910), belgischer Zoologe und Mediziner. Er untersuchte frühe Entwicklungsstadien des Säugereies (1875 von Kaninchen und Fledermäusen, später bei Seeigeln und Wirbellosen), wobei er das Verhalten der Chromosomen und der Reduktionsteilung beschrieb. O. Prof. für Zoologie in Lüttich (1870).

150 [frz.]: Ich glaube nicht, daß man, wie Häckel es gemacht hat, im Laufe der Entwicklung von dieser Metagastrula eine Phase der Morula unterscheiden kann.
} 
[26]

Haeckel an Zacharias

Jena 14 Feb 76

Verehrter Herr Doctor!

Für die freundliche Übersendung Ihrer Übersetzung der Darwinschen Broschüre, sowie des Artikels über Goethe meinen besten Dank. Auch von dem Korallen-Artikel in der „Illustr. Zeitung“ habe ich einen Abzug erhalten.

Mit Van Benedens Schrift über die Gastrula des Kaninchens ${ }^{151}$ seien Sie ja sehr vorsichtig! Die Verhältnisse sind höchst complicirt und ganz anders, als man bisher annahm. [2] Der Passus bezüglich der Morula beruht auf einem Mißverständnisse Van Benedens. Auch die Äußerungen betreffs des Vesicule blastodermique sind cum grano salis zu verstehen. Nur die Hauptsache scheint mir klar, daß die wahre Amphigastrula der Säugethiere nachgewiesen ist. Über die Richtungsbläschen weiß man auch Nichts sicher.

Mit freundl. Gruß in Eile

Ihr E. HKl.

[27]

Zacharias an Haeckel

Dessau den 14. Mai 1876

Geehrtester Herr Professor!

Ich erlaube mir, Ihnen einmal wieder über die projectirte Darwin-Monatsschrift zu berichten. Ich habe die Sache keines wegs aufgegeben, sondern bin im Gegentheil daran, ernstlich mit der Zusammenstellung des ersten Heftes zu beginnen. Prof. G. Jäger will mich mit aller Kraft unterstützen; auch Darwin selbst, der mir dieser Tage wieder sehr liebenswürdig geschrieben hat, wird mich hier u. da mit Stoff versorgen. Oskar Schmidt wird auch mit helfen u. so wird's wohl in der ersten Zeit gehen. Ich denke immer, man muß anfangen, damit die Leute aufmerksam werden. An Sie, Herr Professor, hätte ich noch eine ganz besondere Bitte. Ich möchte Sie nämlich ersuchen - wenn Sie Interesse für den guten Anfang der Sache haben - mir in einer freien Stunde die Skizze zu einer Vignette für den Umschlag der Hefte zu [2] entwerfen. Ich habe folgende Idee: Oben quer über die Umschlagsseite soll bogenförmig der Name der Zeitschrift (Darwinia) stehen. Innerhalb des Bogens kommt dann in Medaillenformat Ihr u. Darwins Brustbild. Eingerahmt soll die ganze Seite werden, von einer arabeskenartigen Darstellung des thierischen Stammbaumes. Diese Composition mit wissenschaftlichem u. künstlerischem Geiste darzustellen, wäre nun Ihr Werk, Herr Professor. Ich will gern reinen Mund darüber halten - wenn Sie mir nur die Sache für den Zeichner andeuten. Beiliegend ist eine

151 Vgl. Anm. 148. 
rohe Skizze von mir in fünf Minuten gemacht. Sie würden das Ganze natürlich schmucku. verständnisvoller anordnen, aber der Grundtypus scheint mir brauchbar. Die Sonne hinter den Medaillons soll sowohl die höhere Einsicht, die intellectuelle Erleuchtung, als auch die physische Macht darstellen, die das Leben anregt u. erfüllt. Die Größe der ganzen Composition würde den Flächen-[3]inhalt des Athenäumformats nicht überschreiten dürfen. Es wäre wirklich im Interesse der ganzen Sache, wenn Sie sich die Mühe des Skizzirens unterziehen wollten. Ein ganz nackter, kahler Umschlag sieht doctrinär aus u. wirkt aus psychologischen Gründen abstoßend auf die anschauungsbegierige Volksmasse. Als Redacteur kennt man seine Pappenheimer schon -- !

Bitte schreiben Sie mir gelegentlich, ob Sie mir meine Bitte erfüllen wollen. Ich kenne keinen andern Menschen, der in gleicher Weise, wie Sie - geehrter Herr Professor - eine solche Vignette zu componiren im Stande wäre.

Zum Schlusse erlaube ich mir noch zu bemerken, daß ich gegenwärtig hier in Dessau, nicht mehr in Görlitz, wohne. Das Anhaltische Ministerium hat mich als Redacteur des Staatsanzeigers ${ }^{152}$ hierher berufen. Mir ist es ja gleich, wo ich existire.

Hochachtungsvoll grüßend

Ihr Otto Zacharias

[28]

Zacharias an Haeckel

Dessau, am 9. Juni 1876

Geehrtester Herr Professor!

Ich danke Ihnen für die nachträgliche Rückantwort auf mein Anfragetelegramm. Ich hätte gern einmal ein Stündchen mit Ihnen über die „Perigenesis der Plastidule“153 geplaudert, damit ich genau verstehe, was Sie mit der Abhandlung, die Sie so freundlich waren mir zuzusenden, bezwecken. Ich muß offen gestehen, daß ich nach einer 6maligen Lectüre noch immer kein einheitliches Band in Ihrem Gedankengange aufgefunden habe. Ihre Abhandlung zerfällt nach meiner Ansicht in 2 ganz verschiedene Theile: nämlich in eine Theorie der Beschaffenheiten der letzten organischen Theilchen $u$. in eine Theorie von deren Bewegungsweisen. Mir persönlich scheint doch schon eine dieser Theorien für die Erklärung der organischen Erscheinungen zureichend. [2] Wenn Sie den Plastidulen „Gedächtniß“ zuschreiben u. daraus die Erblichkeit erklären, so verstehe ich nicht, weshalb nun noch einen Wellenzeugung jener Theilchen stattfinden soll, um die Uebertragung der vererbbaren Eigenschaften zu ermöglichen. Mir scheint bereits das „Gedächtniß“ zu genügen. Es ist möglich, daß ich mich in einem Gedanken ganz verlaufen habe, der falsch ist - aber ich möchte doch offen sagen, was mir in der Schrift aufgefal-

152 Evtl. ist hier das Görlitzer Tageblatt (zugleich Publikationsorgan für die königl. und staatlichen Behörden) gemeint, welches anfangs unter dem Titel: Görlitzer Tageblatt und Anzeiger erschien. Ein Görlitzer Staatsanzeiger war nicht nachweisbar. 1856-[?]

153 Haeckel, Ernst (1876): Die Perigenesis der Plastidule oder die Wellenerzeugung der Lebenstheilchen. Ein Versuch zur mechanischen Erklärung der elementaren Entwicklungsvorgänge. Berlin: Reimer. 
len ist. Der Begriff des „Gedächtnisses“ scheint mir übrigens selbst so erklärungsbedürftig zu sein, daß ich einen kleinen Widerwillen dagegen empfinde, ihn seinerseits zur Erklärung anderer ebenso dunkler Vorgänge zu verwenden. Ich war ganz erstaunt, Sie diesmal so weit in den Äther der Hypothesen aufsteigen zu sehen u. ich versichere Sie, daß mir noch keine Ihrer Schriften soviel Kopfzerbrechen verursacht hat als die Prinizipien der Plastidule. Sie würden mich unendlich verbinden, wenn Sie mir nur à demi[3]mot sagten, wo ich etwa auf Sand gefahren bin. Ich möchte gern im „Auslande“ eine Notiz bringen ${ }^{154}$ - aber ich bin noch gar nicht im Stande mit Selbstgewißheit 10 Zeilen über die Broschüre zu schreiben. -

Prof. Gustav Jäger wird in den nächsten Wochen - wie er mir sagt - eine größere Abhandlung gegen alle darwinistischen Grundbegriffe schreiben (Vererbung, Variabilität etc.) schreiben u. eine neue Auffassung - eine chemisch-physikalische - derselben zu entwickeln suchen.

In neuester Zeit bin ich auch in Correspondenz mit $\underline{\text { Henry Huth }}^{155}$, dem Verfasser der marriage of NearKin getreten. ${ }^{156} \mathrm{Er}$ ist ein junger Gelehrter, dem es darum zu thun ist, einen Menschen auf dem Continent zu haben, der ihn en conrent in litteris erhält. Diese Stelle werde ich ihm gegenüber einnehmen. Natürlich verlange ich insofern Gegenleistung, als er mir darwinistische Abhandlungen aus England senden muß.

[4] Huth würde auch sofort an der projecirten Darwinia arbeiten.

Darwins "The results of cross" 157 etc. wird Ende October die Presse verlassen. Ich werde von ihm ein Exemplar erhalten zur Besprechung in der Illustrierten Zeitung.

..... Das „Athenäum “158 soll sehr schlecht gehen u. Costenoble soll alle Angst vor dem Zeitschriftenverlag bekommen haben - am Ende scheitert die „Darwinia“ mals. Wie's auch kommen mag; den Gedanken selbst gebe ich nicht auf.

Hochachtungsvoll grüßend

Ihr Otto Zacharias

[29]

Zacharias an Haeckel

Dessau d. 28. Juli 76.

Geehrter Herr Professor!

Ich glaube, ich habe Sie schon früher einmal mit der Bitte angegangen, daß Sie mir bei meinem Bestreben die Tagesschriftstellerei mit einer andern befriedigenden Thätigkeit zu vertauschen, behilflich sein möchten. Ich hatte damals irgend eine Beschäftigung vor Augen, bei der ich meine Beschäftigung vor Augen, bei der ich meine Fähigkeit zu

\footnotetext{
154 Zacharias, Otto (1876): Die Perigenesis der Plastidule. - Das Ausland, 49. Jg., Nr. 30, S. 596-598.

155 Huth, Henry Alfred (1815-1878), englischer Schriftsteller.

156 Huth, Henry Alfred (1875): The marriage of Near Kin. London: Churchill.

${ }^{157}$ Darwin, Charles (1876): The effects of cross and self fertilisation in the vegetable kingdom. London.

158 Vgl. Anm. 98.
}

Annals of the History and Philosophy of Biology, Vol. 11 (2006) 
schreiben u. meine zoologischen Kenntnisse verwerthen könnte. Es schwebte mir damals die Stelle eines Assistenten bei dem Director eines zoologischen Gartens oder Aquariums als erstrebenswerthes Ziel vor. ${ }^{159}$

Ich habe dieser Tage erst wieder Betrachtungen über die Nichtigkeiten angestellt, mit denen ich hier meine Zeit verbringe. In Görlitz war ich wenigstens Redacteur eines Civilblattes, wo die freie und umunwundene Meinungsäußerung gestattet war; hier bin ich aber ganz u. gar von dem Hofgeschmeiß abhängig u. habe gar keine eigene Ansicht mehr - darf vielmehr keine haben. Das ist eine traurige Lebenslage, die mich im höchsten Grade [2] verstimmt u. abstumpft. Sollten Sie also gelegentlich einmal etwas von einer derartigen Stellung, wie ich sie angedeutet habe hören u. sollten Sie glauben, daß ich fähig wäre, sie auszufüllen: so erinnern Sie sich ja meiner u. theilen mir das Nöthige darüber mit.

Ich habe auch Dr. Fried. v. Hellwald gebeten mir aus der Zeitungsmacherei herauszuhelfen u. wie er mir schreibt, will er sich Mühe geben etwas ausfindig zu machen. Könnte ich gelegentlich einmal die Redaction eines wissenschaftl. Blattes übernehmen, so wäre mir das natürlich auch recht. Nur keine Politik mehr - !

Das bewußte Buch von Dr. Jäger ist zwar noch nicht erschienen - aber ich habe es in den Aushängebogen gelesen u. die Ueberzeugung gewonnen, daß es für den practischen Forscher sehr gute Winke enthalten muß. Den Nutzen seiner sogen. Neurulaform, die er Ihrer Gastrula gegenüberstellt - begreife ich jedoch nicht. Es wird in einigen Wochen bei Braumüller in Wien erscheinen. ${ }^{160}$ [3] Kennen Sie Achille Quadri ${ }^{161}$ in Siena? Es ist jetzt schon das zweite Mal, daß ich von diesem Herrn darwinistische Essays zugesandt bekomme. Er ist ein eifriger Freund Ihrer Schriften u. trägt nach der ,natürl. Schöpfungs-

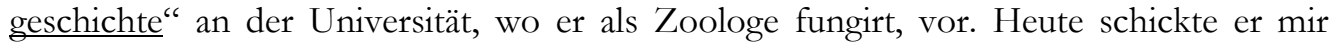
Note alla teoria Darwiniana ${ }^{162}$ - einen Band von 300 Seiten.

Ich hörte neulich von einem Darwin-Album ${ }^{163}$, das man mit Photographien der deutschen Darwinisten versehen am 12. Febr. 77 nach Down schicken wolle. Ihrer u. eines gewissen $\underline{\operatorname{Rade}}^{164}$ geschah dabei Erwähnung u. es hieß der letztere sei der specielle Ver-

\footnotetext{
${ }^{159}$ Vgl. hierzu auch Daum, Andreas (1998), S. 463.

160 Jäger, Gustav (1876): Zoologische Briefe. Wien: Braumüller.

161 Quadri, Achille, (1843-1895): italienischer Zoologe. Quadri studierte in Pisa Naturwissenschaften, promovierte 1865 und arbeitete anschließend im naturgeschichtlichen Museum von Florenz. Quadri ging 1868 an die Universität Bologna, wo er unter den Einfluß der Darwinisten Capellini und de Filippi geriet. Er begab sich 1871 nach Jena, um bei Haeckel und Anton Dohrn histologische und embryologische Studien sowie bei Gegenbaur vergleichende Anatomie zu betreiben. Quadri wirkte nach seiner Rückkehr nach Italien 1873 als Prof. für Zoologie und vergleichende Anatomie an der Universität Siena. Vgl. hierzu auch: Alla memoria del Prof. Achille Quadri. Professore nella R. Universita di Siena. Siena: Maggio 1896. [enthält die italienische Übersetzung eines Briefes von Haeckel an Quadri.]

162 Quadri, Achille (1869): Note alla teoria Darwiniana. Bologna: Vitali.

163 Rade, Emil (1877): Charles Darwin und seine Deutschen Anhänger im Jahre 1876. Eine Geschichte der Deutschen Ehrengabe zu Darwin's 69. Geburtstage. Straßburg: Schneider. Vgl. auch DarwinCorrespondence 10826, Brief Rade an Darwin vom Feb 1877: Sends album of Photographs of German scientist as birthday honour.

164 Rade, Emil (1832-e1907), Rechnungsrat. Biographische Angaben zu Rade waren nur spärlich zu ermitteln. Rade war mit Münsteraner Professor Landois befreundet und initiierte wohl die Schaffung eines Denkmals für diesen.
} 
anstalter. Soll ich einmal im „Ausland“ Propaganda machen?165 Oder hat die Sache schon so wie so Aussicht mit einem guten Erfolg?

Ergebenst grüßend

Ihr Otto Zacharias

[30]

Zacharias an Haeckel

Dessau d. 12. Aug 1876

Geehrter Herr Professor!

Gustav Jäger hat mir vor einigen Tagen die dritte (neueste) Lieferung seiner zoologischen Briefe (in den Aushängebogen) zu einer Besprechung fürs „Ausland“ gesandt. Das Buch ist im Wesentlichen eine Kritik Ihrer Forschungs- und Denkweise in ruhiger, anständiger Form. Wenn Sie wünschen sende ich Ihnen die Schrift auf 3-4 Tage zu u. ich erwarte Ihre darauf bezügliche Antwort umgehend. Damit Sie schneller lesen können, würde ich mir erlauben, Ihnen die auf Sie bezüglichen Hauptstellen anzustreichen. Bekomme ich bis Montag keine Antwort, so bespreche ich das Buch schon in der nächsten Nr. des ,Ausland“'s. ${ }^{166}$

Ergebenst Ihr Otto Zacharias

[31]

Zacharias an Haeckel

Dessau d. 22. Aug. 76.

Geehrter Herr Professor!

Besten Dank für Ihre werthen Zeilen vom 16. d. M.167 Ich habe sofort an Dr. Schwertfegter [?] geschrieben, leider aber zur Antwort erhalten, daß Karl Müller ${ }^{168}$ alles allein besorgen wird. Also mit einer Reformation der „Natur“169 war es nichts.

\footnotetext{
165 Zacharias, Otto (1876): Darwin's neunundsechzigster Geburtstag. Das Ausland, 49. Jg., Nr. 36, S. 720.

166 Zacharias, Otto (1876): Ueber die chemisch-physikalische Natur des Keimprotoplasmas. Das Ausland, 49. Jg., Nr. 36, S. 718-719.

${ }^{167}$ Brief nicht mehr ermittelbar.

168 Müller, Karl (1818-1899), Studium der NW 1843-46, 1849 Promotion in Rostock, später Mitbegründer der Zeitschrift „Die Natur“ und bis 1896 deren Herausgeber, Mitbegründer des Naturwissenschaftlichen Vereins für Sachsen und Thüringen, 1896 Ernennung zum Professor, Gegner der Darwinschen Selektionsund Entwicklungslehre.

169 „Die Natur“, Zeitschrift zur Verbreitung naturwissenschaftlicher Kenntniß und Naturanschauung für Leser aller Stände, übernahm mit ihrem Erscheinen 1853 die Vorreiterrolle der populärnaturwissenschaftlichen Publizistik in Deutschland, vgl. hierzu Daum (1998), S. 346-353.
} 
Aus Görlitz bin ich - damit Sie das genau erfahren - deshalb fortgegangen, weil die Actiengesellschaft, der der „Anzeiger“ gehörte auf dem Aussterbe-Etat stand. Sämtliche Actionäre hatten soviel in der Gründerzeit verloren, daß sie das Blatt nicht mehr subventioniren wollten $\mathrm{u}$. wohl auch nicht konnten. Und subventionirt mußte werden, weil wir zwei Concurrenzblätter hatten. 3 Monate nach meinem Weggange hat die Görl. Anz. Actengesellschaft liquidirt. Das ist der wahre u. wie Sie zugeben werden - trifftige Grund, meines Wegzugs von Görlitz. Mir ist der Ortswechsel weder pecuniär noch moralisch leicht geworden. [2] Mein Referat über Jägers neues Buch habe ich gestern an Hellwald abgesandt. Es wird in der übernächsten Nummer des Ausland erscheinen. ${ }^{170}$ Ich mußte mich auf Hellwalds Bitte sehr mit dem Raum einschränken, ich habe mir aber einen zweiten Artikel vorbehalten. Das Buch erscheint erst in 6-8 Wochen bei Braumüller (Wien).

Wie ich höre wird Costenoble das Athenäum wahrscheinlich eingehen lassen. - Ueber das Darwin-Album habe ich eine Notiz (1/2 Spalte) fürs Ausl. geschrieben u. die klingenden Beiträge etwas locker zu machen gesucht.

Unter Kreuzband sende ich Ihnen eine merkwürdige Abhandlung von Jäger, die Sie gewiß interessiren wird. Ich bitte mir dieselbe vor Ihrer Abreise nach Schottland zurück. ${ }^{171}$

Bestens grüßend

Ihr ergebener Zacharias

[32]

Zacharias an Haeckel

Dessau d. 21. Septbr. 1876

Geehrteste Frau Professor !

Ich ersuche Sie freundlichst dem Herrn Professor nach seiner Rückkunft aus Schottland die nachstehenden Zeilen einzuhändigen.

Ergebenst Dr. Otto Zacharias

Geehrtester Herr Professor!

Nach langem Suchen u. Agitiren bin ich endlich bezüglich der zu gründenden darwin. Zeitschrift mit Herrn Dufft ${ }^{172}$ (ziemlich) handelseinig geworden. Derselbe wird Sie, glaube ich, gleich nach Ihrer Rückkehr aufsuchen um Ihre Ansicht von der Sache zu hören.

\footnotetext{
170 Vgl. Anm. 166.

${ }^{171}$ Im Herbst 1876 besuchte Haeckel eine Versammlung britischer Naturforscher in Glasgow und sah auch anläßlich dieses Besuches einen Teil des Materials der „Challenger-Expedition“, von dem er in den nächsten Jahren u.a. die Radiolarien und Medusen bearbeitete. Haeckel reiste nach seinem Glasgow-Aufenthalt durch Schottland. Vgl. Uschmann, Georg (1983): Ernst Haeckel. Biographie in Briefen. Leipzig: Urania. S. 152/53.

172 Dufft, Hermann, Verleger in Jena. Dufft hatte 1866 den Mauke-Verlag übernommen, dessen Ursprung mit Gründung der Druckerei Werther im Jahre 1661 liegt. Der Verlag von Dufft geriet 1877 in Konkurs und wurde von Gustav Fischer übernommen.
} 
Ich habe ihm zwar schon gesagt, daß Sie das Unternehmen indirect mit allen Kräften [2] fördern würden, habe ihm auch meine Briefe von Darwin eingesandt - aber er scheint es sich nicht nehmen lassen zu wollen mit Ihnen persönlich zu conferiren.

Ich hätte Ihnen gern diese Unbequemlichkeit erspart, aber da Sie doch auch wünschen, daß das Project realisirt wird, ersuche ich Sie freundlichst Herrn Dufft die nöthige Auskunft zu ertheilen. Ich habe dem Herrn gleich gesagt, daß ich mich der Redactionsarbeit nicht umsonst unterziehen könnte, da ich kein reicher Mann sei. Er weiß somit von mir aus Alles, was er als Verleger wissen muß. Ich habe ihm auch gesagt, daß ich als Mitarbeiter der einflußreichsten Zeitschriften in der Lage bin, für genügende Publicität resp. Brutwärme für das sich entwickelnde Unternehmen zu sorgen. Mehr kann er also zunächst nicht verlangen.

Ich würde Ihnen sehr verbun-[3]den sein, geehrter Herr Professor, wenn Sie Herrn Dufft die Lichtseiten des Projects darlegten, ohne ihm die Schattenseiten im Geringsten zu verhehlen. -

Frohe u. erfolgreiche Ankunft wünschend

Ihr Otto Zacharias

[33]

Zacharias an Haeckel

Dessau d. 4. Oct. 1876

Geehrtester Herr Professor!

Ich hatte mir erlaubt, Ihnen brieflich den eventuellen Besuch des Herrn Dufft zu annonciren; derselbe wollte mit Ihnen Rücksprache über die projectirte Zeitschrift nehmen.

Heute schreibt er mir rundweg ab u. sagt: daß ihm „Sachverständige in Jena“ gerathen hätten, die Hände von einer Darwinzeitschrift zu lassen. Ich weiß nicht wer die gelehrten Thebaner gewesen sind.

Ich wollte Ihnen das nur mittheilen, damit Sie wissen: weshalb Herr Dufft nicht erschienen ist. [2] Jetzt stehe ich noch mit $\underline{\text { Schweizerbart }}{ }^{173}$ in Unterhandlung. Wenn der nichts unternimmt, dann gebe ichs auf. Ich bin dann alle deutschen Verleger durch.

Haben Sie von Ihrer Reise nicht ein Ergebniß mitgebracht, das man im „Ausland“ als Notiz veröffentlichen könnte? Ich muß jetzt energischer als je nach Stoff mich umsehen, da ich mir jetzt das tägl. Brod als „Held der Feder“ erkämpfen muß.

Ergebenst Ihr Otto Zacharias

173 Gemeint ist hier die Schweizerbart'sche Verlagsbuchhandlung in Stuttgart, welche ein vorwiegend naturwissenschaftliches Buch- und Zeitschriftenprogramm herausgab. 
Zacharias an Haeckel

Discretionssache.

Dessau d. 22. Nov. 1876

Geehrtester Herr Prof.

Ihre werthen Zeilen vom 23. Oct. sind in meinen Händen ${ }^{174}$. Ich danke Ihnen für Ihre Winke bezüglich der neuen Aufl. des Brehmschen Thierlebens ${ }^{175}$. Zunächst beschäftigt mich jedoch eine andere Angelegenheit, über die ich Ihnen nachstehend berichten will. Es handelt sich wiederum um die Darwinistische Monatsschrift. Ich habe mit dem Chef der bekannten Güntherschen Verlagshandlung ${ }^{176}$ abgeschlossen u. soll nun bis 1. Jan. ein Heft fertigstellen. Sie werden erstaunt sein, daß es nun so schnell gekommen ist; aber unverhofft kommt oft. Ich hatte den ganzen Gedanken beinahe aufgegeben; da schreibt mir auf einmal, ganz von selbst der Inhaber obiger Firma (Carl Alberts ${ }^{177}$ ) u. sagt mir, daß er schon Jahre lang eine solche Zeitschrift wie ich sie in petto habe, projectire. Hellwald hatte ihm in Wiesbaden meine Ideen mitgeteilt u. darauf[2] hin erhielt ich Nachricht. Die Monatsschrift wird mit sehr bedeutenden Mitteln begründet u. rechnet, weil sie gute Honorare zahlt, auch auf Mitarbeiter von Ruf.

Ich muß nun abermals die Bitte an Sie richten: sich in irgend einer Weise an dem Unternehmen zu betheiligen, sonst kommt die Zeitschrift noch in letzter Stunde nicht zu stande. Wenn Ihr Name fehlt, so ist das Unternehmen von vornherein todt: denn alle Welt wird fragen: warum der Hauptvertreter des Monismus indifferent bleibt. Wenn Sie auch, Herr Professor, mir immer schon sagten, daß Sie sich nicht engagiren wollen, so dürfte doch dieser Fall eine Ausnahme machen. Liefern Sie mir irgend etwas für das erste Heft; am besten wäre es vielleicht: wenn Sie einen Wunsch für das Gedeihen der Sache niederschrieben $u$. auf diese Weise Ihre Theilnahme bezeugten. Darwin thut das indirect auch, indem er mich autorisirt hat, schon in Prospect (das nächste Woche erscheint) zu sagen: $\mathrm{daß}$ er das höchste Interesse an dem Unter[3]nehmen hat. Sie verstehen ja so schwungvoll zu schreiben $u$. werden es gewiß im Interesse der Sache thun.

Haben Sie keine Bedenken wegen Ihres berühmten Namens; Sie werden sich in durchaus guter Gesellschaft befinden: indem Oscar Schmidt, Hellwald, Gustav Jäger, Rauber etc. schon zugesagt haben u. Beiträge senden werden. Es muß nun zu einem Resultate kommen. Bitten Sie doch die Hertwigs noch einmal, geehrter Herr Professor, es muß Stoff geschafft werden. Der Titel der Hefte wird sein: Zeitschrift für Monismus u. Darwinis$\underline{\text { mus. }}$.

Ich würde mich unendlich blamiren, wenn ich kein Manuscript zusammenbekäme. Ich selbst kann doch nicht Alles schreiben. Darwins Sohn wirkt auch mit.

\footnotetext{
174 Brief von Haeckel nicht auffindbar.

175 Brehms Thierleben: allgemeine Kunde des Thierreichs. - Große Ausgabe, 2. umgearb. u. verm. Auflage. Bibliographisches Institut Leipzig 1876-79.

176 Im März 1871 wurde die Günthersche Verlagshandlung in Leipzig als Zweigniederlassung des Hauptgeschäfts in Breslau eröffnet und wurde 1882 alleiniger Stammsitz der Firma.

177 Carl Alberts war von 1871-1901 Inhaber des Verlags, der später an die Firma J.A. Barth überging [Auskunft Staatsarchiv Leipzig, Frau Bär].
} 
Ich bitte Sie um schleunigste Antwort, geehrter Herr Prof., damit ich weiß, welche Art von Bei[4]trag fürs erste Heft ich von Ihnen zu erwarten habe. Mein obiger Vorschlag ist glaube ich ganz gut.

Im Februar soll eine Festheftnummer zu Ehren Darwins erscheinen, da heißt es immer wieder Stoff schaffen.

Mein Mitredacteur für den philos. Theil der Zeitschrift ist Prof. Caspari in Heidelberg. Sie haben es jetzt mit in der Hand, Herr Prof., ein Organ lebensfähig zu machen, das der Sache des Monismus sehr wichtig werden kann. Meine Ausdauer kennen Sie.

Das Unternehmen ist solid; alle Leistungen werden anständig honorirt.

Ich bitte um schleunigste Antwort. So eben schrieb ich an Müller-Lippstadt.

Besten Gruß

Ihr Zacharias

[35]

Zacharias an Haeckel

Geestemünde-Bremerhaven

d. 25. Dec. 1876

Geehrtester Herr Professor!

Ich setze voraus, daß Sie sich wieder wohler befinden u. das Weihnachtsfest mit den lieben Ihrigen feiern können. Dr. Engelmann ${ }^{178}$ sagte mir wenigstens, daß Sie nicht mehr bettlägerig seien. Ich wünsche Ihnen fürs neue Jahr einen ruhigen Schlaf u. erstarkte Nerven - denn damit kehrt doch die Gesundheit zugleich zurück. -

Ich danke Ihnen nochmals für die III. Aufl. der Anthropogenie ${ }^{179}$ u. bitte Sie, mich nach wie vor, von Ihren Arbeiten wissen zu lassen. Raubers Bekanntschaft habe ich neulich in Leipzig gemacht u. einen Menschen an ihm gefunden, der eine seltene Liebenswürdigkeit u. Herzensgüte besitzt. Er hat mir seine ganzen [2] Hühnchen- Präparate gezeigt u. sich unendliche Mühe gegeben, mir eine Anschauung von der Gastrulation beim Hühner-Ei zu verschaffen. Ich war am 11. Dec. einen ganzen Vormittag bei ihm u. habe eine Fülle von Kenntnissen mit fortgenommen. $\underline{\text { Rauber }}$ ist ein Bayer u. es liegt etwas ungeheuer Herzliches in seiner Sprache u. seinen Umgangsformen. Mir ist es als kannte ich ihn Jahre lang.

Nun auf einige Worte über mich selbst. Ich bin nach hier verschlagen u. redigire die Nordsee-Zeitung ${ }^{180}$. Das Leben gefällt mir hier unten ganz gut - aber mit dem Herzen bin ich natürlich da wo die Wissenschaft ist. Hier gibt es keine Gelehrten - bloß Rheder, Schiffsmakler u. Spediteure. Darwins u. Ihr Name ist total unbekannt u. von Zoologie ist höchstens bei einigen Capitänen ein wenig die Rede. Der Hafen ist wundervoll [3] u. liegt

\footnotetext{
178 Evtl. ist hier der Verleger Dr. Wilhelm Engelmann gemeint.

${ }^{179}$ Vgl. Anm. 69, III. Auflage 1876.

180 Nordsee-Zeitung: politisches u. wirtschaftliches Organ für Bremerhaven und den Kreis-Lehe. Bremerhaven 1866-[?].
} 
zur Zeit voll amerikanischer, spanischer u. griechischer Schiffe. 11 große Lloyddampfer stehen in einer Abtheilung für sich. Ich hoffe die hiesigen Verhältnisse literarisch auszubeuten u. habe schon den Anfang damit gemacht. Sie lesen es demnächst im „Ausland“. Ich bitte Sie aber trotzalledem immer an mich zu denken, wenn sich einmal eine Custoden- oder Secretärstelle bei einem zoologischen Institute findet. Meine schriftstellerische Thätigkeit bringt mir 3-400 Thaler ein u. ich beanspruche daher nur 6-700 Thaler Gehalt. Die ,,monistische Zeitschrift“ hat durch Ihre Krankheit Aufschub erlitten u. den Artikel, den ich meinerseits dafür bestimmt hatte, erscheint im Januar im „Ausland“. Er handelt Darwins neuestes Werk ${ }^{181}$ u. gibt eine ausführliche Analyse desselben auf 11 Druckspalten. ${ }^{182}[4]$

Prof. Strasburger hat jetzt „Studien über das Protoplasma“"183 veröffentlicht, können Sie ihn nicht bestimmen, daß er mir die Broschüre zuschickt? Ich werde mich durch eine ausführliche Anzeige u. Analyse desselben in irgend einer großen Zeitung revanchiren. Das ist doch immer von Werth für einen Autor. Ich habe neulich das Werk über Zelltheilung gelesen $\mathrm{u}$. besonders die Schlußbemerkungen studirt.

Mein Zeitungskram ist mir stets Nebensache $\mathrm{u}$. ich bestrebe mich auch hier in der zoolog. u. entwickelungsgeschichtl. Literatur au courant zu bleiben .....-

Zur Zeit weht ein scharfer Nordost von der See her u. meine Stube ist wegen der gefrorenen Fenster cinematisch dunkel. Meiner Frau will das hiesige Fischer- u. Schifferleben gar nicht gefallen. Aber ihr sowohl meinem Söhnchen bekommt die Seeluft gut. Mir natürlich auch.

Mit bestem Gruße Ihr Otto Zacharias

[36]

Haeckel an Zacharias

Jena 17. Jan. 77

Verehrter Herr Doctor!

In einigen Tagen sende ich Ihnen der Schluß der Gastraea-Theorie, der endlich fertig gedruckt [ist]. Strasburger wird Ihnen [die] Protoplasma-Studien wohl schicken, wenn er zurück ist. Er ist den ganzen Winter in Nizza, beide Hertwigs in Messina.

Ich gehe, sobald ich kann - hoffentlich Anfang März - auf einige Monate nach dem Süden, um mich zu erholen. [2] Ich bin noch sehr angegriffen, schlafe schlecht und kann sehr wenig arbeiten.

Zu Ihrer Übersiedelung nach Geestemünde wünsche ich Ihnen Glück. Ich erblicke darin einen natürlichen Fortschritt in Ihrer Wanderung von Osten nach Westen und vermuthe, daß Sie der Versuchung nicht lange widerstehen werden, die kleine Wasserfahrt von Bremerhafen nach New York zu unternehmen. [3] Bei Ihren activen Eigenschaften,

181 Darwin, Charles (1877): The effects of cross- and selffertilization in the vegetable kingdom. London: Murray.

182 Zacharias, Otto (1877): Darwin über Kreuzung und Selbstbefruchtung im Pflanzenreiche. Das Ausland, 50. Jg., Nr. 1, S. 4-10.

183 Strasburger, Eduard (1876): Studien über das Protoplasma. Jena: Dufft. 
Ihrer Arbeits-Energie und Ihrem Fleiße, glaube ich, daß Sie als Self-made man Ihr Glück weit eher in Nord America als in Europa machen [werden]. Dort kann ein popu[lär] wissenschaftl. Schriftsteller Ihres Schlages weit mehr vor sich bringen als hier in Deutschland, wo der Kampf ums Dasein für einen Homo literatus viel schwerer ist!

Mit freund. Gruß Ihr Haeckel

[37]

Zacharias an Haeckel

Geestemünde 24. Jan. 1877.

Geehrtester Herr Professor!

Das zweite Heft der „Studien zur Gasträatheorie“ 184 habe ich gestern Abend erhalten u. ich spreche Ihnen umgehend meinen Dank dafür aus. Natürlich bin ich gleich heute darüber hergefallen u. habe mit großem Interesse das Capitel über die Gastrulation der Säugethiere gelesen. Die van Benedensche kleinere Abhandlung ${ }^{185}$ war mir bereits bekannt. Sehr interessant war mir auch die von Ihnen referirte Entdeckung Rabls ${ }^{186}$ über die ersten Anlagen des Mesoderms bei Unio. Daß Sie diesmal der Gasträatheorie eine vorwiegend heuristische Bedeutung vindiciren, wird sehr beruhigend auf Ihre Widersacher wirken; ich freue mich aufrichtig, daß Sie ihnen so den Schuß aus den Händen gewunden haben.

[2] Die angezogenen Mittheilungen über die Dicyemiden haben mich sehr überrascht. Ich hätte es a priori gar nicht für möglich gehalten, daß es rückgebildete u. schmarotzende Gasträaden geben könnte. Die Existenz dieser Gruppe spricht übrigens - wie mir scheint - stark gegen jedes imanente Gesetz der Organisation. Denn wenn in irgend einer organischen Form, so müßte in den Gasträaden der Trieb zum Höhersichentwickeln rege gewesen sein. Ich hätte geglaubt der Parasitismus wäre erst ein späteres Product der Natur u. eine Folge des Mangels an genügendem Raum zum selbständigen Sichentfalten. Gerade wie man kleinere Kisten in größere setzt, wenn in der Rumpelkammer kein Platz mehr ist - so glaubte ich, hätte die Natur kleinere Organismen zum Binnenleben in größeren verurtheilt, wenn nicht genug Raum zur selbständigen Ausbreitung vorhanden ist.

Das ist nur eine Idee, die mir so aufleuchtet.

[3] Daß es Ihnen wieder leidlich gut geht, freut mich von ganzem Herzen. Darwin schrieb mir neulich einige Zeilen u. bedauerte am Schlusse derselben lebhaft ,that Häckel is owerworked“. Darwins Sohn George hat jetzt der Royal Society eine Abhandlung

\footnotetext{
${ }^{184}$ Haeckel, Ernst (1877): Biologische Studien. II. Heft. Studien zur Gastraea-Theorie.

185 Van Beneden, Edouard (1870): Recherches sur la Composition et la Signification et la l'oeuf. Bruxelles.

186 Rabl, Carl (1853-1917), österr. Anatom. Rabl studierte Medizin u. Zoologie in Wien und Leipzig, wurde 1882 promoviert und habilitierte sich ein Jahr später für deskriptive Anatomie. Er wurde 1885 ao. Prof. der Anatomie in Wien, 1886 Ordinarius der Deutschen Universität Prag, wo er 1903 zum Rektor gewählt wurde. Rabl beschäftigte sich vorwiegend mit Entwicklungsgeschichte und vergleichenden Anatomie; Rabl, Carl (1875): Die Ontogenie der Süßwasser-Pulmonaten. Jen. Zeitschrift f. Naturwiss. 1875, IX. Bd.
} 
über die Wanderung der Erdpole vorgelegt. ${ }^{187}$ Er ist zum Schlusse der Ansicht, daß die Eiszeit nicht ein klimatologisches Phänomen, sondern einfach eine Folge davon ist, daß die Erdpole einmal so zu liegen kamen, daß Europa u. Nordamerika die nächste Umgebung des Nordpols bildeten. Als Ursache der Polwanderung werden geologische Veränderungen angenommen. -

Ihren Rath, geehrter Herr Professor, einmal die kleine Wasserfahrt nach New-York zu machen, führe ich am Ende einmal aus. Aber bloß um das paläontol. Museum des Prof. Marshall in Boston zu sehen ${ }^{188}$. Zu einem transatlantischen Leben u. Wirken kann ich mich noch nicht entschließen. Es ist auch, wenn man Weib u. Kind hat, zu viel Risico dabei.

Mein Plan ist: Gründung einer monistischen Zeitschrift u. Sie werden sehen, daß ich das alte Project noch realisire. Aber ich bedarf fürs erste Heft wenigstens irgend etwas aus Ihrer Feder u. wenn es 50 Zeilen sind.

Ich bedaure ungemein, daß ich hier gar keine directe geistige Anregung habe. Ich brauche monatl. fast 4 Thaler Postporto. Dafür weiß ich allerdings, was darwinistisches in England, Holland, Österreich u. Deutschland vorgeht. Aber es kostet eine Heidenarbeit sich so au courant zu halten.

Mit bestem Gruße:

Ihr Zacharias.

PScr. Wissen Sie nicht, was Hillgendorf ${ }^{189}$ s. Z. für eine darwinistische Broschüre geschrieben hat? ${ }^{190}$ Ich las eine Andeutung in der „Post“"191.

187 Darwin, George (1877): On the influence of Geological changes on the earth's axis of rotation. London: Trübner.

188 Angaben zu Prof. Marshall sowie dem paläoontologischen Museum in Boston liessen sich nicht ermitteln. Ein derartiges Museum lässt sich in Boston erst ab 1891 nachweisen.

${ }^{189}$ Eigentl. Hilgendorf, Franz Martin (1839-1904), Zoologe. Studium der NW in Berlin u. Tübingen, Promotion 1863, Direktor des Zoologischen Gartens in Hamburg 1868-70, Dozent am Dresdener Polytechnikum, 1870-73, Prof. der beschreibenden NW an der kaiserlich japanisch med. Akademie in Tokio 1873-76, von 1877 als Museumszoologe in Berlin tätig, 1880 Kustos der Zoolog. Sammlg. Der Universität Berlin, 1893 Königl. Preuß. Prof., Redakteur des Archivs für Naturgeschichte.

${ }^{190}$ Hilgendorf's Promotionsschrift „Planorbis multiformis“ gilt als ein früher Beweis für Gültigkeit der Descendenztheorie.

191 evtl: Die Post: Berliner neueste Nachrichten. Berlin: 1866-1921. 
[38]

Zacharias an Haeckel

Dr. Otto Zacharias

Geestemünde, den 6. Febr. 1877

Geehrter Herr Prof:

Ich bitte Sie um einige Worte der Aufklärung. Sie wissen am besten, wie lange ich mich mit dem Projecte einer darwinist. Zeitschrift trage $u$. wissen auch, daß ich unlängst nahe daran war, daß erste Heft einer solchen bei E. Günther in Leipzig erscheinen zu lassen. Es scheiterte an dem Eintreten Ihrer Nervosität, weil Herr Günther mir erklärte, ohne

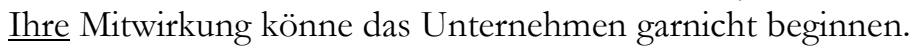

Jetzt höre ich auf einmal, daß am 1. April das erste Heft einer darwinist. Zeitschrift erscheinen soll [2] und zwar, wie es im Prospecte heißt, mit Ihrer u. - Darwins Mitarbeiter-

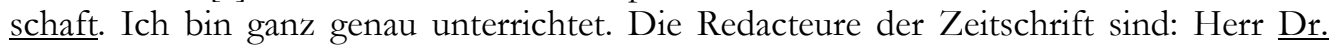
Caspari (Heidelberg), Carus Sterne (Berlin), Dr. Jäger (Stuttgart).

Herr E. Günther hat mit mir 6 Wochen lang correspondirt, Dr. Caspari weniger oft u. Dr. Jäger hat mir erklärt, aus Zeitmangel nicht mitarbeiten zu können. Ich war also mit Günther ganz im Reinen u. höre nun auf einmal, daß er mich hinten herunterfallen läßt. Ich ersuche Sie freundlichst, mir zu sagen, ob Sie wirklich Ihre Mitarbeiterschaft zugesagt haben oder ob das ein Misbrauch Ihres Namens ist. Damals wurde mir [3] Ihre Mitarbeiterschaft zur Existenzbedingung der Zeitschrift gemacht u. jetzt höre ich - wie schon erwähnt - daß mit Ihrem Namen paradirt wird. Ich bin von der Nachricht, daß man mir mein Project entwunden u. mit Hülfe anderer Leute ins Werk gesetzt hat, sehr übel berührt. Schon deshalb, weil ich dadurch quasi bei einer ganzen Reihe von namhaften Leuten in ein schiefes Licht gesetzt werde.

Ich bitte Sie dringend um einige Zeile Aufklärung.

Ihr ergebenster Dr. Otto Zacharias.

[39]

Zacharias an Haeckel

Geehrtester Herr Professor!

\author{
Redaction der „Nordsee-Zeitung“ \\ Dr. Otto Zacharias \\ Geestemünde, den 14. Febr. 1877
}

Ein so offenes Wort, wie Sie mir es in Ihrem letzten Schreiben ${ }^{192}$ sagten, hätte ich gern schon vor $1 \frac{1 / 2}{2}$ Jahren gehört, bevor ich mich mit der ganzen darwinistischen Welt, behufs der Zeitschriftsgründung in Verbindung setzte. Aber es ist mir auch jetzt noch will-

\footnotetext{
192 Gegenbrief Haeckels nicht ermittelbar.
} 
kommen und ich danke Ihnen dafür. Für eine strebsame Natur ist eine scharfe, schonungslose Kritik nur eine Sporn mehr. Ueber Jahr und Tag werde ich - wenn ich Lücken in Herrn Sternes gründlichen Kenntnissen bemerke - das literarische Duell nicht scheuen. Ob Herr Dr. Krause die von Ihnen unbedingt geforderten botanischen, physiologischen, anatomischen etc. Kenntnisse besitzt - habe [2] ich nach der bisherigen Lectüre seiner Zeitungsaufsätze nicht entscheiden können. Es ist möglich daß das Buch über Werden und Vergehen, das ich nur capitelweise kenne, bei dem Entscheide darüber den Ausschlag giebt.

Aber von alledem abgesehen. Ich hätte wenigstens erwartet, daß man mich als Mitarbeiter beibehalten würde, da man Herrn Rechnungsrath Rade eingeladen hat, Aufsätze zu liefern. Daß ich in litteris mit Herrn Rechnungsrath Rade den Vergleich aushalte, würden Sie, geehrter Herr Professor, gewiß nicht in Abrede stellen können. Aber es ist bei der erwähnten Einladung, wie mir scheint, die echte Berliner Speculation dabei, daß man einen Mann, der sich als Veranstalter des Darwin-Albums bekannt gemacht hat, schon um seiner diesfallsigen Publicität willen mit in das Namenverzeichniß aufnehmen muß.

[3] Ich kann nicht leugnen, daß ich etwas piquirt bin - aber das geht bei mir bald vorüber u. macht keinen Menschenhasser aus mir. Verzeihen Sie mir auch den Ton dieser Zeilen! Ich verehre Sie nach wie vor u. bitte um Ihre fortgesetzte wohlwollende Gesinnung gegen mich.

Gegen Jäger u. Caspari als bewährte Fachleute hätte ich selbstverständlich nichts einzuwenden gehabt - das wäre Ueberhebung u. Mangel an Selbstkenntniß gewesen. Aber woher Sternes Verdienste auf einmal solches Gewicht erhalten - der doch keine namhafte originelle Forschung aufweisen kann - das begriff ich nicht u. begreife es auch jetzt noch nicht.

Wenn ich gesund bleibe, geehrter Herr Professor, u. 1-2 Jahr hinter mir habe, so sollen Sie sehen, was mein auch von Ihnen anerkannter Fleiß aus mir zu machen vermag.

Ihr ergebener

Zacharias.

[40]

Zacharias an Haeckel

15. Febr. 77. Geestemünde.

Geehrtester Herr Professor!

Soeben ergeht von Seiten der Kosmos-Redaction die Einladung zur Mitarbeiterschaft an mich, die ich natürlich annehme. ${ }^{193}$ Ich erlaube mir, Ihnen dies mitzutheilen, damit von der peinlichen Correspondenz, die ich nicht bloß mit Ihnen, sondern mit 6 andern Leuten hatte, fernerhin nicht mehr die Rede ist.

193 Zacharias wird auch im ersten Band der Zeitschrift Kosmos als Mitarbeiter genannt, tatsächlich erschien hier jedoch kein einziger Artikel von ihm. 
Auch bitte ich Sie, die in meinem letzten Briefe gefallenen Äußerungen als unter Discretion mitgetheilt bekommen, zu betrachten. Ueber frühere personelle Auslassungen Ihrerseits habe ich auch bis auf diese Stunde das effectivste Schweigen beobachtet u. werde es auch ferner thun.

Mit bestem Gruße Ihr ergebener Zacharias.

[41]

Zacharias an Haeckel

Dr. Otto Zacharias

Geestemünde, den 21. Mai 1877

Geehrter Herr Professor!

In der Zeit, wo Sie verreist waren, entdeckte ich, ganz per Zufall, eine recht interessante Anomalie beim Schwein. Dasselbe besaß nämlich an den Vorder-Füßen einen vollständig ausgebildeten Daumen, mit dem es wirklich den Boden berührte u. auftrat. Wenn man den Fuß aufdrückte, so hatte man beinahe den Eindruck wie von einer Hand. Beide Füße waren mit einer solchen Zehe versehen u. letztere besaß in beiden Fällen dieselbe Länge (5-6 Cm.) An den hinteren Extremitäten sah ich nichts außergewöhnliches. - Ich acquirirte das Schwein sofort, ließ nach dem Niederstechen die Pfoten abhacken u. schickte dieselben an Darwin mit der Bitte [2] mir zu sagen: ob der Fall ihm interessant sei u. ob ihm schon ein solcher vorgekommen sei. Darwin schrieb mir sofort wieder u. sagte mir, daß er den interessanten Fuß an H.W. Flower ${ }^{194}$ nach London spedirt habe, damit der ihn osteologisch untersuchen u. präpariren solle ${ }^{195}$. Flower ist, glaube ich, Vorstand des thierärztl. Instituts in London.

Gestern bekam ich nun einen längeren Brief von Mr. Flower, worin mir derselbe seine große Freude über das schöne Specimen ausspricht u. sich über die sonstige Beschaffenheit des qu. Schweins erkundigt. Ich habe natürlich umgehend geantwortet. Prof. Flower sagt mir, daß ihm der Fall deshalb besonders interessant sei, weil der Zeh auch ein überzähliger Karpelknochen entspreche. [3] In dem Teratolog. Museum in London befindet sich bereits ein ähnlicher Schweinsfuß - aber nach Flowers Aussage ist die Mißbildung an demselben lange noch nicht so expressiv.

Ich habe Ihnen vorstehend den Fall ausführlich mitgetheilt, weil ich der Meinung bin, daß derselbe auch für Sie ein gewisses Interesse hat. Er beweist, nach meiner Ansicht, daß der fünfzehige Typus (durch Rückschlag) auch da zum vollständigen Ausdruck kommen kann, wo durch Anpassung bereits das ganze Knochengerüst des Fußes eine Umbildung erfahren hat. --

194 Flower, William Henry (1831-1899), Mediziner, Anatom. Kurator des Hunterian Museums 1861-64, Anatomieprofessor am Royal College of Surgeons 1870-84, dann Direktor des Naturhistorischen Museums 1884-1898.

195 Dieser Briefwechsel zwischen Zacharias, Darwin und Flower ist in der Darwin Correspondence belegt, Briefnummer 10936, 10941, 10949, 10950, und 10962. 
Vom „Kosmos“ habe ich bis dato nicht viel gehört. Damit ein neues Unternehmen reussirt bedarf es nicht bloß berühmter Namen u. fleißiger Mitarbeiter, sondern auch unausgesetzter journalistischer [4] Agitation. Ich, meinerseits, habe jetzt - nachdem ich kein Mitredacteur bin - begreiflicherweise nur ein allgemeines Interesse an der Sache u. sehe mich nicht veranlaßt für das zu wirken, was mich nur indirect angeht. Wenn der „Kosmos“ durchdrückt, so ist mir das natürlich eine aufrichtige Freude.

Der Fehler an dem Unternehmen ist meiner Meinung nach der, daß man glaubt mit bloBer Gelehrsamkeit das Publikum zu packen. Das ist niemals der Fall. Zur Einführung eines neuen derartigen Journals gehört die unausgesetzte Erwähnung desselben in allen möglichen Tageblättern u. Wochenschriften. Aber wer soll das thun? Caspari u. Jäger haben jedenfalls mit der Beschaffung von Manuscripten soviel zu thun, daß sie nicht daran denken können. Und sonstige Journalisten haben weder das Interesse noch Verständniß. Ich wußte damals ganz genau, wie es anzufassen gewesen [5] wäre, um einen durchschlagenden Erfolg zu erreichen. Die Art u. Weise aber wie man mich abgesattelt hat, benimmt mir selbstverständlich jedes Interesse für die nächste Folgezeit.

Den Gedanken mich an die Spitze einer Zeitschrift zu schwingen gebe ich nicht auf, sondern bin jetzt mit verdoppelter Energie dabei, Kräfte für ein philosophisches Organ zu gewinnen. Diesmal werde ich es aber klüger machen u. mir erst dann einen Verleger suchen, wenn ich das Manuscript zum I. Hefte bereits im Pult liegen habe. Man muß factisch auch die Wissenschaft geschäftlich betreiben, wenn man nicht übervortheilt sein will.

Nach meiner Meinung giebt es ebenso gut einen wissenschaftlichen Journalismus wie einen politischen $u$. ein Journalist von der ersten Categorie scheint mir zu den Fachmännern [6] in demselben Verhältniß zu stehen, wie der Zeitungsschreiber zu den Abgeordneten u. Staatsmännern.

Der „Kosmos“ scheint insofern wieder ein recht „deutsches“ Unternehmen zu sein, als man factisch grade diejenigen davon ausschließt, die am besten geeignet wären die Sache in Gang zu bringen. Es soll eben immer alles ,gelehrt“ zugehen. Freilich ist wieder, was das Gelehrtenthum anbelangt, auch nicht alles immer Gold was glänzt.

Ich gestehe Ihnen offen und ehrlich, daß es mich immer noch wurmt, mir eine solche Zeitschrift aus den Händen gewunden zu sehen. Ich habe zwei Jahre darangesetzt, um sie ins Leben zu rufen u. nun kommt ein beliebiger Anderer u. copirt mir die Sache weg. - - - doch genug davon! - Sollte Ihnen der Fall mit den oben erwähnten

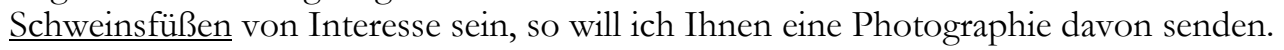

Hochachtungsvoll grüßend

Ihr Zacharias. 
[42]

Zacharias an Haeckel

Geestemünde d. 27. Juli 77

Geehrtester Herr Prof.

Jetzt ist wieder einmal eine Gelegenheit gekommen, die ich ergreifen muß, um den Versuch zu machen aus der Zeitungsmeierei herauszukommen. Ich glaube Sie könnten mir ohne Gefährdung Ihres berühmten Namens - dabei behilflich sein. Soeben - heute früh - höre ich aus Leipzig, daß dort ein gewisser Dr. Oscar Schneider (?) eine permanente mikroscopische Ausstellung à la Zencker ${ }^{196}$ zu eröffnen gedenkt u. mit dieser Ausstellung auch eine Sammlung von Lehrmitteln für den naturwissenschaftl. Unterricht zu errichten beabsichtigt. Als ich dies hörte kam mir sofort der Gedanke, ob bei diesem Unternehmen nicht ein passender Platz [2] für mich ausfindig zu machen wäre. Dr. Schneider gedenkt 50 Mikroskope aufzustellen u. zoologische, botanische u. mineralogische Präparate zur Ansicht darzubieten.

Wenn es mir gelänge bei einem solchen Manne Assistent zu werden, so wollte ich es über Jahr u. Tag schon zu etwas bringen. Mir fehlt es nur an Anschauungen, an Logik u. Combinationsgabe sicher nicht. Zum Beweis für den Besitz der letzteren kann ich neuerdings anführen, daß ich Herrn Prof. Rauber vor einigen Wochen eine kleine Arbeit über die muthmaßliche Prologenie der Wirbelsäule zugesandt habe, die derselbe - wie er mir schreibt - einer eingehenderen Prüfung für Werth erachtet.

Ich wollte Sie nicht belästigen, sonst hätte ich zuerst Ihr Urtheil mir erbeten. Grade eine Stelle der Anthropogenie hat mich auf jene obige [3] Erklärungsmöglichkeit gebracht.

Doch genug hiervon. Der Zweck meiner heutigen Zeilen ist, Sie freundlichst zu ersuchen (falls Sie Dr. O. Schneider kennen) sich bei demselben für mich zu verwenden resp. demselben einen Wink zu geben, sich mit mir in directe Verbindung zu setzen.

Sie sehen, ich ergreife jeden Strohhalm um mich in eine meiner Natur gemäßeren Lebenssphäre hinauszuretten.

Prof. Gegenbaur hat mir über den Schweinsfuß ausführlich geschrieben. Ich sende Ihnen gelegentlich die Briefe. - Daß man in Solnhofen ein zweites (viel vollständiger) Exemplar von Archäopteryx lithogr. gefunden hat, hörten Sie wohl. ${ }^{197}$ Ich besitze einen ganz genaue Beschreibung desselben vom Finder persönlich.

Mit ergebensten Gruß

Ihr Otto Zacharias

\footnotetext{
196 Biographische Angaben zu Oscar Schneider und Zencker waren nicht ermittelbar.

197 Häberlein, Ernst (1819-1896), Steuereinnehmer und Fossiliensammler. Häberlein erwarb den 1876 in einem Steinbruch auf dem Blumenberg bei Eichstätt gefundenen Ur-Vogel. Dieses Exemplar des Archäopteryx lithographica gilt als schönster und vollständigster Fund. Mit Hilfe der finanziellen Unterstützung durch Werner von Siemens (20 000 Goldmark) konnte dieser Fund vom Berliner Museum für Naturkunde 1880 angekauft werden.
} 
[43]

Zacharias an Haeckel

Geestemünde d. 24. Oct. 1877

Geehrter Herr Professor!

Ich habe Ihre Münchner Rede ${ }^{198}$ allerdings in den Zeitungen gelesen, kann mir daraus allerdings kein genaues Bild von Ihren Ausführungen machen. Gerade diejenigen Partien des Vortrags, die mir am interessantesten sind - Umgestaltung der Moral, Reform unserer religiösen Begriffe etc. - fand ich in den Referaten ganz stiefmütterlich behandelt. Es wäre mir demnach sehr erwünscht, wenn Sie die Güte hätten u. mir nach dem Erscheinen der zweiten Aufl. ein Exemplar des Vortrags zusendeten.

Ich will dann für die Frankf. Zeitung oder die Wiener „Presse“ einen eingehenden Aufsatz schreiben. So - ohne Ihre Rede studirt zu haben - darf ich nicht wagen, mich über die Differenz zwischen Ihnen u. Virchows Ansichten auszusprechen. -

Hier am Orte habe ich kürzlich Gelegenheit gehabt zu sehen, daß auch die Seesterne in der Zahl ihrer Arme recht variiren. Ich habe 3, 4, 5 u. sogar 12armige Seesterne (aus der Nordsee) vorgelegt bekommen.

Ebenso sind einige sehr interessante Fälle von Mimikry vorgekommen. Ein Capitän brachte eine Anzahl tropischer Heuschrecken mit, von denen einige solche blattähnliche Oberflügel befassen, das man [3] sie im Laubwerk nicht hätte unterscheiden können. Die Blattähnlichkeit nur in Farbe u. Aderbildung so groß, daß ich erst ein Artefact vor mir zu haben glaubte. Ich konnte allerdings schon aus Wallaces ${ }^{199}$ Berichten die unter den Orthopteren so häufigen Fälle von Mimikry, aber wenn man sie mit eigenen Augen sieht, frappiren sie doch sehr. Der von Wallace beschriebene Schmetterling (Kallima paralecta) ${ }^{200}$ kann in seiner Blattähnlichkeit nicht frappanter sein, als die in Rede stehenden Locustiden. Dieselben sind dem hiesigen Museum einverleibt worden. -

Mit der Bitte um Erfüllung meines Eingangs ausgesprochenen Wunsches

Ihr ergebenster Otto Zacharias

\footnotetext{
198 Haeckel, Ernst (1877): Freie Wissenschaft und freie Lehre. Stuttgart: Schweizerbartsche Verlagsbuchhandlung.

199 Wallace, Alfred Russel (1823-1913), Naturforscher. Er hörte ab 1837 Vorlesungen in der Hall of Science London, führte mit seinem Bruder Vermessungsarbeiten durch und war von 1844-45 als Lehrer tätig. Wallace begab sich 1848 auf eine Südamerikareise (Amazonasgebiet), um Evolutionshypothesen über Artwandel zu prüfen. Wallace erlitt auf der Rückreise 1852 Schiffbruch und Verlust der Sammlungen. Er begab sich 1854-62 auf eine Forschungsreise ins Malayische Archipel, machte wichtige tiergeographische Beobachtungen und erkannte das Selektionsprinzip als Ursache des Artwandels. Wallaces war ab 1862 als Privatgelehrter tätig.

200 Kallima paralecta: Indischer Blattfalter.
} 
[44]

Zacharias an Haeckel

Geestemünde d. 19. Febr. 1878

Geehrtester Herr Professor!

Seiner Zeit machten Sie mich darauf aufmerksam, daß es ebenso wichtig als lehrend? sei, das Entwickelungsgesetz in der psychologischen u. socialen Erscheinungen zu studiren und ich habe Ihren Rath dieses Studium zu verfolgen meinerseits beherzigt. Aus dem beifolgenden, unter Kreuzband eingeschossenen Artikel, werden Sie ersehen, in welcher Weise ich mir die Behandlung socialer Probleme in der von Ihnen angedeuteten Richtung denke. Eine paar darauf bezügliche Worte der Zustimmung oder Kritik aus Ihrem [2] Munde, würden mir Muth machen das begonnene Studium fortzusetzen.

Außerdem hätte ich noch eine Bitte an Sie. Ich habe bis jetzt fast in allen renommirten Zeitschriften Artikel veröffentlicht - nur in der Gartenlaube ${ }^{201}$ noch nicht. Ich weiß sehr wohl, daß der Ihnen nahe stehende Dr. Sterne für dieselbe schreibt, aber ich werde dem gewiß keine Concurrenz machen können, da derselbe wie Sie ja selbst sagen, ein so ausgezeichneter Gelehrter ist. Es wäre mir ungemein erwünscht, geehrter Herr Professor, wenn Sie mir der Weg zu Keil etwas ebnen könnten. Ich will in der Gartenlaube einige Artikel über sociale Entwickelung (im Zusammenhange mit der Arbeiterfrage) publiciren u. für dieses Gebiet trauen Sie mir am Ende doch journalistischen Blick u. psychologische Vorbildung genug zu.

Ich weiß das allerdings nicht - aber ich liefere Ihnen anbei einen Probeartikel, der zeigen soll, wie ich derartige Fragen behandeln will.

Sollten Sie geneigt sein, mir einige empfehlende „Zeilen“ an Keil202 mitzugeben, so realisiren Sie Ihre liebenswürdige Absicht recht bald; sollten Sie es aber nicht aus Ueberzeugung thun können, so ist mir unumwundene Offenheit wie früher so auch jetzt das An[4]genehmste. Ich will mir Ihre Anerkennung nicht erschleichen, geehrter Herr Professor, sondern verdienen. Was für die „Weserzeitung“ - ein an allen norddeutschen u. überseeischen Plätzen gelesenes Blatt - geeignet ist, sollte, meiner Meinung nach auch für die „Gartenlaube“ nicht unpassend sein.

Hochachtungsvoll

Otto Zacharias

$\mathrm{Nb}$. Ich hätte Ihnen beinahe vergessen mitzutheilen, daß eine längere Besprechung Ihres Münchner Vortrags, demnächst im „Salon“203 (10.000 Aufl.) erscheint. Der Aufsatz ist von der Redaction bereits genehmigt. d.O.

\footnotetext{
201 Die Gartenlaube: illustrirtes Familienblatt. Leipzig: Keil; später Berlin: Scherl, 1853-1937.

202 Ernst Keil (1816-1878), Verleger. Er gründete 1853 die als Familienblatt konzipierte Zeitschrift „Die Gartenlaube“, welche sich in den nachfolgenden Jahren äußerst erfolgreich etablierte.

203 Der Salon für Literatur, Kunst und Gesellschaft. Leipzig: Payne 1867-1890.
} 
[45]

Zacharias an Haeckel

Geehrtester Herr Professor!

Ich bin in einer eigenthümlichen Lage! Die Verleger des Prof. Jäger ersuchen mich, etwas gegen die Angriffe zu thun, welche die Seelenentdeckung Tag für Tag erfährt u. ich bin auch nicht abgeneigt, öffentlich zu sagen, was mir an Jägers Forschungen werthvoll erscheint. Aber der Mißerfolg in Baden-Baden bedarf großer Mittel, um zugedeckt zu werden.

Da besitze ich nun von Ende 1876 eine Postkarte von Ihrer Hand, auf welcher zu lesen ist, daß sie Jägers Duftforschungen im Princip für ganz richtig halten, daß Sie aber an der Zoochemie, welche hier mit im Spiel ist, verzweifeln. Sie sagen auf der Postkarte, daß die zoochemische Forschung noch zu sehr im Rückstande sei, um Jägers Bestrebungen fördern zu können. Ich richte nun die Frage an Sie, [2] geehrter Herr Professor, ob Sie mir gestatten, den Wortlaut dieser Postkarte zu citiren u. damit zu beweisen, daß die Lehre von den Speciesdüften (denn nur darum handelt es sich 1876) auch Ihre Billigung findet. Da Jäger Redacteur des „Kosmos“ ist u. Sie den letztern unter Ihre Protection genommen haben, so dürfte Ihnen jeder Artikel, der vorsichtig u. sachlich für Jäger eintritt, eigentlich nur willkommen sein. Ich erwarte irgendeine Antwort von Ihnen u. ersuche Sie höflichst, da die Sache wichtig ist, mich nicht zulange warten zu lassen. Wollen Sie Ihre Zustimmung zu Jägers Forschungen diplomatischer fassen, so bitte ich dies gleichfalls recht bald zu thun u. mir Ihre Nachricht zu geben.

Mit größter Hochachtung

Ihr Otto Zacharias

[46]

Zacharias an Haeckel

19. Dec. Hirschberg 79

Geehrtester Herr Professor!

Anfang nächster Woche erscheint die beifolgende Broschüre von mir u. wird in einigen tausend Exemplaren in Schlesien verbreitet. Es wäre mir sehr lieb, wenn Sie mir Ihre Meinung über die Anwendung darwinist. Principien auf die Volkswirtschaft (Siehe beifolg. Aushängebogen) in einer Form mittheilten, die ich publiciren könnte. Ich würde diese Ihre Zeilen der Broschüre vordrucken u. Ihr Urtheil die weiteste Verbreitung schaffen.

Ihre werthen Zeilen müßten Montag in meinen Händen sein. Ich ersuche Sie freundlichst mir im negativen Fall zu depeschiren: „Abgelehnt“. Im positiven: „Gewährt“. Ich 
lege die Telegraphiegebühren in Postmarken bei. Meine Adresse ist: Zacharias, Hirschberg, Schlesien.

Hochachtungsvoll Ihr Zacharias

NB Bitte sofort nach Empfang d. Z. zu depeschiren.

[Bemerkung Haeckels]: Abgelehnt! Hkl

[47]

Zacharias an Haeckel

z.Z. Neumünster (Holstein)

d. 6. April 1881

Geehrtester Herr Prof.

Eine süddeutsche Verlagsbuchhandlung, welche ein Lieferungswerk herauszubringen beabsichtigt, hat mich mit der Abfassung Ihrer u. Mr. Darwins Biographie beauftragt. Dem Text sollen auch Portraits beigegeben werden.

Ich besitze nun zwar Ihr Photogramm von früher her in 2 Exemplaren (Brustbilder) u. könnte es also -ohne Sie vorher zu incommordiren - nach der Hylograph. Anstalt absenden, aber ich wollte doch vorher bei Ihnen nachfragen, ob Sie vielleicht ein neueres Bild besitzen, dessen Wiedergabe in der Öffentlichkeit Ihnen wünschenswerther erscheint als die Reproduction einer älteren Photographie. Ich bitte darüber uns recht schleunige Auskunft, resp. um baldgef. Uebersendung eines neueren [2] Bildes.

Wie Sie sich erinnern werden, habe ich früher einmal für die „Illustrierte“ eine biografische Skizze von Ihnen geschrieben u. ich bin mit den meisten Hauptpunkten Ihrer wissenschaftl. Entwickelung durch Sie selbst unterrichtet worden. In den letzten Jahren habe ich jedoch nicht die Ehre gehabt, persönlich als schriftlich mit Ihnen zu verkehren u. so wäre mir sehr erwünscht zu wissen, was Sie in diesem Zeitraum an größeren Arbeiten oder Aufsätzen publicirt haben. Die Skizze soll ja möglichst actuelle Daten enthalten. Ich werde Ihnen selbstverständlich seiner Zeit eine Belegnummer der betr. Hefte aus jenem Werk zusenden. Da im Letzteren auch schöne Abbildungen eine große Rolle spielen, so habe ich möglicherweise auch Gelegenheit aus Ihrer Korallenmonographie einige Holzschnitte abzudrucken u. kann dabei dieses Prachtwerkes wieder einmal in einem sehr großen Leserkreis Erwähnung thun. ${ }^{204}$

Ich bitte also um eine recht baldige gütige [3] Antwort u. um die erbetenen Angaben.

Mit hochachtungsvollem Gruß Otto Zacharias, Hirschberg

z.Z. Neumünster

${ }^{204}$ Nähere Angaben zu den Artikeln von Zacharias sowie dem möglichen Erscheinungsort liessen sich nicht ermitteln. 
NB. Im Sommer (von Mitte Juni ab) wohne ich wieder in Hirschberg (Schlesien), wo ich eine kleine Villa bewohne u. ganz unabhängig meinen litterar. Bestrebungen lebe. So weit bin ich doch endlich gekommen. d.O.

Zacharias an Haeckel

Hirschberg (Schlesien)

26. April 1882.

Villa Friedrich.

Hochgeehrter Herr Professor!

Ich gratuliere Ihnen zuvörderst aufrichtig zu Ihrer glücklichen Rückkehr aus Ceylon und Egypten, u. zu der - wie ich las - reichen Ausbeute Ihrer Forschungsreise ${ }^{205}$. Möge Ihnen Kraft und Muße gegönnt sein, die erworbenen Geistesschätze auch Anderen zugänglich zu machen, die nicht so glücklich waren, die von Ihnen erschauten tropischen Herrlichkeiten mit eigenen Augen zu sehen. Das sind meine aufrichtigen Wünsche aus der Ferne!

Ein merkwürdiger, recht betrübender Umstand war es, daß Ihre Wiederkehr beinahe zusammentraf mit dem Todestage Darwins ${ }^{206}$. Es muß Sie eigenthümlich berührt haben, gerade von dem Ableben des berühmten Forschers in einem Augenblicke Kenntniß zu erhalten, wo Sie vielleicht daran dachten, ihm von Ihren Erfahrungen u. Beobachtungen Kunde u. Nachricht zu geben. Aber - wer konnte diese Fügung abwenden? Es ist ja ein Wunder, daß Darwin so lange lebte u. thätig war: er war ja fast immer [2] kränklich in den letzten Jahren. Ehre und Friede seinem Angedenken!

Ich mache absichtlich hier einen Strich, weil der folgende Theil meines Briefes eine Angelegenheit behandelt, die nicht sehr erquicklich ist, die ich aber nicht länger unerörtert lassen kann, weil dieselbe Sie indirect mit berührt. Ich habe sehnlichst auf Ihre Rückkehr gewartet, um an Sie zu schreiben. Der Fall betrifft die unqualifizierte Handlungsweise des Ihnen nahe stehenden Carus Sterne.

Dieser Herr, der bekanntlich mit seinen journalistischen Arbeiten immer 3-4 Wochen später kommt, als ich mit meinen Aufsätzen über dieselben Themata, hat sich unlängst erdreistet bei einer Zeitungsredaction (die mir den Brief Sternes zur Ansicht übergab) in der gemeinsten Weise gegen mich zu intriguiren, in der offenbaren Absicht dort das Feld für sich allein zu erobern, wie in der „Gartenlaube“. Ich habe mich natürlich eingehend rechtfertigen müssen $u$. die betreffende Redaction hat mir für diese Rechtfertigung ihren Dank ausgesprochen. Sternes Argumentation ging dahin, daß er nur allein der wahre Introgant darwinistischer Gedanken sei u. daß ich eigenthlich nur Irrthümliches zu Tage fördere u.s.w.

\footnotetext{
${ }^{205}$ Haeckel führte seine erste Tropenreise 1881/82 nach Indien und Ceylon. Die wissenschaftlichen Ergebnisse erfüllten jedoch nicht die Erwartungen Haeckels. Vgl. hierzu Krauße (1984): Ernst Haeckel, 98 f.

${ }^{206}$ Darwin starb am 19. April 1882.
} 
[3] Geehrtester Herr Professor! Seit 1874, dem Jahre, wo Sie einmal die Güte hatten, mich auf große Lücken in meinem Wissen aufmerksam zu machen, sind 7 Sommer verflossen. Mit dem „Fleiße u. der Energie“, die Sie früher an mir wahrgenommen u. gerühmt haben, bin ich bestrebt gewesen, diese Lücke auszufüllen u. selbst ein Mann, wie der berühmte Patholog Dr. Beneke207, hat mich in hygienischen Essays aus seiner Feder wie einen anatomischen Lapsus zu constatiren nöthig gehabt. Ich habe mittlerweile auch (wie Andere) gelernt mit meinem Hartnack [?] zu arbeiten, kann ebenso gut meine Dutzend Querschnitte auf den Millimeter machen, u. verstehe es gerade so gut, wie jeder Andere Präparate aller Art vorzurichten, zu färben, einzukitten u. aufzubewahren. Ich kann wohl sagen, daß ich in den letzten Jahren zu meinem größten Erstaunen autoptisch aufgenommen habe, wieviel unsinnige Abbildungen von embryonalen Erscheinungen eigentlich ein Schmach sind $u$. wie wenig die Darstellungen den Thatsachen entsprechen. Erst durch den Vergleich der Graaf'schen Follikel aus den Eierstöcken der verschiedensten Thiere, erst durch slbstständige Beobachtungen über die Art ihrer Einbettung in das Stroma, habe ich mir ein wirklichen Begriff von der Herkunft u. dem Charakter der sogenannten „Ureier“ verschafft. Auch sonst habe ich mich mit der Biologie der Zelle (von der ich früher wie ein Blinder von der Farbe sprach) eingehend beschäftigt u. ganz besonders die von Ihnen 1854 schon beobachteten amöboiden [4] Bewegungen hüllenloser Zellen (in den Hoden des Frosches u. Salamanders) hinlänglich beobachtet. Wenn das auch auf keine neuen Entdeckungen sind, so beruht doch aber das, was ich schrieb auf Autopsie $u$. hat nicht jene, blasse lediglich literarischreproductiven Charakter des Elaborrata Sternes, der meinetwegen ein ,guter Botaniker“" sein mag, aber von Anatomie u. Physiologie keine Ahnung hat.

Ich bitte Sie nun bloß, diesem Herrn, der mich gar nicht persönlich kennt u. höchstwahrscheinlich nur von Ihnen weiß, wie ich mich vor 7 Jahren nach Kräften zu orientieren suchte - daß Sie diesem Herrn Vorsicht im Urtheil anempfehlen u. ihm vor Allem gelegentlich die dreiste Anschwärzung verbieten. Ich dachte Sie sehen, auf wie schwachen Füßen das von diesem Herrn geleitete Unternehmen (des Kosmos) steht u. wie es immer mehr an Leserzahl zurückgeht. Woher kommt das? An der Art wie dieses Organ redigirt wird $u$. wie es eingeführt worden ist, liegt der Fehler.

Es kann weder Ihnen noch Ihrer wissenschaftl. Sache förderlich sein, wenn Sie sich mit solchen sichtlich mangelhaften Persönlichkeiten umgeben, die nicht durch Leistungen, sondern durch Verunglimpfen Anderer aus ihrer Unbedeutendheit aufzutauchen suchen. Der p.p. Krause hat sich durch sein Vorgehen gegen mich moralisch compromittirt u. hat mir das Recht in die Hand gegeben, ihn mit den einzig richtigen Namen zu benennen, der ihm für sein Betragen zukommt. Solch sittlich defecte Individuen können der Entwickelungslehre nur [5] zum Schaden gereichen, weil sie die Schlußfolgerung nahe legen, daß die niederträchtigsten Eigenschaften, die sie besitzen, einer Einwirkung der Doctrin vom „Kampfe um die Existenz“ auf das Gemüth entspringen. Was würden Sie wohl dazu sagen, wenn einer Ihrer Gegner Metschnikoffs Bemerkungen über Ihre Kalk-

\footnotetext{
207 Beneke, Friedrich Wilhelm (1824-1882) Pathologe. Er studierte 1842-46 in Göttingen, nach der Promotion noch ein Semester in Prag und ließ sich als praktischer Arzt in Celle. Beneke war 1849-51 Hausarzt des deutschen Hospitals in London, ab 1853 Leibarzt des Großherzogs in Oldenburg. Er erhielt 1855 eine Lehrbefugnis an der Univ. Marburg, wurde 1858 Direktor des Pathologisch-Anatomischen Institutes, 1867 o. Prof. der Pathologischen Anatomie und Allgemeinen Pathologie.
} 
schwammforschungen dazu verwenden wollte, um Sie als Forscher zu verdächtigen? Und was bei Ihnen im Großen gilt, das gilt bei mir im Kleinen. Es ist unbedingt Darwins sittliche Größe, sein ehrenwerther, liebevoller u. neidloser Charakter, welcher dem siegreichen Vordringen der Evolutionslehre so förderlich gewesen ist. Ein paar Bestätigungen mehr oder weniger kommen dem gegenüber gar nicht in Betracht! Aber wenn das Publikum sieht, daß ein Mann, der eine so revolutionirende Lehre aufstellt, doch ein sittlich hochstehender Mann ist, so beginnt es zu glauben, u. die Vorurtheile abzulegen. Sie werden mir hierin Recht geben müssen u. es, wenn Sie es mir auch nicht zu gestehen, für einen großen faux pas diesen Sterne halten, daß er sich auf literarische Eifersüchteleien einläßt u. es nicht verschmäht, die allerniederträchtigsten Mittel in Bewegung zu setzen, um einen Concurrenten auszubohren.

Sie werden natürlich jede Solidarität mit Herrn Dr. Krause in Abrede stellen u. ich bin ja [6] auch weit davon entfernt zu glauben, daß Sie ein näheres Verhältniß zu solch' einem Menschen haben. Aber bei der eifrigen Agitation, welche s. Z. wegen des Zustandekommens des „Kosmos“ entfaltet wurde, ist es manchmal auch für einen namhaften Mann schwer, sich alle Leute gehörig vom Leibe zu halten, die für den Zweck des Unternehmens nicht entbehrt werden können. Ich war neulich in einer Gesellschaft von namhaften Männern (in Leipzig) zugegen u. weiß, für was man den „Kosmos“ dort ansieht. Es wird nun u. nimmermehr gelingen, diese Zeitschrift in die Kreise, für die sie eigentlich bestimmt ist, einzuführen.

Ich gebe zu, hochgeehrter Herr Professor, daß dieser Brief nicht gerade erquicklich für Sie sein kann; aber ich möchte Sie doch nicht im Unklaren darüber lassen, daß - wenn mich Sterne in meinen Bezirken fernerhin stört - ich diesen „Darwianer* ganz gründlich auf den Leib rücken werde; ohne ein wenig Staub würde es natürlich nicht abgehen können, da ich über die Interna des „Kosmos“ jüngsthin auf einer Reise durch Süddeutschland gut informiert worden bin. Nichts für ungut! -

Ihr ganz ergebener Dr. O. Zacharias

*der eigentlich den Namen Darwins zur Unehre gereicht

Zacharias an Haeckel

Hirschberg i. Schlesien 25.1.1883

Hochverehrter Herr Prof.

Anbei sende ich Ihnen das Referat über einen meiner jüngsten Vorträge. Ich gehe jetzt nach Leipzig, um auch dort zu sprechen. In gewisser Hinsicht interessiren Sie sich am Ende doch für mein Unternehmen, es wird mir ja überall der größte Beifall entgegengebracht. Der Sache, die Sie vertreten, kann ja eine möglichst wenig verballhornisirte Darstellung nur Vorschub leisten. Was C. St. [Carus Sterne, d. V.] geschadet hat, ist unermeßlich. Glücklicherweise hat ihn nun auch die „Gartenlaube“ kalt gestellt!

Hochachtungsvoll Dr. O.Z. 
[50]

Zacharias an Haeckel

Leipzig 7/7 1883

Zootom. Institut

Thalstr. $15 \mathrm{~b}$

Hochverehrter Herr Professor!

Ich nehme mir die Freiheit, Ihnen anbei einen neueren Aufsatz über Darwin zuzusenden, der Ihnen beweisen soll, daß ich nach wie vor bestrebt bin, der Lehre von der Entwicklung der Species Eingang in weiteren Kreisen zu verschaffen. ${ }^{208}$

Ihren früheren Rath, mich um das Detail der zoolog. Forschung zu kümmern, habe ich nun auch befolgt $u$. ich bin seit Jahr u. Tag bemüht, auch im hiesig. Zootom. Institut mit der unerläßl. histolog. Technik vertraut zu machen. Dann werde ich meine philosoph. Studien fortsetzen [2] u. hoffentlich dann dem Vorwurf, den Sie s.Z. gegen mich erhoben, entgehen, daß meine Argumentationen nicht auf dem Boden der exacten Forschung stehen.

Mit dem Fleiße, den Sie mir stets zugesprochen haben, sitze ich nun seit langen am Präpariertische, um mich thunlichst mit den Grundverhältnissen der thierischen Organisation vertraut zu machen. Und was die induviduelle Entwickelungsgeschichte betrifft, so kann ich wohl keinen besseren Lehrer haben als Prof. Rauber, dessen Practicum ich besuche. Das ist ein so freundlicher u. lieber Mann, dem es auf Stunden nicht ankommt, wenn es sich um die Klärung eines schwierigen Punktes handelt!

Ich schreibe Ihnen das alles so detaillirt, um Ihnen zu beweisen, daß ich jeden Ihrer früheren Ratschläge befolgt [3] habe u. ich knüpfe hieran die Bitte, daß Sie die s. Z. zwischen uns getretenen Differenzen vergessen möchten. Sie sind dem Fortschrittt der Sache wahrlich nicht günstig gewesen! Ich ersuche Sie höflichst, mir, wie früher, von Zeit zu Zeit Kunde von Ihren Arbeiten zu geben, u. so zur Erweiterung meines wissenschaftl. Horizontes beizutragen.

Mit ausgezeichneter Hochachtung

Dr. Otto Zacharias

${ }^{208}$ Evtl. ist hier die Veröffentlichung in der „Gegenwart“ gemeint: Zacharias, Otto (1882): Wann concipierte Darwin den Grundgedanken seiner Theorie? Gegenwart 1882 (21), Hft. 10, S. 147-149. (Ders.) (1882): Charles Darwin. Nebst bisher ungedruckter brieflicher Mitteilungen. Gegenwart 1882 (21), Hft. 19, S. 290293. 
[51]

Zacharias an Haeckel

Privat-Laboratorium für mikeroskopische und zootomische Untersuchungen Hirschberg i. Schl., den 14. Jan. 1885

Hochgeehrter Herr Professor!

Anbei nehme ich mir die Freiheit, Ihnen zwei kleine Arbeiten von mir zu übersenden, denen in der Kürze noch einige weitere folgen werden.

Ich habe nun das Gebiet der Zoologie betreten, u. hoffe mir auf demselben irgendwelche, wenn auch nur bescheidenen, Platz zu sichern.

Inzwischen habe ich zahlreiche Verbindungen im In- und Auslande angeknüpft, u. die Genugthung, endlich am Fuße des Berges angelangt zu sein, den ich nun zu erklimmen ersuchen werde.

$\mathrm{Zu}$ alledem regt sich nun aber auch der Wunsch in meinem Herzen, mich mit Ihnen einmal auszusprechen, auch wenn es möglich sein sollte, wieder Fühlung mit Ihnen zu nehmen. Die Basis, auf der sich [2] früher Mißverständnisse u. Verstimmungen bilden konnten, ist jetzt entfernt. Ich habe die Schiffe, die mich an die öde Küste des Journalistenlebens zurückführen konnten, vollständig verbrannt (?) u. eine Concurrenz mit solchen Leuten, die an dieser Küste hausen, besteht nicht mehr.

Ich trete Ihnen jetzt als ein bescheidener Arbeiter in dem Fache entgegen, wo Sie es seit Langem zur Meisterschaft gebracht haben, und ich richte die offene u. ehrliche Frage an Sie, geehrter Herr Hofrath, ob Sie mich gelegentlich einmal persönlich empfangen wollten.

Ich habe gegen Ende des Monats in Weimar zu thun, u. könnte da leicht einmal zu Ihnen herüber kommen. Wünschen Sie jedoch meinen Besuch nicht, oder wollten Sie ihn auf ein anderes Jahr verschieben, so theilen Sie mir das gefälligst mit. Auf jeden Fall war ich autorisirt, Ih[3]nen von meinen verehrten Freunde Prof. A. Rauber „die freundlichsten Grüße“ zu überbringen. ${ }^{209}$

Ich reise morgen nach Dresden, u. ein Brief von Ihnen würde mich dort bis zum 19. Jan (incl.) treffen: Alaunstrasse, 82. I

Mit vorzüglicher Hochachtung

Otto Zacharias

NB. Die beifolg. Räderthier-Arbeit ${ }^{210}$ hat vielleicht wegen des stricten Nachweises eines mittl. Keimblattes einiges Interesse für Sie (?). Z.

\footnotetext{
${ }^{209}$ Vgl. hierzu die Briefe Raubers an Haeckel, Bestand EHH.

${ }^{210}$ Evtl. Zacharias, Otto (1884): Über Fortpflanzung und Entwicklung von Rotifer vulgaris. Ein Beitr. zur Naturgeschichte der Räderthiere, Zeitschrift für wissenschaftliche Zoologie 41, 226-251.
} 
[52]

Zacharias an Haeckel

Biologische Station

Plön (Holstein), 4. April 1898.

Sehr verehrter Herr Hofrath!

Vor einigen Tagen erhielt ich einen Brief von Dr. Krieschnick ${ }^{211}$ aus Apolda, worin mir derselbe das Ansuchen ausspricht, eventuell an der hiesigen biolog. Station eine Assistenstelle zu bekleiden, wenn eine solche vorhanden und zu vergeben sei. Die Bewerbung geschah unter ausdrücklicher Berufung auf Ihre autoritative Empfehlung u. demgemäß erlaube ich mir, auch bei Ihnen danach zu erkundigen, ob Herr Dr. Krieschnick gerade für solche Studien, wie sie hier betrieben werden, der [2] geeignete Mann sein würde. Ich verhehle Ihnen dabei nicht, daß ich ganz ausgezeichnet $u$. histologisch vorzüglich geschulte Leute zeitweilig in unserem Laboratorium gehabt habe, die sich im Uebrigen in Betreff der Süßwasserfauna (u. Flora) wie hülflose Kinder anstellten. Wenn ich auch momentan nicht in der Lage wäre, Herrn Krieschnick eine besoldete Stelle zu verschaffen, so besteht doch einige Aussicht, daß dies in nicht allzuferner Zeit der Fall sein könnte. Ich habe darüber erst vor kurzem mit einer maaßgebensten Persönlichkeit im Ministerium gesprochen.

Mit vorzüglicher Hochachtung.

Otto Zacharias

\section{Literatur}

Bense, M. [Hg.] (1943) Briefe grosser Naturforscher und Mathematiker. Staufen-Verlag, Köln.

Daum, A. (1998) Wissenschaftspopularisierung im 19. Jahrhundert. Bürgerliche Kultur, naturwissenschaftliche Bildung und die deutsche Öffentlichkeit 1848-1914. Oldenbourg Verlag, München.

Elsner, N. [Hg.] (2000) Das ungelöste Welträtsel. Frida von Uslar-Gleichen und Ernst Haeckel. Briefe und Tagebücher 1898-1903, 3 Bde., Wallstein-Verlag, Göttingen.

Franz, V. (1943) Ernst Haeckel. Sein Leben, Denken und Wirken. Eine Schriftenfolge für seine zahlreichen Freunde und Anhänger. Verlag von Wilhelm Gronau, W. Agricola. Jena und Leipzig:

Franz, V. (1944) Ernst Haeckel. Eine Schriftenfolge zur Pflege seines geistigen Erbes. Jena und Leipzig: Verlag von Wilhelm Gronau, W. Agricola.

211 Angaben zur Person waren nicht ermittelbar. 
Gegenbaur, C. (1859) Grundzüge der vergleichenden Anatomie. Engelmann, Leipzig.

Haeckel, E. (1866) Generelle Morphologie der Organismen. 2 Bde. Reimer, Berlin.

Haeckel, E. (1872) Monographie der Kalkschwämme. 3 Bde. Reimer, Berlin:

Haeckel, E. (1874) Anthropogenie oder Entwicklungsgeschichte des Menschen. Gemeinverständliche wissenschaftliche Vorträge über die Grundzüge der menschlichen Keimes- und Stammesgeschichte. Leipzig.

Haeckel, E. (1875) Die Gastrula und die Eifurchung der Thiere. Jenaische Zeitschrift für Naturwissenschaft 9, 402-508.

Haeckel, E. (1921a) Entwicklungsgeschichte einer Jugend. Briefe an die Eltern 1852/1856. Verlag von K. F. Koehler, Leipzig.

Haeckel, E. (1921b) Italienfahrt. Briefe an die Braut 1859/60. Eingeleitet von Heinrich Schmidt. Verlag von K. F. Koehler, Leipzig.

Haeckel, E. (1923a) Von Teneriffa bis zum Sinai. Reiseskizzen. A. Kröner Verlag, Leipzig.

Haeckel, E. (1923b) Berg- und Seefahrten 1857/1883. Verlag von K. F. Koehler, Leipzig.

Haeckel, E. (1927) Himmelhochjauchzend ... Erinnerungen und Briefe der Liebe. Herausgegeben und eingeleitet von Heinrich Schmidt. C. Reissner Verlag, Dresden: (2. Aufl. unter dem Titel: Anna Sethe. Die erste Liebe eines berühmten Mannes in Briefen. Dresden 1929).

Hoßfeld, U., Breidbach, O. (2005) Haeckel Korrespondenz: Übersicht über den Briefbestand des Ernst-Haeckel-Archivs. VWB-Verlag, Berlin.

Huschke, K. (1950) Ernst und Agnes Huschke. Ein Briefwechsel. Urania, Jena.

Jahn, I. (1985) Ernst Haeckel und die Berliner Zoologen: eine Auswahl aus seinem Briefwechsel mit Edouard von Martens, Wilhelm Peters und Karl Möbius. Acta Historica Leopoldina 16, pp. 65-109.

Junker, T., Richmond, M. (1996) Charles Darwins Briefwechsel mit deutschen Naturforschern. Ein Kalendarium mit Inhaltsangaben, biographischem Register und Bibliographie. BasiliskenPresse, Marburg.

Junker, T., Hoßfeld, U. (2001) Die Entdeckung der Evolution. Eine revolutionäre Theorie und ihre Geschichte. Wissenschaftliche Buchgesellschaft, Darmstadt.

Kockerbeck, C. (1999) Carl Vogt, Jacob Moleschott, Ludwig Büchner, Ernst Haeckel. Briefwechsel. Basilisken-Presse, Marburg.

Krauße, E., Hoßfeld, U. (1999) Das Ernst-Haeckel-Haus in Jena. Von der privaten Stiftung zum Universitätsinstitut (1912-1979). Verhandlungen zur Geschichte und Theorie der Biologie 3, pp. 203-232. 
Nöthlich, R. [Hg.] (2002) Ernst Haeckel - Wilhelm Bölsche. Briefwechsel 1887-1919. VWBVerlag, Berlin.

Nöthlich, R. [Hg.] (2006) Ernst Haeckel - Wilhelm Bölsche. Kommentarband zum Briefwechsel 1887-1919. VWB-Verlag, Berlin.

Nöthlich, R., Weber, H., Hoßfeld, U., Breidbach, O., Krauße, E. (2006) „Substanzmonismus“ und/oder „Energetik“: Der Briefwechsel von Ernst Haeckel und Wilhelm Ostwald (1910 bis 1918). VWB-Verlag, Berlin.

Olsson, L., Hoßfeld, U. (2003) Ernst Haeckel’s Swedish Correspondences. Uppsala Newsletter for History of Science 34, pp. 1-3.

Olsson, L., Hoßfeld, U. (2004) En översikt den internationella Haeckelreceptionen och början till en kartläggning av Ernst Haeckels svenska korrespondens. Lychnos - Annual of the Swedish History of Science Society, pp. 207-226.

Olsson, L., Hoßfeld, U. (2006) Netzwerke: Die Korrespondez von Ernst Haeckel nach Schweden. Verhandlungen zur Geschichte und Theorie der Biologie 12: 157-175.

Starck, D. (1980) Die idealistische Morphologie und ihre Nachwirkungen. Medizinhistorisches Journal 15, pp. 44-55.

Sterne, C. (1876) Werden und Vergehen. Eine Entwicklungsgeschichte des Naturganzen in gemeinverständlicher Fassung. Bornträger, Berlin.

Thienemann, A. (1917) Otto Zacharias. Ein Nachruf. Archiv für Hydrobiologie und Planktonkunde [AHP] 1917 (11), Heft. 4.

Uschmann, G., Hassenstein, B. (1965) Der Briefwechsel zwischen Ernst Haeckel und August Weismann. In: Kl. Festgabe aus Anlaß der hunderjähr. Wiederkehr d. Gründung des Zool. Inst. d. Friedrich-Schiller-Universität Jena im Jahre 1865 durch Ernst Haeckel (Hg. M.

Gersch). Jenaer Reden und Schriften, pp. 6-68.

Uschmann, G., Jahn, I. (1959/60) Der Briefwechsel zwischen Thomas Henry Huxley und Ernst Haeckel. Ein Beitrag zum Darwin-Jahr. Wiss. Zschr. Univ. Jena, math.-nat. Reihe 9 (1/2), pp. 7-33.

\section{Quellen}

Universität Jena, Institut für Geschichte der Medizin, Naturwissenschaft und Technik, ErnstHaeckel-Haus: Briefe von O. Zacharias an E. Haeckel; Briefe von A. Rauber an E. Haeckel

Universität Kiel, Universitätsbibliothek [UBK] ; Nachlaß Zacharias: Briefe von E. Haeckel an O. Zacharias

Landesarchiv Schleswig Holstein [LASH], Akte Abt. 309, Nr. 12279. 
Max-Planck-Institut Plön [MP], Bibliothek, Sammlung Zacharias.

Universitätsbibliothek Wroclaw [UBW], Briefe von O. Zacharias an W. Bölsche.

\section{Address for correspondence:}

Rosemarie Nöthlich/Uwe Hoßfeld

Ernst-Haeckel-Haus

Friedrich-Schiller-Universität Jena

Berggasse 7

D- 07745 Jena, Germany

Uwe.Hossfeld@uni-jena.de

Nadine Wetzel

Am Schafberg 3

D- 07819 Oberpöllnitz/Triptis, Germany

Lennart Olsson

Institut für Spezielle Zoologie und Evolutionsbiologie mit Phyletischem Museum, Friedrich-Schiller-Universität Jena

Friedrich-Schiller-Universität Jena

Erbertstr. 1

D- 07745 Jena, Germany

Lennart.Olsson@uni-jena.de 


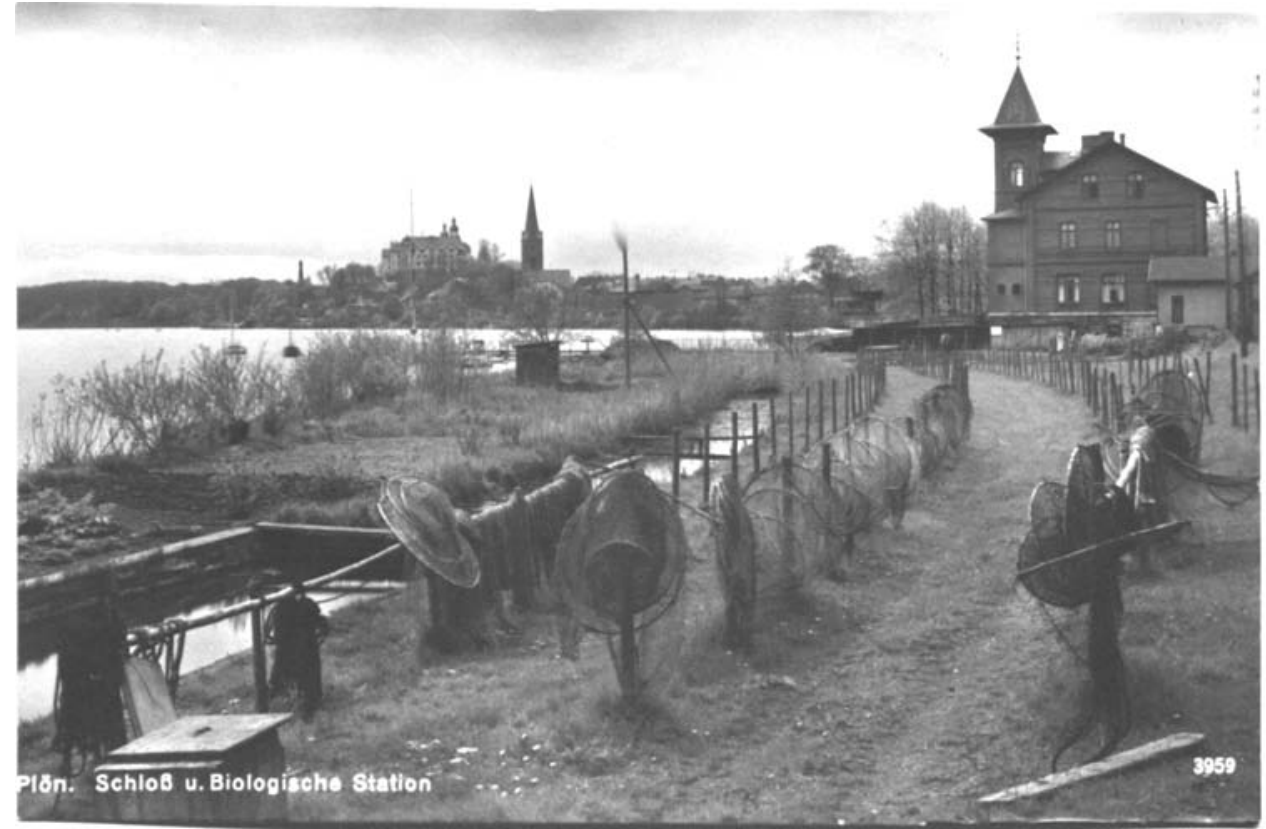

Abb. 1: Biologische Station in Plön um 1892 [MPI Plön, Sammlung Zacharias].

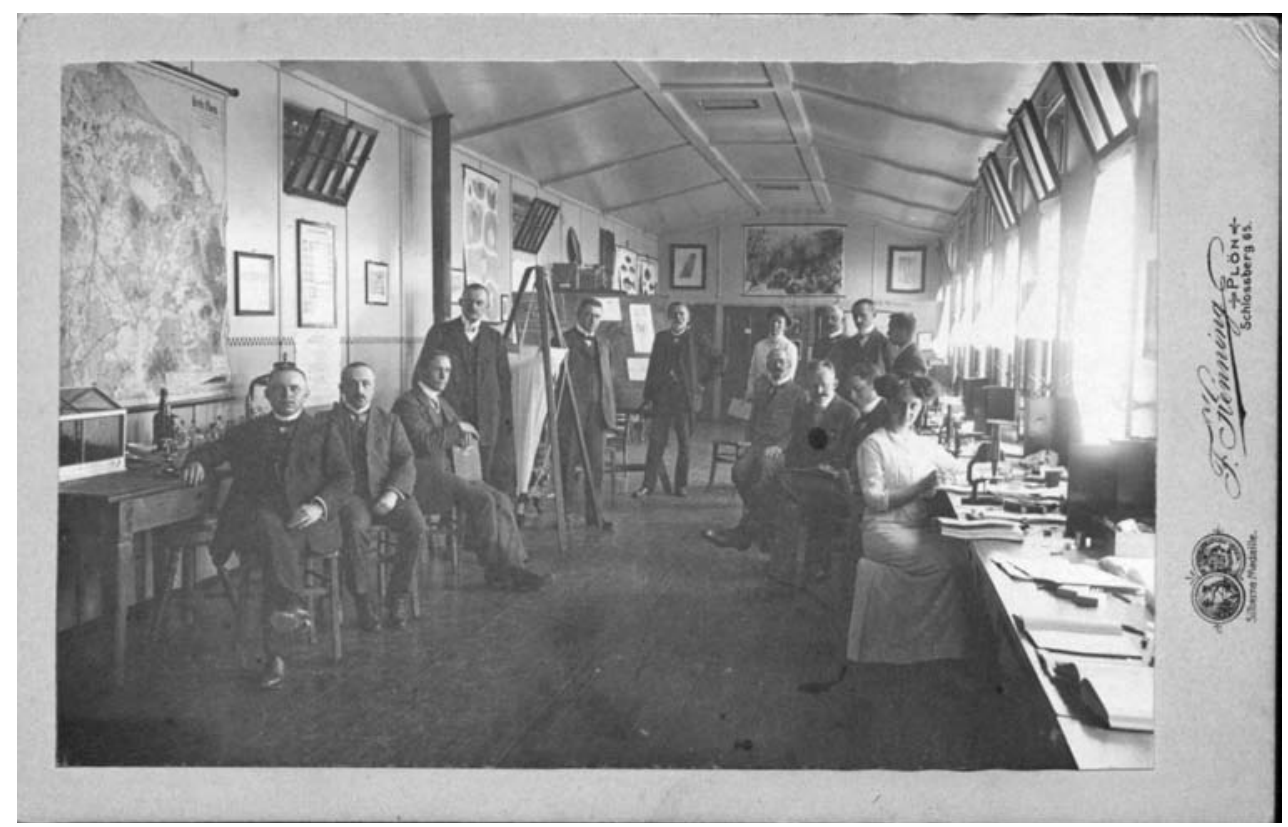

Abb. 2: Teilnehmer eines bydrobiologischen Ferienkurses in Plön 1910 [MPI Plön, Sammlung Zacharias].

Annals of the History and Philosophy of Biology, Vol. 11 (2006) 


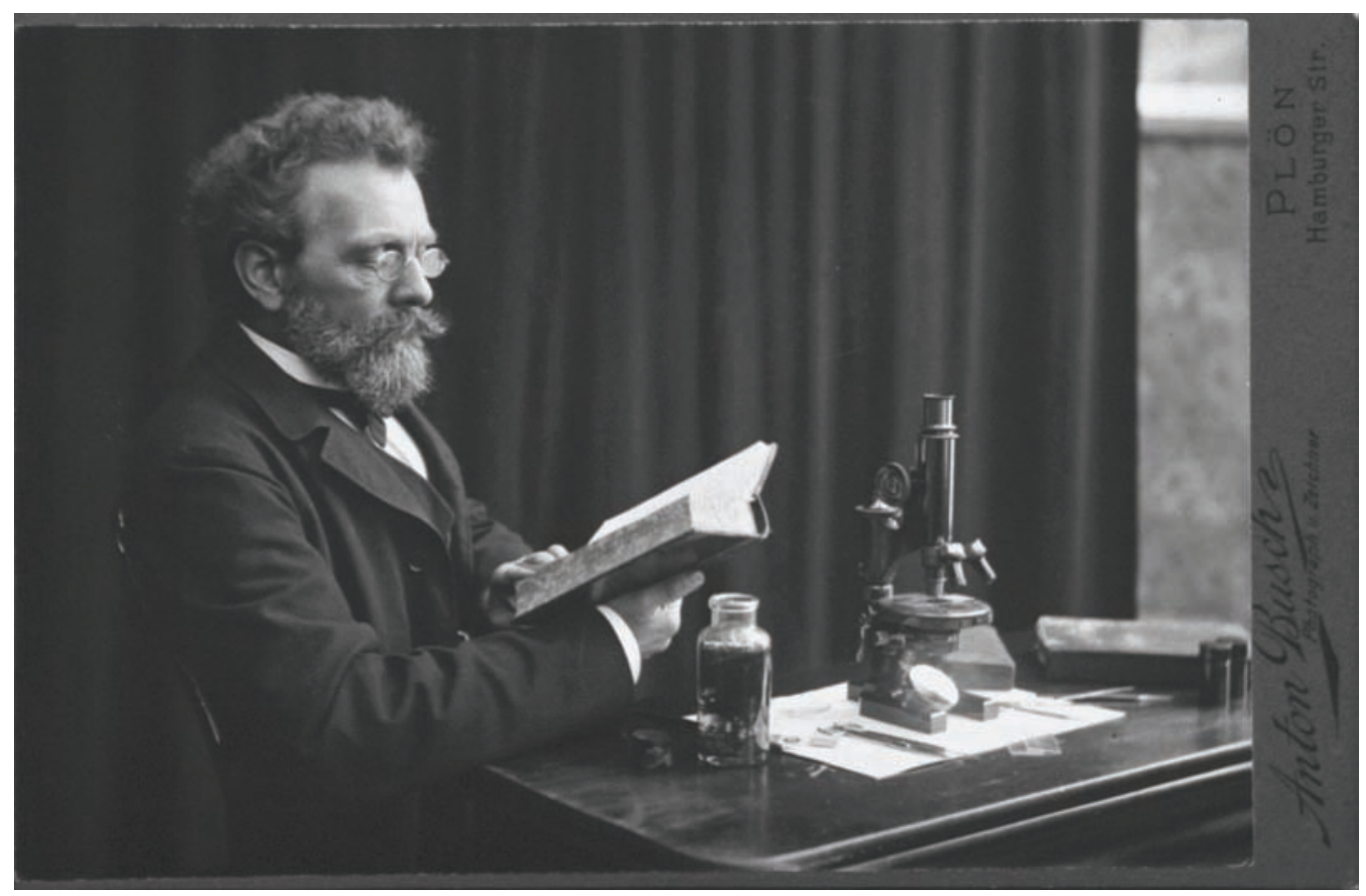

Abb. 3: Porträt von Emil Otto Zacharias, um 1890 [MPI Plön, Sammlung Zachrias] 
248

Rosemarie Nöthlich, Nadine Wetzel, Uwe Hoßfeld \& Lennart Olsson

19. bee. Yirplay. 89

Grafoulen ther fromflllar!

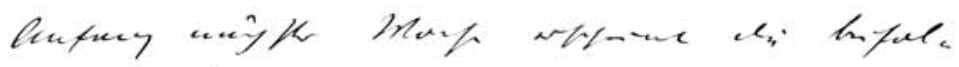

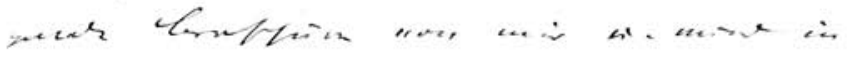

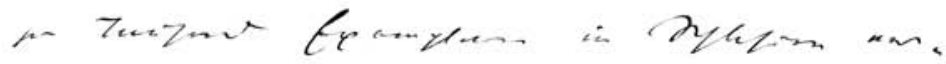

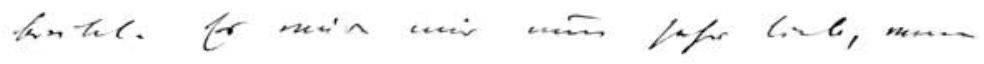

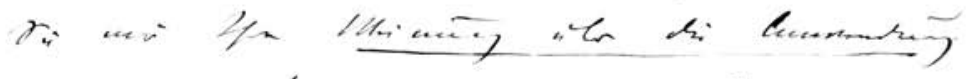

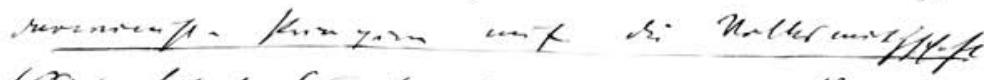

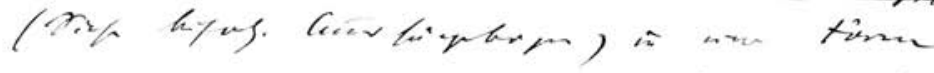

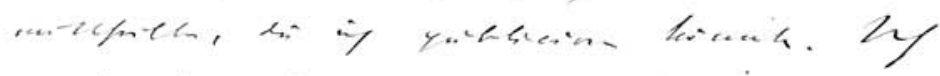

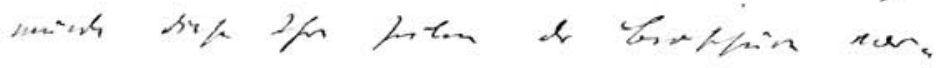

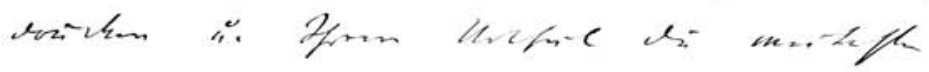

Mantariey Hefth.

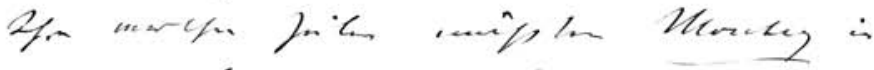

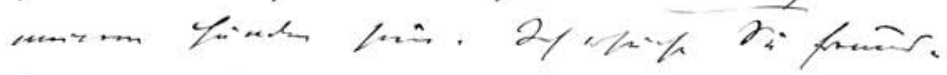

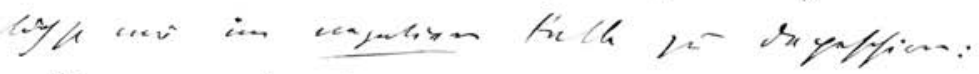

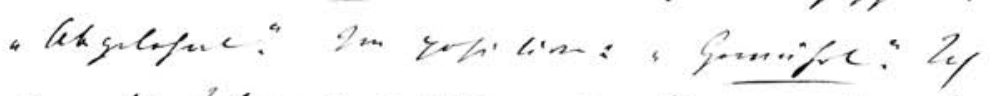

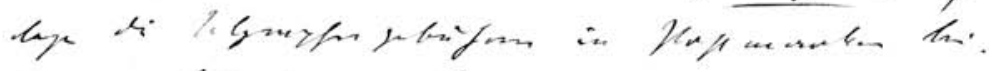

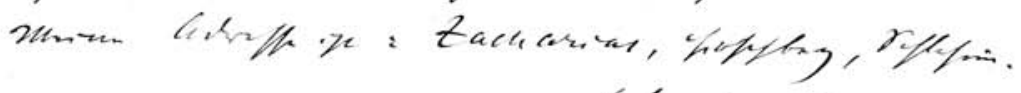

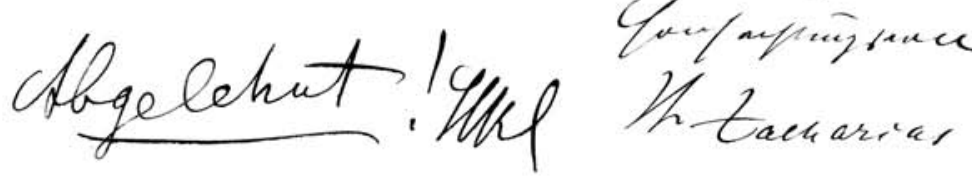

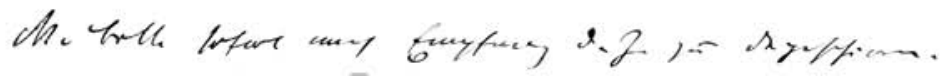

Annals of the History and Philosophy of Biology, Vol. 11 (2006) 


\title{
Internationalism and the History of Molecular Biology
}

\author{
Hans-Jörg Rheinberger
}

\begin{abstract}
The history of molecular biology has been told a number of times over the past three decades, and its bistoriography has thereby experienced a number of reorientations. Questions of periodization, as usual, have been and still are a matter of debate, but most observers will probably agree that the history of molecular biology can conveniently been divided into three major phases. The first phase is marked by a new conjuncture between physics, chemistry, and biology rougbly between 1930 and 1950, and it was mediated by a set of innovative research technologies, with a focus on protein analysis and genetics. The second spanned roughly the decades between 1950 and 1970, from the physical elucidation of the structure of the DNA double helix, through its climax with the biochemical deciphering of the genetic code in the early 1960s, to its eclipse, the advent of a properly molecular biological gene technology in the early 1970s. The third phase took its starting point from the construction of the first transgenic DNA molecules in the early 1970 s and resulted, a decade later, in the human genome project.

This paper concentrates on the international aspects of the development of molecular biology. Internationalism took distinctively different forms within the three periods just mentioned. These different forms are, on the one hand, intimately connected to the changing national and international political contexts: the interwar period and World W ar II; the period of the Cold War; and the period of post-communist globalization. On the other hand, they are as well an epistemic function of the evolving and diversifying objects of molecular biology. These different constellations shall be considered more closely.
\end{abstract}

The history of molecular biology has many facets. I will concentrate on the international aspects of its development. Internationalism took distinctively different forms within the three periods just mentioned. These different forms are, on the one hand, intimately connected to the changing national and international political contexts: the interwar period and World War II; the Cold War era; and the time of post-communist globalization. On the other hand, they are as well an epistemic function of the evolving and diversifying objects of molecular biology.

First, let us have a look at the 1930s and the 1940s. It has repeatedly been pointed out by historians of science that philanthropic institutions - and in particular the Rockefeller Foundation with its head of the natural sciences division, Warren Weaver - played a vital role in the early days in setting the stage for what was to become molecular biology. As Pnina Abir-Am (Abir-Am 1993), Robert Kohler (Kohler 1991) and others have argued, Weaver was dedicated to fostering transdisciplinary research on what he then called "vital processes", and he did so by funding physicists, chemists, and mathemati- 
cians who were willing to engage with biological questions and, moreover, to direct their often novel research instruments toward biological objects. Protein research and genetics were in the foreground of his research agenda. He not only thought in interdisciplinary but also in international categories. Through Wilbur Tisdale and Harry Miller, the Rockefeller Foundation officers in Paris, Weaver spun a network of funding that went far beyond the United States and included interdisciplinary collaborations in post First World War Europe's major research sites as well. The Rockefeller Foundation thus vitally contributed to re-establishing international scientific bonds that had been broken by the hostilities of World War I and the immediate postwar turmoils. Most of the individual research projects during this time, however, featured local collaborations and were not international in themselves. In order to compensate for this lack, the Rockefeller Foundation sponsored international workshops and conferences. In addition, through its fellowship program, it funded young European scholars to spend a postdoctoral year in major American or other European laboratories.

When the Nazis came to power in Germany and initiated an unprecedented exodus of Jewish and politically liberal and leftist scientists from Germany and other European countries later occupied by Nazi Germany or having fascist governments themselves, the Rockefeller Foundation helped many of them to settle in their new surroundings. It can be stated that this exodus, in a way, initiated a kind of compulsory internationalism that had a deep impact on the early history of molecular biology. A quick look at the roster of persons who count among the founders of the new biology shows us that many of its first generation leading figures were either enforced or voluntary émigrés: Erwin Chargaff, a chemist from Czernowitz at Columbia University; Max Delbrück, a physicist from Berlin at the California Institute of Technology (Rockefeller fellowship); Salvador Luria, a medical doctor from Turin at the University of Indiana (Guggenheim fellowship) and then at the University of Illinois; Severo Ochoa, a medical doctor from Asturia at the University of New York; Max Perutz, a chemist from Vienna at Cambridge, England; Gunther Stent, a refugee from Berlin and later a physical chemist at Berkeley, and many others as well. This traffic was one-way however; the following World War II resulted in a thorough international isolation of a substantial part of the European continent's scientists, and not only in the realm of emerging molecular biology.

However, there is also an epistemic aspect to internationality in this early phase in the history of molecular biology. As I already mentioned, it rested technically on an array of new analytical instrumentation, such as ultracentrifugation, electron microscopy, electrophoresis, X-ray crystallography, UV-spectroscopy, and other sophisticated apparatus targeted towards diverse phenomena of life at a macromolecular level. Initially, there were only a few privileged places where these different instruments were constructed and eventually put to biological use. This also meant that the knowledge going into their operation was thoroughly local, if not monopolized by one research team, at least for a certain period of time. In this phase of technological development, the instruments did not travel; rather, the people who wanted to construct or learn to work with these instruments had to travel, thereby crossing national boundaries - and disciplinary boundaries as well, since the operation of most of these instruments intrinsically necessitated a collaboration between physicists, chemists, and biologists. Protein crystallography was particularly strong in Cambridge, England, and at the California Institute of Technology; 
ultracentrifugation in Uppsala; UV-spectroscopy in Stockholm and New York; electron microscopy at RCA's New Jersey laboratories, just to give a few examples. As we will see, this epistemic situation continued over the first decade after World War II. It was not until the late 1950s that these technologies became black-boxed and began to spread widely.

After World War II, the political situation in the Western world changed radically. With respect to molecular biology, within a few years, an international network of researchers formed and organized itself around a few centers, among them the phage group with Max Delbrück at Caltech and Cold Spring Harbor with its annual phage course, the Medical Research Council Unit for the Study of Molecular Structure of Biological Systems around Max Perutz and John Kendrew in Cambridge, the Pasteur Institute around Jacques Monod and André Lwoff in Paris, but also less well known ones such as the electron microscopy unit organized around Jean Weigle at the University of Geneva, or the Rouge-Cloître group of biologists, physicists, and biochemists around Jean Brachet at the University of Brussels. There were frequent personal exchanges among these groups. Postdoctoral visits across the Atlantic resumed, and international scientific figures like Leo Szilard, a newcomer to the field, promoted the new biology on their relentless travels. These exchanges temporarily slowed down at the height of the Cold War in the beginning of the 1950s, where, for example, Linus Pauling was forbidden to travel to Europe, and Jacques Monod was denied a visa to enter the United States.

The particular history of each of the groups mentioned above is, meanwhile, welldocumented, with case studies by Lily Kay on Caltech (Kay 1993), Soraya de Chadarevian on Cambridge (de Chadarevian 2002), Jean-Paul Gaudillière on Paris (Gaudillière 2002), Bruno Strasser on Geneva (Strasser 2005) and Denis Thieffry on Brussels (Thieffry 2005). Rich and abundant material has been accumulated. There is also a recurrent pattern to be found in these studies that appears to be pertinent to our discussion of early molecular biology's internationalism. Soraya de Chadarevian has expressed it for the British center in Cambridge as follows: "It has been argued that molecular biology profiting from an increased mobility of people created especially by new science policies and funding schemes in the Cold War era - constituted itself in an international space (Abir-Am 1993). My view is that the increase in international exchanges modified the relations between local settings, and thus the local settings themselves, but did not do away with them." For the Institut Pasteur in Paris, Jean-Paul Gaudillière (Gaudillière 2002) has similarly observed "a scientific strategy taking as its starting point the exploitation of a local system quite different from the dispositifs privileged in the United States. [...] On the one hand, the mobilization of a vast array of human and material resources offered by the United States; on the other hand the preservation of a home-made approach that granted the autonomy and the possibility of an alternative to the bacterial genetics at Caltech, Cold Spring Harbor, or Columbia." In their assessment of molecular biology in postwar Europe, de Chadarevian and Strasser talk about a "glocal" picture in this respect.

What does that mean epistemically though? There is a message here that appears to be characteristic of the development of molecular biology in the two and a half decades after World War II, in which the new approach toward the molecular basis of living systems became scientifically visible and during which the tag "molecular biology" was in- 
creasingly used for the self-identification and self-vindication of those who wanted to be perceived as partisans and participants in the new biology movement. In this phase, molecular biology formed itself into a patchwork of different experimental systems, often centered around a particular technology, sometimes a big and demanding research instrument such as an electron microscope or an X-ray machine. However, this was not always necessarily so: small scale tools such as radioactive tracing or biochemical in vivo and in vitro assays were equally important - and also just as demanding in their finetuning. Together, these experimental systems formed a landscape of experimentation, with neighboring systems sharing material constituents, and with only indirect links to systems further away. It resulted from a differential exploitation of the vast array of research technologies described for the previous period that were initially disconnected from each other, but became increasingly adapted to sophisticated biological applications and systems and therefore linked to each other. Secondly, it rested on the cultivation of a few distinct model organisms, in particular lower fungi, bacteria, and a variety of viruses and phages. Each of these organisms required a certain amount of idiosyncratic manipulative knowledge. On the other hand, the standardization of certain model organisms such as Escherichia coli served as a reference point not only for those who worked with them, but also for those comparing and judging their results obtained from other organisms, and in this way the models also became connected to each other. From a third perspective, the formation of this landscape involved different interdisciplinary skills biophysical, biochemical, biomedical, biomathematical, in slightly different local combinations.

Thus, an ideal situation for international circulation was created that resulted in cooperative effects on an unparalleled scale. And, indeed, if we look at the major findings that punctuated the establishment of molecular biology as a new discipline in the course of the 1950s and the early 1960s, we realize that many, if not the most important of them, resulted from international cooperation between two or three individual researchers from different local cultures in different countries. To start with, the elucidation of the structure of the DNA double helix in 1953 was the result of a collaboration in Cambridge between a British scholar, Francis Crick, and an American scholar, Jim Watson, one of them a physicist, the other a biologist by training. The work that led to the identification of messenger RNA was done in Paris by the Pasteurians Jacques Monod and François Jacob in cooperation with Arthur Pardee from Berkeley; at Caltech by Jacob from Paris, Sidney Brenner from Cambridge - himself a South African MD - and Mathew Meselson from Pasadena; at Harvard by François Gros from Paris and James Watson from Cambridge/MA. The deciphering of the first code words happened at the National Institutes of Health in Bethesda and involved the American biochemist Marshall Nirenberg and the German physiologist Heinrich Matthaei. The Swiss physicist Jean Weigle from Geneva published phage work together with Delbrück as well as with Meselson from Pasadena. Frederick Sanger in Cambridge worked on the primary structure of the insulin chain - the first protein to be completely sequenced - together with the Austrian biochemist Hans Tuppy from Vienna. Many more international and interdisciplinary couples such as these could also be named here. Throughout the 1950s, they all conveyed to molecular biology its appearance as a paragon of an international science. It was based on distributed, locally embedded resources that lent themselves to being 
triggered and leading to major results by sometimes minor inputs from neighboring, slightly different experimental systems.

Around 1960, the visibility of rising molecular biology had reached the planning circles of European governments and became, to a certain extent, a state affair. Throughout the following decade, molecular biology became a target for national science advancement plans aiming at a reorganization of research and teaching in the life and biomedical sciences. This led to the foundation of molecular biological research institutes in all major European countries. For Germany, it was Max Delbrück who assumed a leading function in the process. The perception of a necessity to balance the perceived American supremacy in the field also gave rise to increasing efforts for advancing molecular biological research at a European level. These efforts finally resulted in the foundation of a European Molecular Biology Organization and eventually a European Molecular Biology Laboratory. John Krige (Krige 2002) has argued that it was not the distributed character of molecular biological technology - as sometimes purported - that prevented the early establishment of a facility for molecular biology like that of CERN, the European organization and laboratory for particle physics. According to him, it was, rather, the perception of national deficits that put the national strengthening of molecular biology first on the agenda of the major European countries, and left a common European laboratory as a matter of the next step. Arriving at this order of events, however, despite Krige's argument, could, after all, have something to do with the distributed and therefore locally entrenched character of what we can call - in view of the subsequent developments - the classical period of molecular biology.

Towards the end of this extremely compressed overview of forms of internationalism implied in the development of molecular biology, let me briefly come to the third phase, the era of gene technology. After a few years of self-imposed caution, the recombinant DNA technologies that emerged in the early 1970s in the United States led to a major rearrangement of the field. On the one hand, molecular biology, now in the form of a genetic technology, entered the world of commerce, and with that, of international economic competition. Gene patenting, on the one hand, has brought back constraints for transnational collaboration. On the other hand, the advent of powerful gene sequencing technologies opened up the perspective of projects like the human genome project, that by their very size and nature necessitated a more or less stringent international collaboration, no longer just as a spontaneous activity of individuals, but now as a coordinated effort of the major players of the scientific community. Molecular biology entered the era of global, planned, large sized collaborations. In parallel, the vast amounts of genomic information resulting from these collaborative enterprises necessitated the construction of new kinds of collectively usable data pools. They have become a major target of bioinformatics of our day, wiring together the contemporary bio-molecular laboratories from all over the world in a virtual space and creating an unprecedented form of scientific communication over an ever-increasing pool of shared information.

However, we also stand before possible applications of gene technology in reproductive biology and genetic germ line intervention that urgently call for international regulations. Today, such regulations are far from being established. Different countries in the world respond to these challenges with quite different rules. An internationalism of a particular slant could result: a kind of science tourism that would lead ambitious scien- 
tists who feel themselves to be restricted by their national regulations choosing work in countries where such restrictions do not apply. Internationalism, after all, is not one singular, well-defined thing or relation. On the contrary, it comes in numerous guises and many variants. The history of molecular biology certainly displays some of the major forms it took throughout the long second half of the twentieth century, and, as we have seen, it combines them with patterns that incorporate shifting global political trends as well as changing epistemic configurations.

\section{References}

Abdrakhmanov, I. (2004) Die Anfänge der Molekularbiologie in der Sowjetunion. Das Institut für Biophysik der Akademie der Wissenschaften der UdSSR in den Jahren 1953 bis 1965. In: Netzwerke. Beiträge zur 13. Jahrestagung der DGGTB in Neuburg an der Donau (Kaasch, M., Kaasch, J., Wissemann, V.; eds.) VWB Verlag, Berlin: pp. 333-339.

Abir-Am, P. (1993) From multidisciplinary collaboration to transnational objectivity: International space as constitutive of molecular biology, 1930-1970. In: Denationalizing Science (Crawford, E., Shinn, T., Sörlin, S.; eds.) Kluwer, Dordrecht: pp. 153-186.

de Chadarevian, S. (2002) Designs for Life. Molecular Biology after World War II. Cambridge University Press, Cambridge.

de Chadarevian, S., Strasser, B. (2002) Molecular biology in postwar Europe: towards a 'glocal' picture. Studies in History and Philosophy of Biological and Biomedical Sciences 33C (3), Special Issue: Molecular biology in Postwar Europe, Introduction, pp. 361-365.

Gaudillière, J.-P. (2002) Inventer la biomédecine. La France, l'Amérique et la production des savoirs du vivant (1945-1965). Editions la Découverte, Paris.

Kay, L.E. (1993) The Molecular Vision of Life. Caltech, the Rockefeller Foundation, and the Rise of the New Biology. Oxford University Press, Oxford.

Kohler, R.E. (1991) Partners in Science. Foundations and Natural Scientists 1900-1945. The University of Chicago Press, Chicago.

Krige, J. (2002) The birth of EMBO and the difficult road to EMBL. Studies in History and Philosophy of Biological and Biomedical Sciences 33C (3), Special Issue: Molecular biology in Postwar Europe, pp. 547-566.

Strasser, B. (2005) L'invention d'une nouvelle science: La biologie moléculaire à Genève 19451970, Olschki, Florence.

Thieffry D. (1997) History and Philosophy of the Life Sciences 19 (Special Issue).

\section{Address for correspondence:}

Hans-Jörg Rheinberger

Max-Planck-Institut für Wissenschaftsgeschichte

Boltzmannstraße 22

D- 14195 Berlin, Germany 


\section{Instructions for Authors}

Ann Hist Phil Biol reports research results from all fields of history of sciences written in English or German. Manuscripts must be of general interest and not only addressed to specialists, Contributions from all over the world are welcome. Ann Hist Phil Biol preferentially publishes research and review papers (of up to 25 printed pages maximum) that will be reviewed with high priority.

Papers will be accepted that have not been published previously. Concise presentation is required. Although the nonspecialist reader should be kept in mind when abstracts, introductions and discussions are written, lengthy review-type introductions and speculative discussions should be avoided. Diffuse and repetitive style should be avoided. Illustrations and tables should be limited to the truly essential material.

\section{Length of Papers}

Papers should not exceed 25 printed pages. One printed page in the journal (without figures and tables), usually has about 600 words or 3000 characters.

References: About 22 references usually fill one printed page.

\section{Arrangement}

Title page: The first page of each paper should indicate: The title, the author's names and affiliations, a short title for use as running head, the name, address, e-mail address, phone and fax number of the corresponding author.

Abstract: All articles must be accompanied by an english abstract of up to 450 words.

\section{Tables}

Each table should be typed on a separate sheet, numbered with arabic numerals and accompanied by a short instructive title line. Each table must be referred to in the text.

\section{Figures and Graphics}

Please do not embed any tables and/or figures in the text document.

Figures and graphics should be submitted separately in digital form.

Colour illustrations can be published if necessary and and if the author makes a contribution to the additional printing costs.

\section{References}

References should be quoted in the text as follows:

1. One author:

“... as described by Darwin (1859)."

"... as given in the published article (Darwin, 1859)." 
2. Two authors:

"... as described by Darwin and Huxley (1860)."

"... as given in the published article (Darwin and Huxley, 1860)."

3. Three or more authors:

Darwin, Huxley \& Haeckel (1861): use name of first author with: Darwin et al., 1861.

\section{List of references}

References in the article should be listed at the end of the paper in strict alphabetic order, i.e., firstly by the name of the first author, then by the name of the second author. Order should be by year of publication if all authors and their sequence are identical for more than one reference. If the first author and the year of publication are the same for more references, small letters behind the year must be used both in quotations in the text and in the list of references to allow unambiguous allocation of each reference. Format of references is as follows:

- Articles in Journals with one, two or more authors:

Darwin, C. (1859) Instructions for apes. Ann. Hist. Phil. Biol. 1, pp. 1, pp. 1-9.

Darwin, C., Huxley, T.H. (1859) Additions to instructions for apes. Ann. Hist. Phil. Biol. 1, pp. 1, pp. 10-19.

Darwin, C., Huxley, T.H., Haeckel, E. (1859) What is biology? Some evolutionary aspects on additions to instructions for apes. Ann. Hist. Phil. Biol. 1, pp. 1, pp. 20-191.

- Articles in multiauthor books:

Fi, X., Ferti, G. (2006) Instructions for more apes. In: How to write a high quality manuscript for Ann Hist Phil Biol (Gossy, P., Fam, E., Her, O.; eds.) Salana Press, Göttingen, Jena: pp. 48-52.

- Books:

Gossi, P., Fam, E., Her, O. (2006) How to write a high quality manuscript for Ann

Hist Phil Biol. Salana Press, Göttingen, Jena.

\section{Reprints}

The author(s) receive(s) a PDF-file free of charge and are permitted to post it Open Acess on their personal website or an institutional repository if they disclose the original source. 
Annals of the history and philosophy of biology, Volume 11 (2006)

\section{Contents}

Olaf Breidbach, Michael T. Ghiselin

Baroque Classification: A Missing Chapter in the History of Systematics

Rudolf Hagemann: Curt Stern (1902 - 1981)

Drosophila-Genetiker und Human-Genetiker in

Deutschland und den USA

David Hull

Essentialism in Taxonomy: Four Decades Later

Hans Werner Ingensiep

Organism, Epigenesis, and Life in Kant's Thinking -

Biophilosophy between transcendental philosophy, intuitive analogy, and empirical ontology

Ulrich Kutschera, V. M. Epshtein

Nikolaj A. Livanow (1876 - 1974) and the living relict

Acanthobdella peledina (Annelida, Clitellata)

Georgy S. Levit \& Lennart Olsson

"Evolution on Rails": Mechanisms and Levels of Orthogenesis

James Moore

Wallace in Wonderland

Kärin Nickelsen

„In deutlichen Beschreibungen und richtigen Zeichnungen

gemeinnütziger" - Abbildungen in der Gesellschaft Naturforschender

Freunde zu Berlin (GNF), 1773-1800

Rosemarie Nöthlich, Nadine Wetzel, Uwe Hoßfeld \& Lennart Olsson

„Ich acquirirte das Schwein sofort, ließ nach dem Niederstechen die Pfoten

abhacken u. schickte dieselben an Darwin“ - Der Briefwechsel von Otto

Zacharias mit Ernst Haeckel (1874-1898)

Hans-Jörg Rheinberger

Internationalism and the History of Molecular Biology

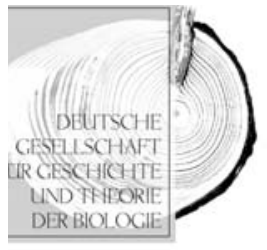


The name DGGTB (Deutsche Gesellschaft für Geschichte und Theorie der Biologie; German Society for the History and Philosophy of Biology) reflects recent history as well as German tradition. The Society is a relatively late addition to a series of German societies of science and medicine that began with the "Deutsche Gesellschaft für Geschichte der Medizin und der Naturwissenschaften", founded in 1910 by Leipzig University's Karl Sudhoff (1853-1938), who wrote: „We want to establish a ,German“ society in order to gather German-speaking historians together in our special disciplines so that they form the core of an international society...". Yet Sudhoff, at this time of burgeoning academic internationalism, was "quite willing" to accommodate the wishes of a number of founding members and "drop the word German in the title of the Society and have it merge with an international society". The founding and naming of the Society at that time derived from a specific set of historical circumstances, and the same was true some 80 years later when in 1991, in the wake of German reunification, the "Deutsche Gesellschaft für Geschichte und Theorie der Biologie" was founded. From the start, the Society has been committed to bringing studies in the history and philosophy of biology to a wide audience, using for this purpose its Jahrbuch für Geschichte und Theorie der Biologie. Parallel to the Jahrbuch, the Verhandlungen zur Geschichte und Theorie der Biologie has become the by now traditional medium for the publication of papers delivered at the Society's annual meetings. In 2005 the Jahrbuch was renamed Annals of the History and Philosophy of Biology, reflecting the Society's internationalist aspirations in addressing comparative biology as a subject of historical and philosophical studies. 
From January 1, 2006 manuscripts should be submitted to the managing editor V. Wissemann. Submissions will be peer reviewed. The preferred language is English.

Articles in German should be accompanied by a short (max. 1.000 words) summary in English.

Editors

we Ho/sfeld, Jena, Germany

Kristian Kochy, Kassel, Germany

Lennart Olsson, Jena, Germany

Volker Wissemann, Gießen, Germany - managing editor-

Institut für Allg. Botanik und Pflanzenphysiologie

Bereich Allgemeine Botanik, AG

Justus-Liebig-Universitä Gießen,

rolker.wissmone

\section{Editorial Board}

Peter Boweler, Belfast, UK

Olat Breidbach, Jena, Germany

Eve-Marie Engels, , Tubingen, Germany

Christoph Friedrich, Marburg, Germany

Nick Hopwood, Cambridge, UK

David L. Hull, Evanston, USA

Thomas Junker, Frankfurt/Main, Germany

Ulrich Kutschera, Kassel, Germany

Jane Maienschein, Tempe, US $A$

Renato Mazzolini, Trient, Italy

Peter McLaugblin, Heidelberg, Germany

James R. Moore, Milton Keynes, UK

Kaerin Nickelsen, Bern, Swizzerland

Ronald L. Numbers, Wisconsin-Madison, USA

Wolf-Ernst Reif, Tübingen, Germany

Hans-Jorg Rheinberger, Berlin, Germany

Marsha L. Richmond, Detroit, USA

Robert Richards, Chicago, USA

Alexander Rosenberg, Durham, USA

Nicolaas A. Rupke, Göttingen, Germany

Michael Ruse, Tallahassee, USA

Hans-Konrad Scbmutz, Winterthur, Switzerlan

Marcel Weber, Basel, Switzerland
Annals of the history and philosophy of biology, Volume 11 (2006)

Contents

Olaf Breidbach, Michael T. Ghiselin

Baroque Classification: A Missing Chapter in the History of Systematics ...........

Rudolf Hagemann: Curt Stern $(1902$ - 1981)

Drosophila-Genetiker und Human-Genetiker in

Deutschland und den USA …………………………………………………………. 31

David Hull

Essentialism in Taxonomy: Four Decades Later

Hans Werner Ingensiep

Organism, Epigenesis, and Life in Kant's Thinking -

Biophilosophy between transcendental philosophy

Ulrich Kutschera, V. M. Epshtein

Nikolaj A. Livanow $(1876$ - 1974) and the living relict

Acanthobdella peledina (Annelida, Clitellata) .....

Georgy S. Levit \& Lennart Olsson

"Evolution on Rails": Mechanisms and Levels of Orthogenesis ......................... 99

James Moore

Wallace in Wonderland

Kärin Nickelsen

„In deutlichen Beschreibungen und richtigen Zeichnungen

gemeinnütziger" - Abbildungen in der Gesellschaft Naturforschender

Freunde zu Berlin (GNF), 1773-1800

Rosemarie Nötblich, Nadine Wetzel, Uwe Hoßfeld \& Lennart Olsson

"Ich acquirirte das Schwein sofort, ließ nach dem Niederstechen die Pfoten

Zacharias mit Ernst Haeckel (1874-1898) _......................................... 177

Hans-Jörg Rheinberger

Internationalism and the History of Molecular Biology 249
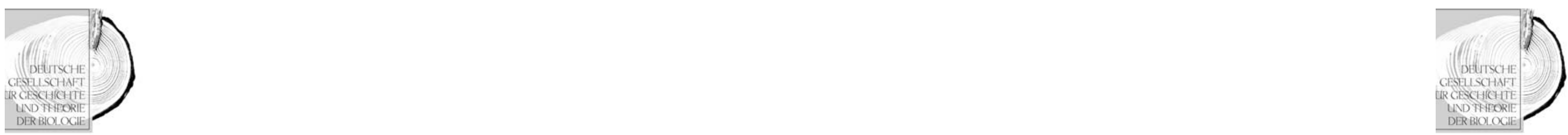